
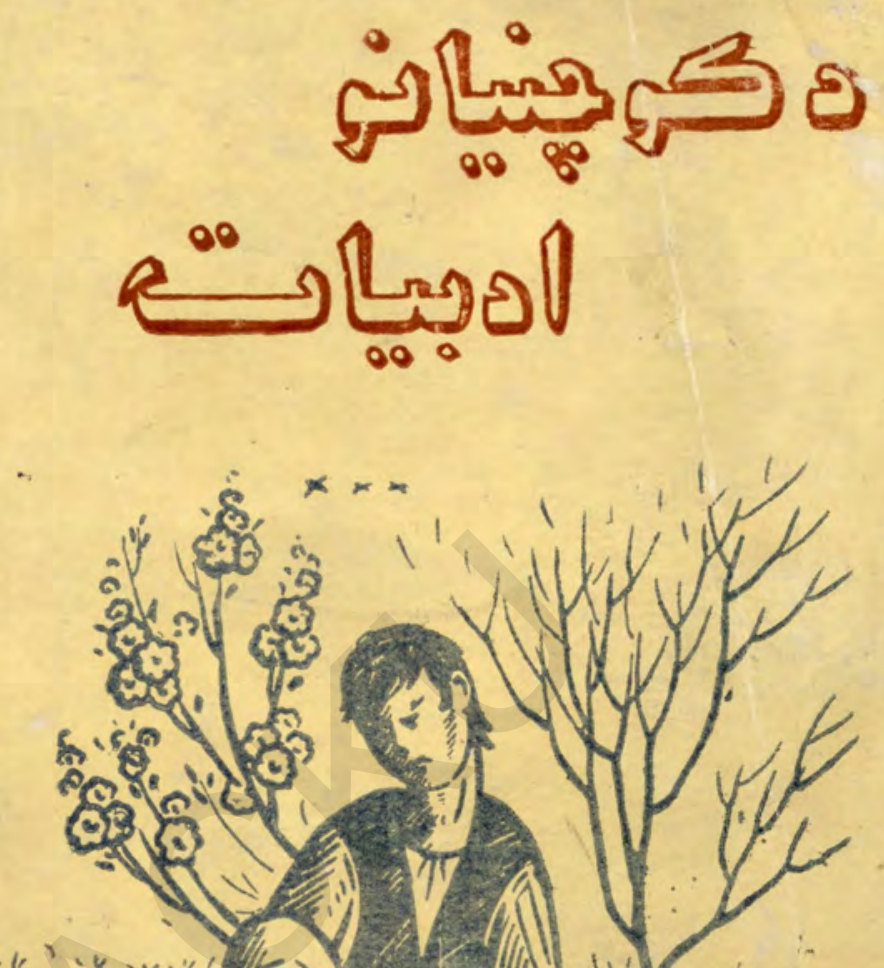

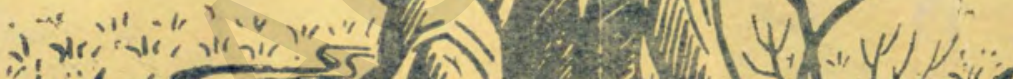

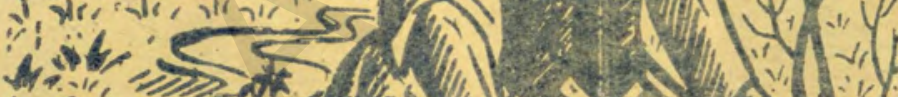

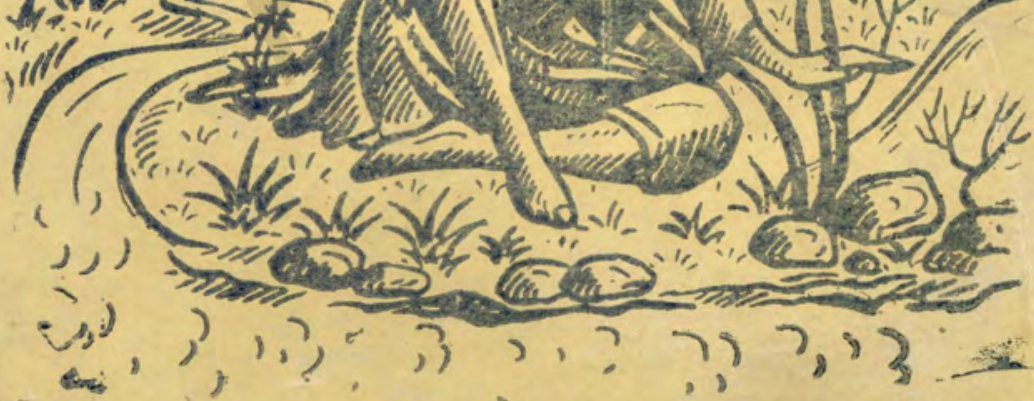

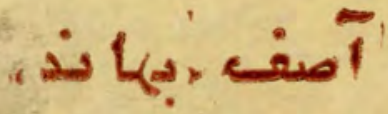




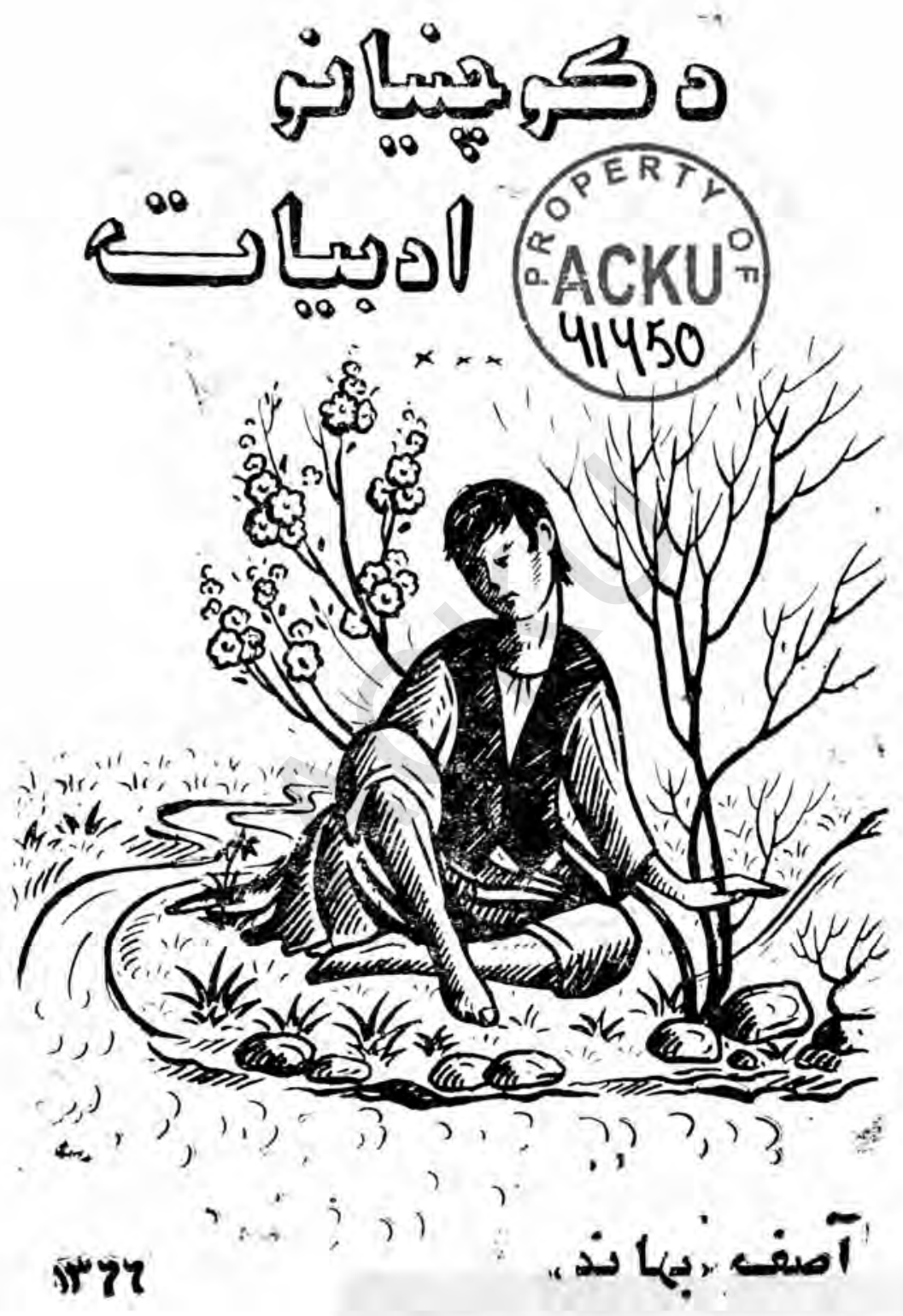

AFGHANISTAN CENTRE AT KABUL UNIVERSITY

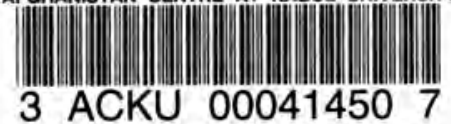




$$
\begin{aligned}
& \text { دكتابنوم : دكوحنياذوادبيات }
\end{aligned}
$$

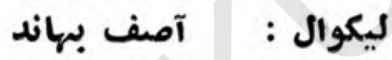

$$
\begin{aligned}
& \text { كLוJ : : } \\
& \text { شماره : : : : } \\
& \text { تيراز } \\
& \text { د حاي خحاى : دولتى مطبعه }
\end{aligned}
$$




$$
\text { :|lo| }
$$

$$
\text { تولوكمو تجنيا نو ته }
$$




\section{ف8ر ستت}

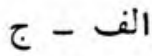

$$
\begin{aligned}
& \text { r- دكوجنيانو ادبيات دييه يوية اوبدوكى } \\
& r v-r \\
& \text { זـ یه فولكلور كى دكوجنيانو: ادبياتو برخه }
\end{aligned}
$$

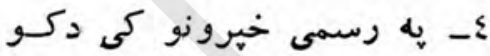

$$
\begin{aligned}
& T 1-r \Lambda
\end{aligned}
$$

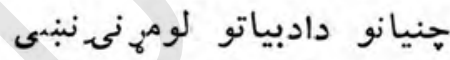

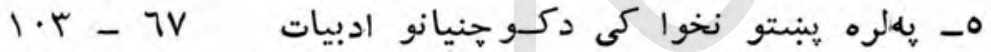

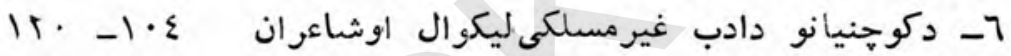

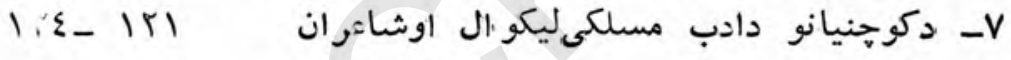

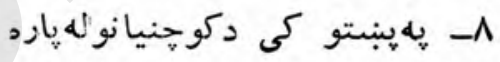

$$
\begin{aligned}
& 119-150 \\
& \text { ليكل شوى اوزبارل شوى كتابونه } \\
& \operatorname{lit}-t h
\end{aligned}
$$

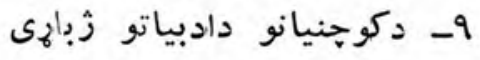

$$
\begin{aligned}
& \text { I:A - rio }
\end{aligned}
$$

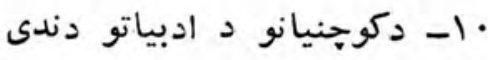

$$
\begin{aligned}
& \text { ir - rTh }
\end{aligned}
$$

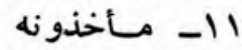




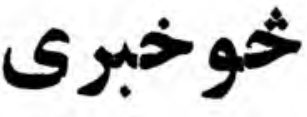

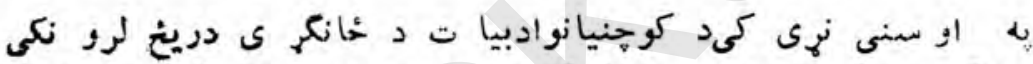

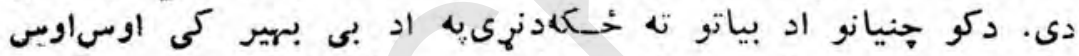

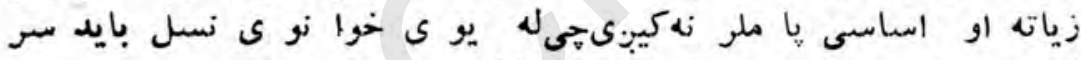

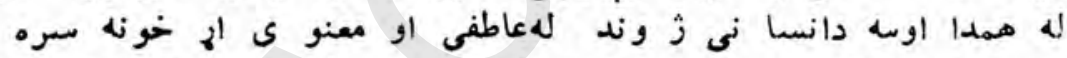

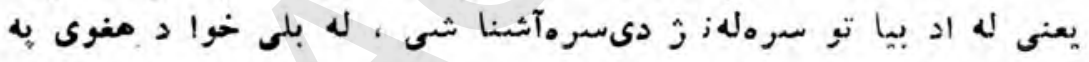




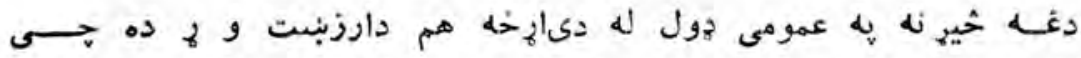

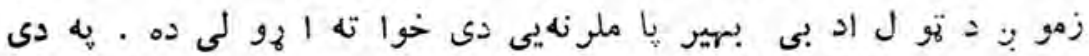

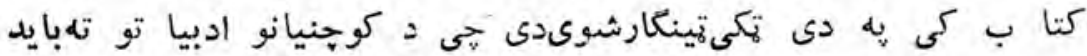
زمهوب تول ليكوال تول شا عراناو فر هنكيا ن اسا سيى غور وكئى

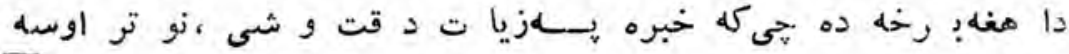

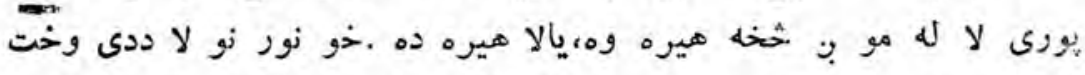

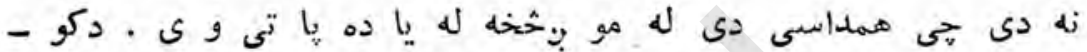

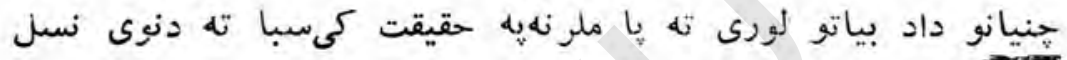

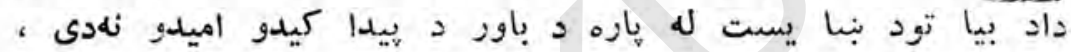

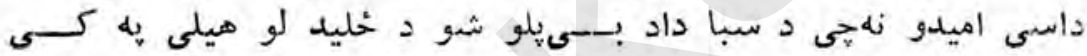

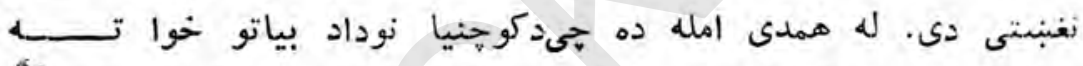

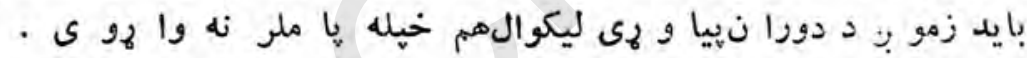

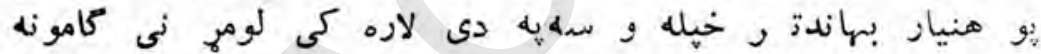
او جت كهل .د دى اثر يهخيريدلو سره به زموبز دغه اميدونه لا تـاند

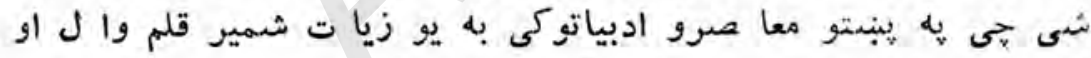

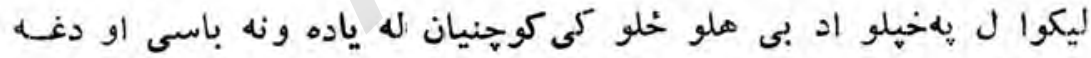

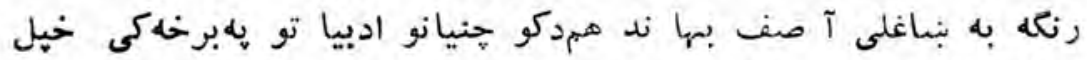

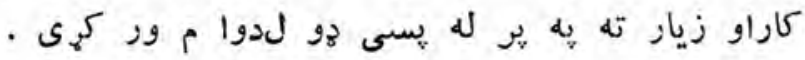

\section{زرين 1زْْور}

77,010 


\section{دكوجنيانو ادبياتد بيميريويه اوي دوكى}

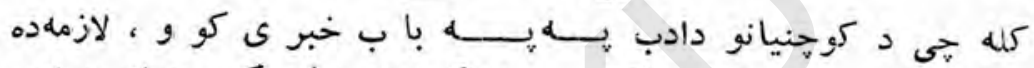

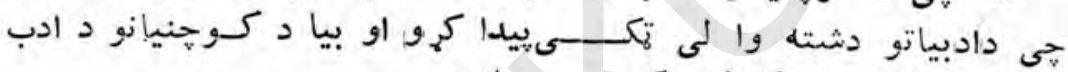

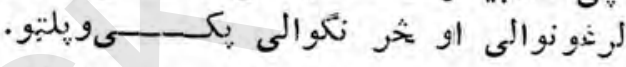

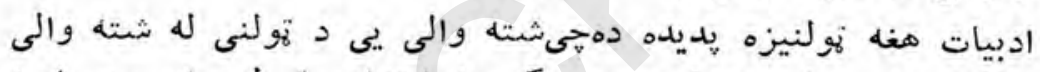

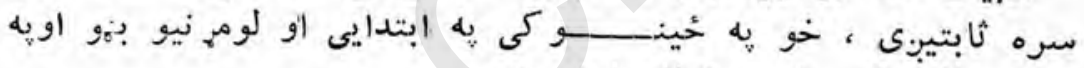

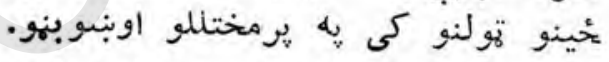

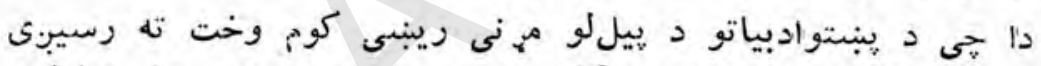

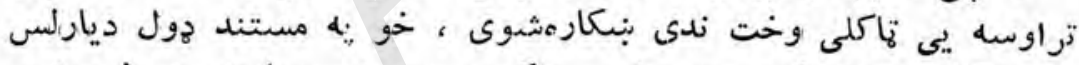

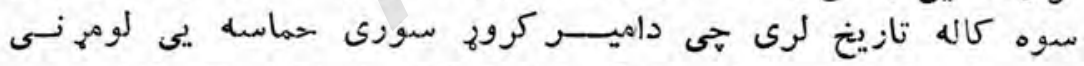

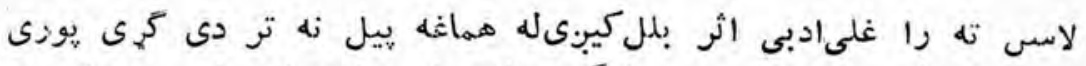

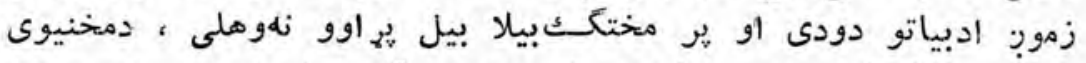

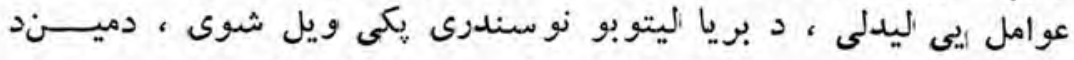

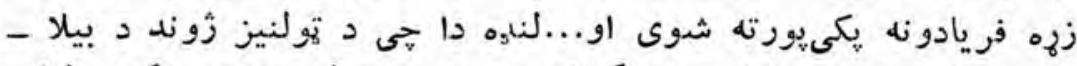

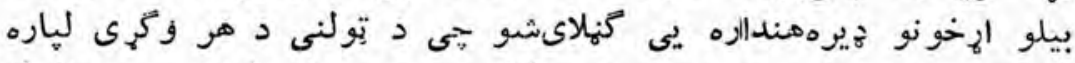

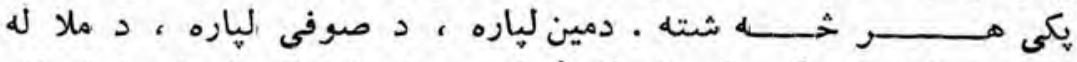
ياره عد خوار او كميدلى انسان لهيازه ،دباد شاهانو او أمهرا تورانو 


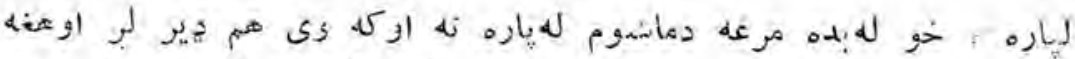

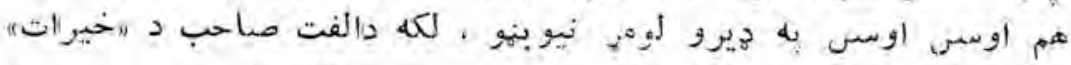

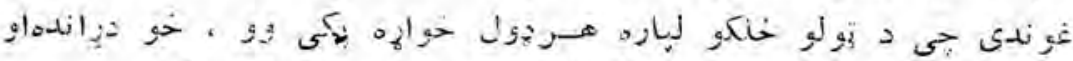

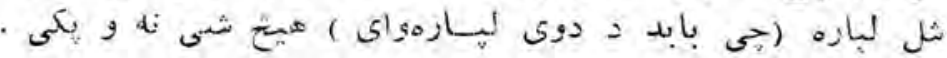

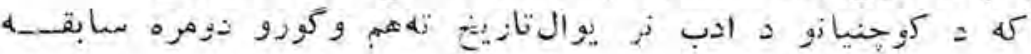

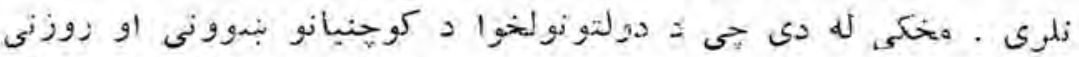

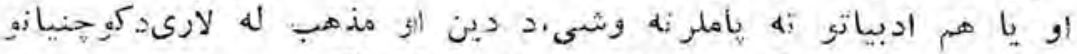

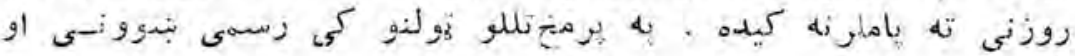

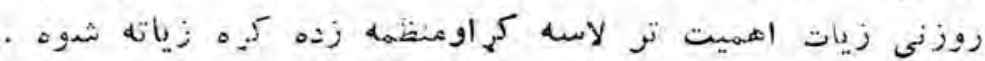

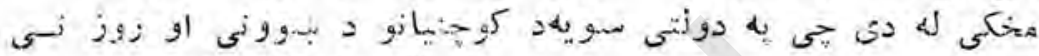

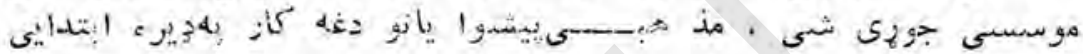

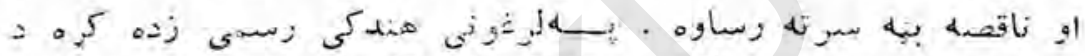

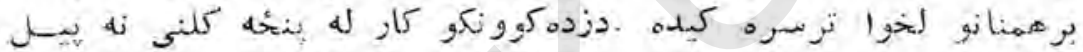

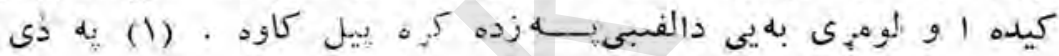

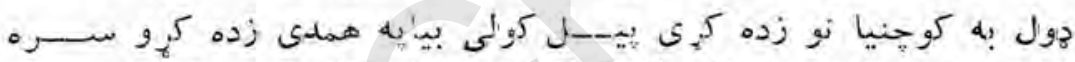

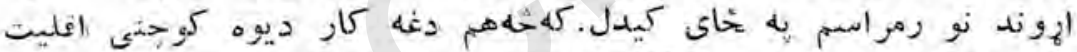

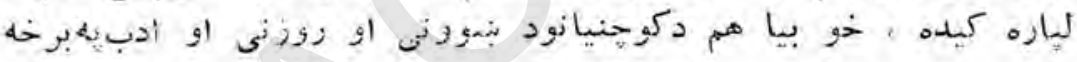

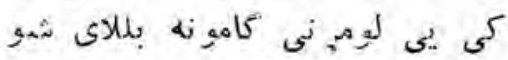

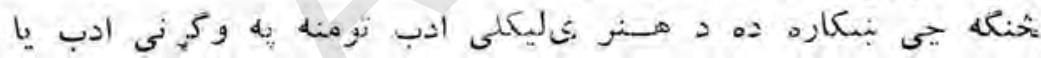

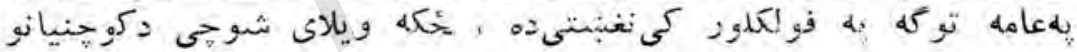

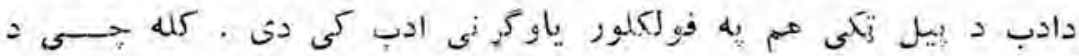

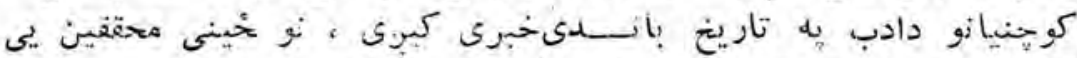

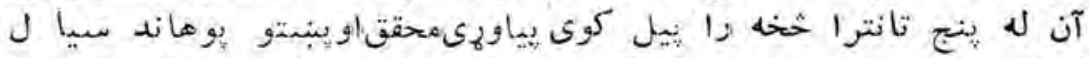

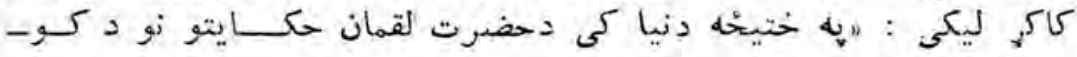

تكين (مجله تى بى باتوموزنوز (جامعه شناسىى تعليم وتو بيت (1)

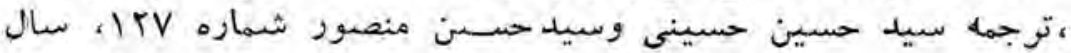
09 . Iros 


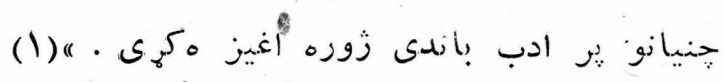

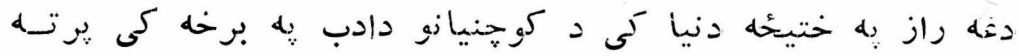

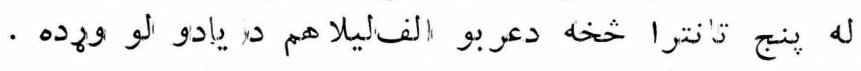

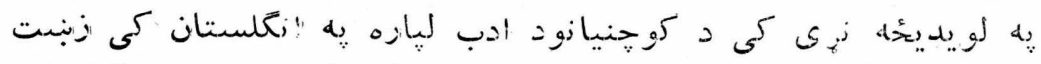

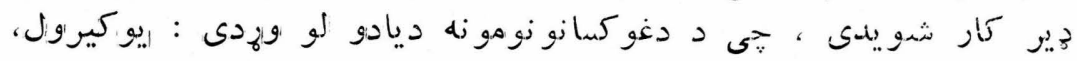

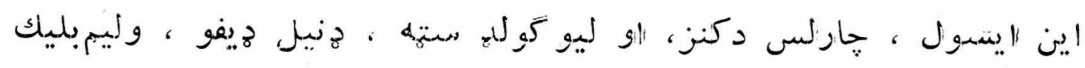

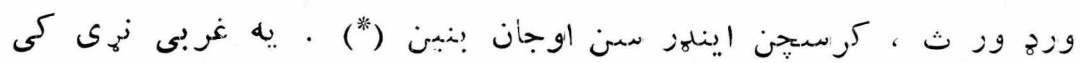

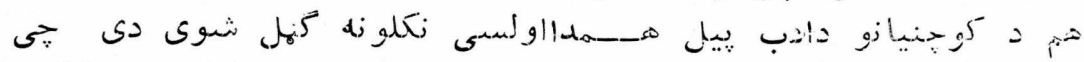

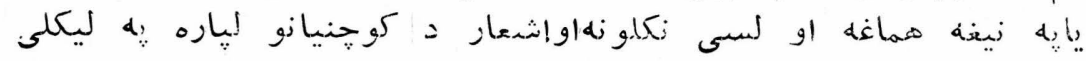

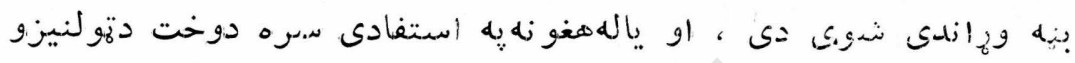

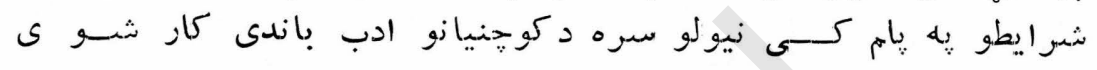
دى .

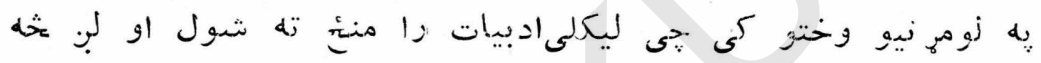

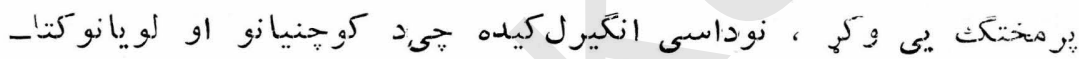

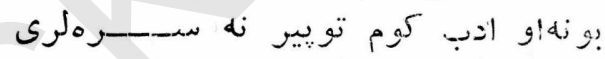

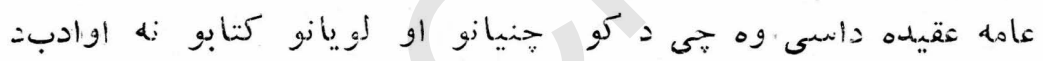

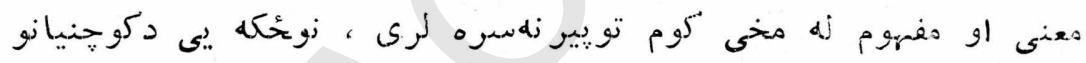

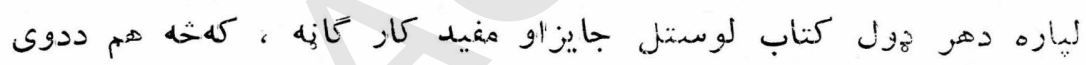

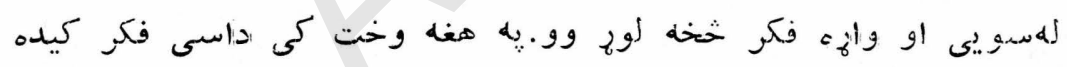

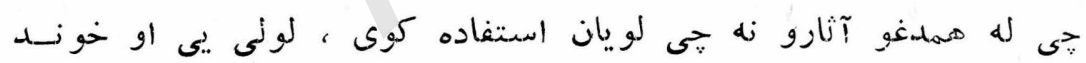

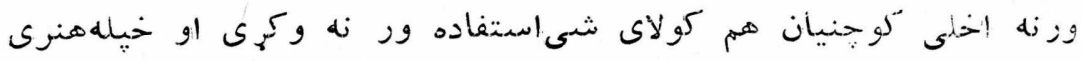

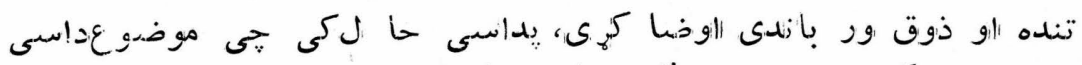

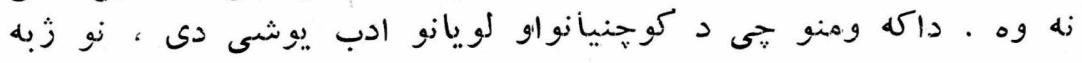

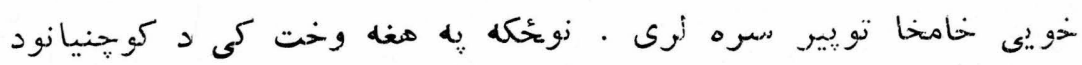

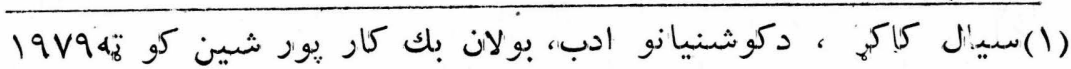

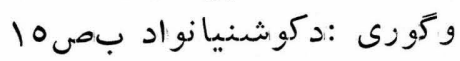

كال ، ص عال كاكي 


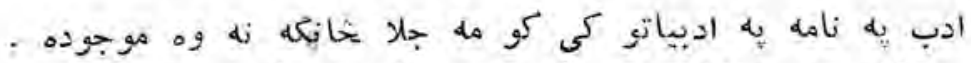

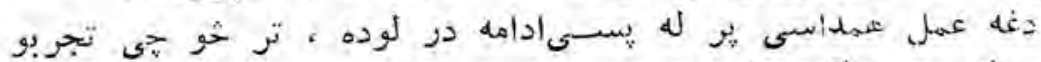

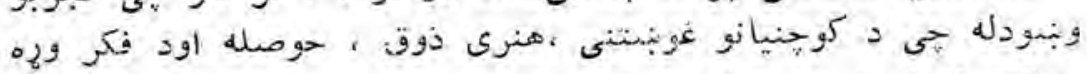
-

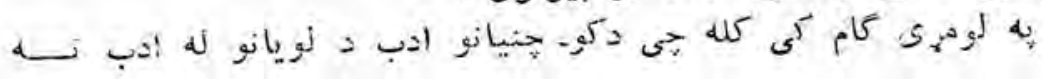

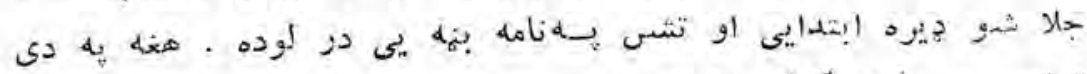

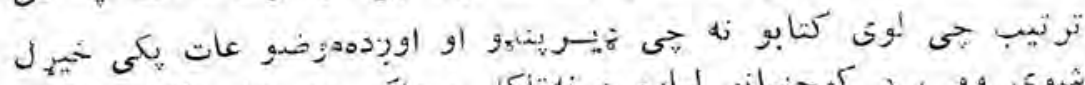

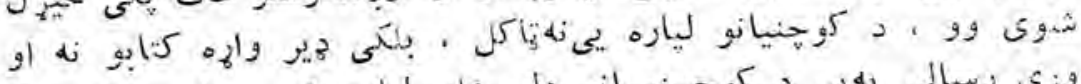

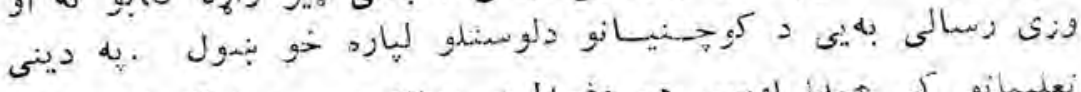

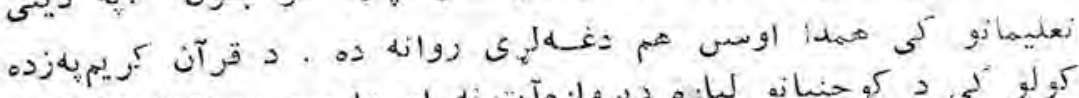

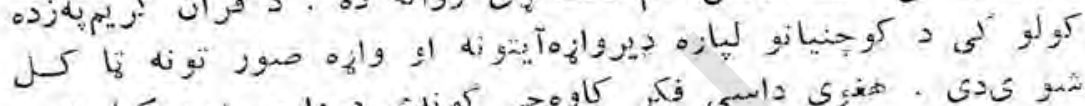

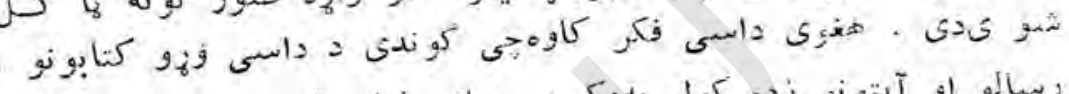

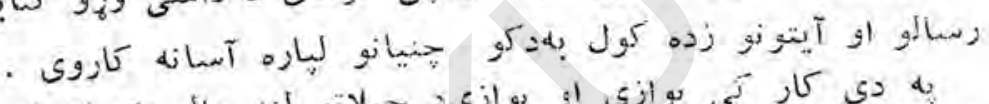

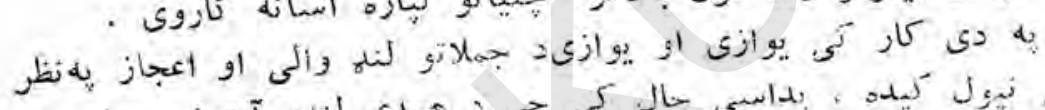

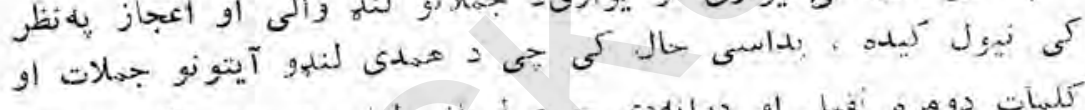

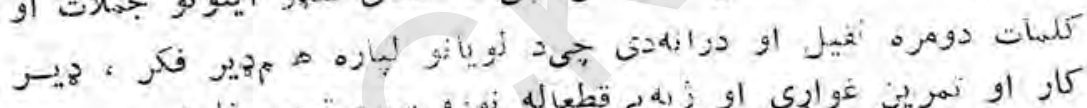

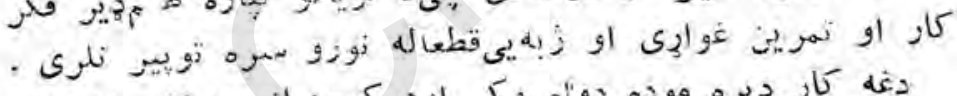

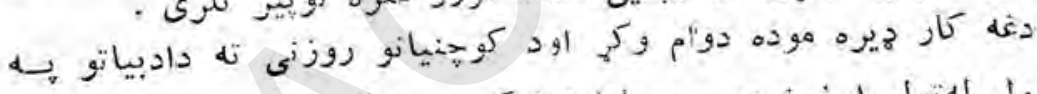

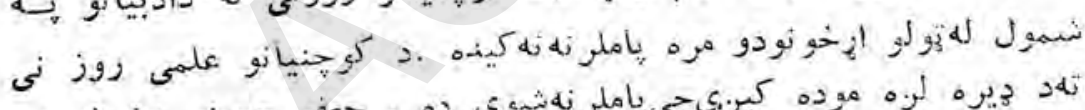

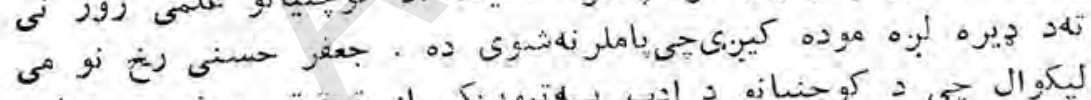

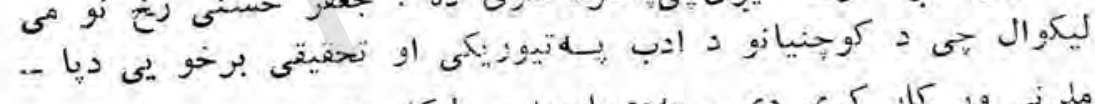

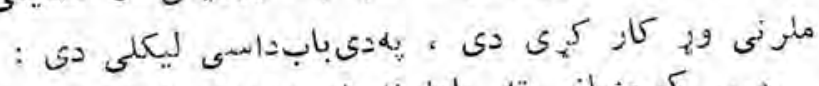

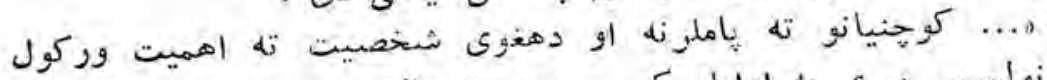

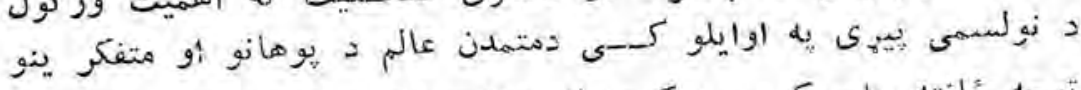

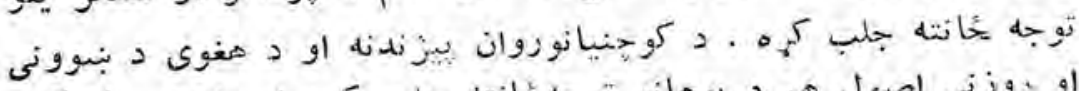

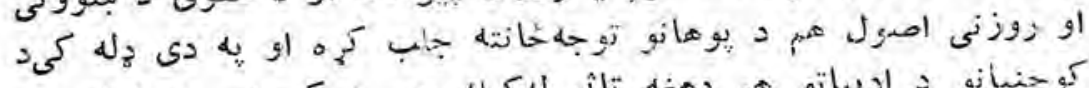

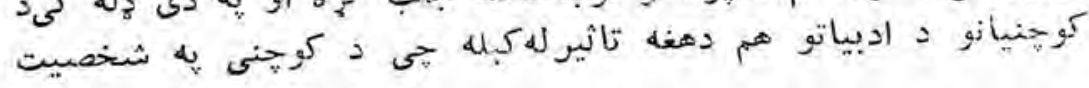

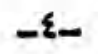




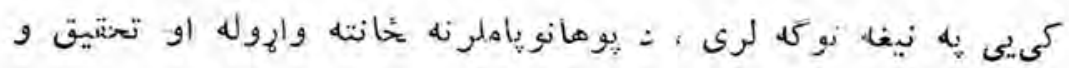

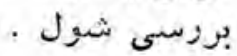

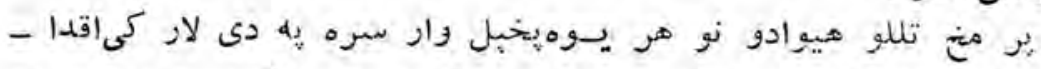

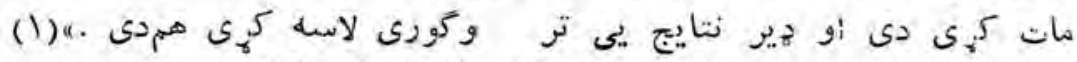

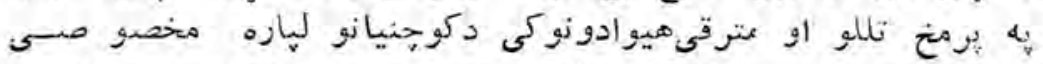

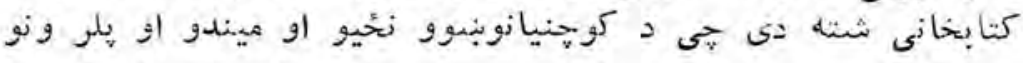

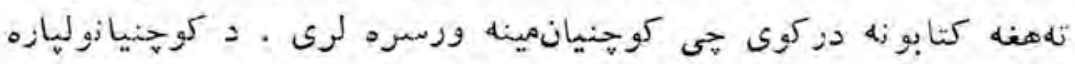

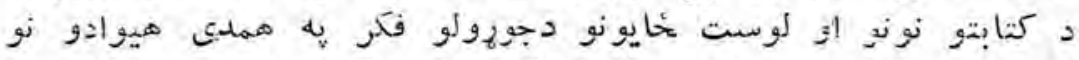

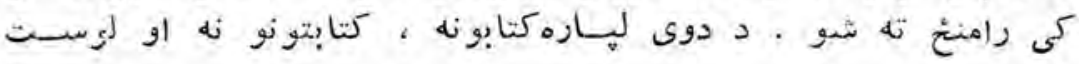

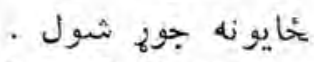

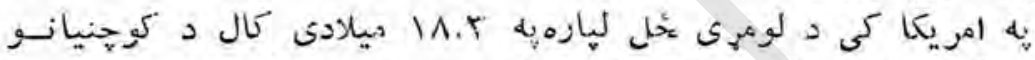

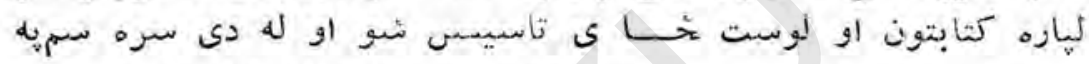

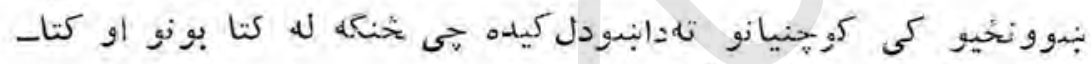

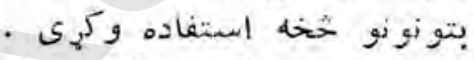

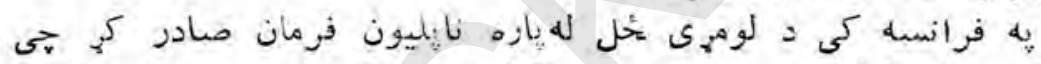

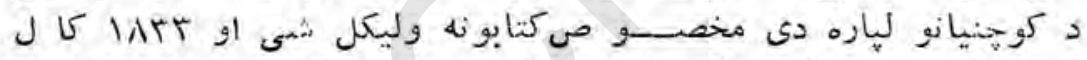

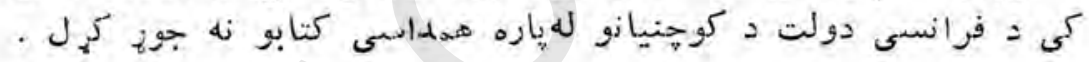

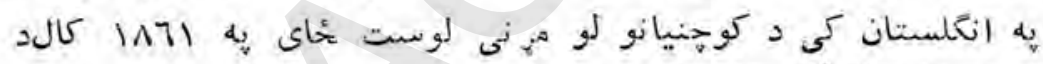

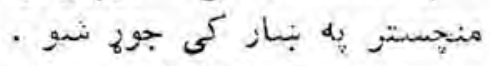

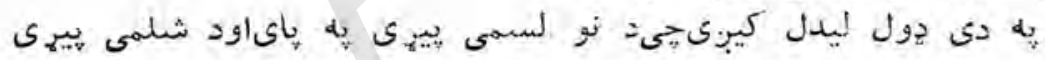

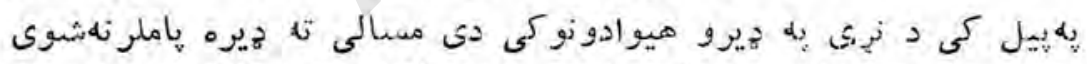

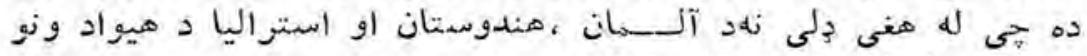

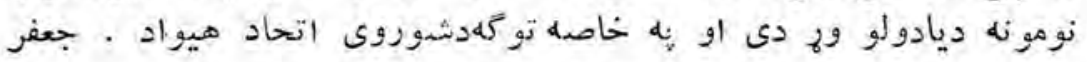

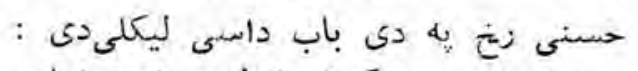

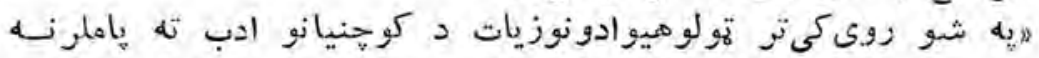

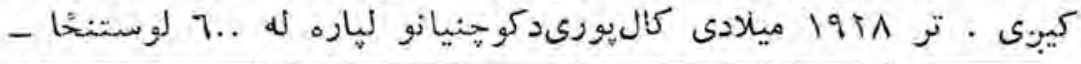

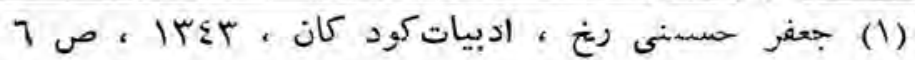




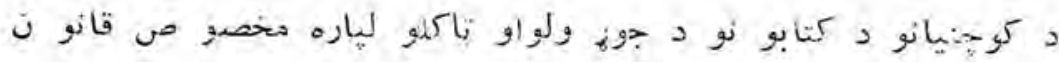

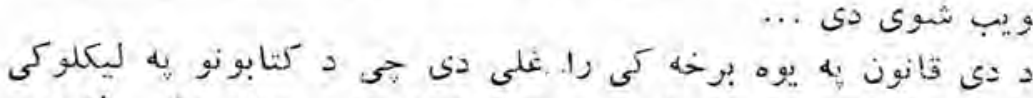

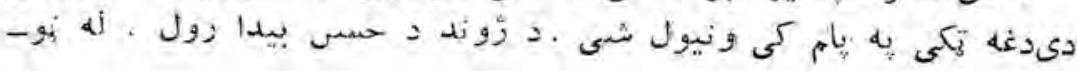

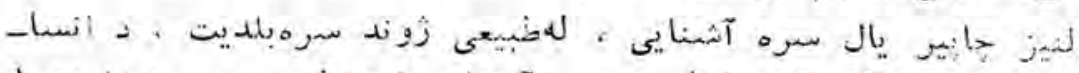

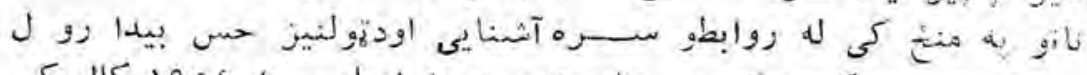

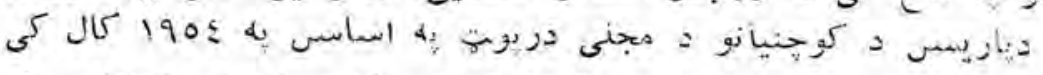

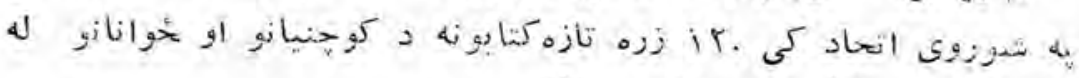

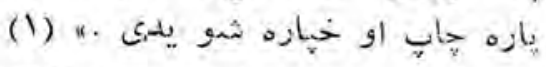

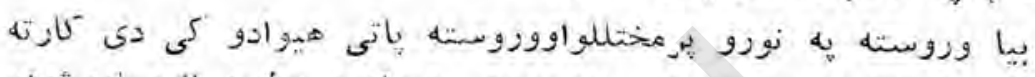

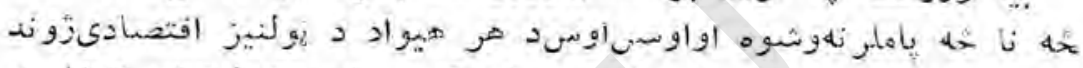

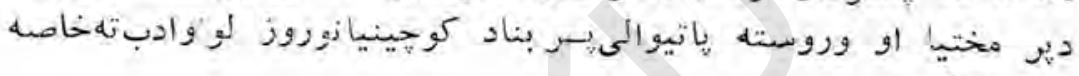

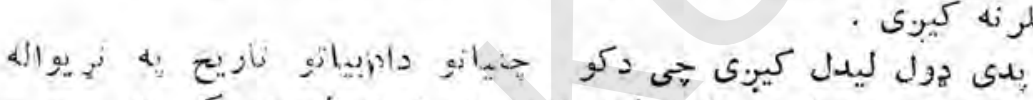

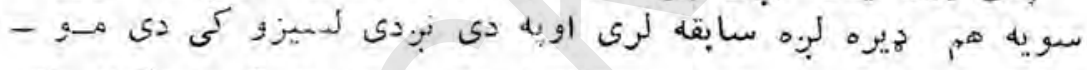

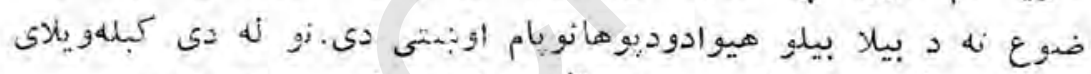

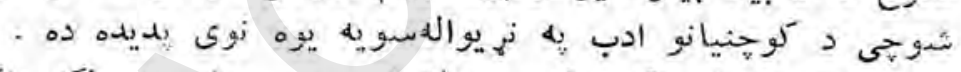

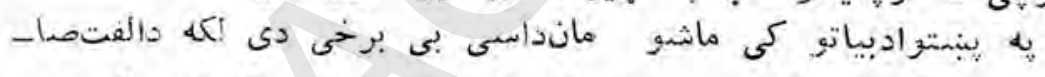

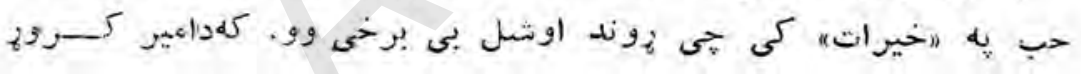

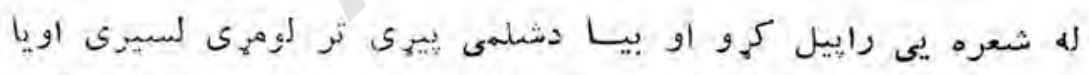

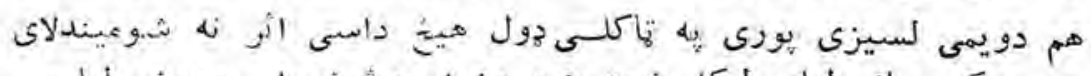

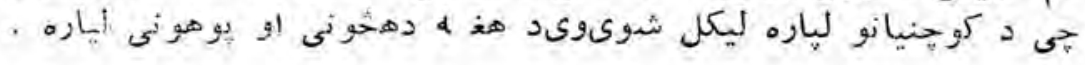

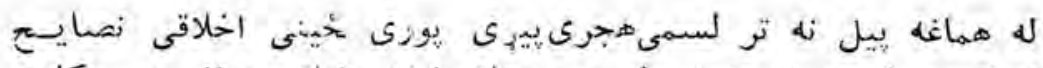

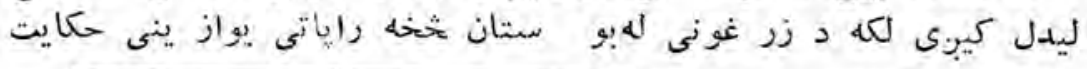




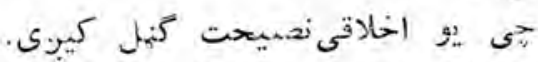

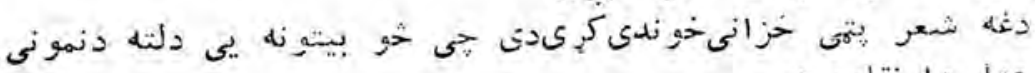

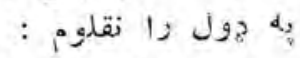

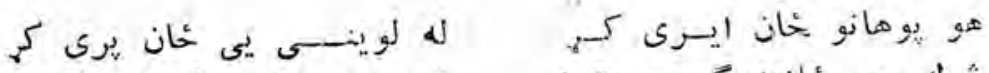

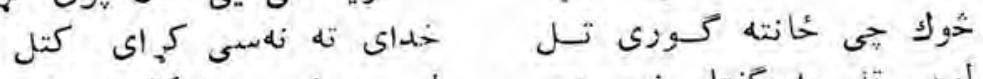

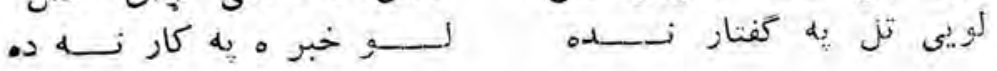

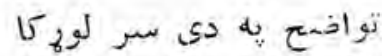

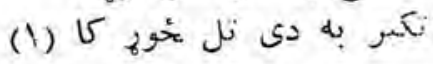

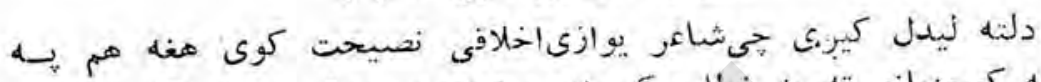

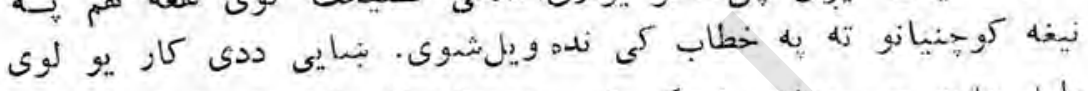

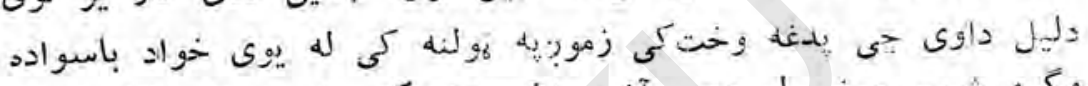

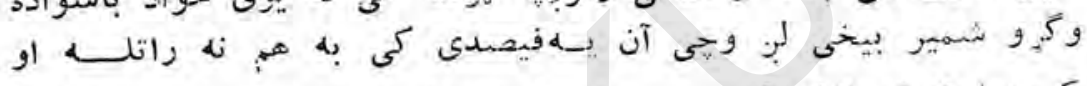

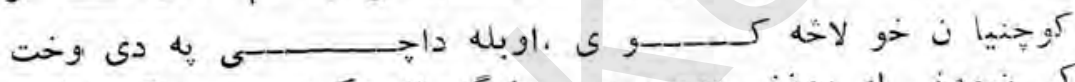

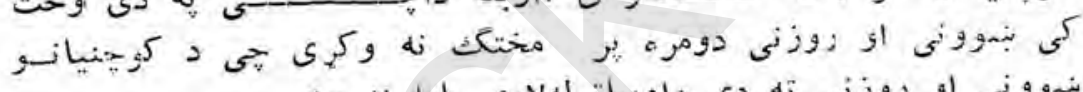

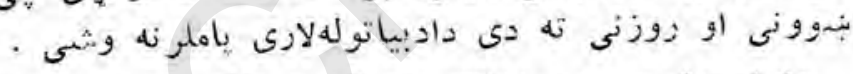

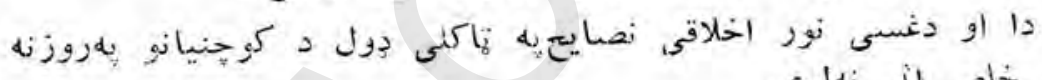

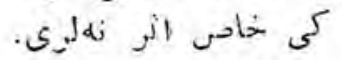

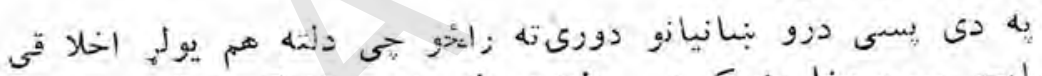

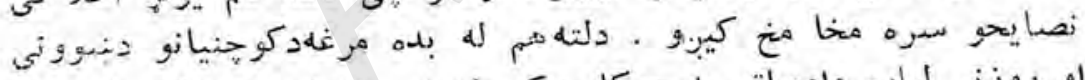

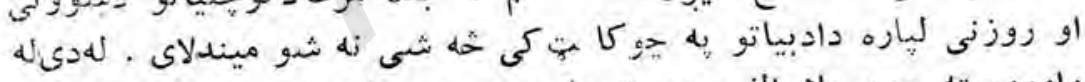

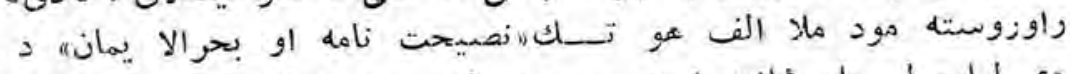

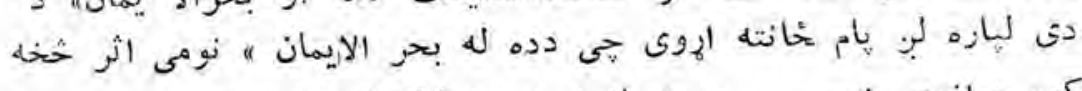

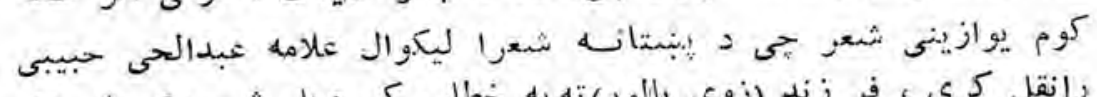

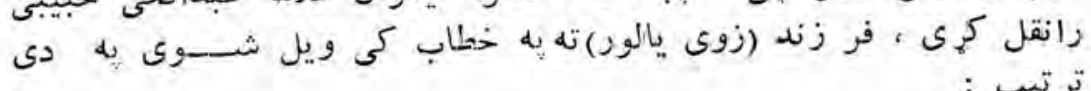
ترتيب :

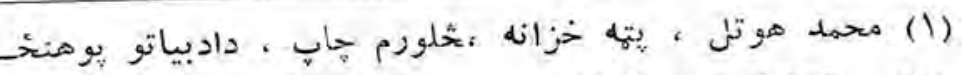
خبرونه ، 11507 


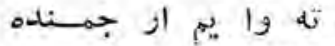

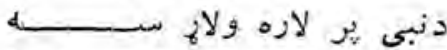

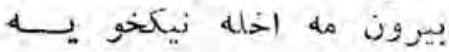

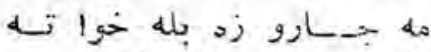

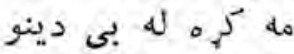

(1) لها

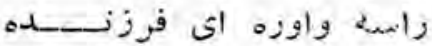

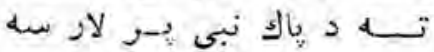

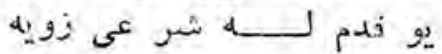

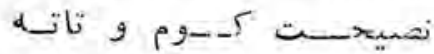
هجلس هــر هجاس مجس

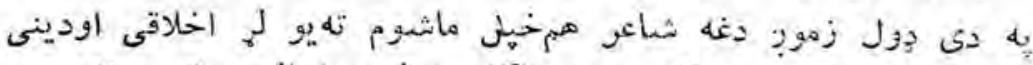

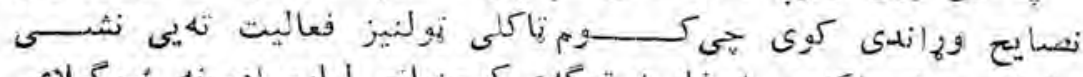

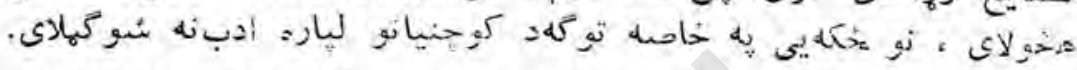

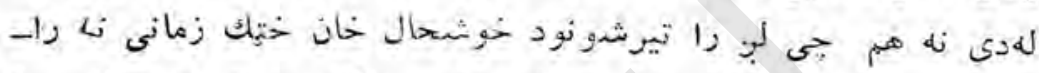

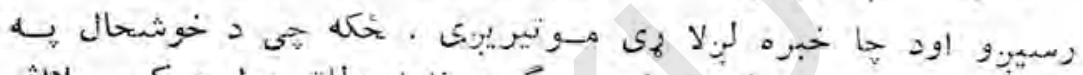

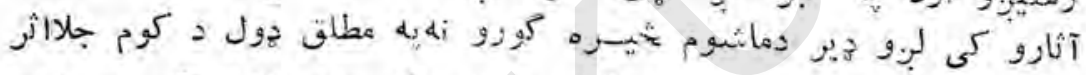

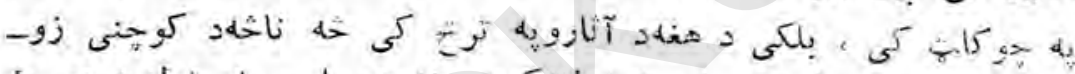

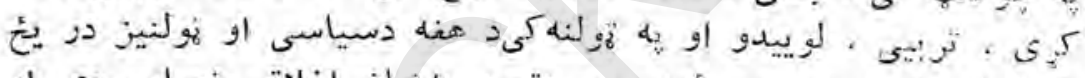

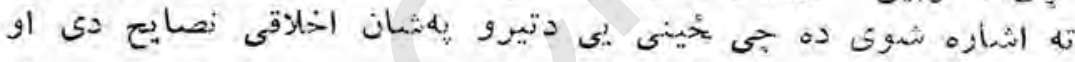

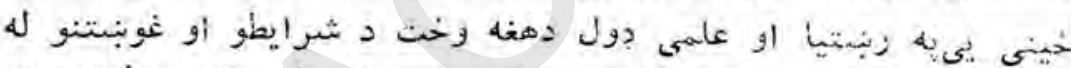

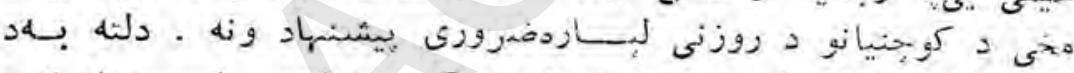

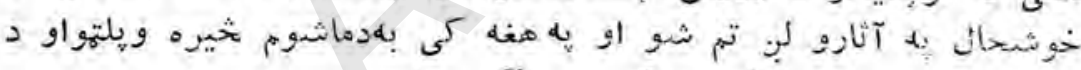
ك

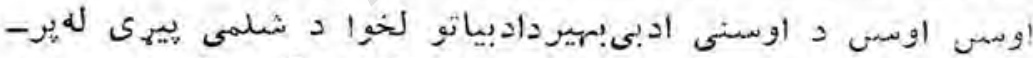

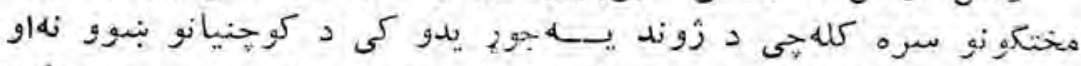

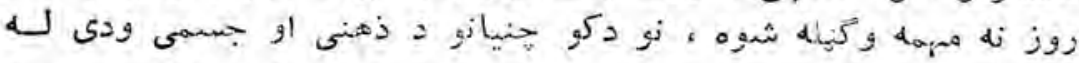

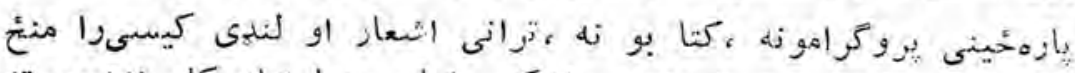

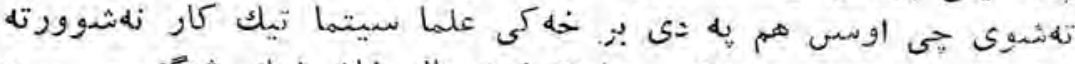

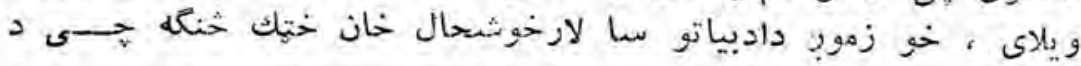

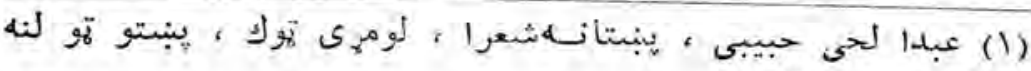

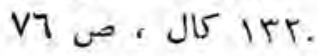




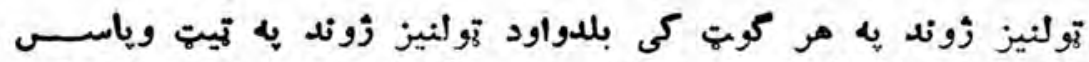

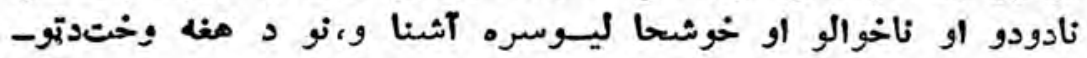

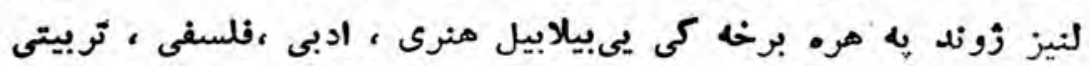

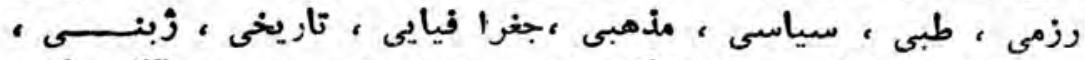

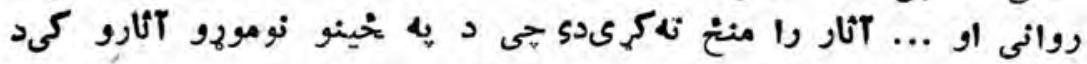

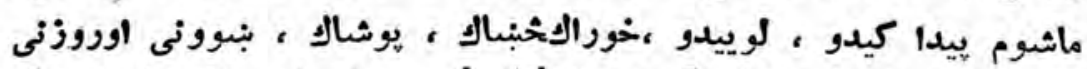

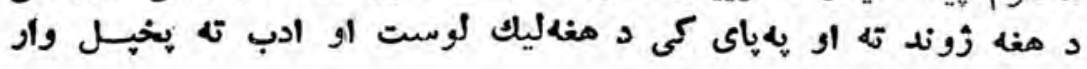

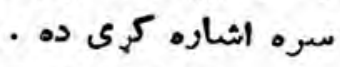

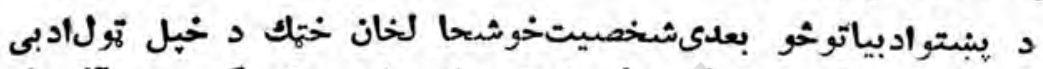

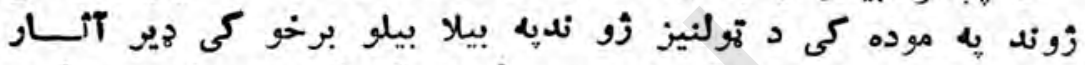

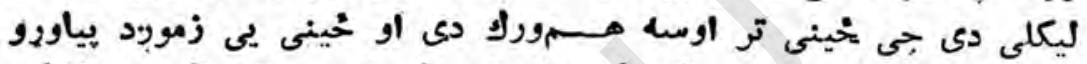

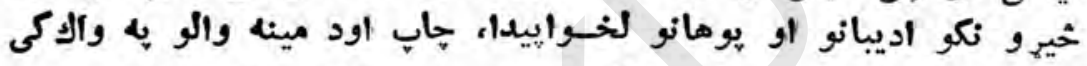

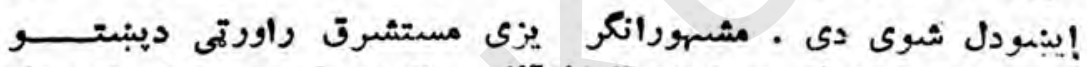

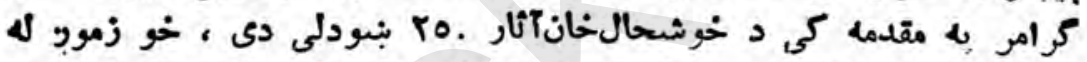

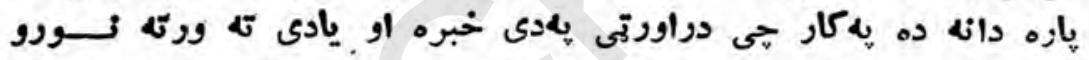

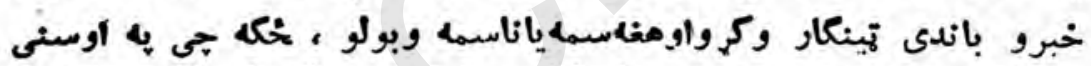

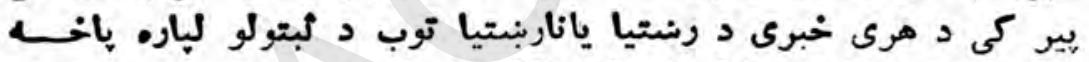

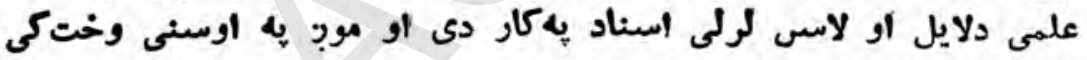

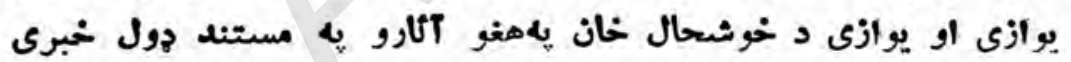

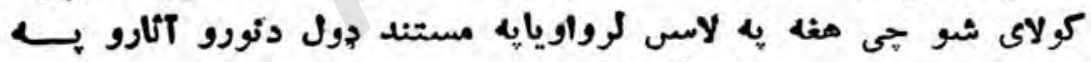

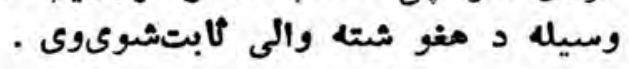

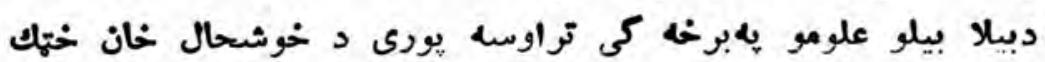

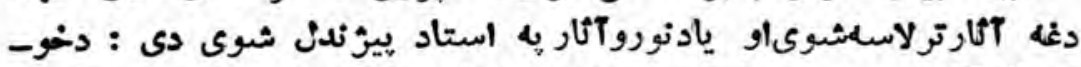

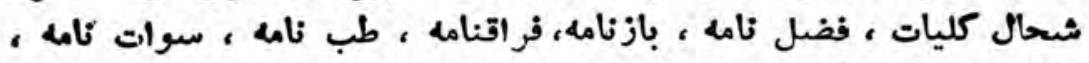

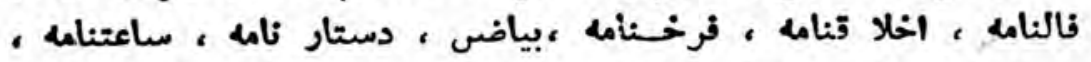

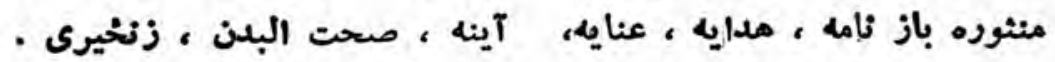




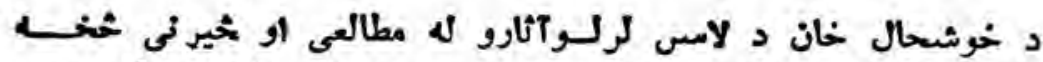

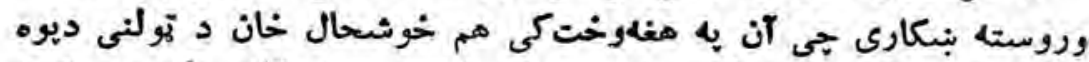

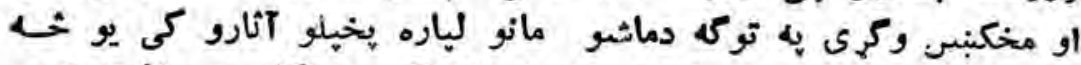

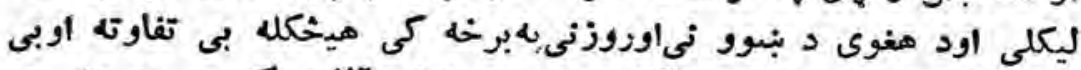

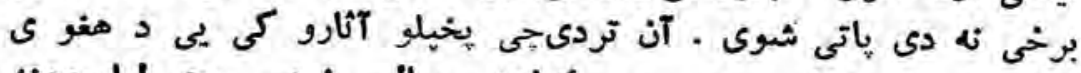

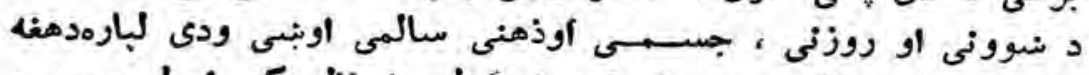

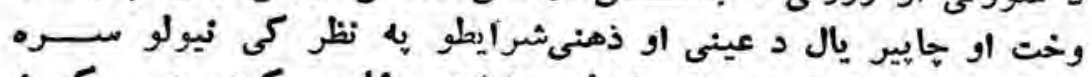

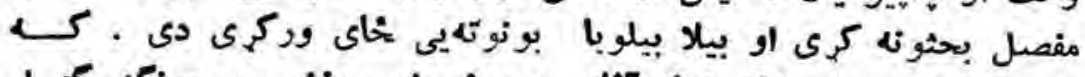

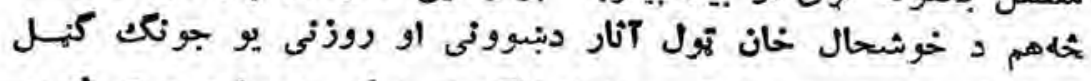

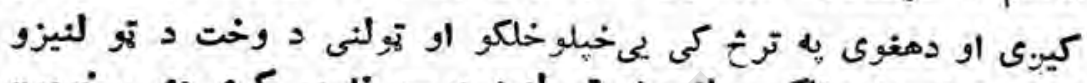

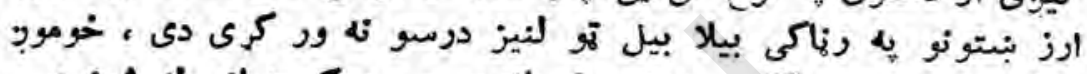

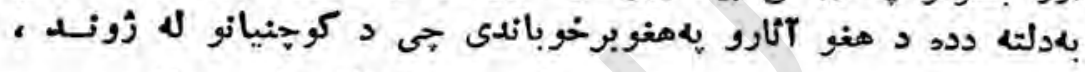

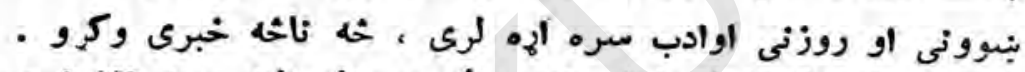

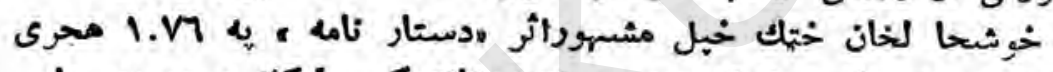

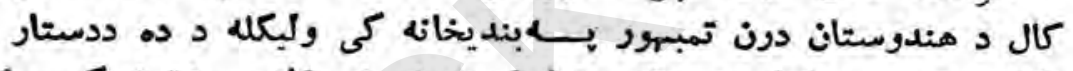

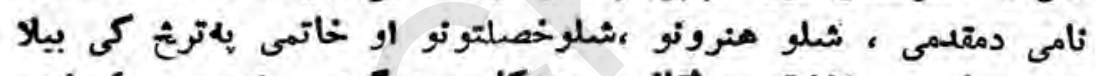

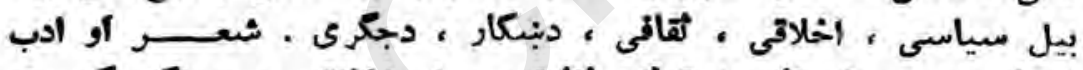

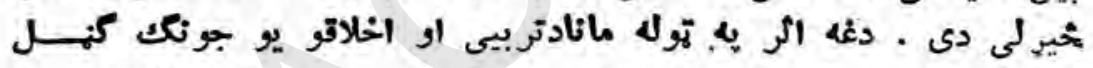

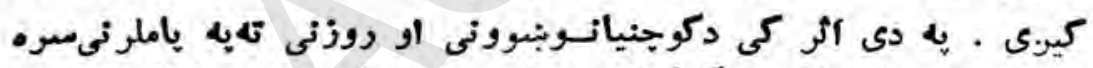

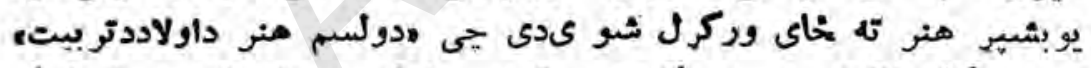

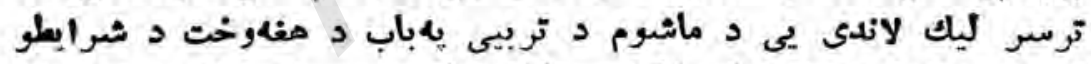

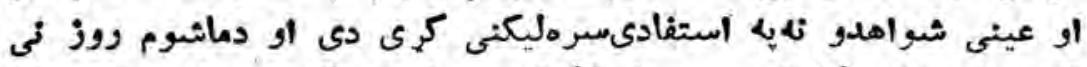

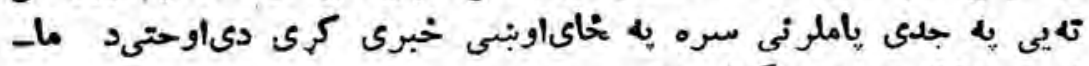

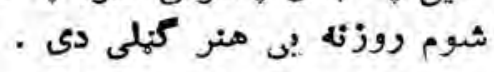

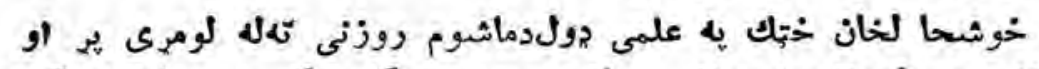

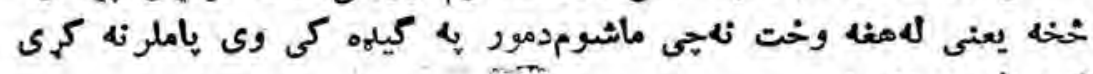
او ويلى يیى : 
راولاد يازوى وى يا لور، خو جىعود تينه به فرزند ركه شى نوريع

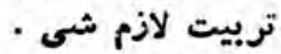

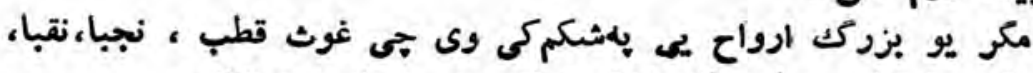

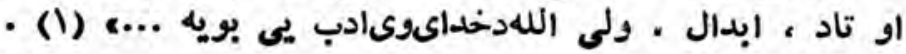

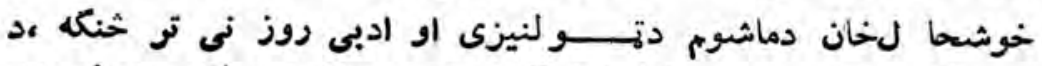

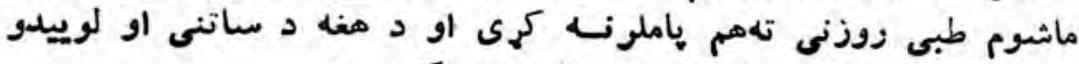

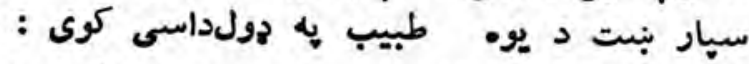

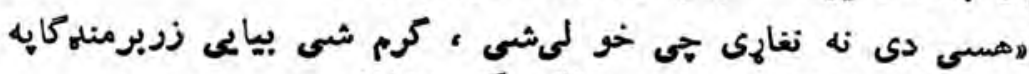

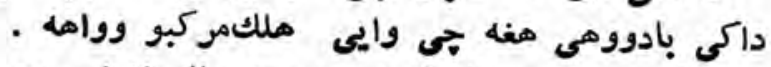

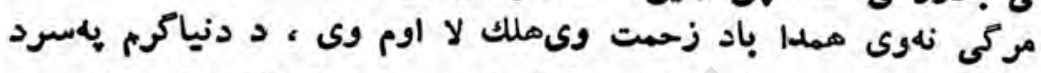

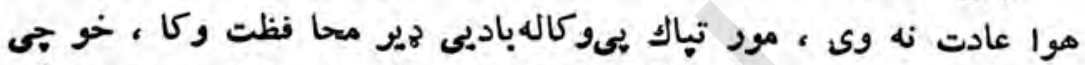

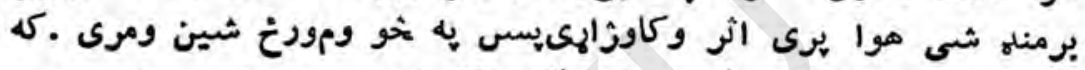

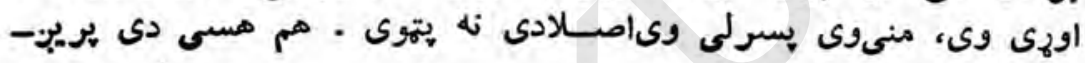

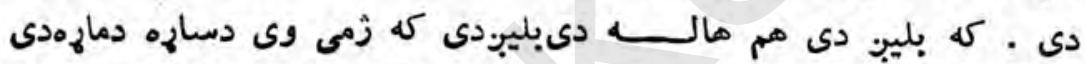

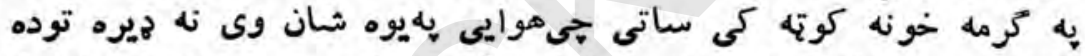

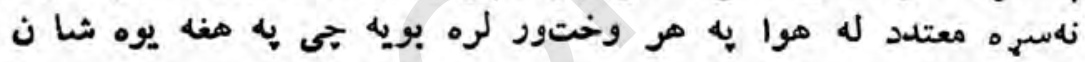

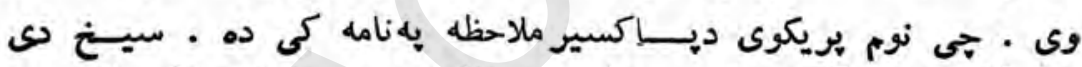

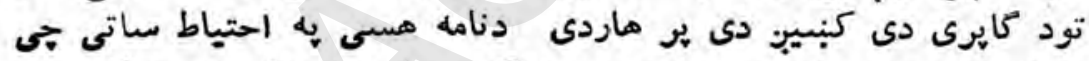

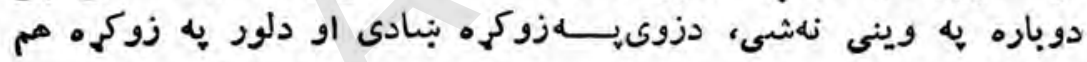

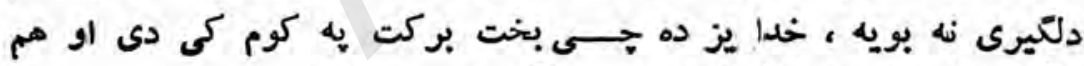

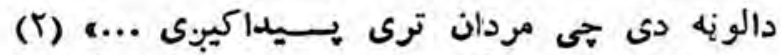

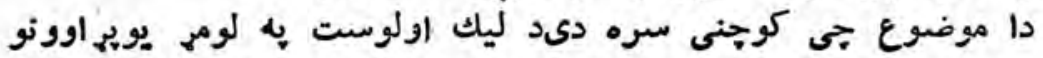

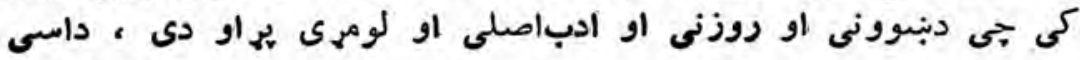

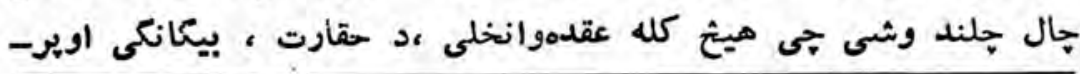

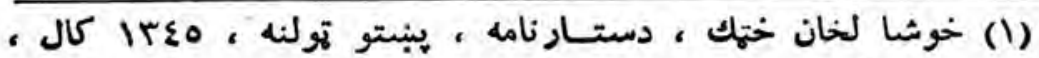
صص (10 (1) ممدا اثر ، ممدا مخونه 
ديتوب احساس ونه كيى او حـهترنظر بدور نشى جى بـ به واتلونكى

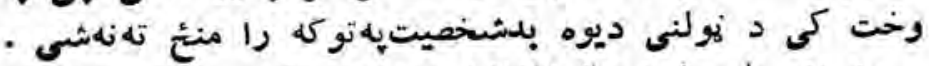

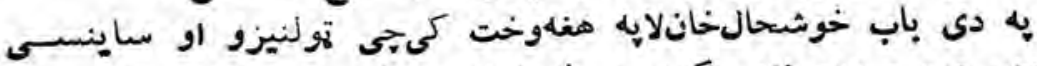

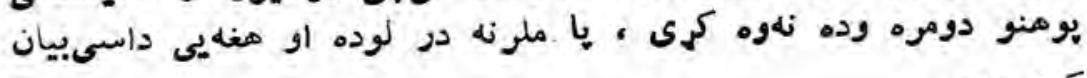

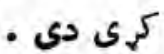

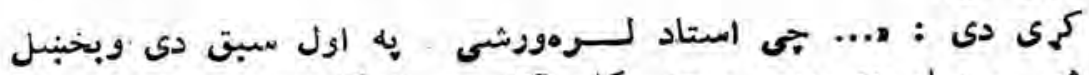

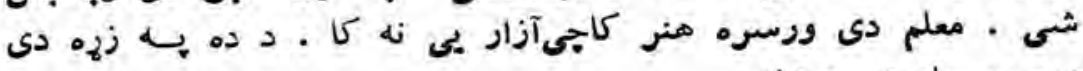

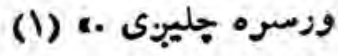

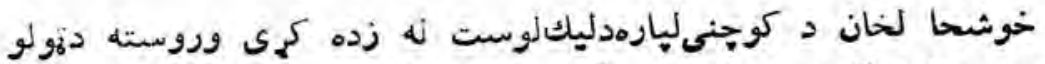

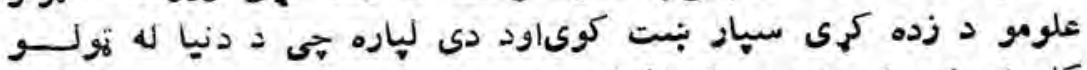

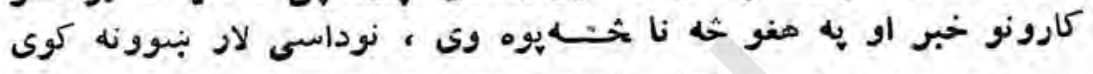

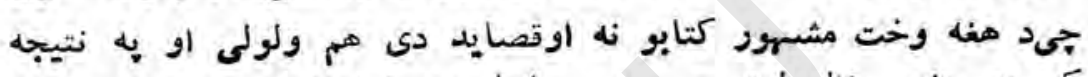

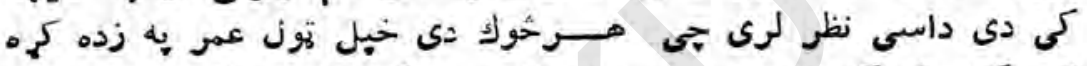

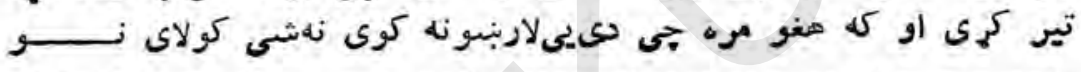

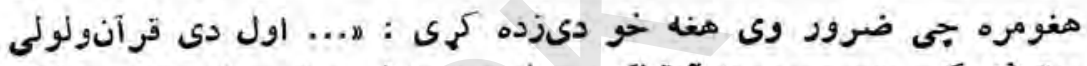

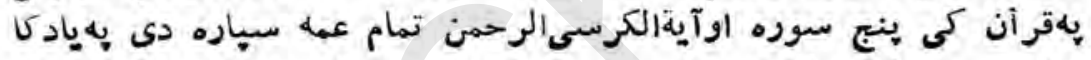

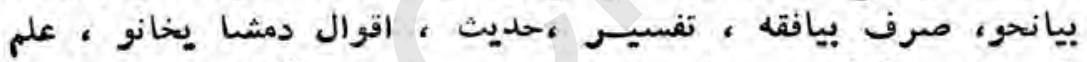

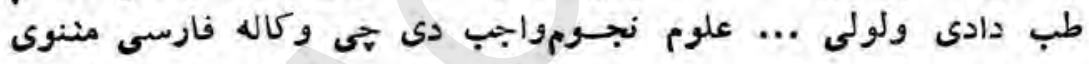

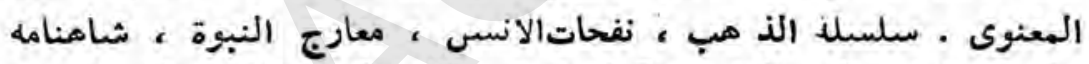

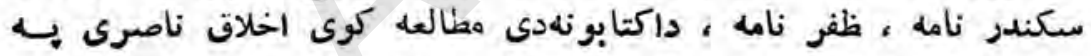

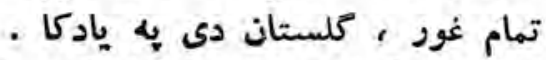

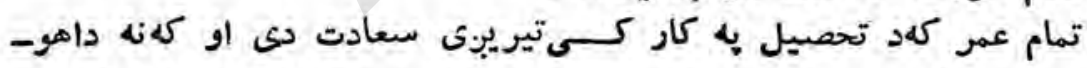

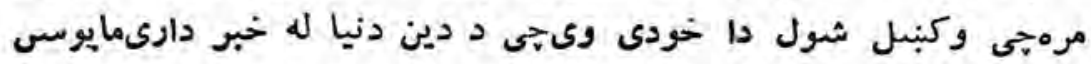

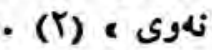

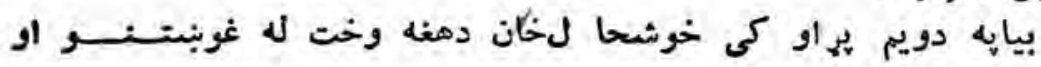

$$
\text { (1) (1) (1) }
$$

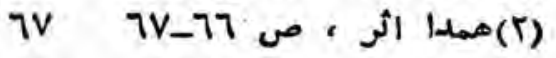




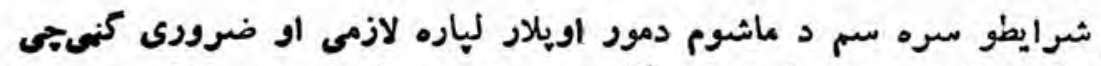

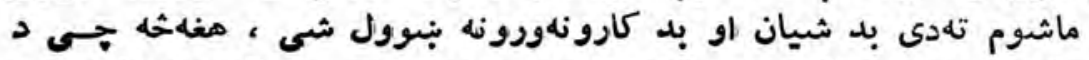

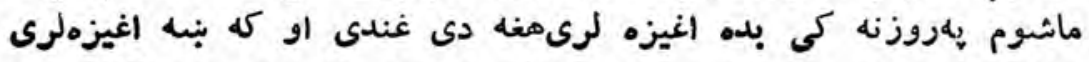

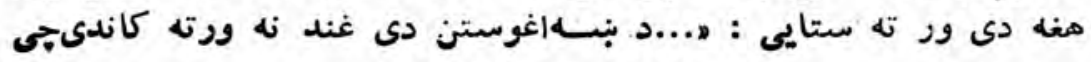

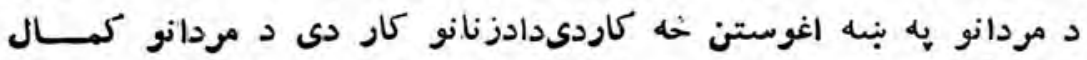

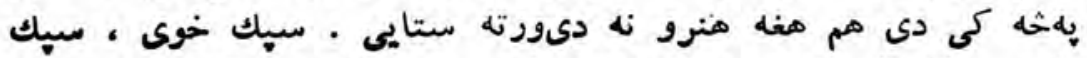

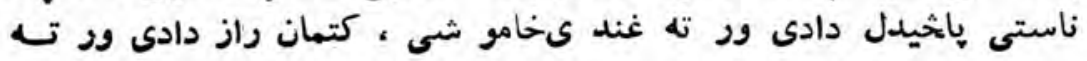

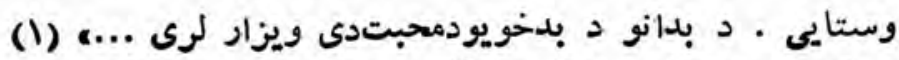

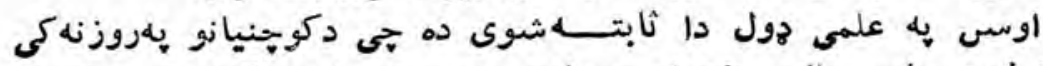

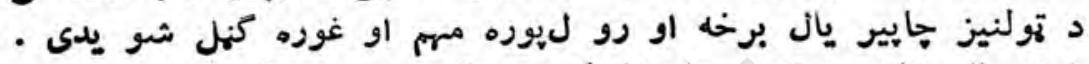

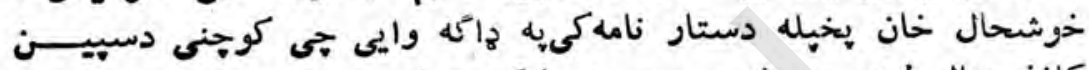

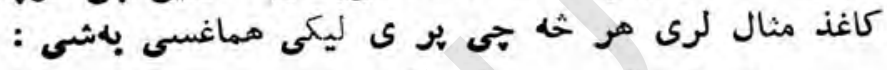

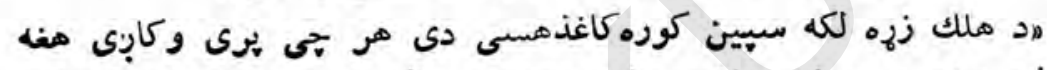

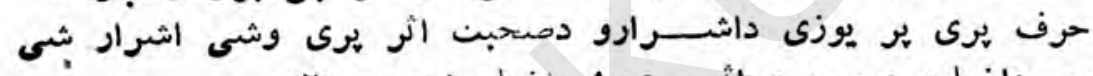

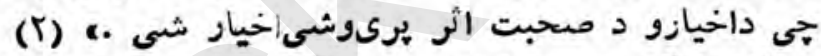

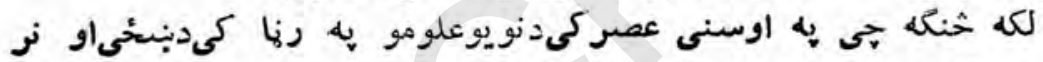

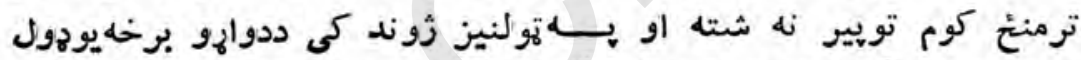

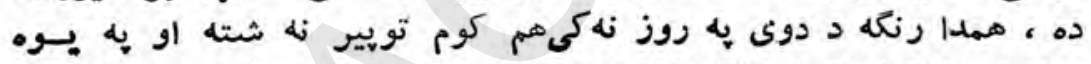

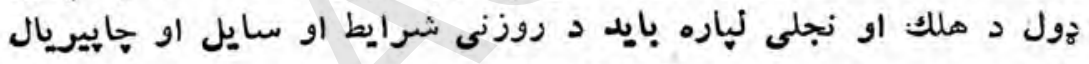

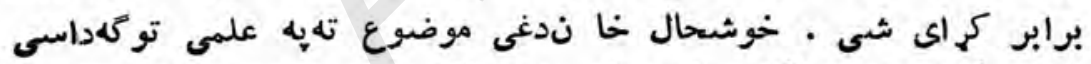

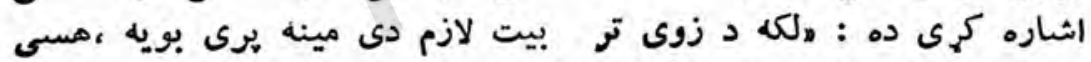

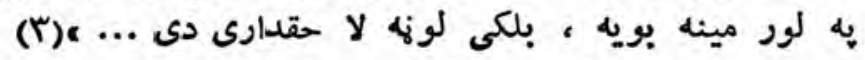

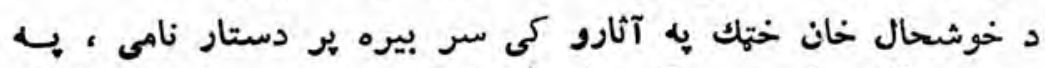

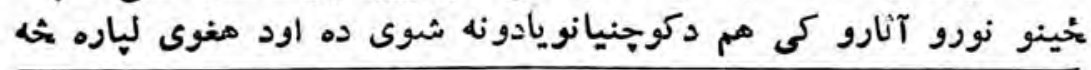

$$
\begin{aligned}
& \text { (1) (1) هملدا اثر ، ممدا منح }
\end{aligned}
$$

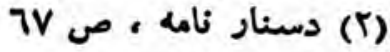

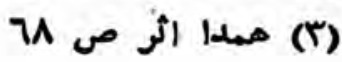

$$
\begin{aligned}
& \text {-. Ir }
\end{aligned}
$$


اخلاقى · تربيتى لار بنبوونى شتهجىهره يوه يخبل وار سره ديادولـــو ول ده -

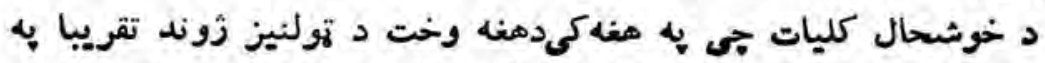

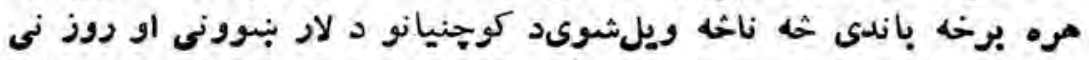

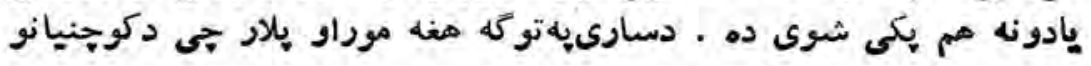

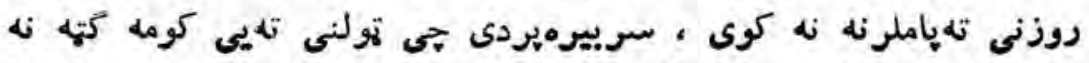

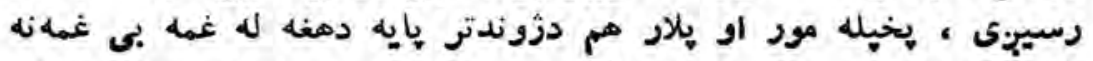

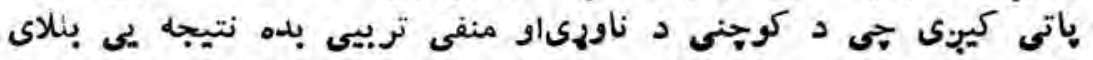

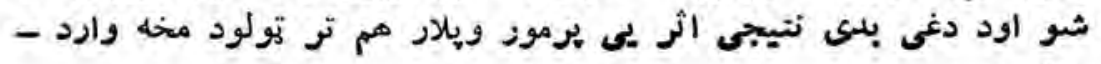
- ميزى

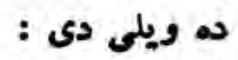

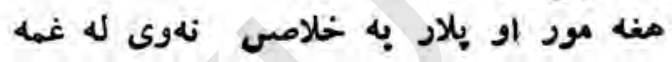

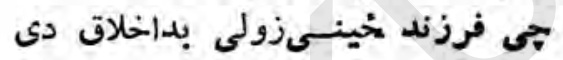

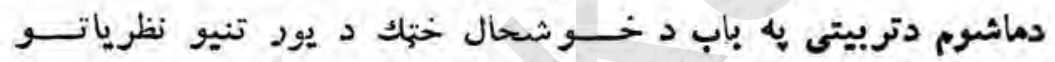

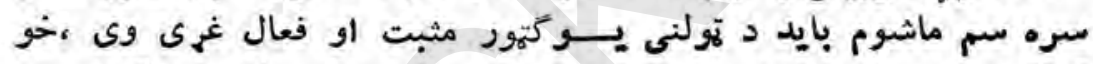

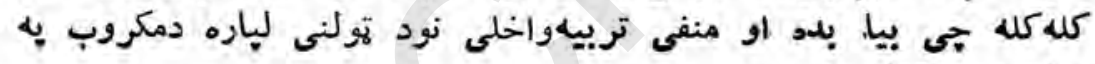

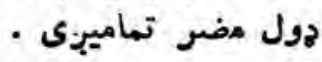

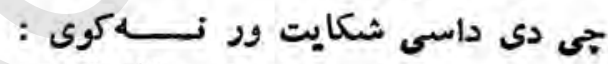

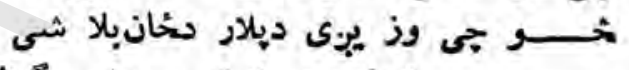

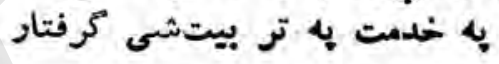

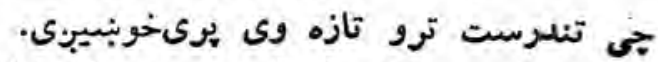

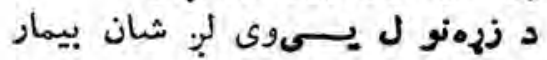

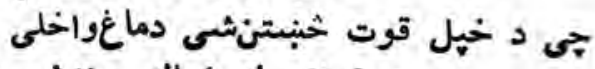

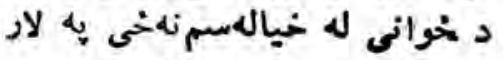
له خودى نه مسى مست بيخودهلائ شى لهى خو يوزه يم جسى ييدا شوم به به داداد

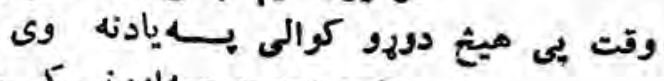

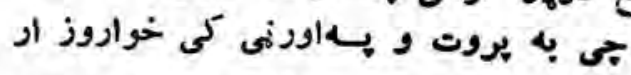
-12 - 


$$
\begin{aligned}
& \text { توان طاقت د مَّ شـل ور خخهـنهو } \\
& \text { به ماتنه بهيى موركاوه تيمار } \\
& \text { كه مور يلار يى وبنسو خارو و تهبولى } \\
& \text { نصيحت دمورو يلاروى وزته نارو نار }
\end{aligned}
$$

دغه راز د ناويى تربيى به بابيى بل غُاى داسى ويلى :

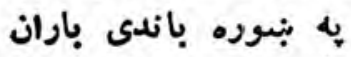

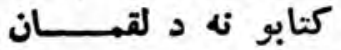

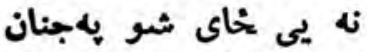

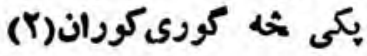

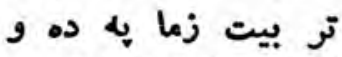

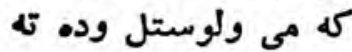

نه اثرور باندى وثلى وثر وده

آنينه كه ور ته كيبندى واند

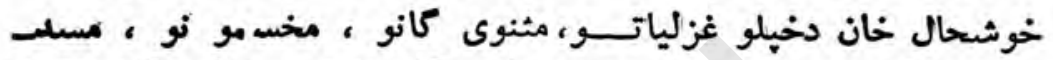

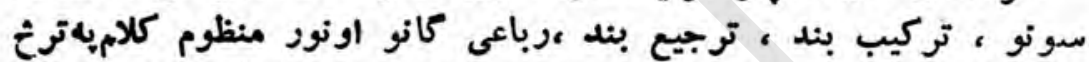

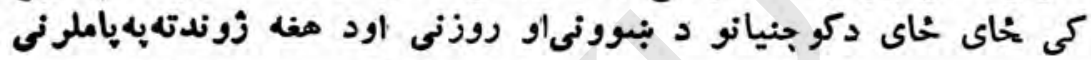

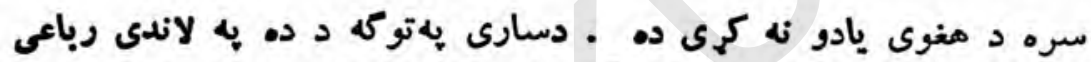

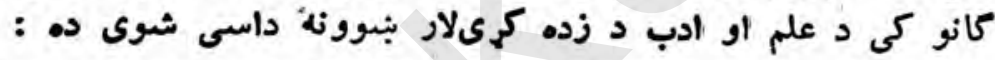

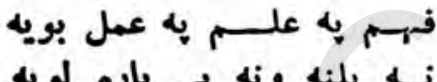

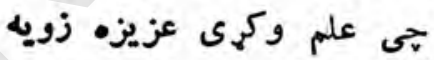

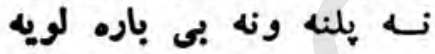
كمكه و نه بار داره ونهـ

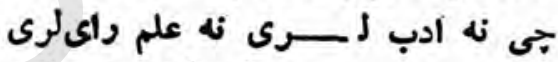

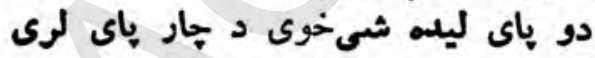

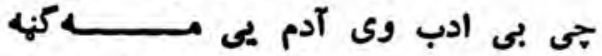

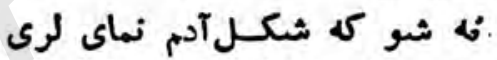

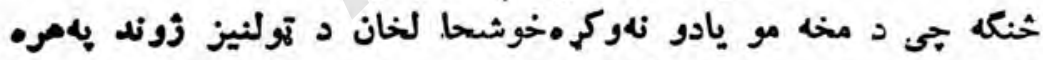

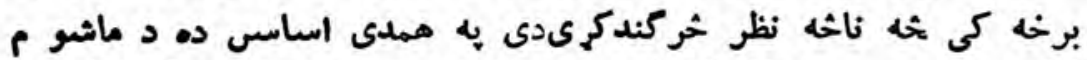

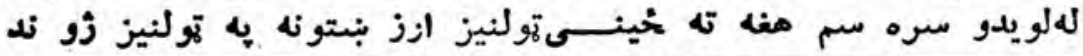

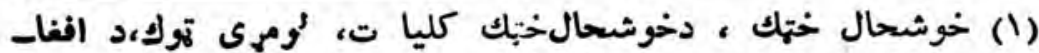

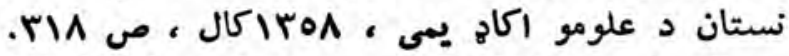

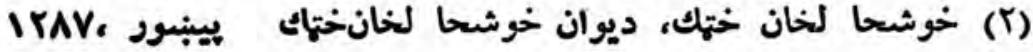




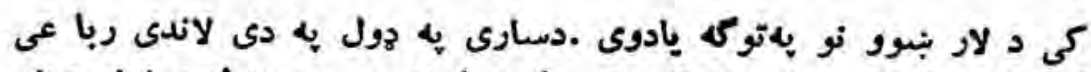

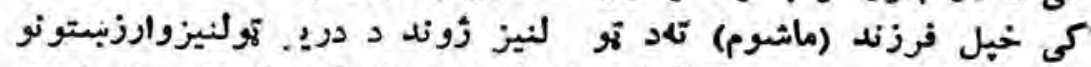

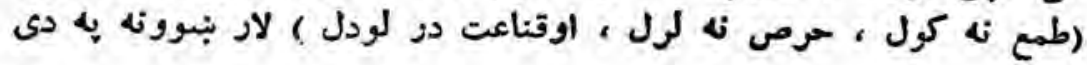

$$
\begin{aligned}
& \text { جول كوى . . }
\end{aligned}
$$

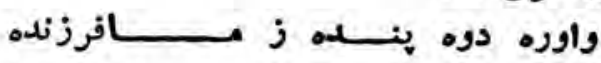

$$
\begin{aligned}
& \text { خى طمع حرصلرىخؤارى خركنده }
\end{aligned}
$$

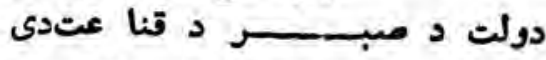

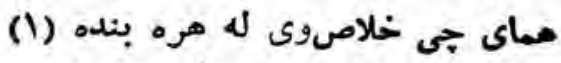

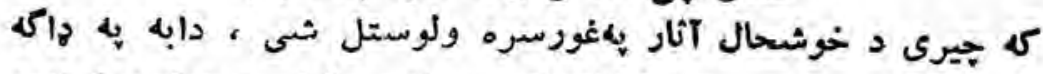

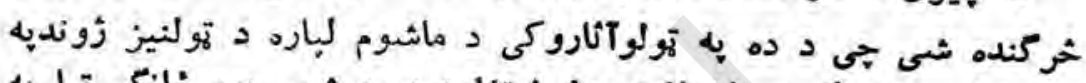

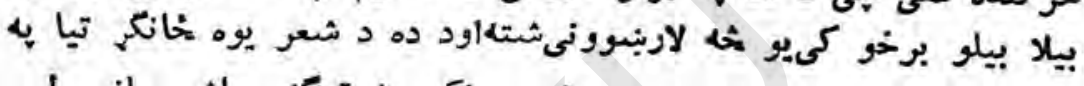

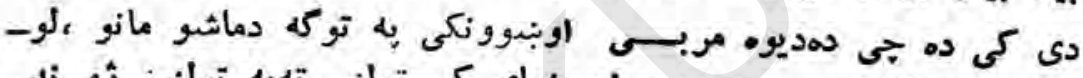

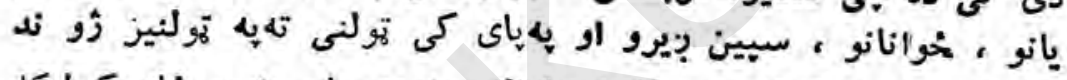

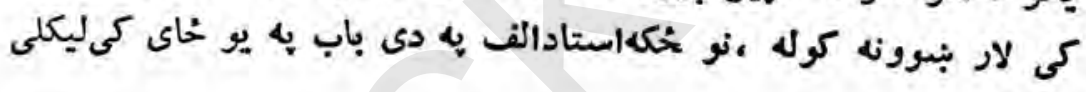

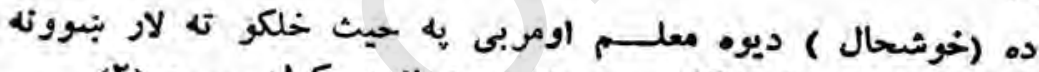

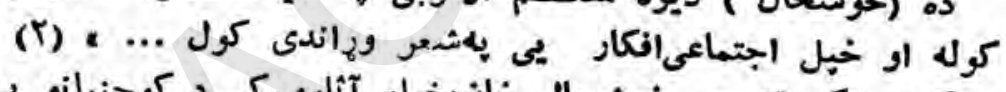

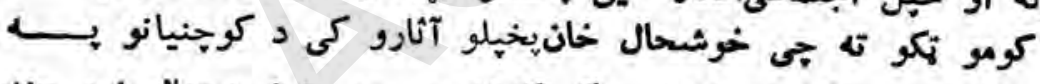

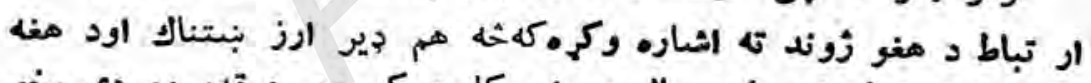

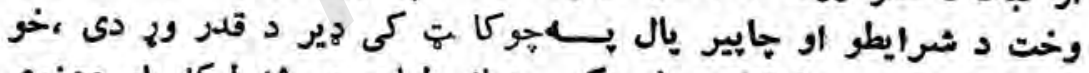

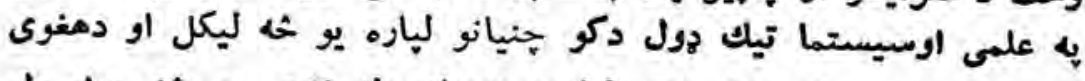

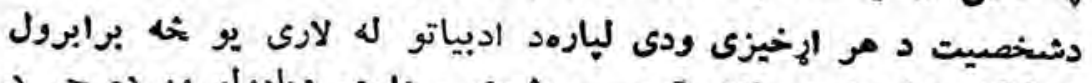

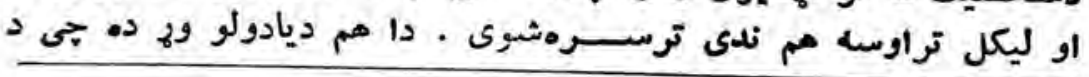

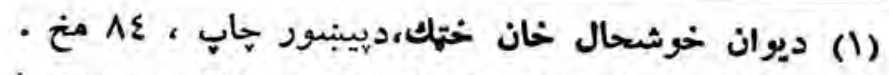

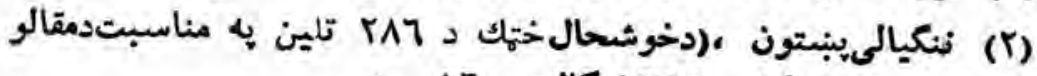

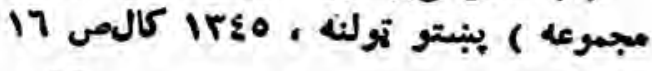
- 


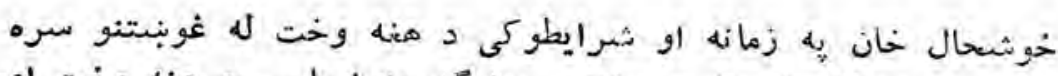

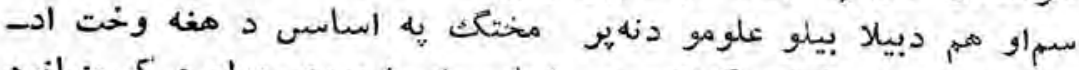

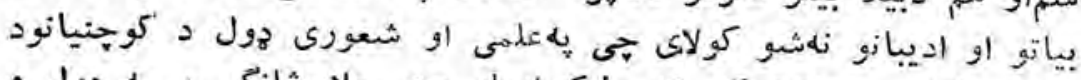

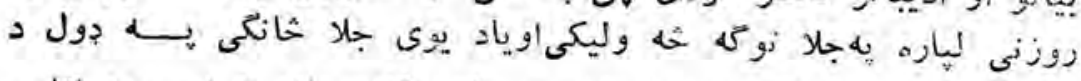

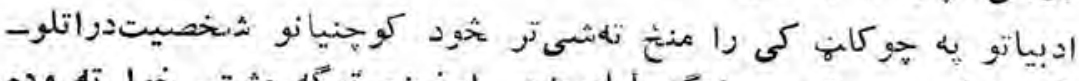

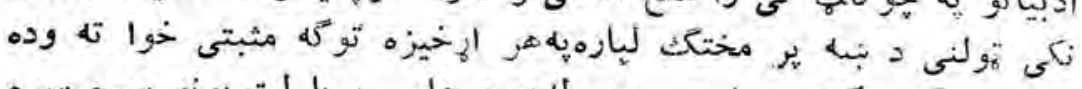

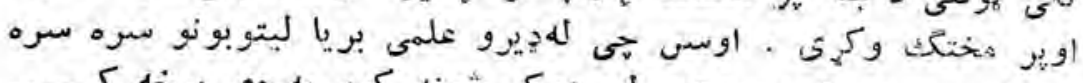

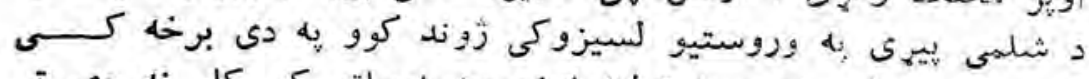

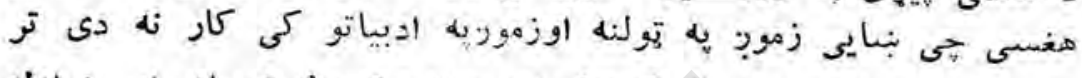

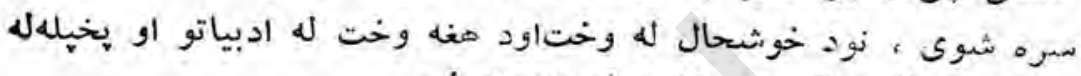

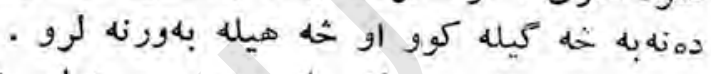

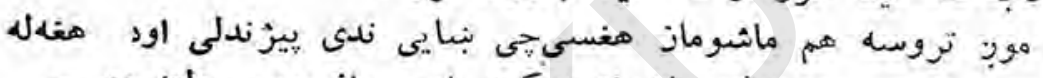

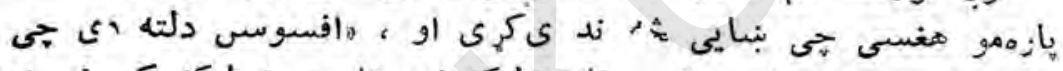

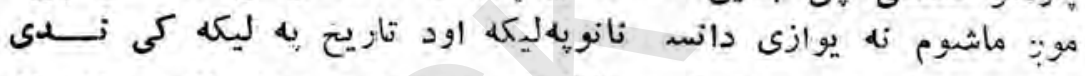

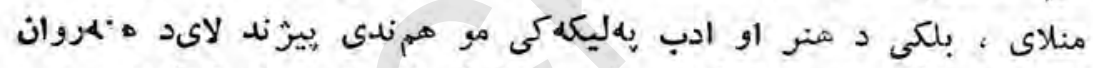

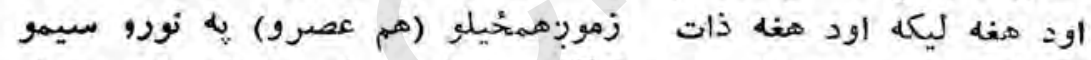

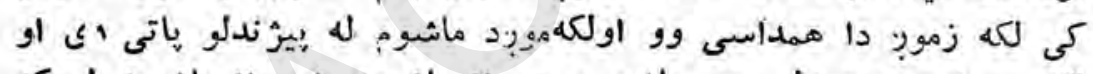

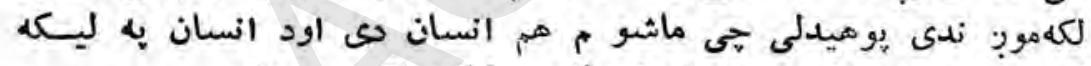

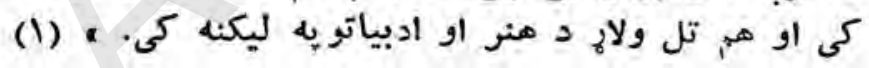

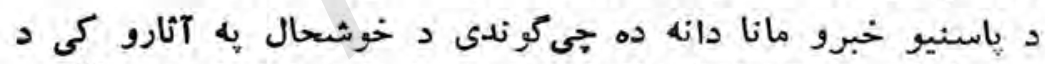

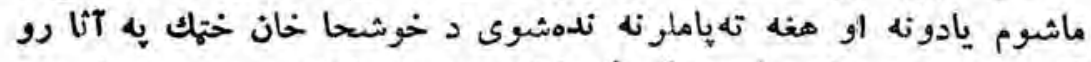

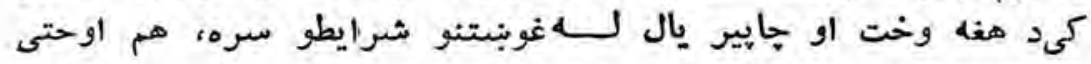

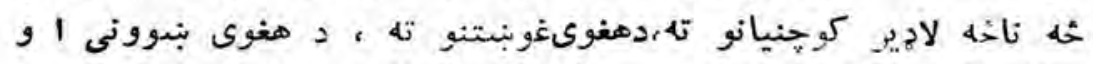

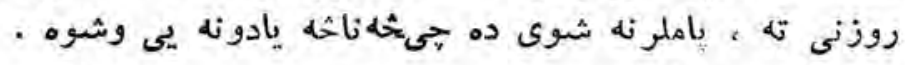

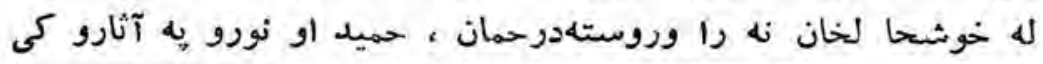

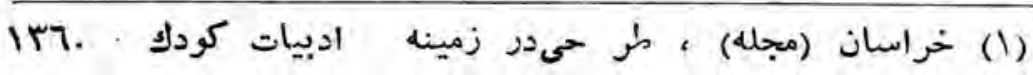
TV 


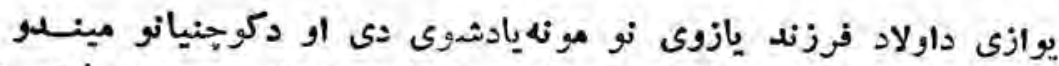

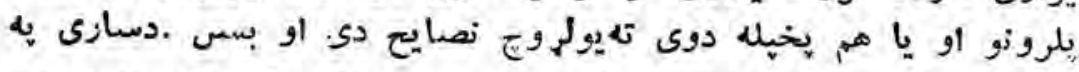

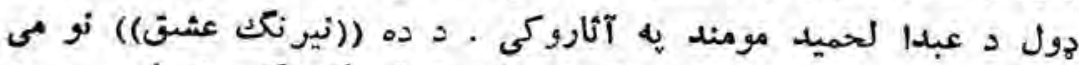

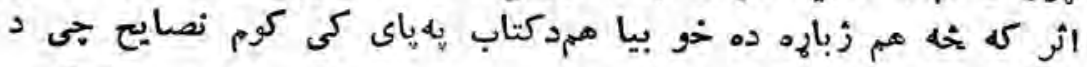

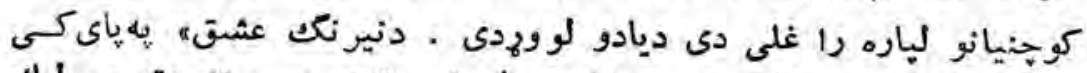

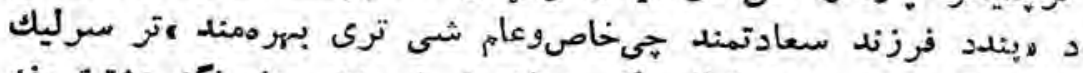

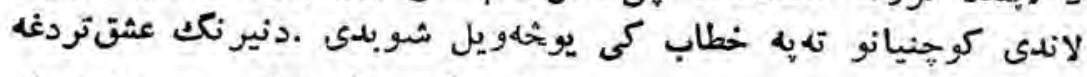

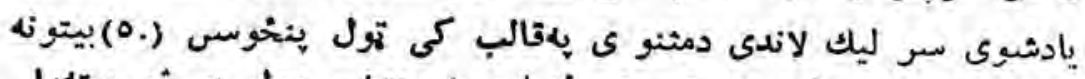

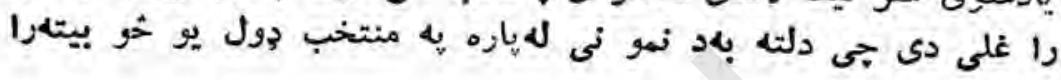

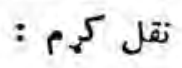

\section{خـو دى لاس وسى له هره كناهتبنته}

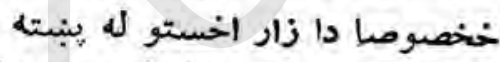

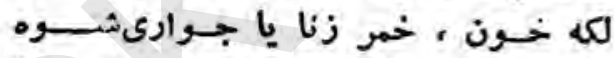

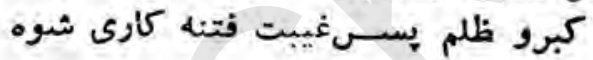

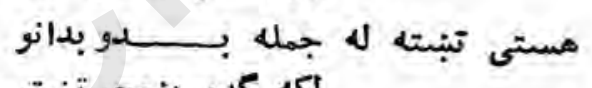

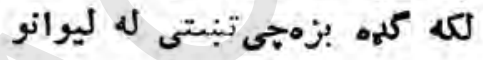

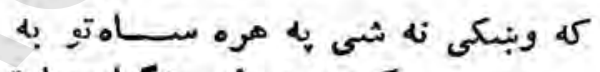

$$
\text { كره دور خي هره به كناهسبا توبه }
$$

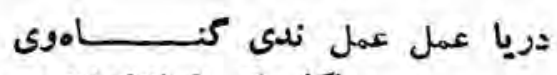

رياكار ثر خيله خدايهرو سياه وى

$$
\text { خواه نا خواه مه كوه زورزنهارزنهار }
$$
به دا يند كوه عمل زيليل ونهار ده وى كم علم معاشس زده كـيه لانه

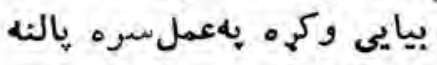

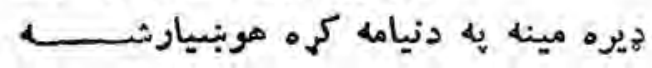

باخلاص له قناعتهره ينارث يار شه 


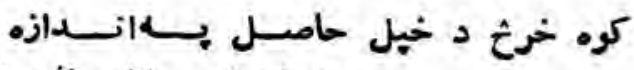

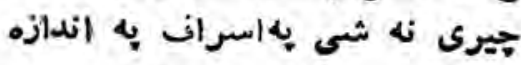

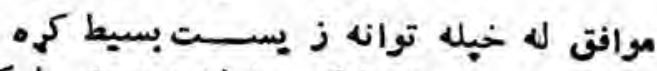
مه افراط كوه يكلختهمه ثفريط كمه

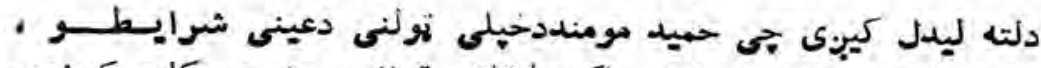

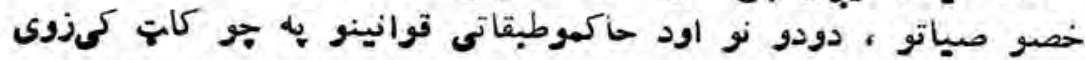

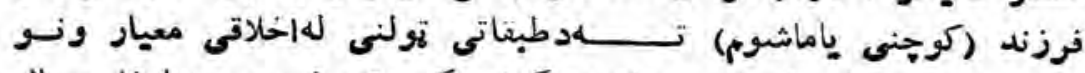

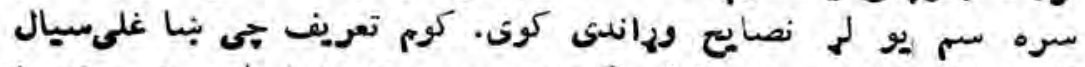

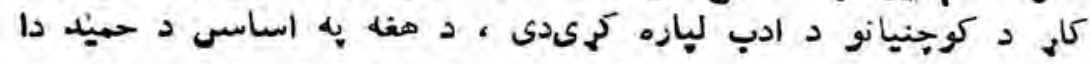

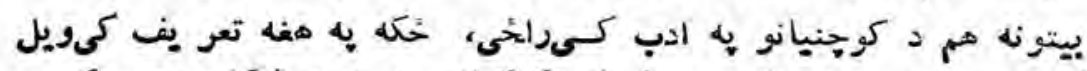

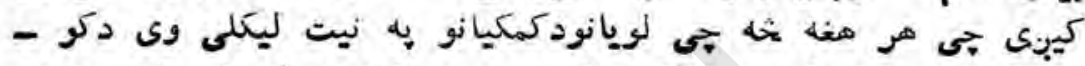

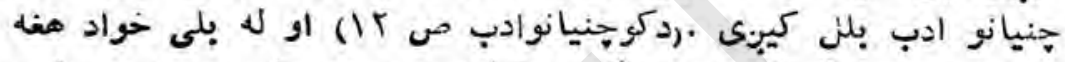

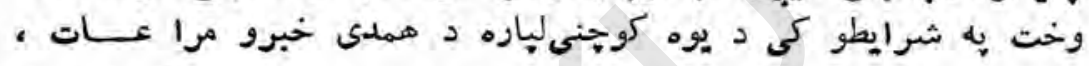

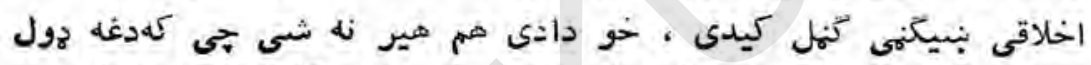

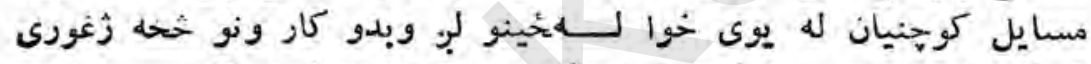

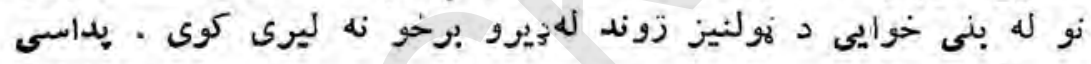

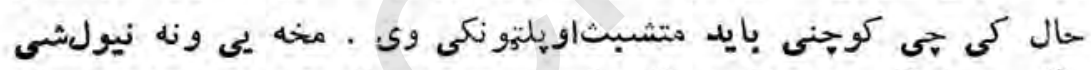

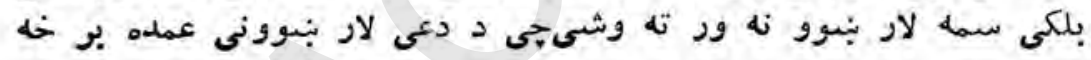

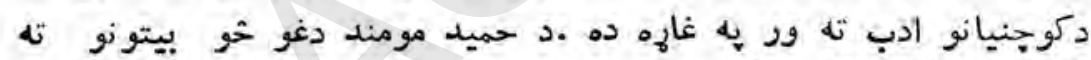

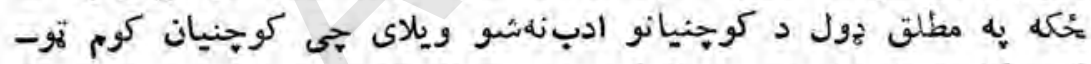

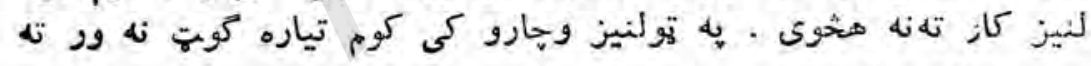

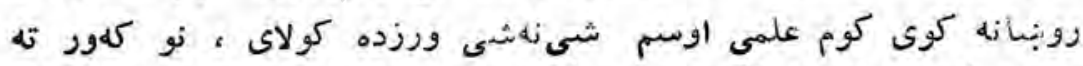

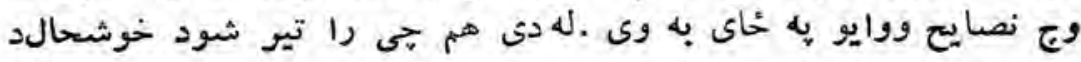

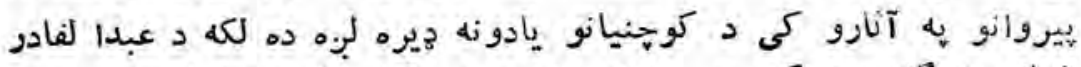

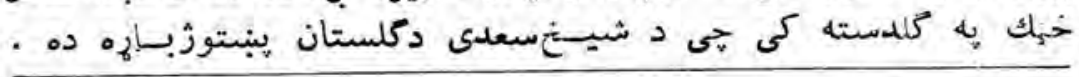

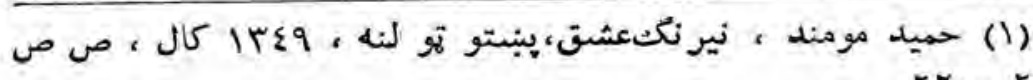

rr. rio 


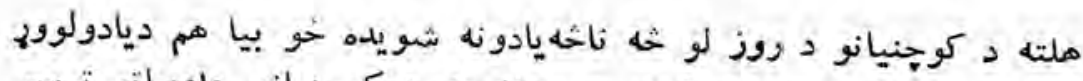

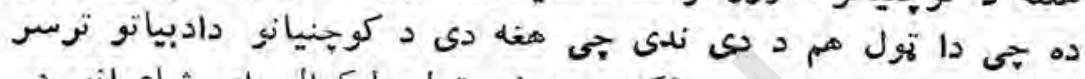

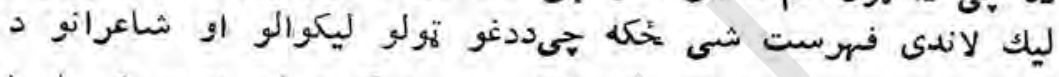

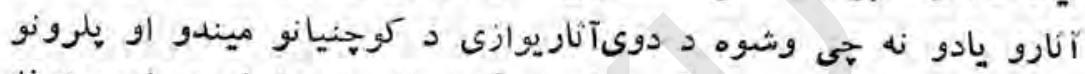

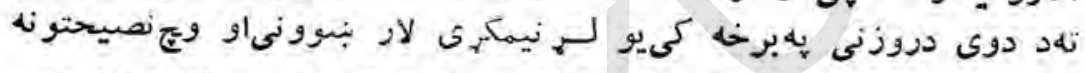

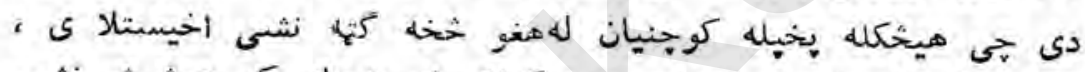

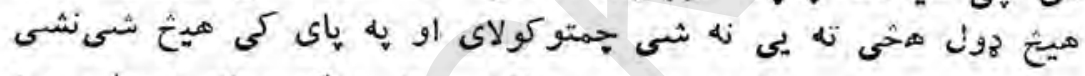

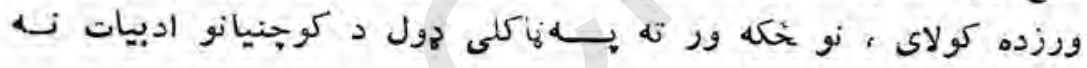

$$
\text { شو ويلاى . }
$$

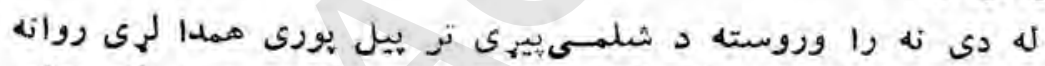

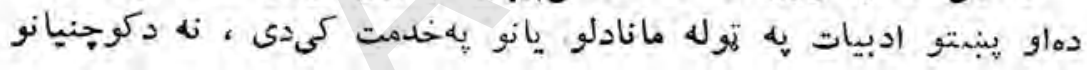

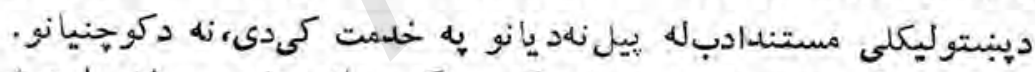

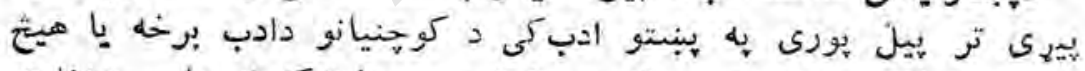

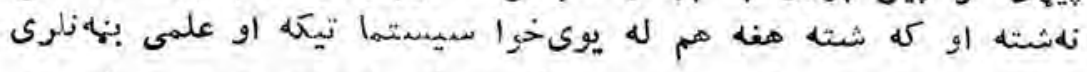

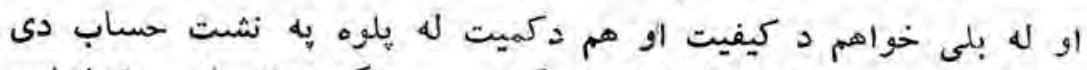

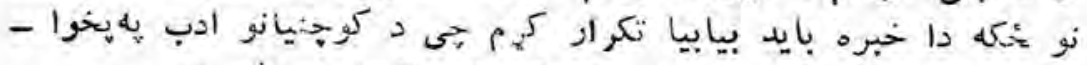

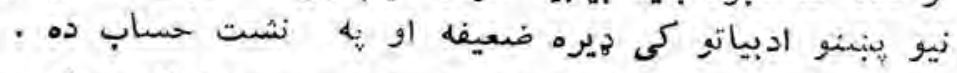

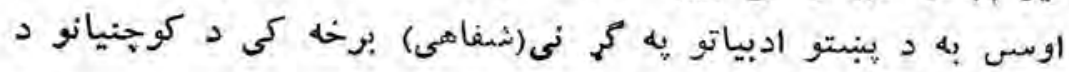
ادب يلتهنه وكيم م. 


\section{يهفلكلوركى دكو جهنيانو دادب برخه}

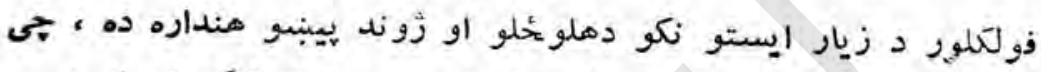

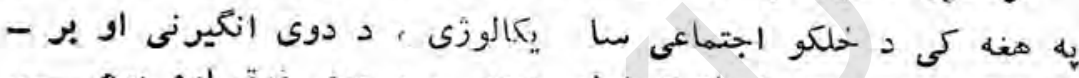

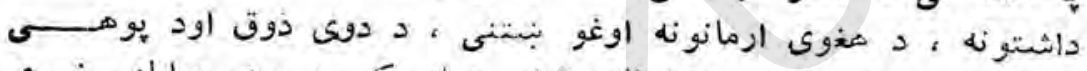

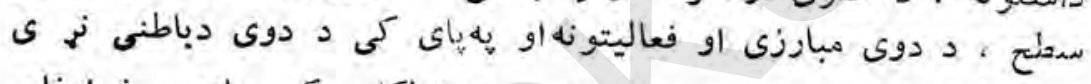

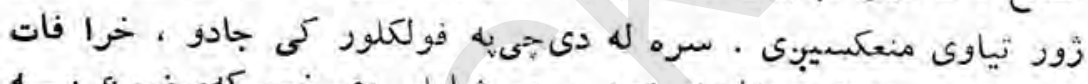

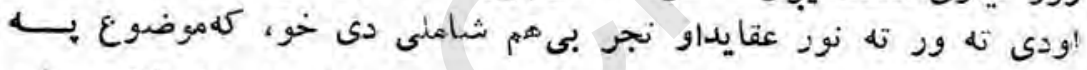

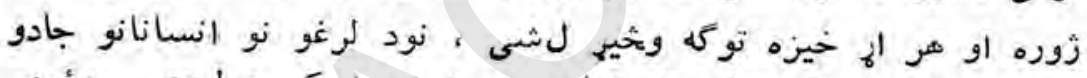

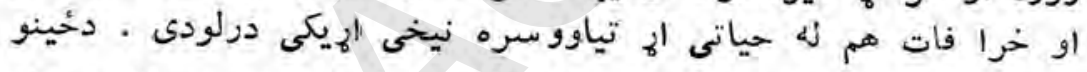

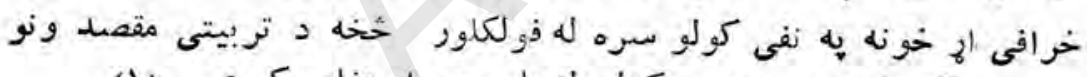

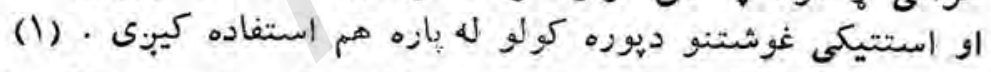

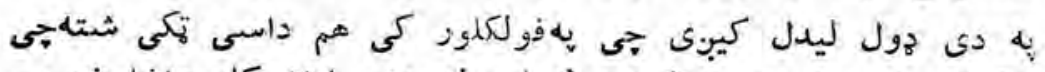

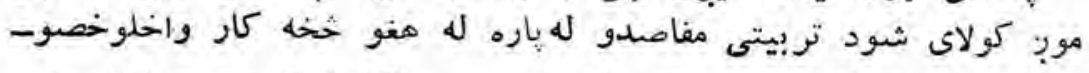

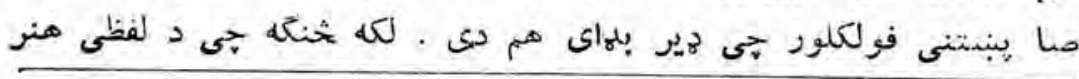

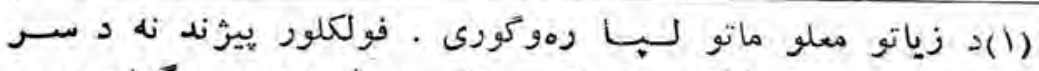

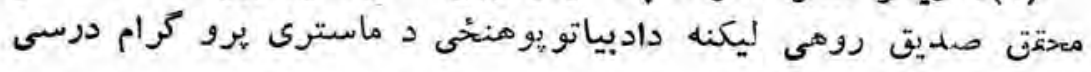
نوبت (قتمى) ص ص 
ييل به فولكلور كى نغبتى دى ،بهتيره د كوجنيانو بنوو نه او دوزنه

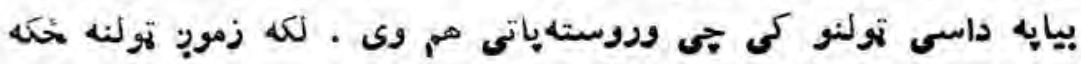

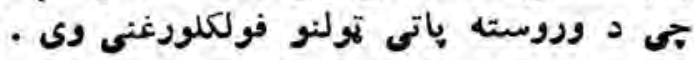

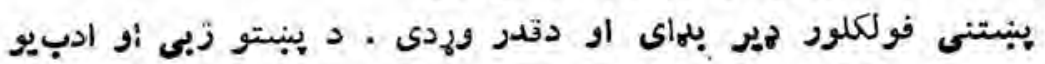

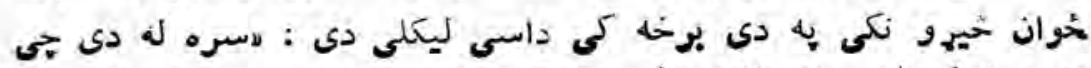

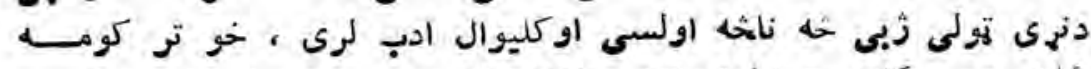

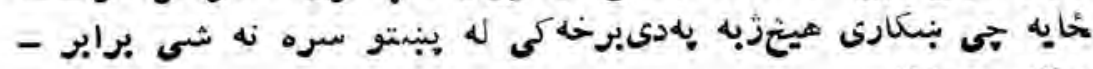

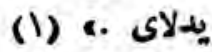

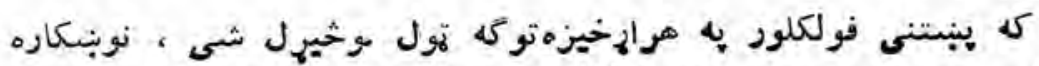

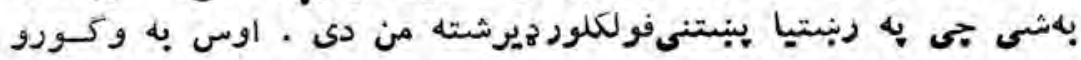

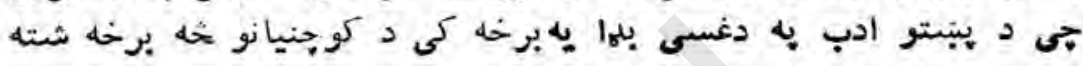

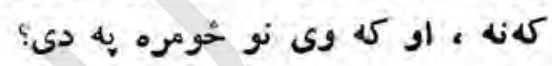

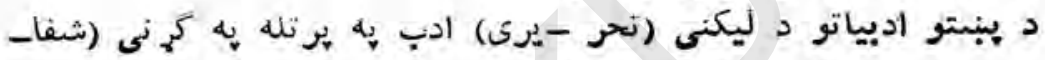

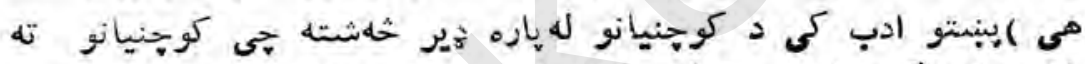

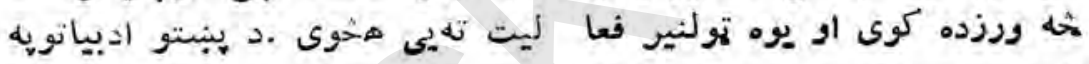

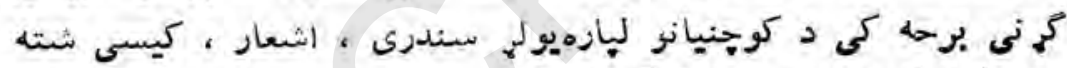

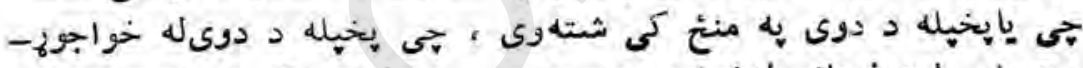

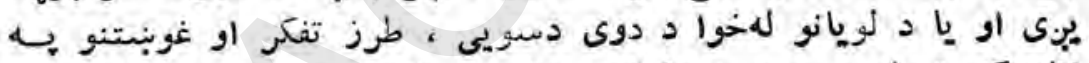

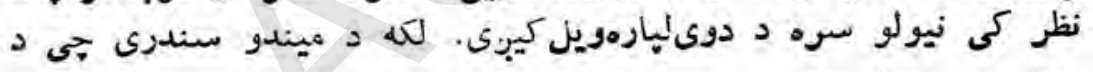

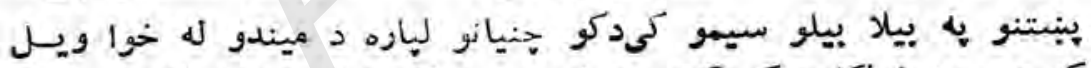

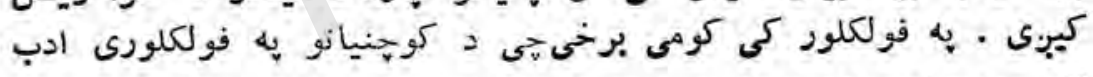

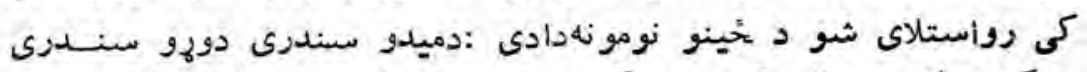

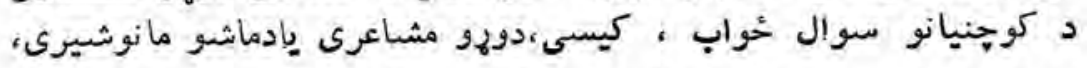

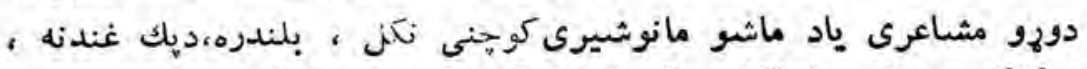

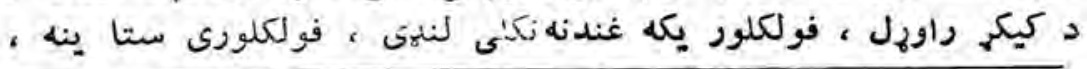

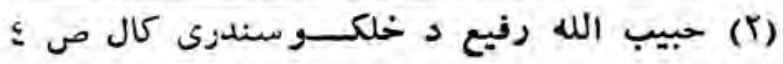
$-r r_{-}$ 


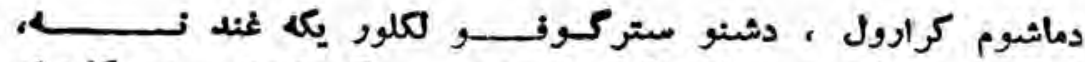

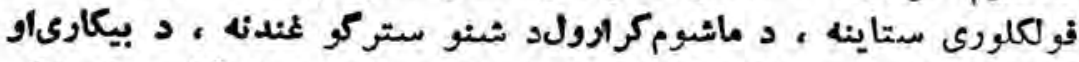

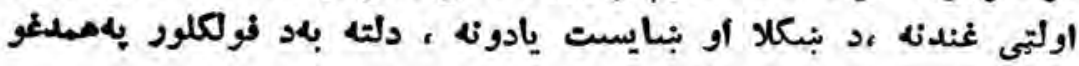

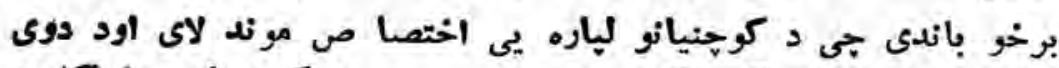

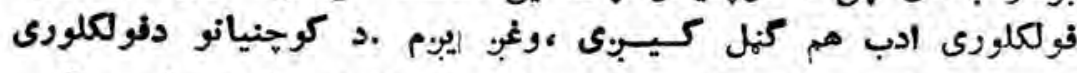

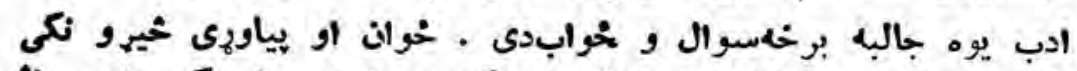

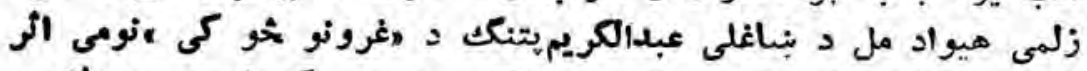

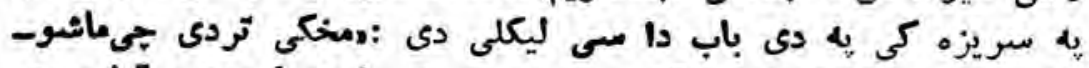

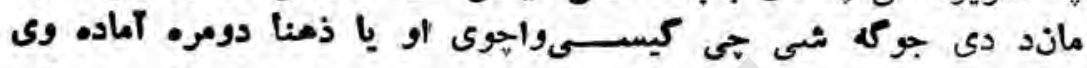

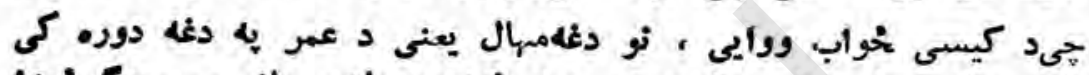

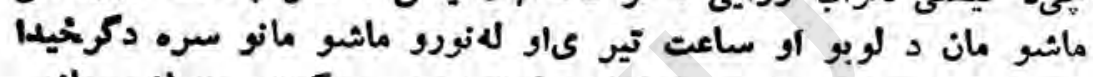

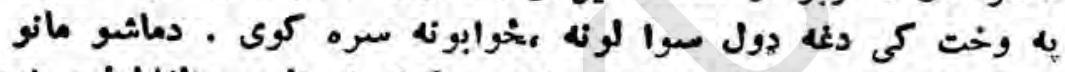

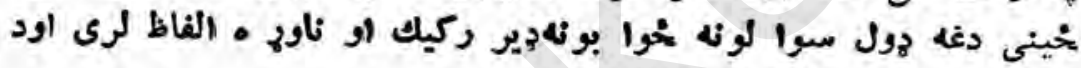

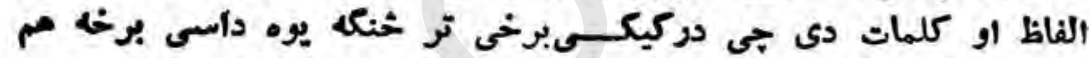

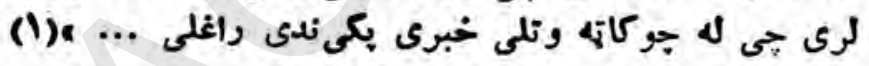

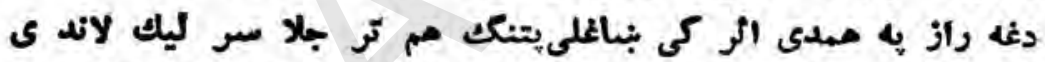

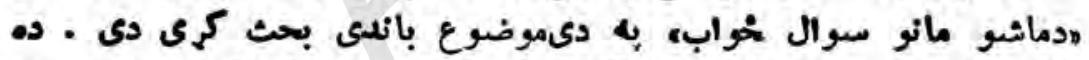

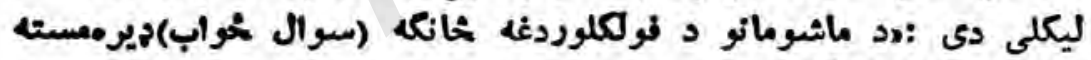
او خندونكى خانكه ده ...

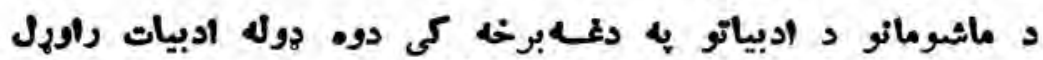

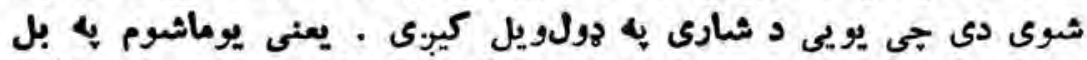

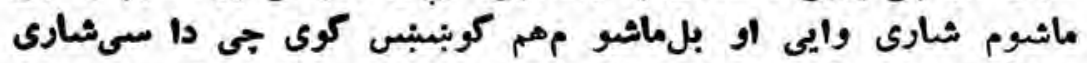

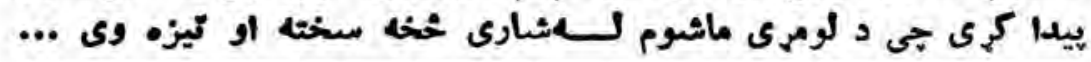

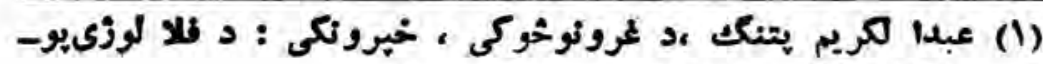

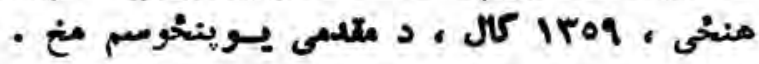
-rr- 


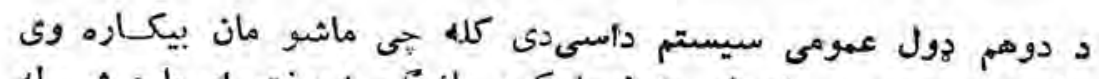

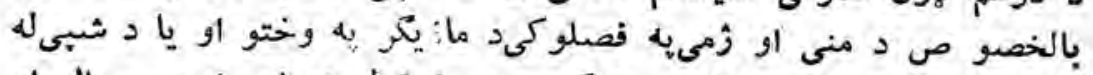

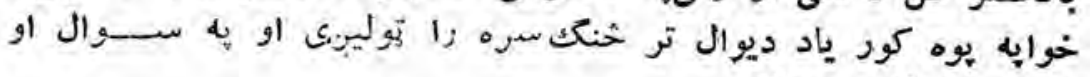

خواب بيل كوى .ه (1)

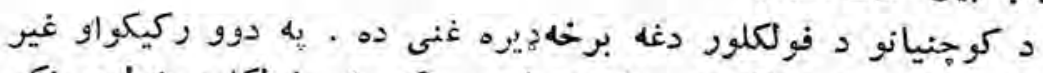

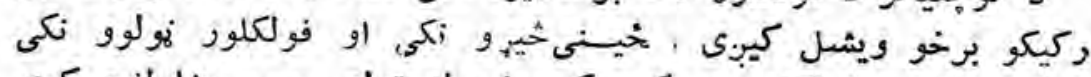

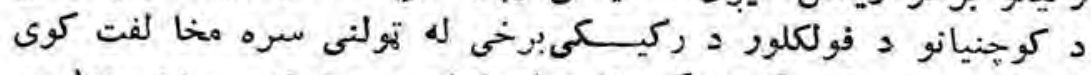

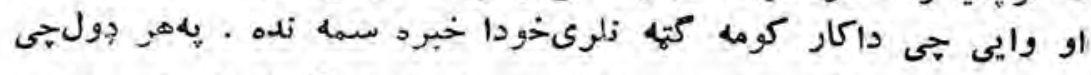

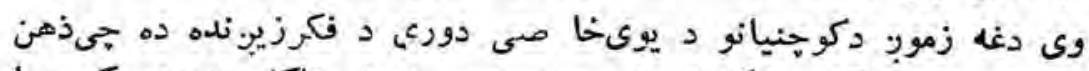

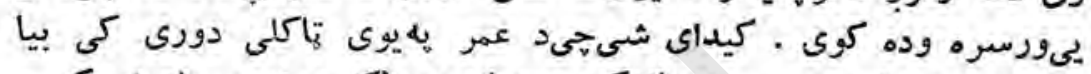

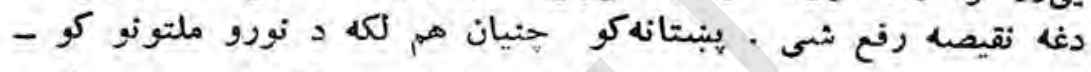

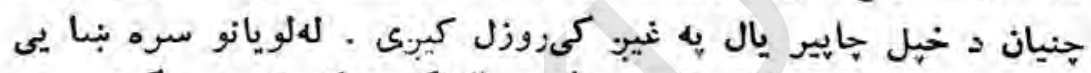

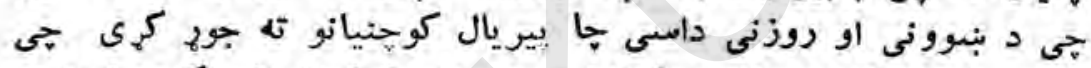

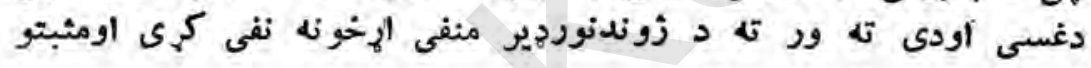

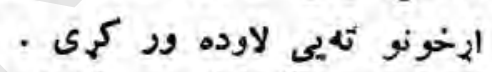

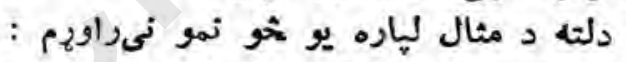

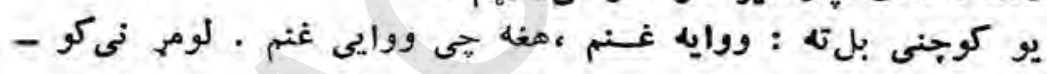

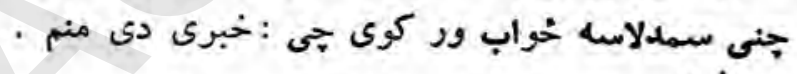
:

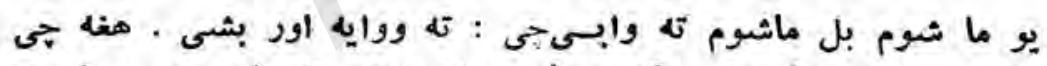

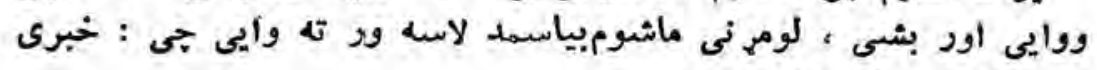

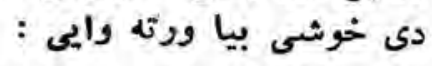

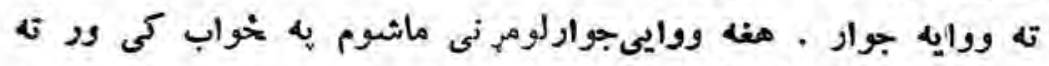

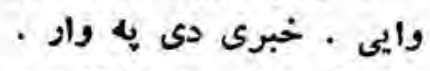

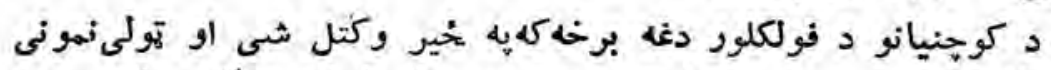

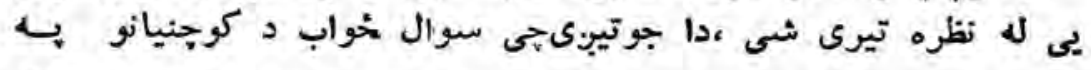




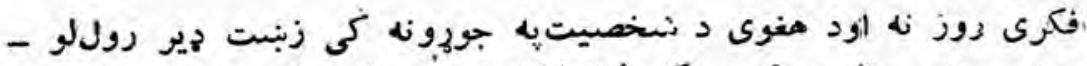

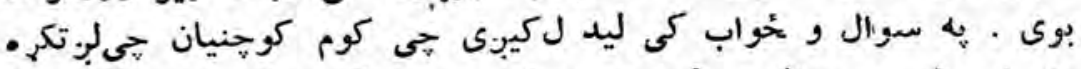

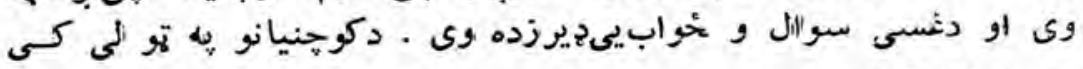

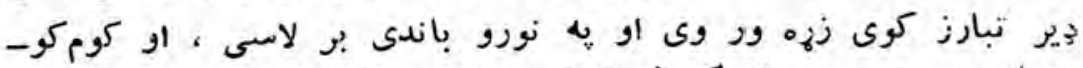

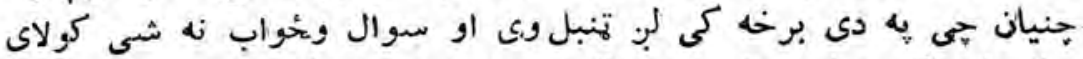

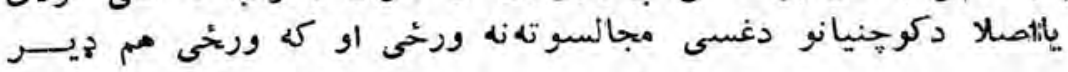

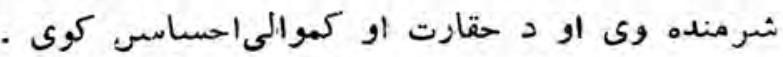

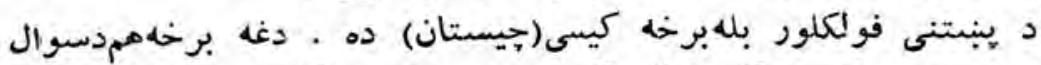

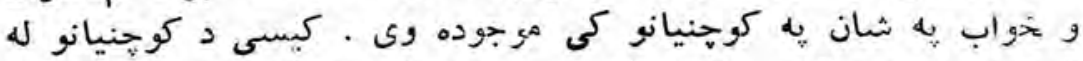

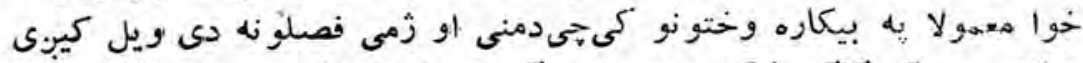

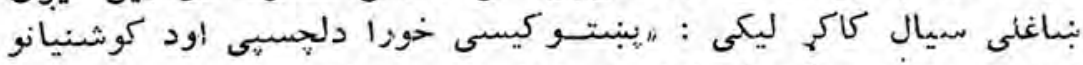

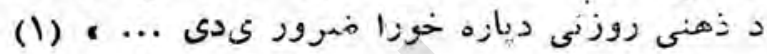

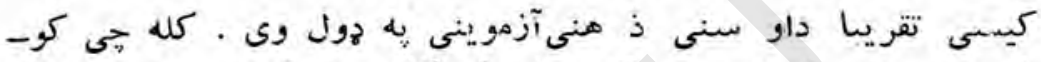

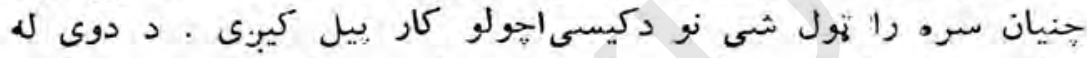

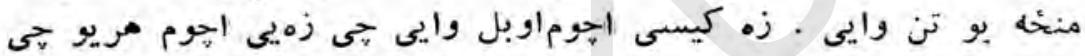

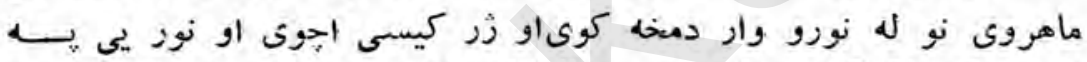

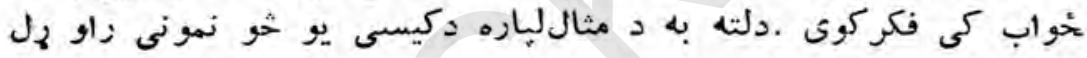

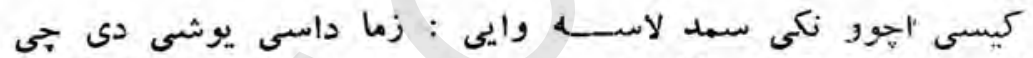

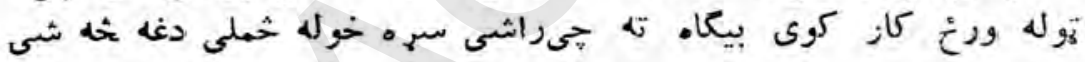

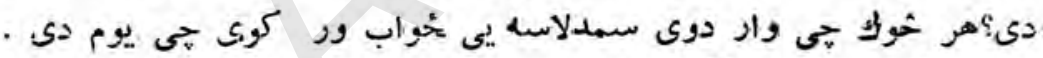

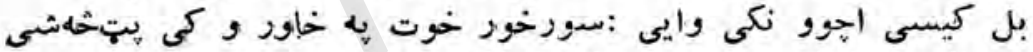

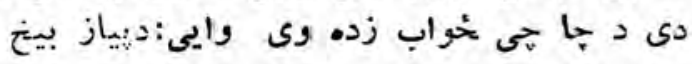

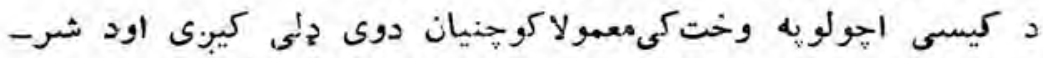

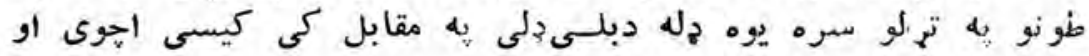

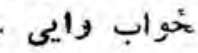

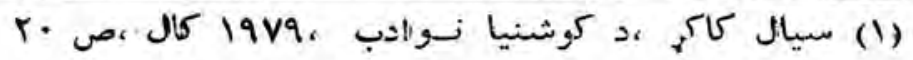

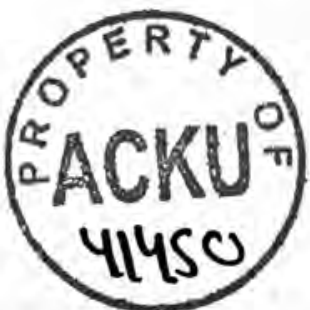
-ro_ 


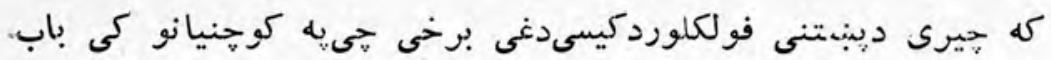

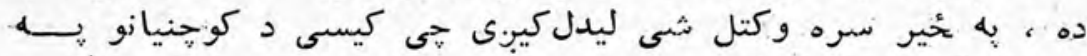

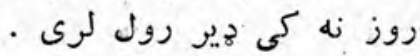

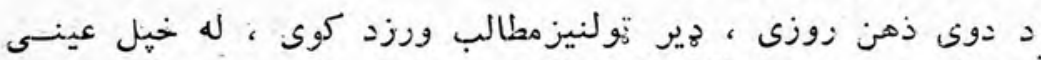

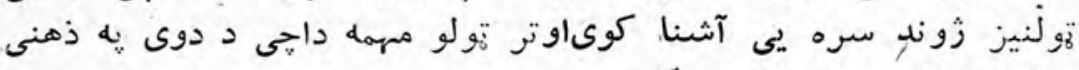

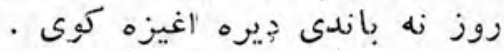

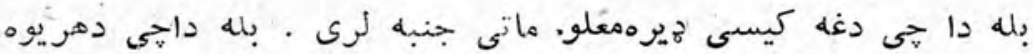

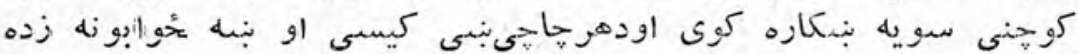

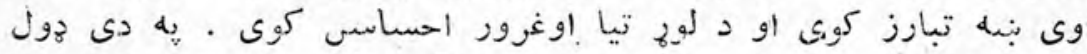

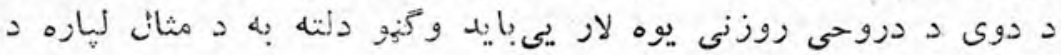

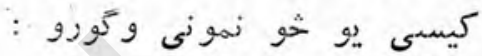

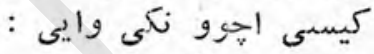

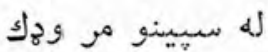

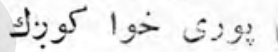

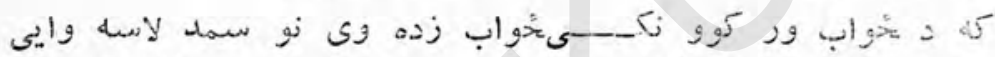

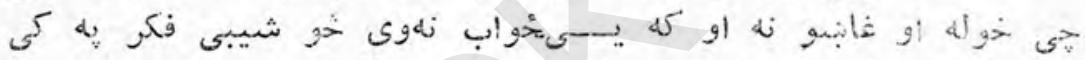

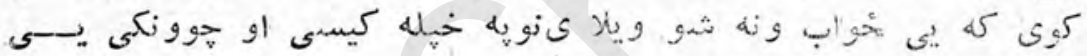

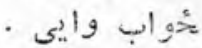

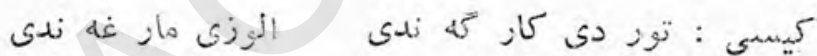

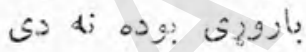

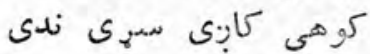

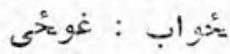

سبل سره ميندى دى

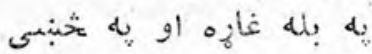

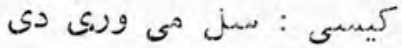

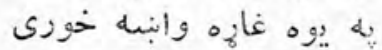

•

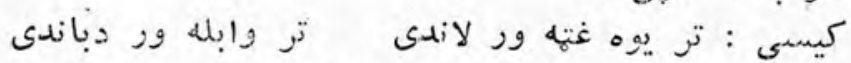
دياتو كتو ني ون باندى

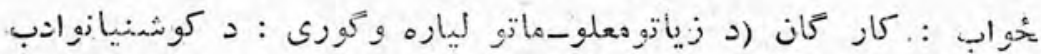
(ro - r) $-r 7$ 


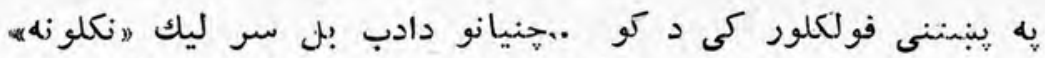

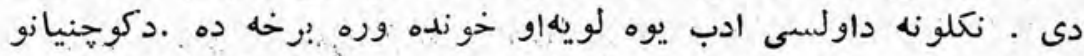

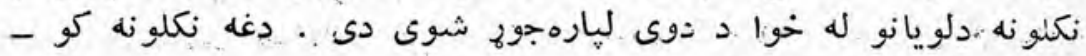

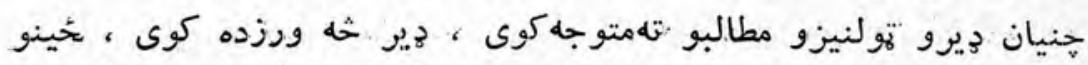

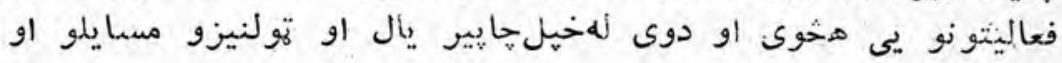

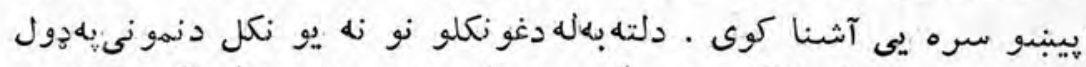

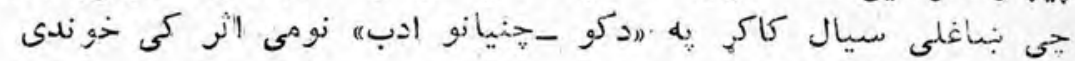

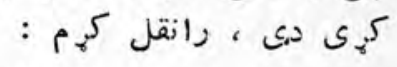
مئرى او :

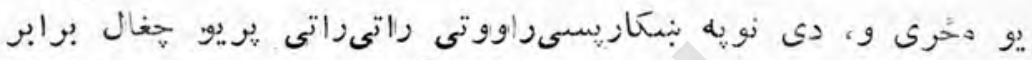

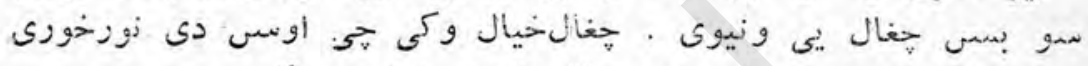

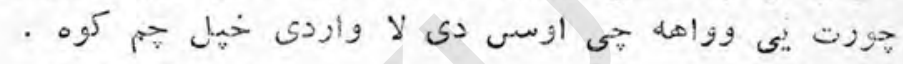

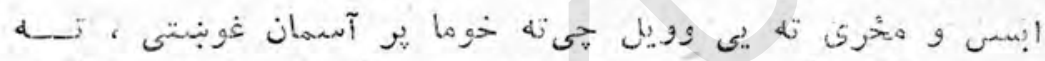

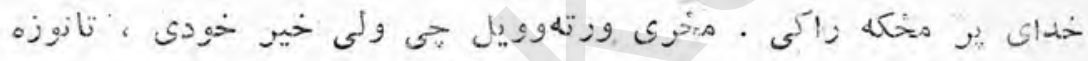

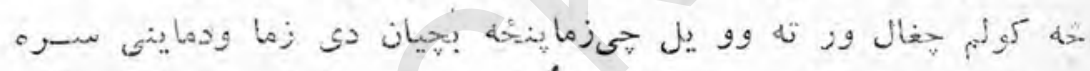

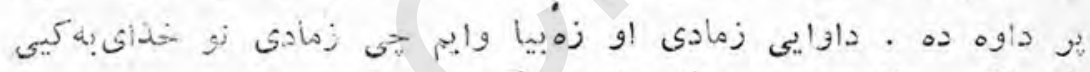

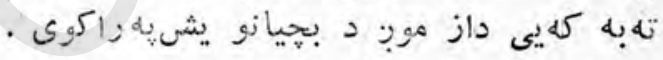

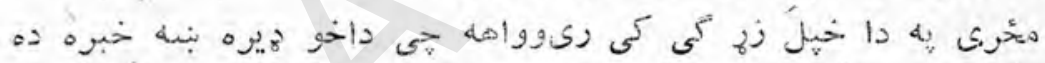

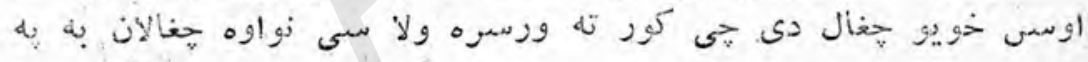

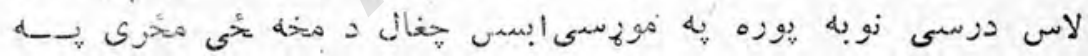

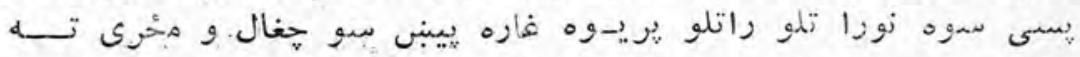

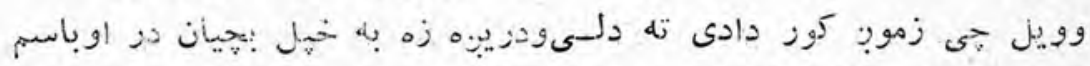

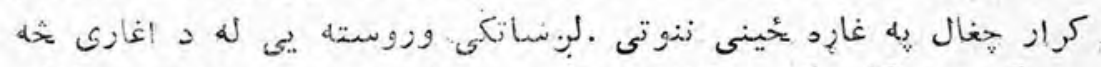

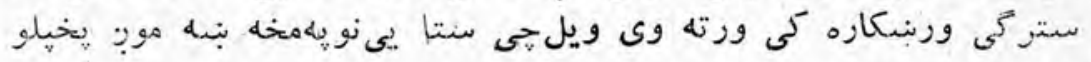

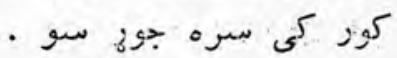

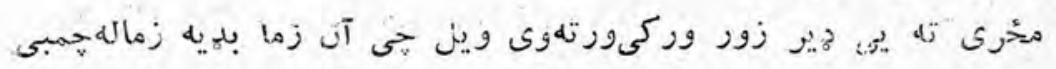
- 


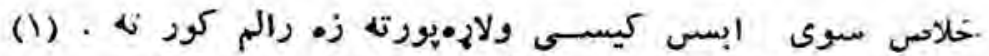

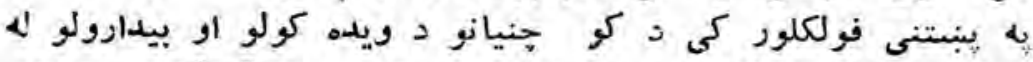

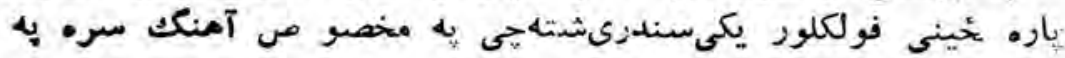

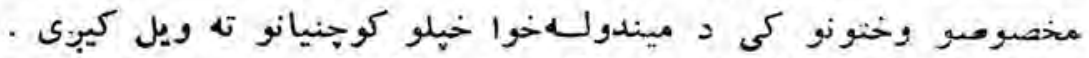

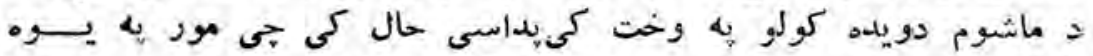

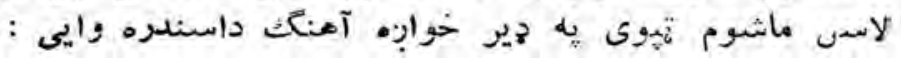

$$
\begin{aligned}
& \text { سرد شازلمو زو يـ امبه } \\
& \text { اللو للو زويه } \\
& \text { بيشومه را ئه دغرو } \\
& \text { اللو - للو - نيشو لهو }
\end{aligned}
$$

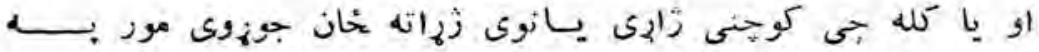

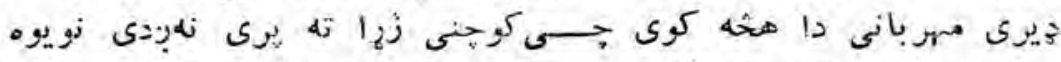

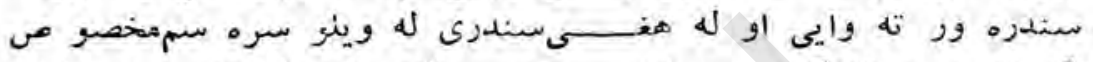

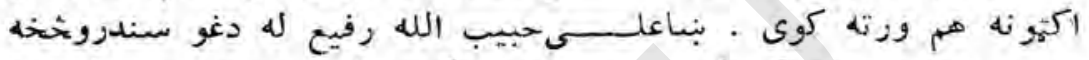

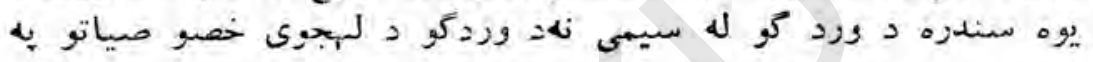

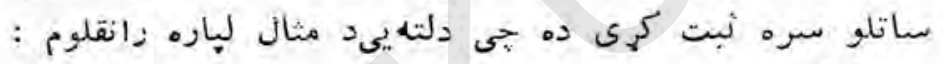
جاوينى

$$
\begin{aligned}
& \text { بإلانكى جان جان جاويلى }
\end{aligned}
$$

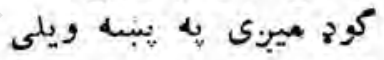

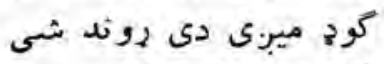

$$
\begin{aligned}
& \text { نن ينى بيه ويلى }
\end{aligned}
$$

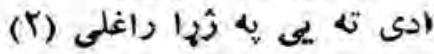

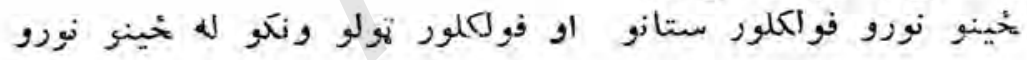

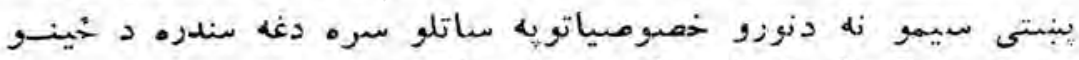

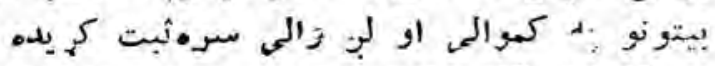

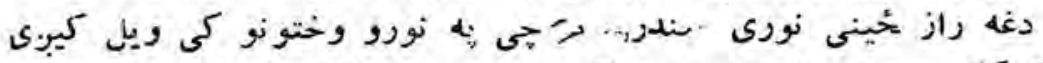

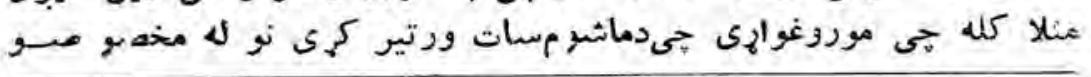

(1) $-\mathbf{r A}_{-}$ 


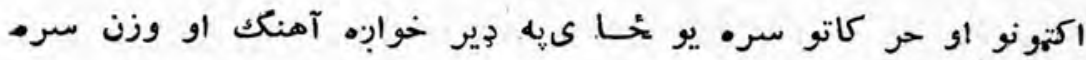
دغه سندزه ور تو ته وايى :

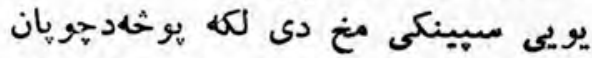

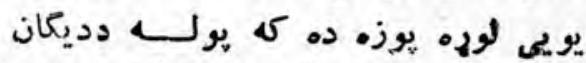

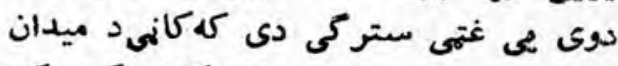

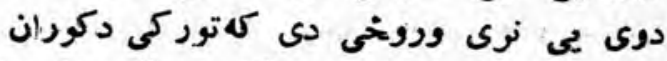

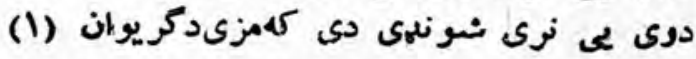

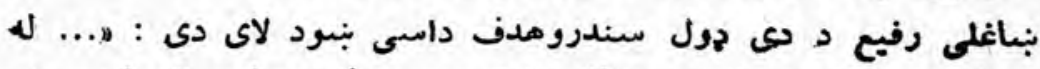

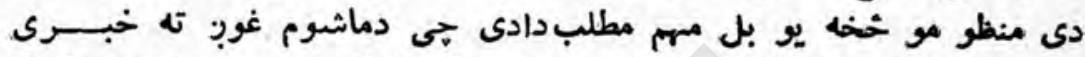

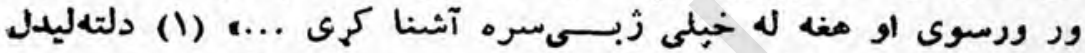

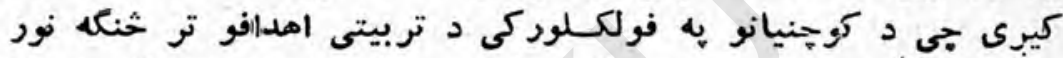

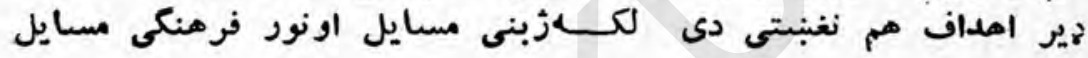

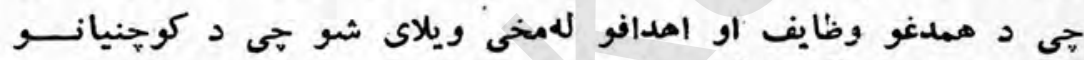

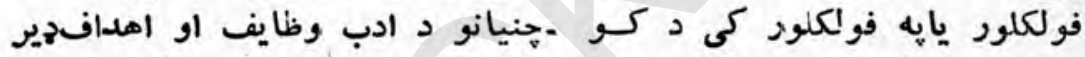

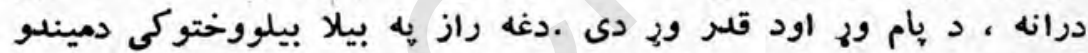

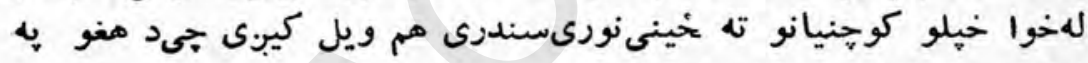

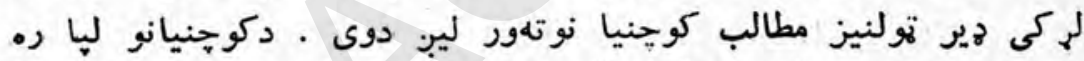

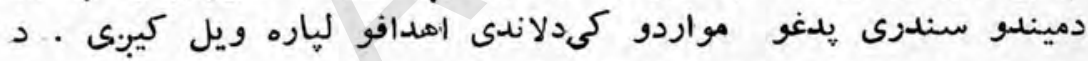

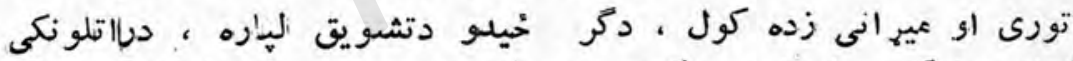

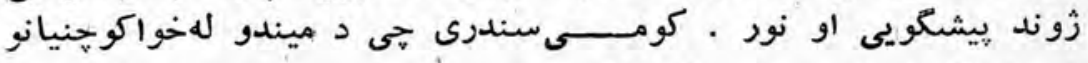

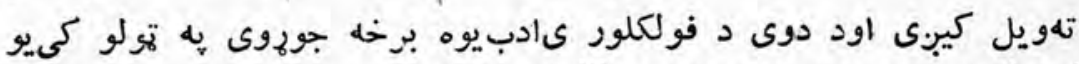

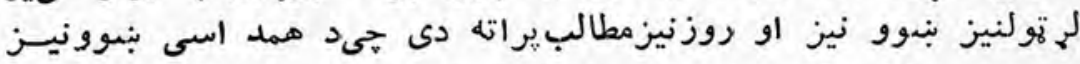

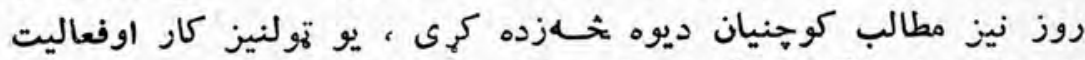

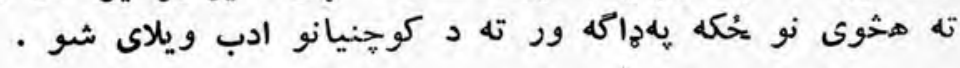

¿9 (1) 


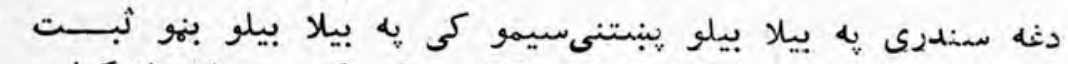

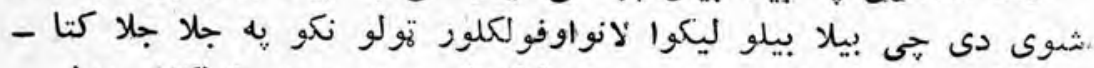

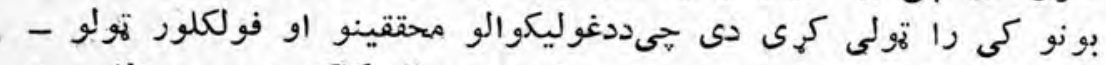

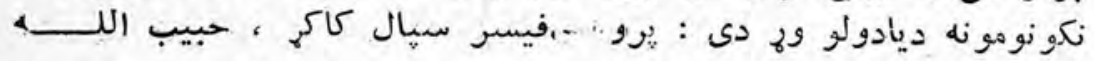

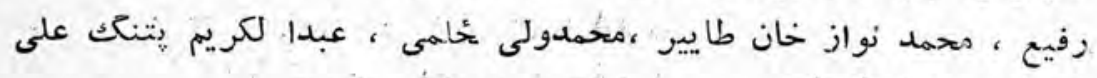

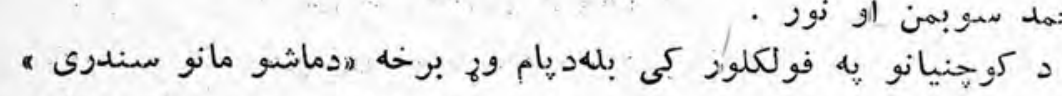

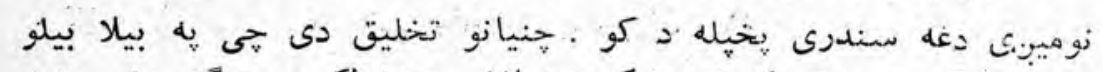

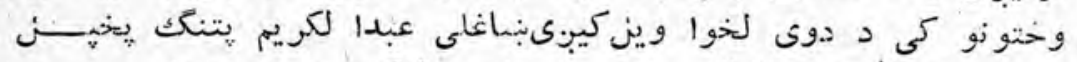

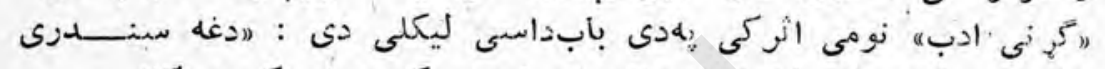

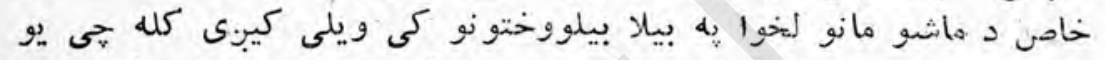

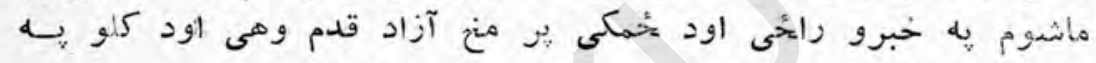

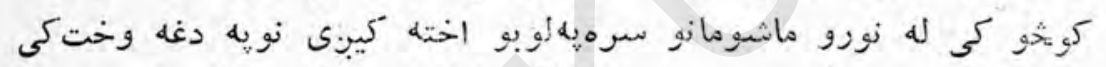

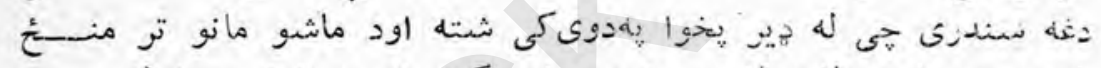

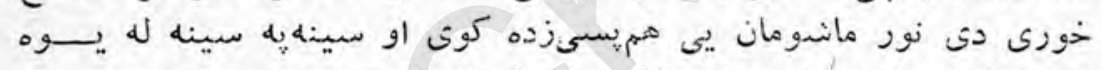

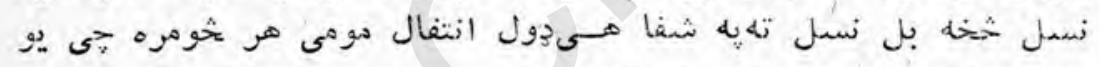

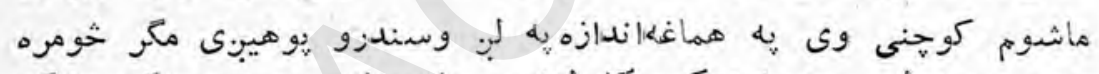

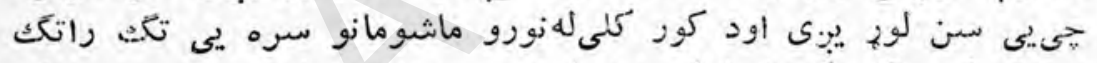

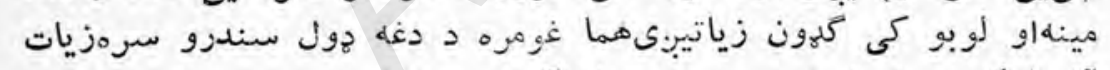

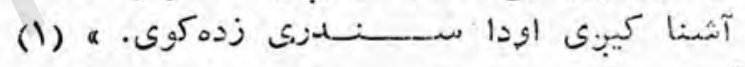

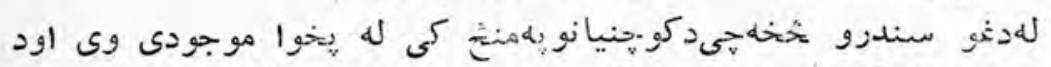

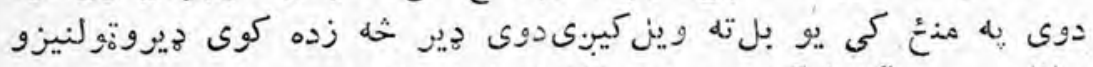

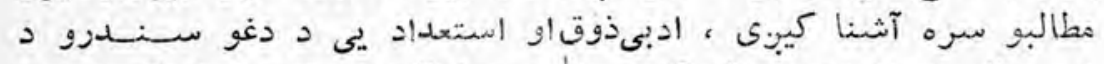

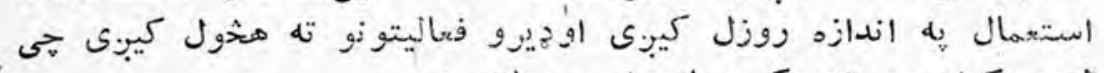

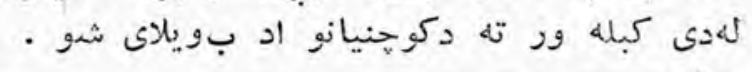

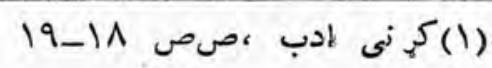




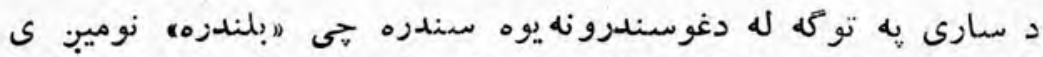

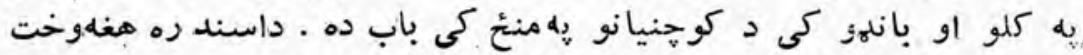

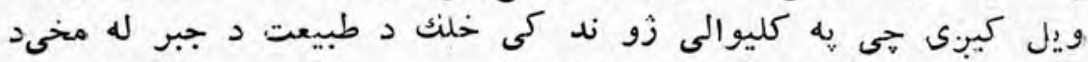

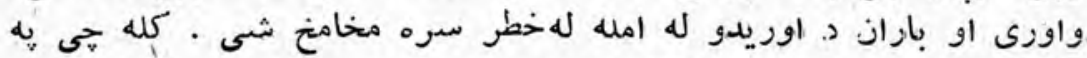

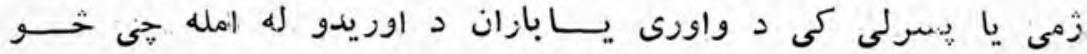

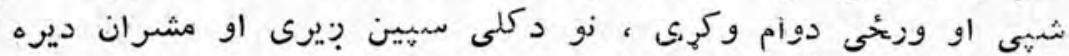

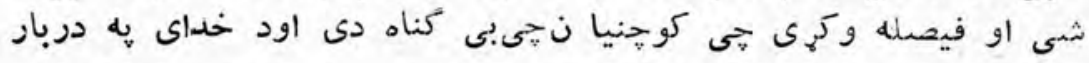

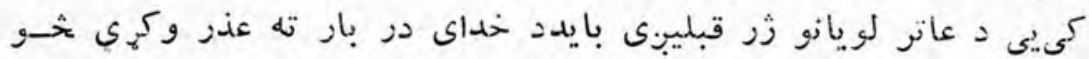

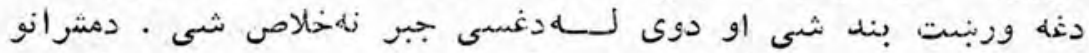

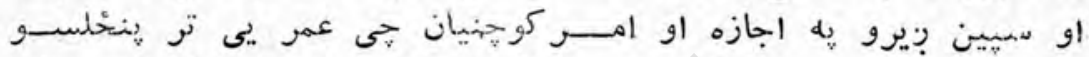

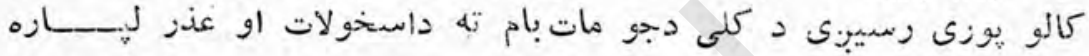

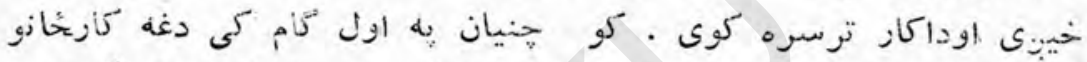

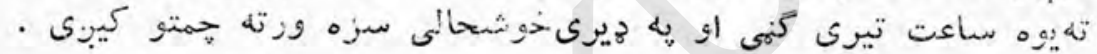

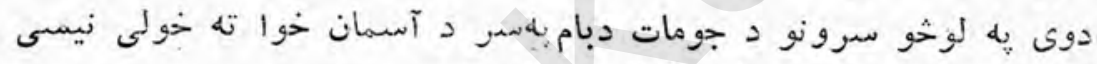

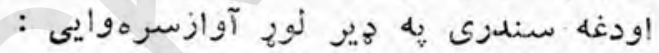

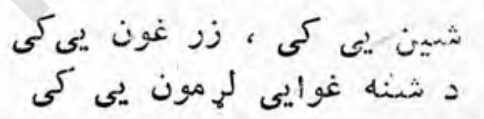

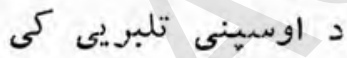

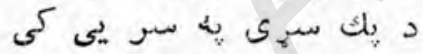

$$
\begin{aligned}
& \text { زموبز جونه هيه هينهى كى كى }
\end{aligned}
$$

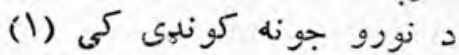

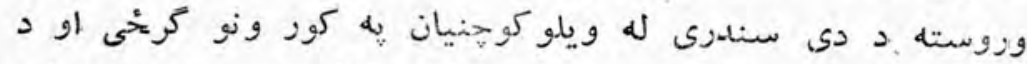

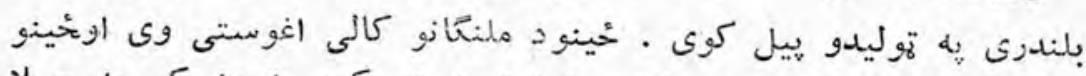

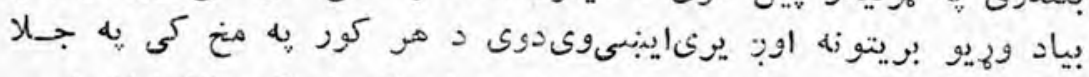

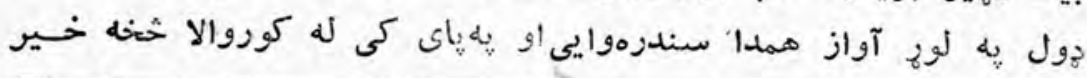

ז ص 


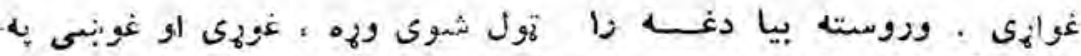

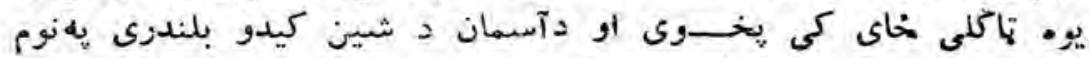

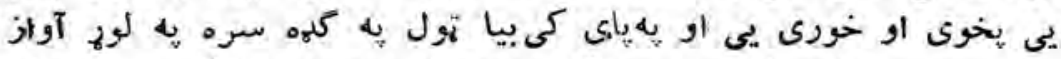

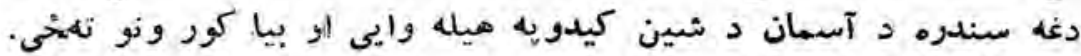

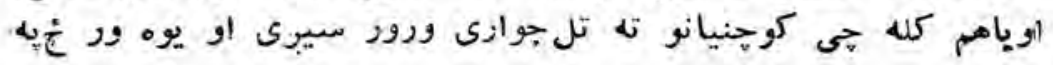

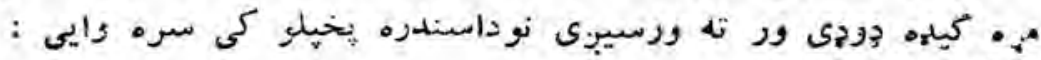

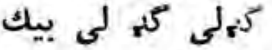

$$
\begin{aligned}
& \text { نغن نغن بيك }
\end{aligned}
$$

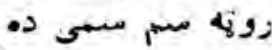

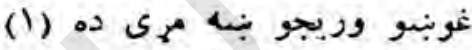

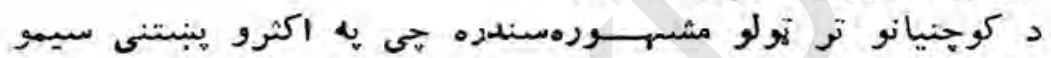

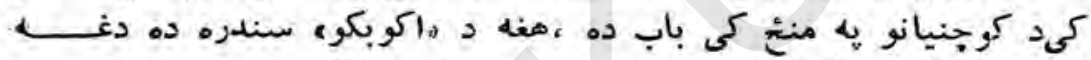

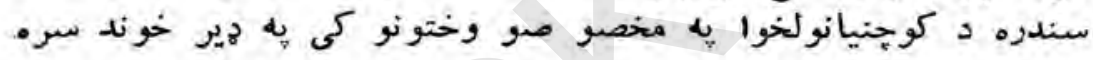

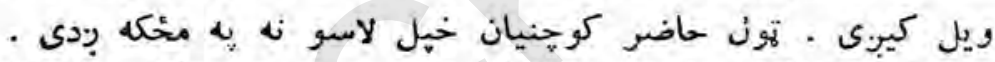

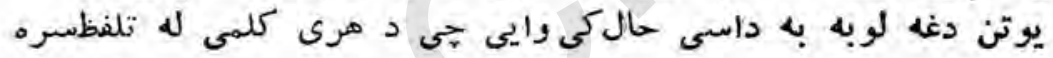

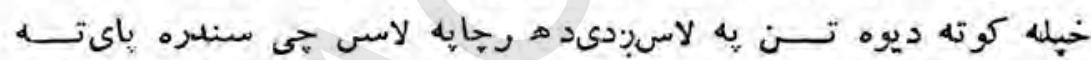

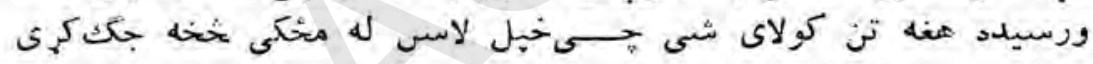

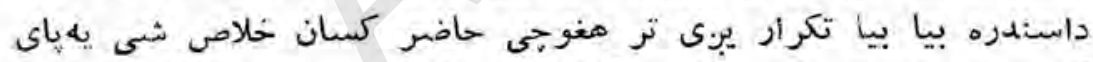

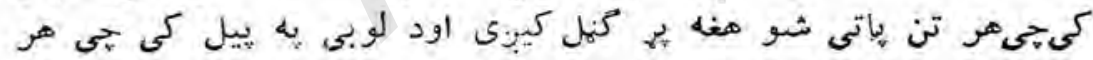

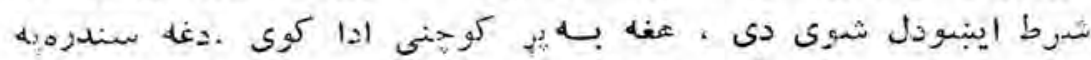

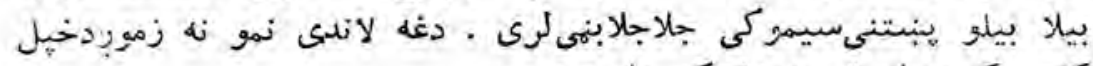

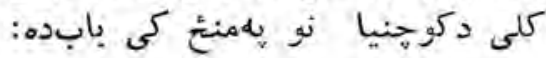

$$
\begin{aligned}
& \text { اكو - بكو } \\
& \text { د نبالكو } \\
& \text { سر سيند كو نوالو } \\
& \text { غوامى لإهـ يه تريكل كو يكو }
\end{aligned}
$$

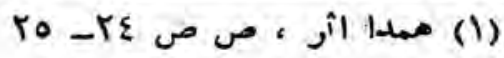




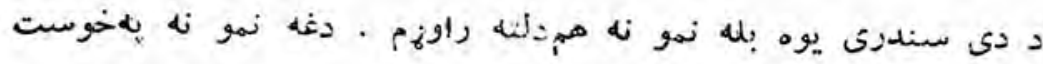

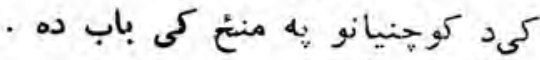

$$
\begin{aligned}
& \text { اكو - بكو } \\
& \text { د نبالكو } \\
& \text { سييه لإهد هيه تبى }
\end{aligned}
$$

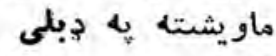

$$
\begin{aligned}
& \text { نه ين سرو نه نه لمكى }
\end{aligned}
$$

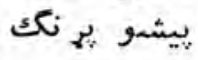

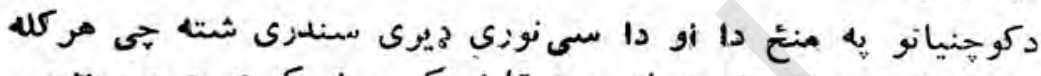

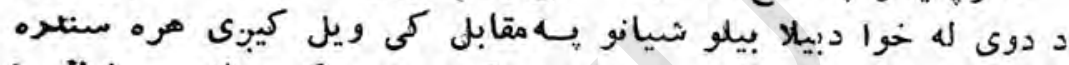

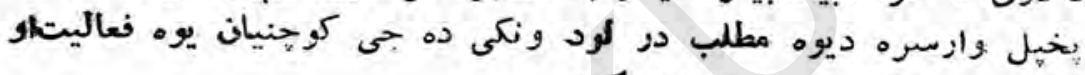

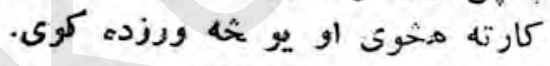

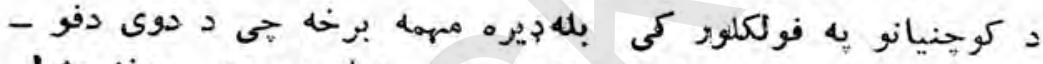

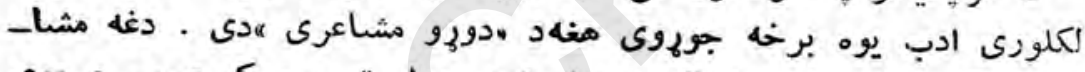

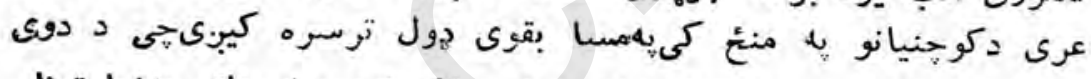

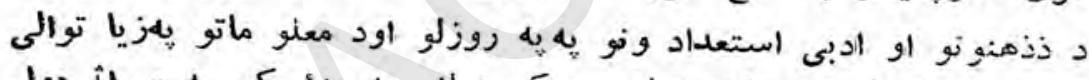

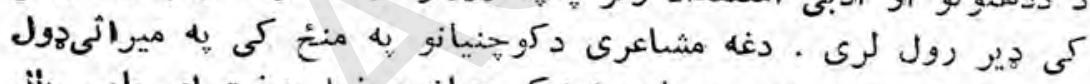

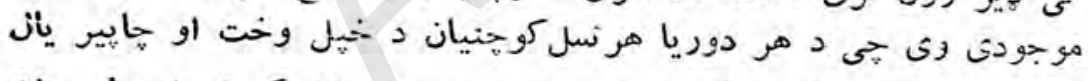

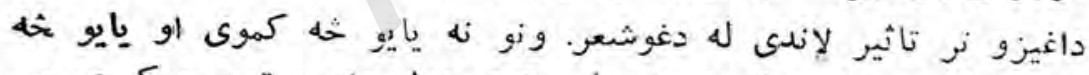

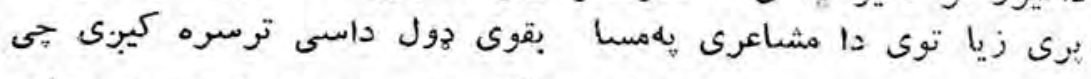

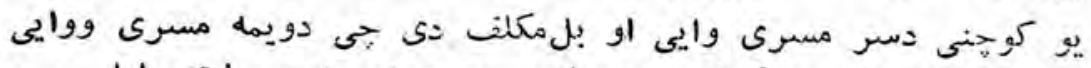

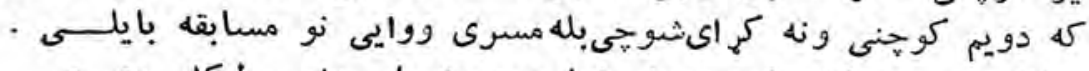

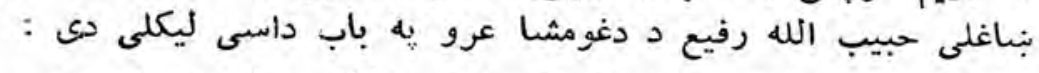

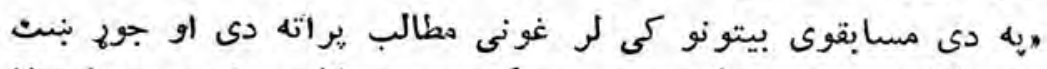

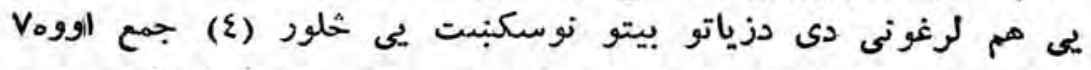

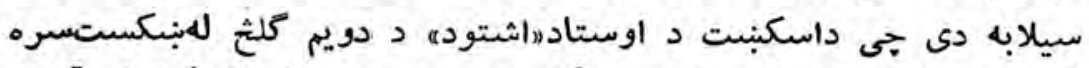

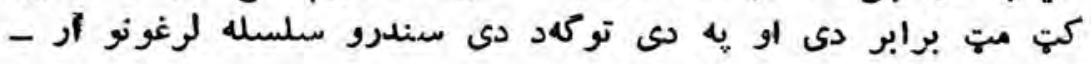


يايى سرود ونو ته رسيبنى · ؛

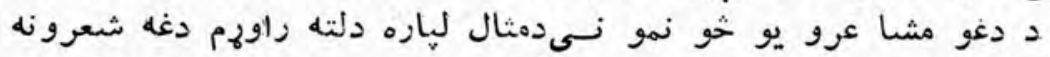

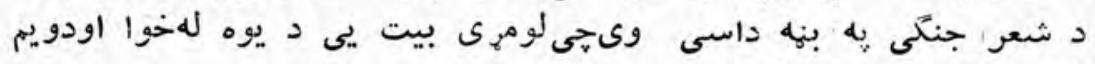

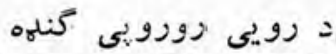

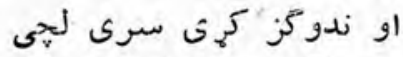

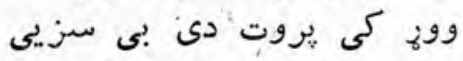

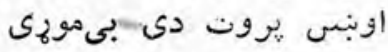

$$
\begin{aligned}
& \text { د كابل دروازه بله }
\end{aligned}
$$

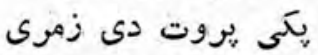

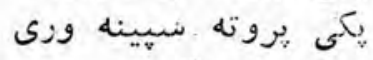

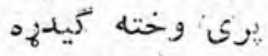

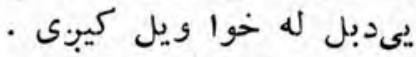$$
\text { د يو تر ميلنه }
$$

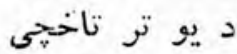$$
\text { د يو ترغزنى تر تاخيى }
$$$$
\text { ديو تر لوزي تونى }
$$

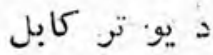

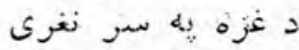

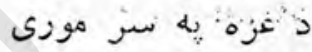

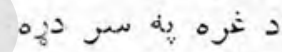

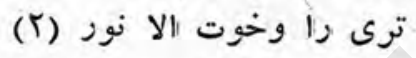

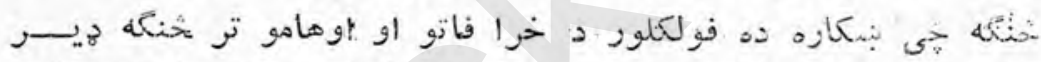

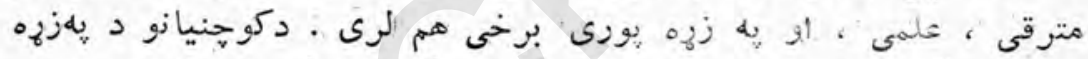

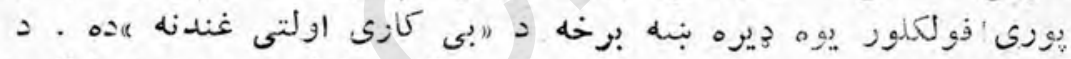

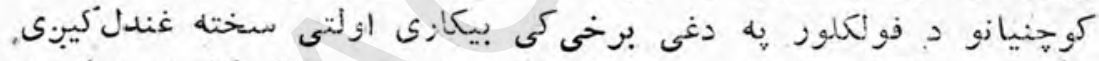

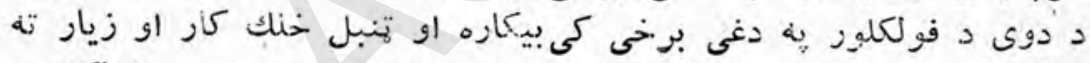

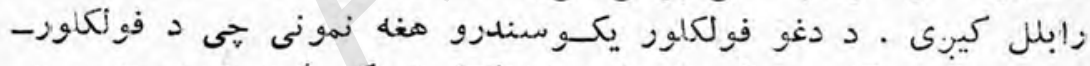

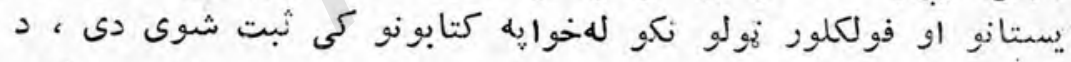

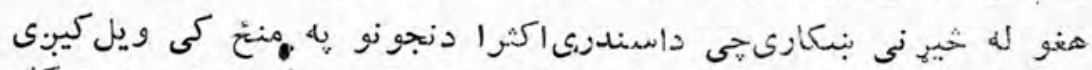

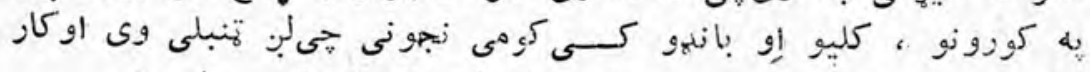

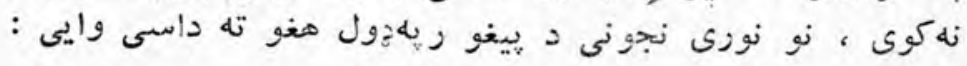

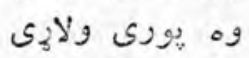

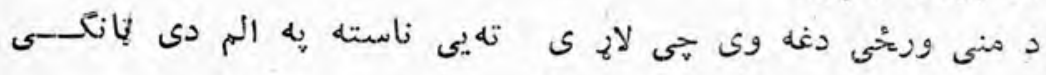

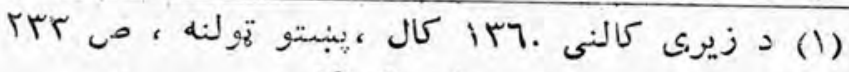

$$
\begin{aligned}
& \text { }
\end{aligned}
$$




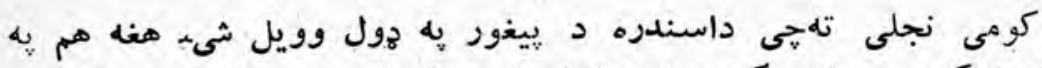

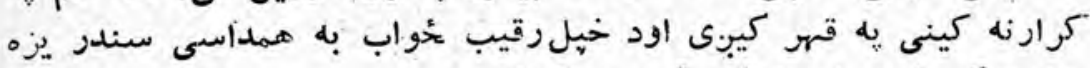

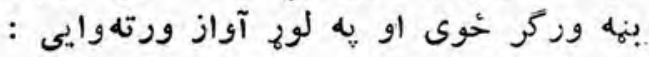

وه يوزى ولاهى

جينك دارى ميره غوالهى

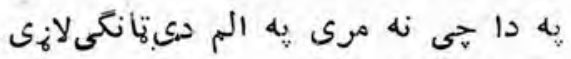

وه يورى ولاهى (1)

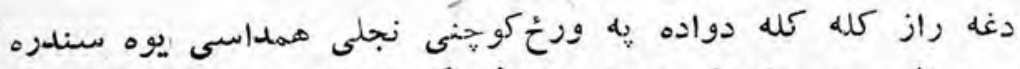

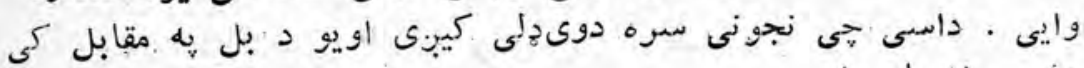

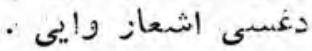

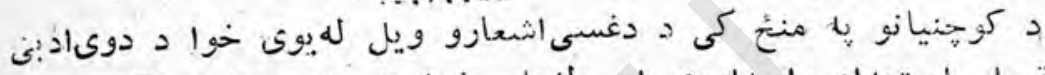

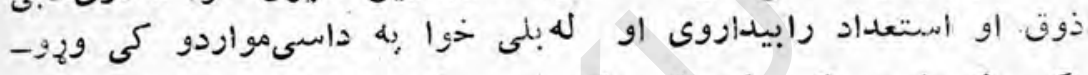

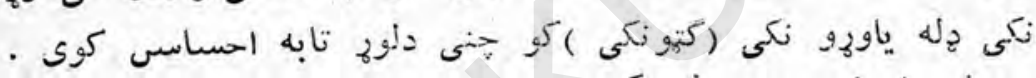

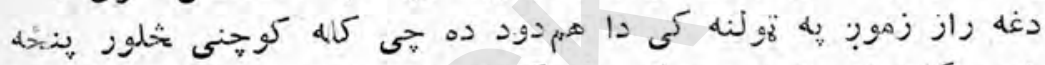

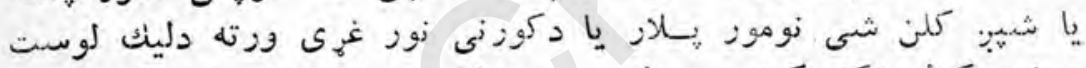

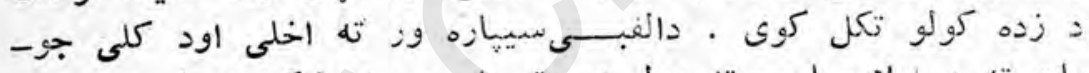

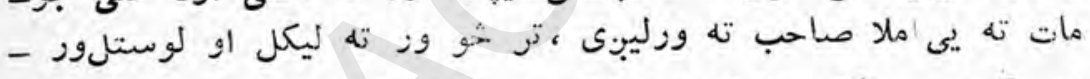

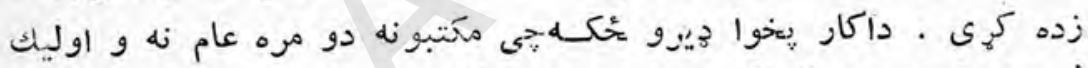

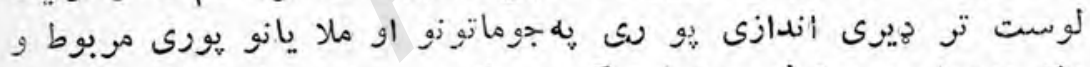

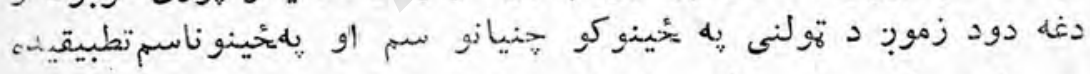

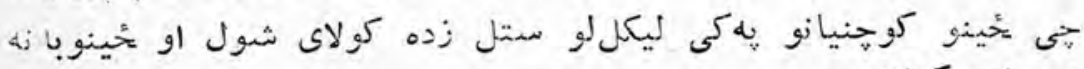
شو زده كولاى مون

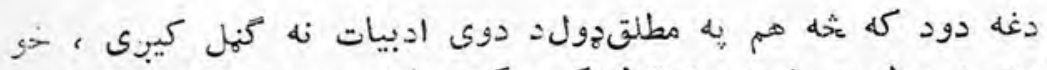

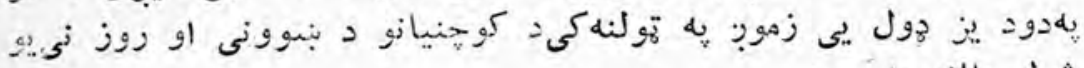
- خ

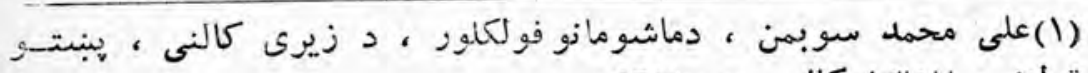

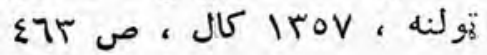




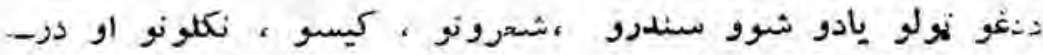

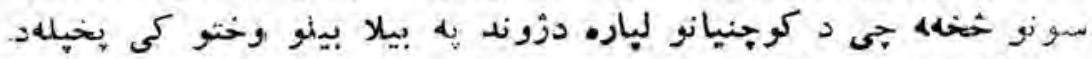

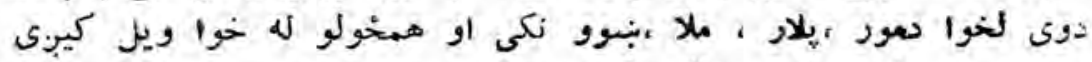

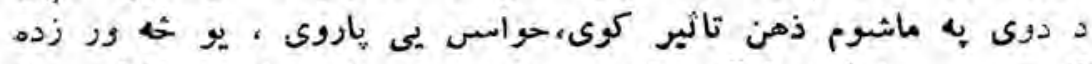

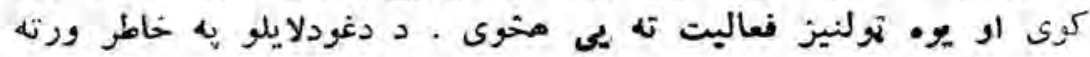

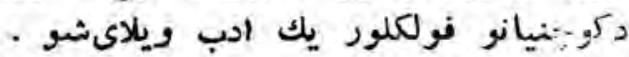

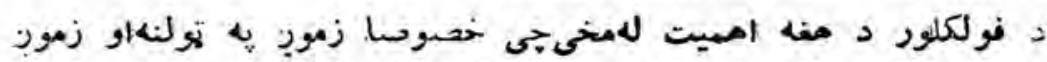

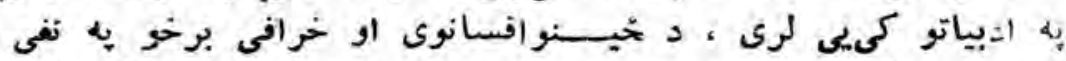

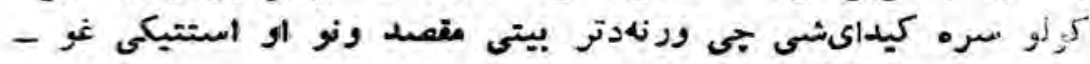

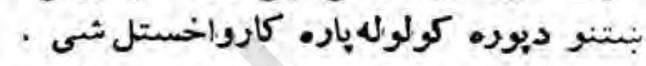

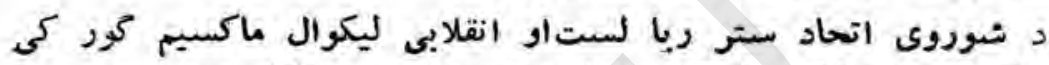

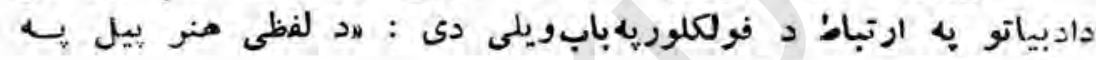

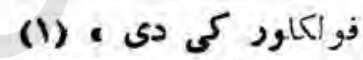

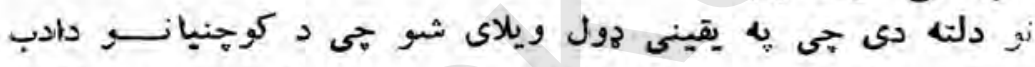

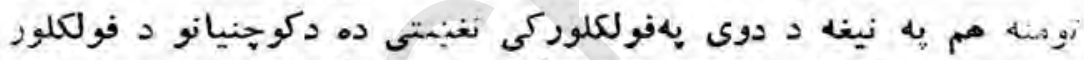

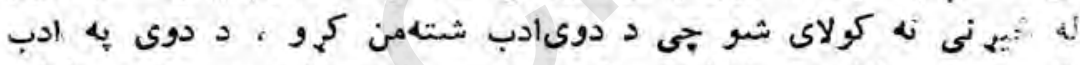

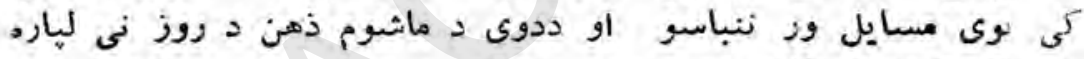

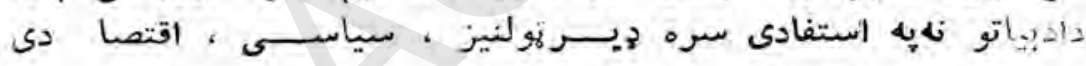

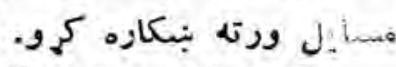

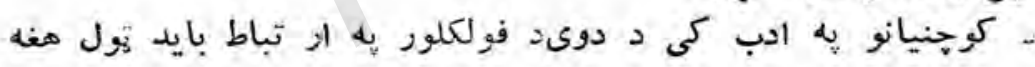

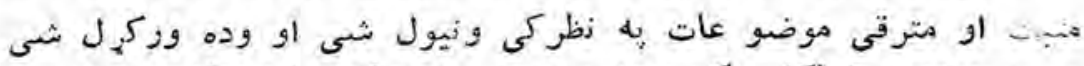

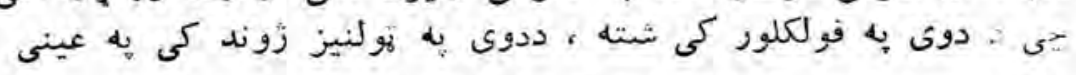

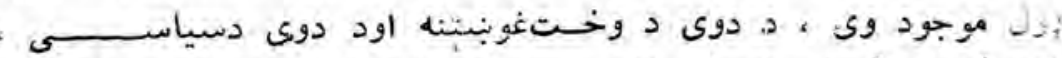

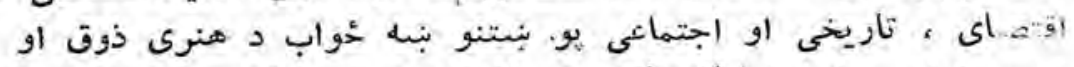

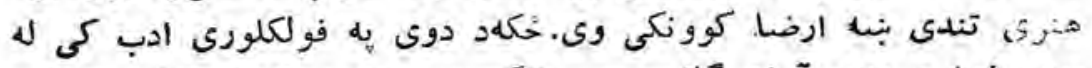

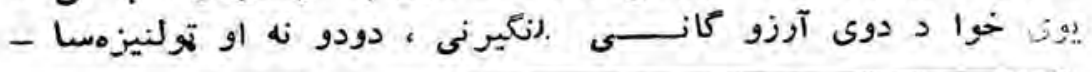

$$
\text { فولكلور يميز ندنه (قلمى) ،ص } 9
$$




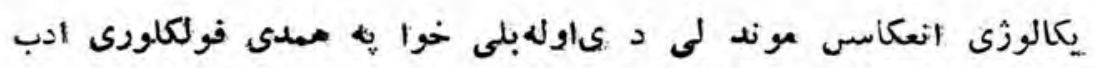

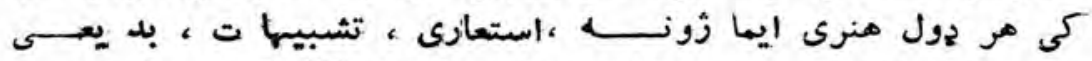

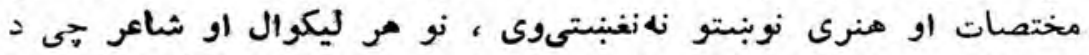

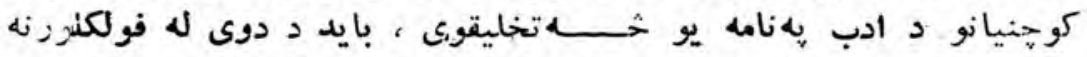

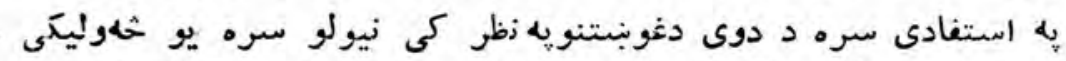

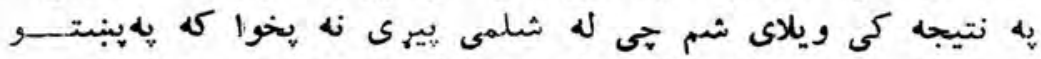

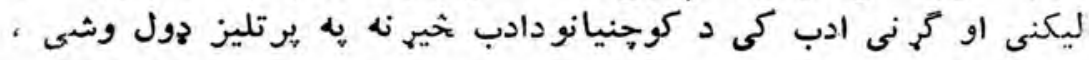

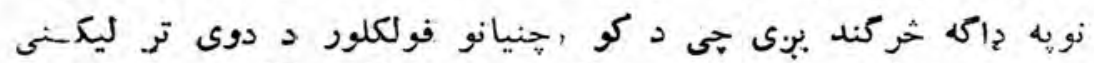

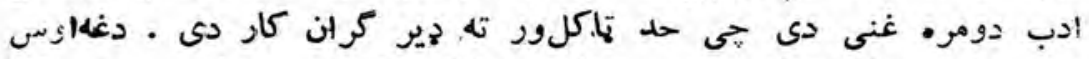

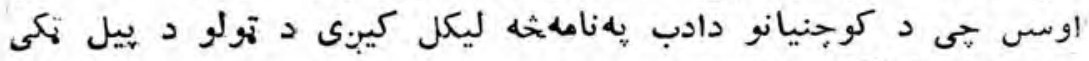

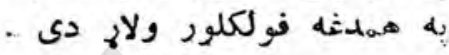

$-r v$ 


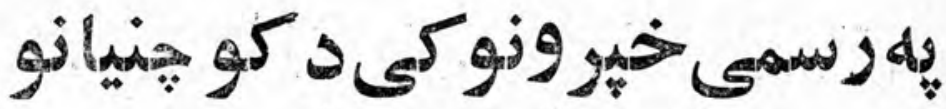

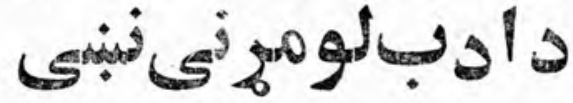

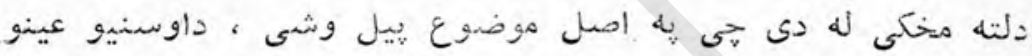

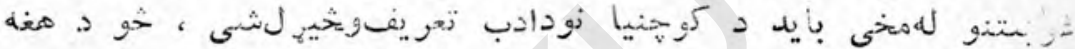

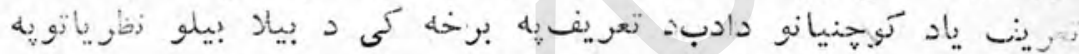

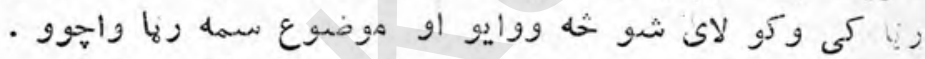

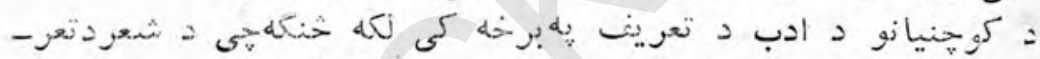

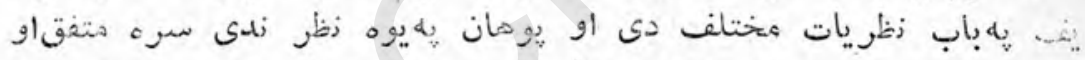

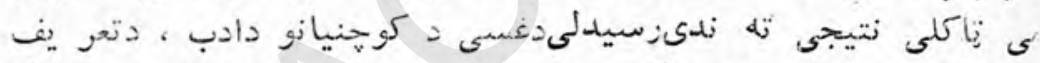

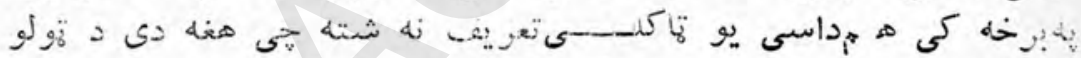
لبه

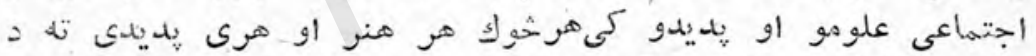

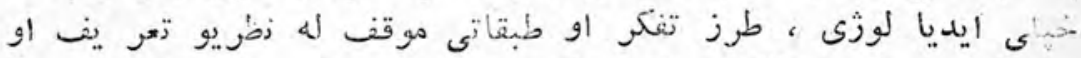

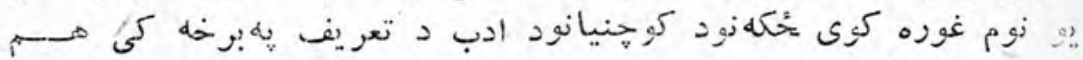

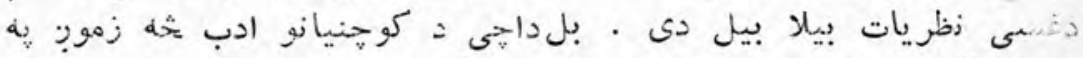

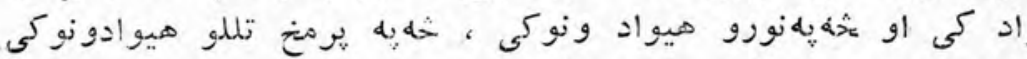

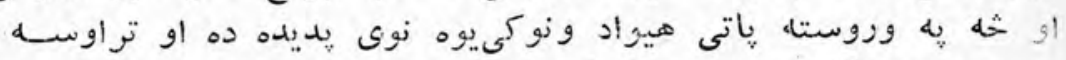

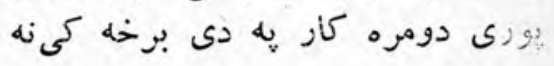


دى ترسوه شوى ، دومره تجاربنهدى تر لاسه ثموى خى د هغوى هيه

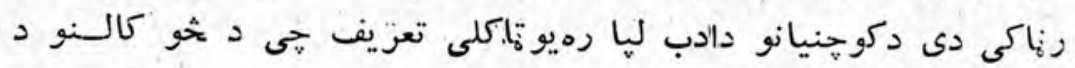

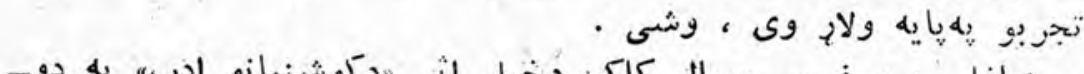

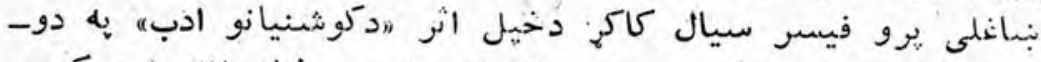

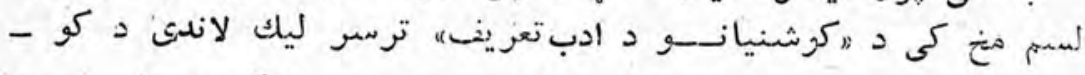

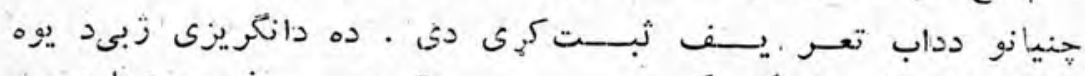

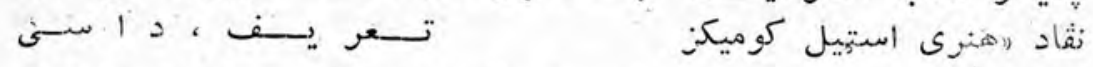

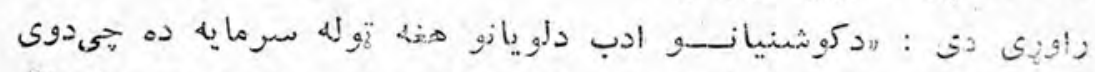

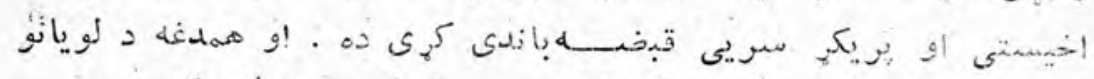

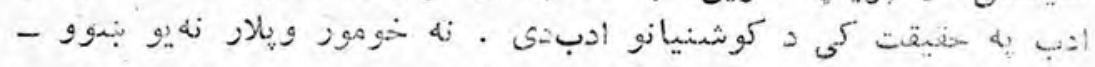

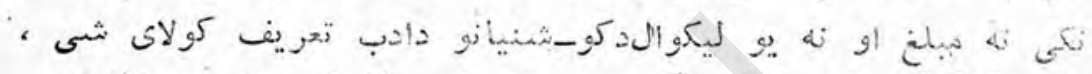

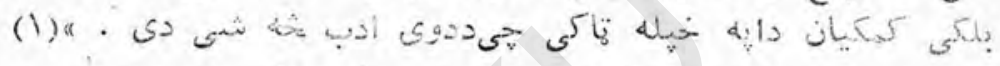

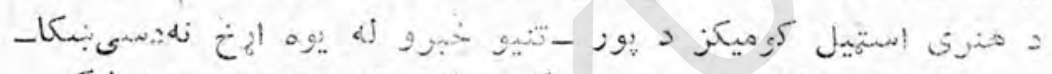

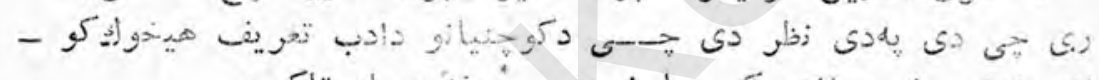

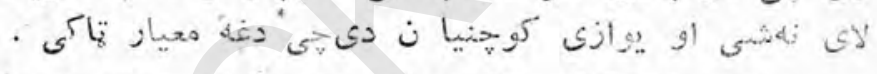

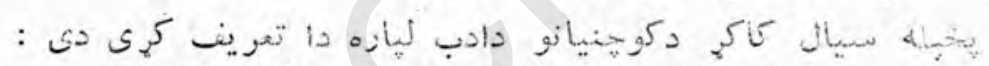

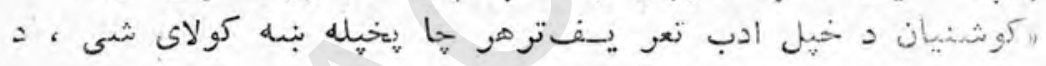

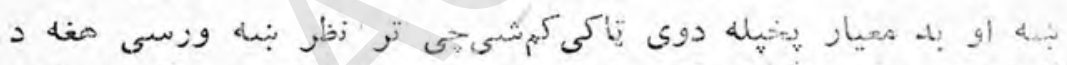

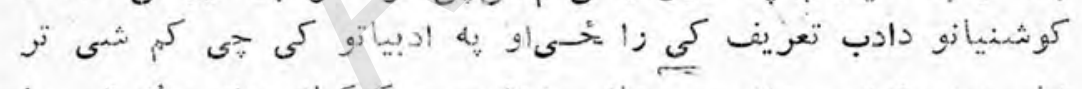

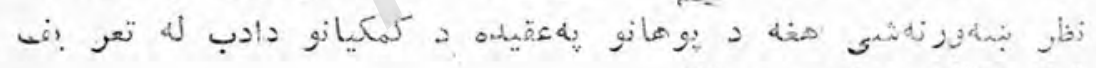

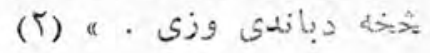

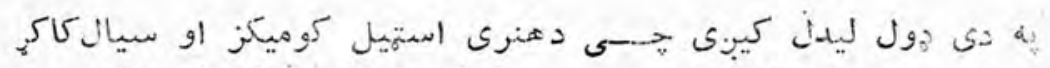

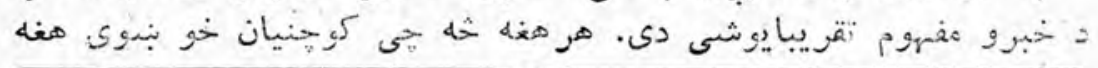

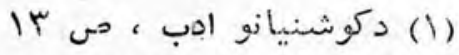

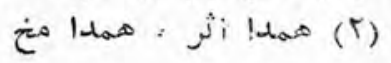




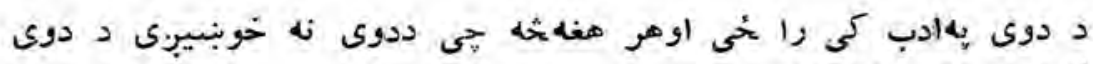

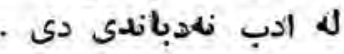

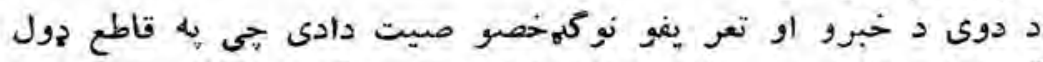

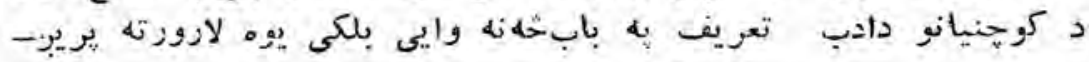

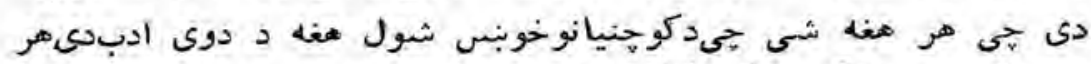

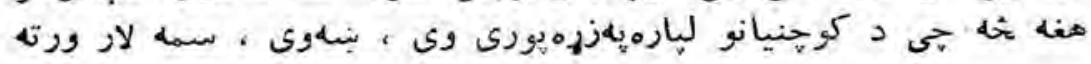

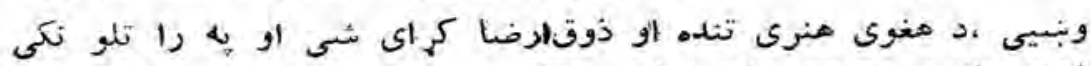

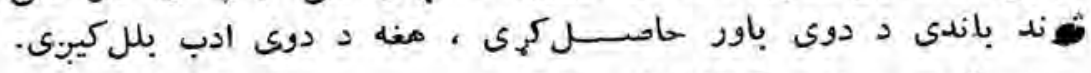

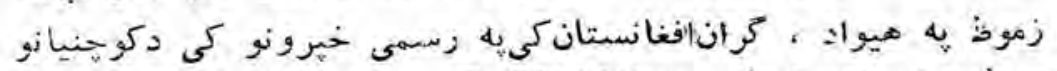

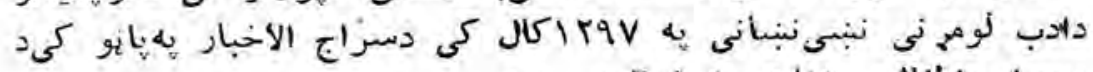

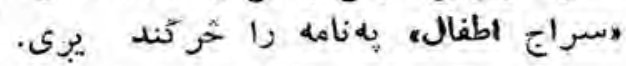

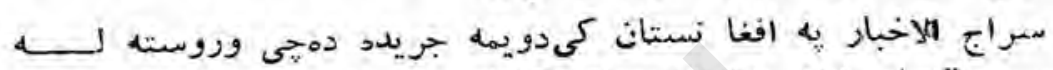

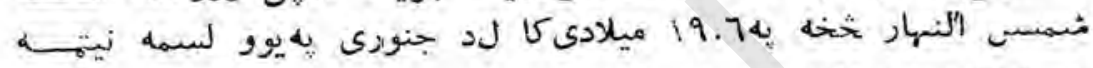

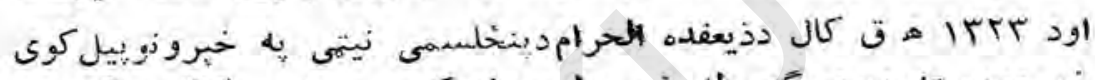

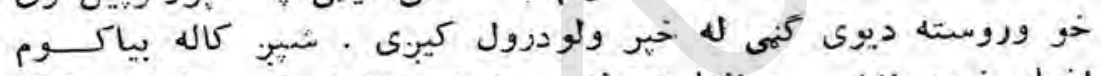

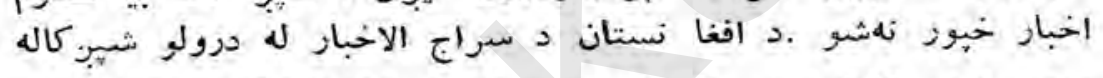

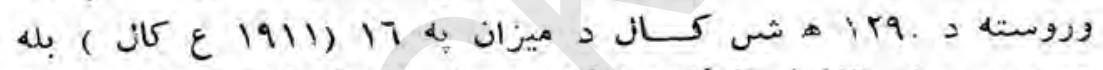

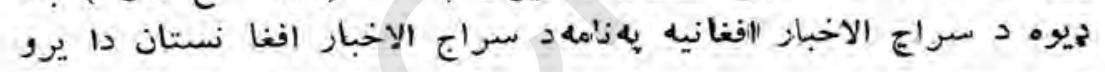

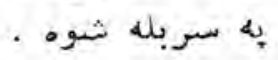

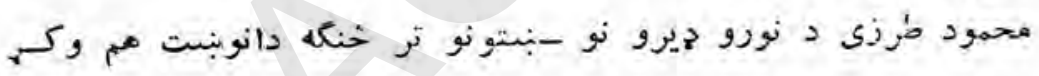

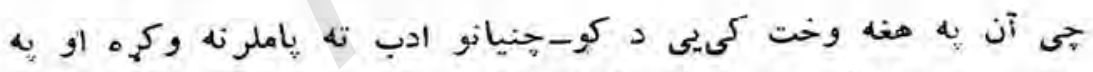

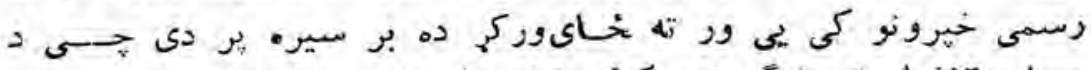

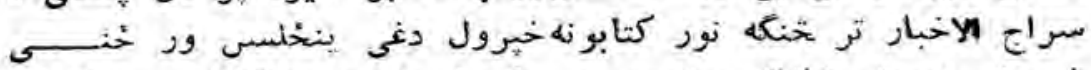

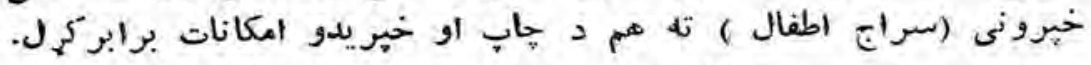

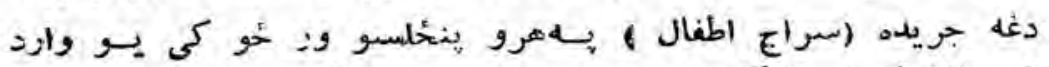

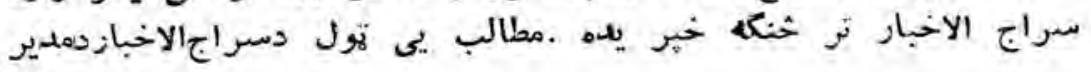




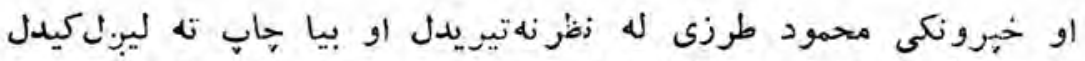

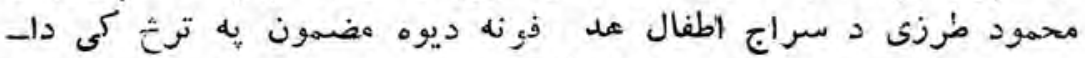

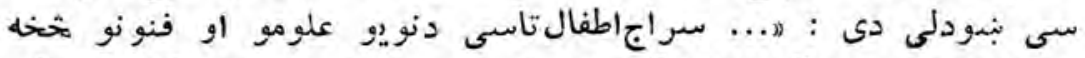

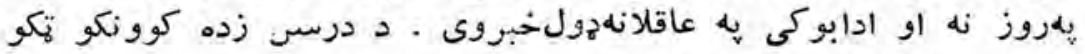

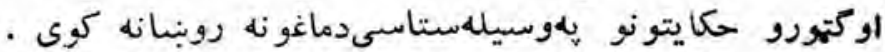

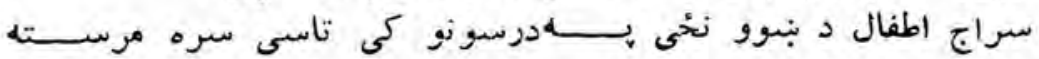

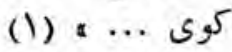

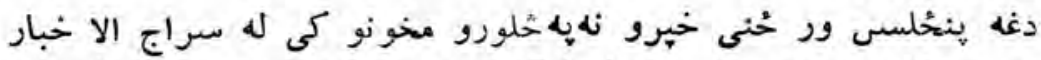

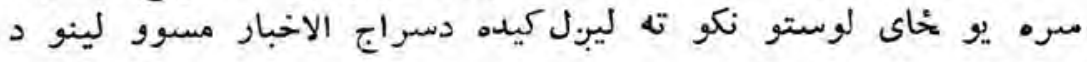

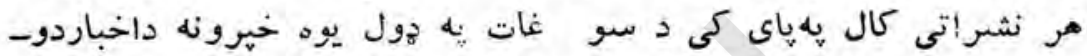

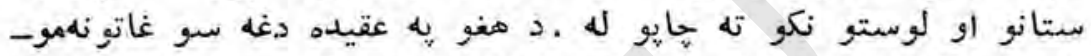

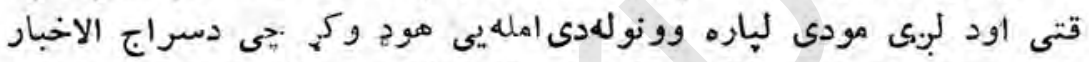

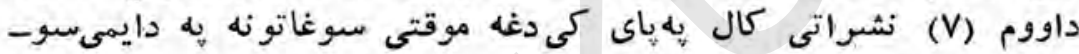

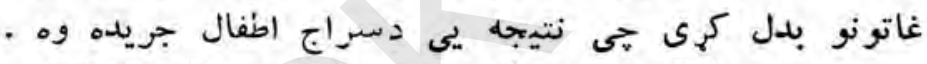

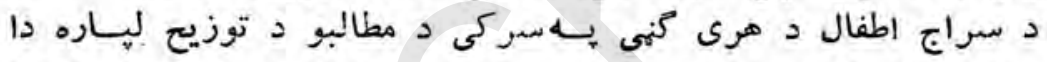

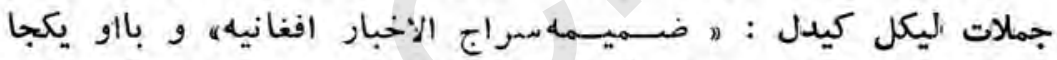

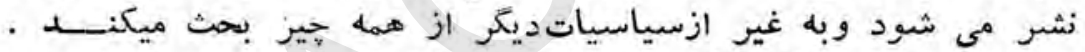

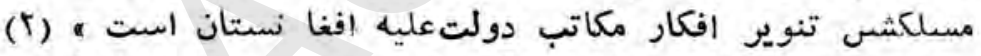

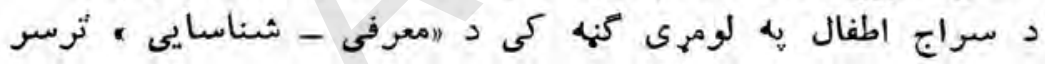

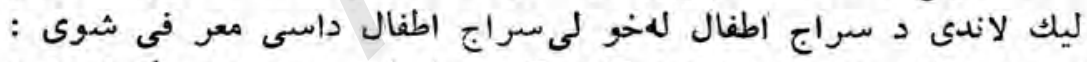

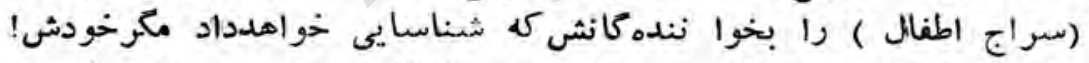

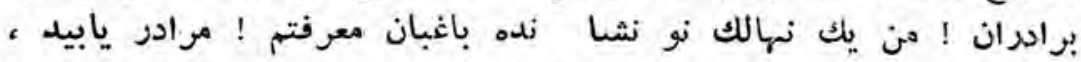

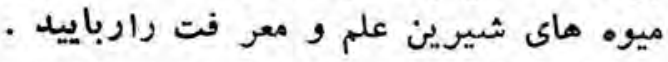

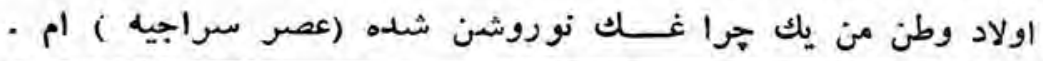

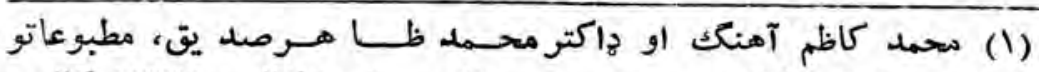

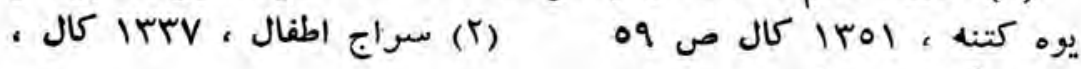

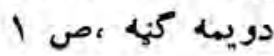


روغنم انواز حكمت است مرا درهر جاييكه بيابيد بكيريد ! روشنى فكر

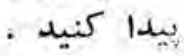
شاكردان عزت مند ! من يكذذرهام كه آفتاب حقيقت درمن جلــوه

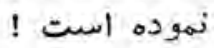

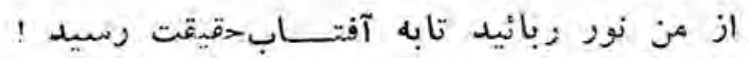

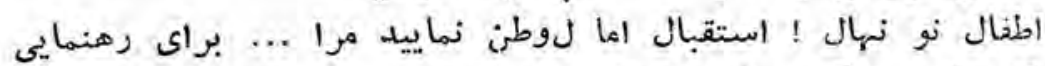

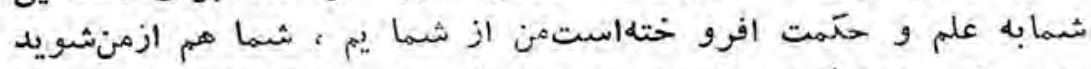

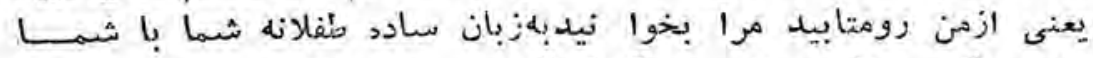

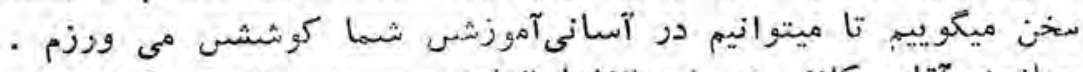

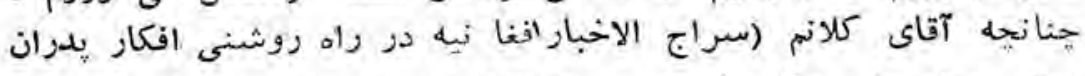

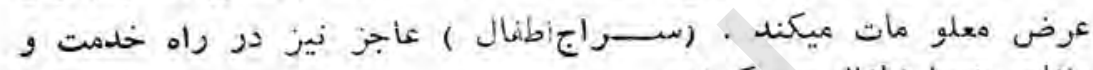

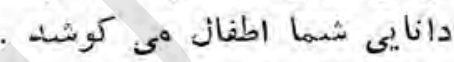

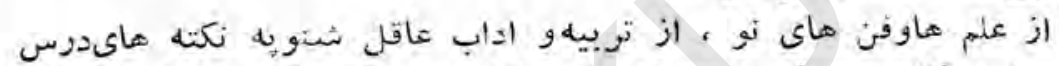

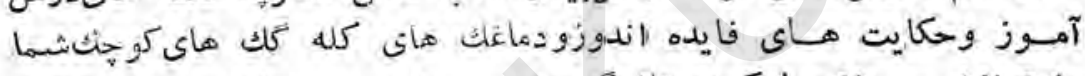

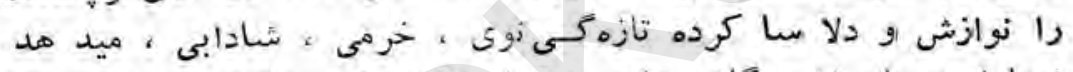

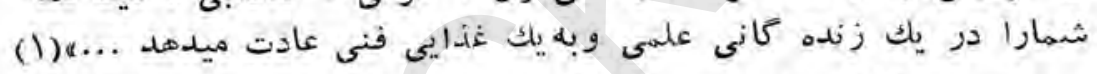

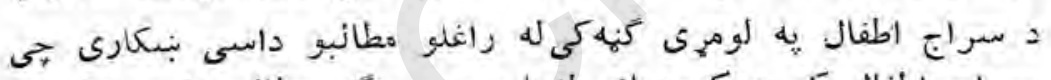

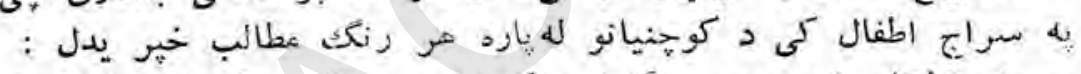

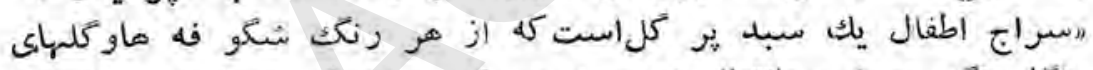

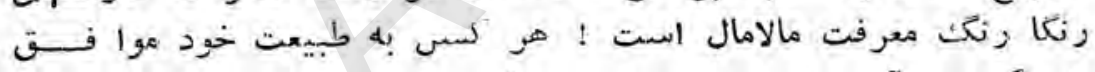

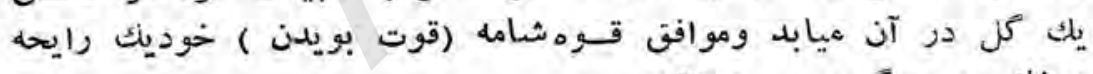

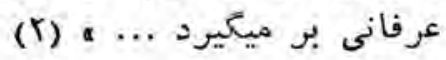

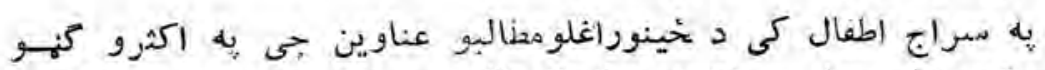

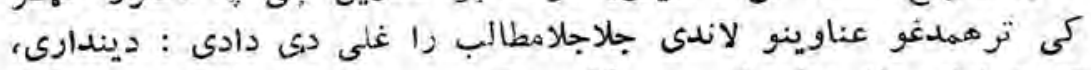

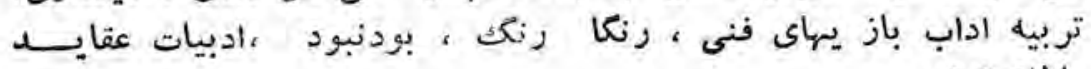
باطله اونوز ادوب

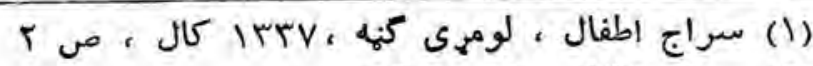

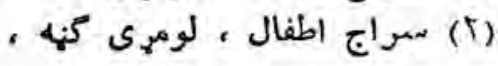




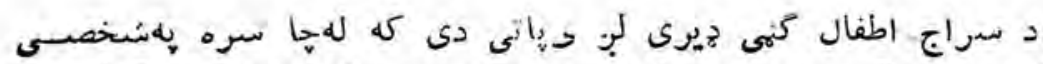

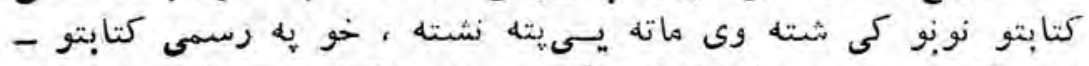

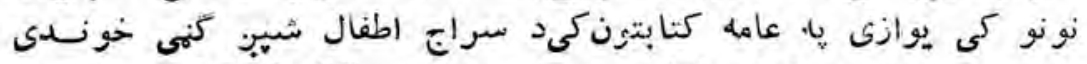

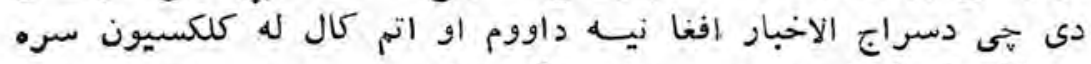

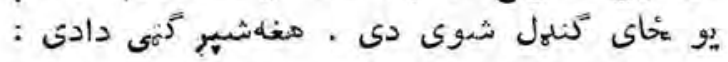

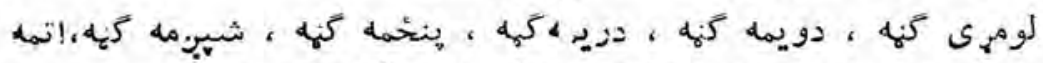

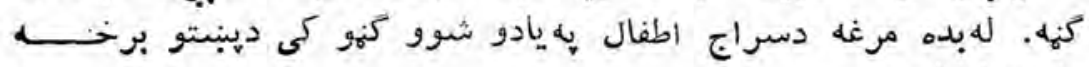
ماونه ليدله لهان مرنان

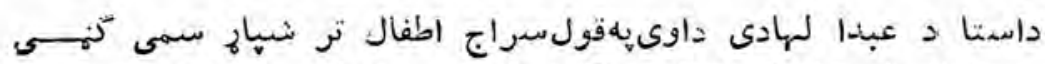

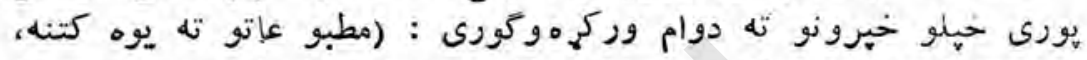

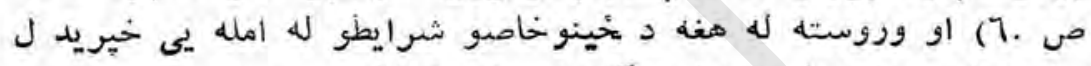

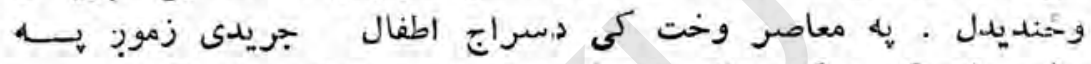

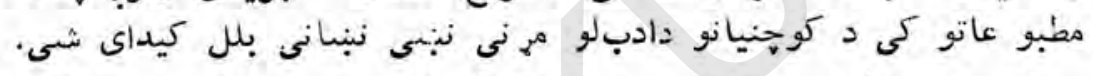

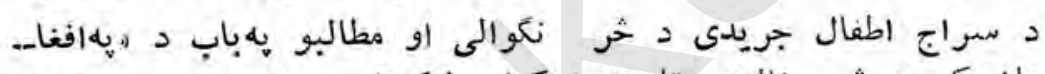

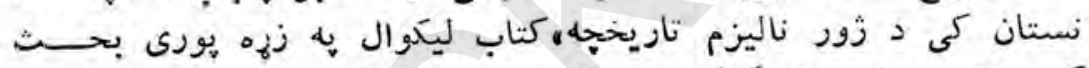

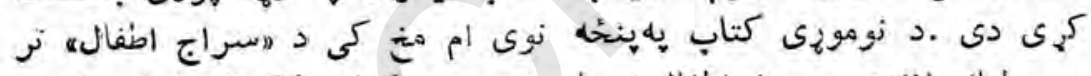

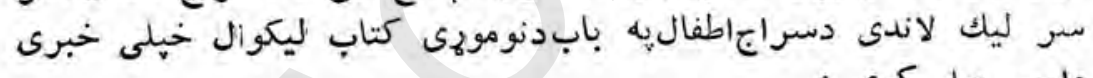
داسنى نيل كوى ليك لاندى :

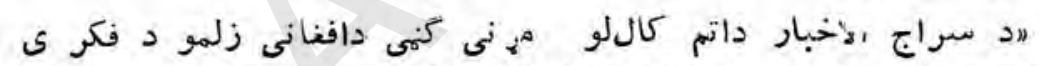

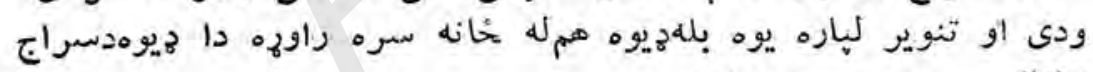

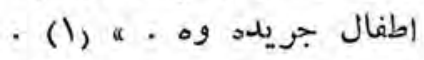

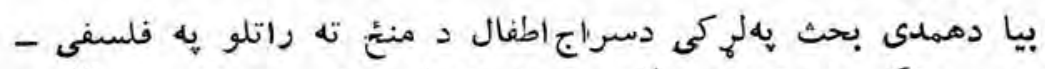

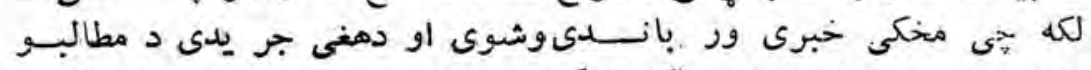

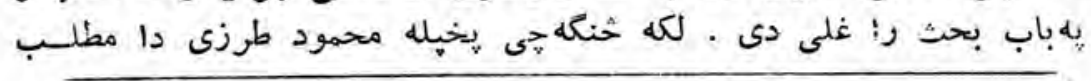

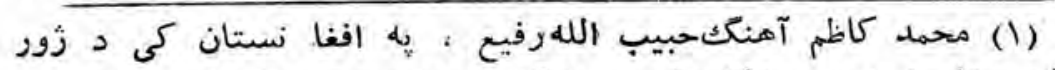

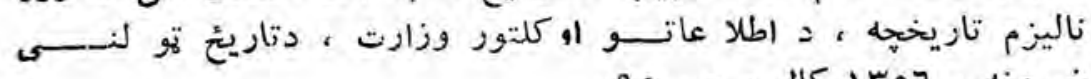

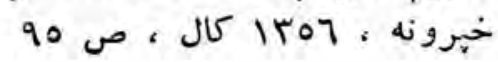




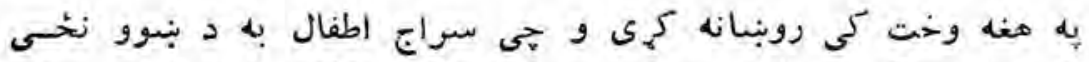

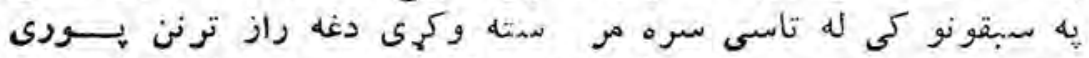

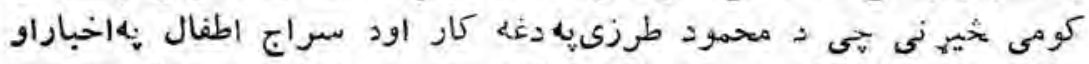

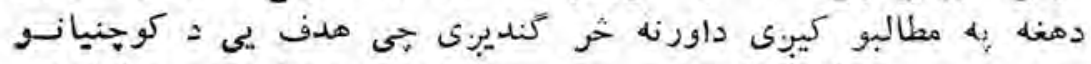

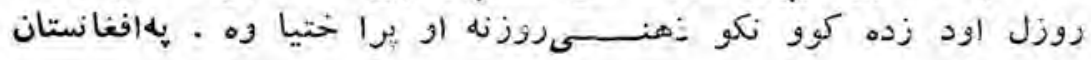

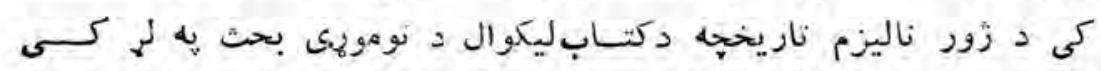

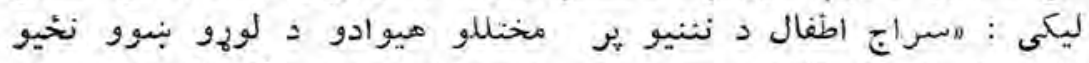

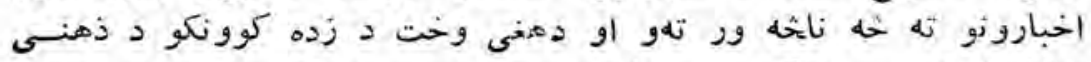

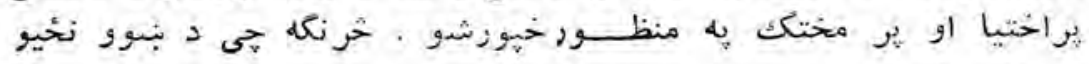

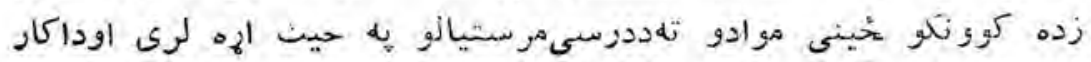

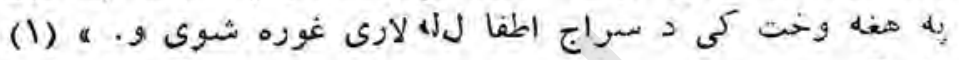

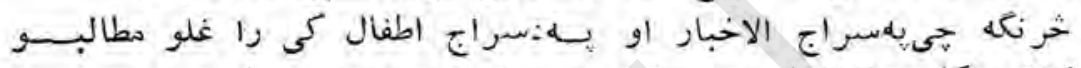

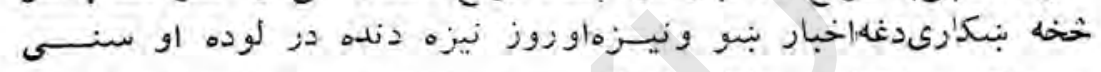

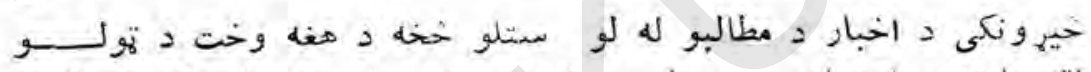

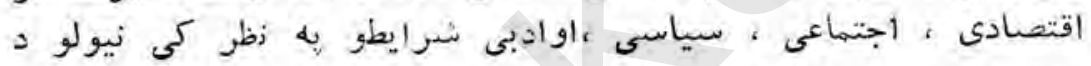

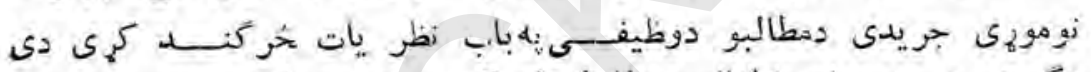

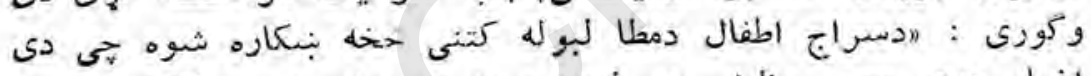

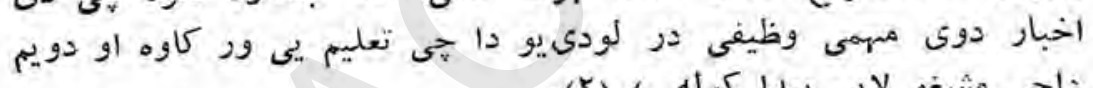

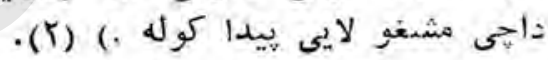

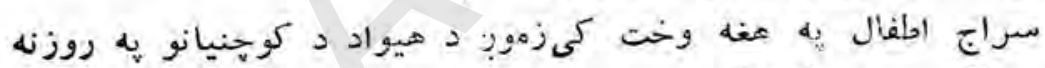

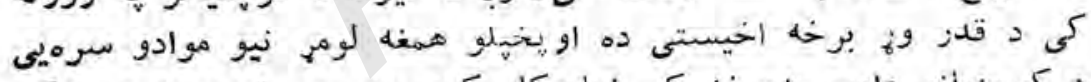

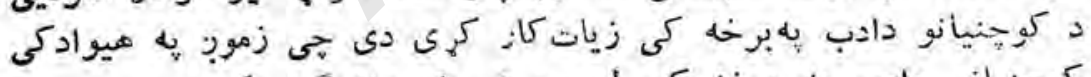

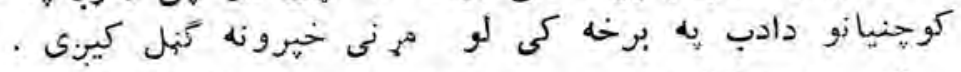

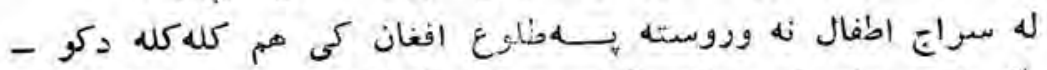

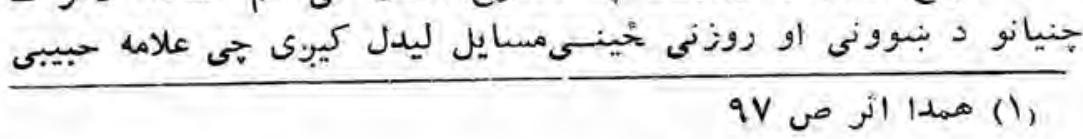

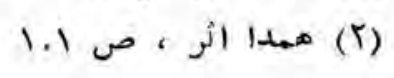




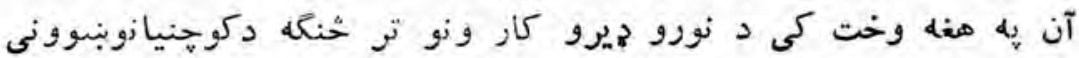

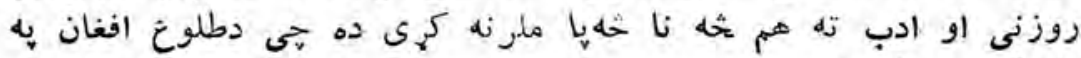

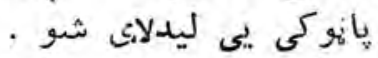

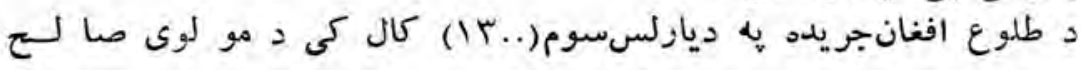

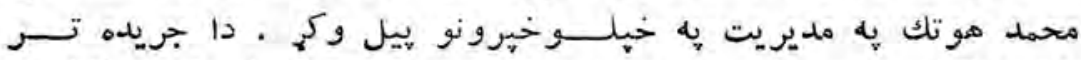

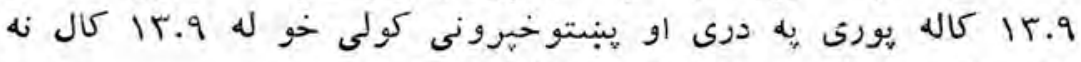

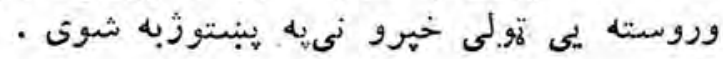

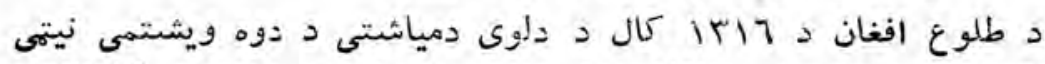

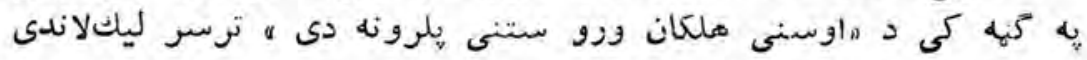

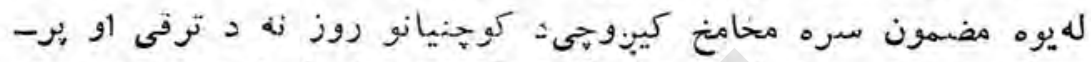

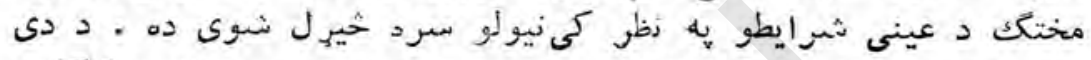

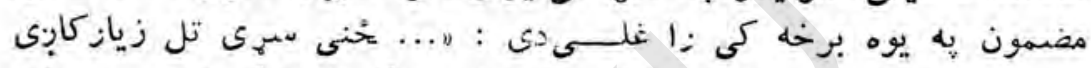

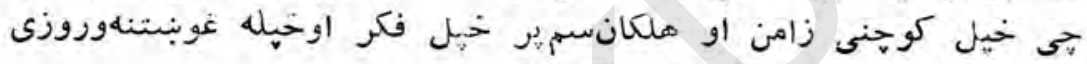

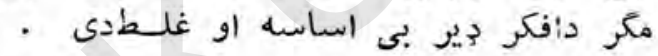

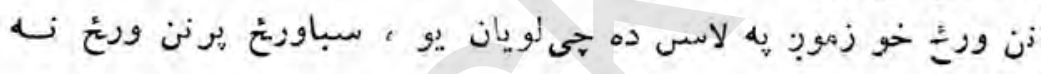

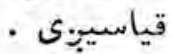

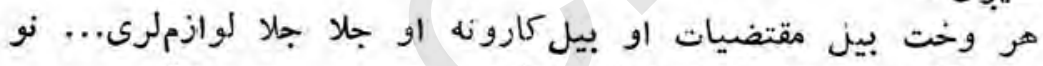

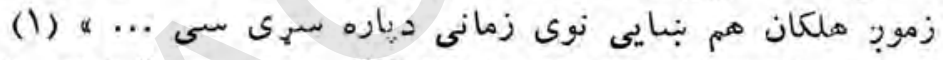

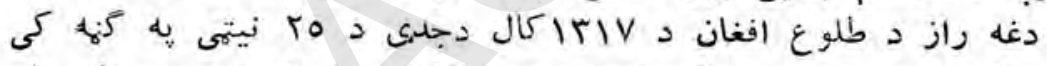

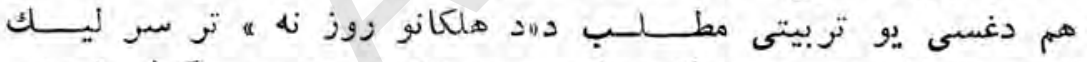

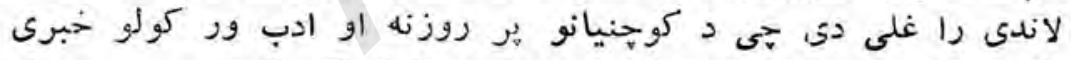

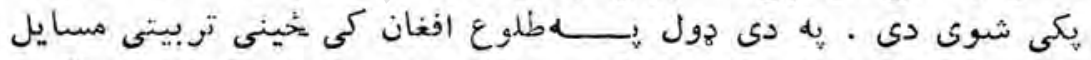

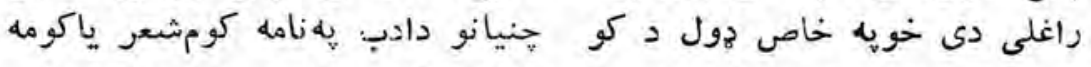

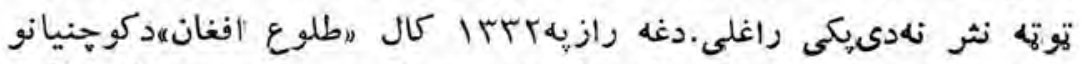

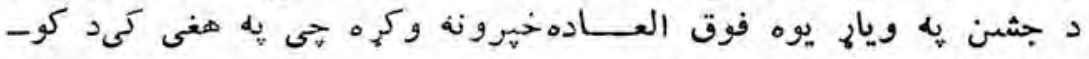

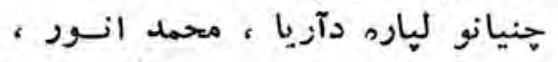

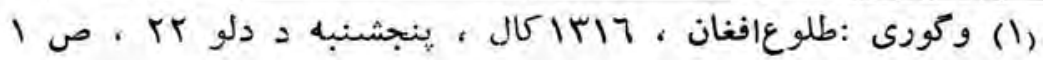
$-\varepsilon 0_{-}$ 
ايازى ، باور رحيمى ، ناصرئصرتايوبى ، عبدا لروف مخلصس اومحمد

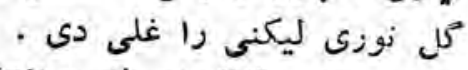

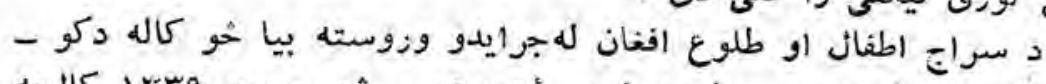

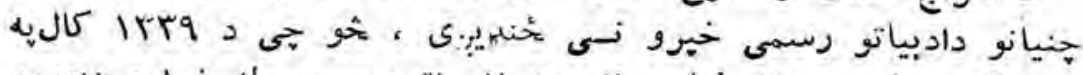

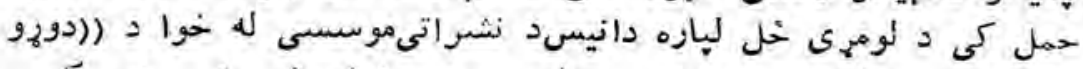

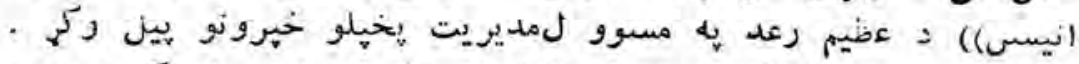

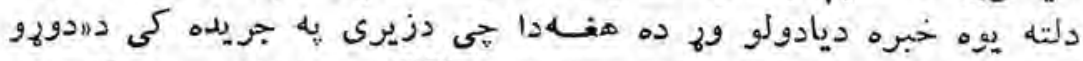

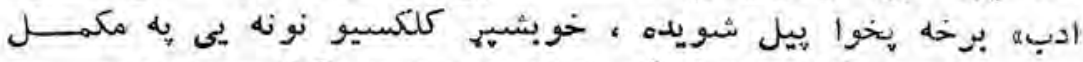

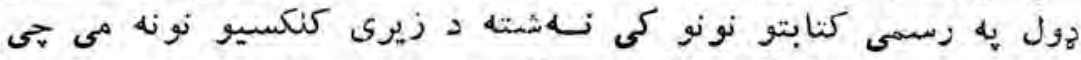

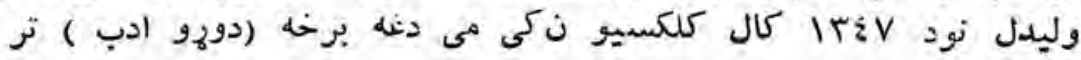

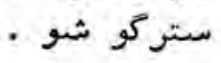

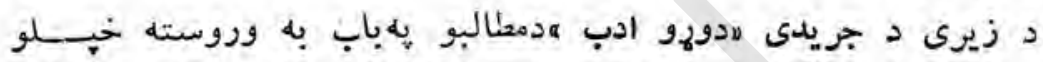

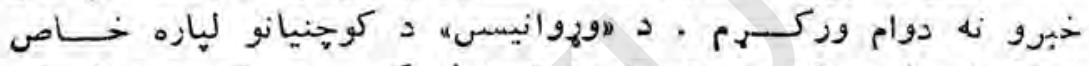

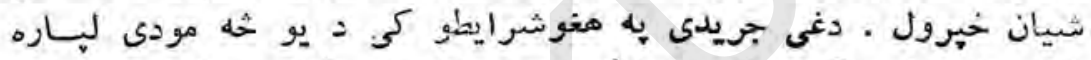

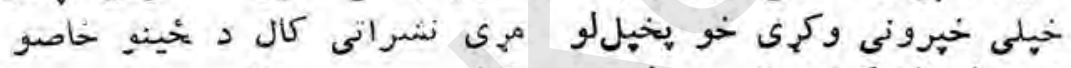

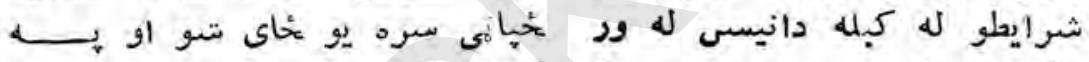

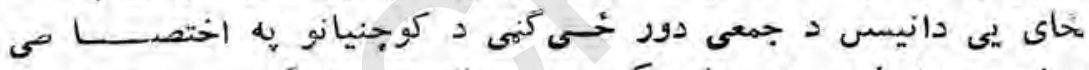

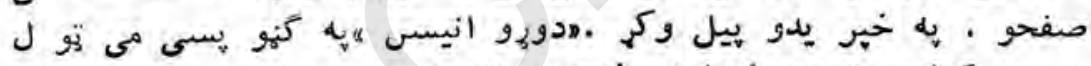

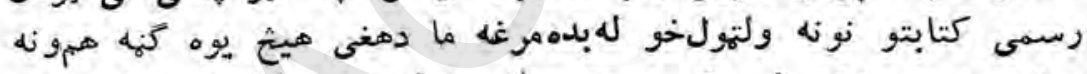

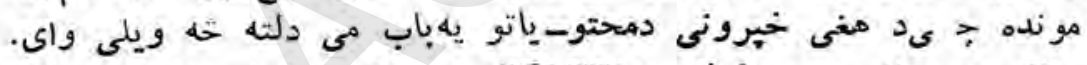

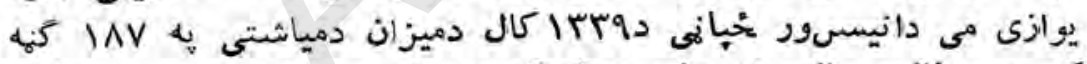

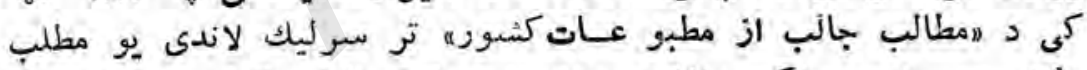

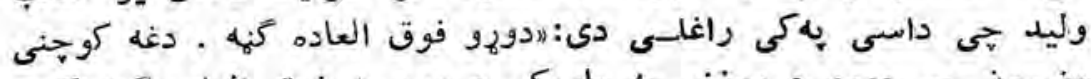

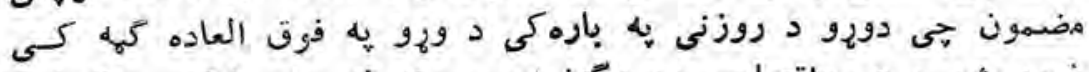

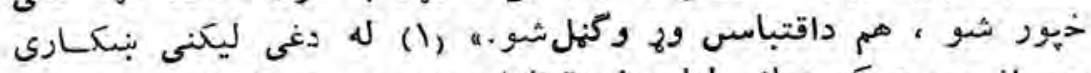

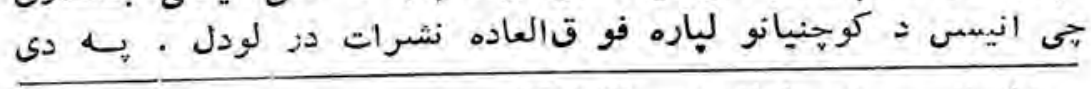

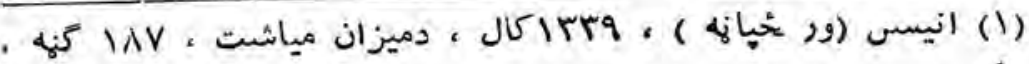




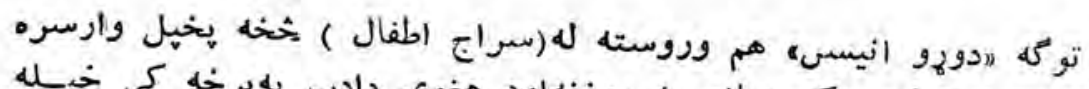

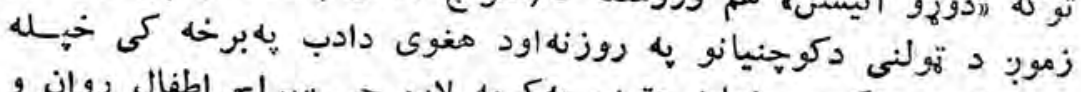

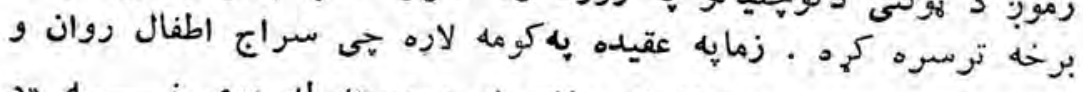

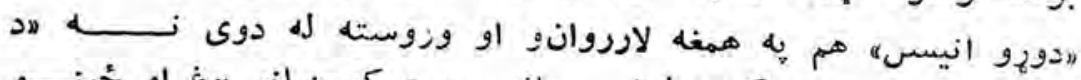

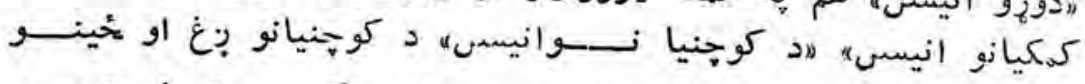

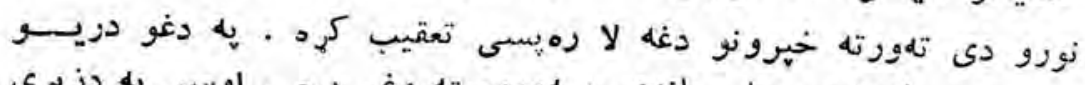

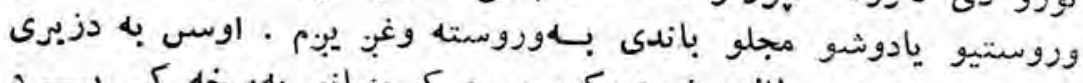

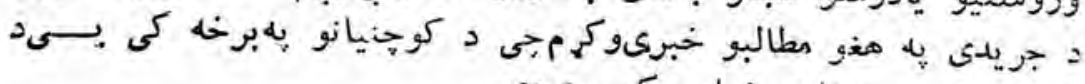

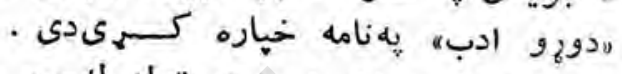

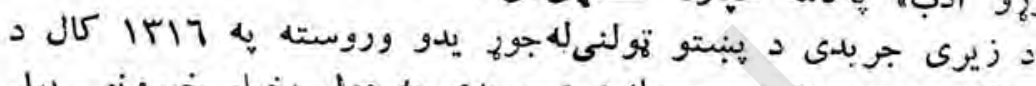

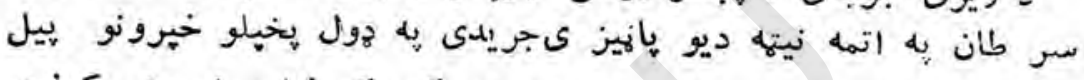

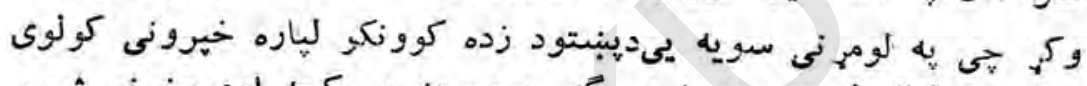

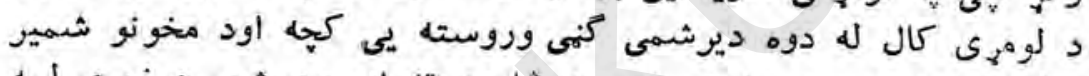

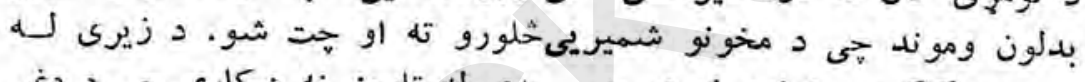

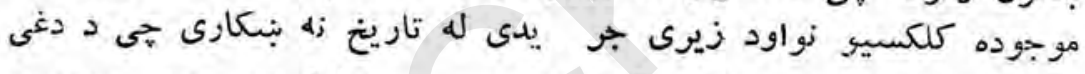

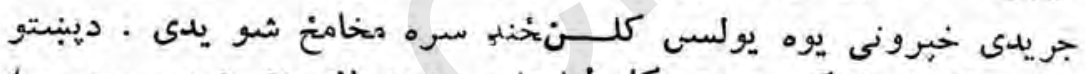

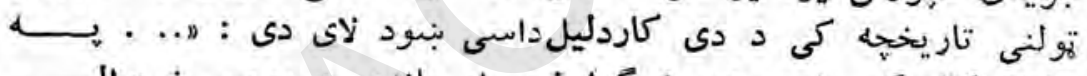

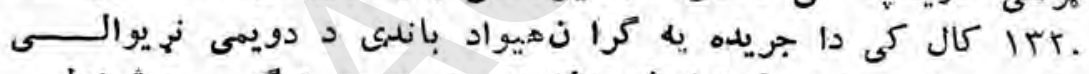

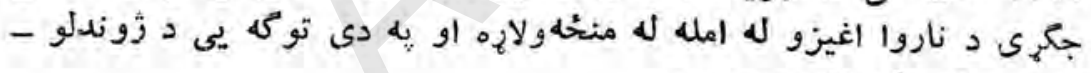

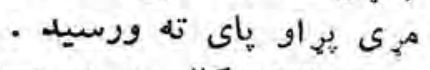

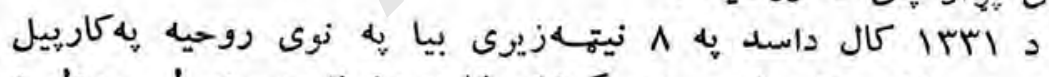

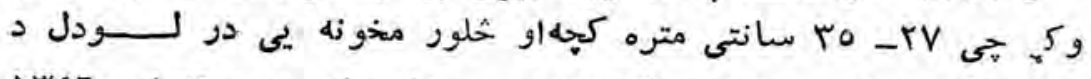

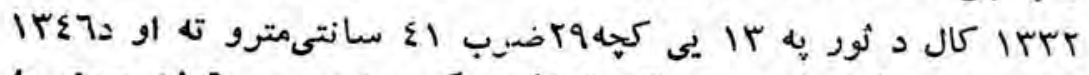

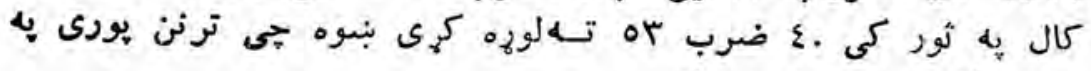

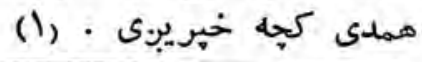

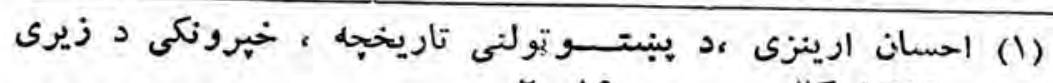

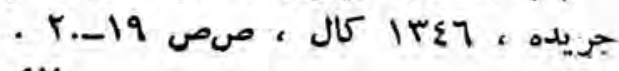
- $\varepsilon V_{-}$ 


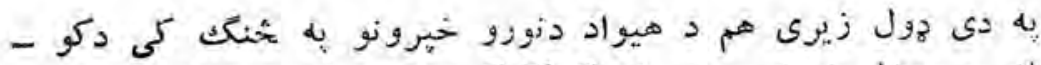

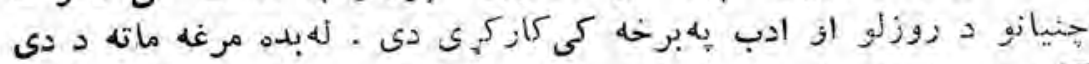

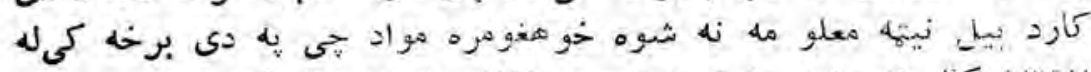

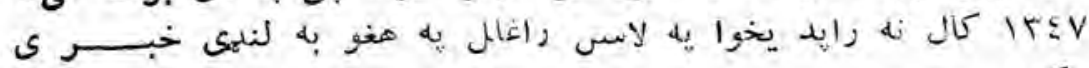
कर:

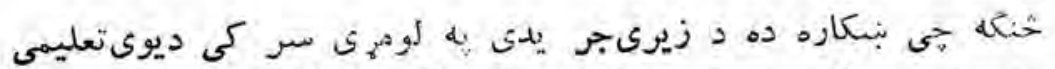

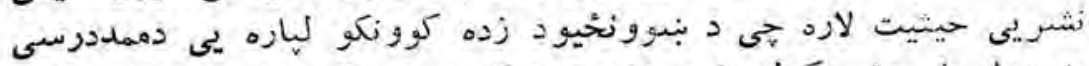

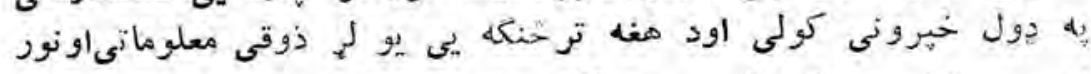

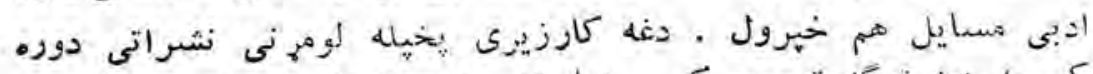

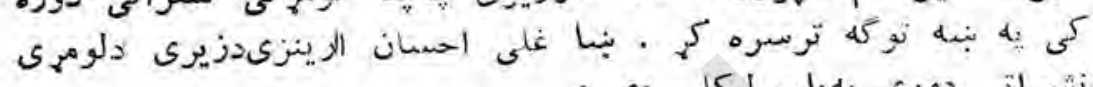

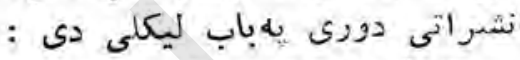

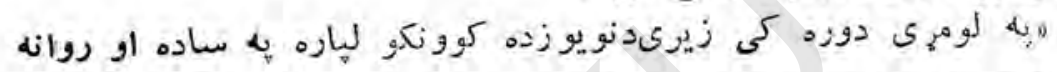

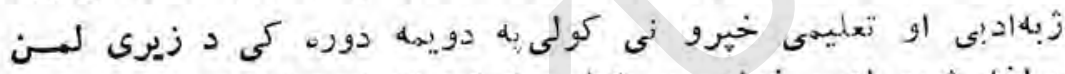

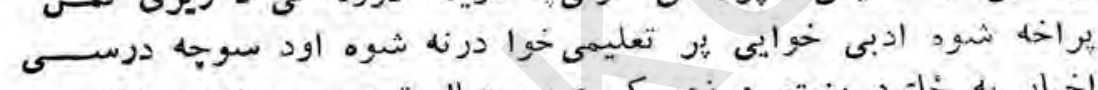

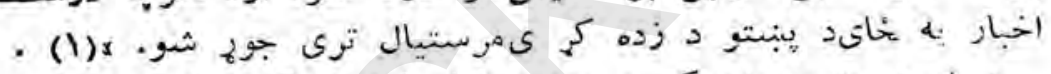

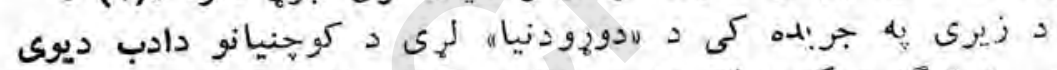

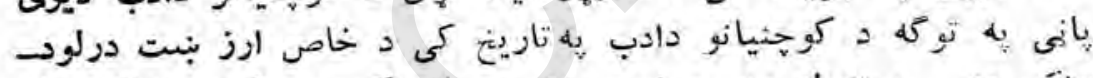

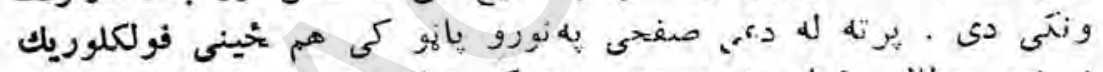

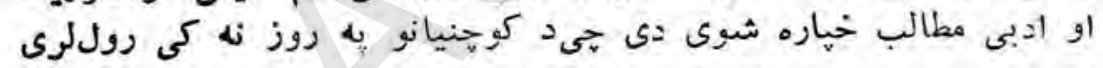

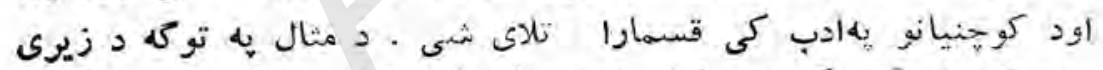

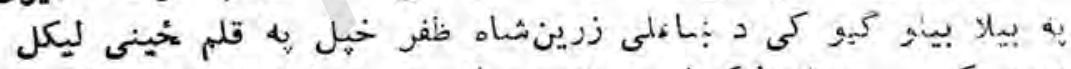

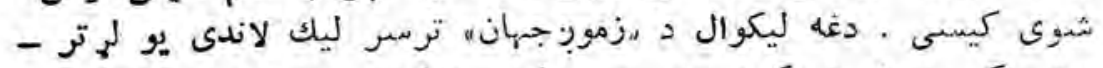

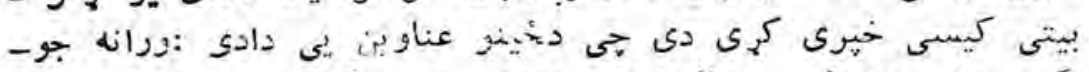

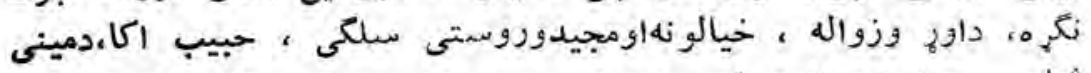

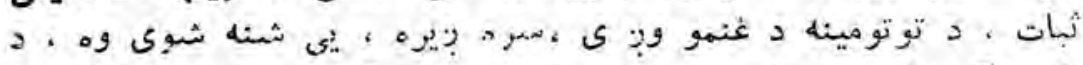

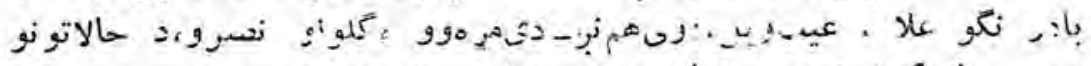

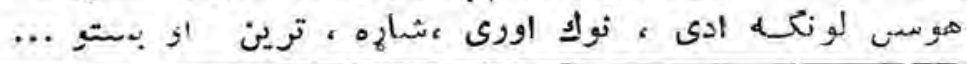

r. صما (1) 


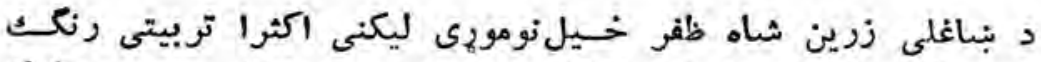

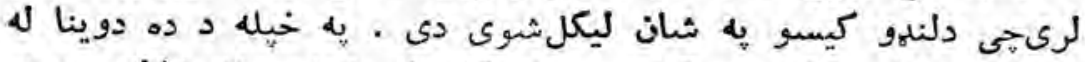

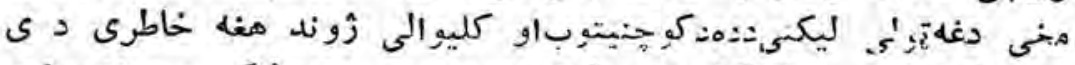

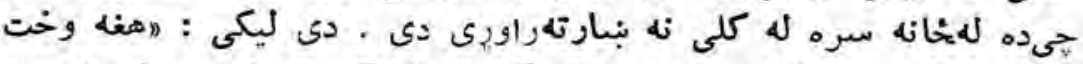

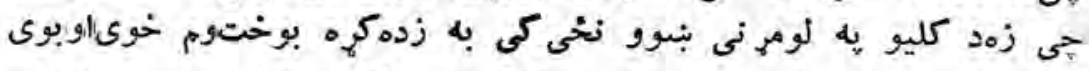

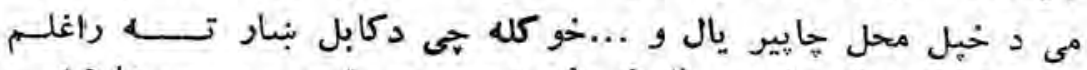

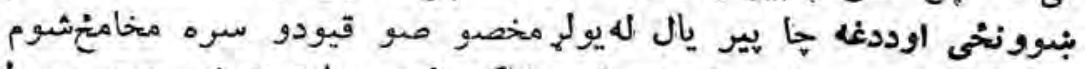

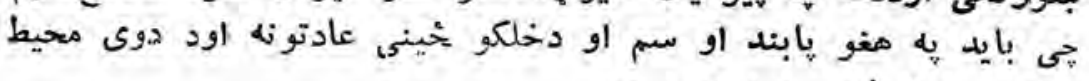

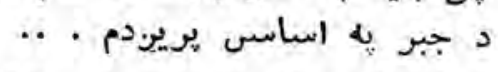

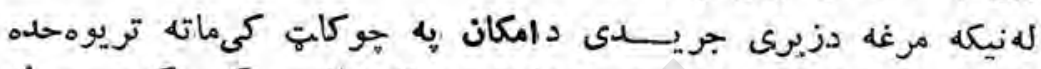

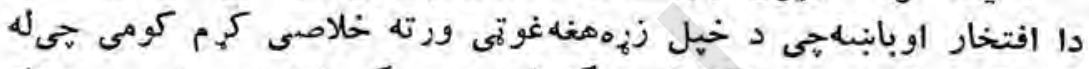

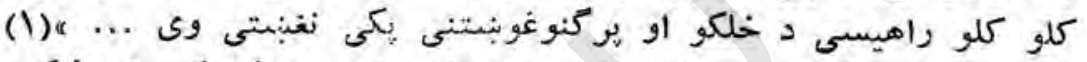

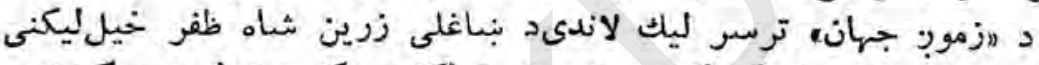

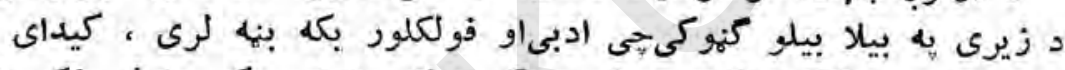

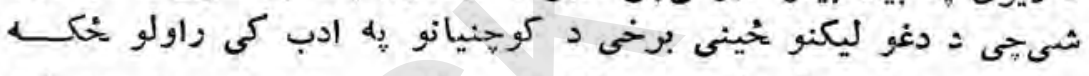

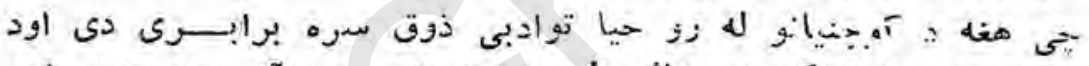

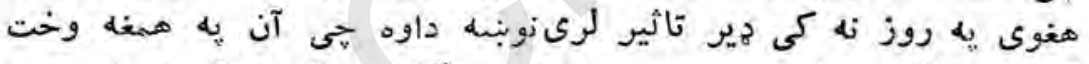

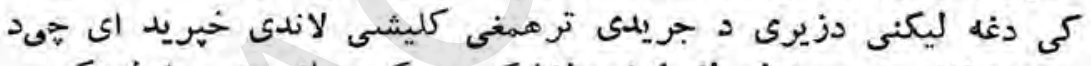

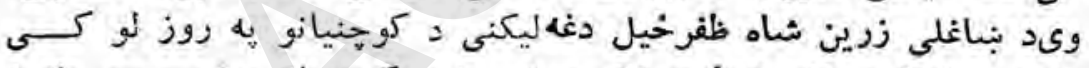

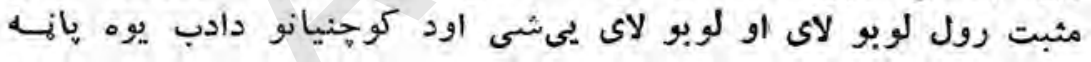

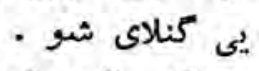

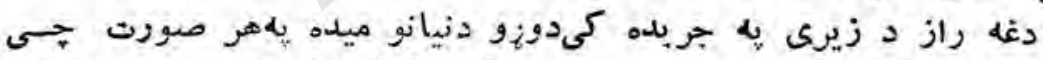

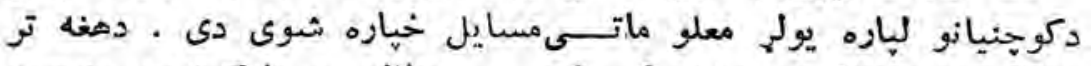

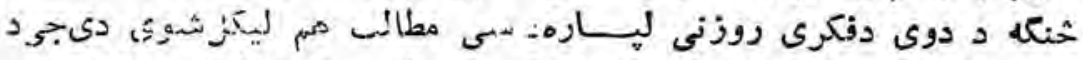

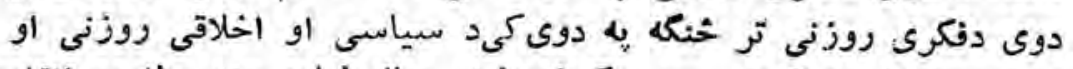

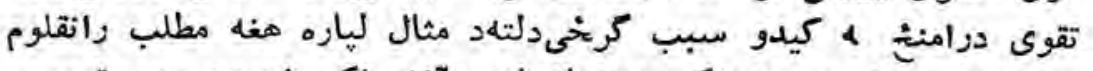

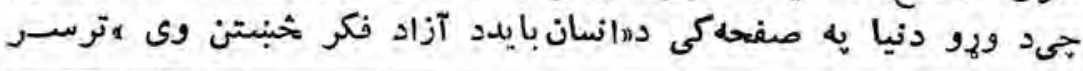




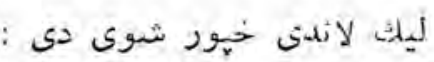

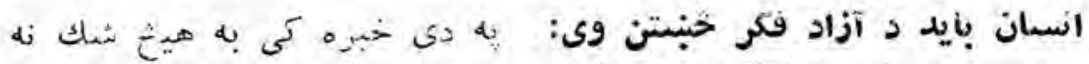

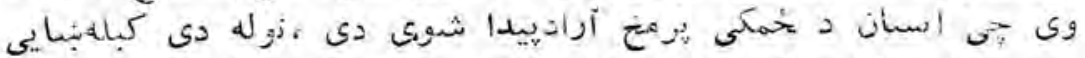

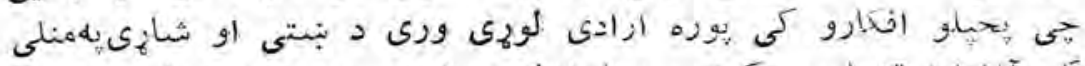

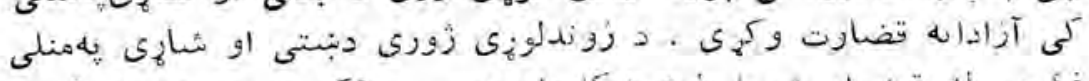

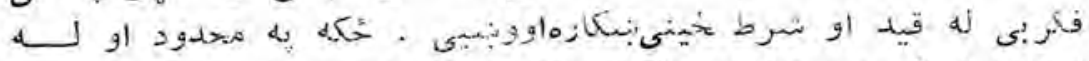

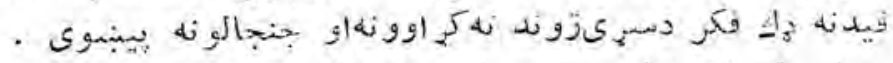

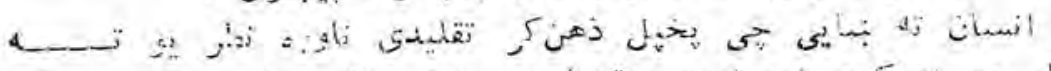

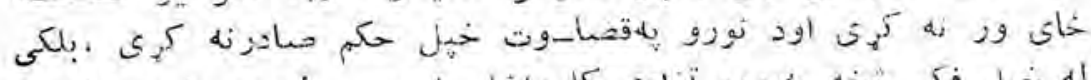

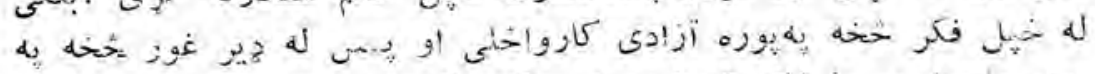

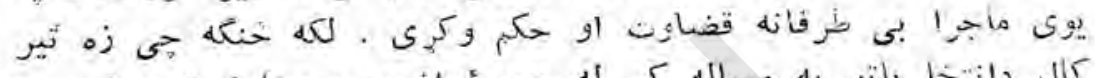

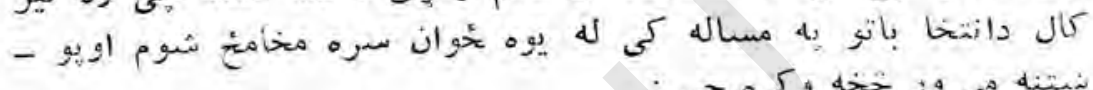
: بن

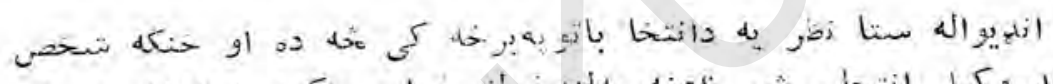

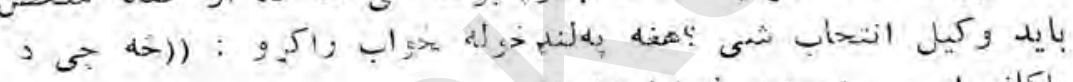

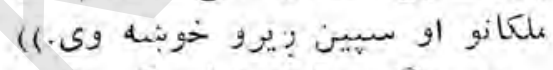

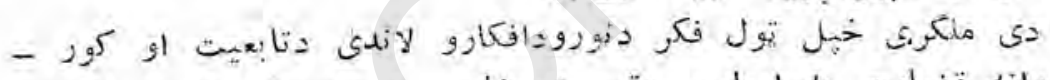

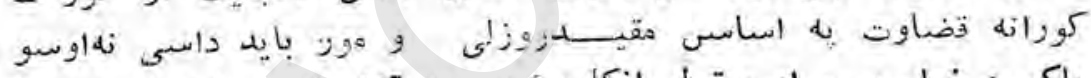

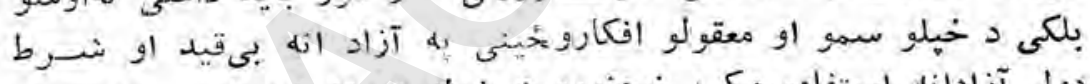

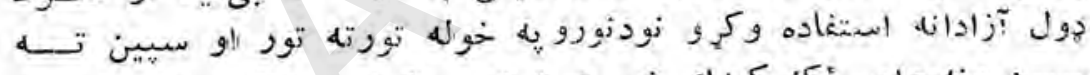

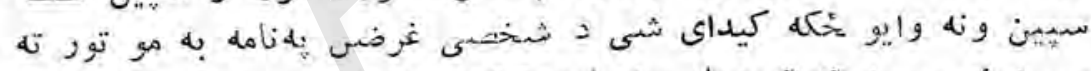

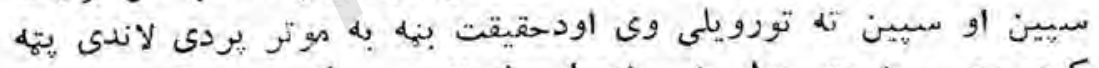

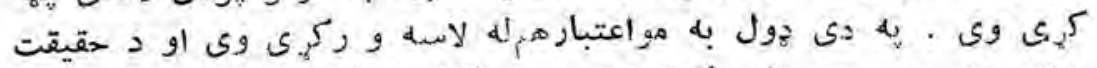

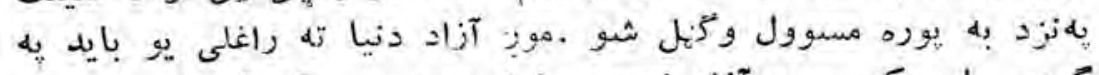

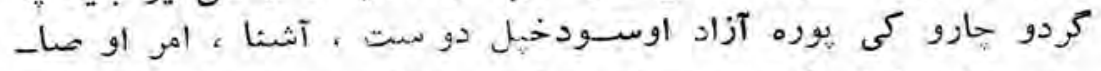

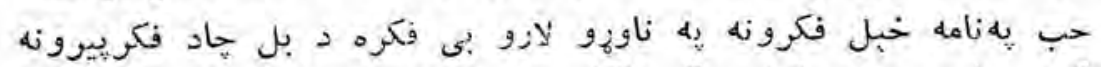

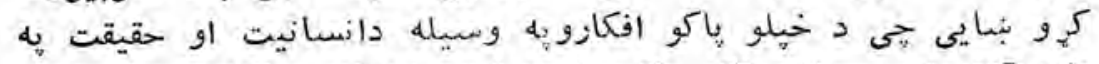

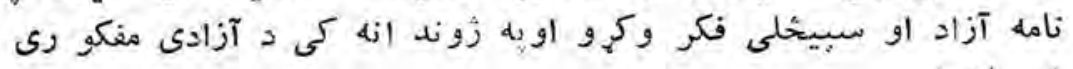

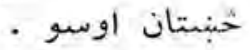




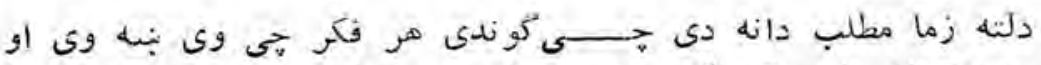

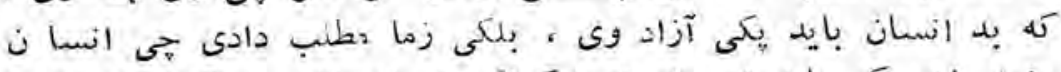

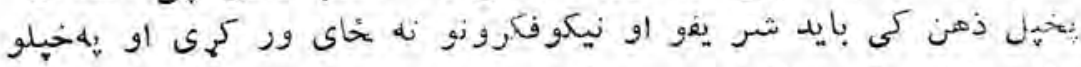

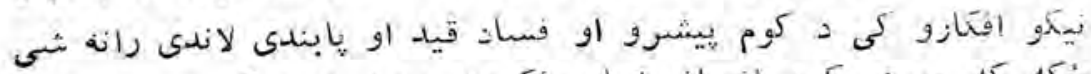

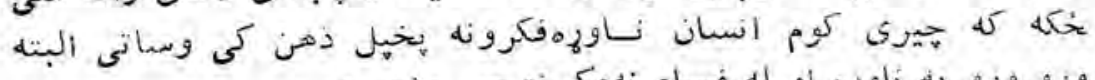

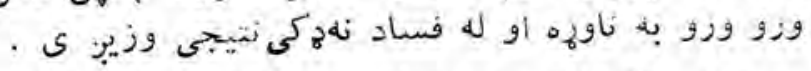

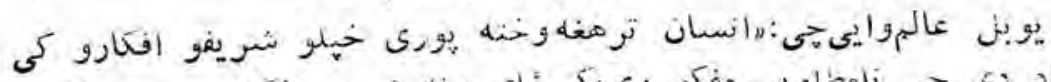

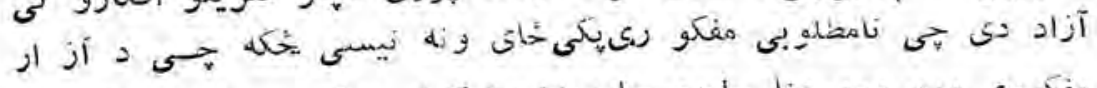

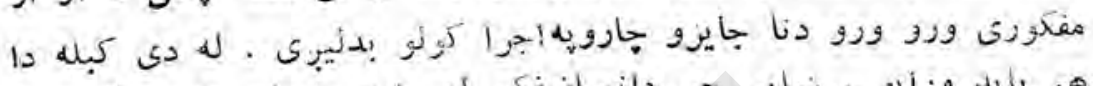

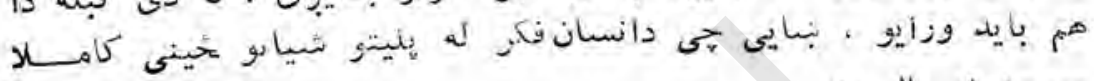

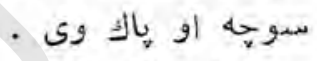

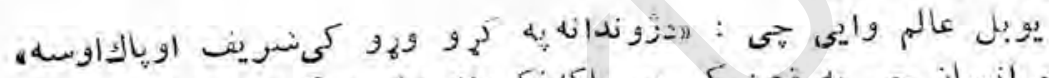

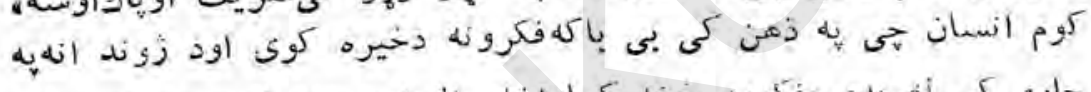

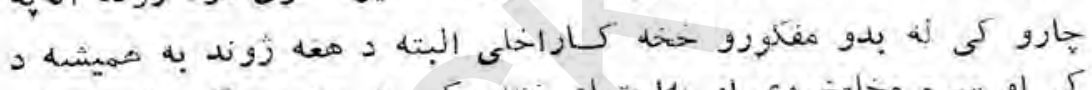

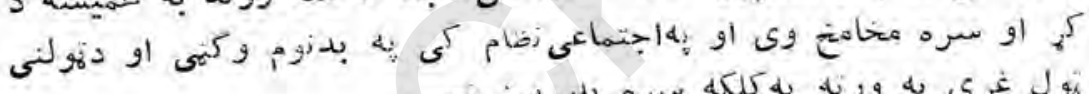

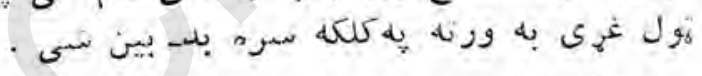

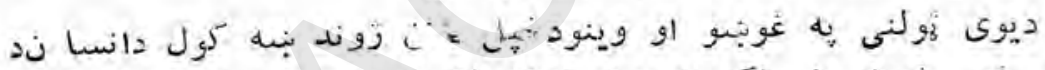

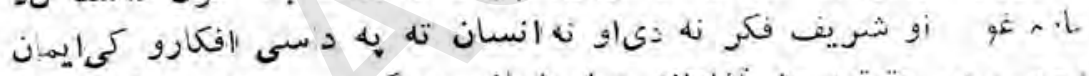

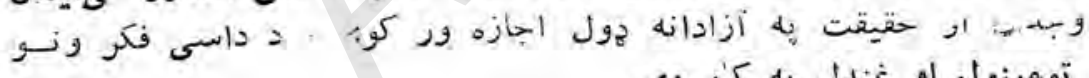

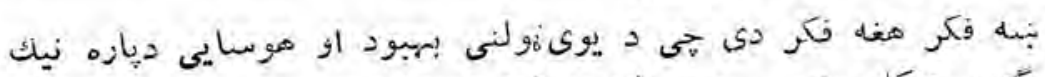

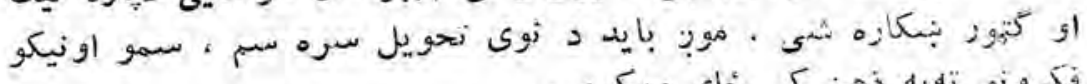

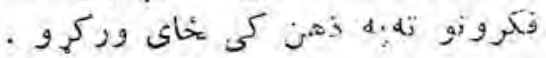

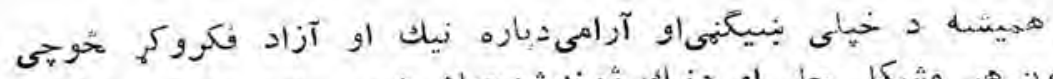

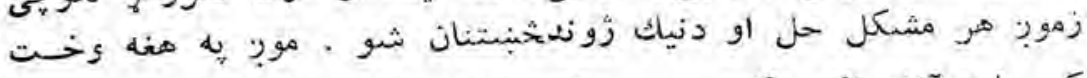

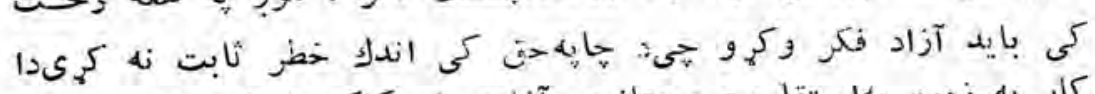

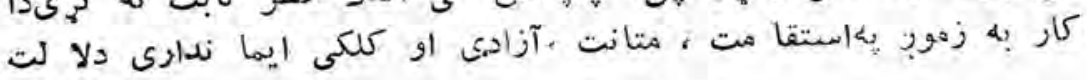


وكيى او بس (1)

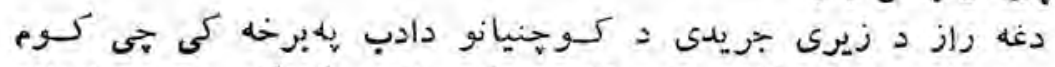

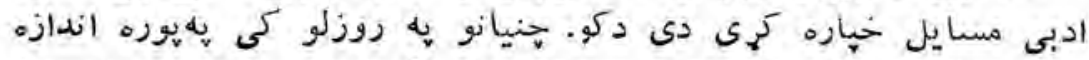

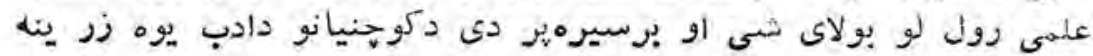

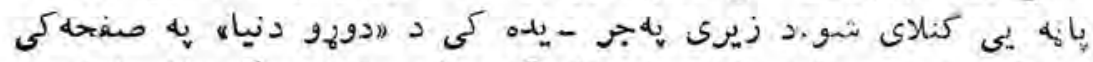

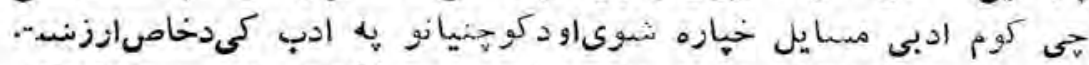

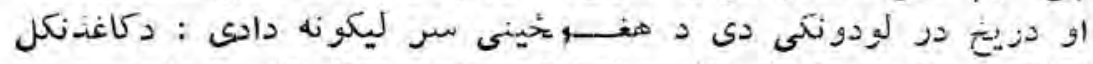

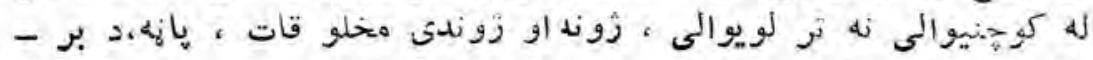

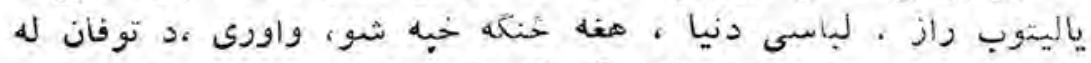

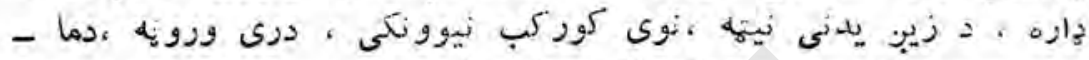

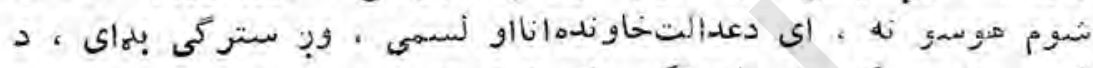

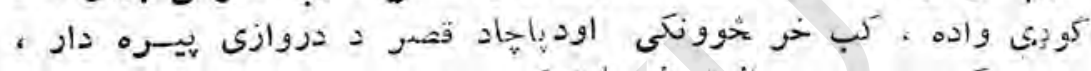

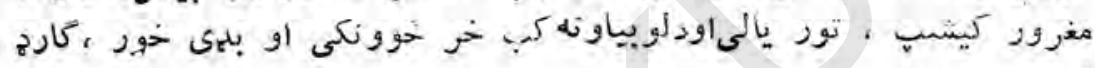
... gl

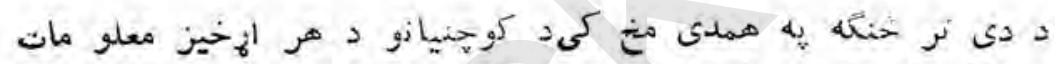

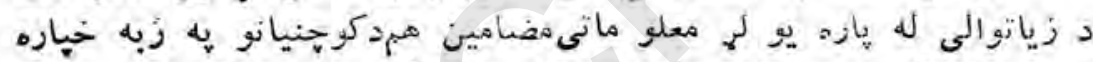

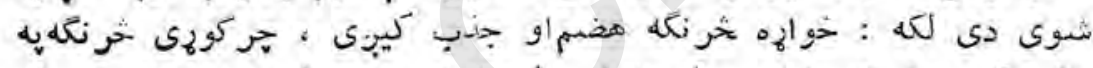

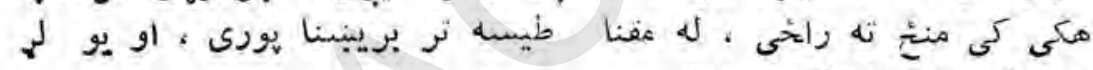

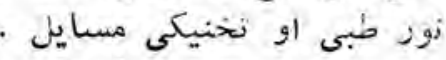

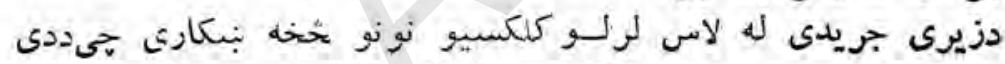

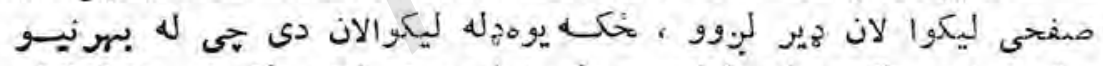

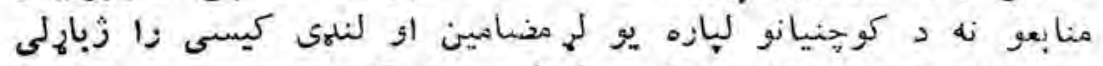

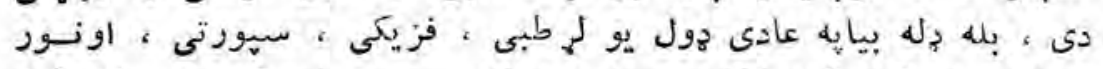

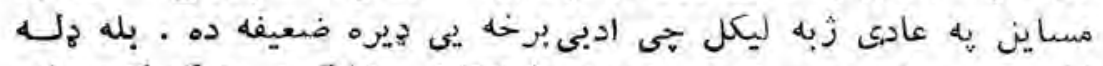

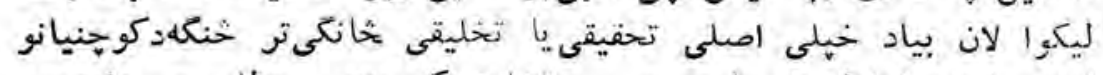

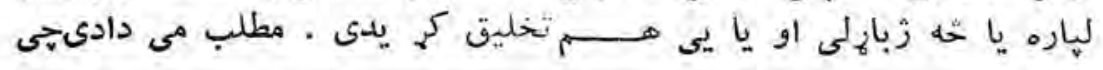

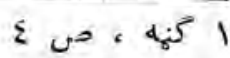

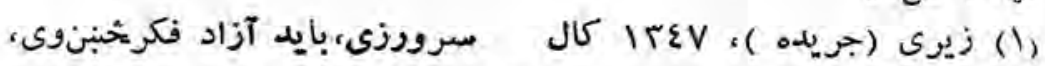




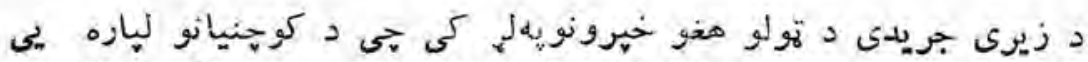

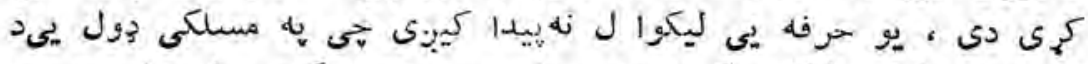

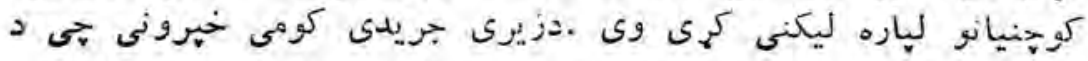

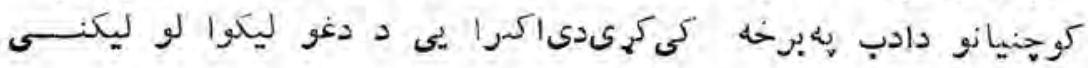

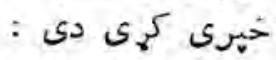

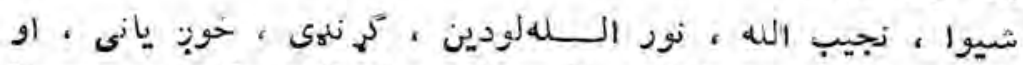

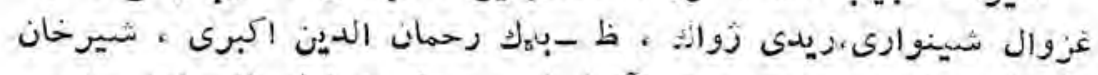

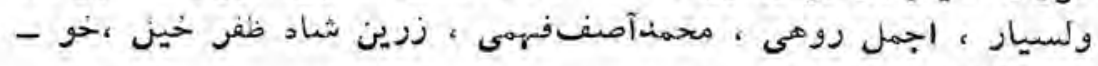

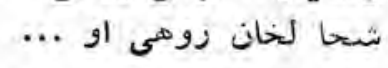

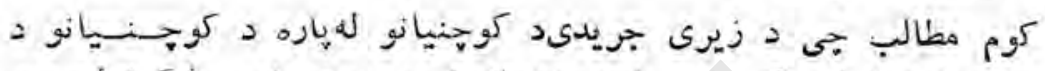

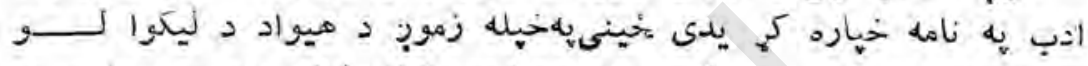

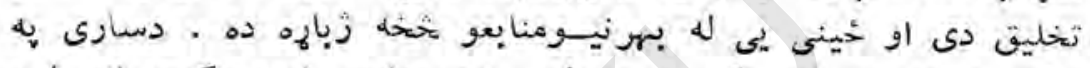

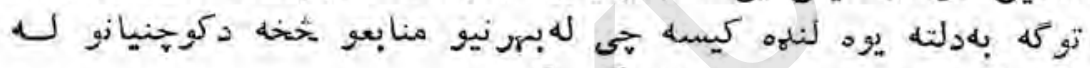

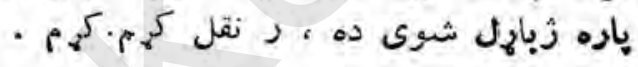

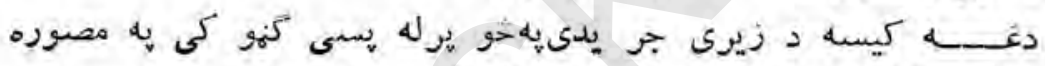

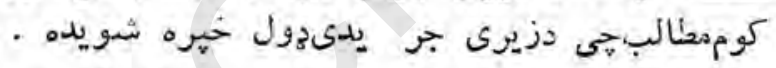

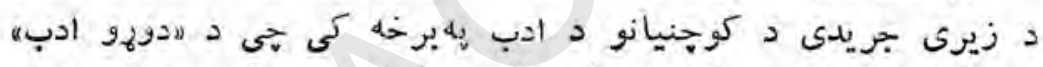

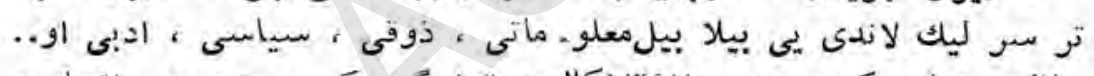

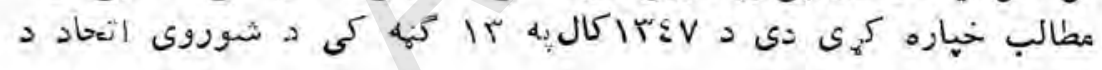

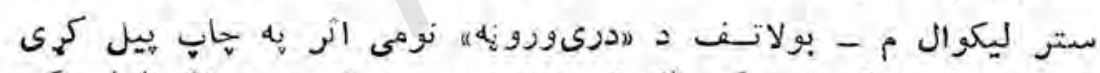

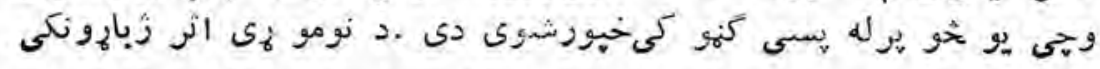

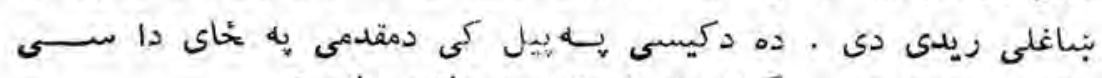

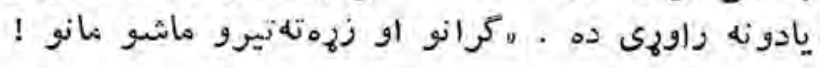

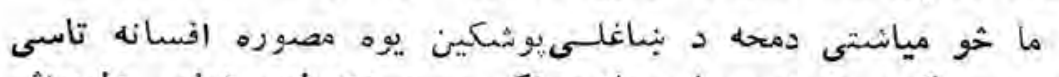

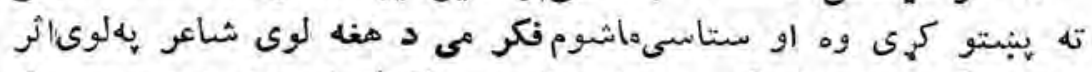

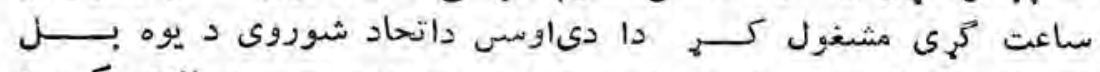

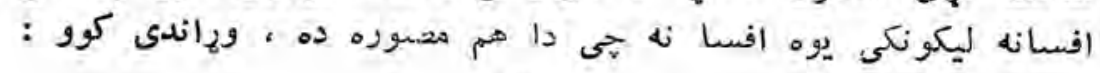
- or- 


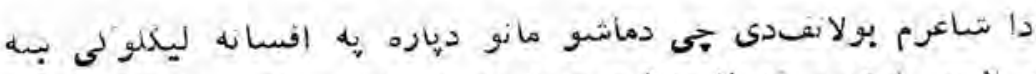

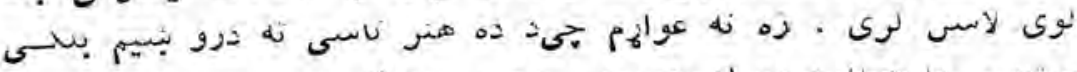

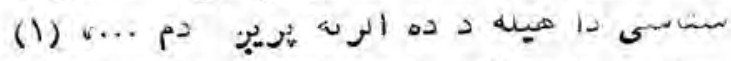

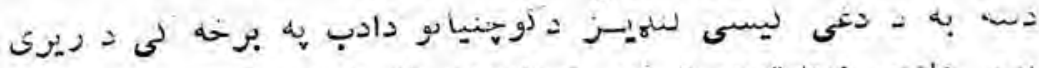

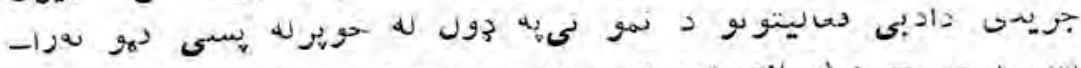

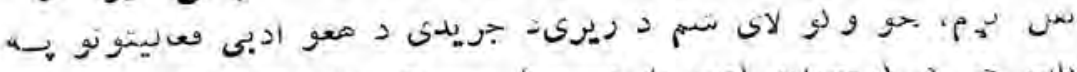

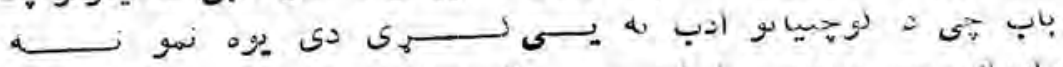

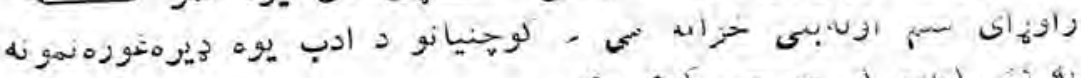
.

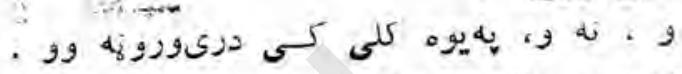

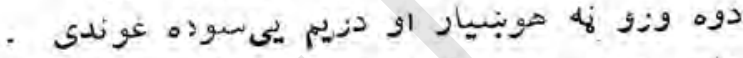

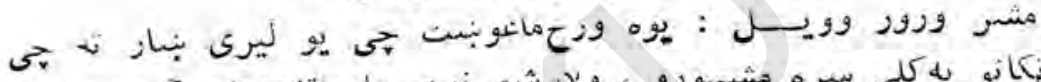

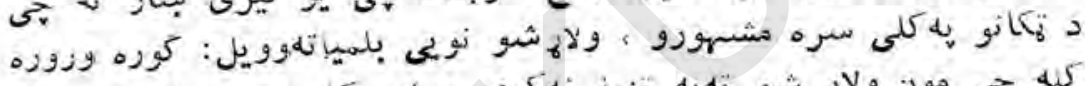

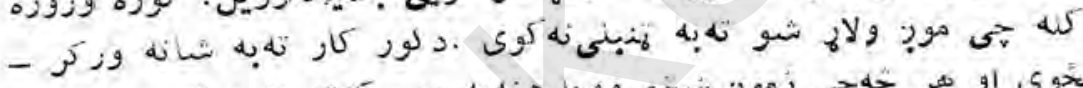

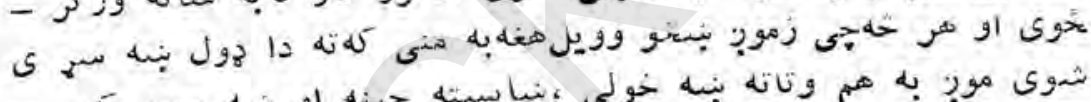

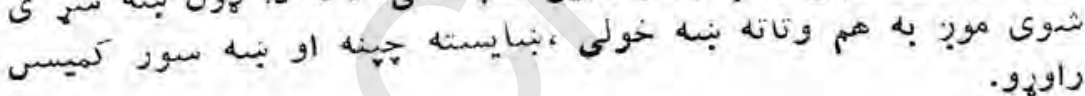

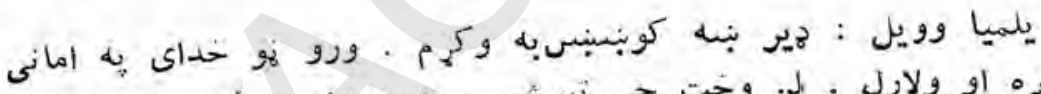

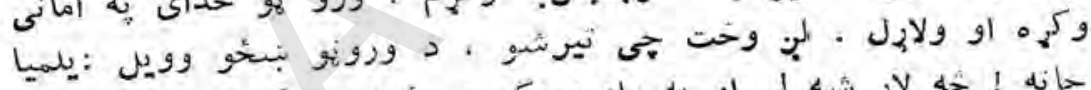

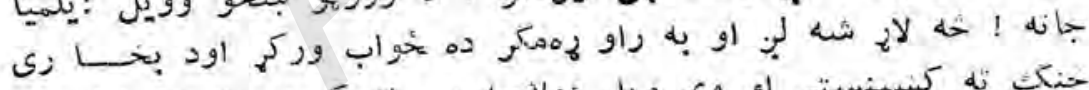

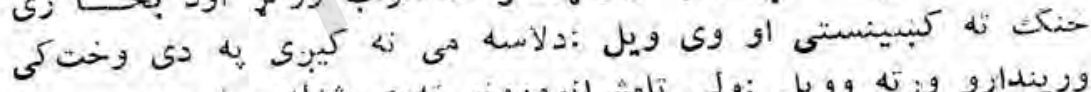

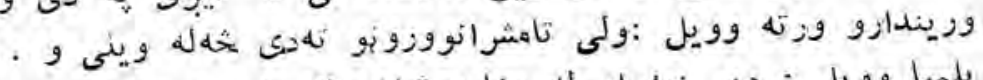

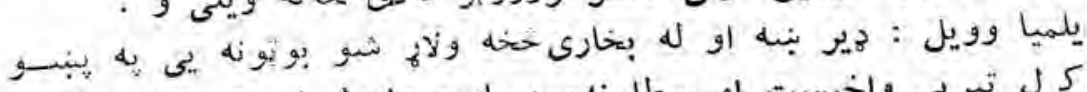

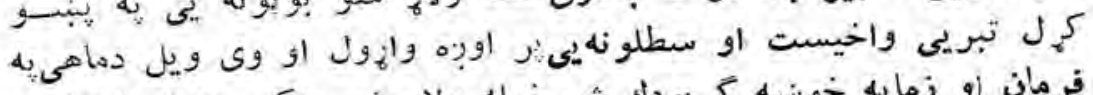

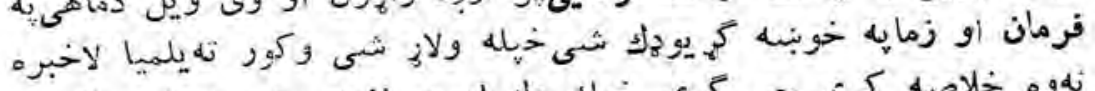

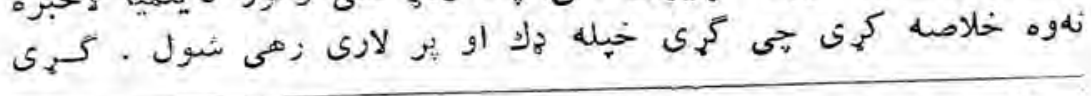

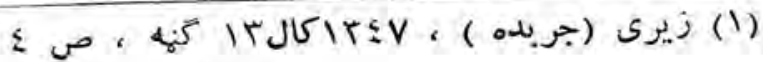


لكه ايلى كابه وابِه ير لارى تلـاويلميا د دوى تر شارهى و خنـدل

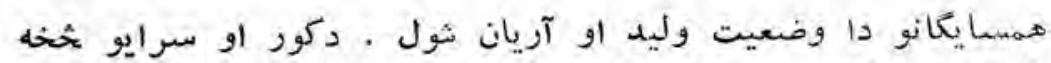

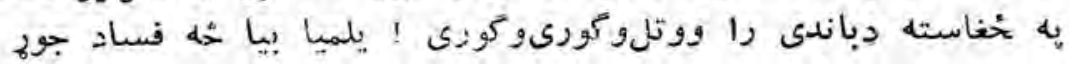

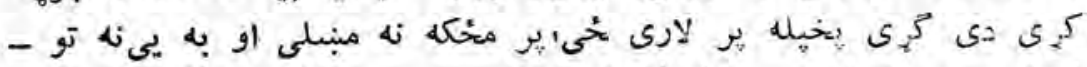

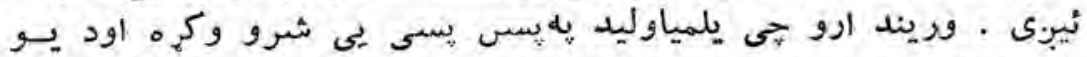

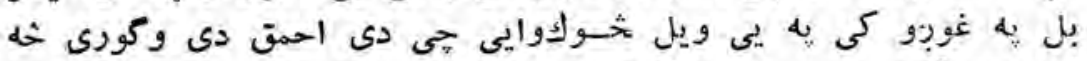

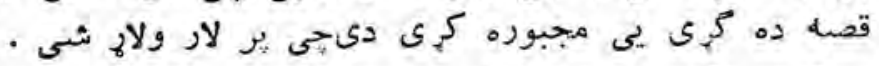

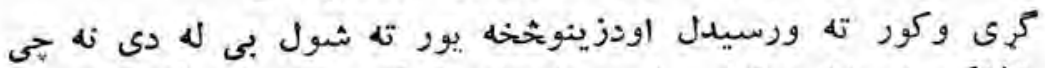

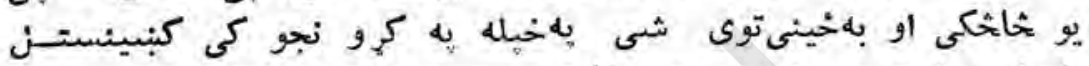

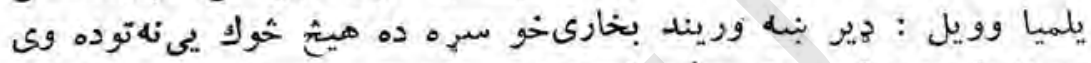

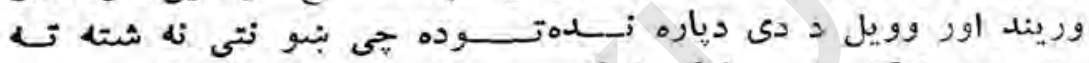

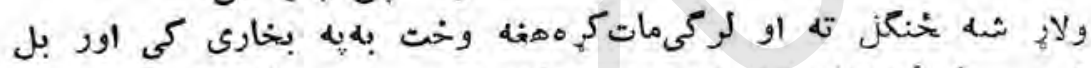

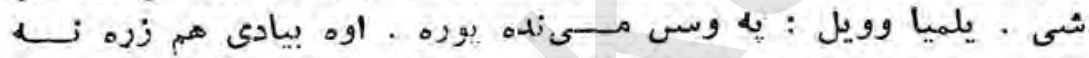

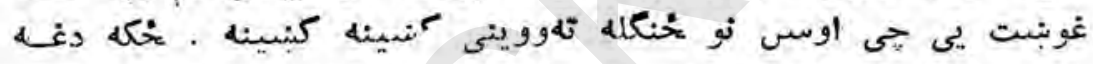

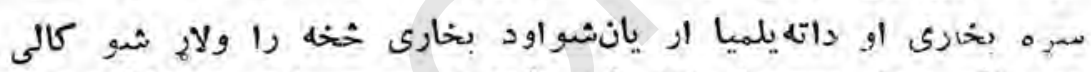

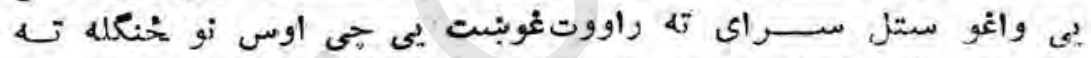

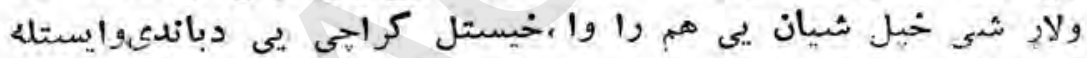

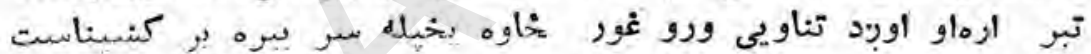

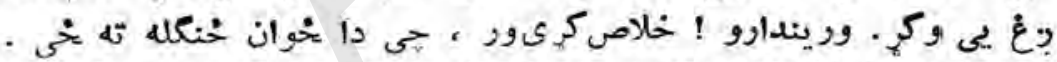

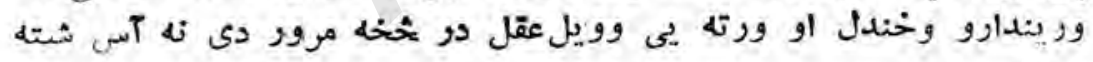

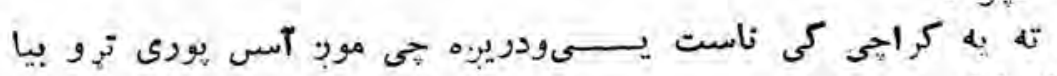
ولايح شه . ماته

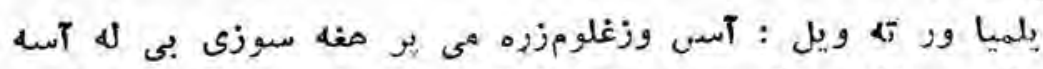

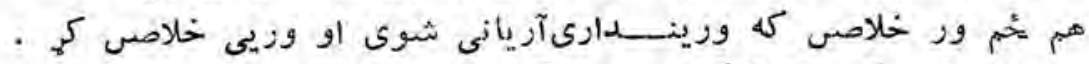

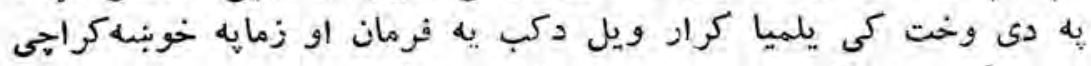

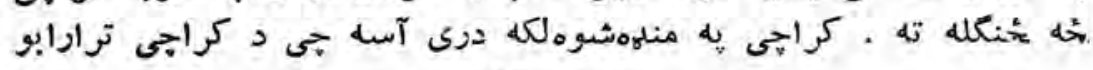




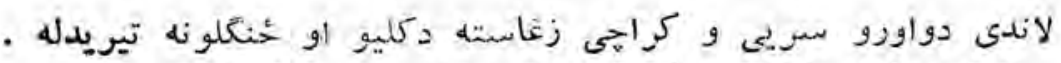

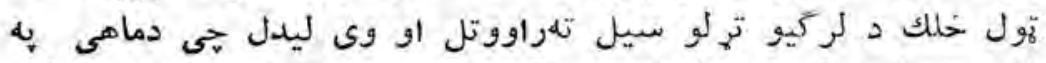

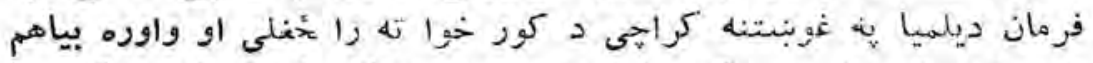

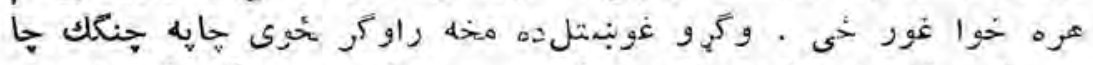

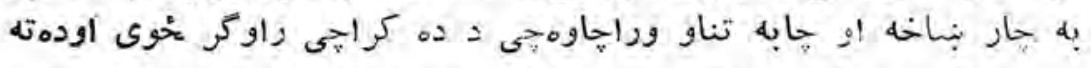

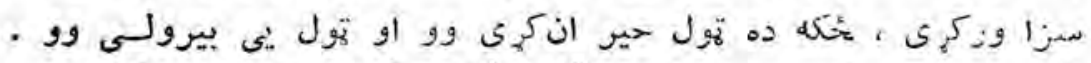

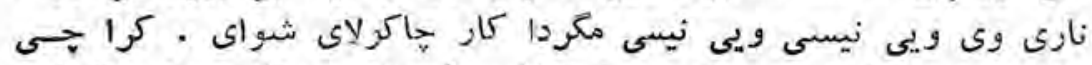

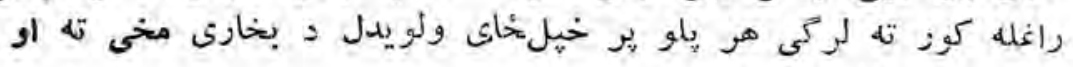

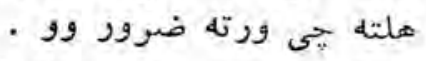

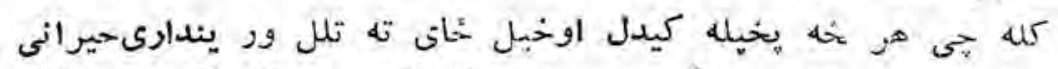

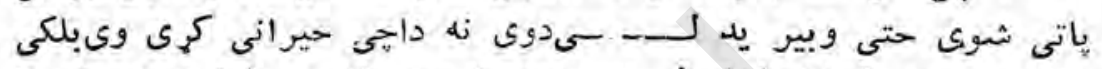

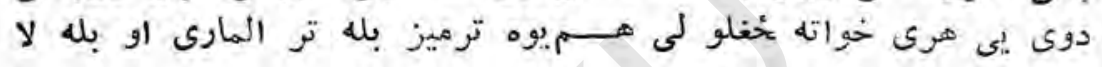

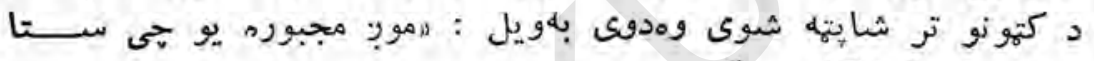

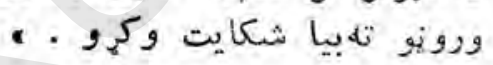

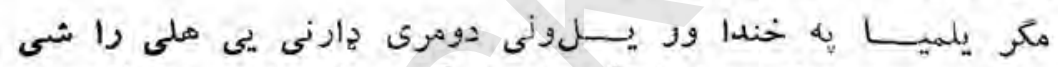

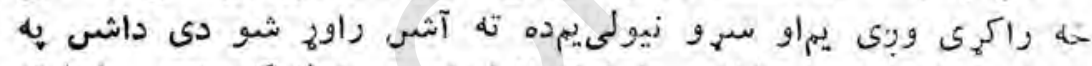

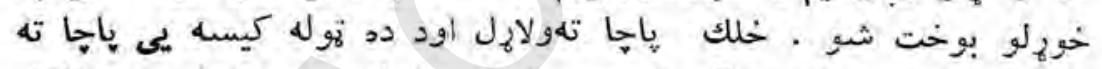

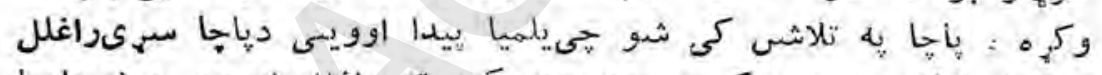

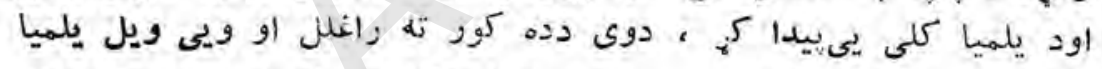

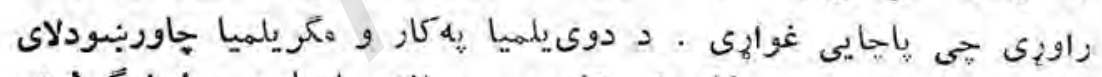

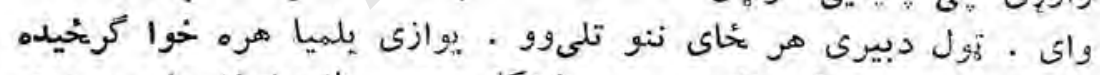

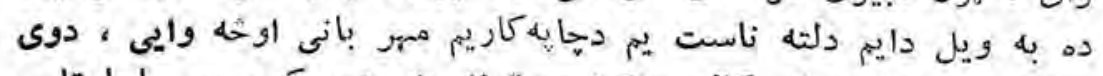

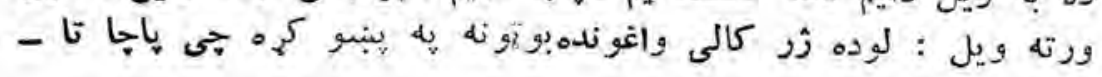
غورازئ ورته

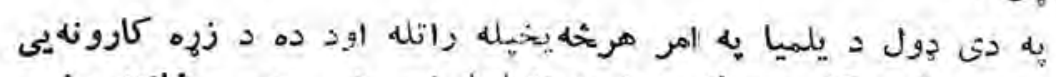

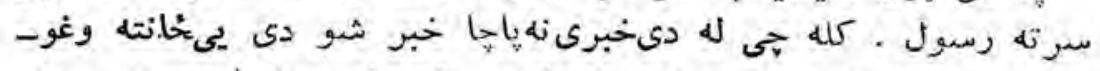

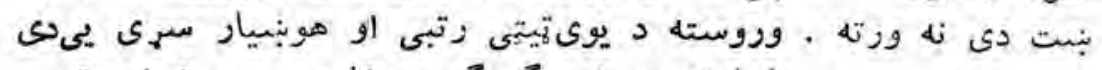

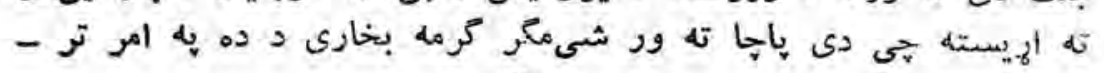
- O L 


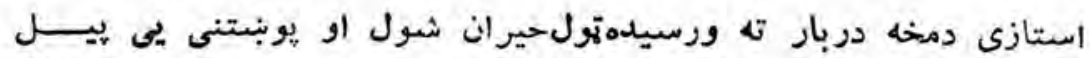

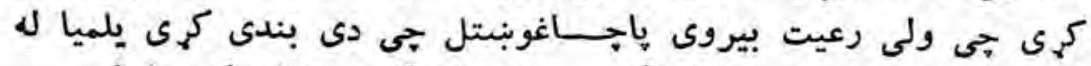

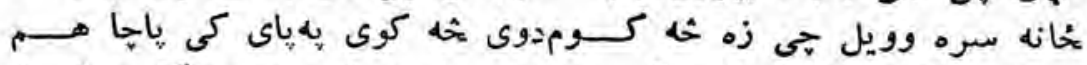

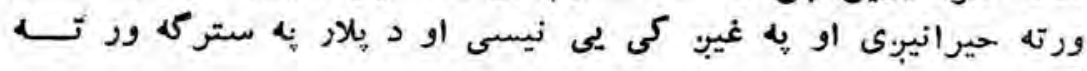
كورى .

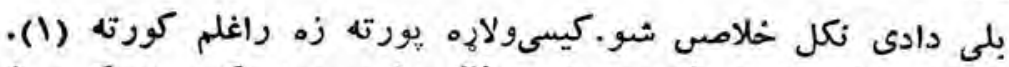

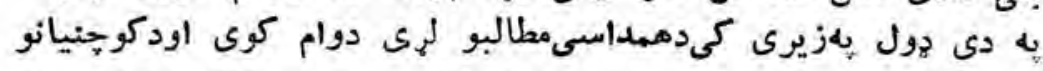

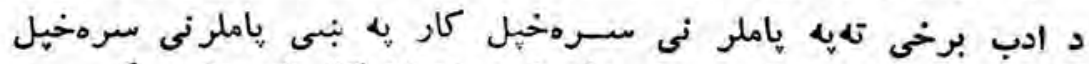

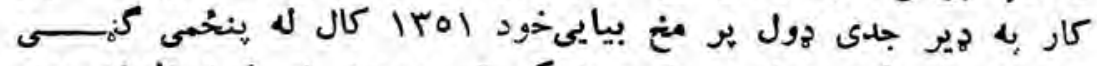

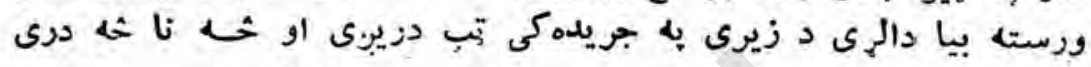

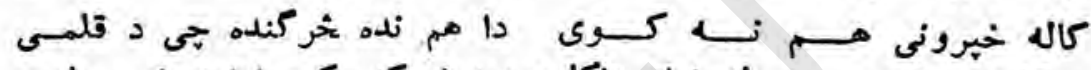

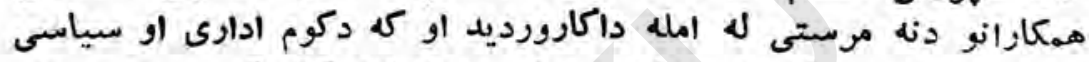

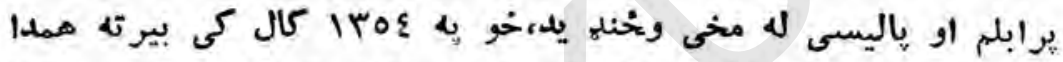

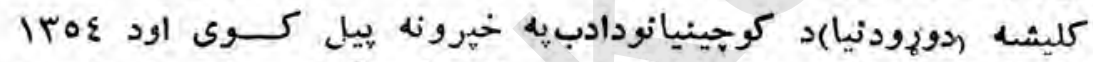

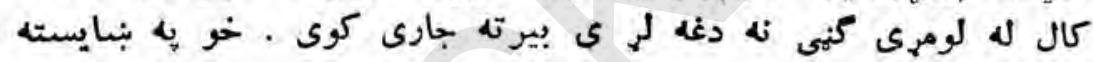

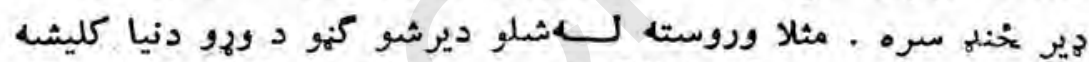

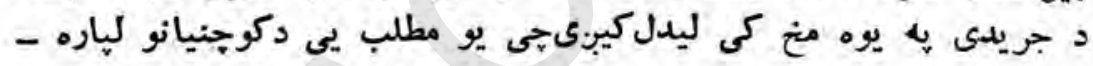

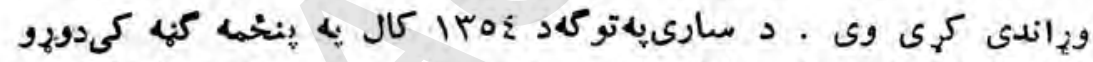

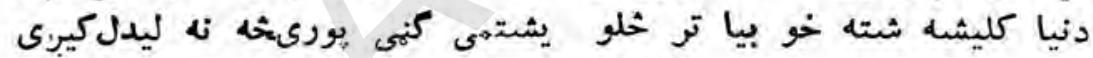

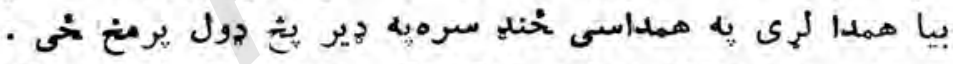

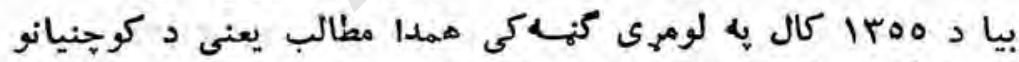

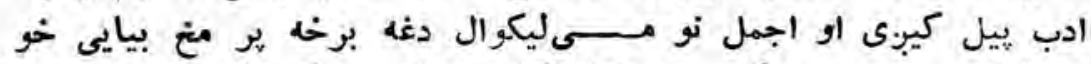

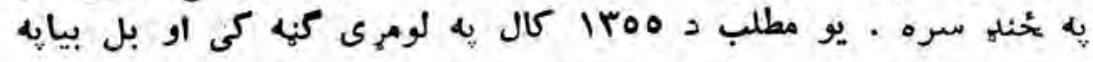

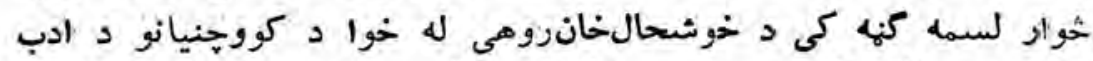

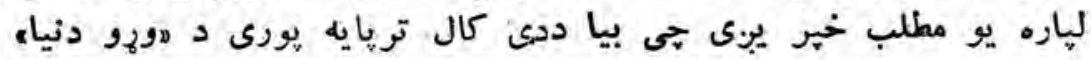

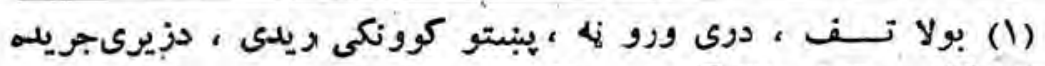
ع ש ז $-\bullet V_{-}$ 


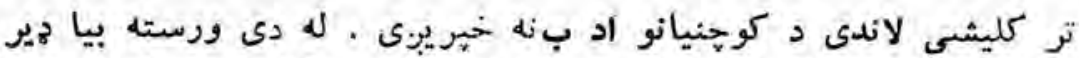

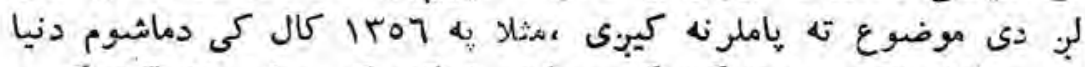

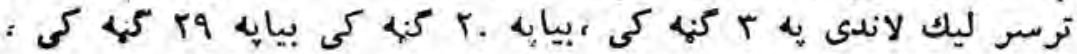

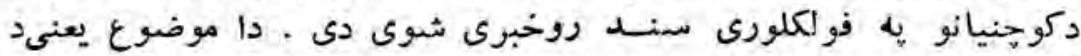

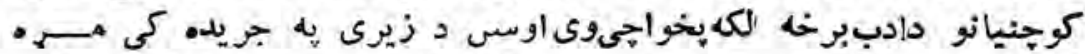

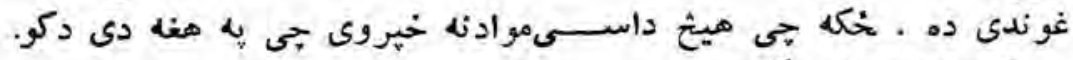

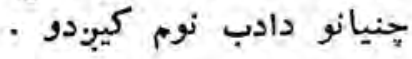

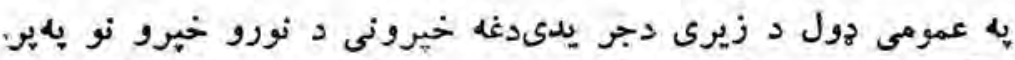

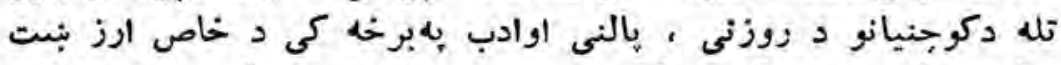

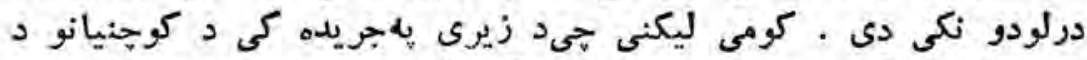

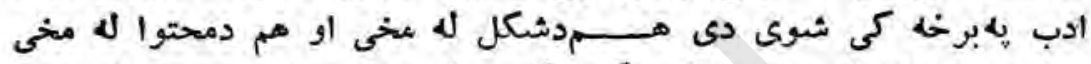

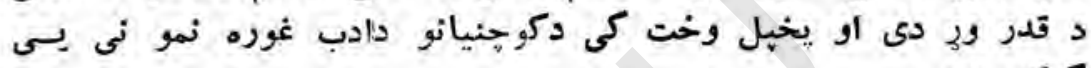

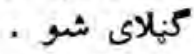

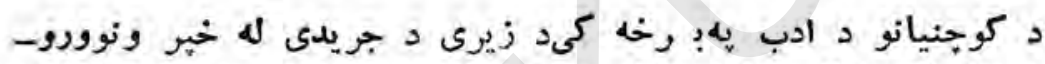

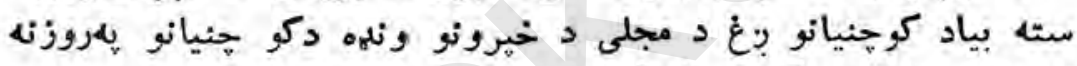

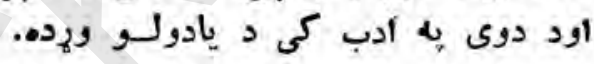

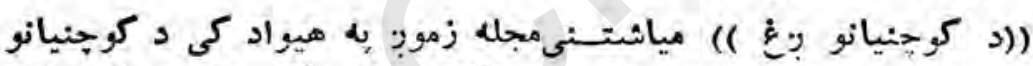

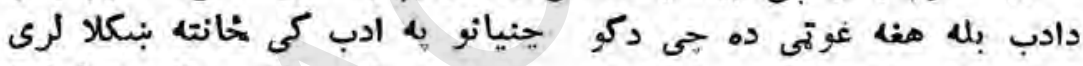

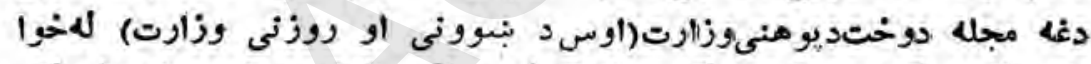

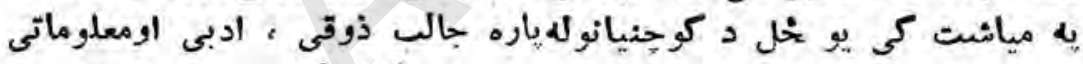

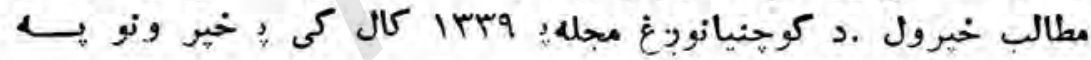

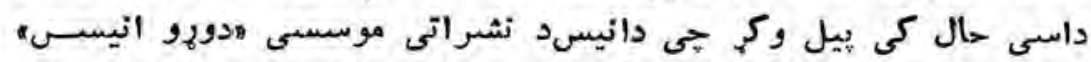

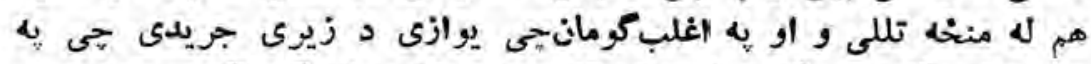

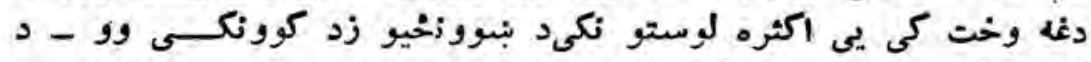

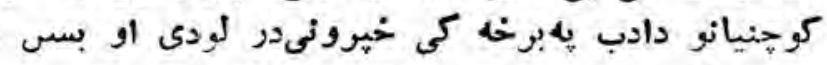

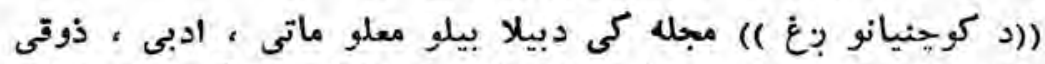

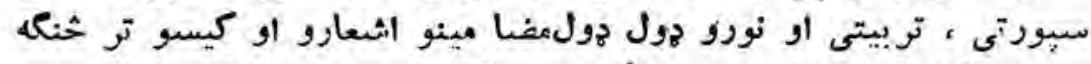

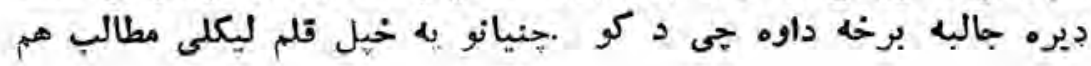


خهريدل اود يوى د تشوين لبازهيىدممتازو كو جنيانو عكسو نه هـم

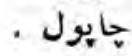

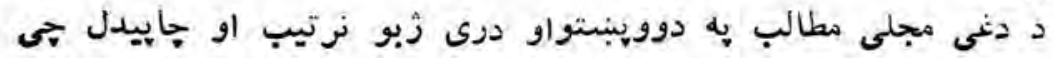

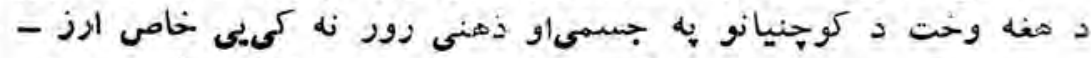

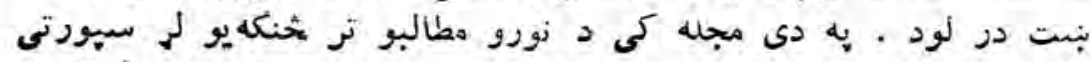

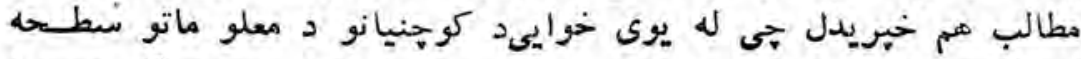

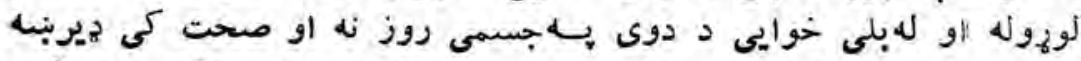

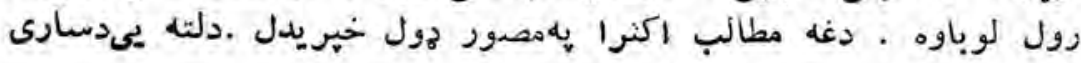

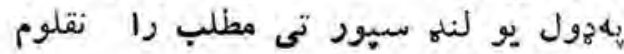

\section{دسيورت اهميت}

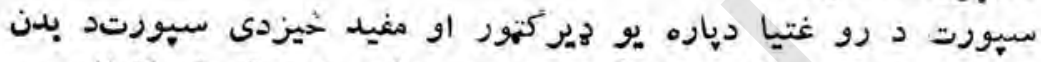

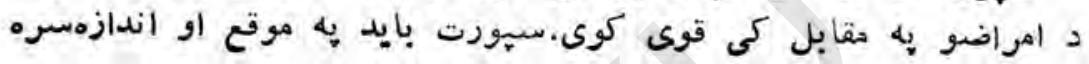

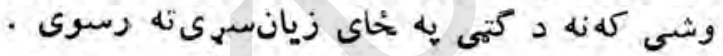

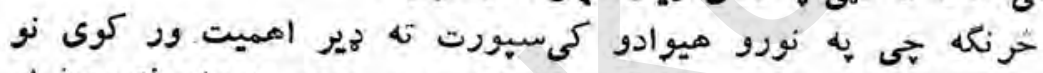

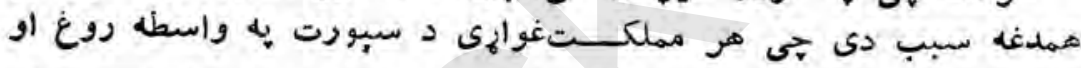

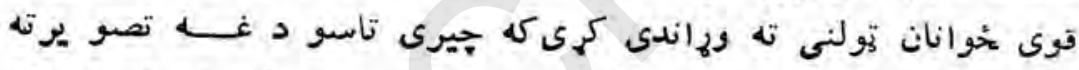

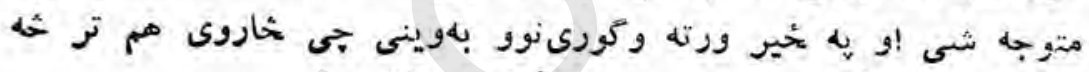

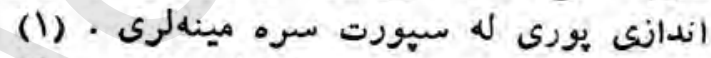

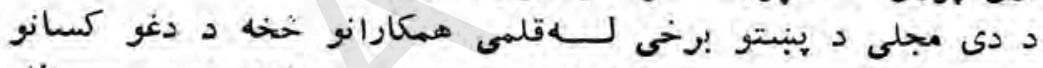

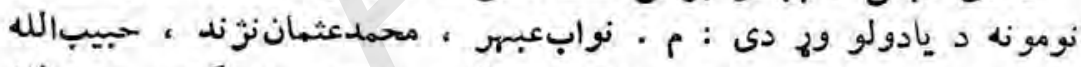

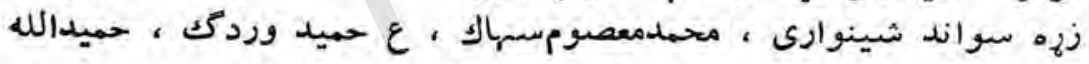

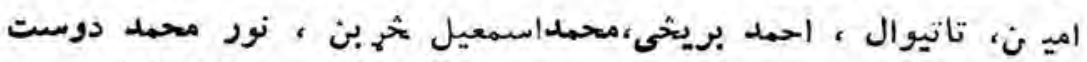

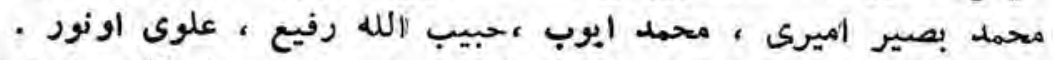

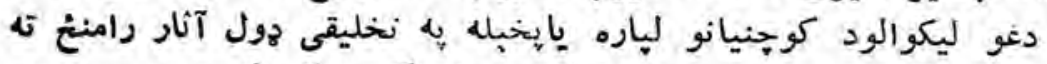

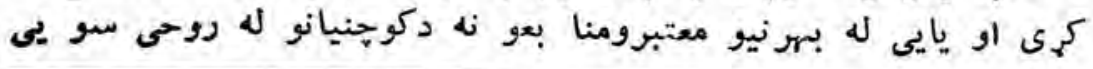

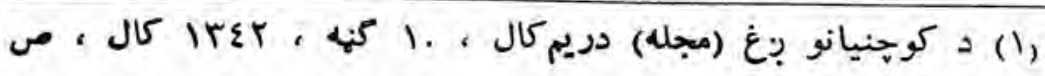




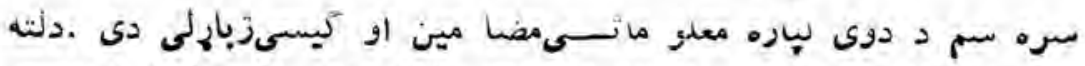

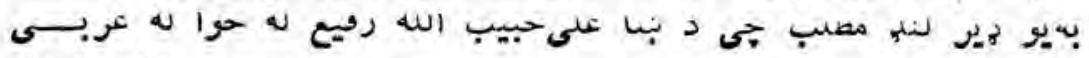

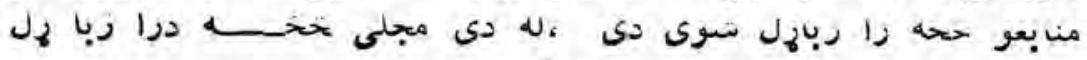

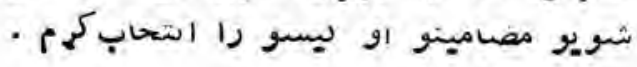

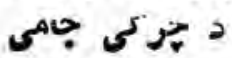

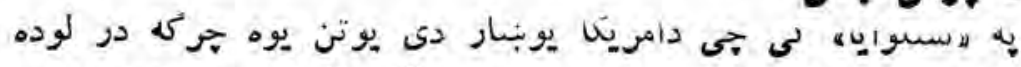

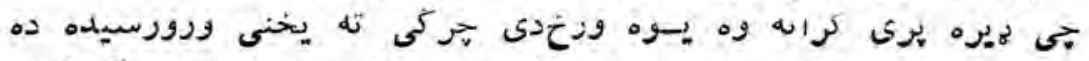

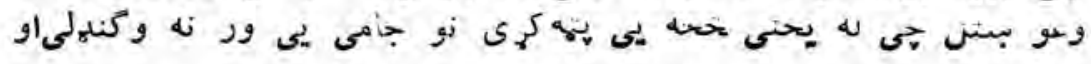

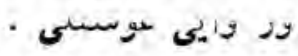

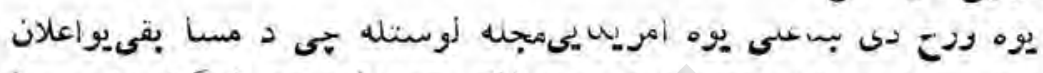

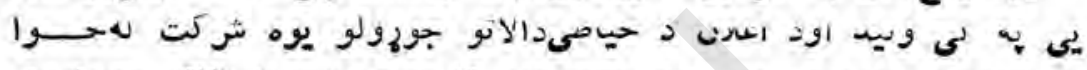

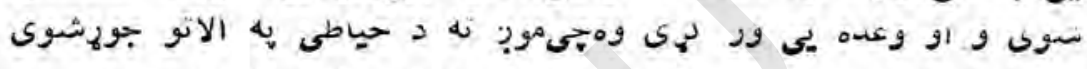

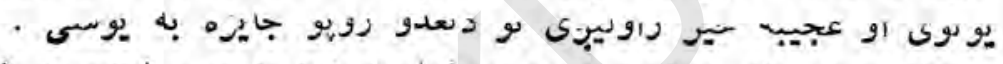

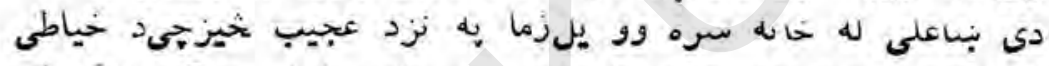

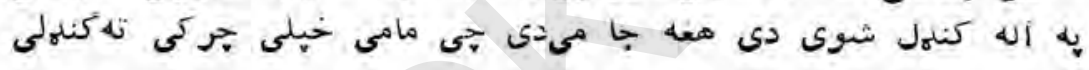

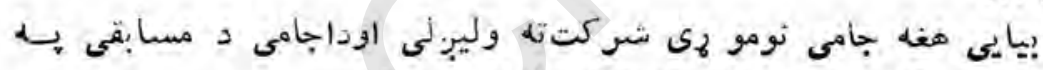

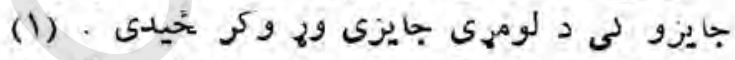

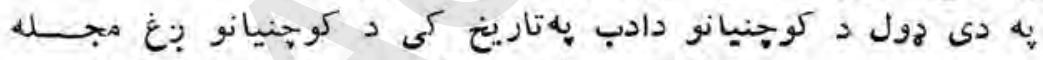

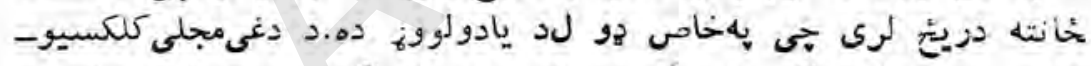

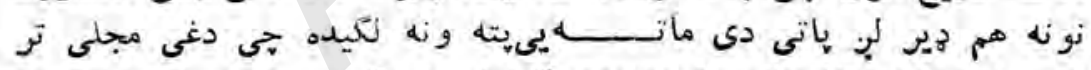

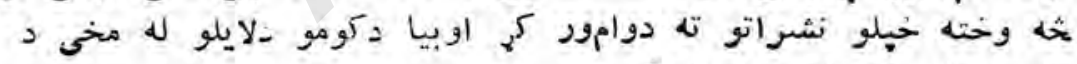

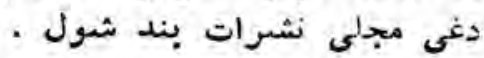

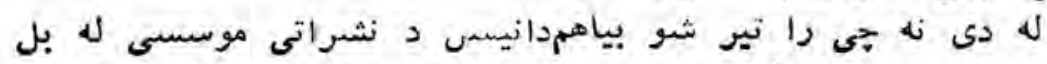

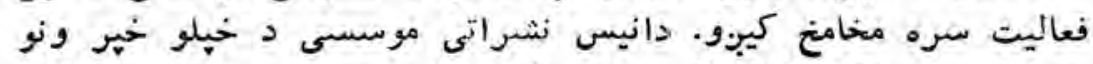

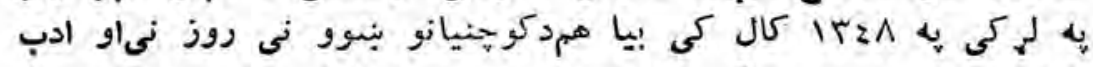

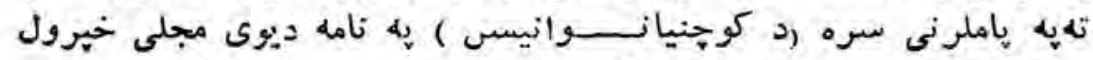

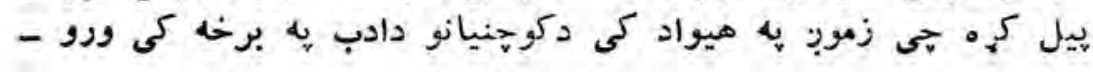

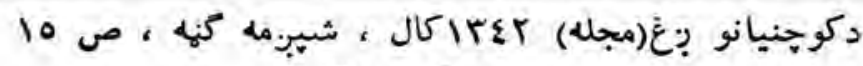




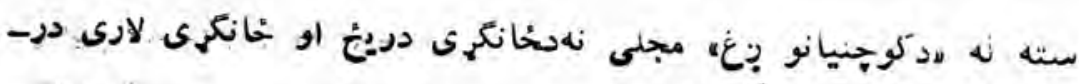
لودونكى مجله كهل كيله كيبنى

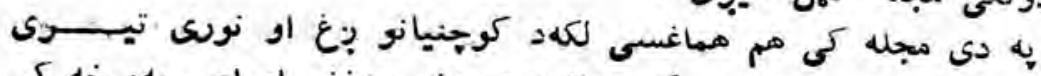

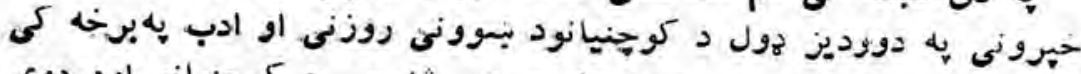

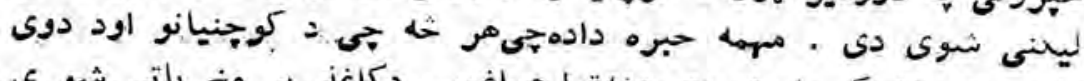

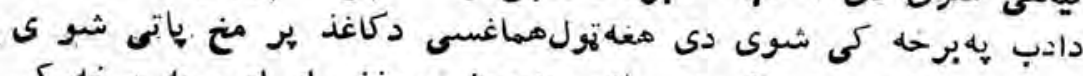

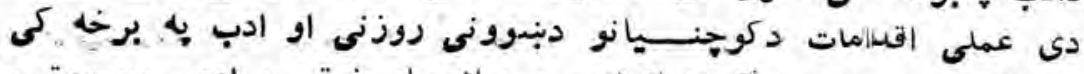

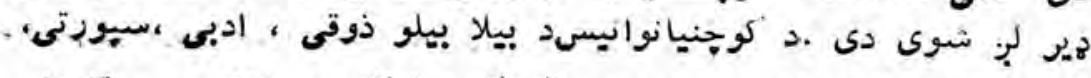

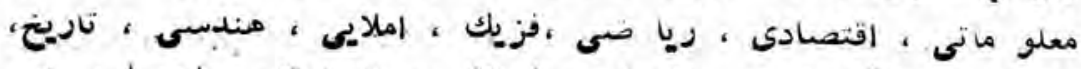

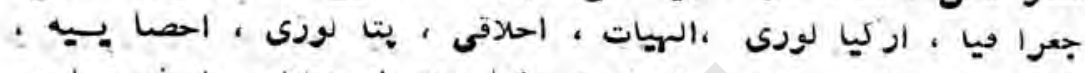

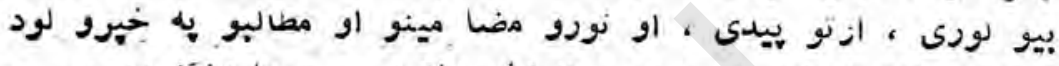

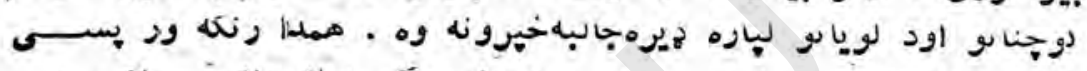

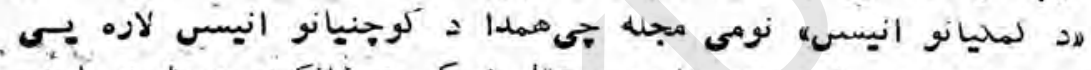

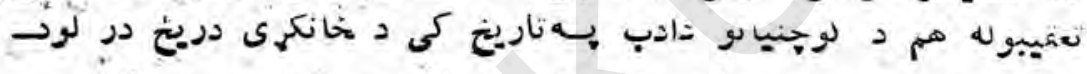

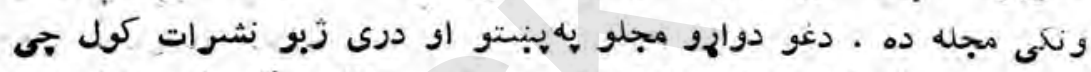

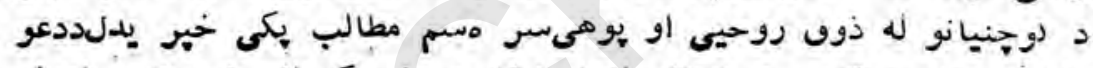

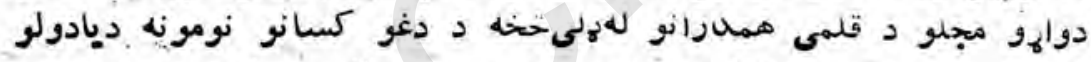

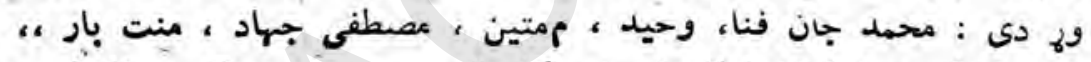

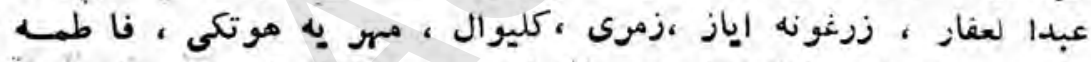

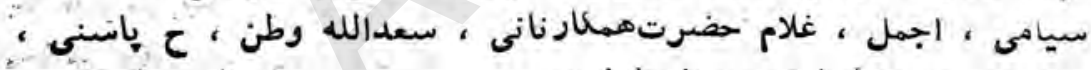

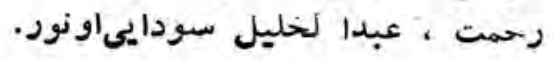

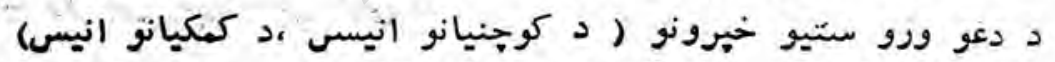

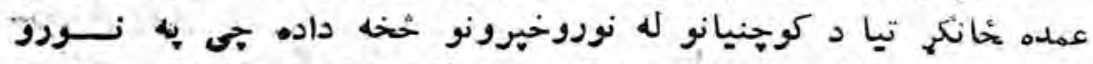

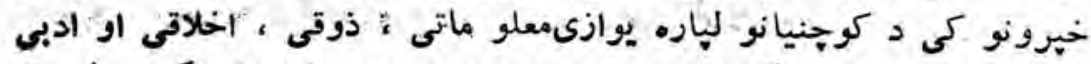

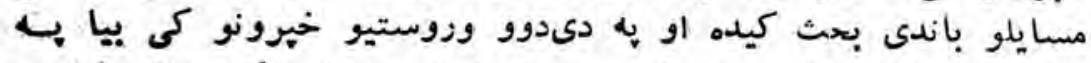

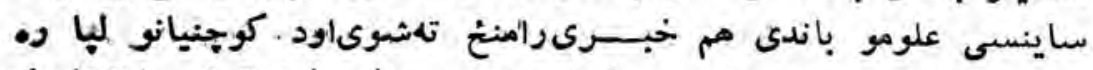

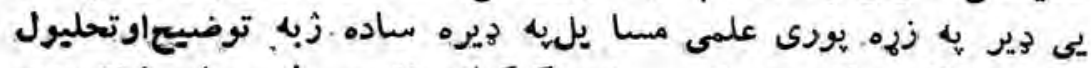

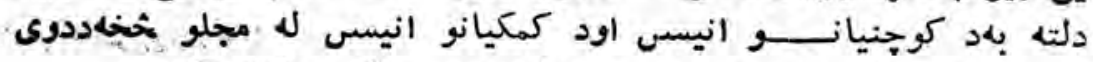

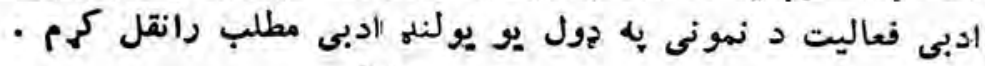




\section{حكن كاكا هم بُّه مغوان و}

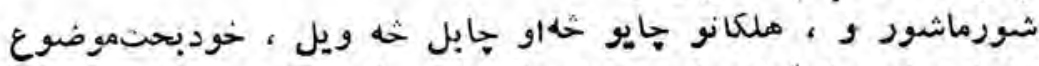

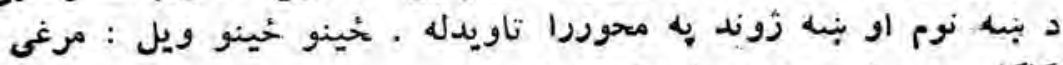

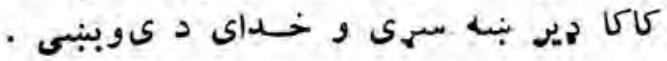

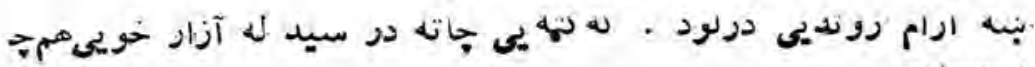

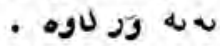

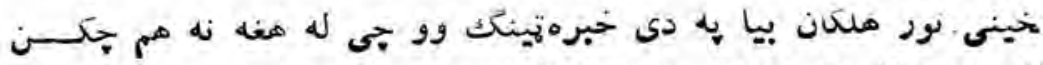
كv

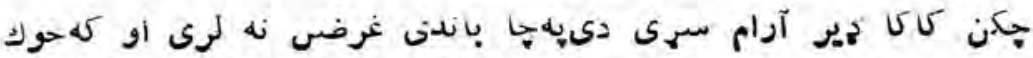

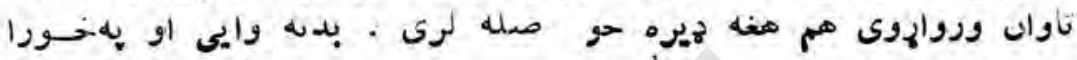

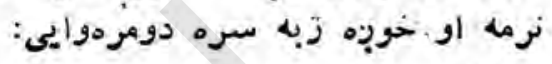

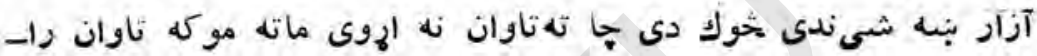

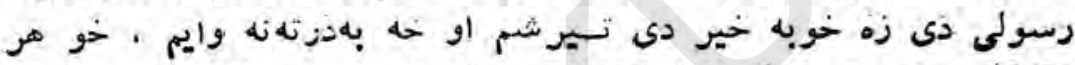

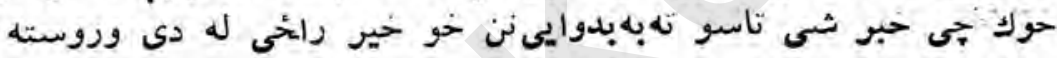

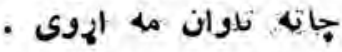

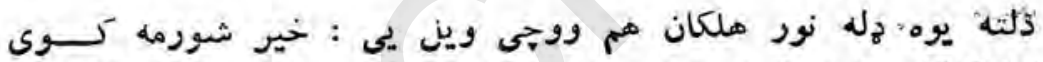

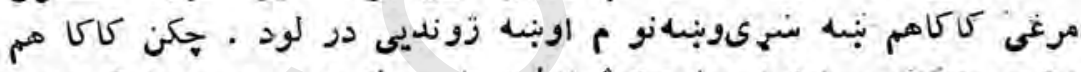

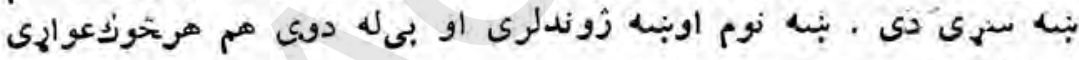

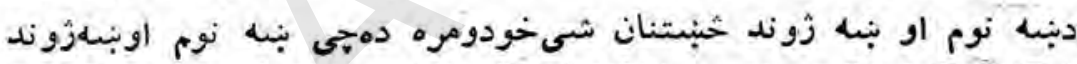

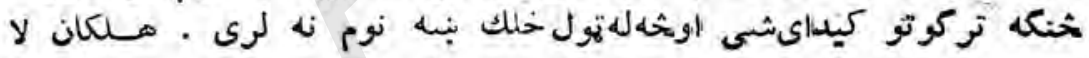

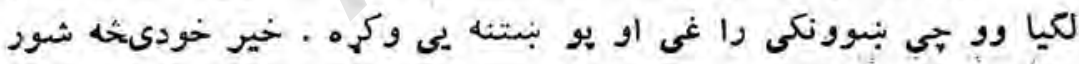

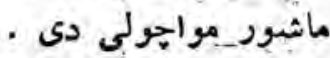

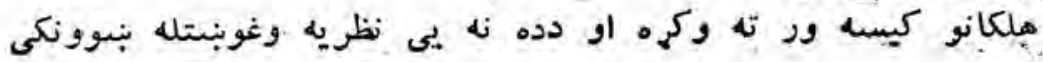
وويل : بنه نوم او بنه روند خورا بنبه موضوع دد او موب بهابه ننتى لوست

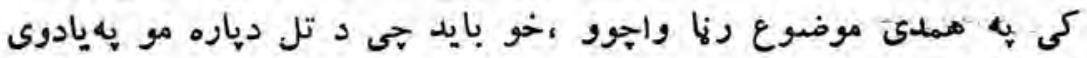

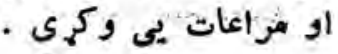




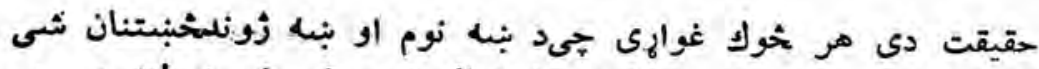

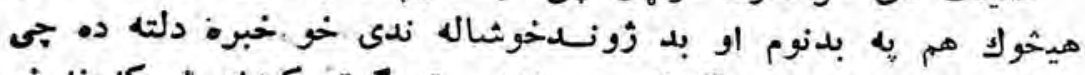

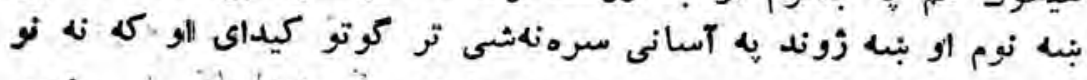

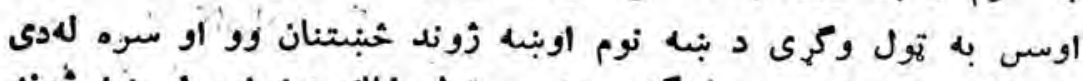

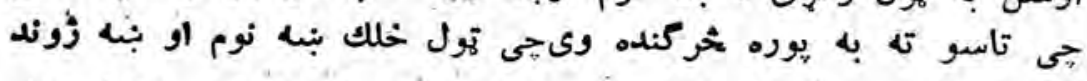

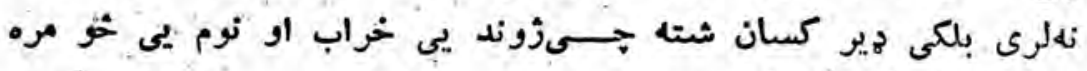

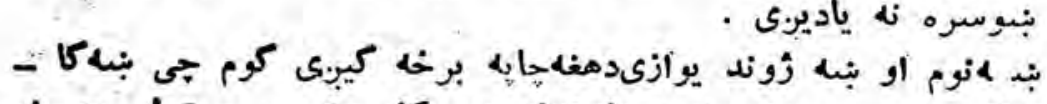

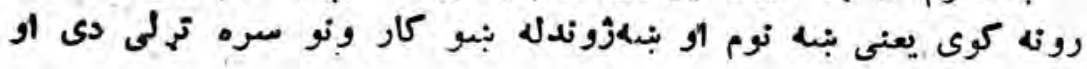

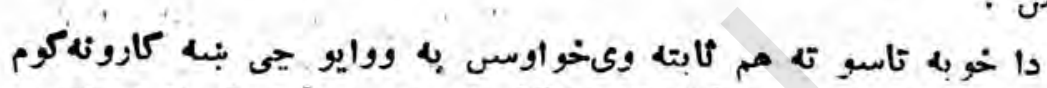

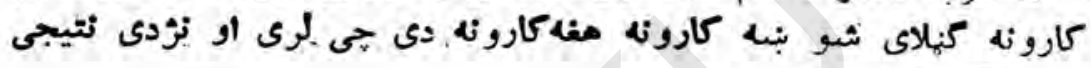

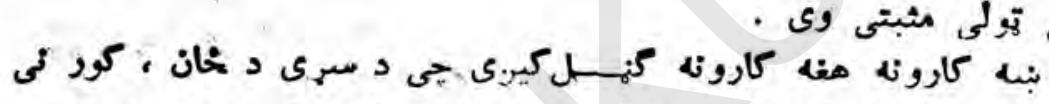

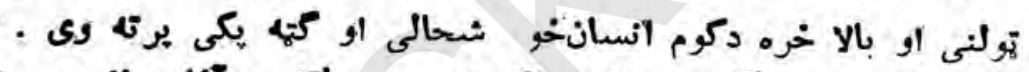

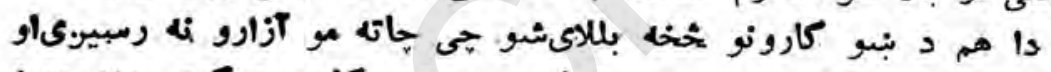

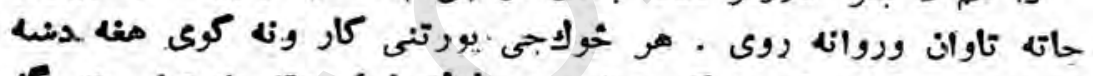

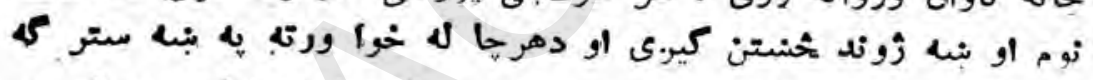

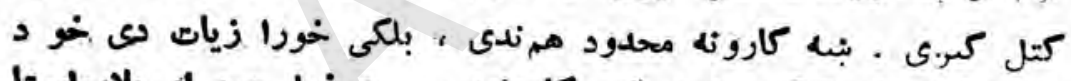

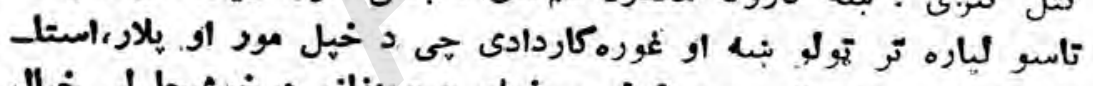

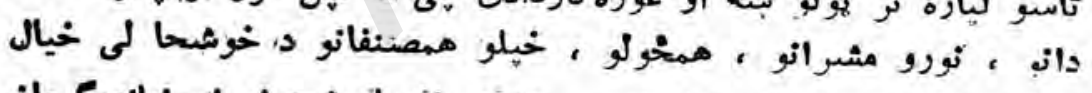

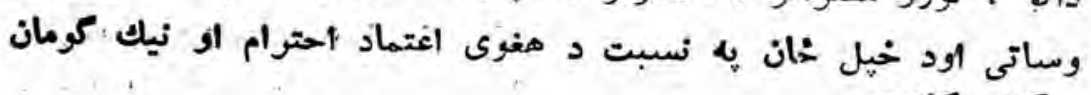

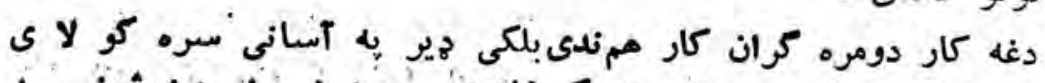

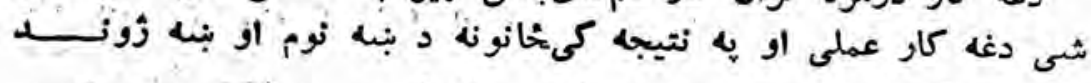

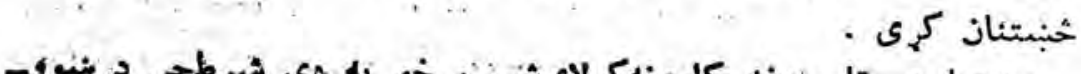

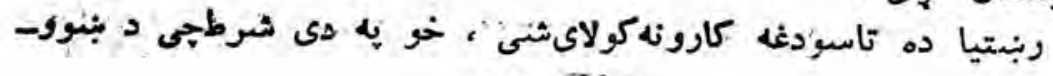
-7r_ 


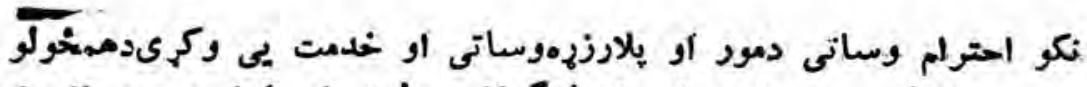

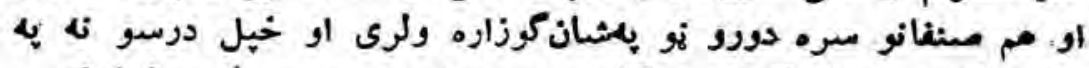

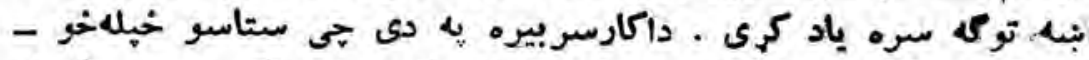

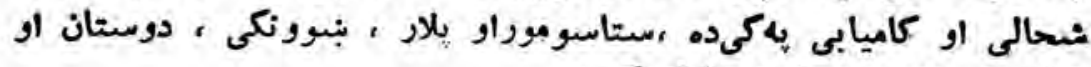

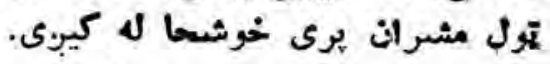

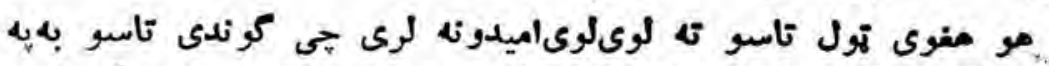

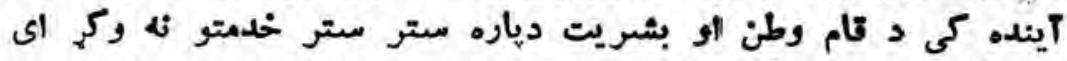

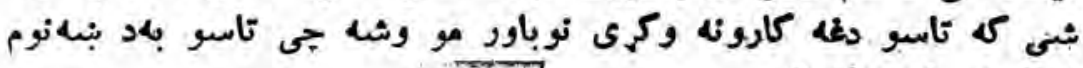

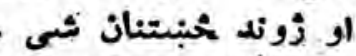

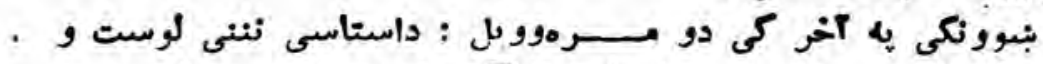

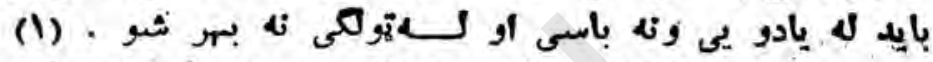

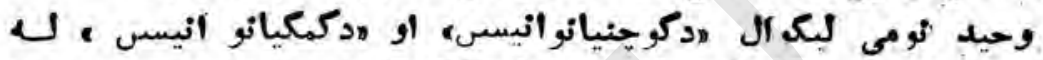

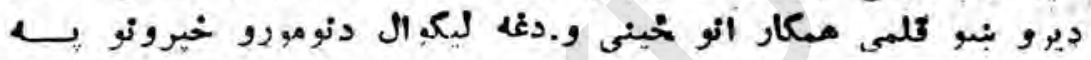

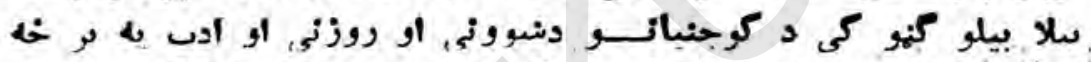

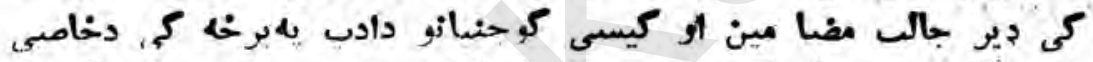

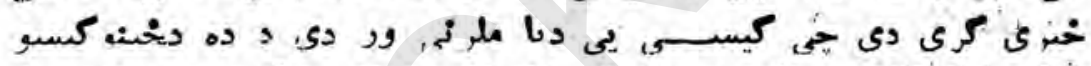

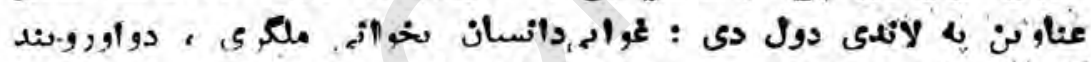

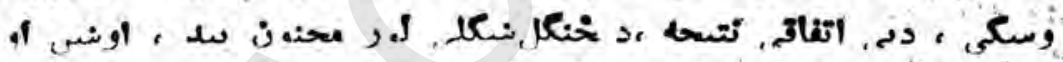

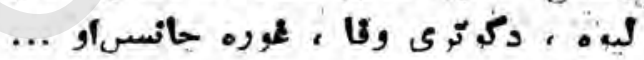

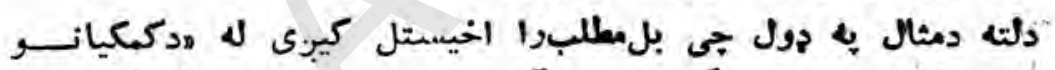

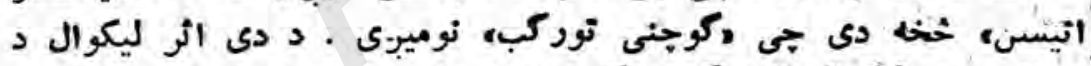

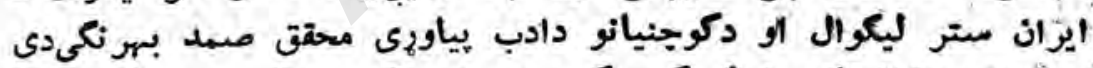

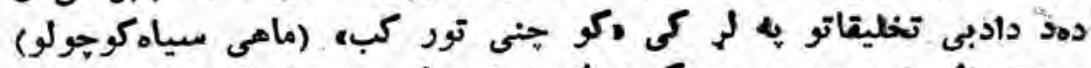

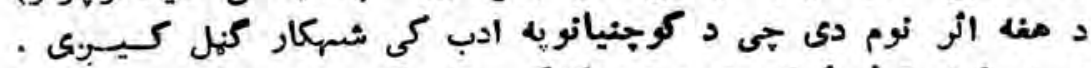

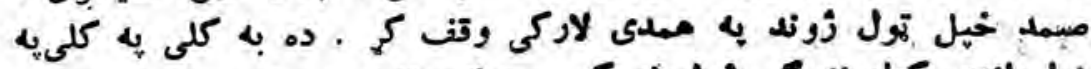

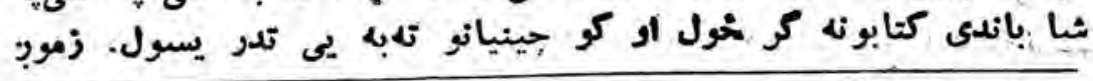

(1) ? $-7 \varepsilon-$ 


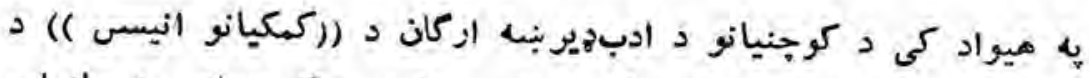

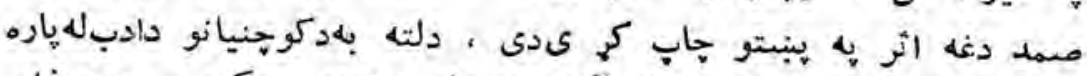

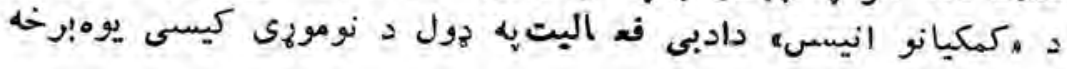

\section{كوجنى تور كب}

رانقل كميم

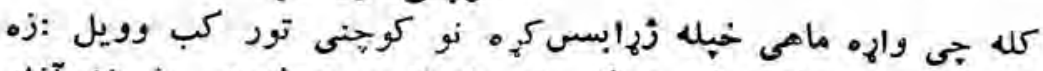

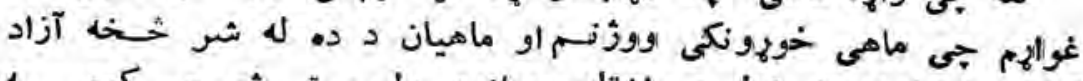

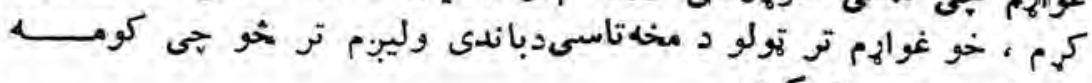

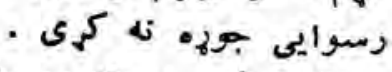

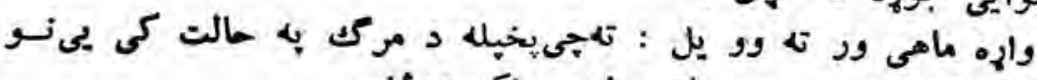

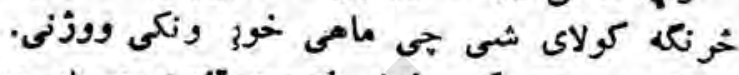

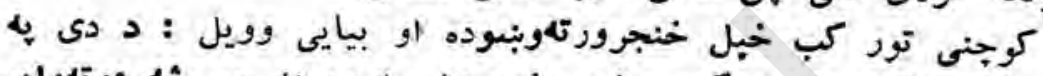

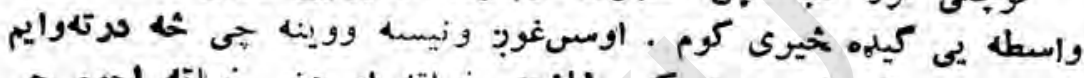

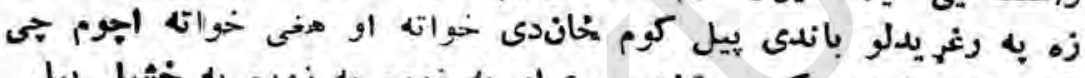

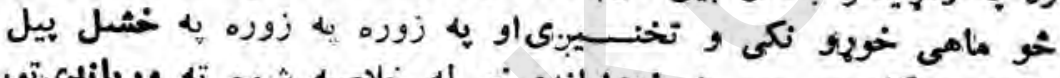

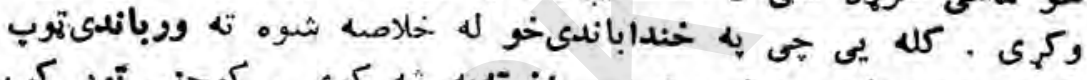

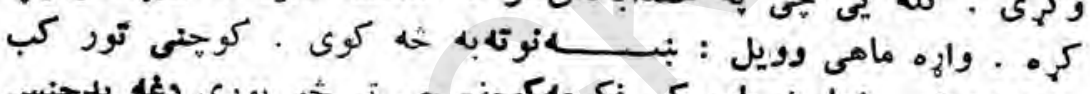

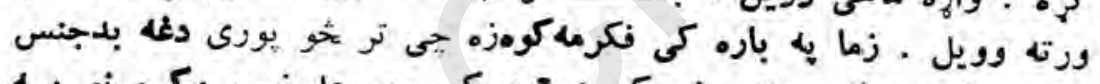

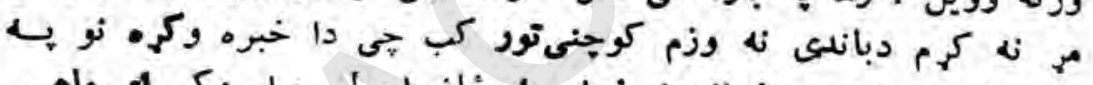

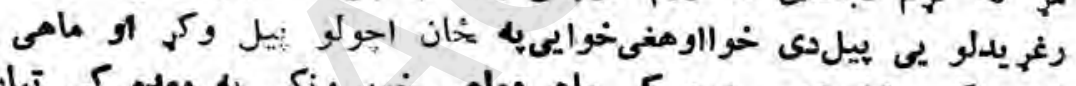

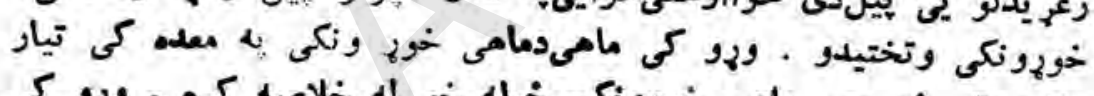

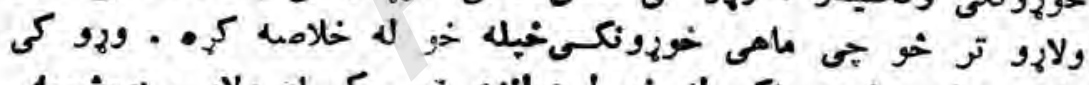

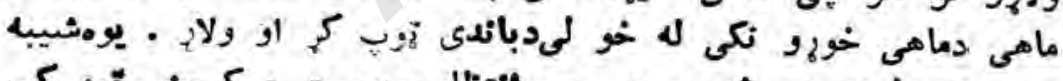

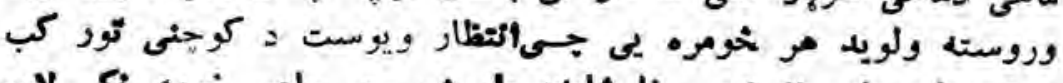

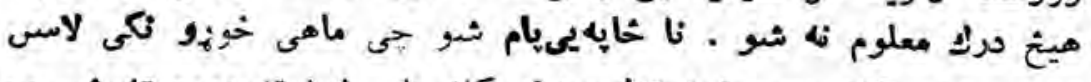

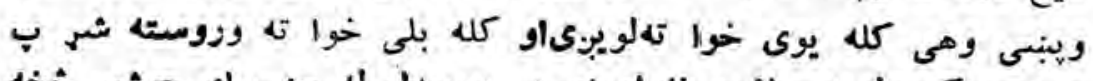

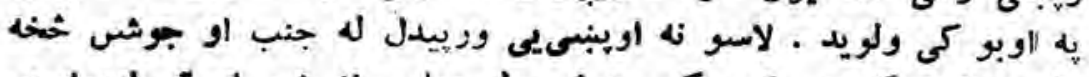

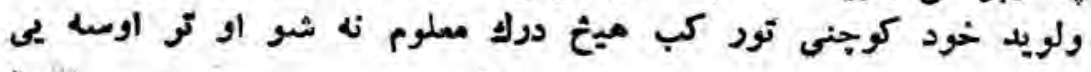
Li? 


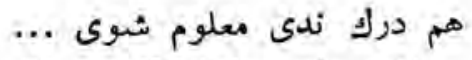

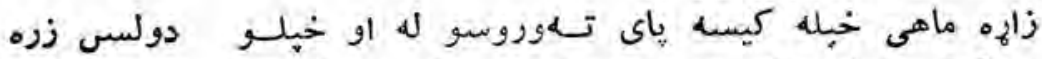

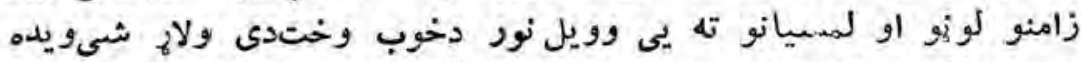

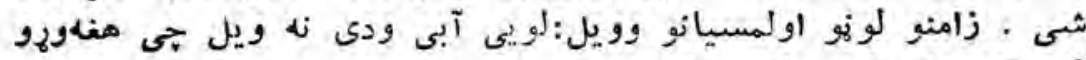

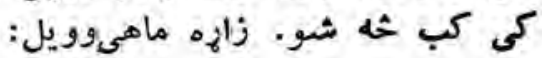

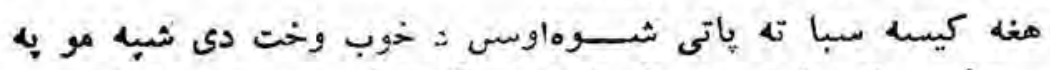

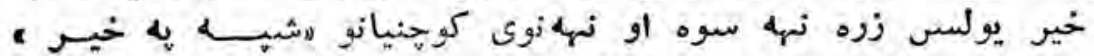

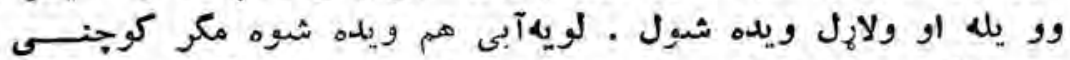

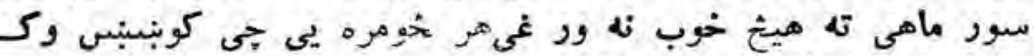

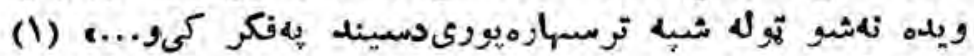

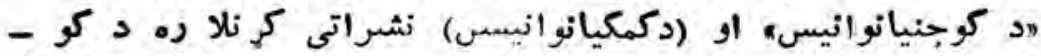

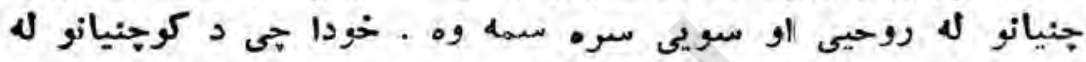

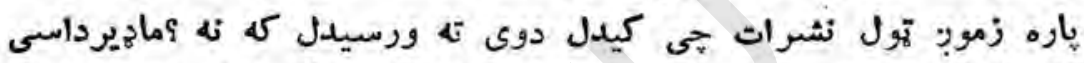

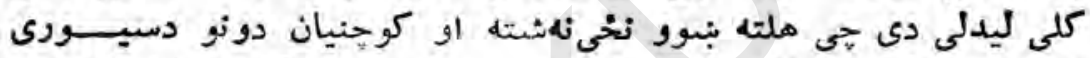

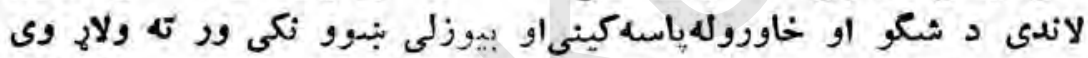

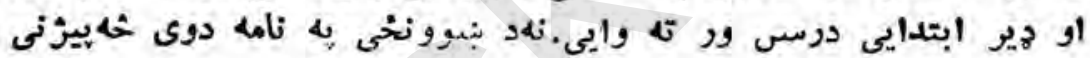

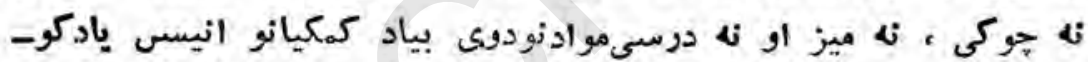

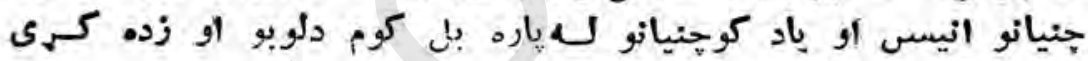

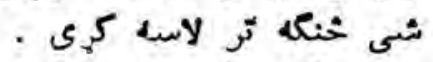

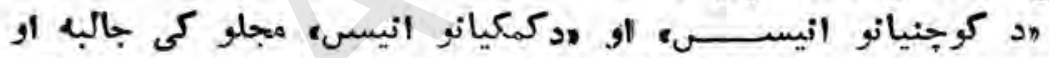

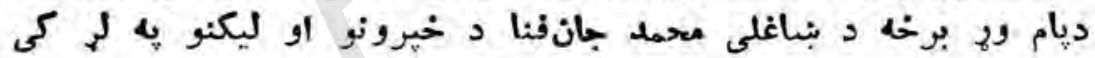

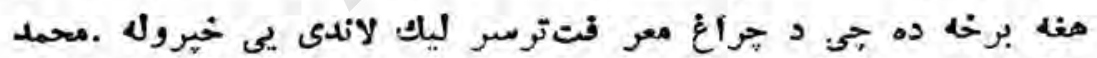

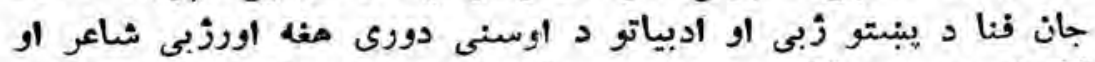

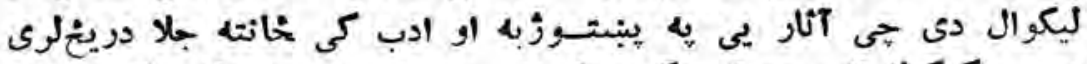

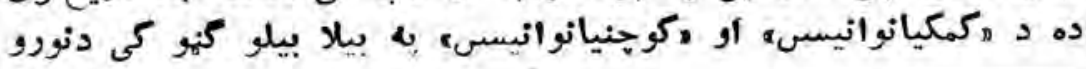

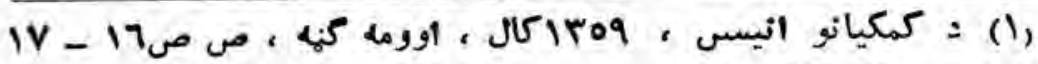

(د زرغونه اياز خاحى زباهُ ) 


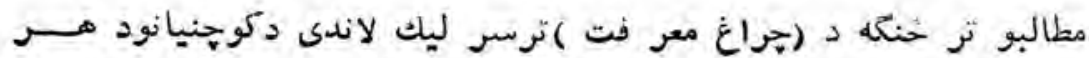

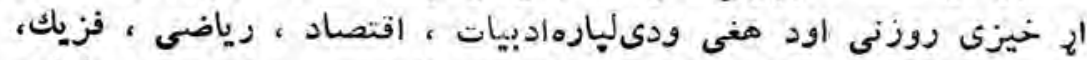

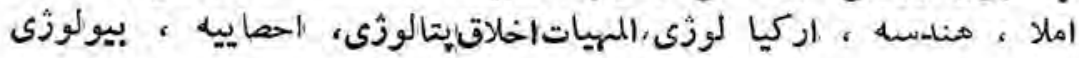

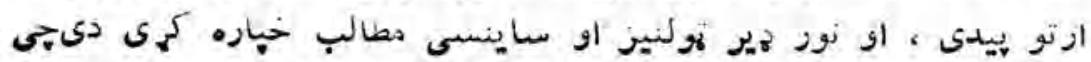

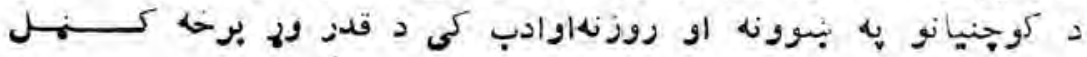
- كيبزى

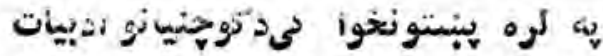

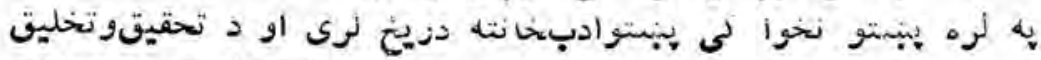

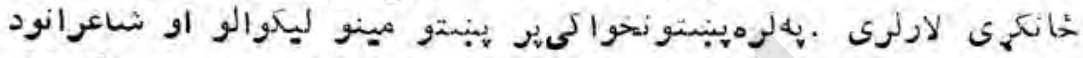

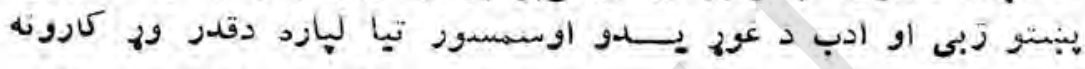

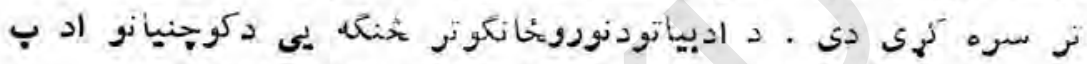

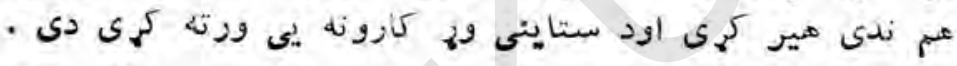

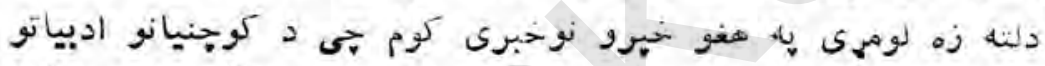

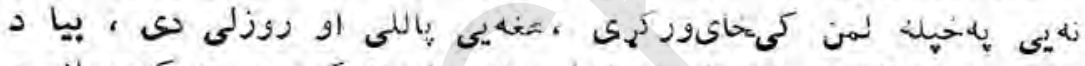

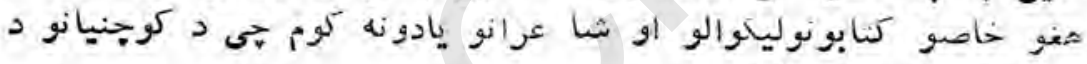

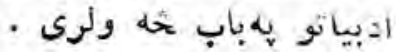

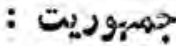

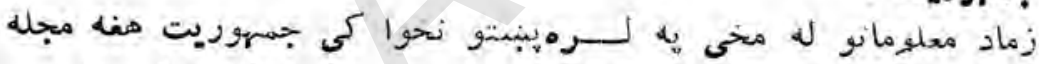

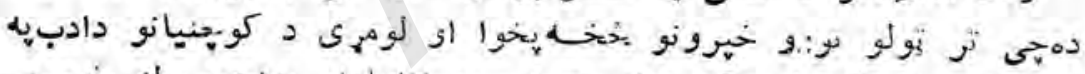

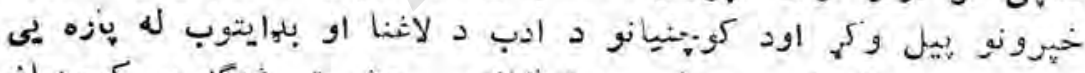

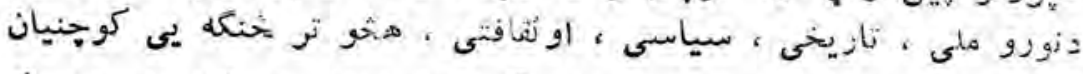

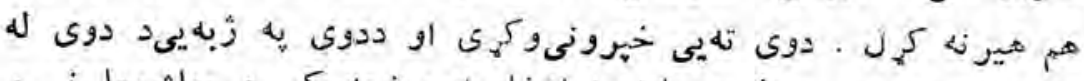

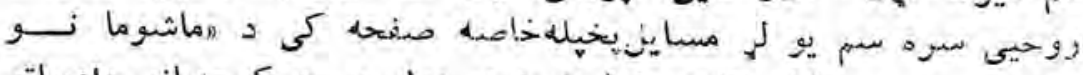

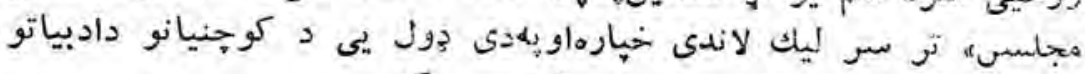

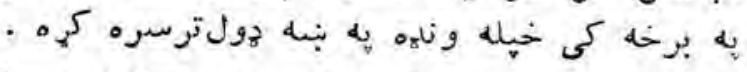

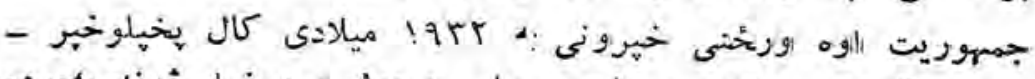

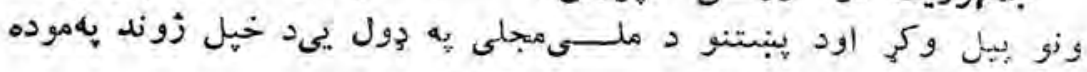
$-7 V$ 
كى جير بنه علىى ، تاريخى ،سياسسى ، او ادبى مسايل خباره كهى - 52

جمهوزيت خهبه شرانى باليسىداسى اعلان كئى وه : لاجمهوريت

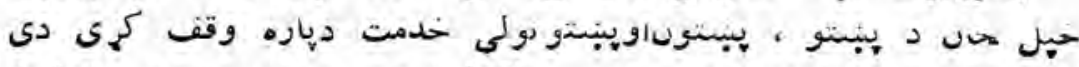

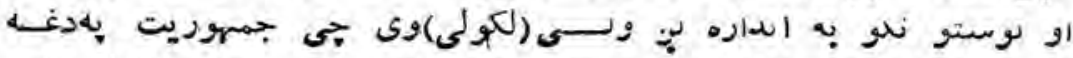

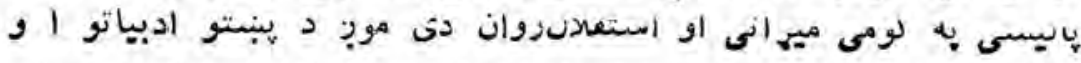

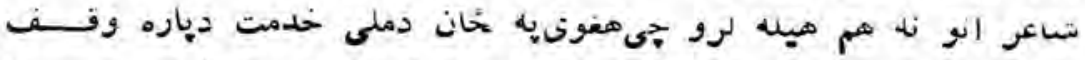

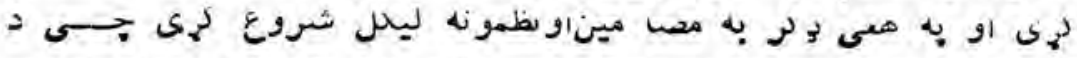

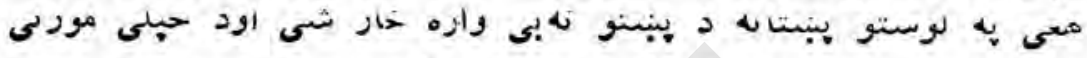

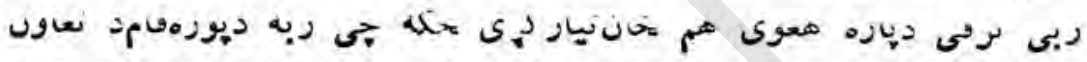

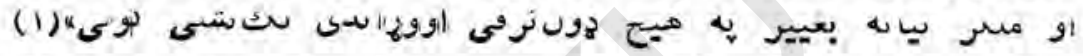

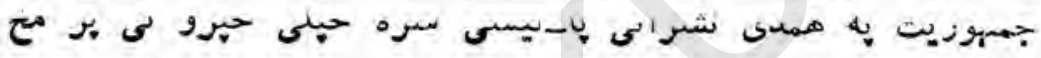

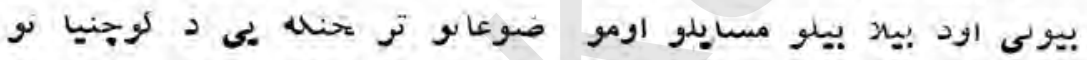

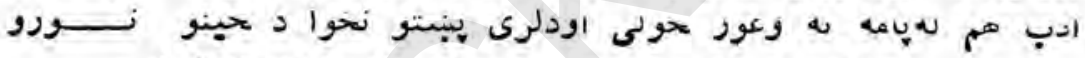

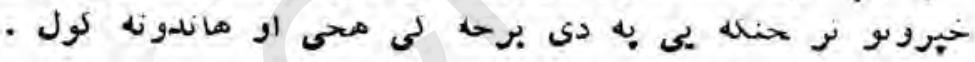

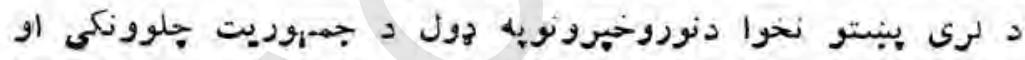

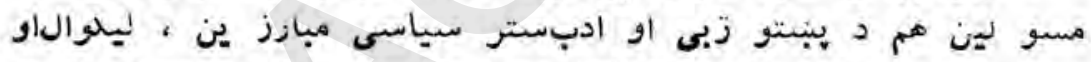

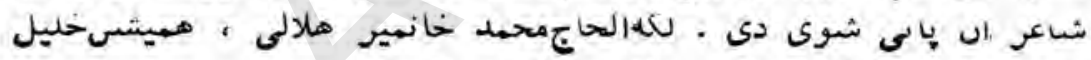

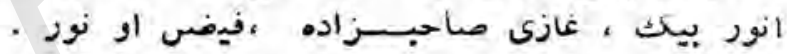

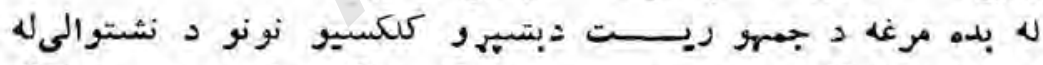

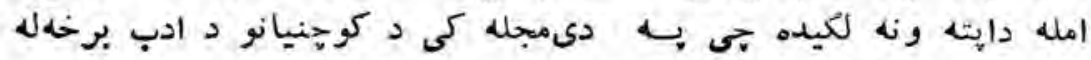

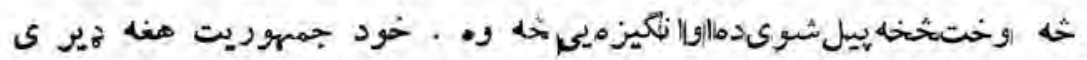

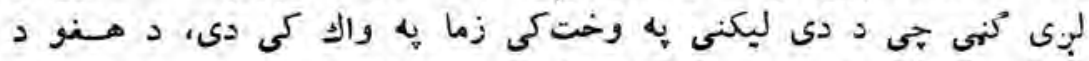

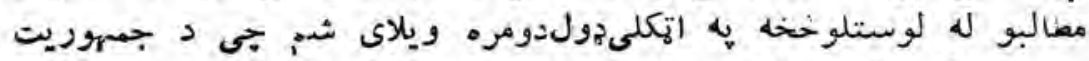

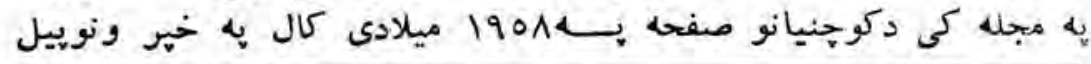

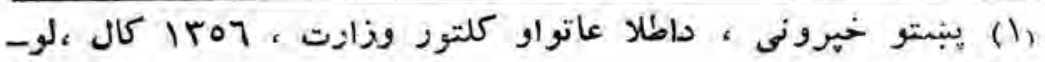

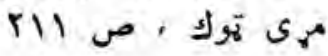




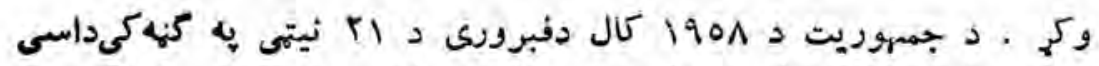

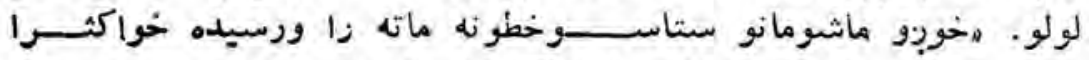

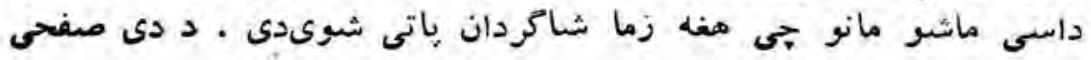

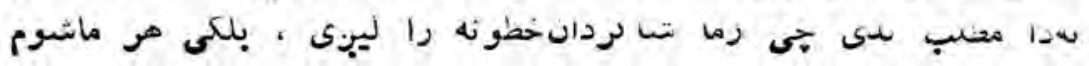

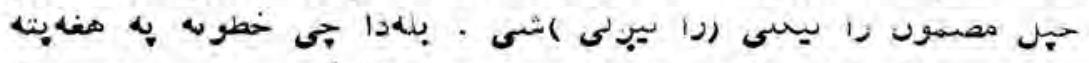

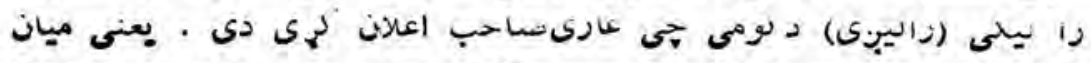

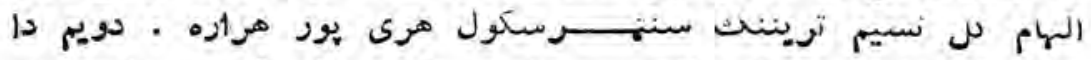

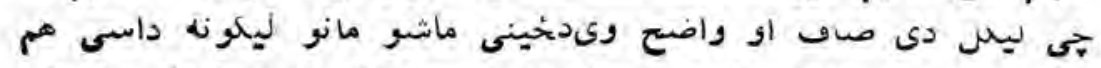

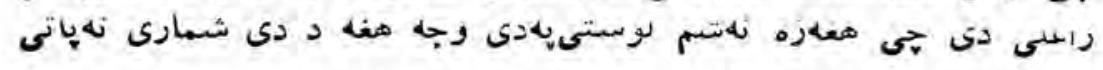

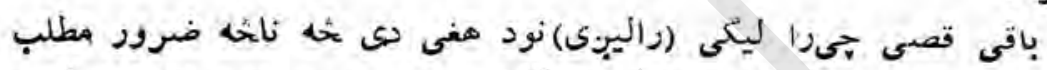

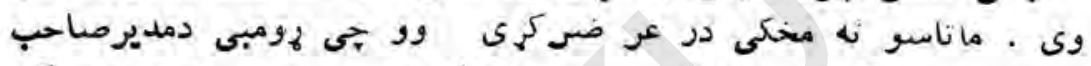

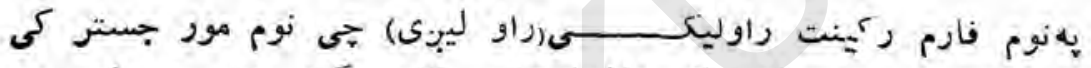

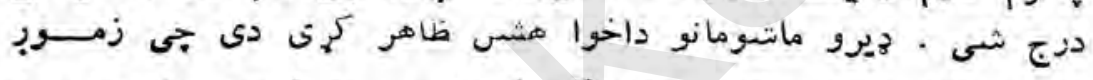

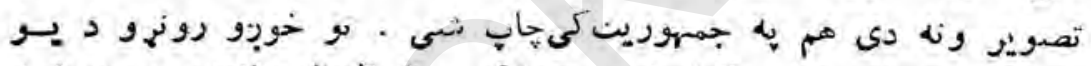

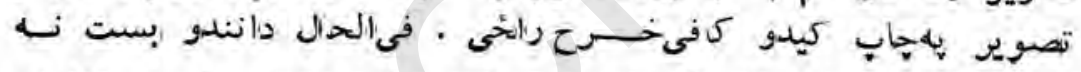

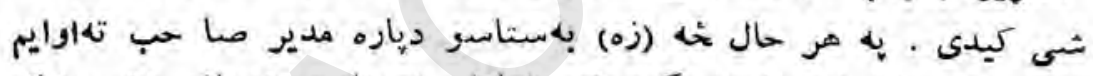

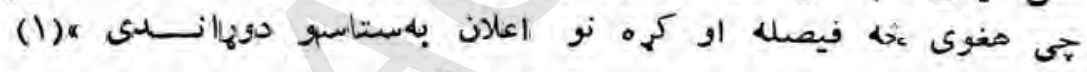

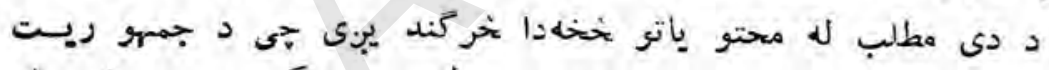

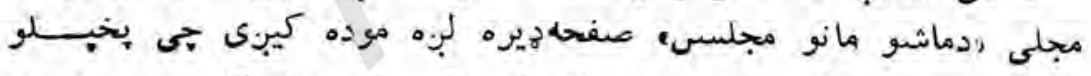

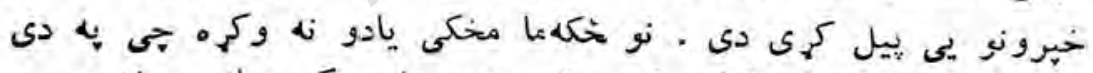

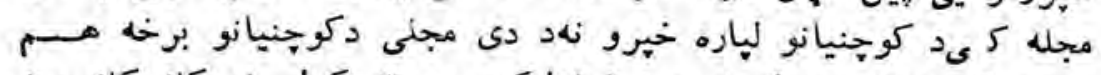

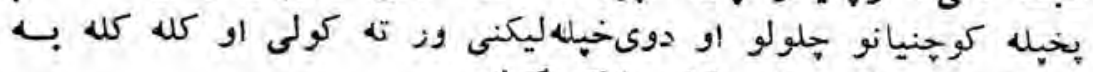

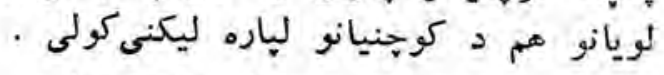

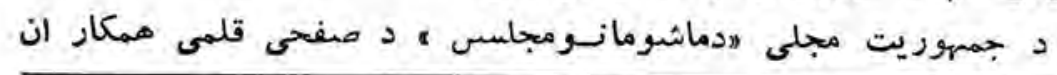

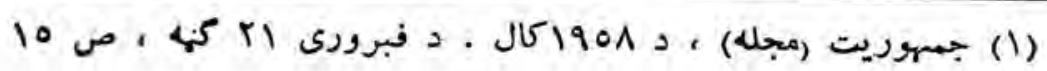




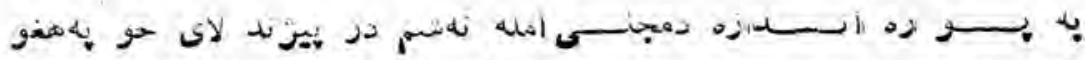

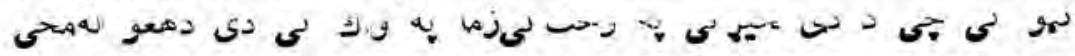

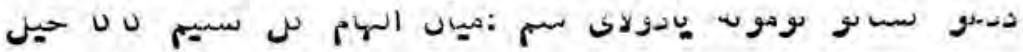

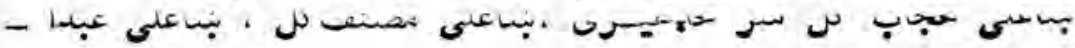

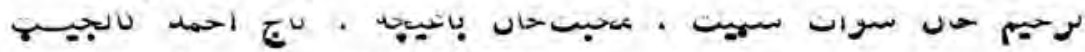

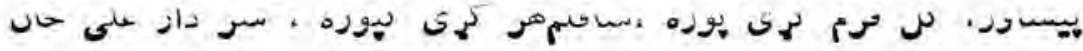

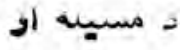

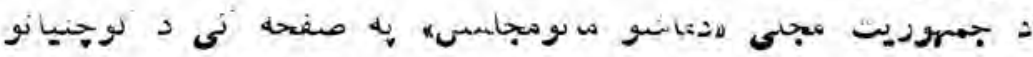

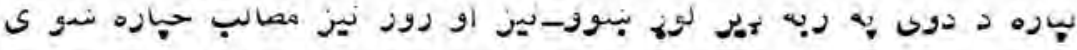

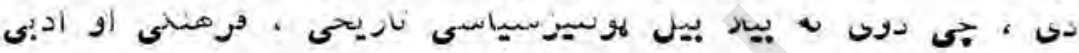

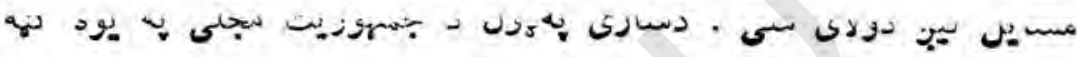

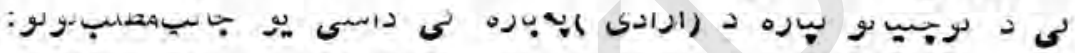

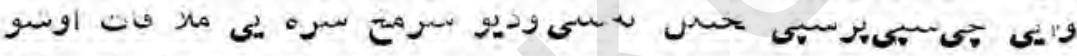

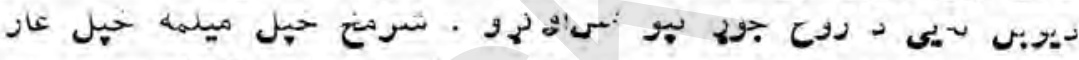

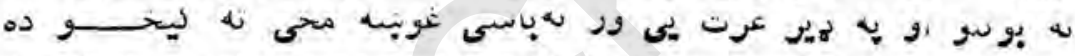

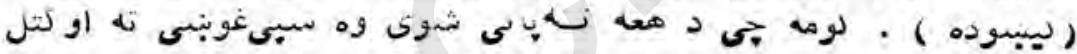

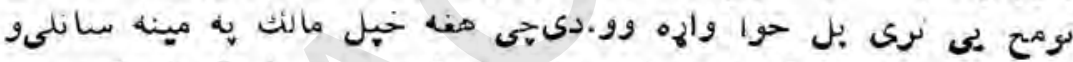

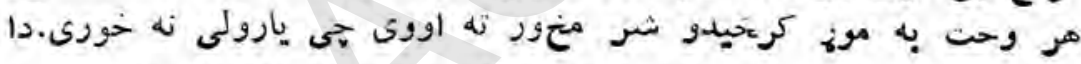

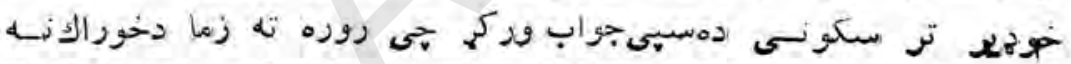

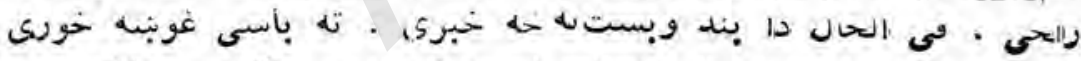

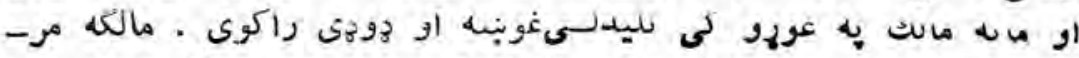

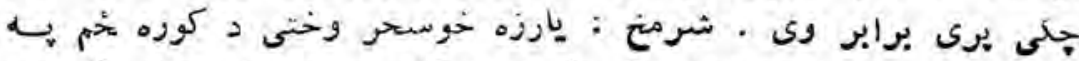

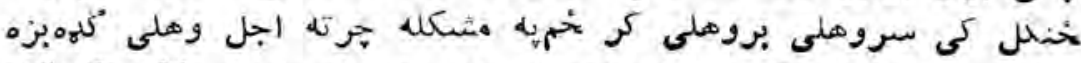

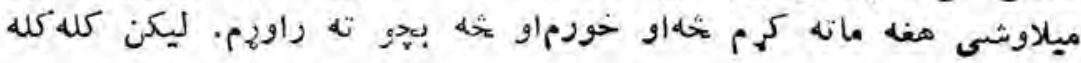

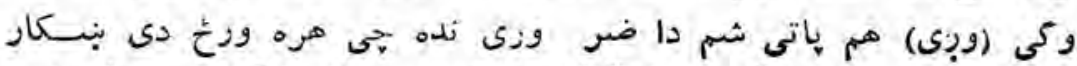

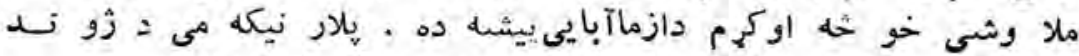

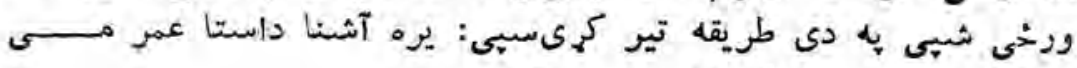

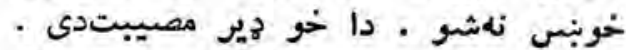
$-V \cdot-$ 


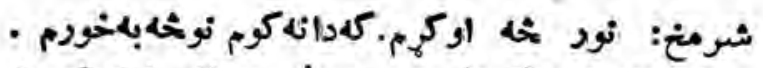

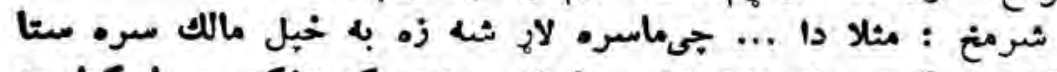

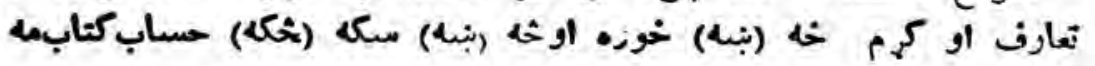
. Li.

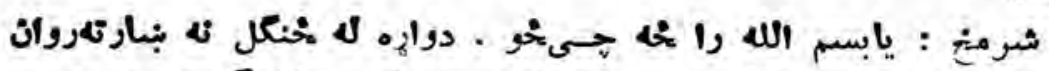

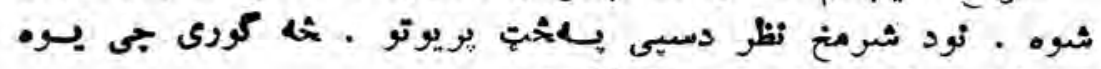

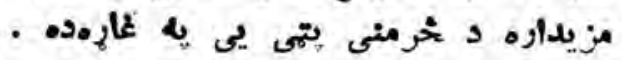

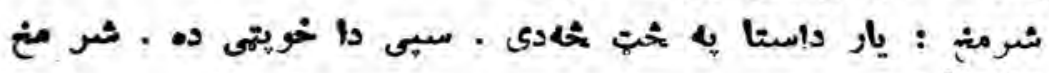
داد غندياره .

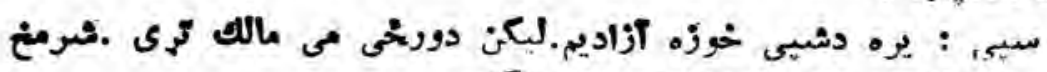

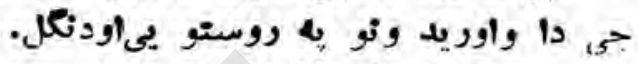

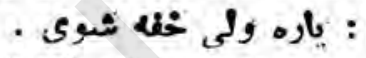

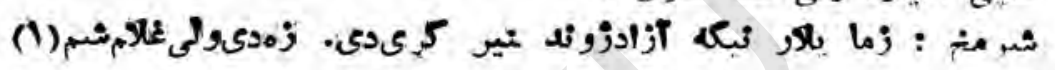

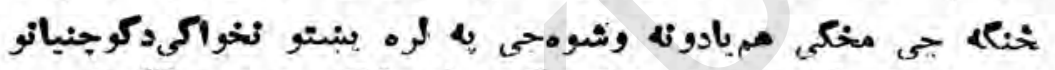

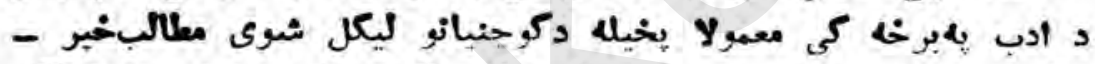

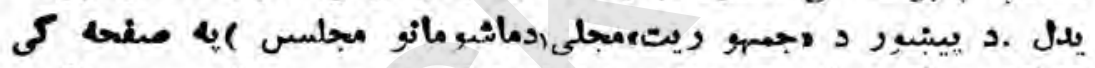

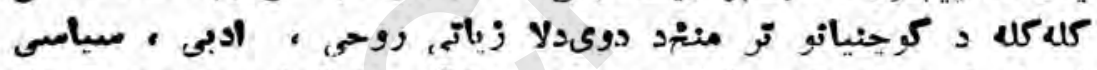

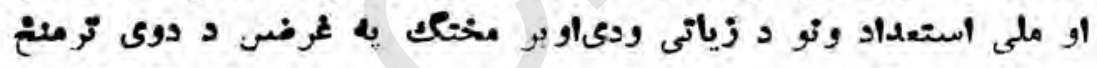

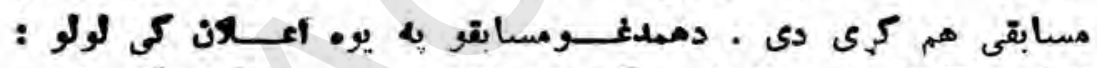

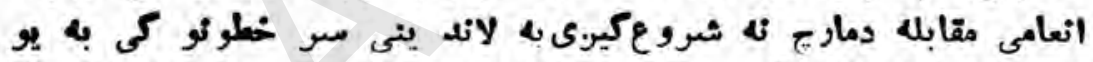

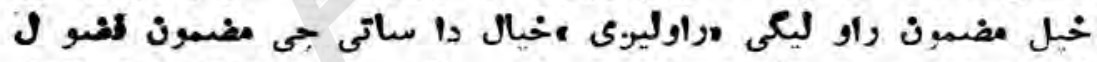

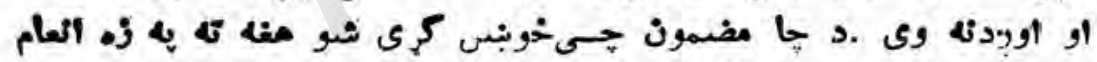

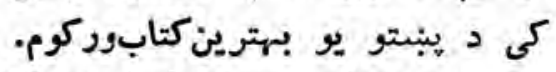

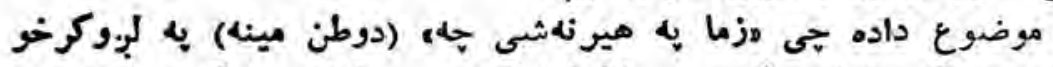

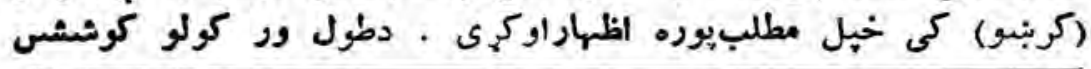

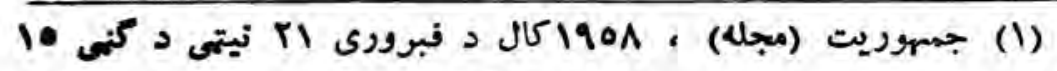


(r) $(\cdot$.

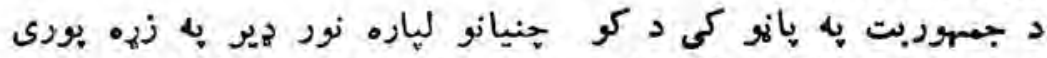
مطالب هم ليدل كيبيى لكه خينسى معلو مأتى هضامين ، لطيفى اونور .

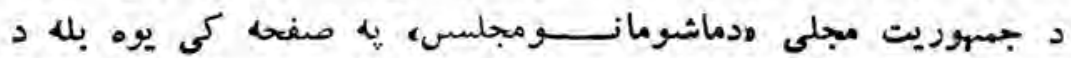

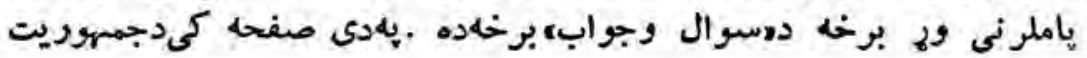

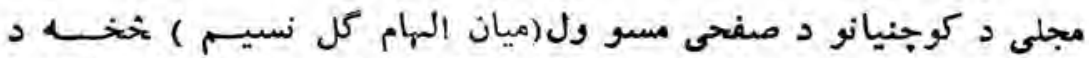

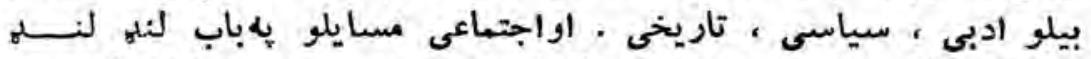

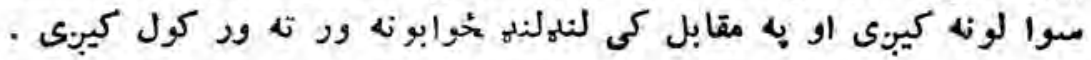

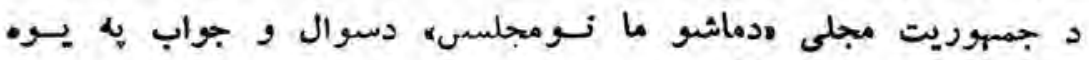

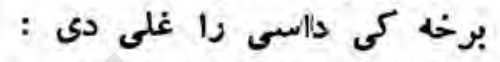

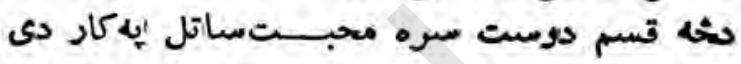

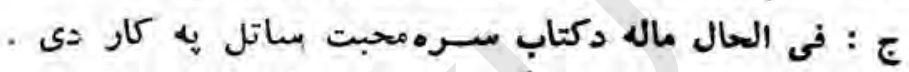

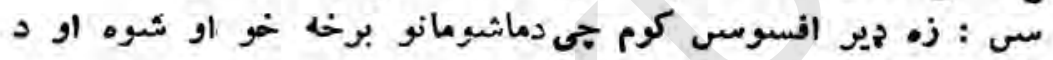

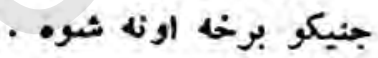

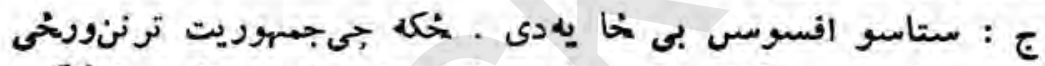

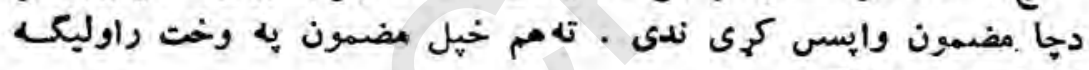

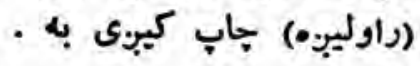

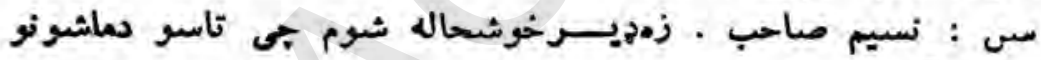

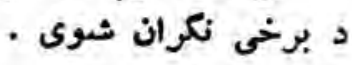

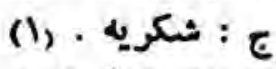

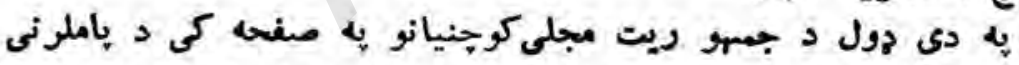

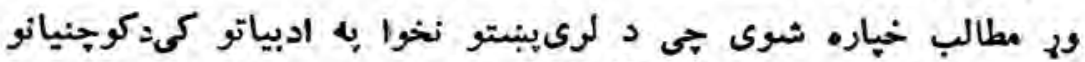

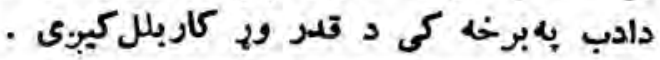

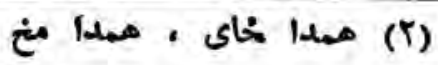

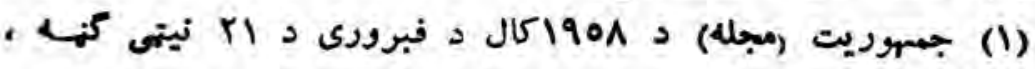
م $-r_{-}$ 


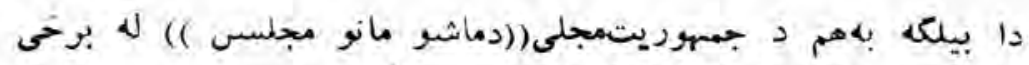

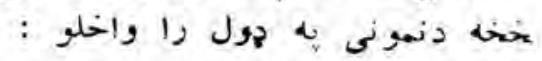

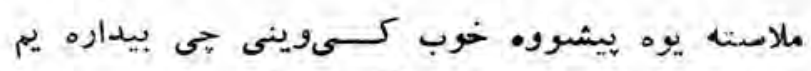

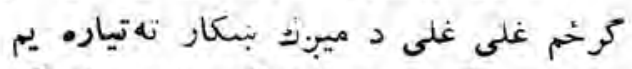

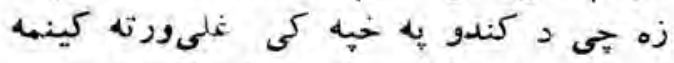

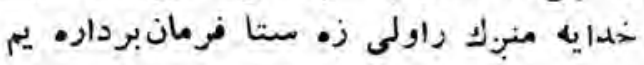

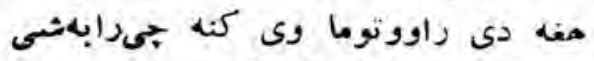

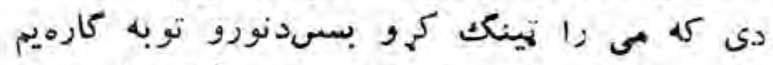

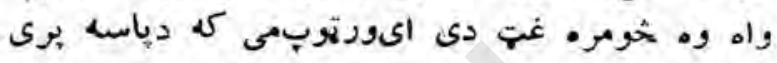

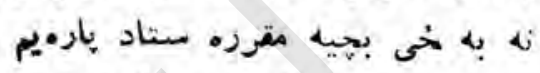

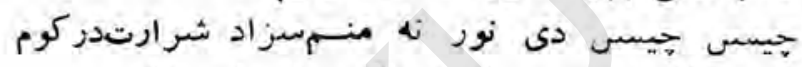

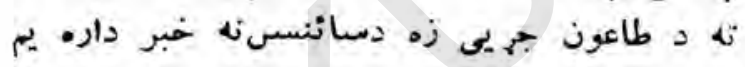

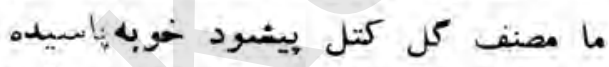

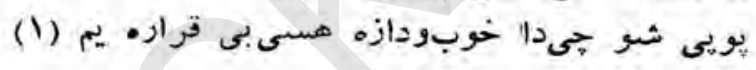

$$
\text { رهبر : رن }
$$

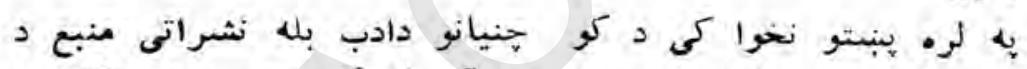

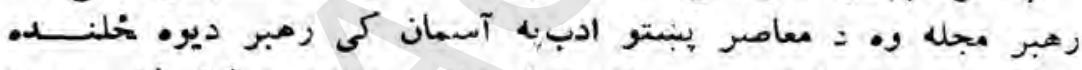

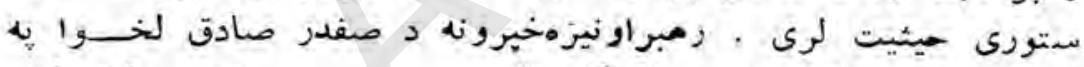

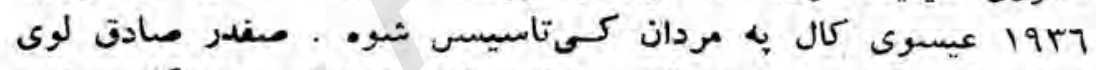

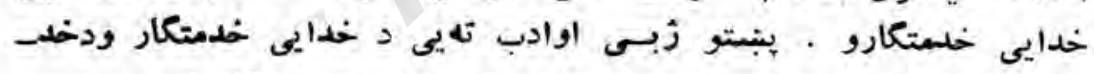

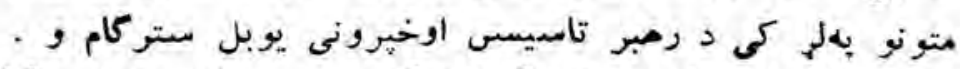

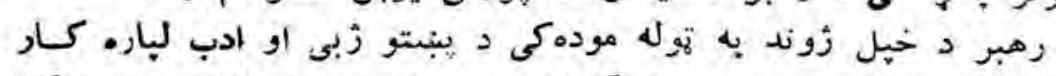

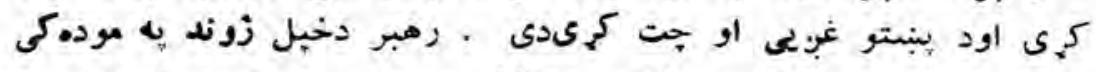

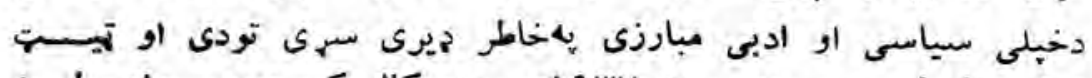

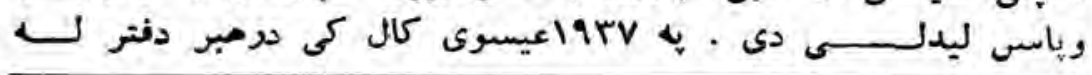

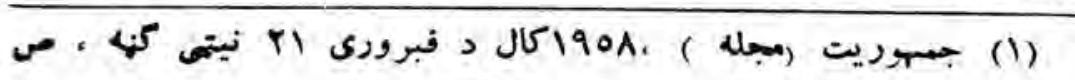
$-r$ 


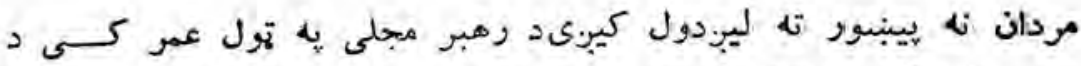

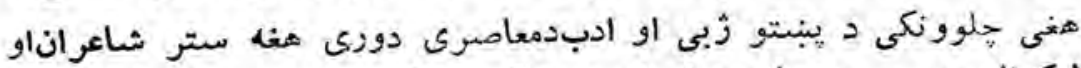

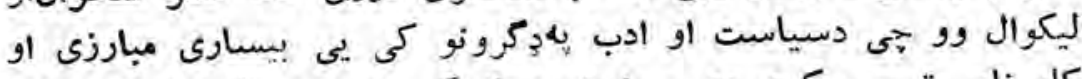

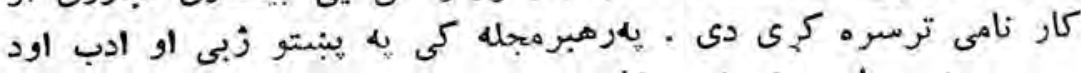

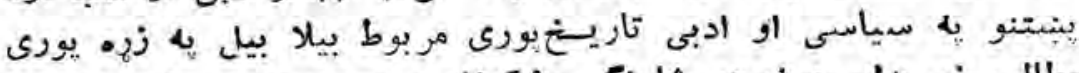

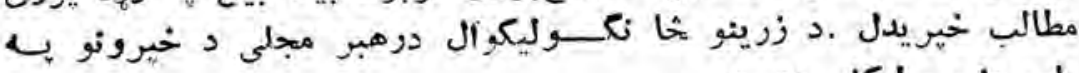
باب داسى ليكلى دى :

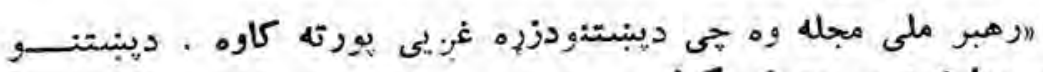

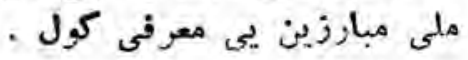

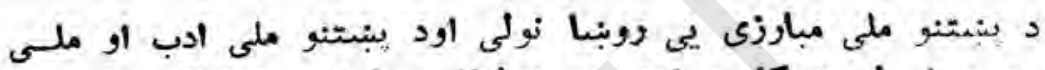

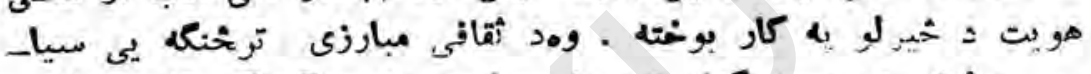

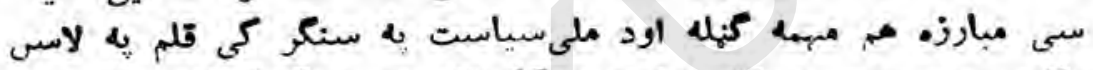

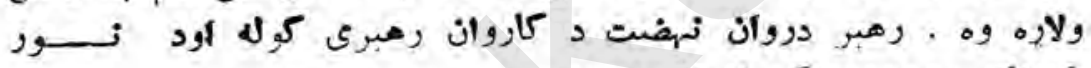

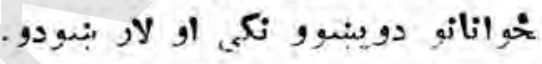

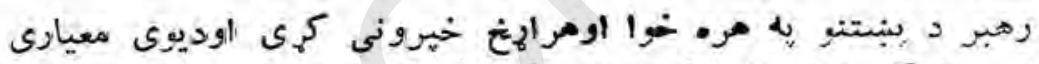

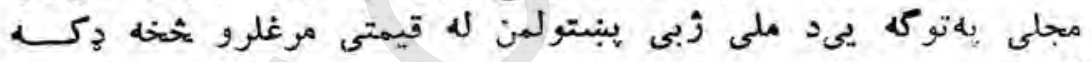
(1). . . . o s 5

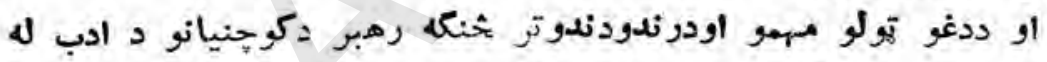

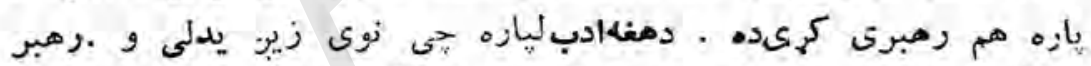

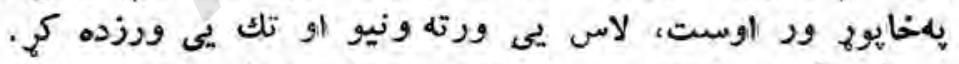

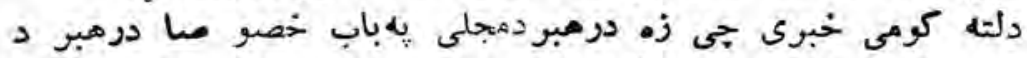

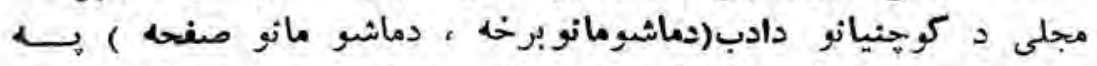

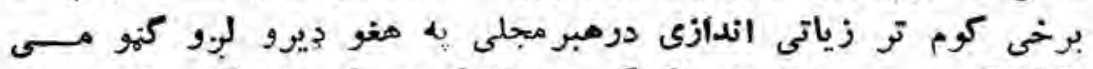

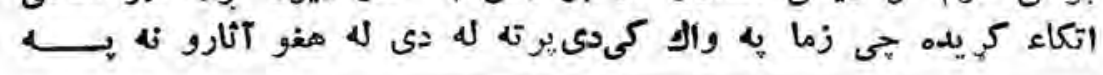

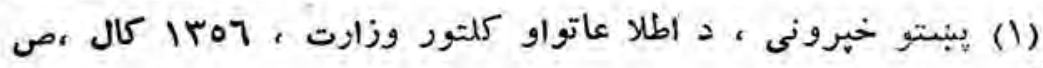




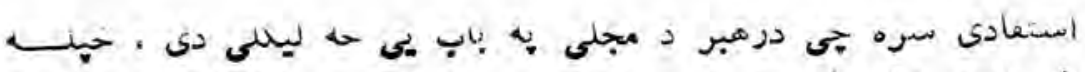

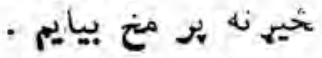

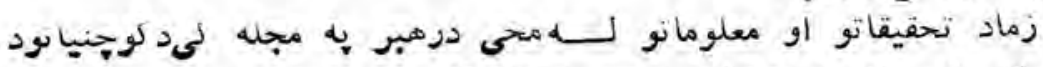

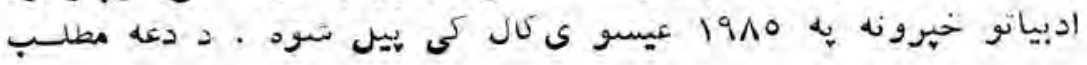

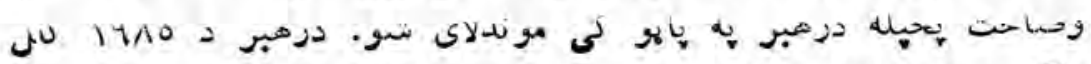

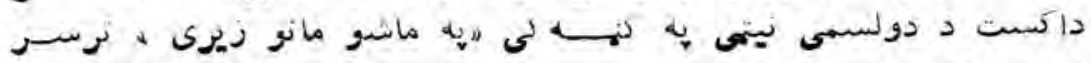

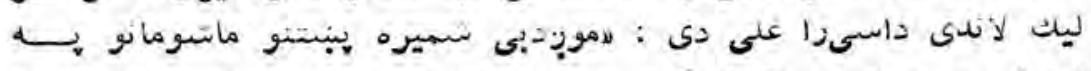

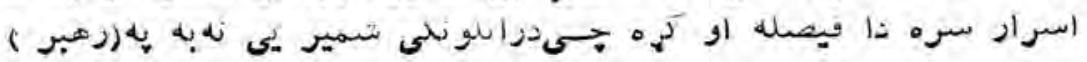

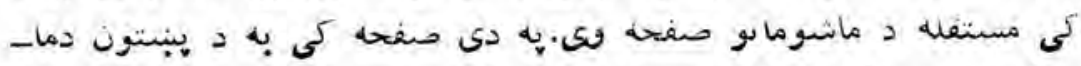

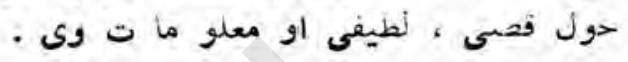

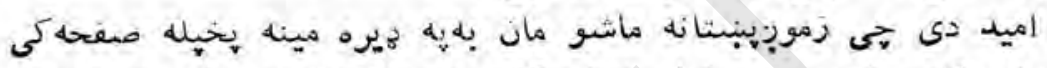

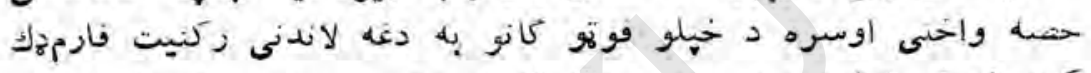

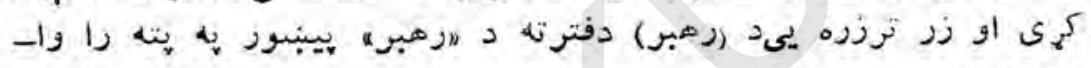

$$
\begin{aligned}
& \text { ستوى : } \\
& \text { ركينت فارم } \\
& \text { نامه ... ولديت فين ... } \\
& \text { عمر ... بيداوبنبت ... } \\
& \text { تعليه .... مشغله .... } \\
& \text { (1)... يوزه بنه }
\end{aligned}
$$

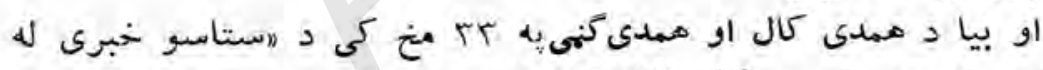

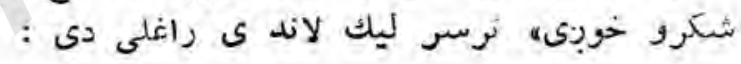

دماشومانو صفهه

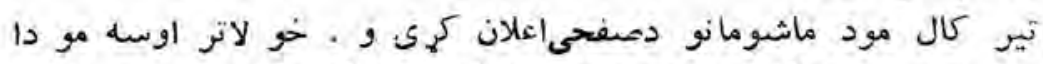

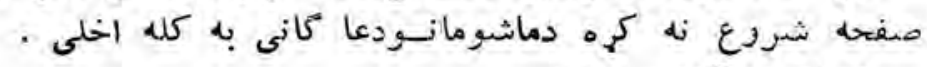

$$
\begin{aligned}
& \text { اى نور رنك - بنون } \\
& \text { عالمعير خان }
\end{aligned}
$$

$$
\begin{aligned}
& \text { (1) رهبر (مجله ) ، 1901 داكست זr نيته ، ص } \\
& -V 0_{-}
\end{aligned}
$$




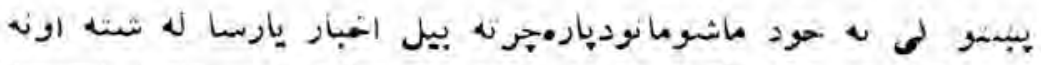

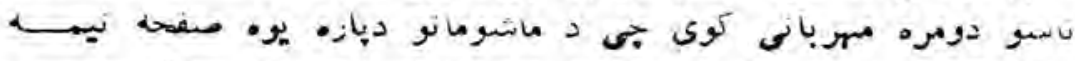

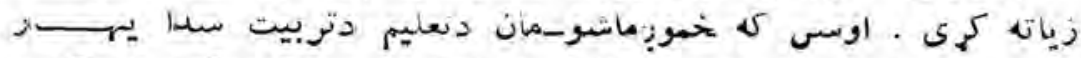

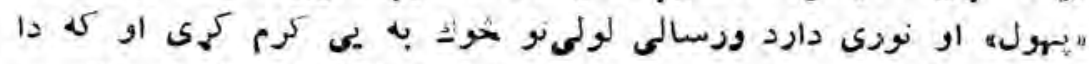

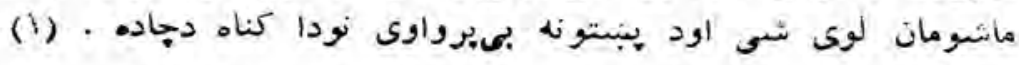

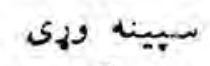
سبد شـركت غلى شاء

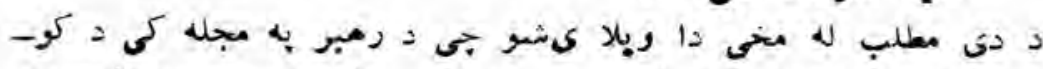

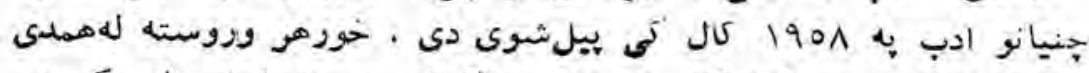

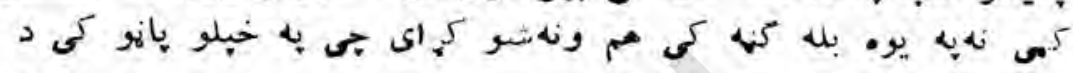

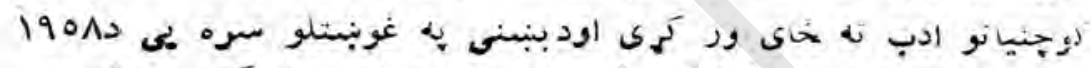

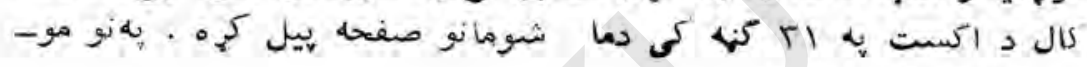

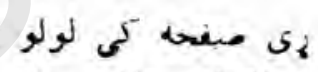

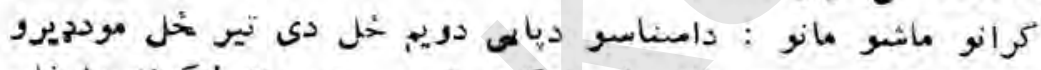

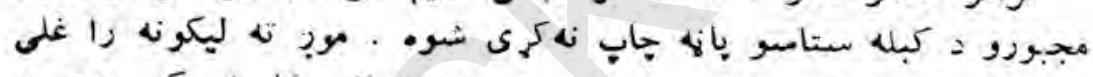

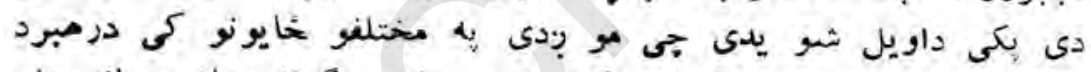

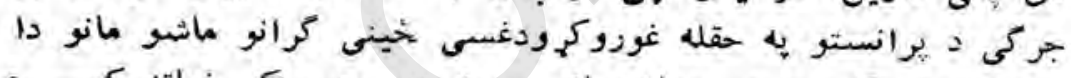

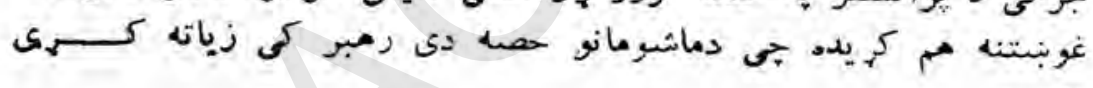

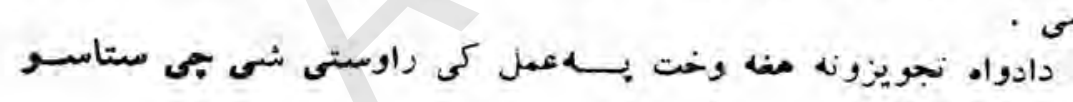

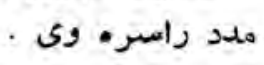

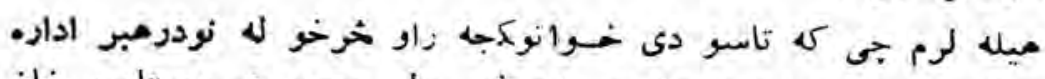

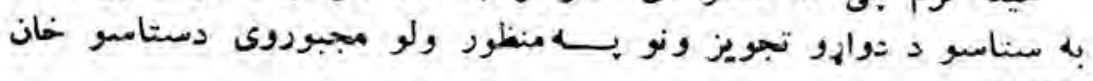

(r) ע

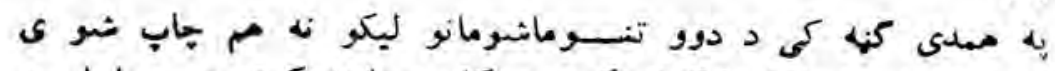

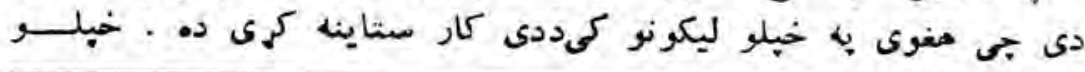

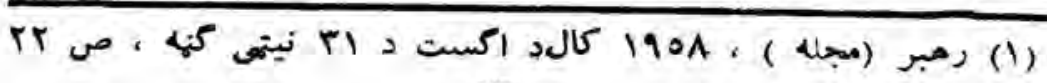

$$
-\mathrm{V} \text { - }
$$




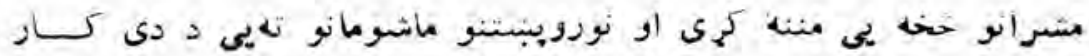

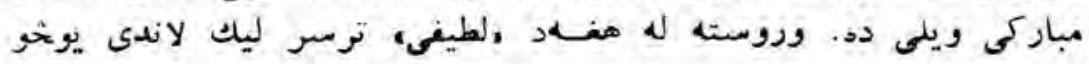

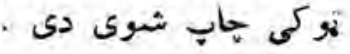

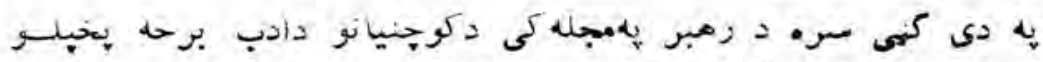

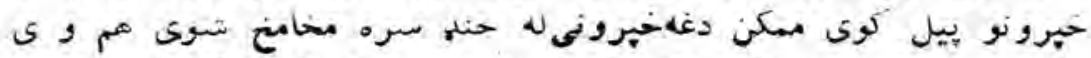

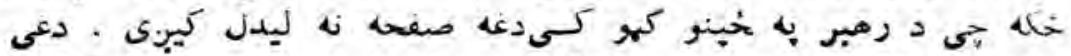

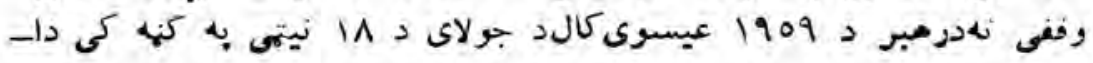

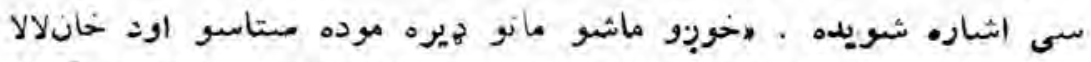

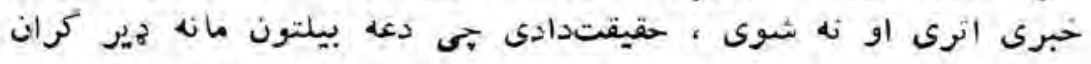

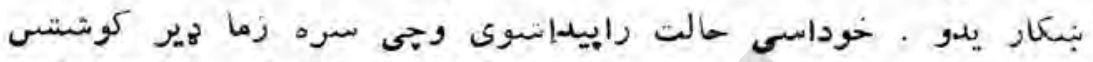

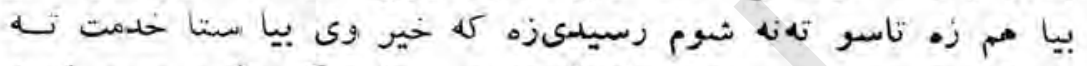

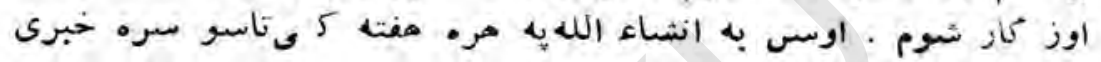

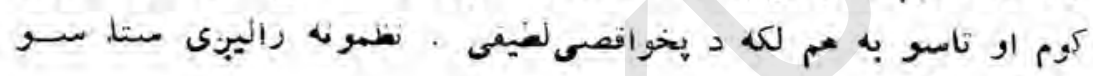
(1) IVIu

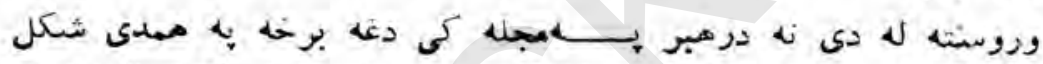

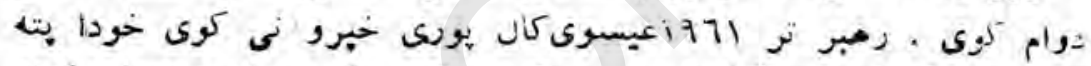

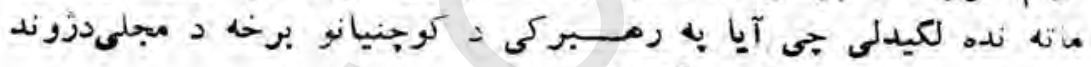

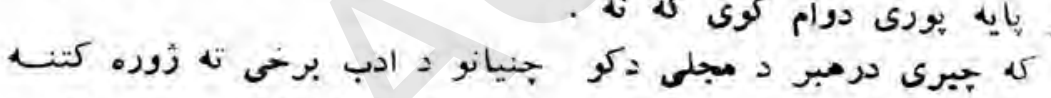

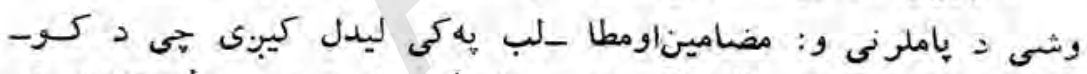

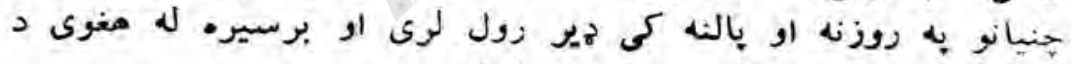

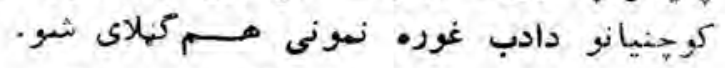

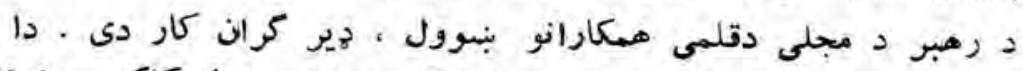

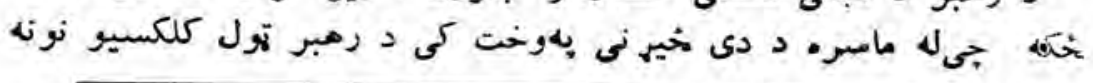

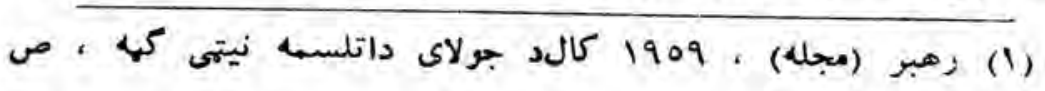




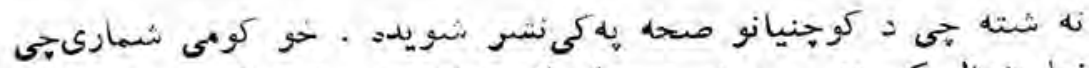

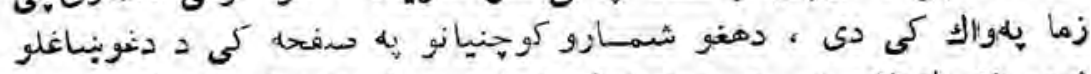

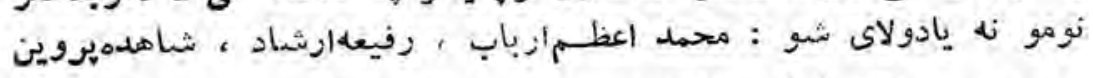

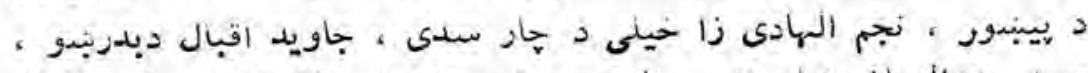

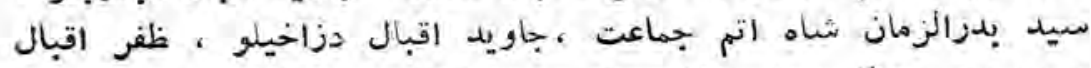

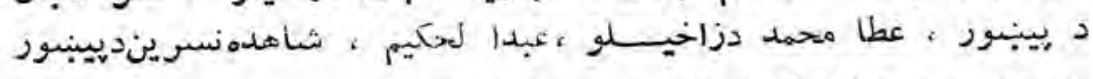

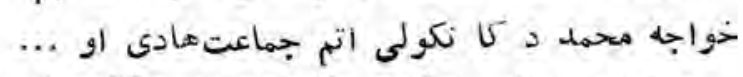

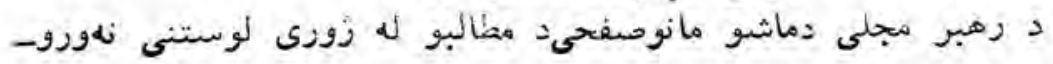

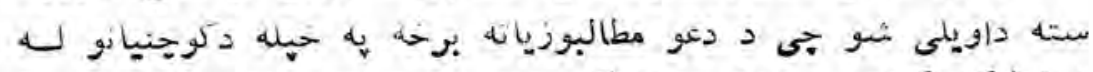

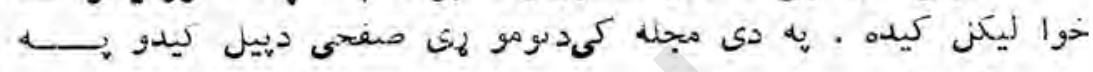

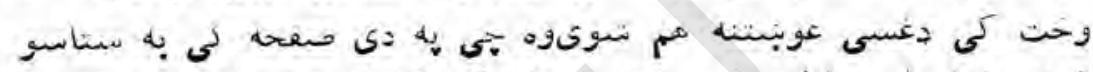

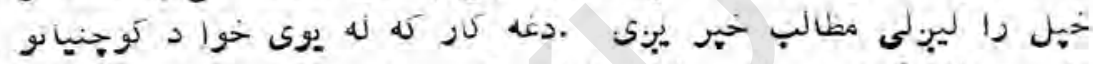

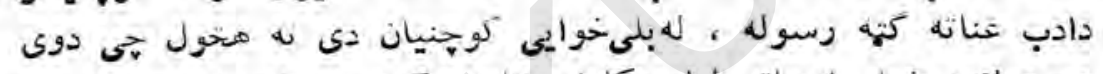

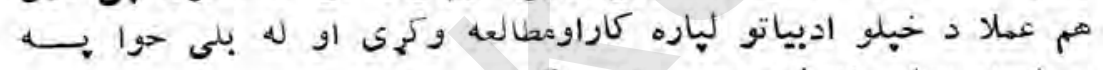

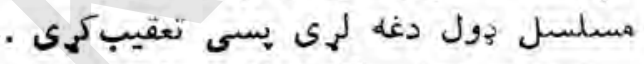

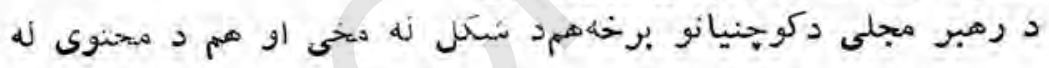

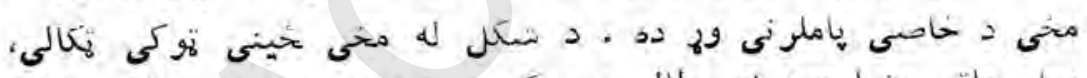

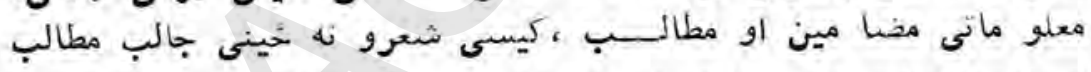

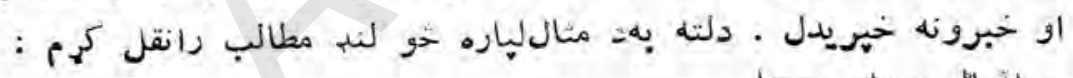
اقوال بوعلى سينا

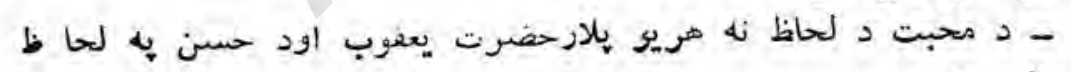
يوسف دى .

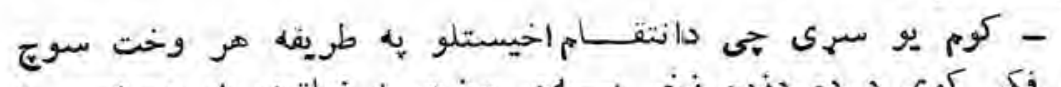

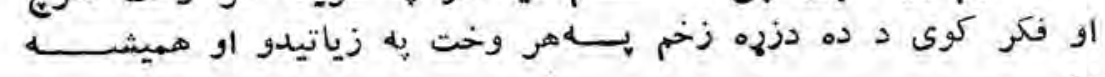
وى

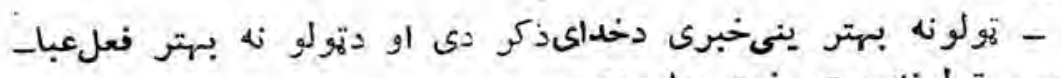

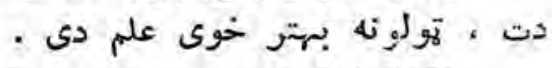




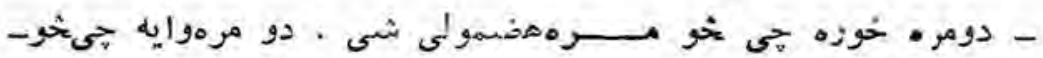

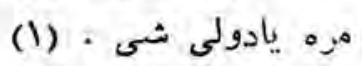

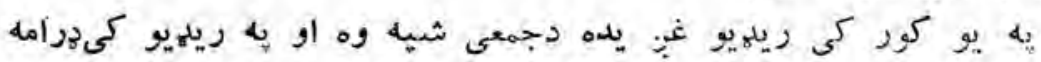

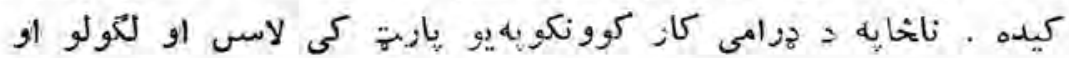

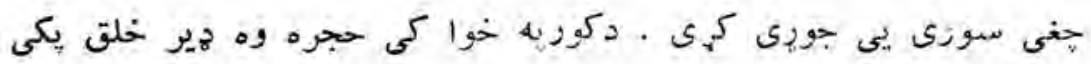

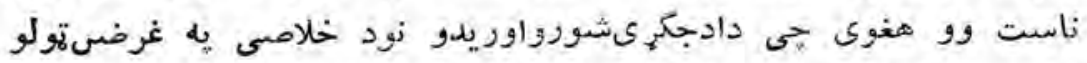

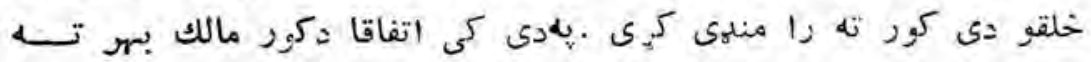

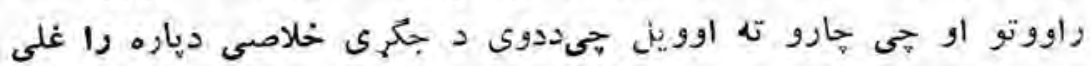

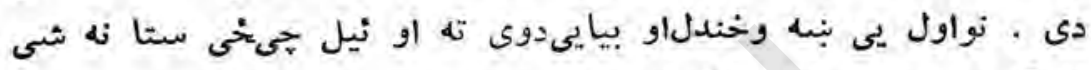

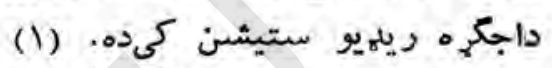

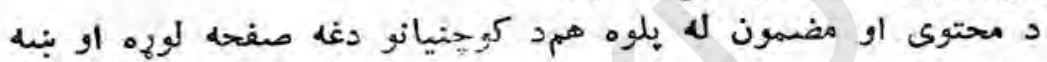

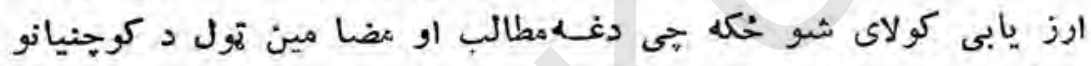

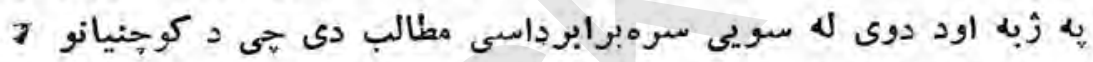

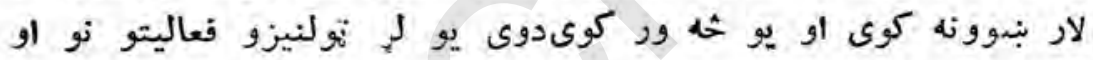
كارونو ته هخوى . دوى تله د ثتو لنيز زوند تياره كوتهو نه رونا كوى

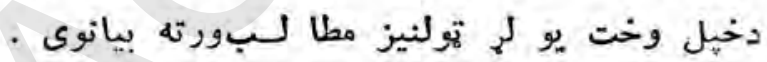

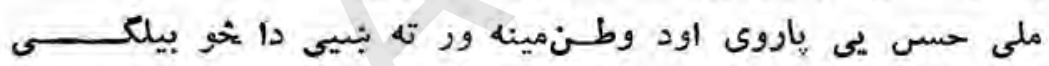
: وكورى :

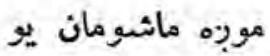

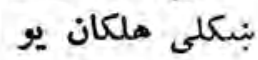

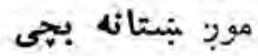

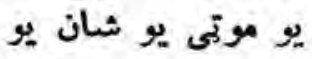
جور به شى كلشن زونى

(T) رهبر (مجله) ، د 1909 كالداكست 14 نيتى كنه ، ص آ - V - 
موج بهيح طوطيان يو

مينه عوطن لرو برو

تل به ترى قربان يو نرو

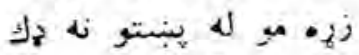

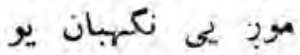

موب؛. ماشبومان يو نهان

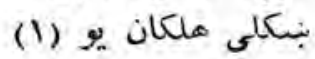

خها يو. كوترى ون ونان

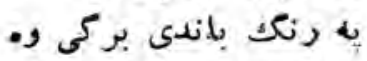

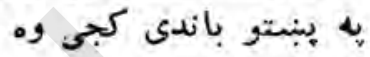

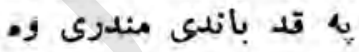

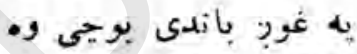

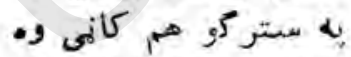

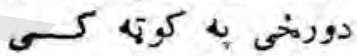

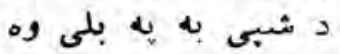

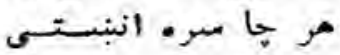

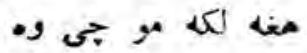

لومه. ور ته هيث وهي وه وهن

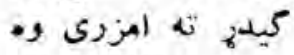

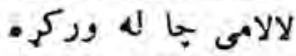

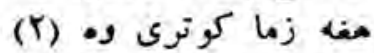

د ملا تات وخت ونت ون

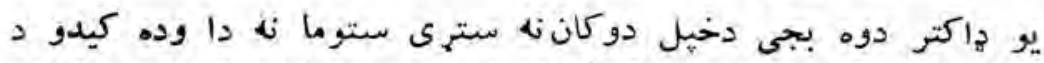

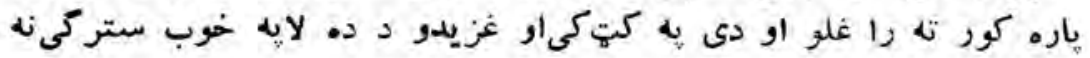

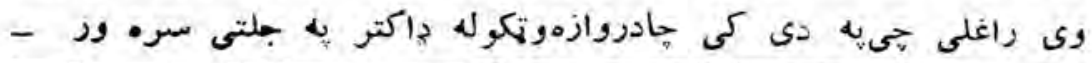

19 (1)

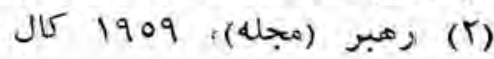

- $\Lambda^{\cdot-}$ 


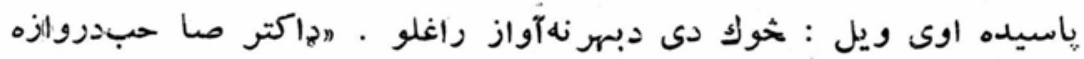

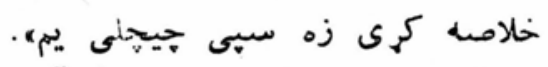

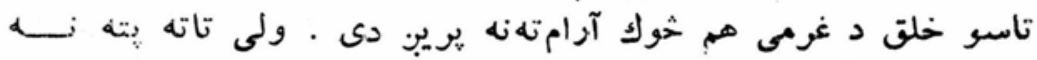

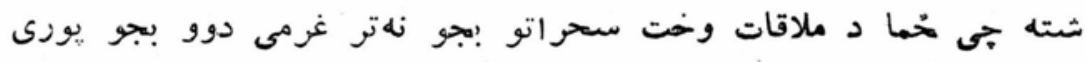
دى

بهر نه آواز را غلو ماته خوجنابيته ده ، مكو هغه سبى ته غا لبا

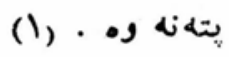

• كلستان

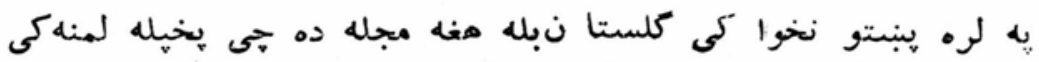

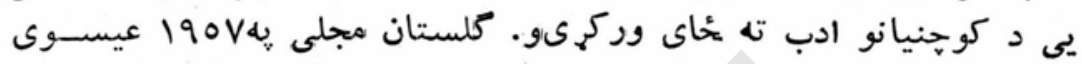

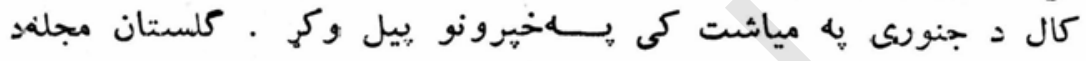

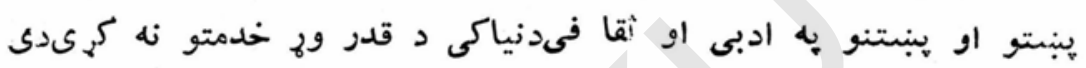

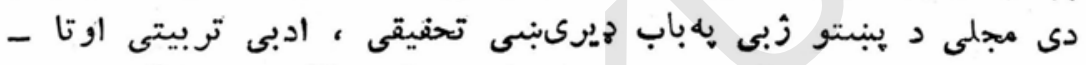

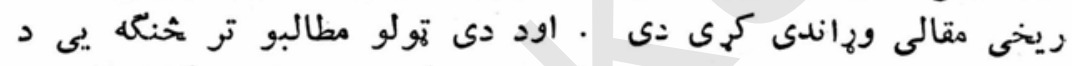

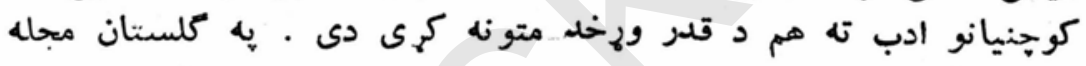

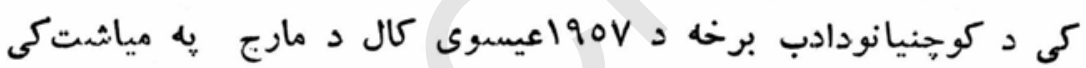

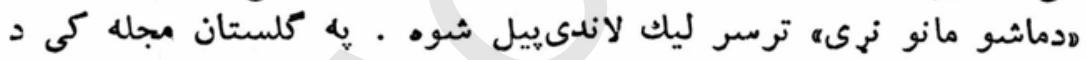

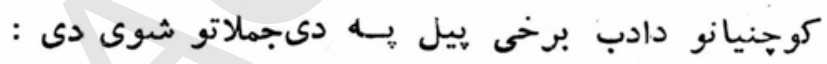

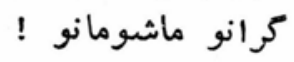

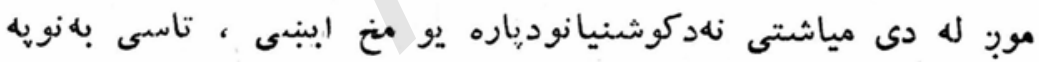

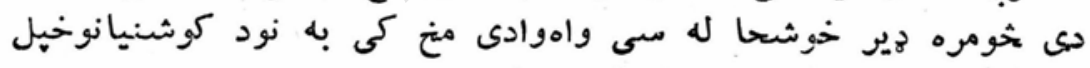

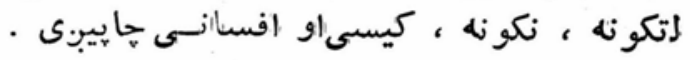

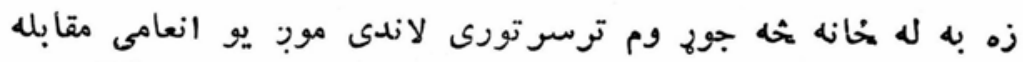

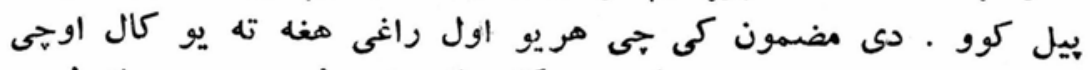

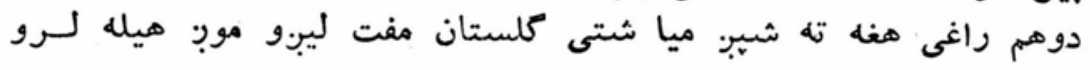

رهبر (مجله) ، د 1909 اكالد جولاى د عץ نيتهى كنه : ص 19 


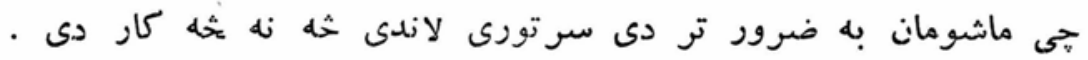

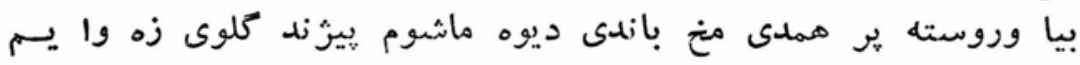

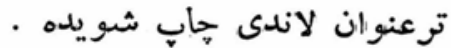

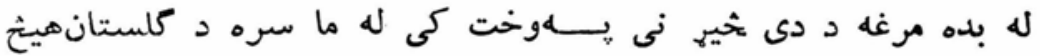

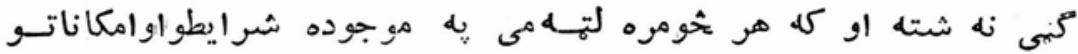
كى وكهه ، كومه كنه يه ونه نهرسوله

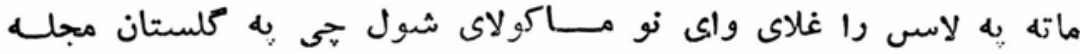

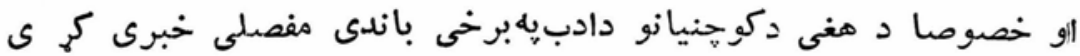

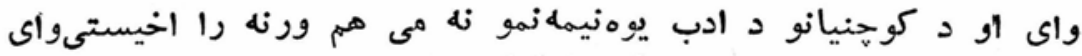

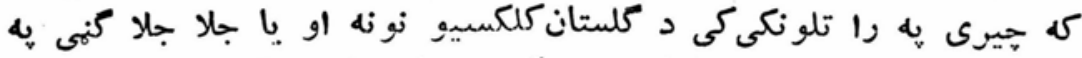

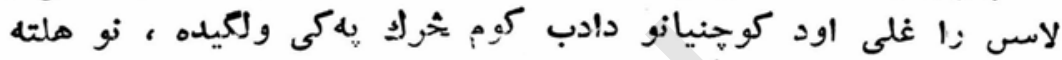

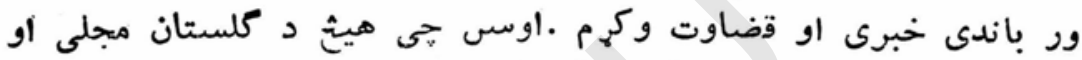

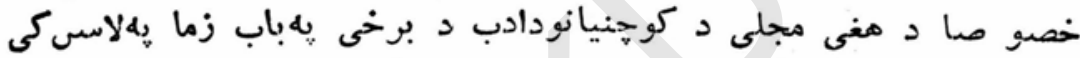

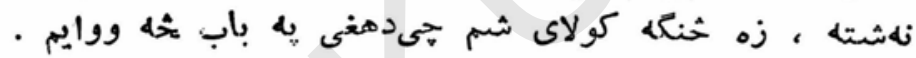
غنجهه :

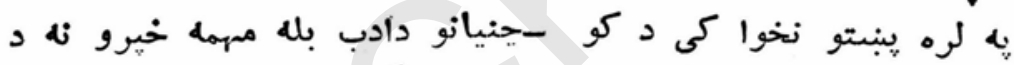

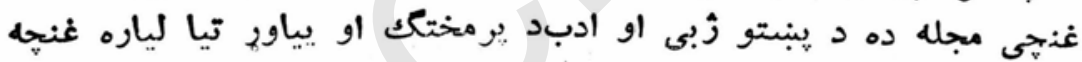

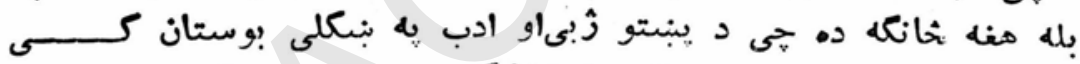

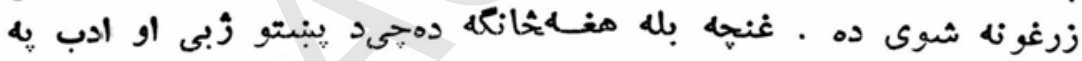

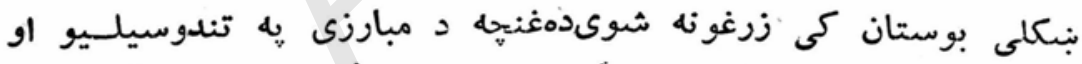

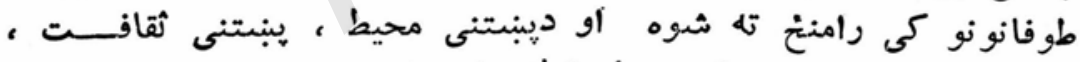

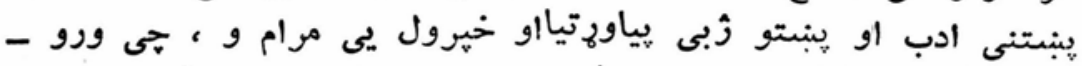

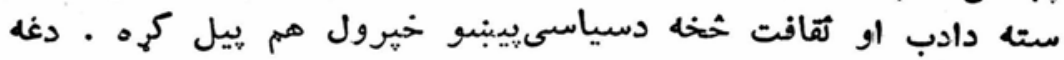

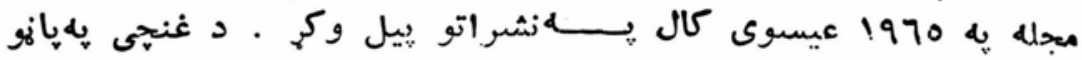

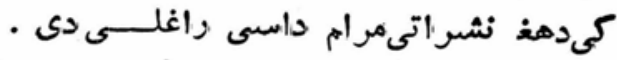

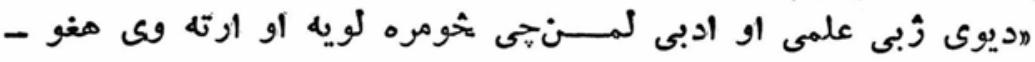

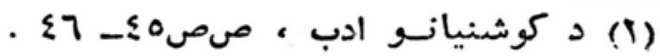

-Ar_ 


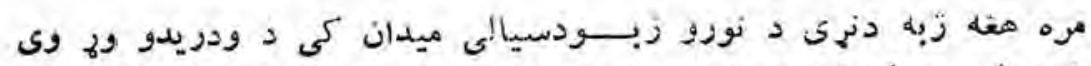

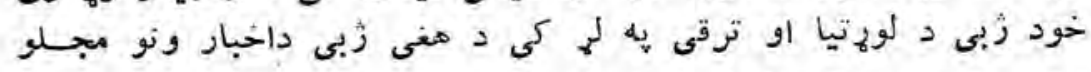

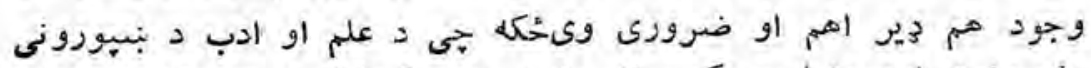

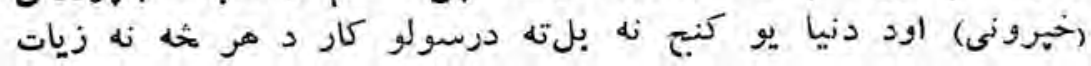
اخبارونه مجلى سر ته دسون دسوى .

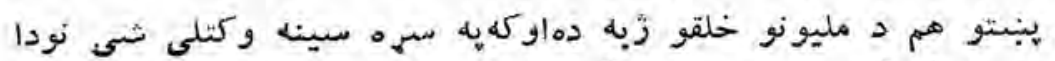

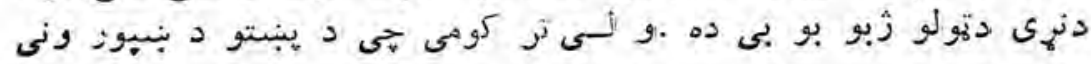

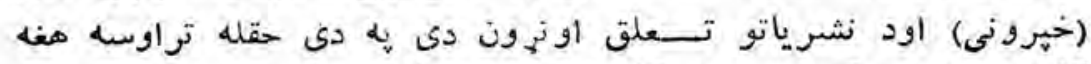

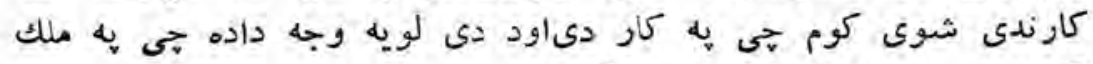

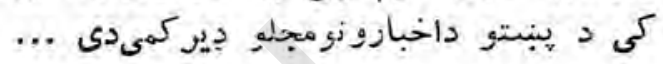

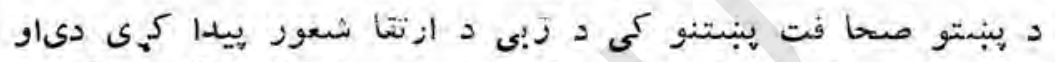

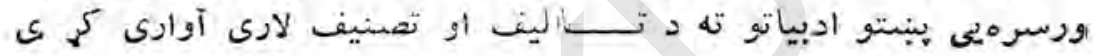

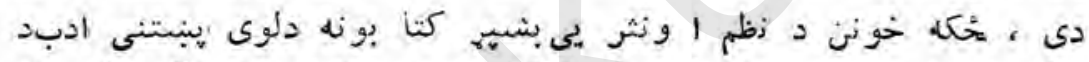

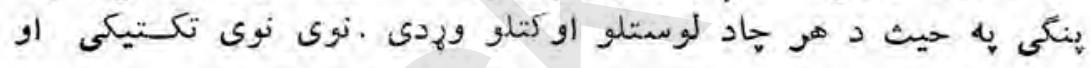

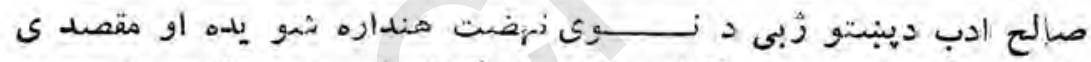

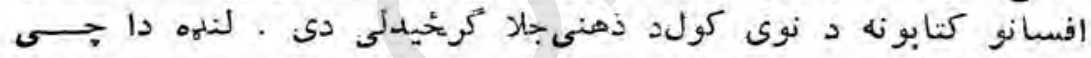

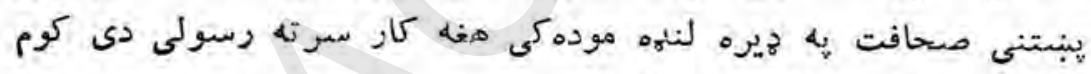

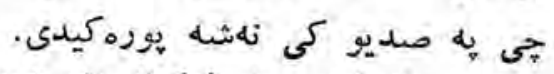

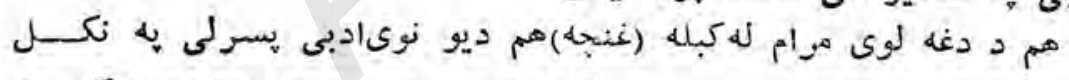

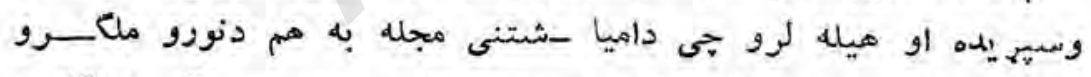

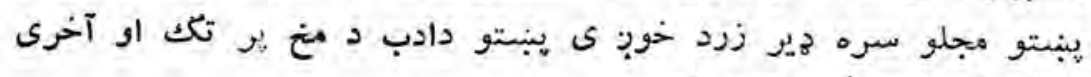

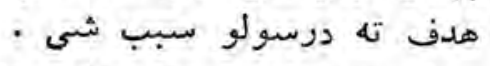

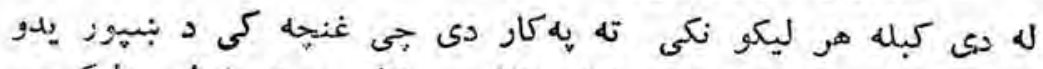

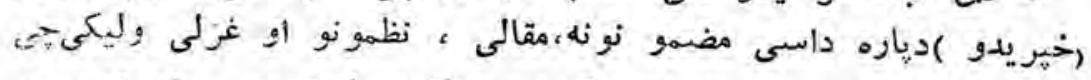

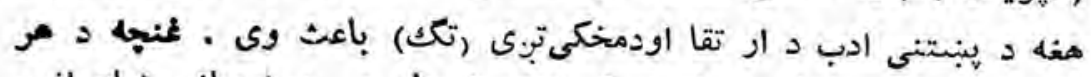

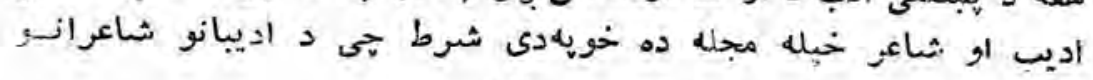
$-\wedge r$ 


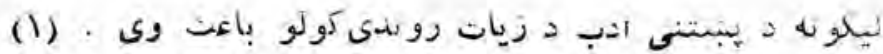

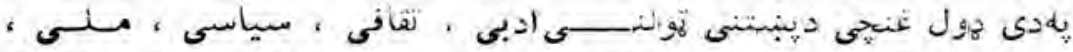

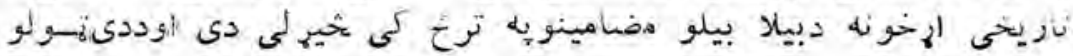

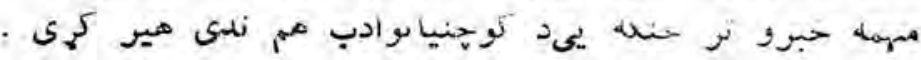

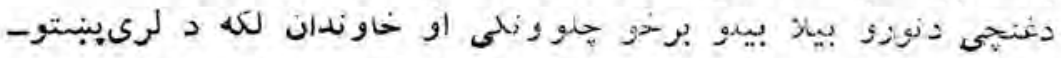

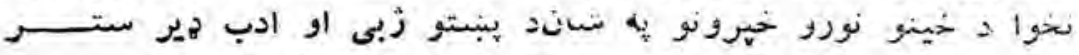

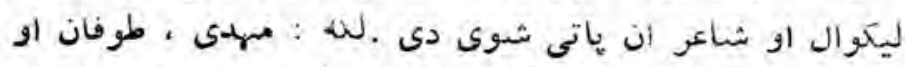

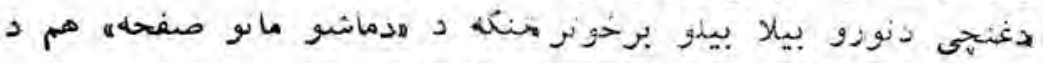

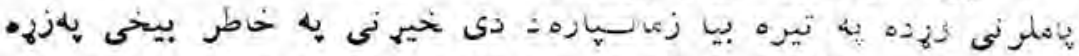

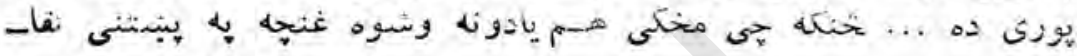

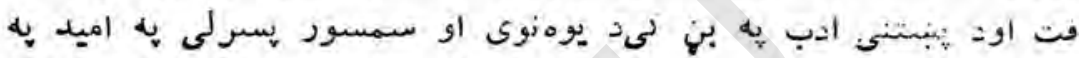

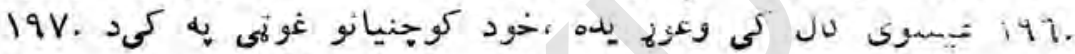

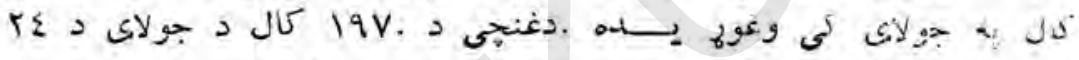

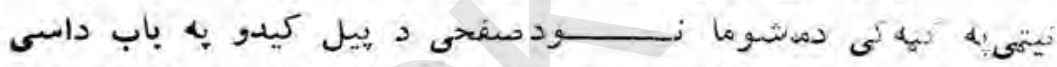

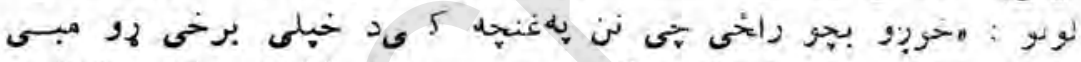

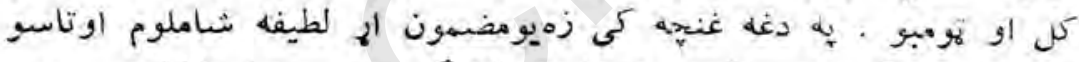

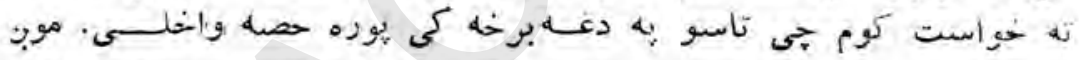

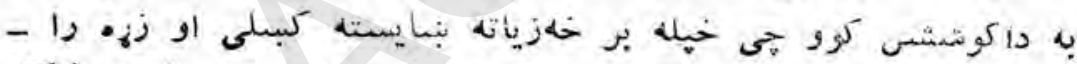

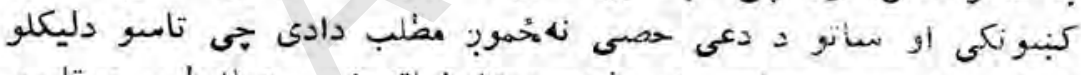

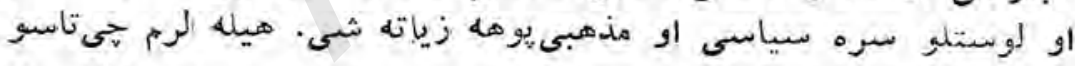

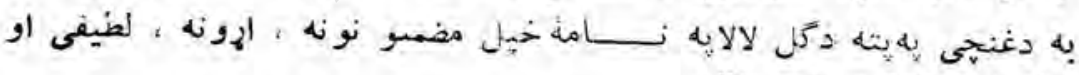

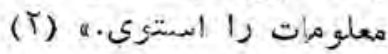

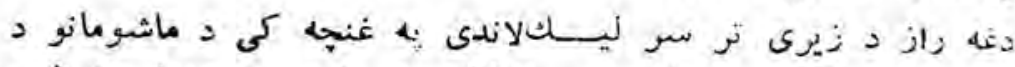

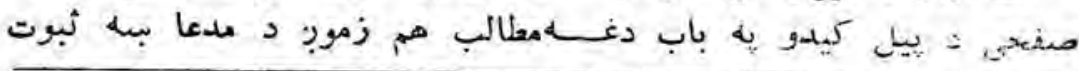

$$
\text { (1) }
$$

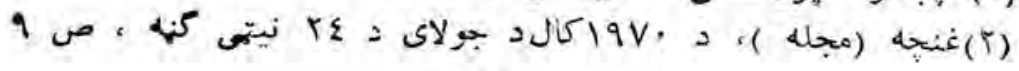




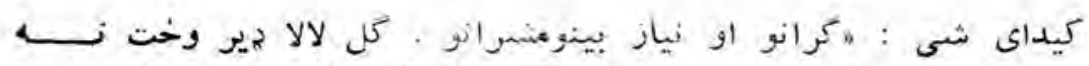

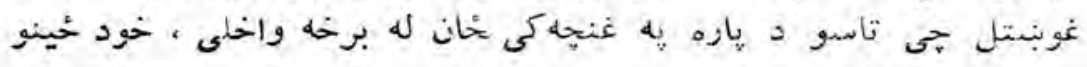

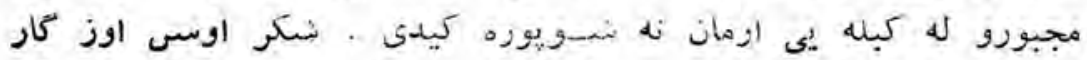

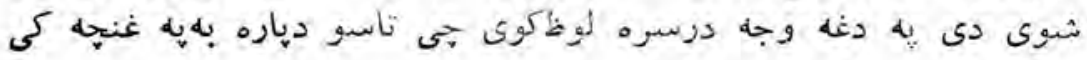

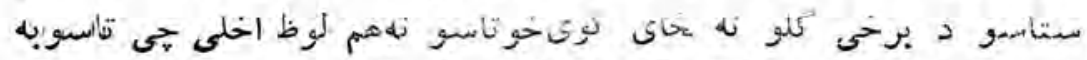

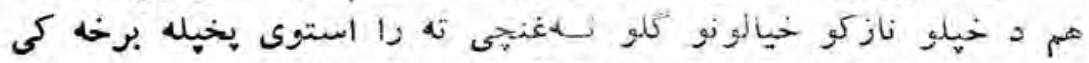

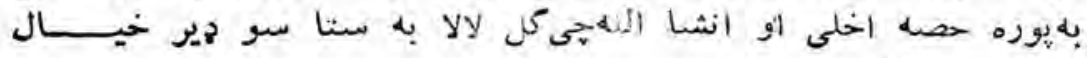

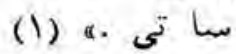

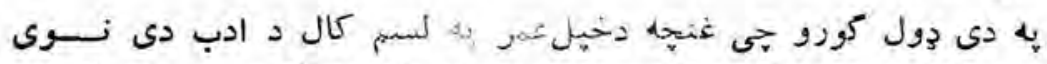

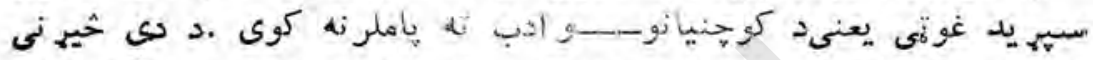

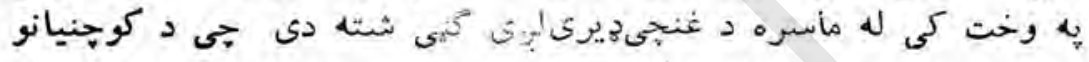

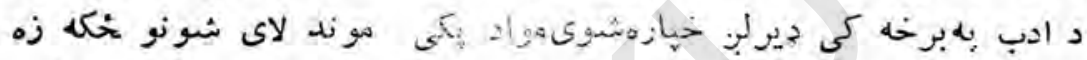

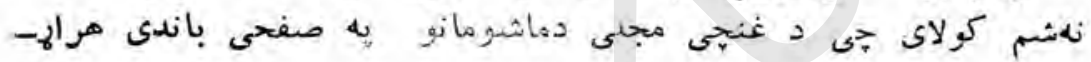

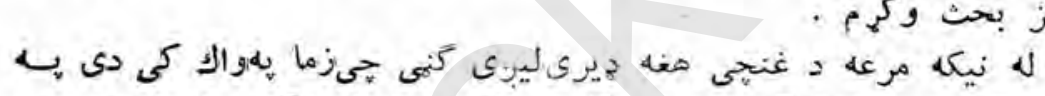

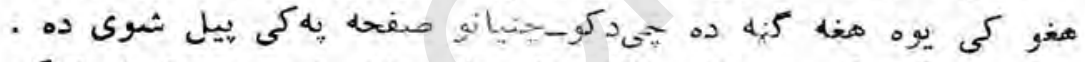

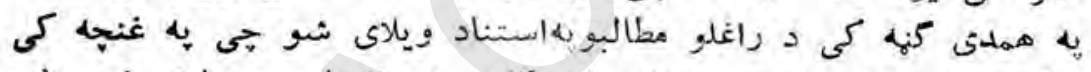

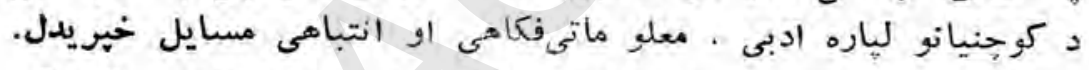

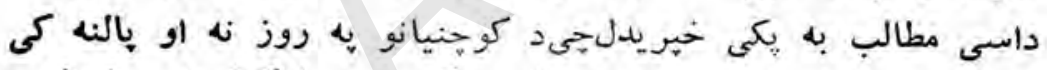

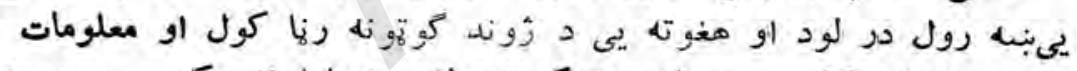

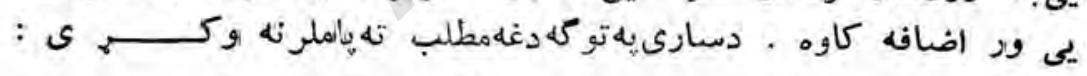
3ُ

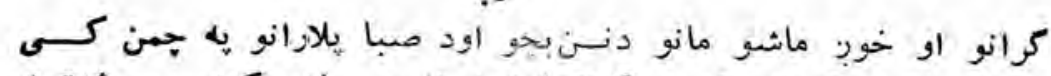

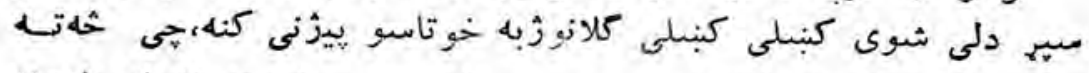

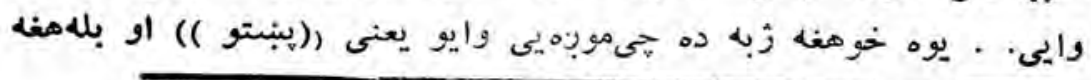

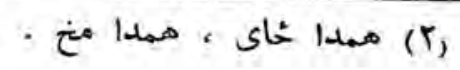




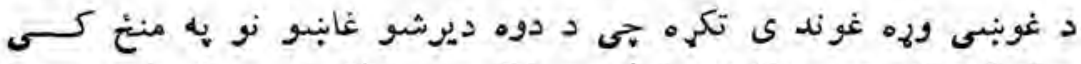

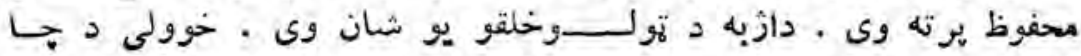

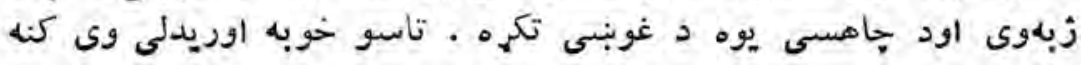

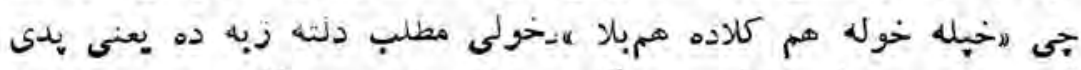

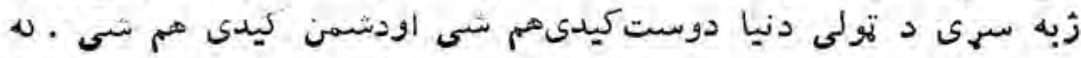

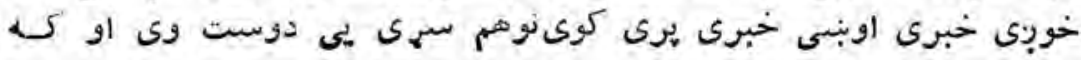

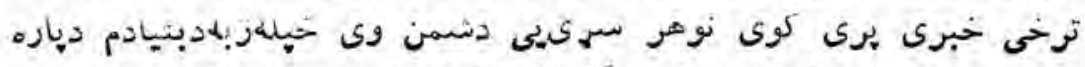

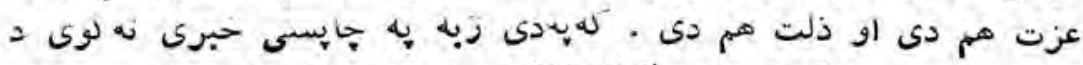

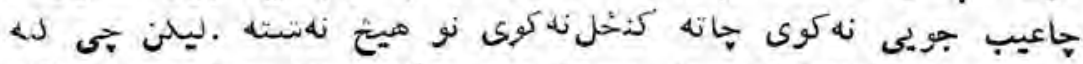

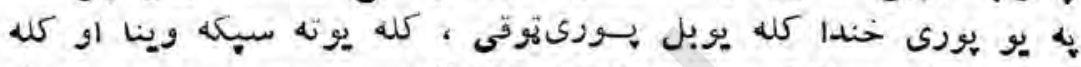

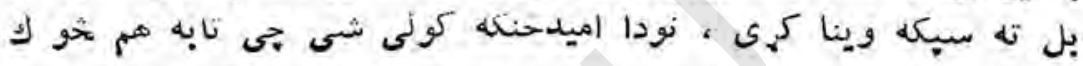

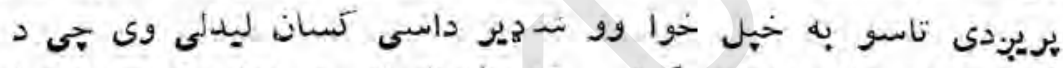

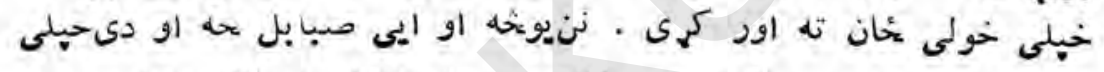

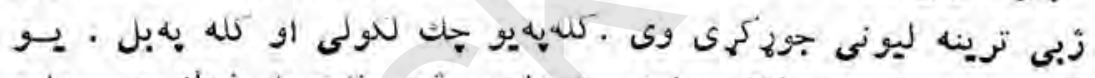

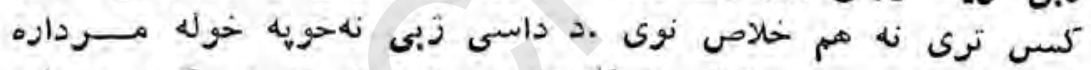

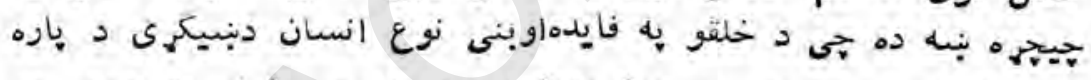

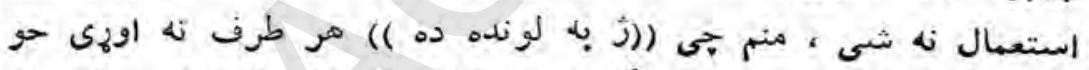

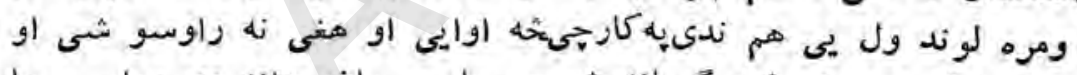

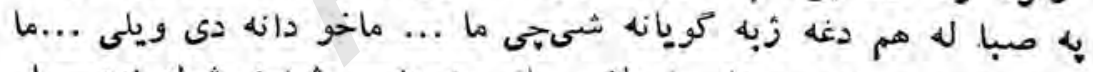

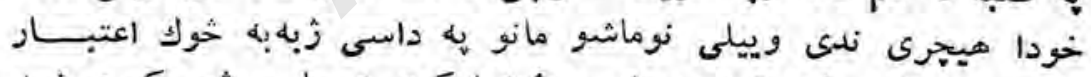

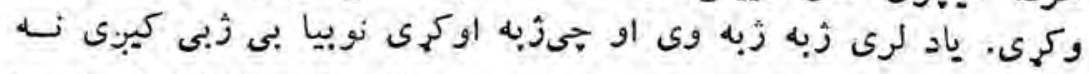

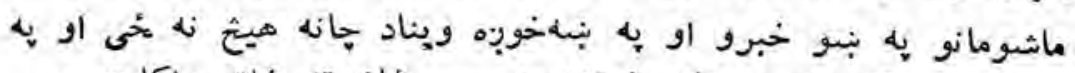

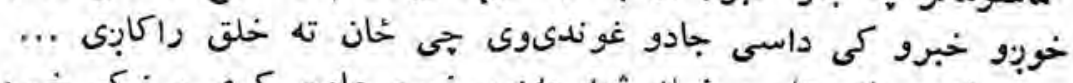

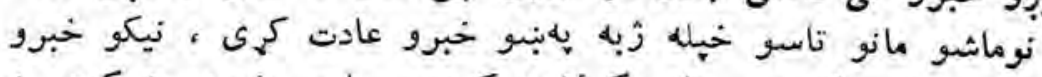

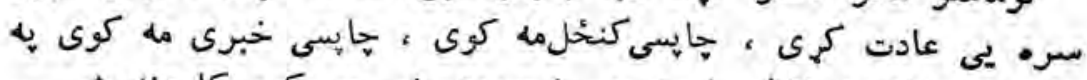

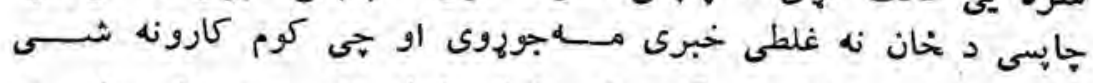

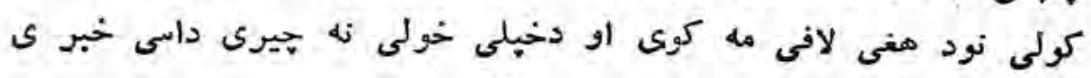




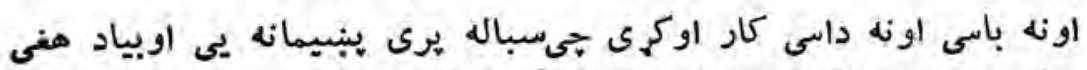

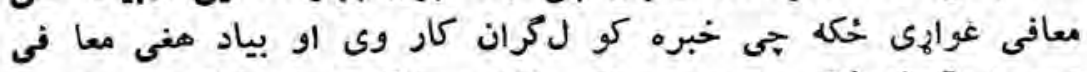

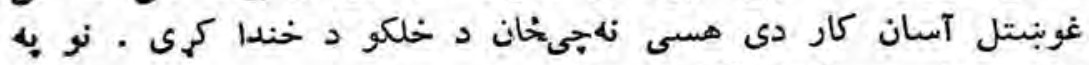

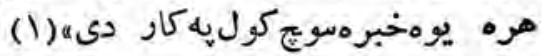

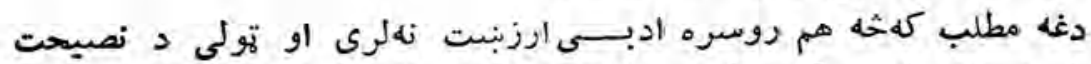

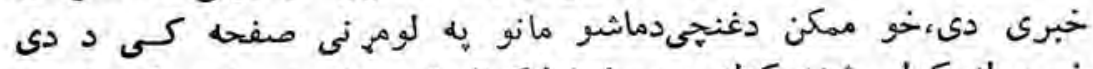

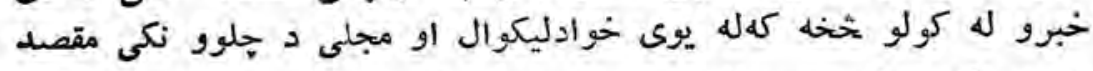

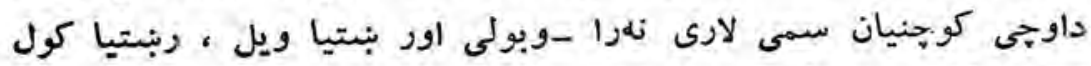

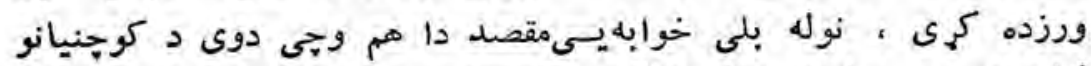

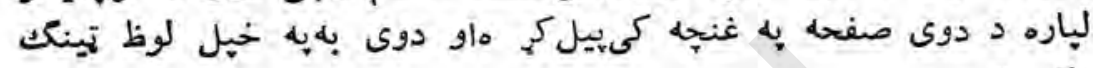
،ياتى شى · لياره

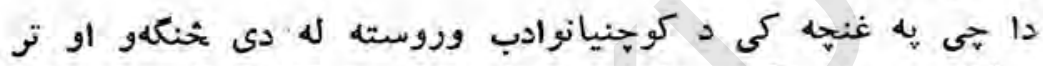

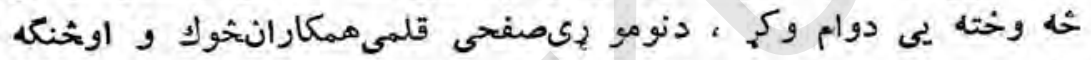

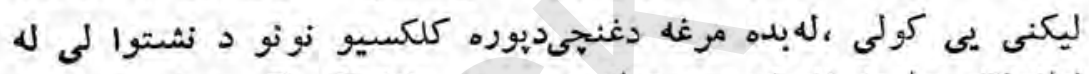

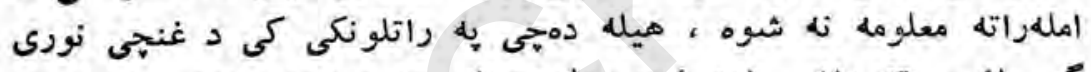

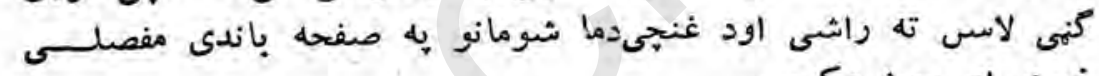

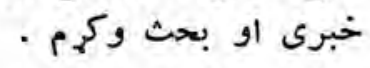

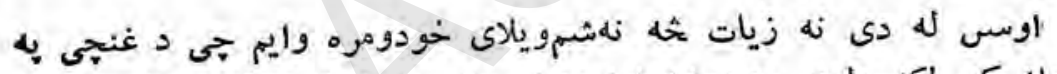

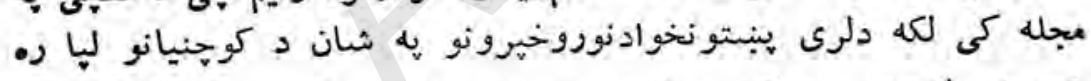

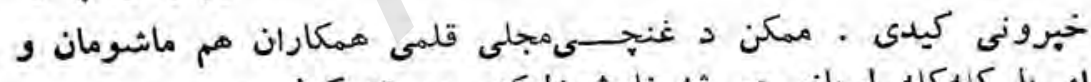

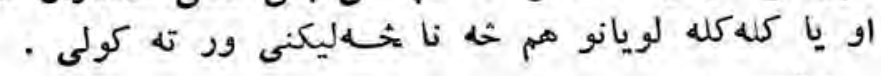

اولس :

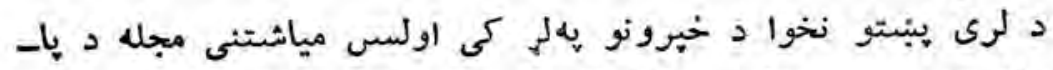

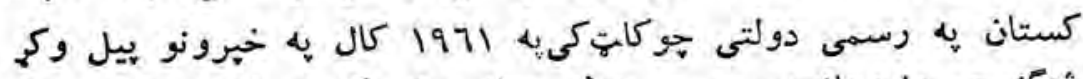

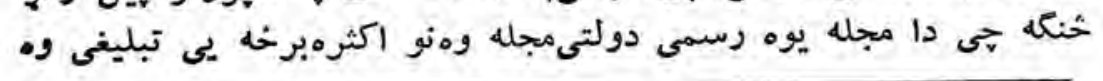

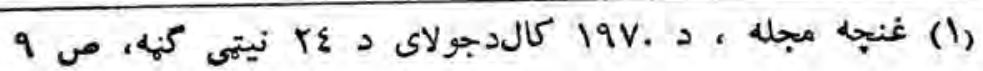
-Av_ 


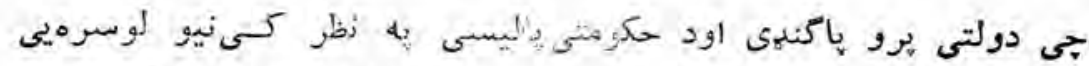

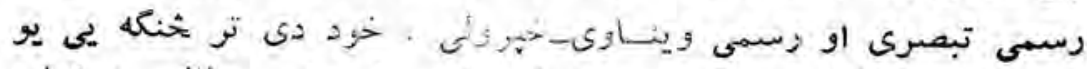

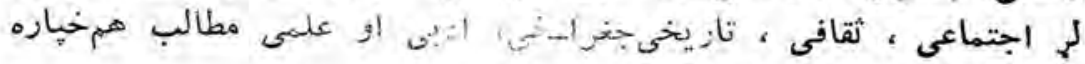

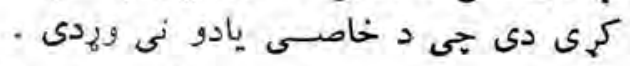

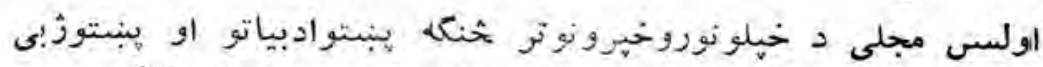

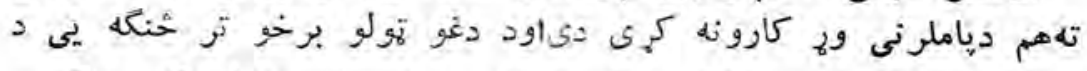

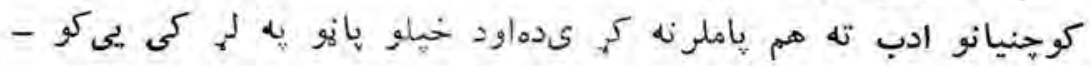

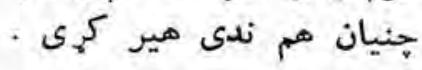

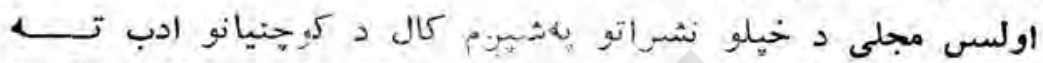

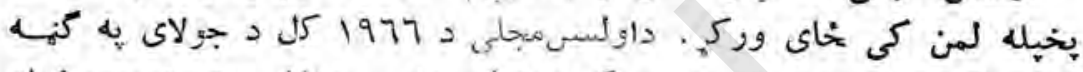

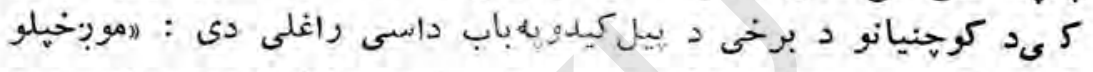

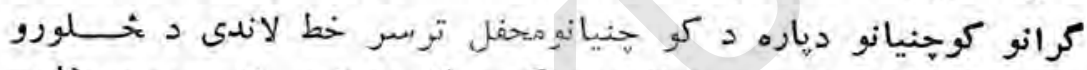

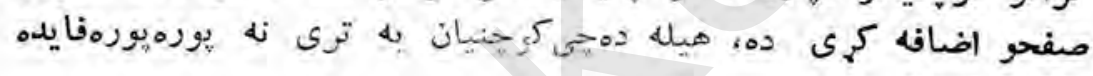

(1) واخلى (1977

له

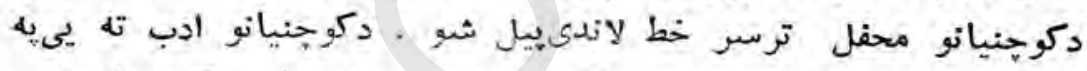

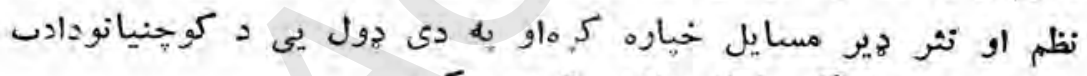

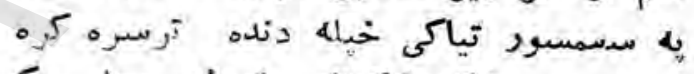

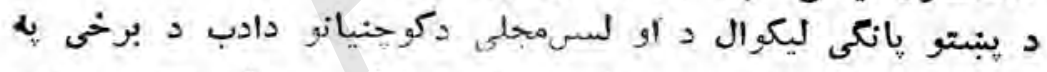

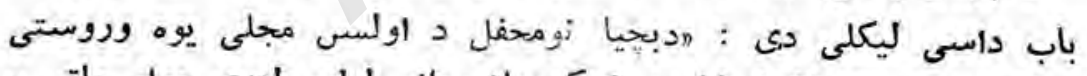

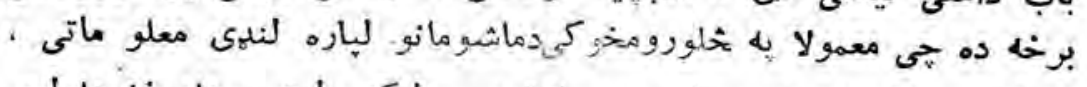

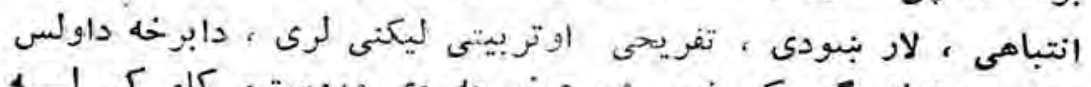

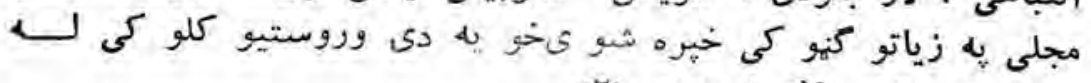

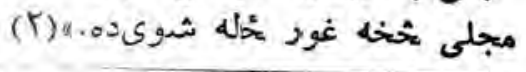

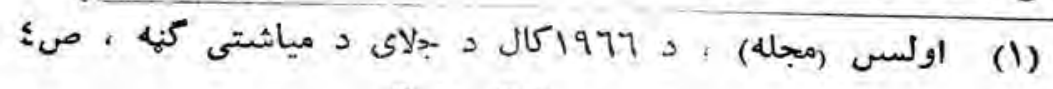

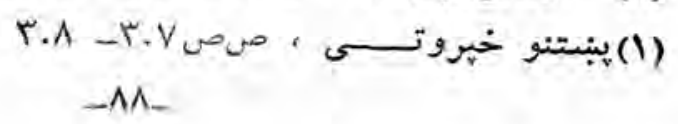




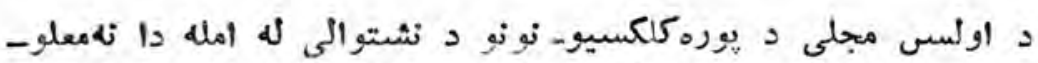

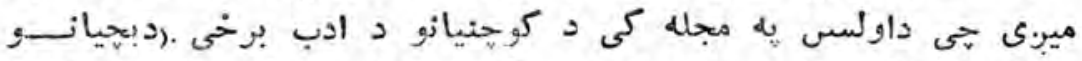

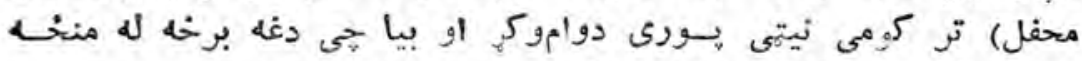

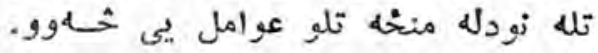

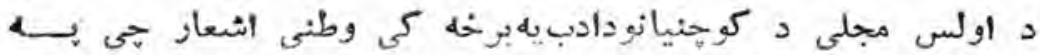

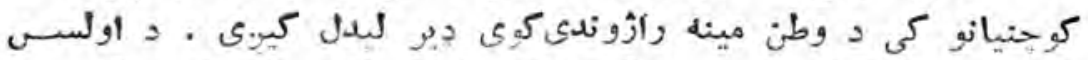

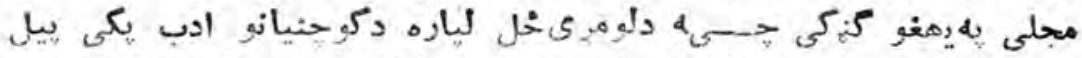

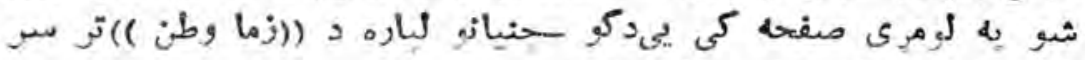

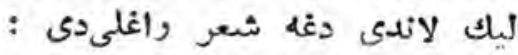

ما ما مي، داباد وطن دا مى دلربا وطن

دغانه دى زما وطن

خان بهبرى قريان كرئ

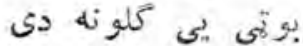

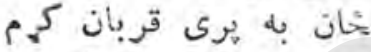
دشت او به به دمنو كى قري

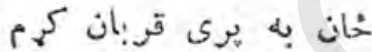
نهان جاد زورومهان

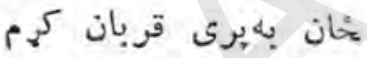

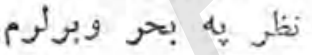

خان به يرى قربان كهي

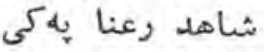

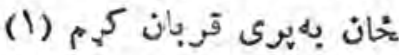

كانى ينى لعلو نه دي

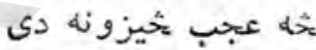

زه يى غرو لمنو كى

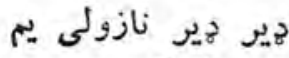

زه اول كمزورو مه نام

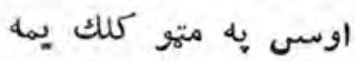

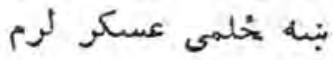

توره د حيدر لرم دمث

دين ده هم دنيا به كيه كى كري

آهوى شهبلا يكى ده دئ

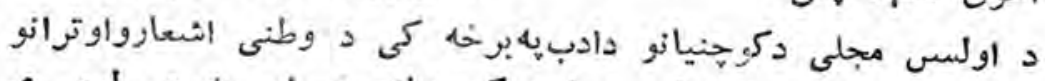

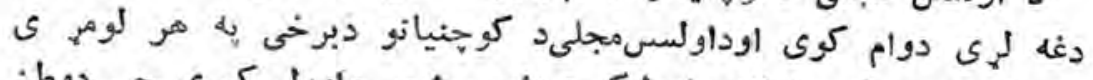

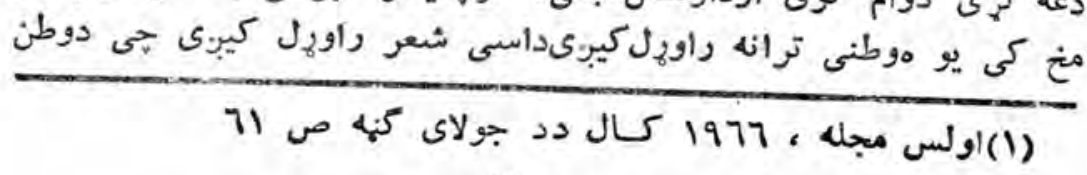

-19- 


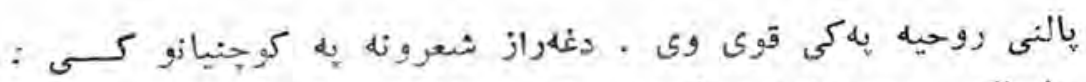

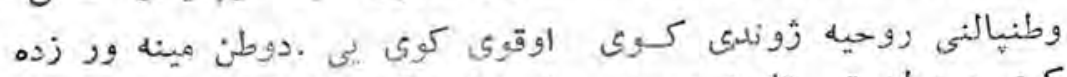

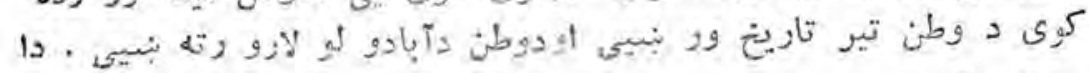
نمونه وكورى :

وطن

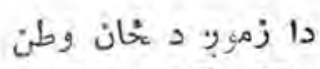
بنكلى كلستان وطن

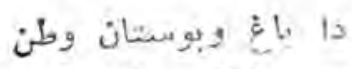
سيور شك جهان وطن وطن

موربِ وطن كتيلى دى

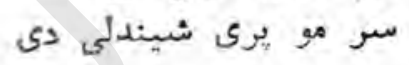

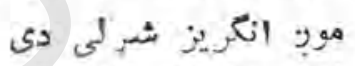
زموبٍ به. زور وتلى دى لى

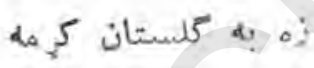

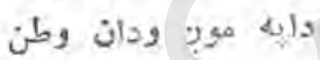

بناد به خيل وطن كي مه

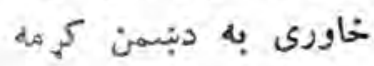

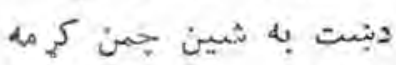

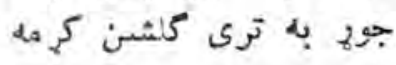

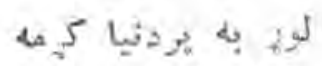

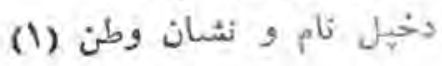

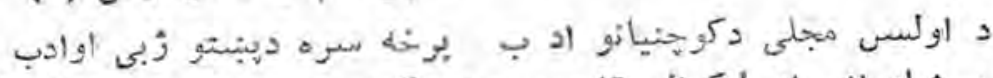

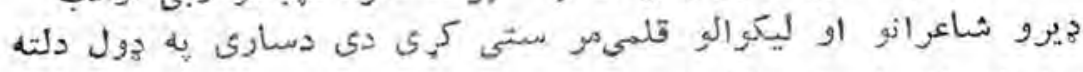

ديو خو تنو نوهونه الخلو :

so اولسن مجله ، (1972 (1972

-9.- 
حبيب الر حمنحبيب ، احمداللهاحمد، محمدل جميل جوهر ، مطيـع

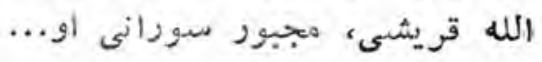

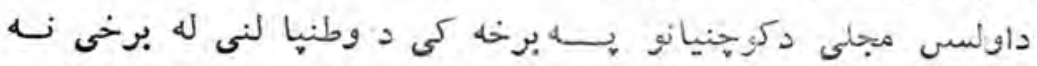

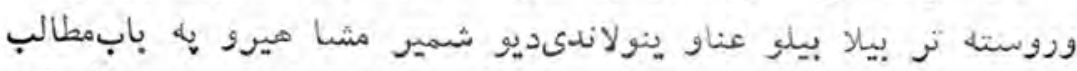

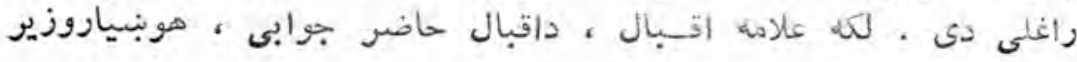
او نوز .

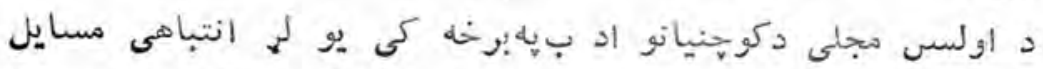

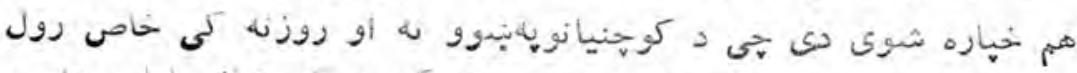

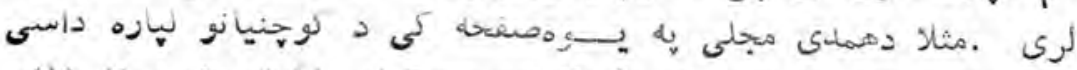

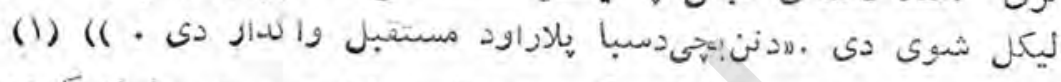

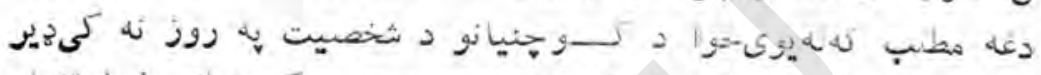

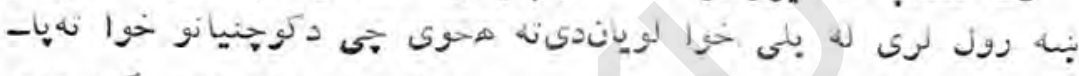

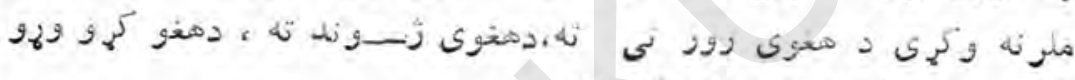

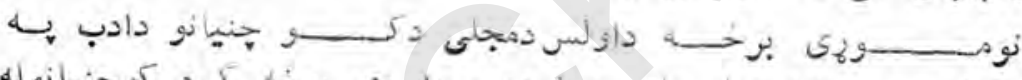

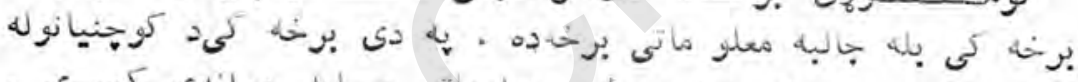

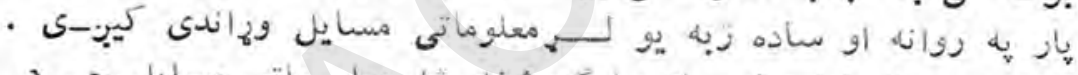

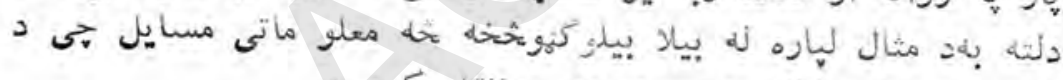

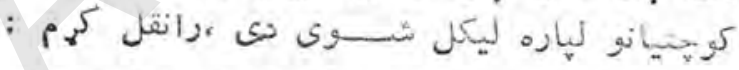

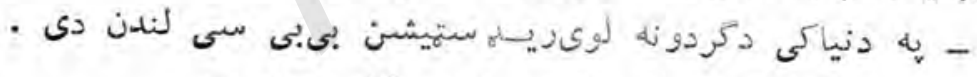

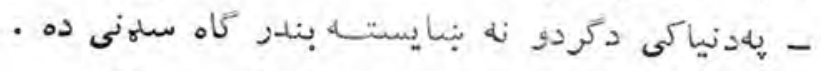

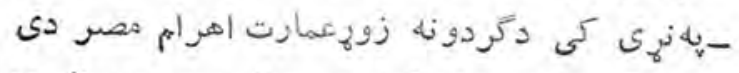

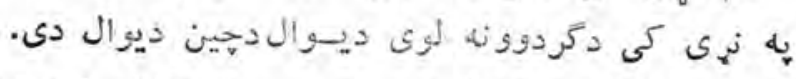

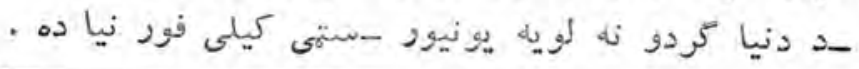

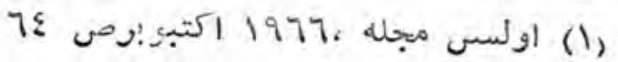




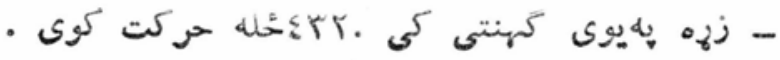

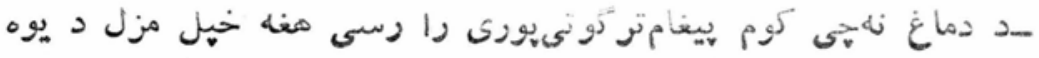

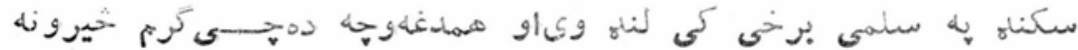

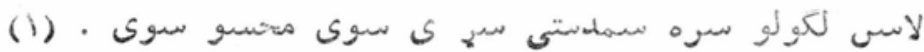

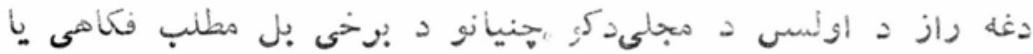

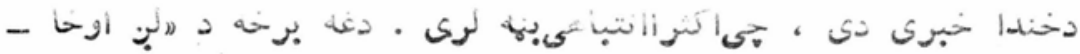

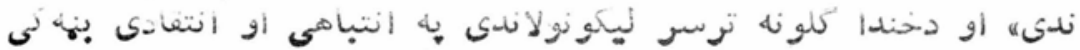

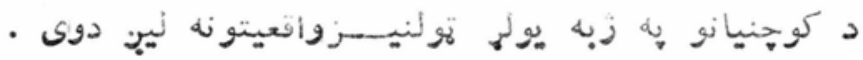

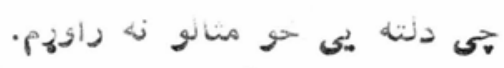

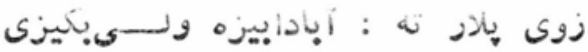

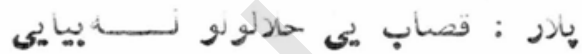

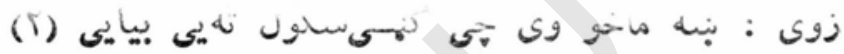

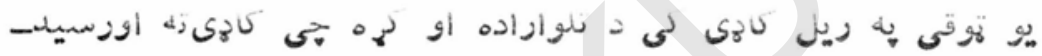

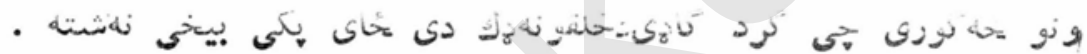

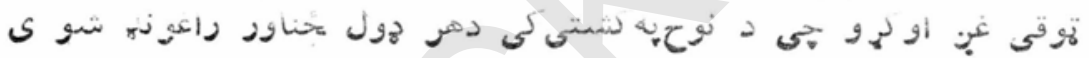

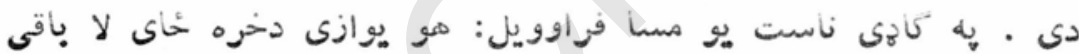

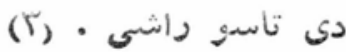

استاد شاكود ته : تانة مشسور مشسور جنكونه ياد دى

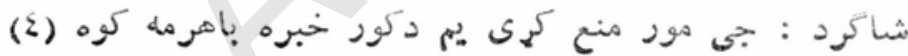

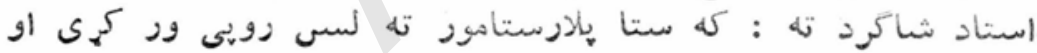

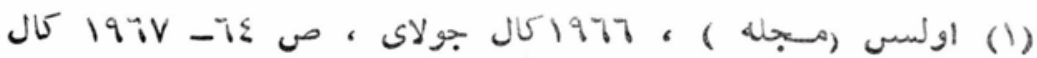

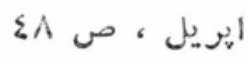

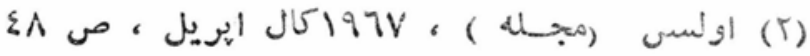

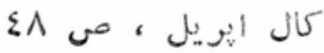

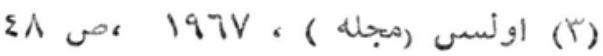

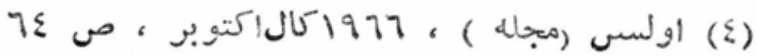




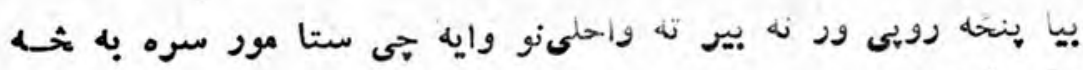

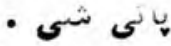

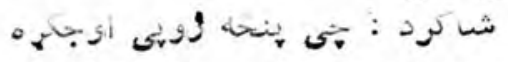

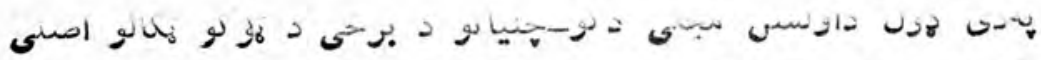

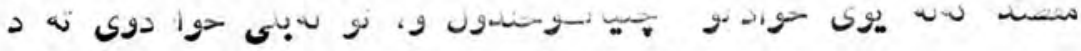

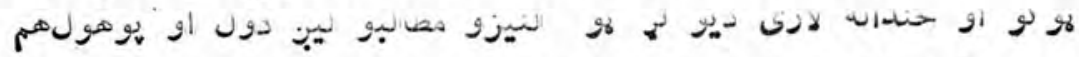

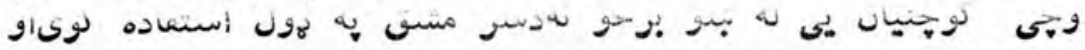

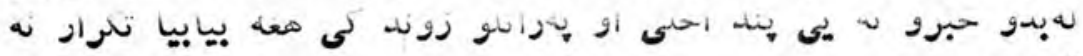
ك.

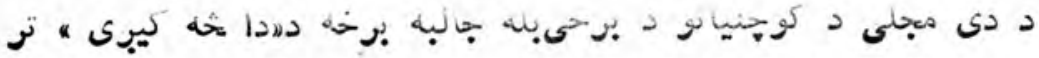

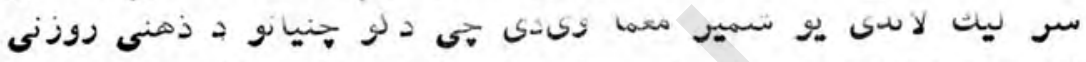

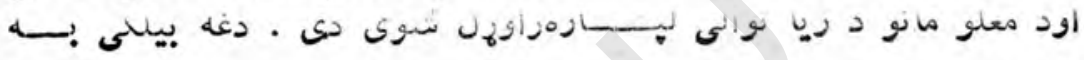
و كورو :

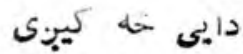

$$
\text { 20 (1) }
$$

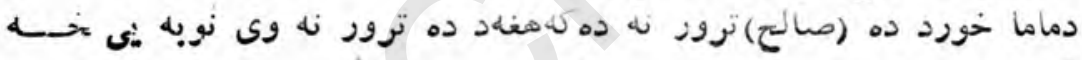
كي.ى

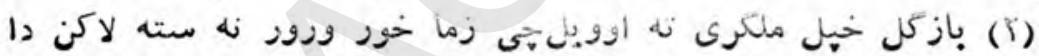

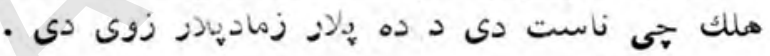
جوابات - (1) (1) (r)

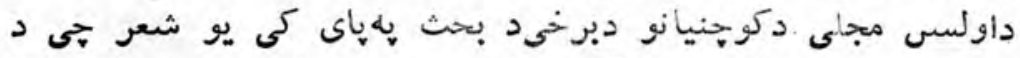

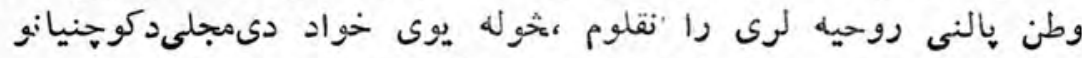

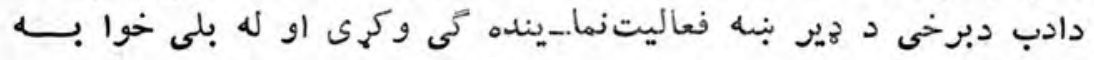

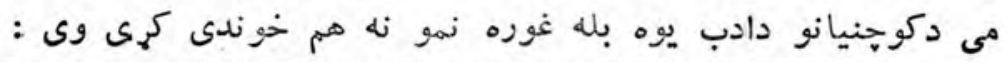

(1) اولسس (مجله ) ، $-94$ 


$$
\begin{aligned}
& \text { خها بنكلى ون زمو } \\
& \text { شها بنكلى وطن زموب. }
\end{aligned}
$$

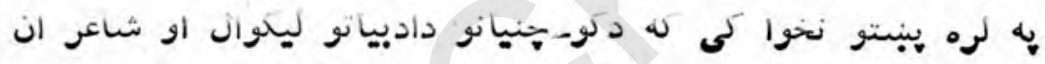
• هـ دوو هو وويشو نودأسى بنه

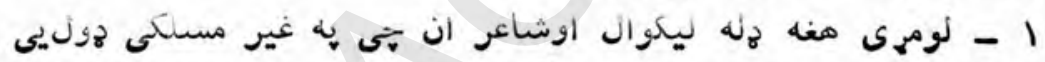

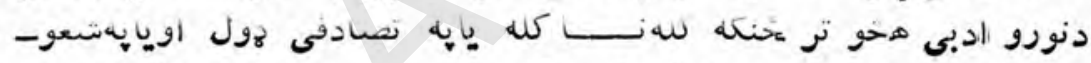

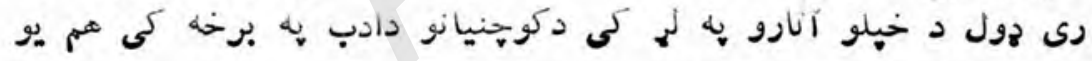

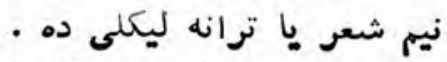

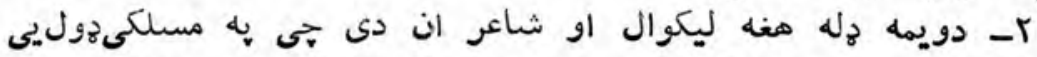

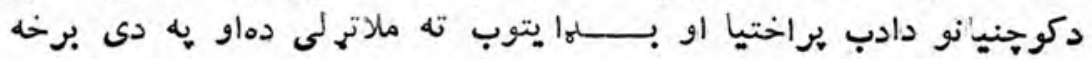

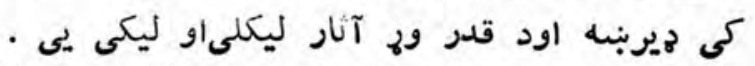

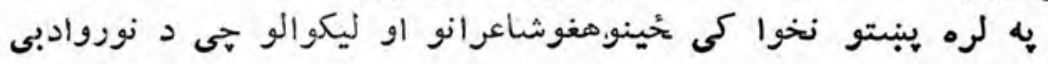

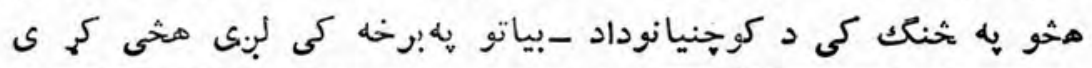

7. اولس (مجله ) ، 1977 كالسيتمبز ، صع (1) $-9 \varepsilon$ 


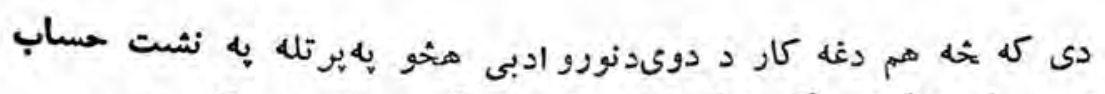

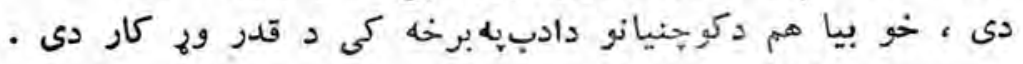

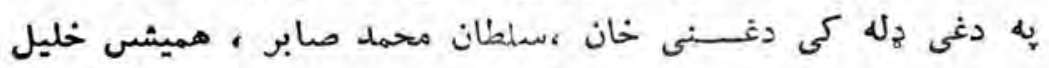

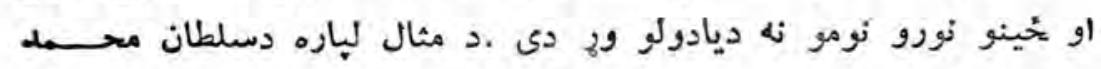

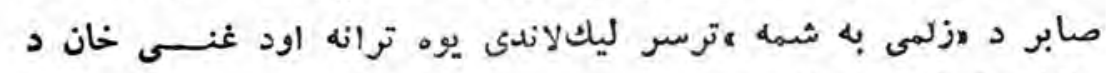

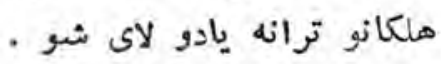

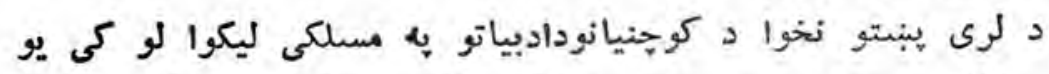

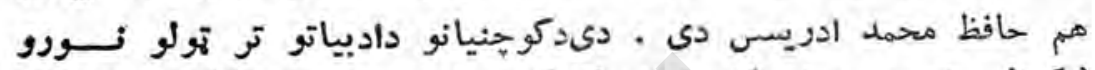

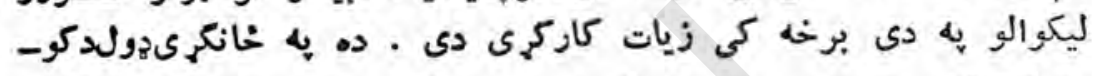

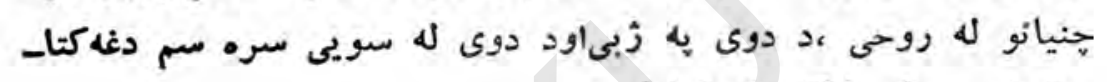

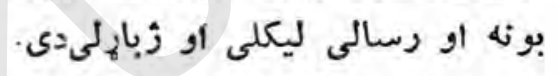

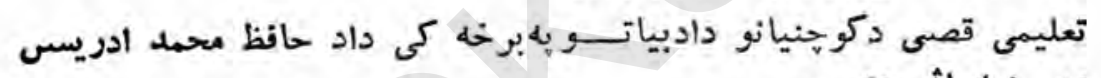

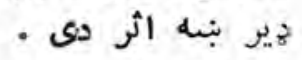

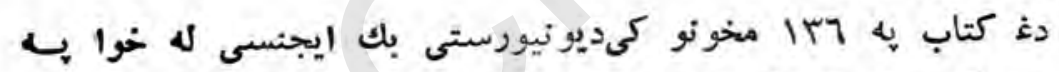

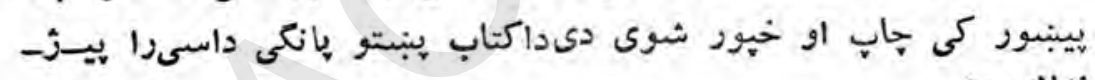
ندلاى دى .

$$
\begin{aligned}
& \text { تعليمى كصى } \\
& \text { ليكونكى : حافظ محمد ادريس : }
\end{aligned}
$$

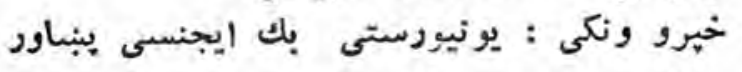

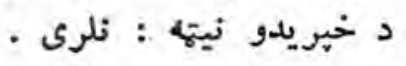

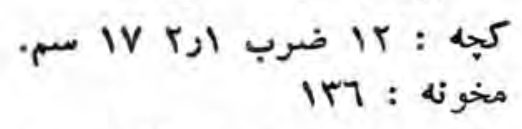

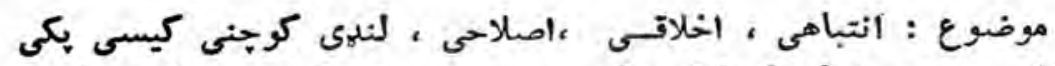

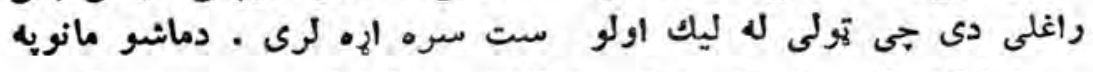

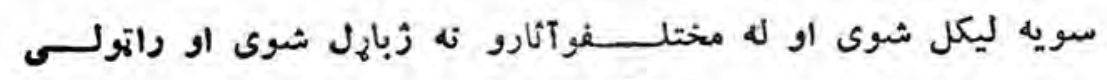
$-90-$ 


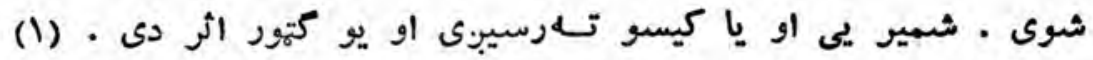

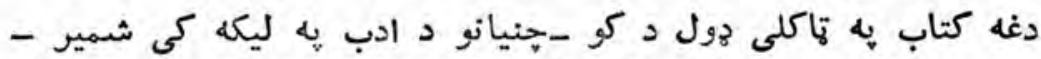

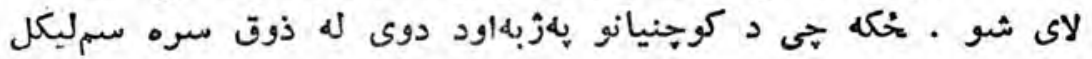

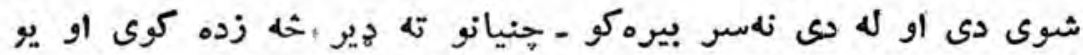

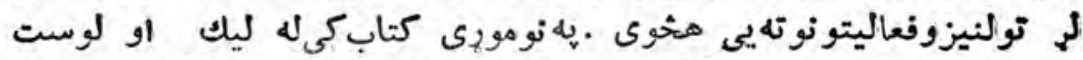

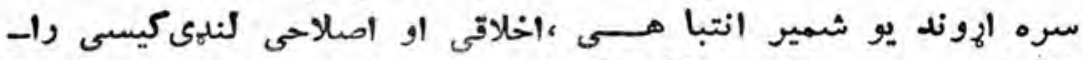

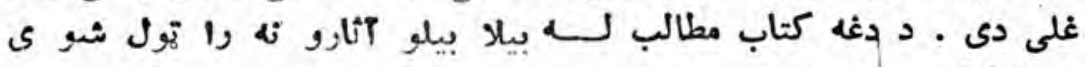

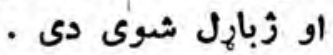

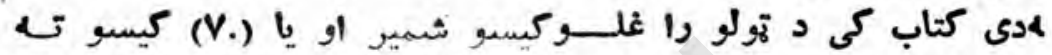

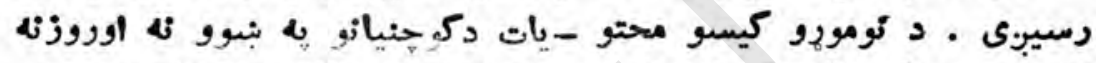

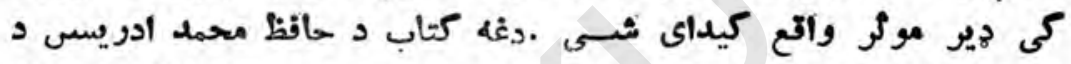

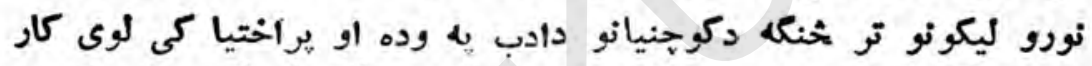

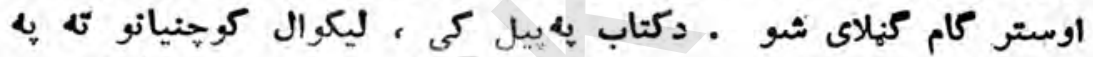

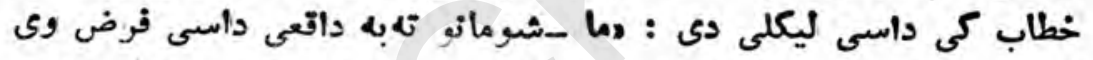

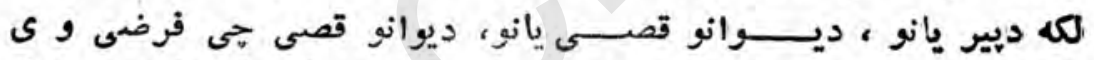

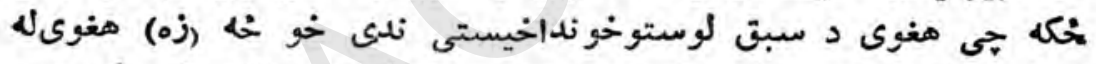

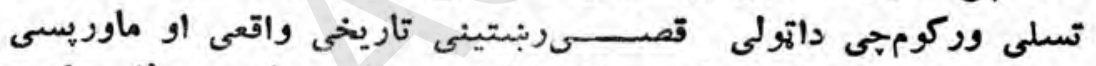

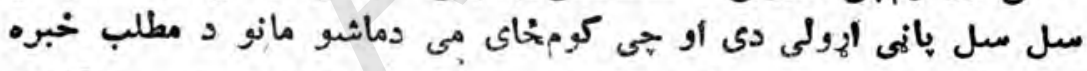

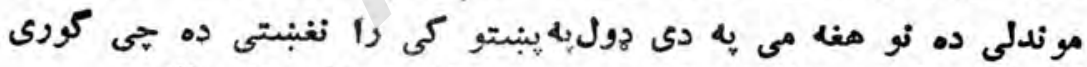

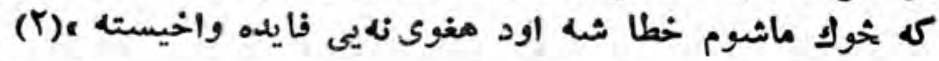

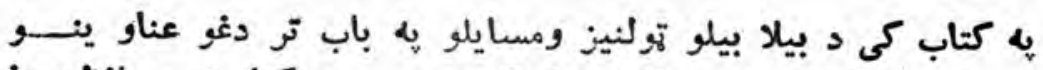

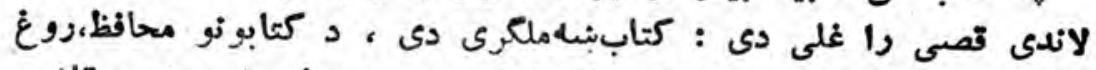

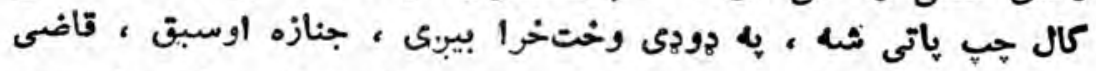

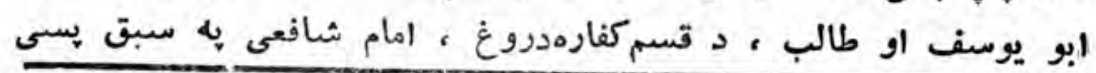

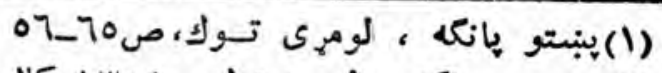

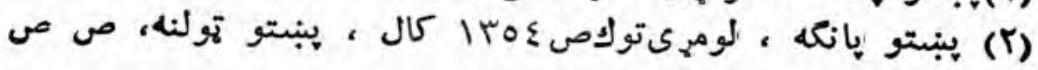




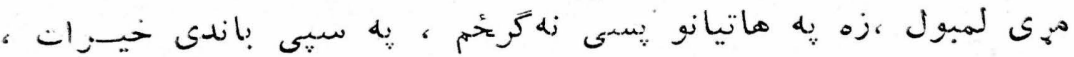

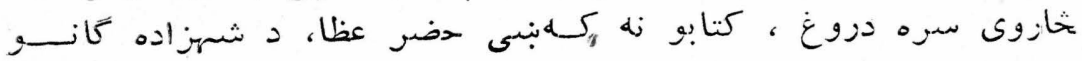

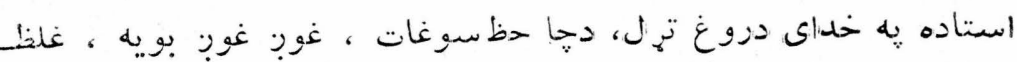

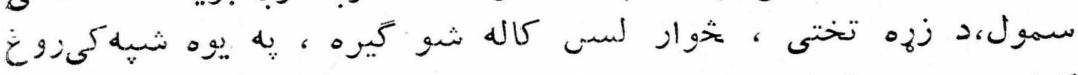

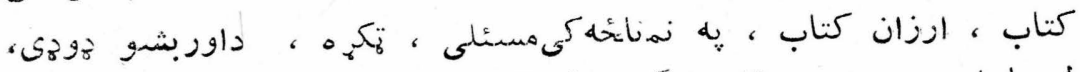

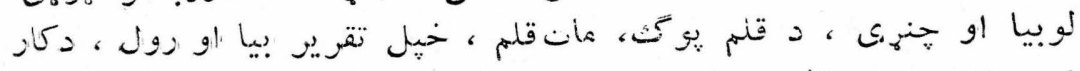

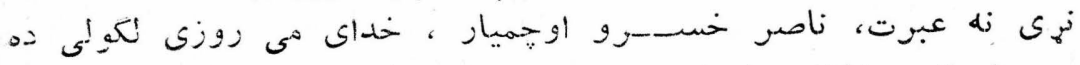

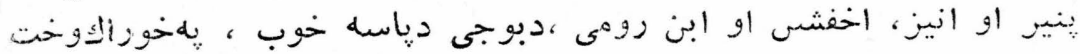

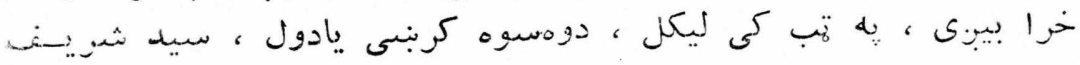

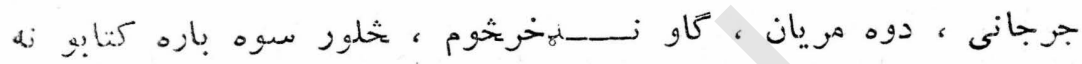

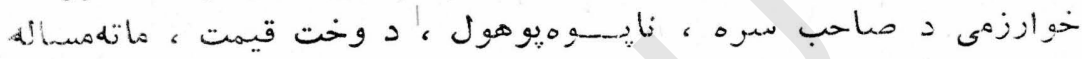

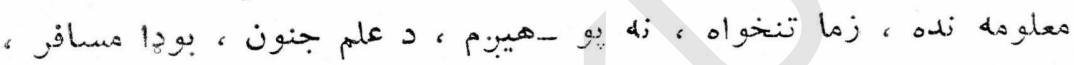

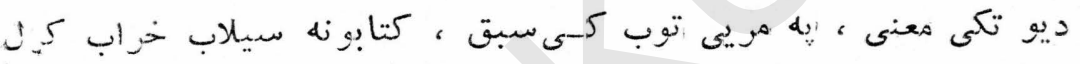

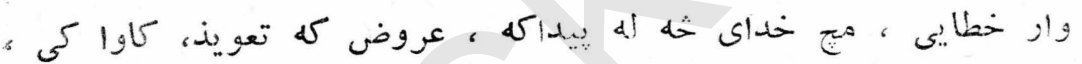

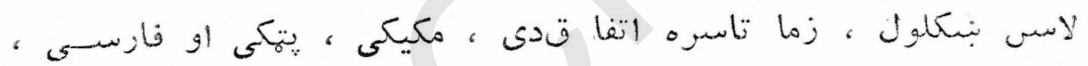

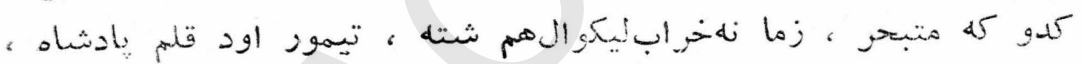

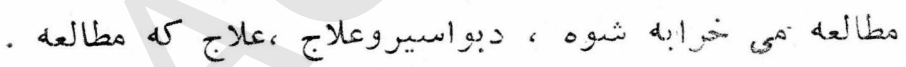

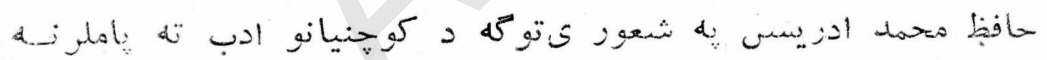
.25

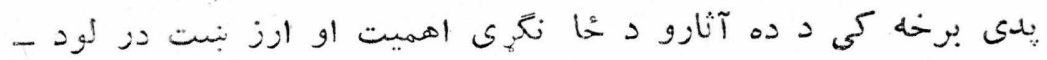

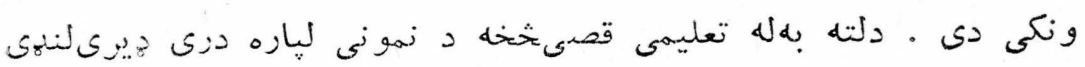

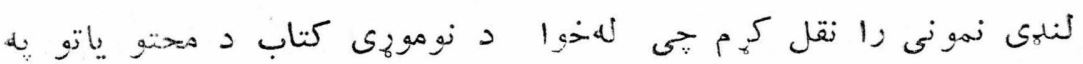

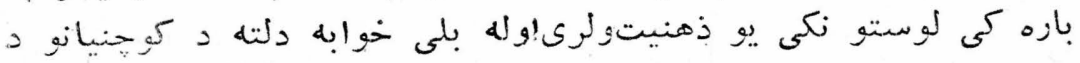

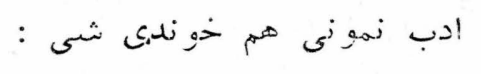

r in (1) 


\section{كتاب بنه ملكرى دى}

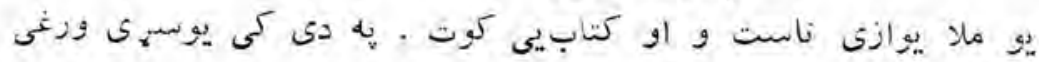

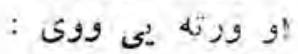

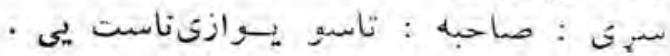

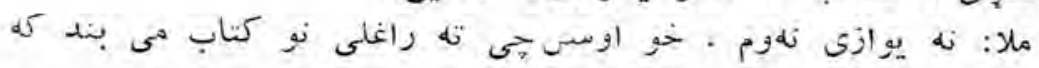

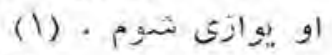

\section{د كتابونو محافيظ}

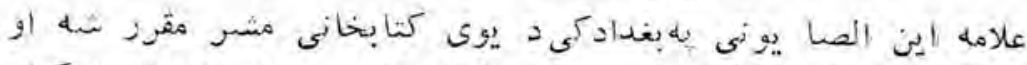

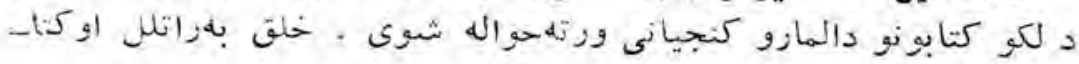

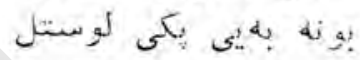

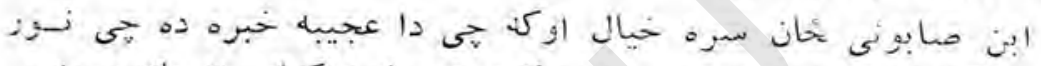

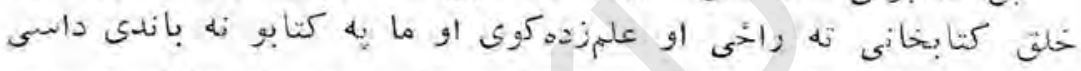

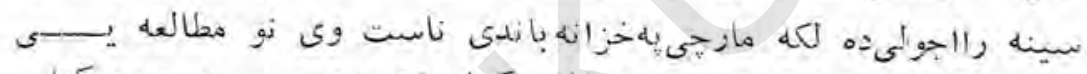

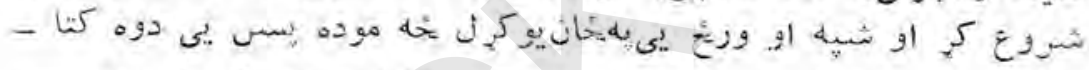

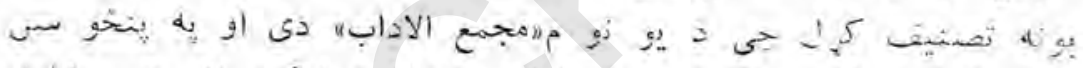

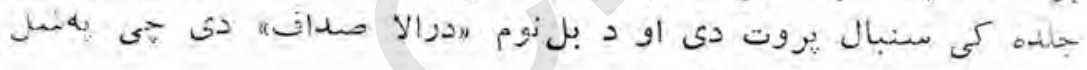

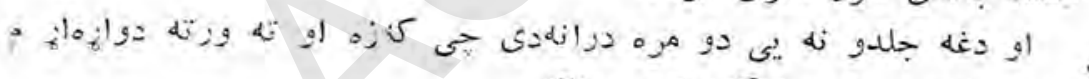

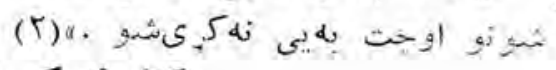

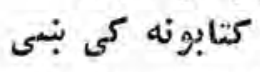

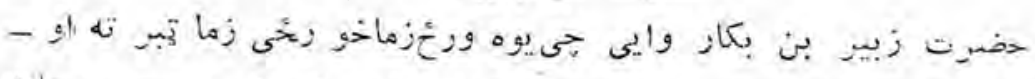

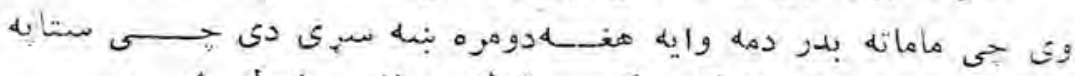

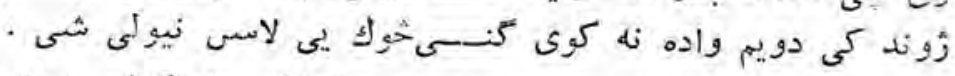

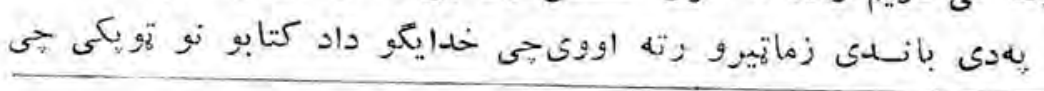

$$
\begin{aligned}
& \text { - (1) }
\end{aligned}
$$

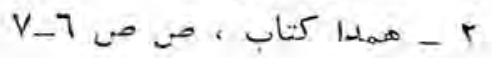


يى راثه او دزولى دى داماته ددزيو بنو نه زيات تكليف زسوى .

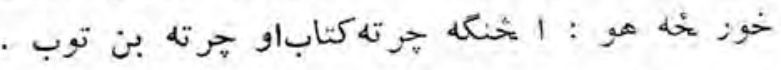

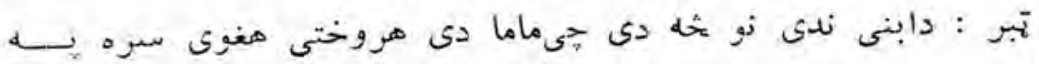

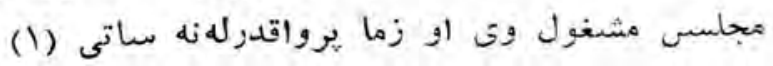

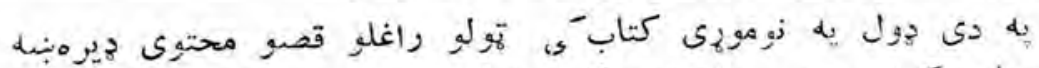

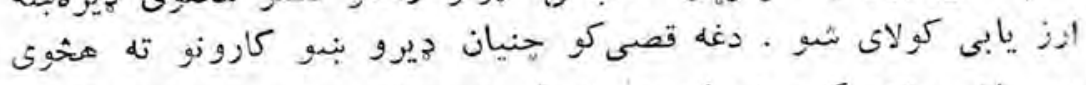

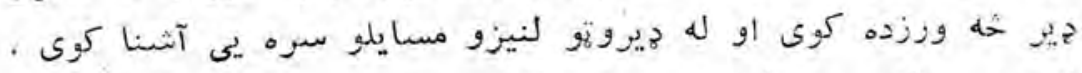

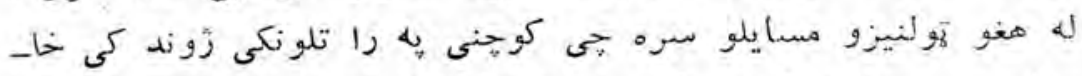

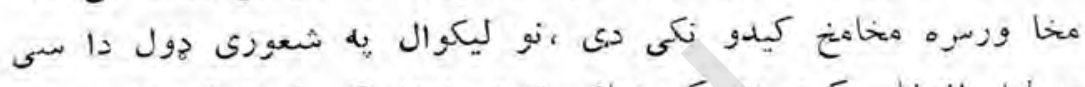

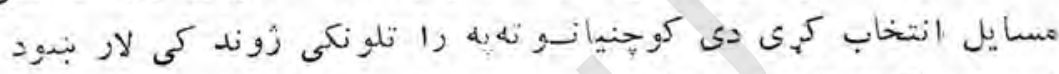

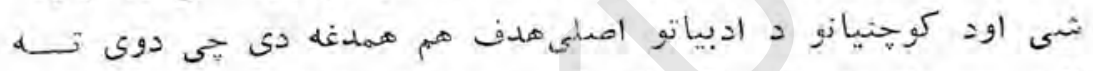

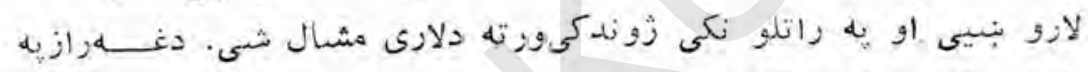

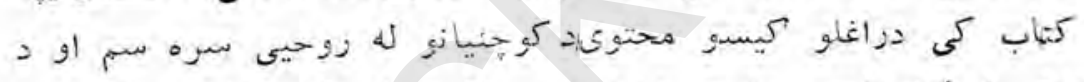

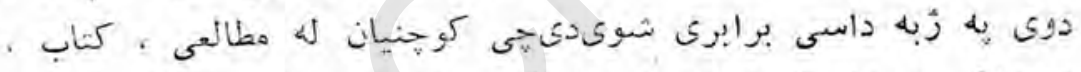

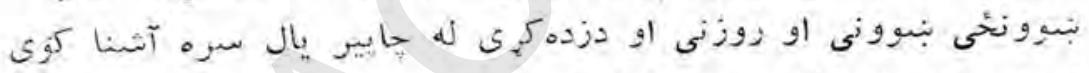

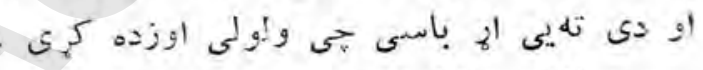

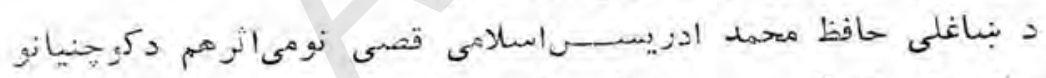

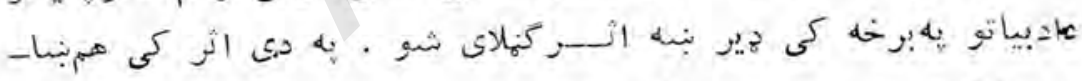

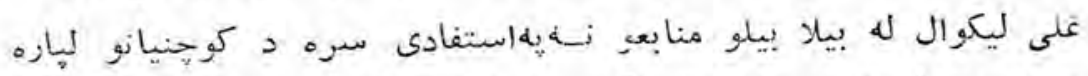

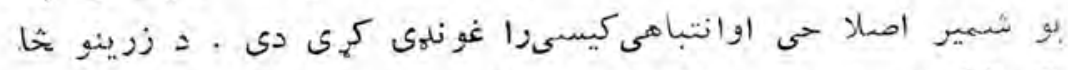

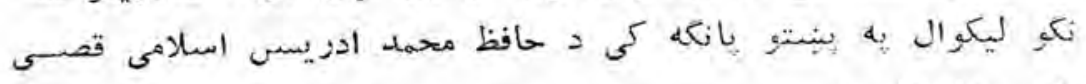

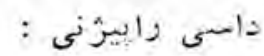

$$
\text { Et }
$$




$$
\begin{aligned}
& \text { اسلامى قصىى }
\end{aligned}
$$

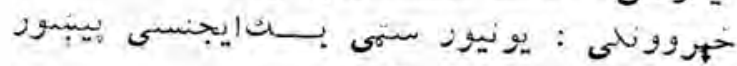

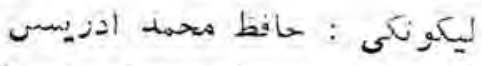

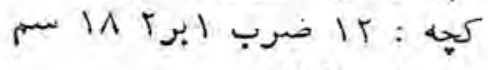

$$
\begin{aligned}
& \text { IVT. הخونة : مونه : }
\end{aligned}
$$

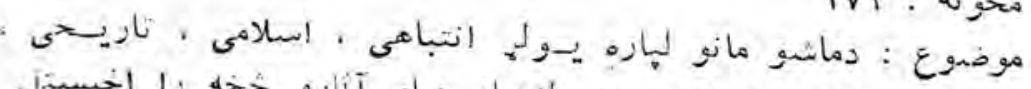

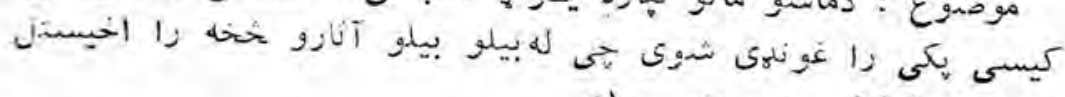

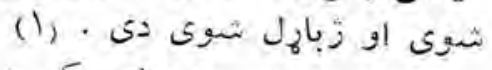

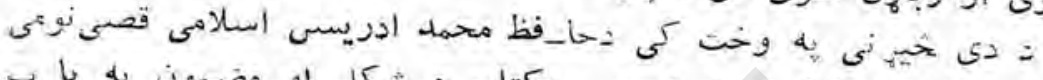

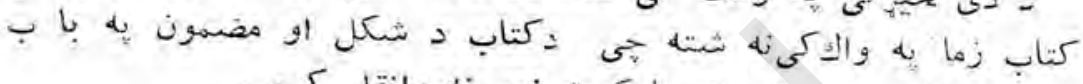

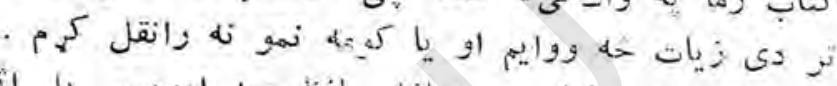

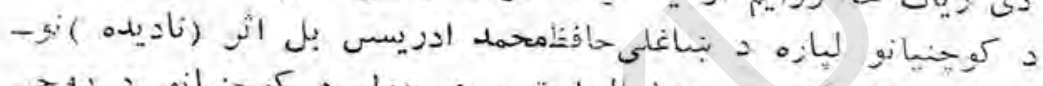

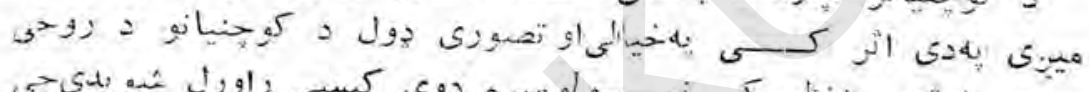

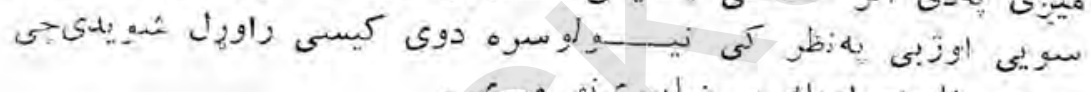

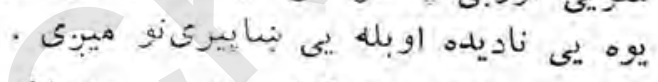

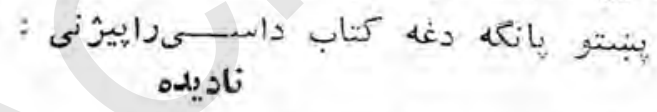

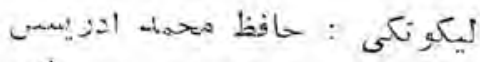

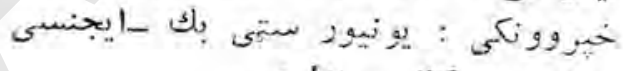

$$
\begin{aligned}
& \text { - خ خهريد : } \\
& \text { ك : إن : }
\end{aligned}
$$

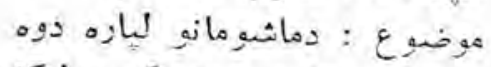

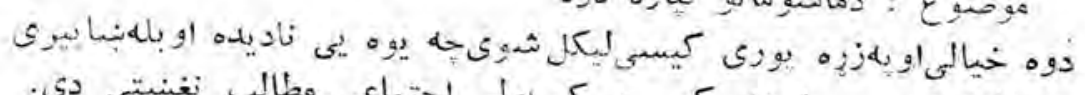

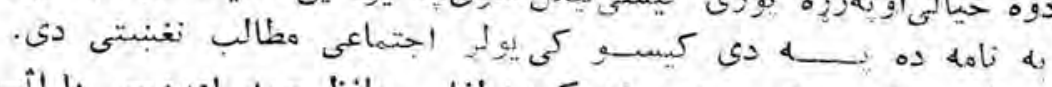

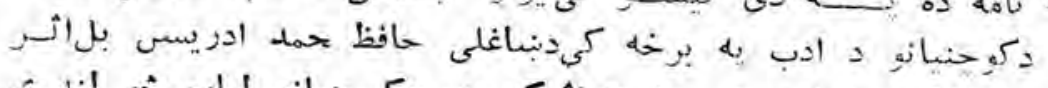

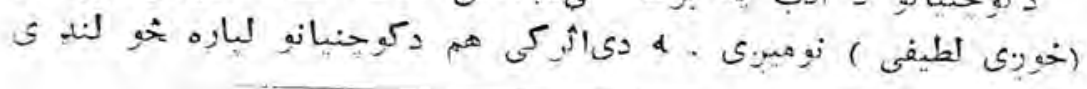

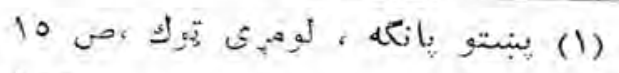


كميدى ، انتباهى كيسـى راورلشوى دى . د دى كتاب يهباب بيا

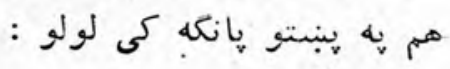
خوبزى لطيفى

ليكونكى : حافظ حمد ادريس : حونس

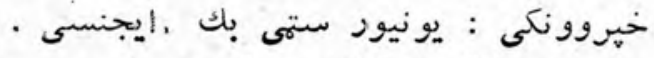

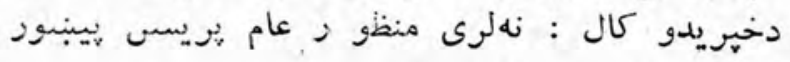

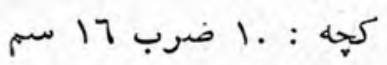

$$
\begin{aligned}
& \text { مخونه : مخ : }
\end{aligned}
$$

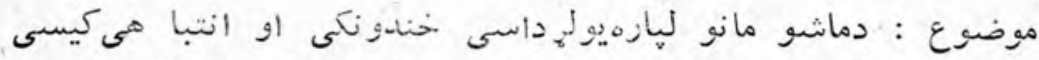

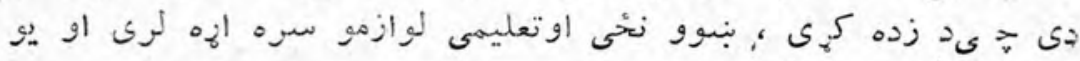

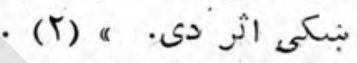

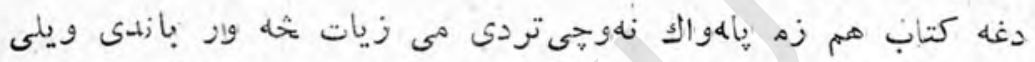

واى .

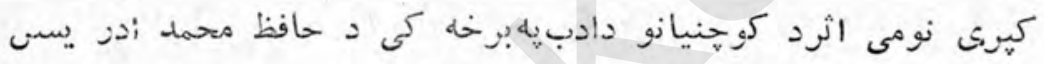

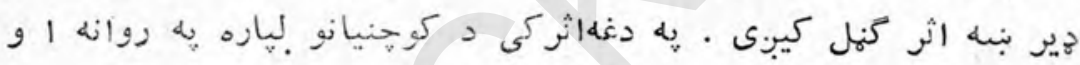

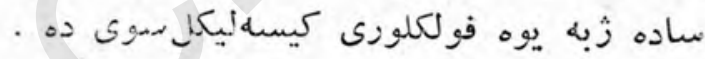

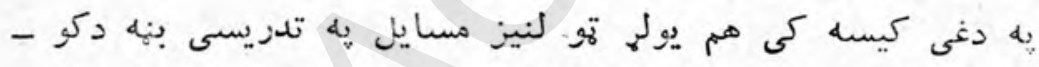

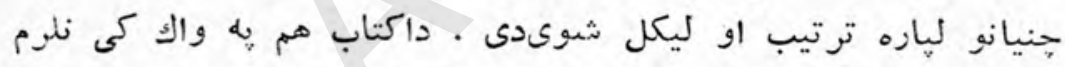

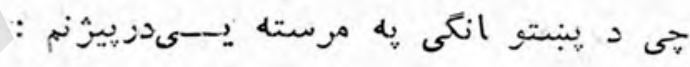

\section{كيرى (ككرى )}

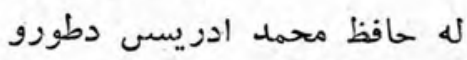
خيروونكى : يونيور ستهى بك ايجنى دطورو ايجنى

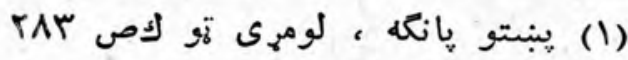

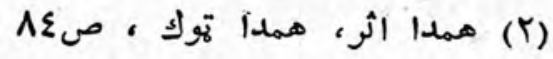


ج خبريدو خاى : حميد يه برقى يريس يشاور .

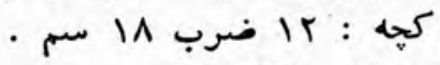
مخونه : كبه :

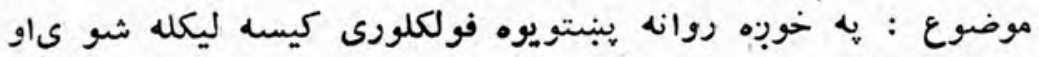

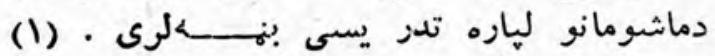

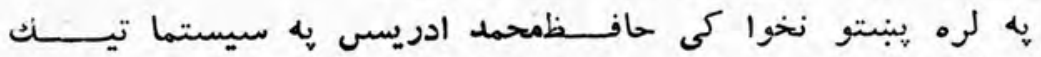

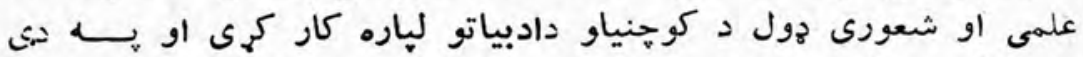

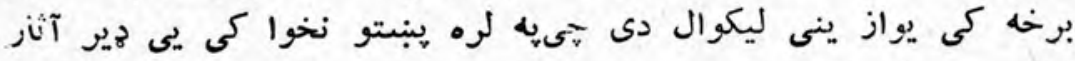

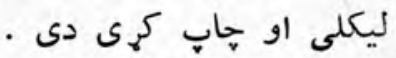

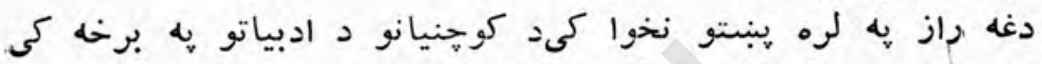

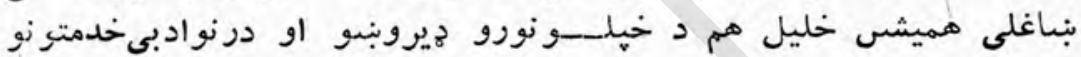

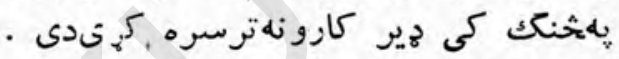

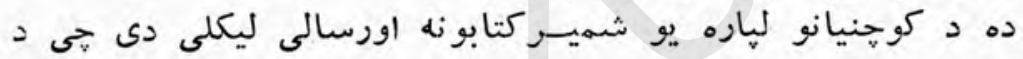

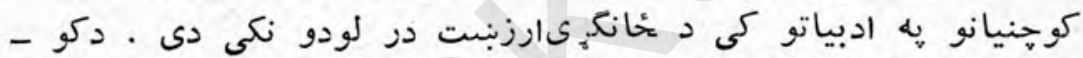

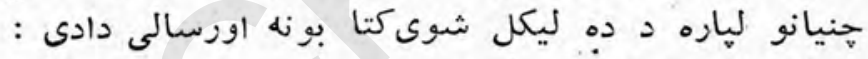

$$
\begin{aligned}
& \text { 1- خداى روزى رسان دى } \\
& \text { - r منيكى بدله }
\end{aligned}
$$

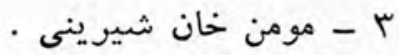

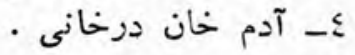

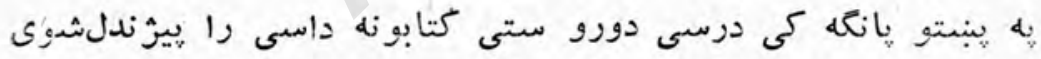

\section{د نيكى، بدله}

:

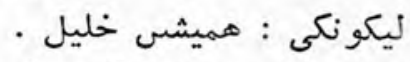

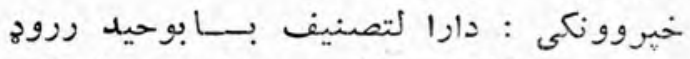

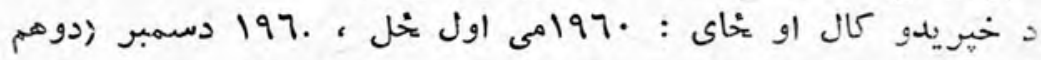

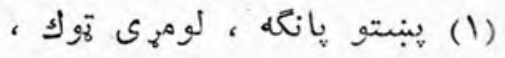


خال ) هيبك آربخ هويس كֶه : 17 : مخونه

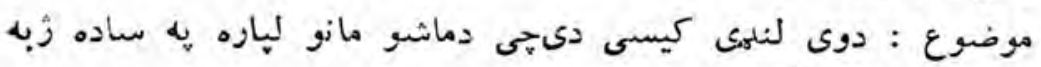

كنبل شوى دى (1)

مومن خان شير ينى

ليكو نكى : مهيشس خليل

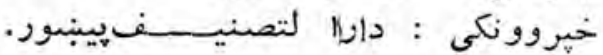

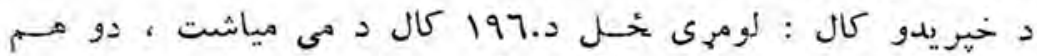

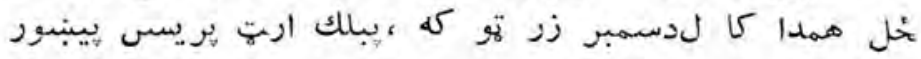

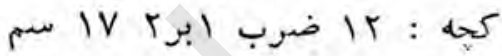
مخونه : 17

موضوع : د هومن خان شير ينىملى كيسه به ساده الفا ظو دوهو لله

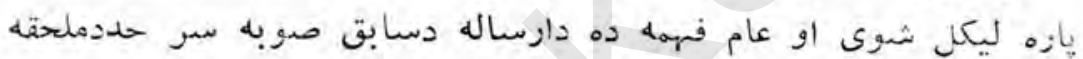

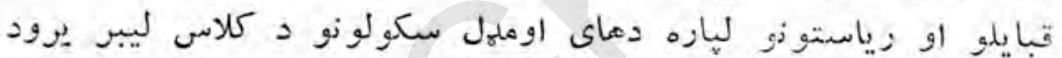

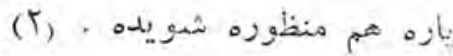

آدم خان اودرخخانى

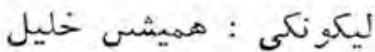

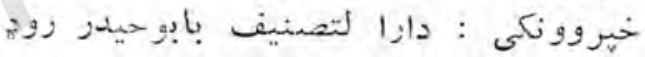

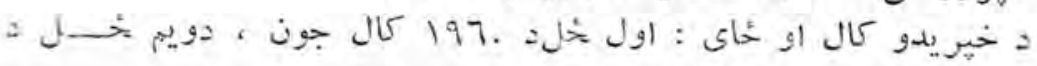

• 197.

كن

17 : هis

071 - 07 (1)

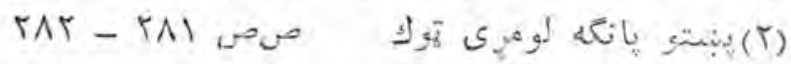

$-1 \cdot 5$ 


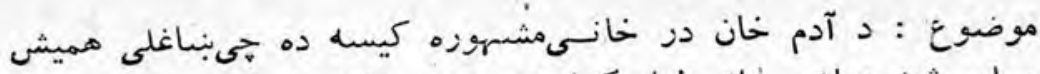

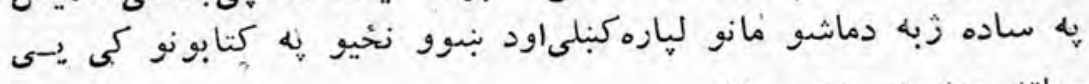

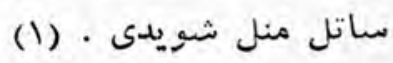

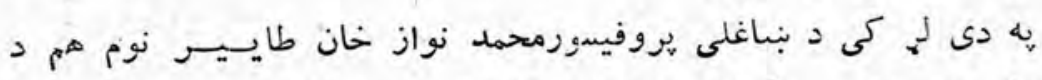

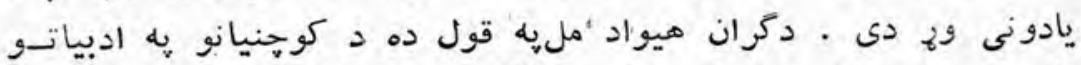

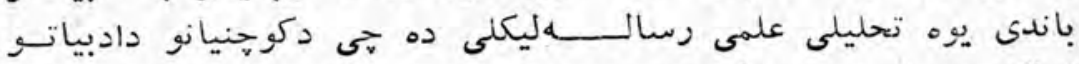

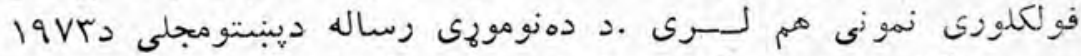

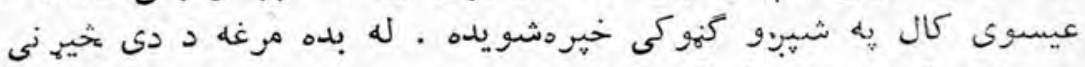

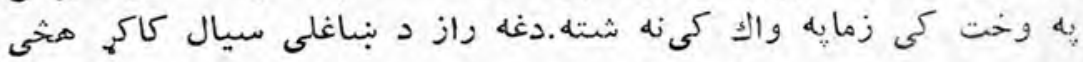

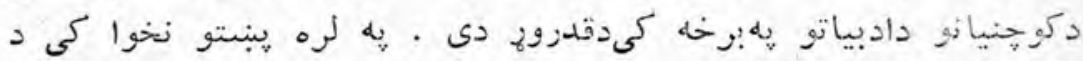

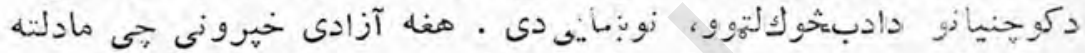

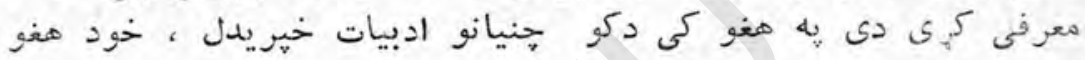

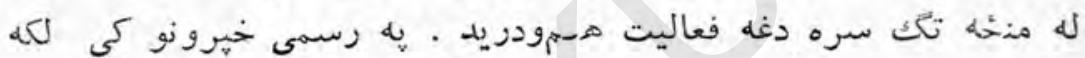

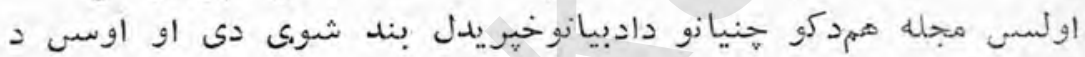

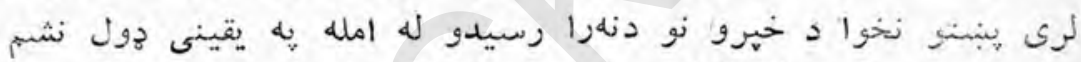

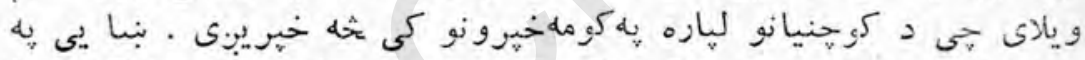

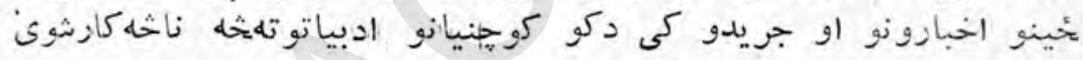

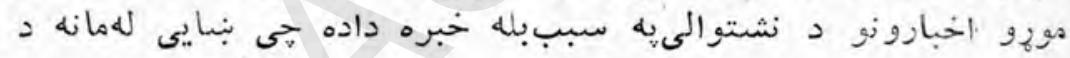

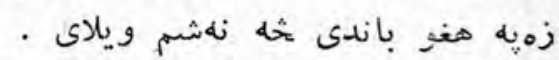

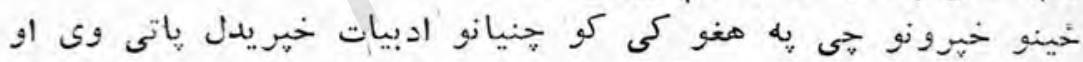

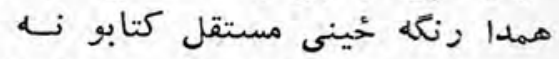

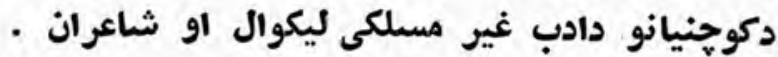

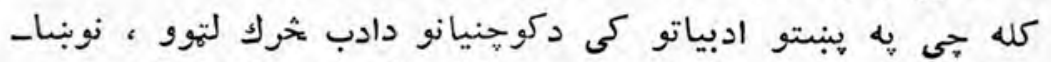

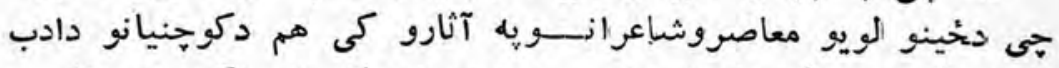

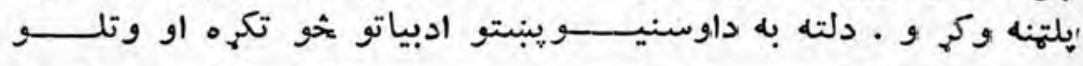

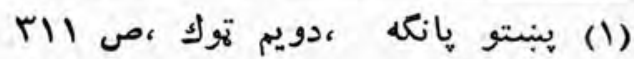




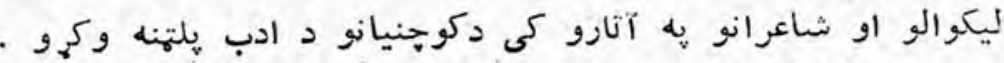

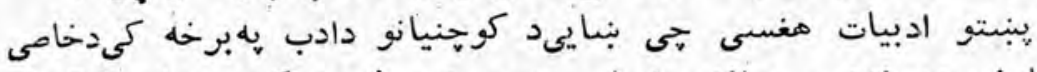

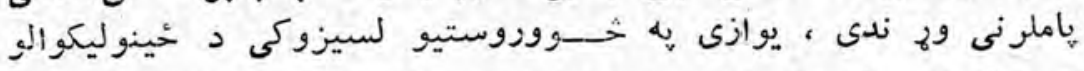

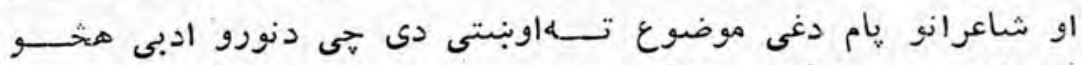

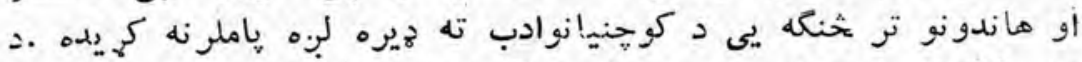

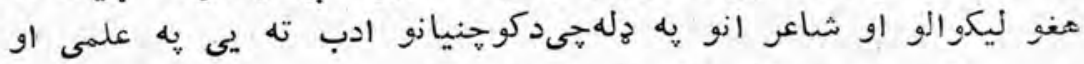

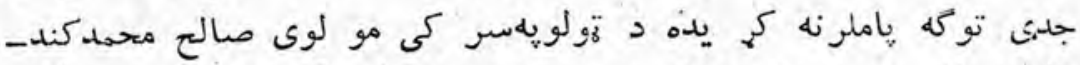

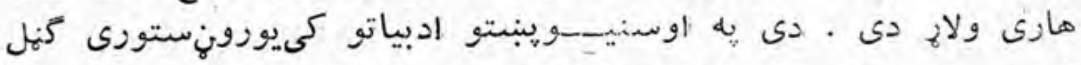

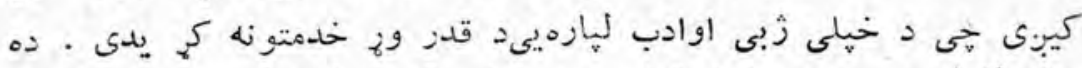

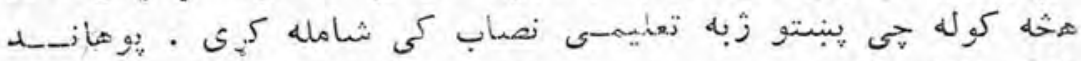

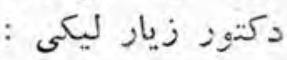

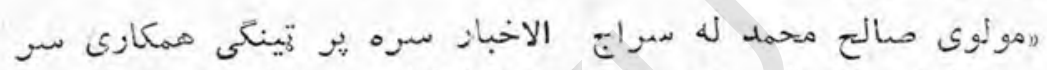

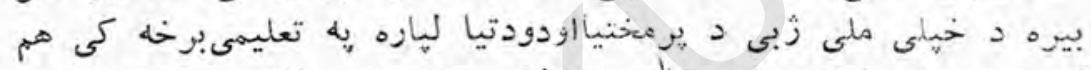

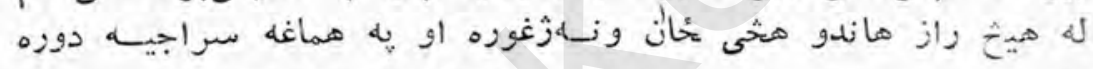

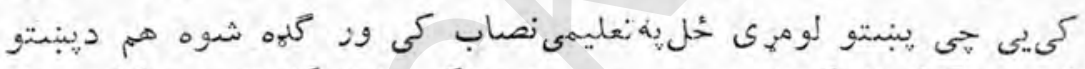

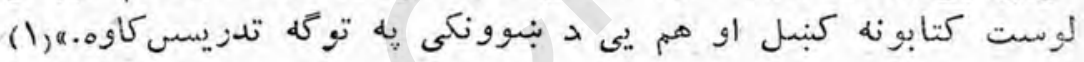

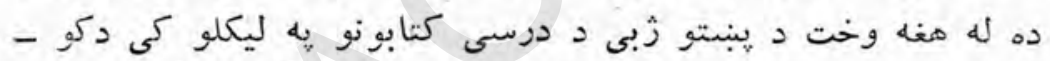

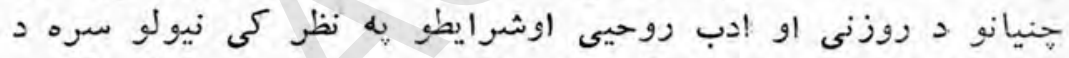

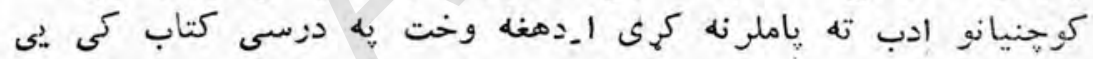

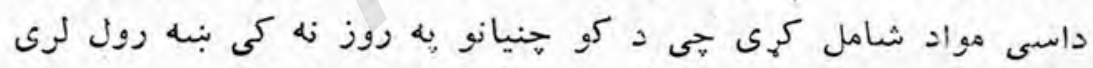

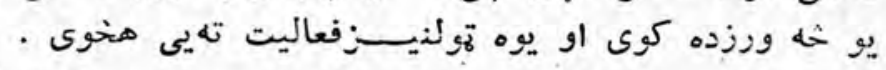

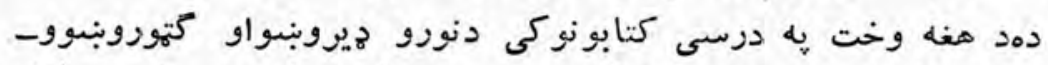

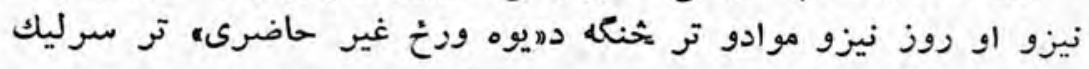

(1) زلمى هيواد مل د غلام محى الدين افغان افكار او آثار (يهسراج

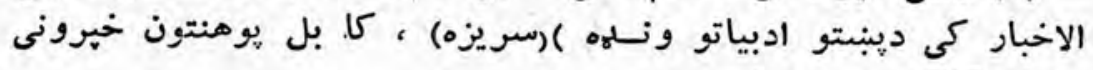

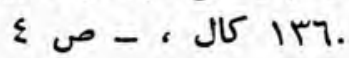




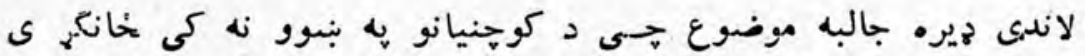

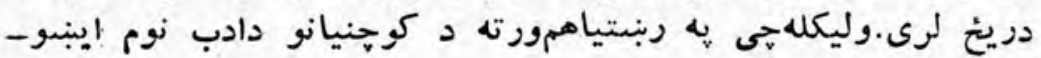

لاى شو •

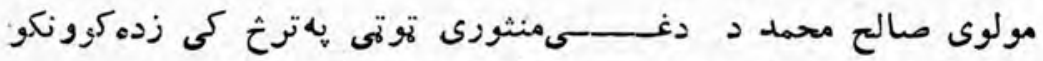

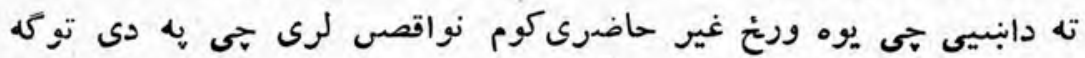

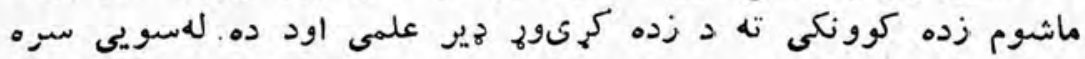

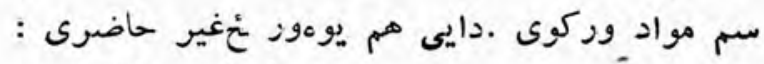

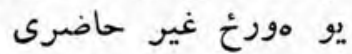

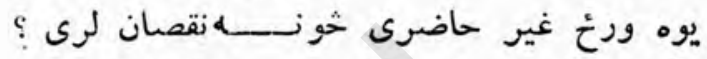

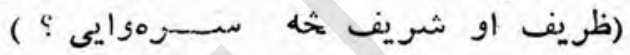

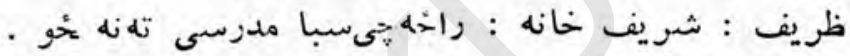
شريف : ولى : : شريف

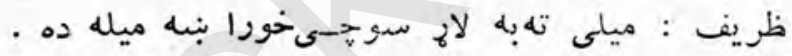

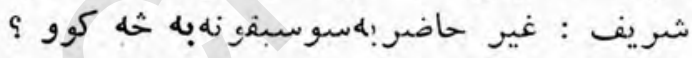

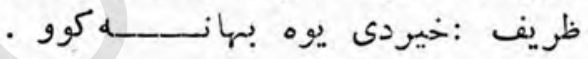

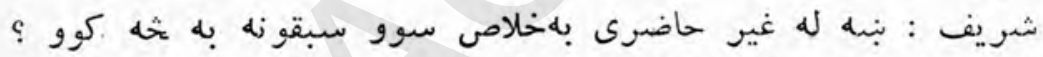

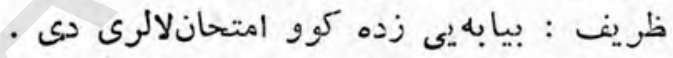

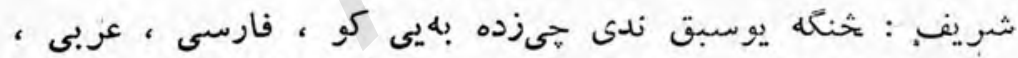

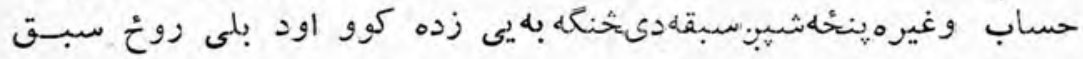

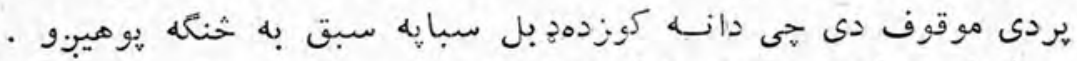

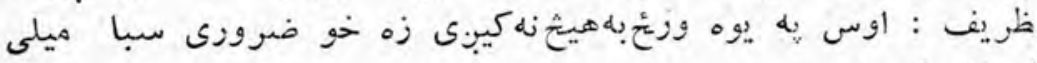

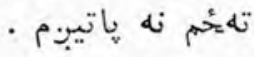

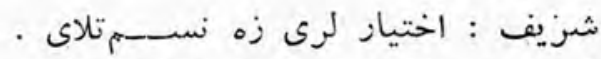

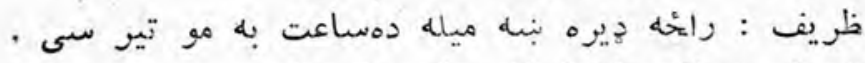

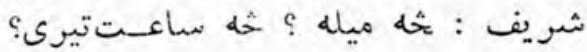
مدرسه هاته ، سبقونه قضا، غيرحاضر ، سترى ستومانه ، $-1 \cdot 7-$ 
ووينى ؟ ثله به واورى ؟ يو خولو جكان سره يو خاى شوى دى ،قمار

$$
\begin{aligned}
& \text { كوى يا غرلى وايى له واون } \\
& \text { دا خها ميله ده ؟ }
\end{aligned}
$$

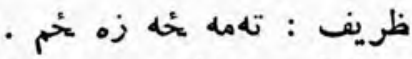

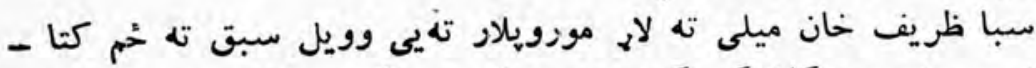

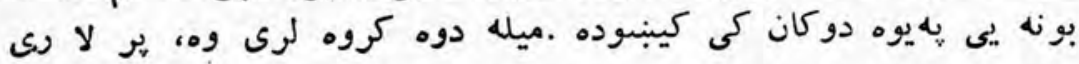

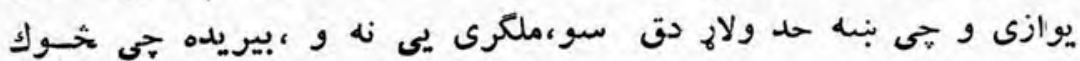
يقيونه وهى . يوان ميلى ته ورسيد ساعت يى تير نهسو يس له دوه درى ساعته رارهى

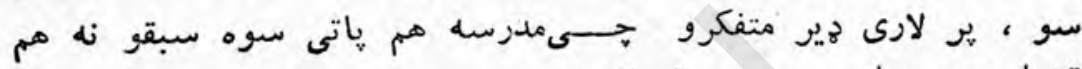

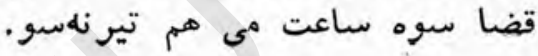

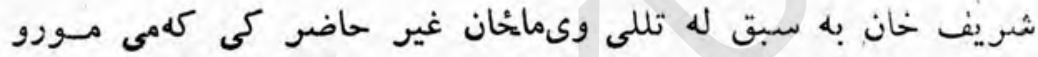

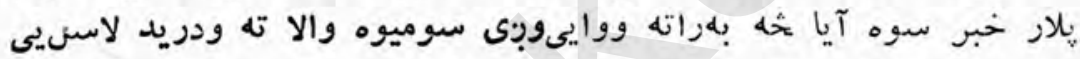

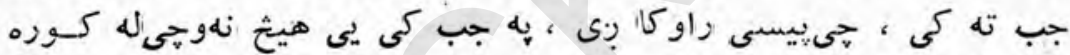

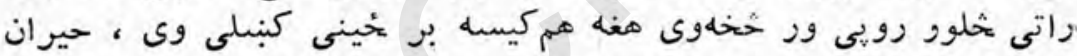

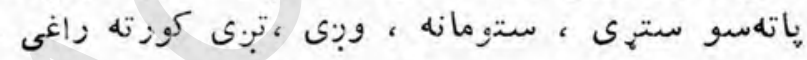

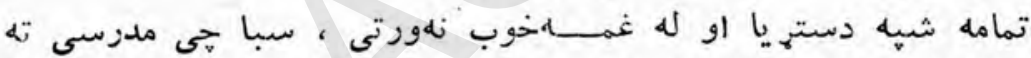

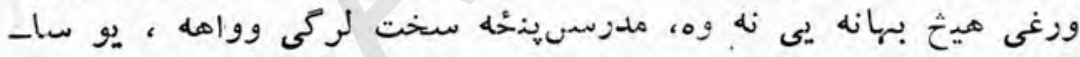

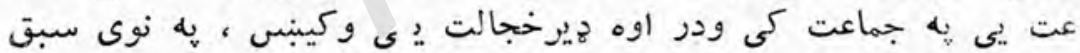

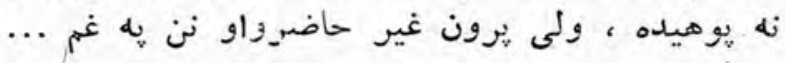

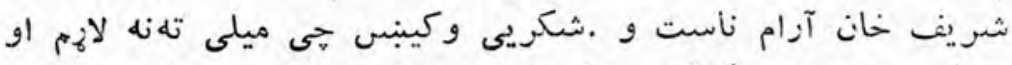

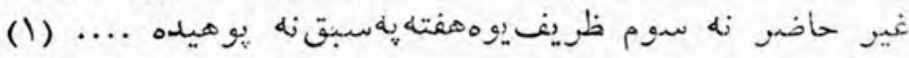

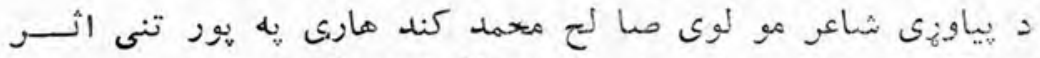

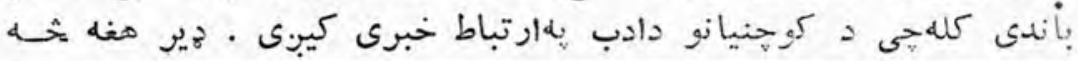

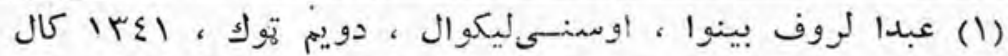

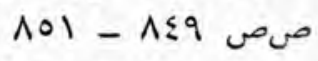




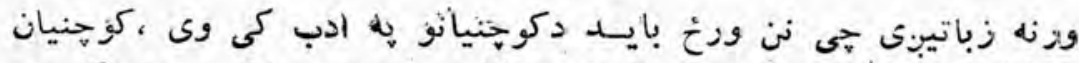

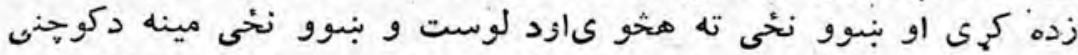

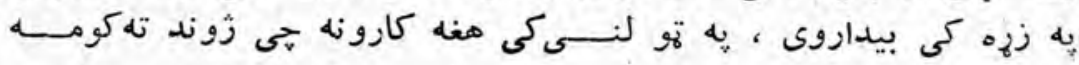

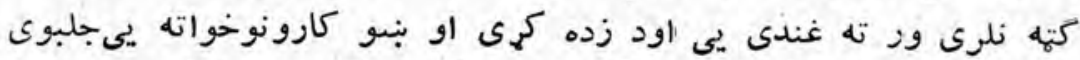

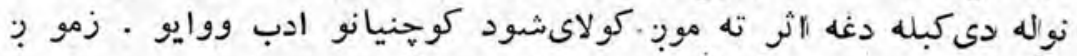

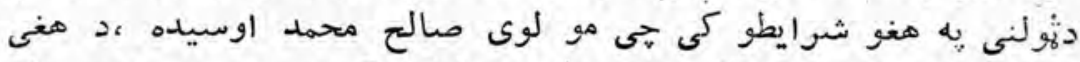

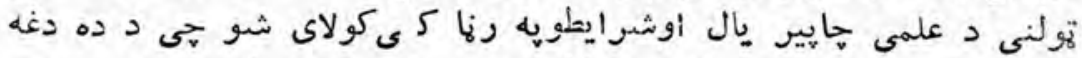

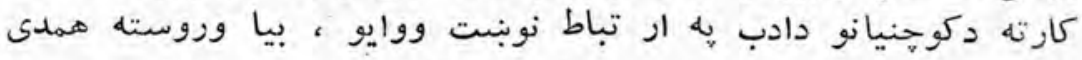

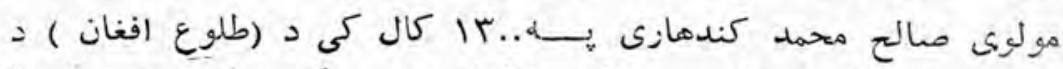

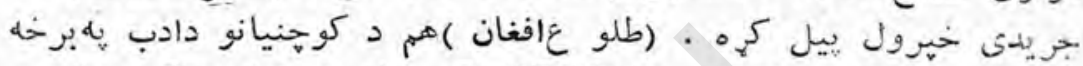

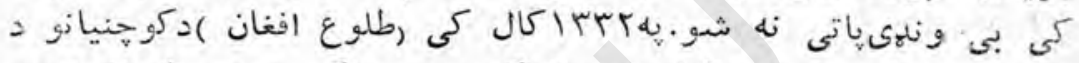

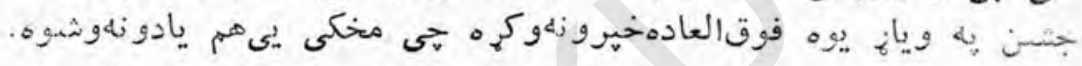

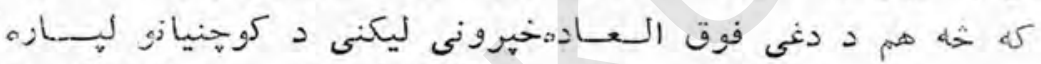

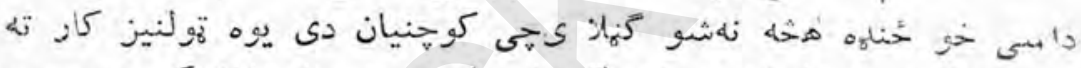

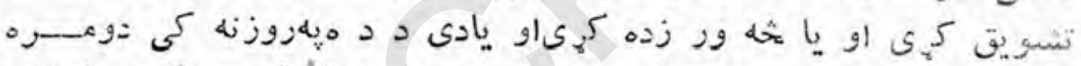

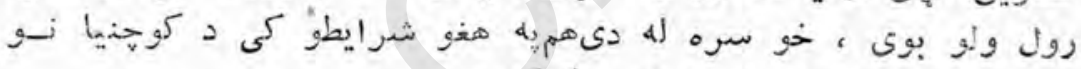

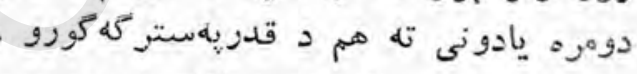

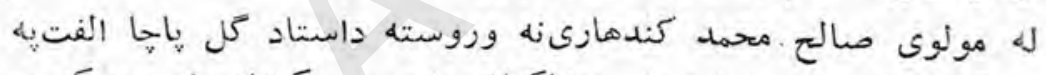

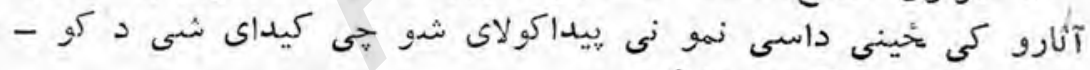

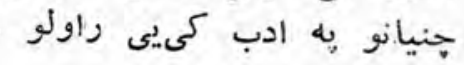

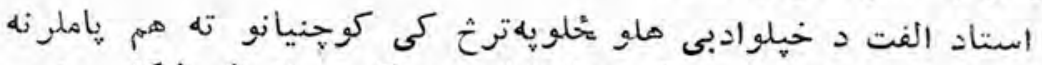

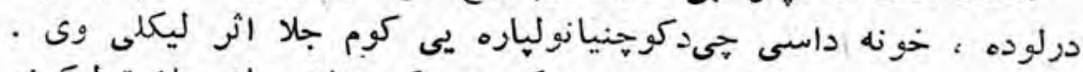

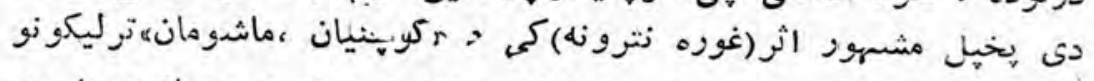

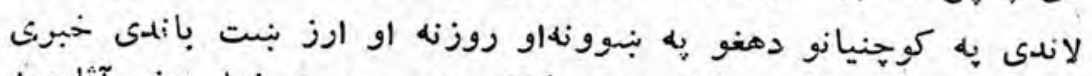

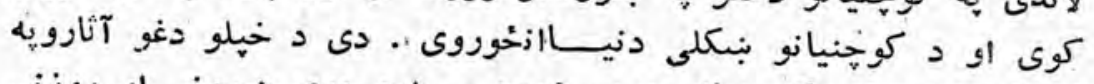

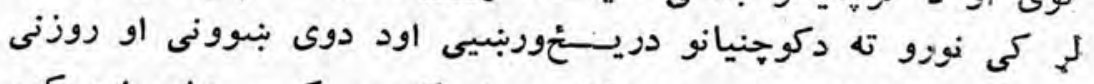

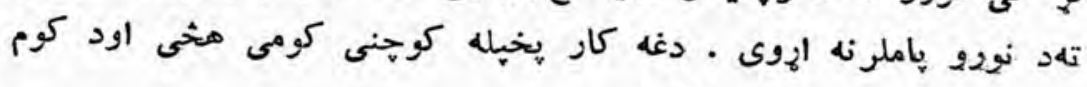




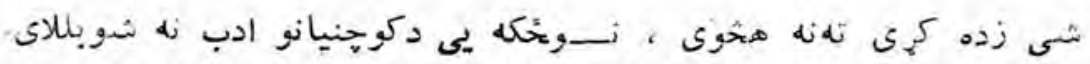

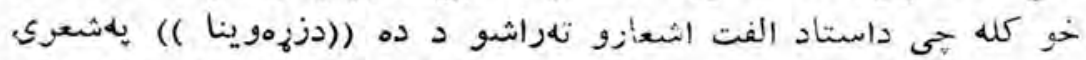

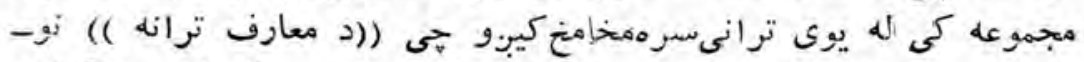

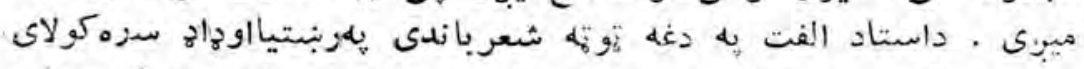

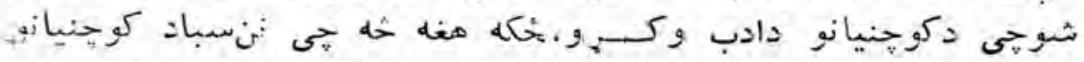

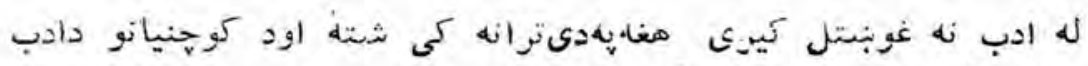

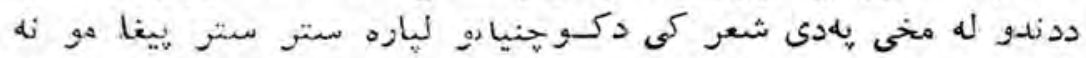

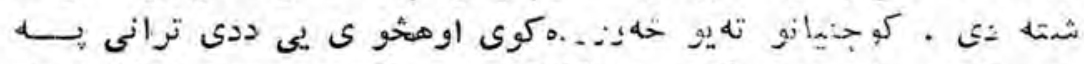

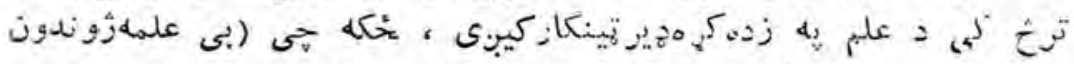

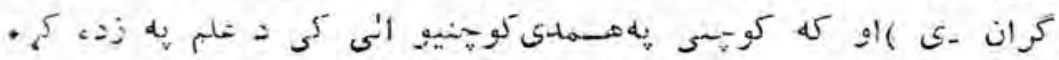

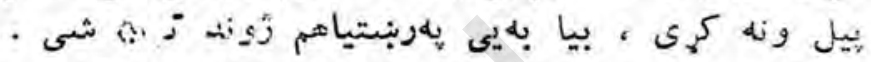

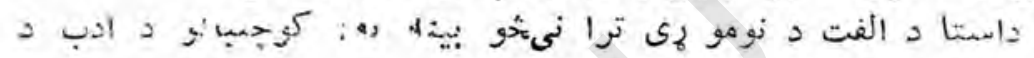

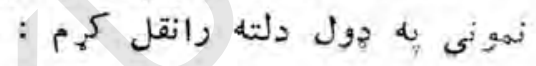

\section{د معارف ترانه}

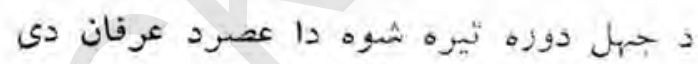

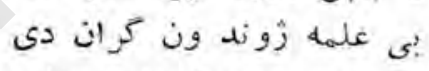

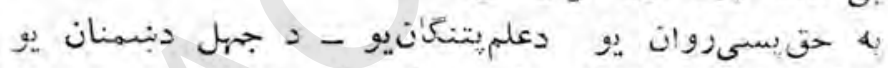

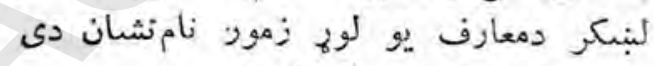

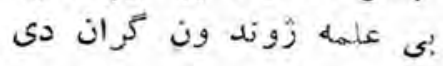

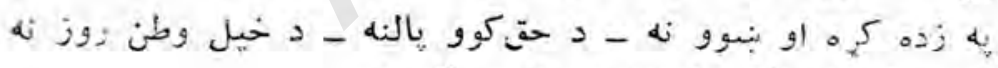

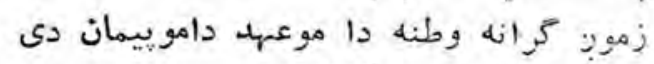
نى

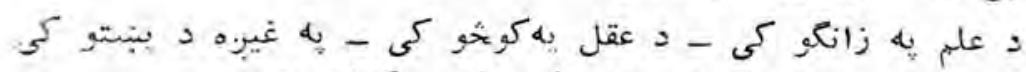

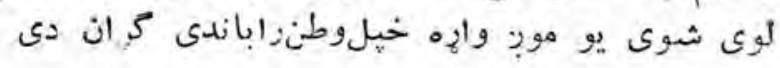

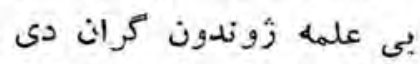

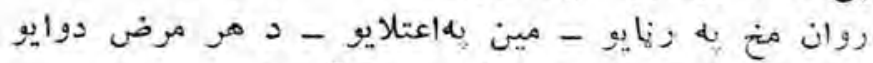

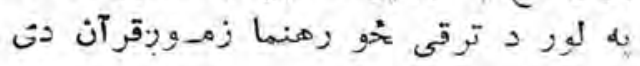
$-1 \cdot 9$ 


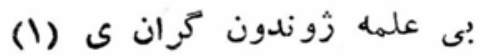

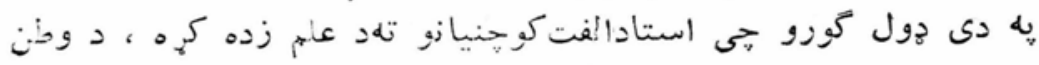

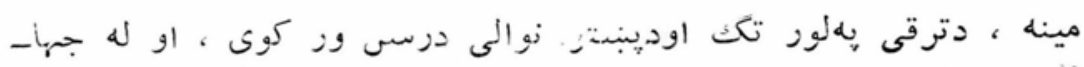

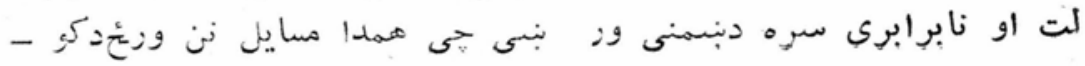

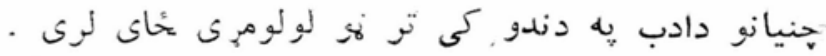

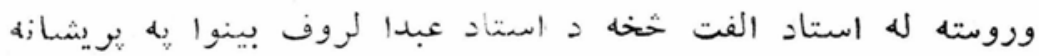

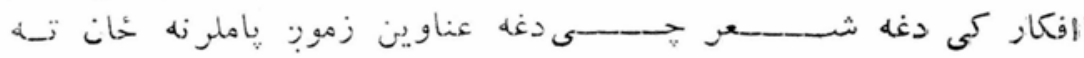

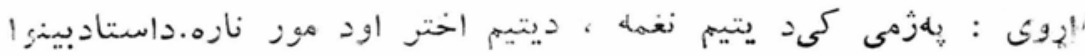

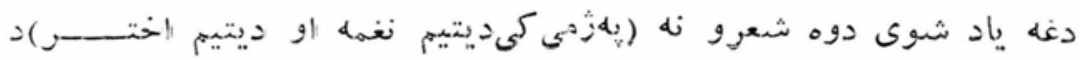

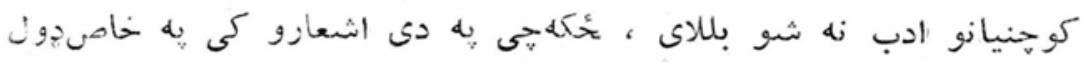

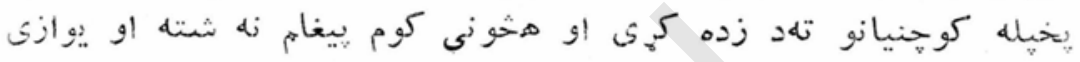

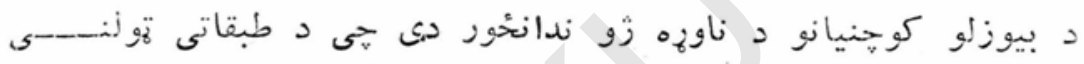

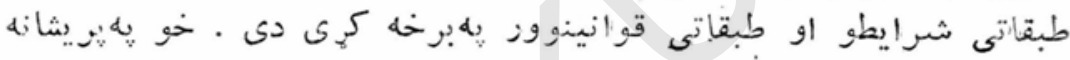

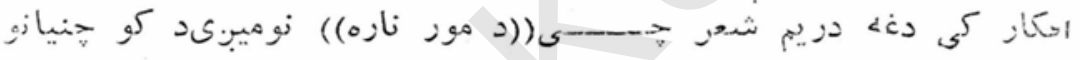

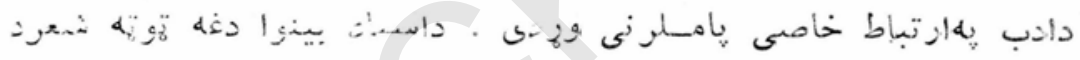

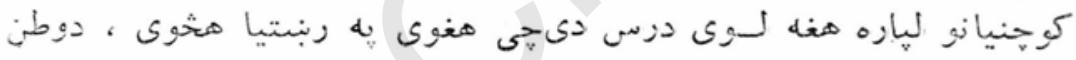

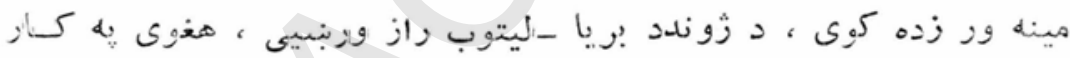

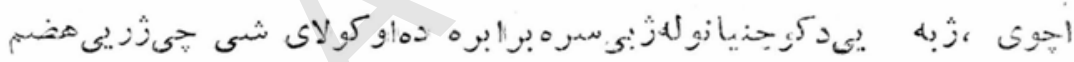

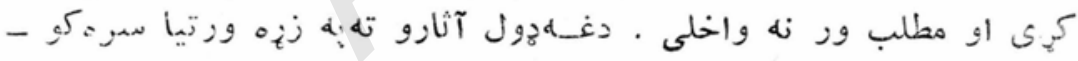

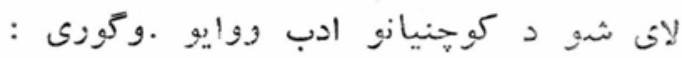
د مور ناره

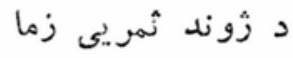

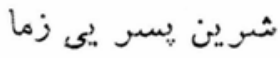

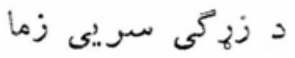

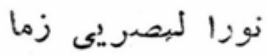

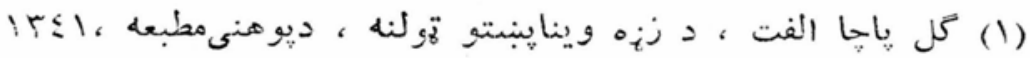
كال ، ص م

$-11 \cdot-$ 
مله ياخثيبه زويه زوزيه

زر تورته كيبهه زويه

وطن يى تهول نيولى وخي وخت د وينيتوب نيول را غلي

زو يكه لمر ختلى خال دويدنى تللى لمى خيلى

بلبلان بيا حغيبيى

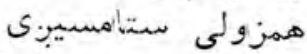

خيل روز كار ونه كوى

هر لور سيلو زيله كوى

هر تخوك كارونه كويى

ملتب ته تئى هلكان نيه خدمتونه كوى كارون

دوطن نزى كلان

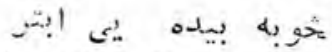

نه هم رايوز ته شه زئ

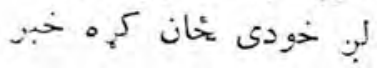

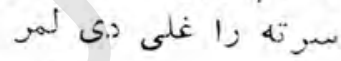

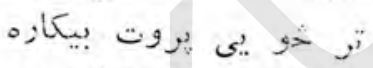

زويه ! دخداى ديازه

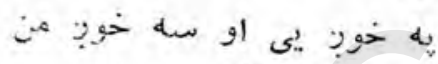

يوين ده كند له به بي ستن

وتاته هاتى زبن

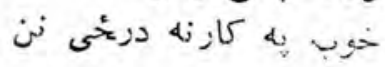

و سمي ميدا نته نه ووزه

نوى جهان تله ووزه

د بِلاز عزت وساته

خبل شان شئ كت وساته

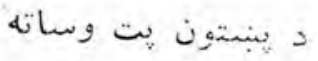

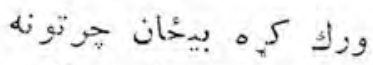

انسا نيت وساته

دسرى غريى خو بونه

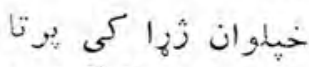

خوك و اويلان

دنبسمن خندا كئى ليونا

هلته دنبهمن شور خو شحال

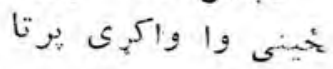

خيلوان دى كريخى ملال

-111- 


$$
\begin{aligned}
& \text { يابه جار جار بلى } \\
& \text { خوب تله مى نه ساتلى } \\
& \text { ماته جيى نبه روزلى }
\end{aligned}
$$

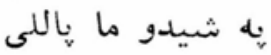

$$
\begin{aligned}
& \text { ته ولى وغَّيدى }
\end{aligned}
$$

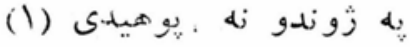

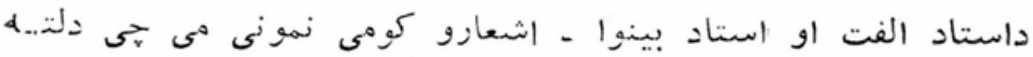

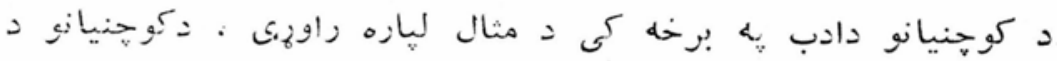

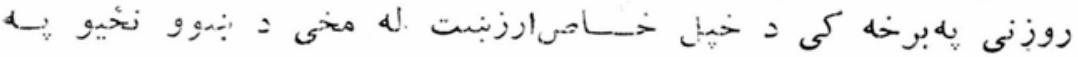

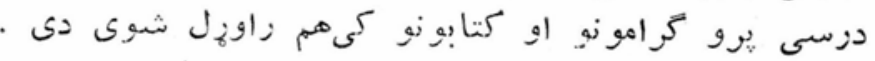

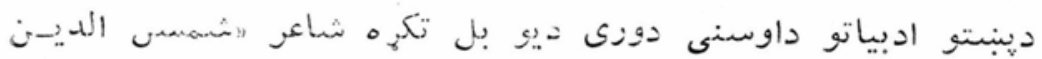

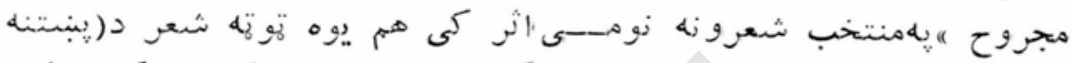

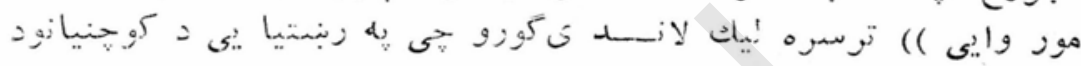

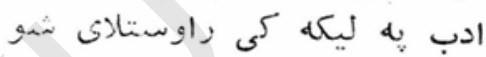

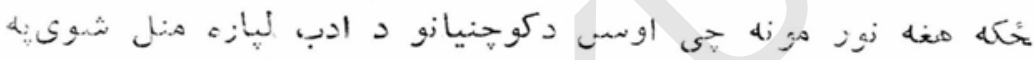

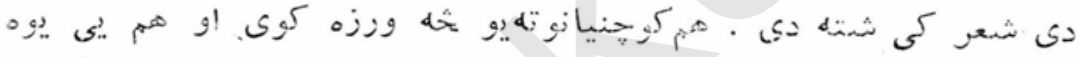

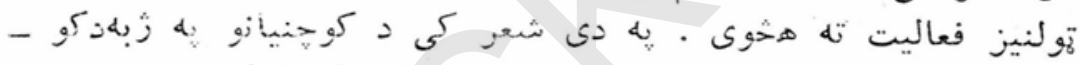

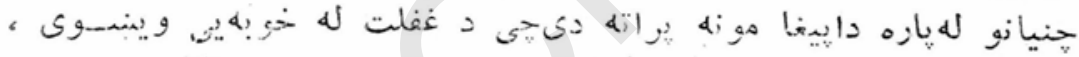

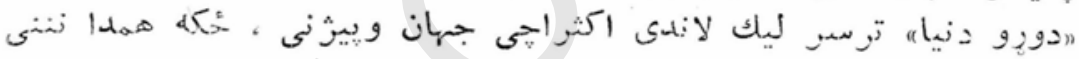

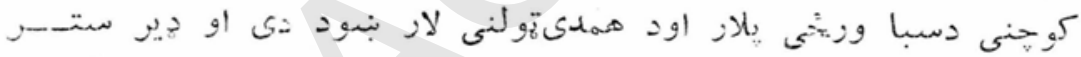

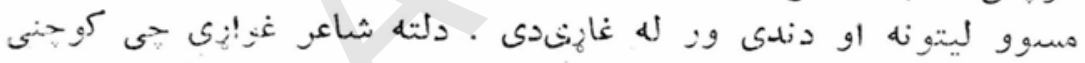

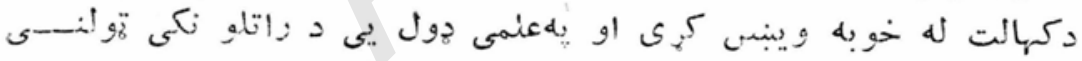

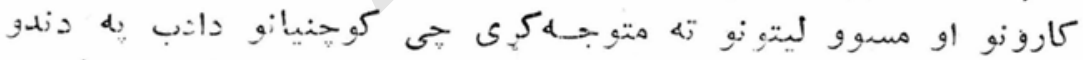

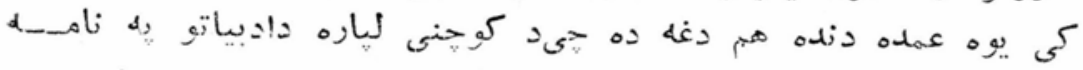

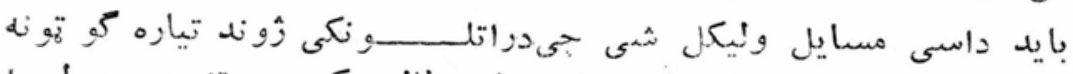

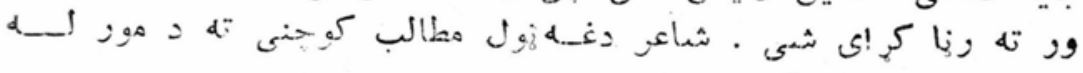

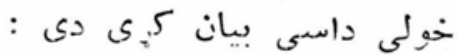

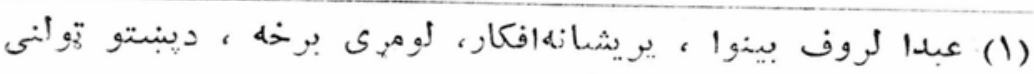

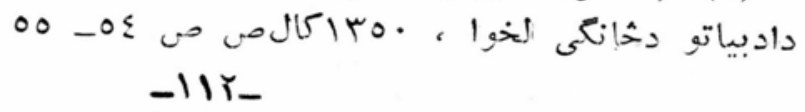


يبنتنه مور وايى

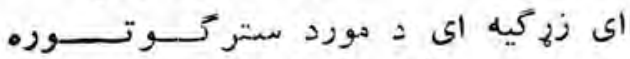

للو نه وايم خبرهمى لوده نورو

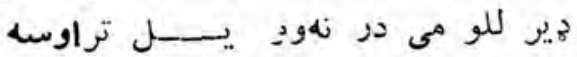

اوسس دى وخت دويبنيد ودى خبر اوشيه

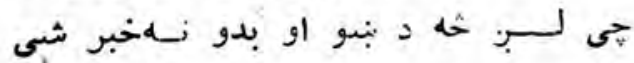

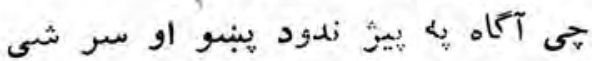

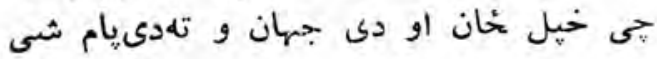

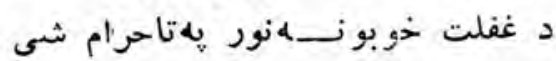

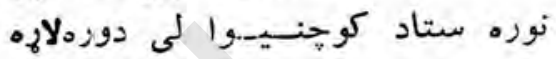

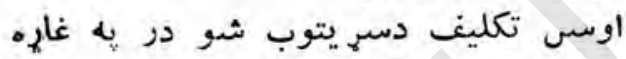

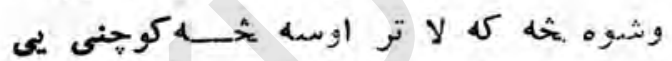

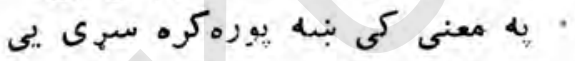

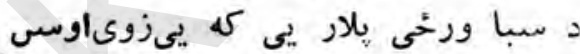

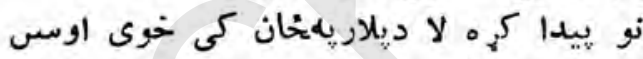

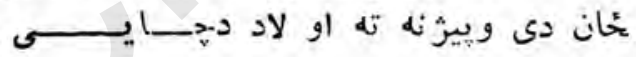

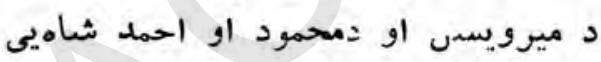

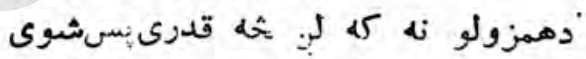

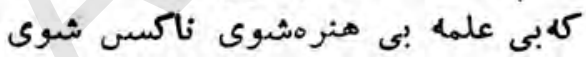

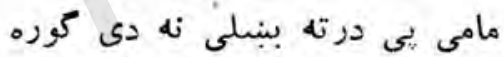

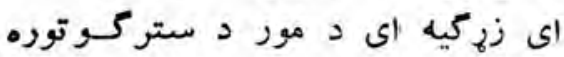

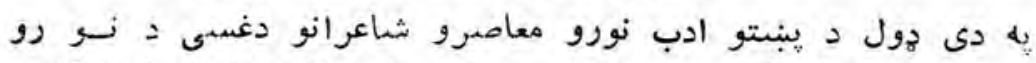

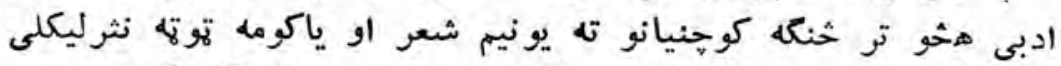

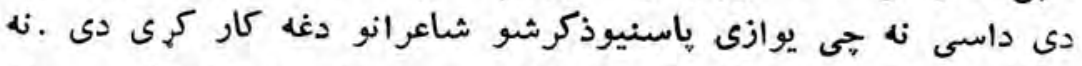

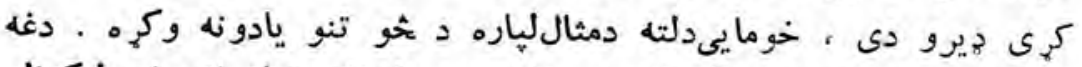

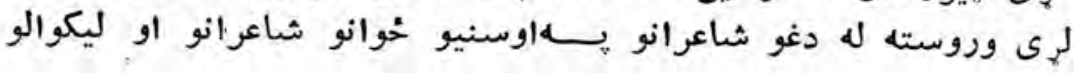

-l1r_ 


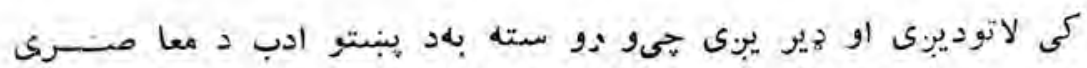

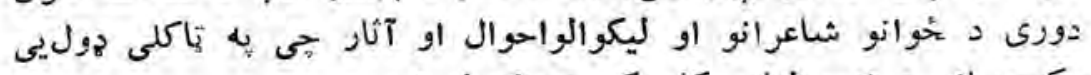

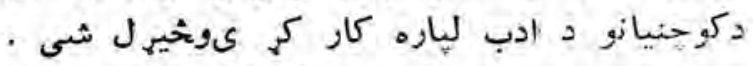

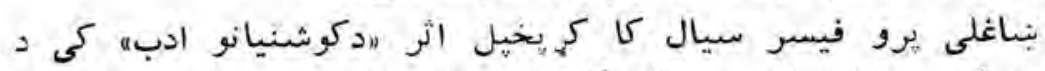

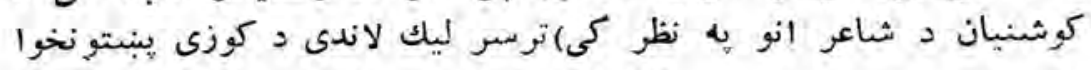

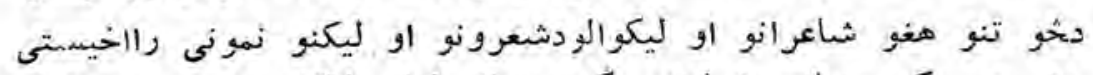

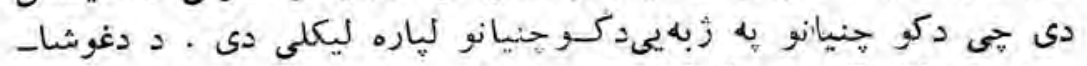

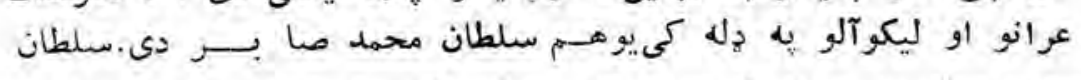

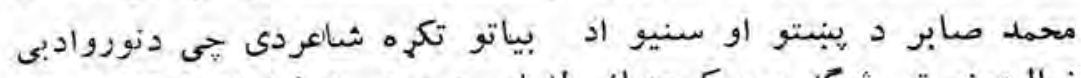

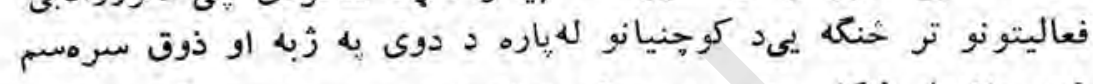

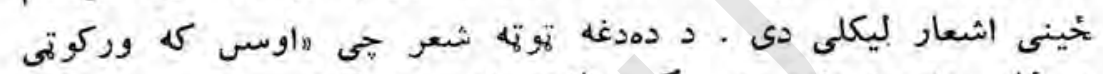

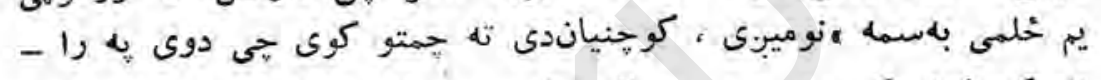

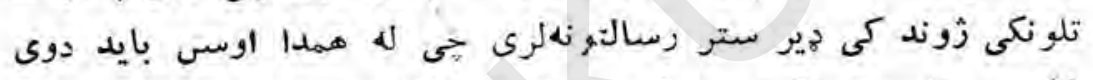

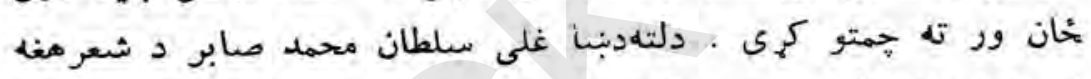

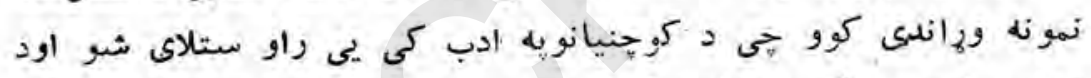

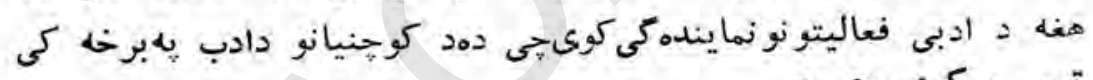

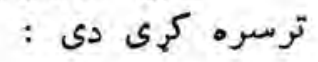

\section{زلهى به شمه}

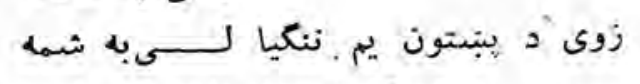

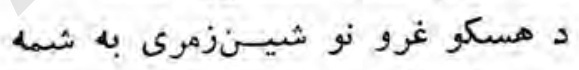

لكه نهنك به طو فانو بريالــــيه شيه

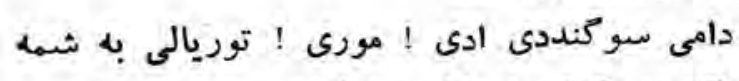

\section{اوس كه ور كوتى يم زلمى بهشهه}

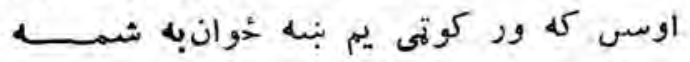

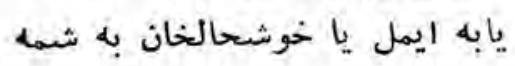

- IIE_ 


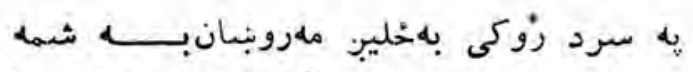

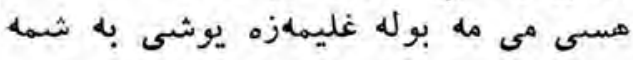

\section{اوس كه وركوتى يم زلمى بهشمه به بها}

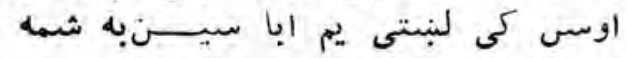

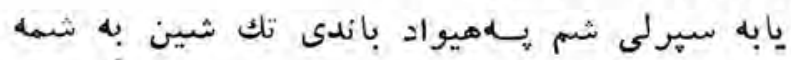

$$
\text { لكه خا تول يخبلووينو كىرنكين بهشهيه }
$$

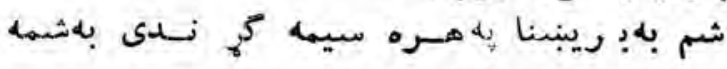

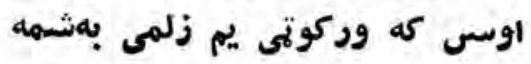

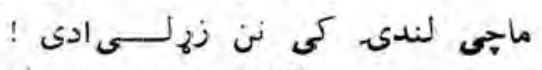

ماته ميرو يسن نن لله فردوسه خها به كتلى ادى

$$
\text { ستركو زما دى نن دباز ستركى ليدلى اده }
$$

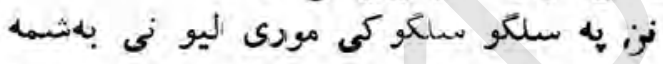

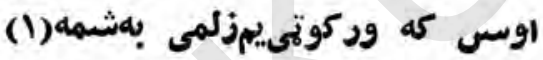

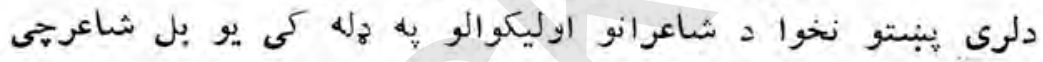

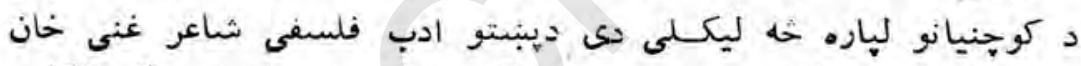

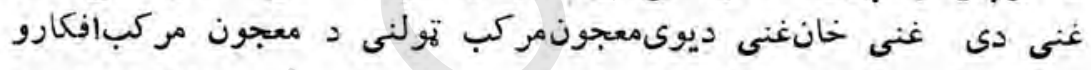

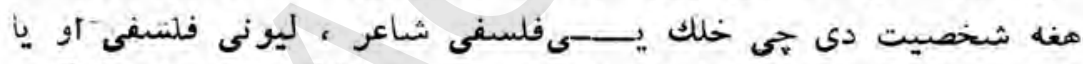

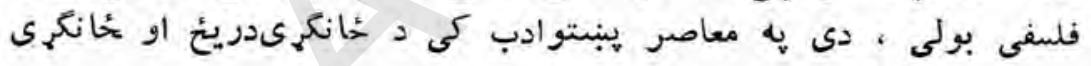

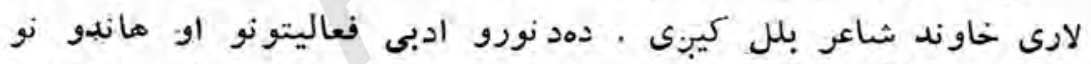

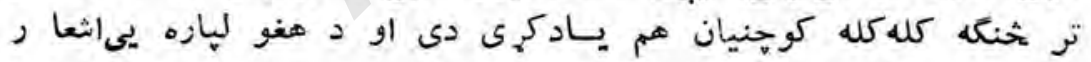

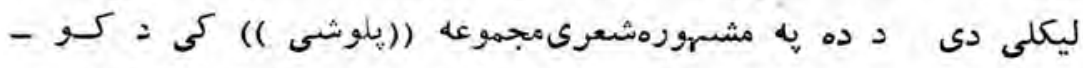

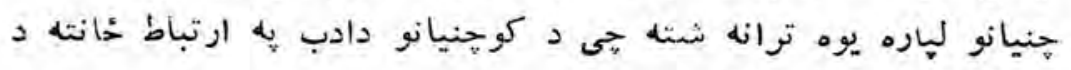

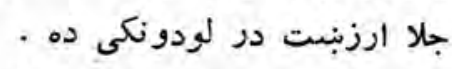

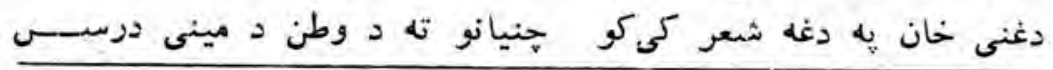

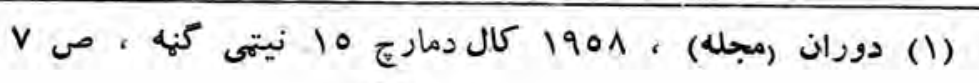
$-110-$ 
وركول كيب.ى إو كوحنيأن د قام اوخلكو آزادى ته جمتو كيبنى · دىبه

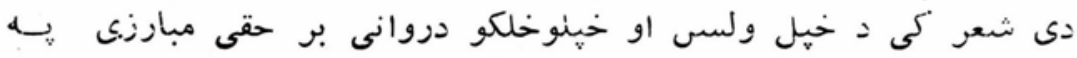

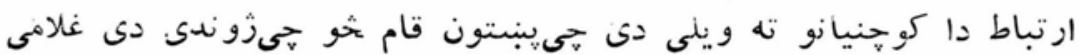

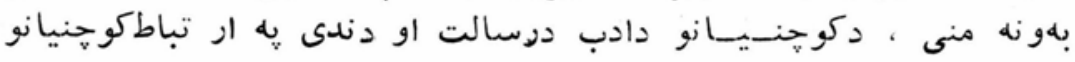

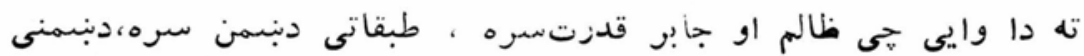

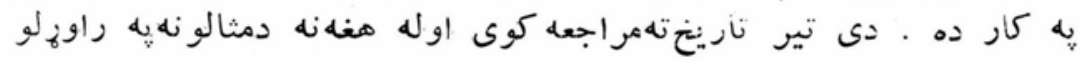
سره كوحينيانو ته دننك غير يت درسى ور كوى اود طبقا تى دبنمهن

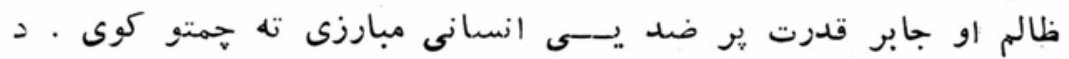
غنى خان دغه شعر (دهلكانو ترانه )نوميب.ى ، وكورى :

\section{د هلكانو ترانه}

خوبج دى ماته ملك زما ، خوبزتو كل جهان

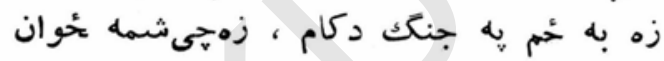

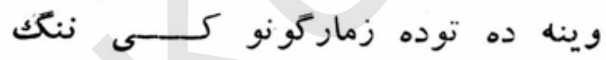

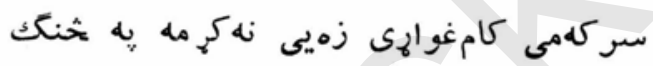

$$
\begin{aligned}
& \text { زور دى ماليدلى هم د توب هــــم دتفنك }
\end{aligned}
$$

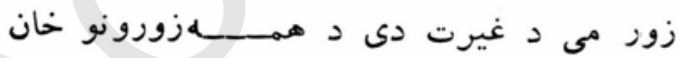

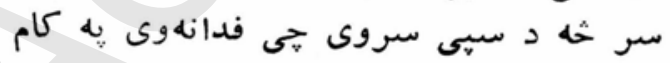

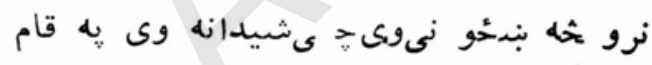

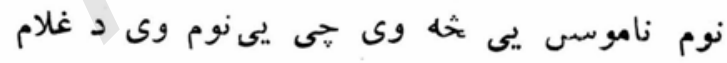

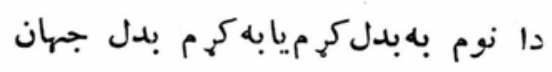

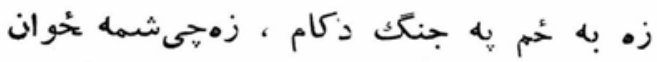

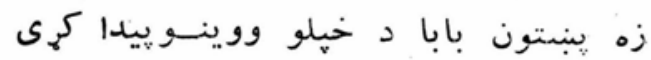

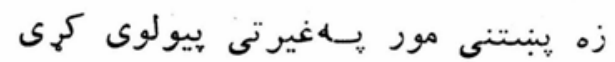

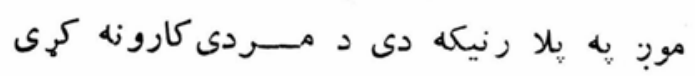

زه به غلام نه شــم كه غلام شى تهول جهان 


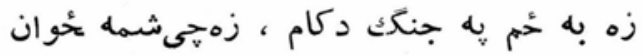

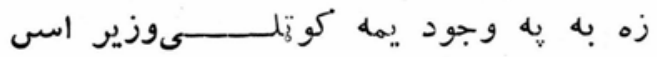

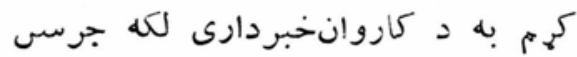

$$
\begin{aligned}
& \text { يم به دظالم ستر كو كى تلد ستر كوخس } \\
& \text { زه به لكه بازيمدنسرتوب مرد ميدان }
\end{aligned}
$$

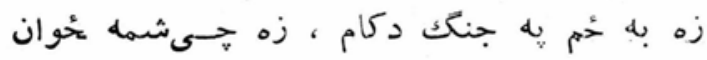

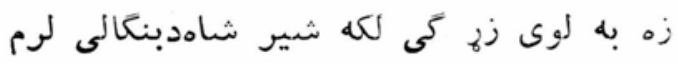

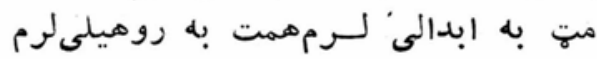

$$
\begin{aligned}
& \text { سر به بنكتلة زه كهم كل زركوزنه مثالى لرم }
\end{aligned}
$$

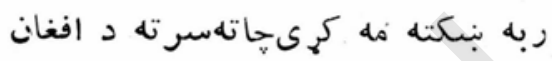

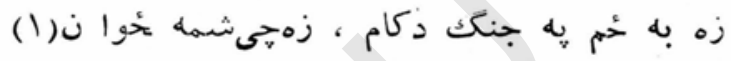

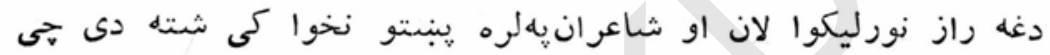

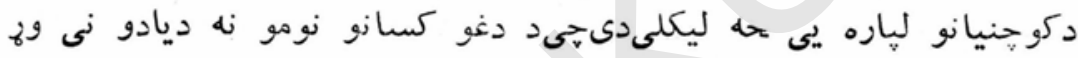

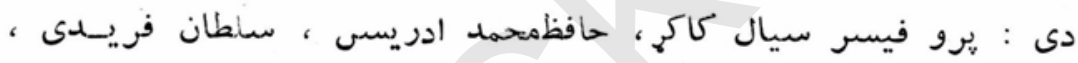
هميشس خليل نباغلى حافظ محمد ادريسىدكو خنيانو لإه خو كتابه ليكلى دىجى د تخينو نومو نه يىدادى : اسلا مىقصى ، خوبِى لطيفى ، ناديـده ، كيرى ، ورى قصى او تعليمىقصىد بنباغلى حافظ محمد ادريسى كارد

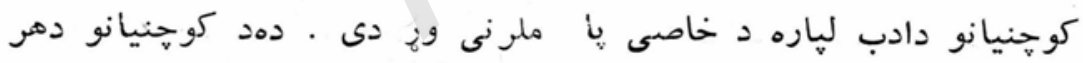

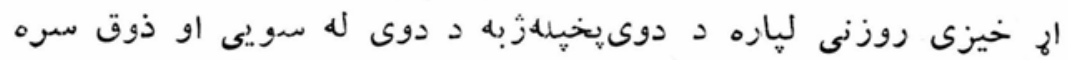

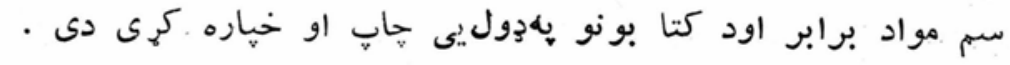

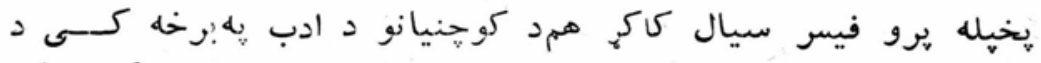

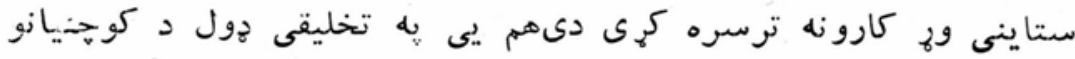

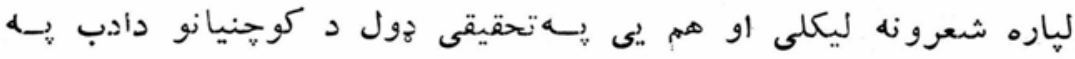

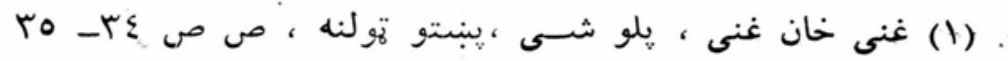

$$
-11 v_{-}
$$




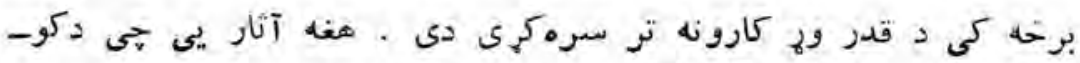

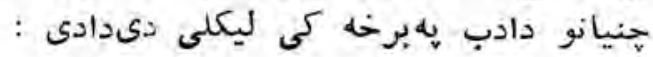

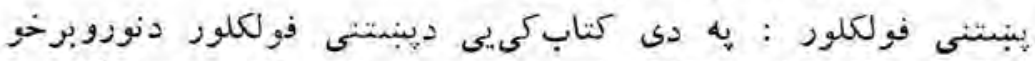

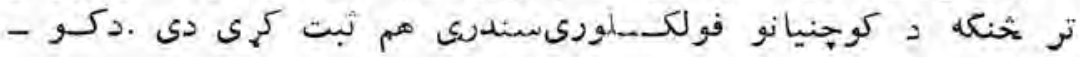

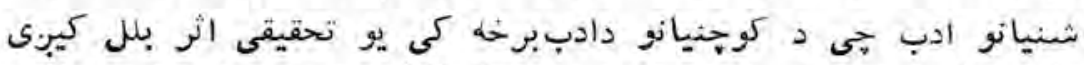

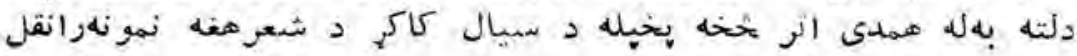

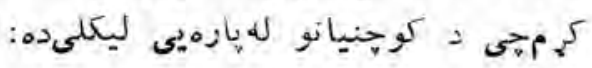

خود به و كتيى ميدان

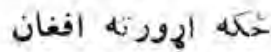
سى بله دوى قهرما نان يقى ويالى خيل كوشنيان

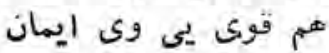
ستورى سى بلى بلى آسمان

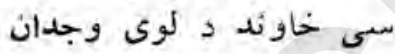
مشاكلات يى سبى آسان

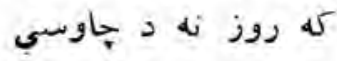

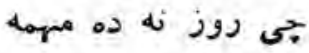

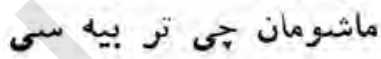

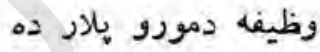

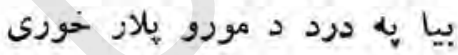

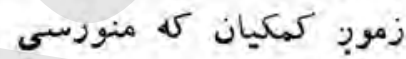
بيا نظريى يو لثبر وى

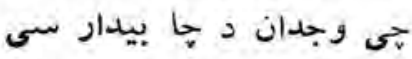

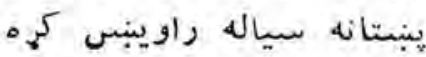

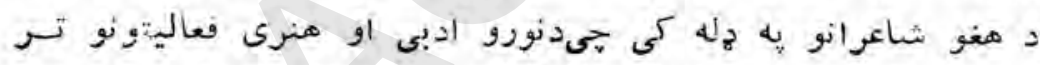

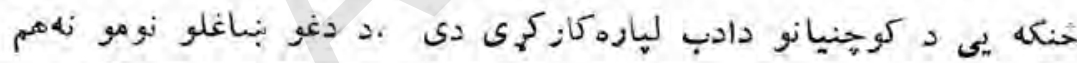

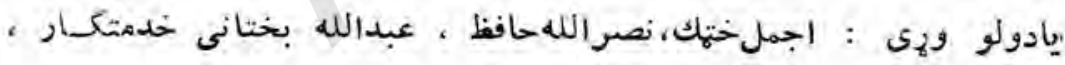

كبراء مظهرى

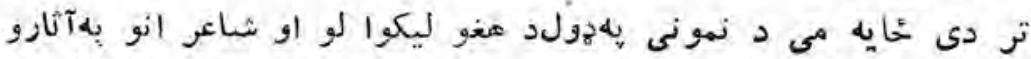

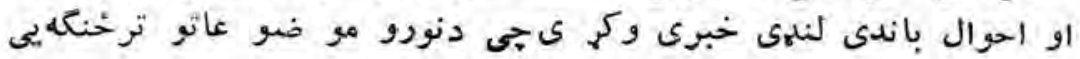

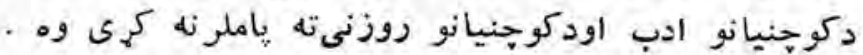

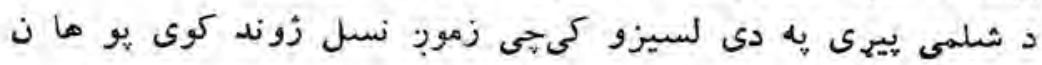

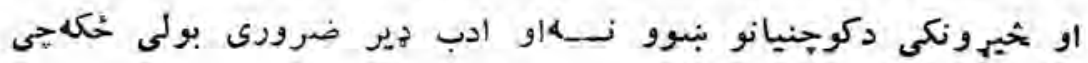
$-111$ 


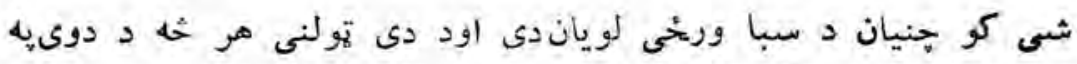

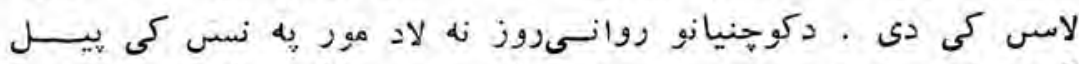

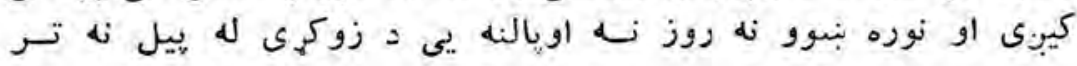

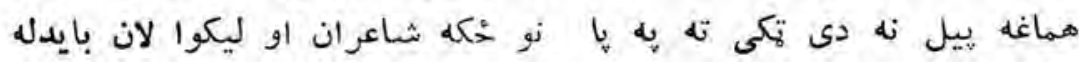

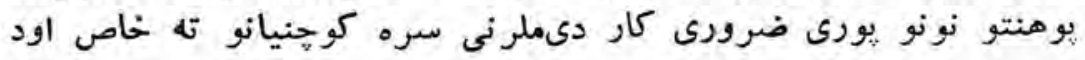

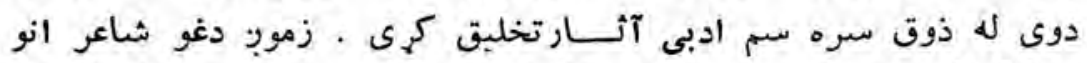

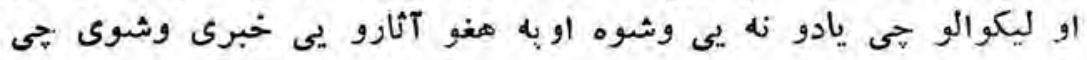

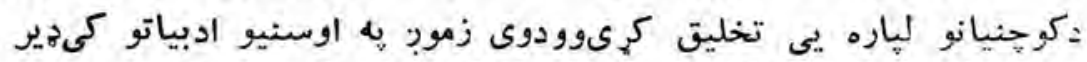

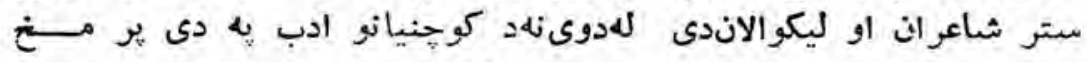

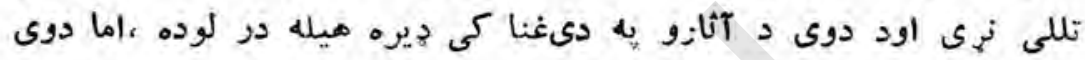

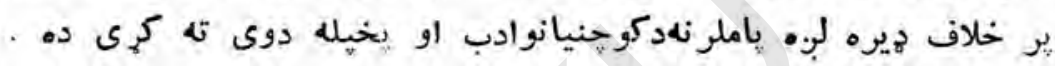

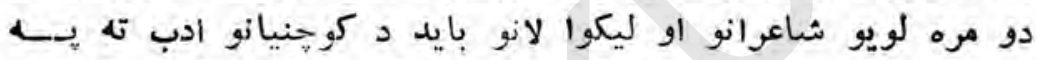

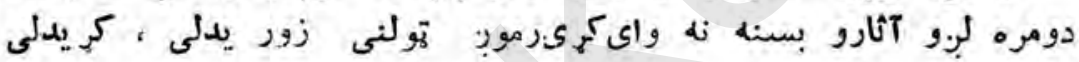

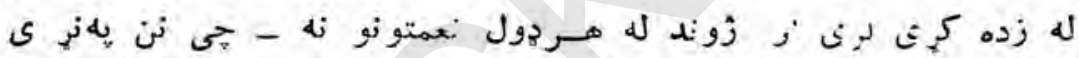

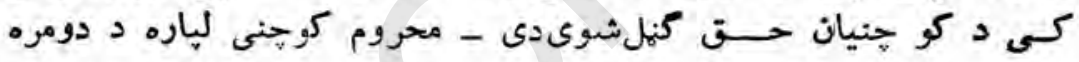

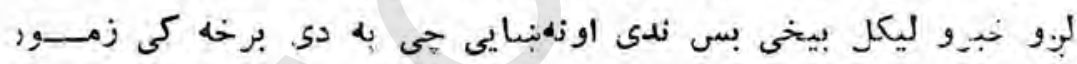

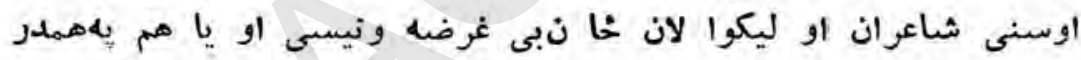

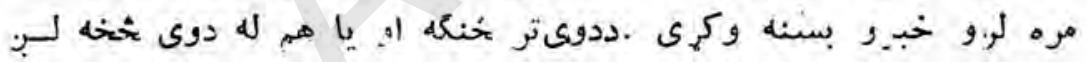

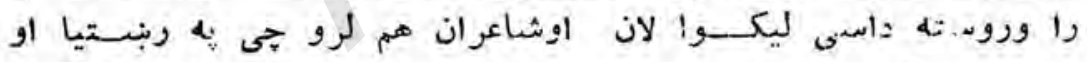

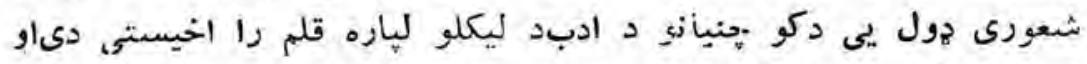

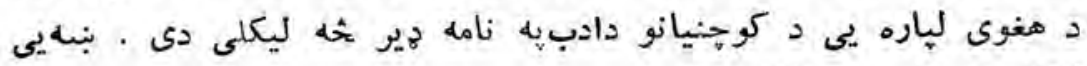

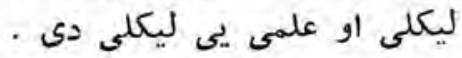

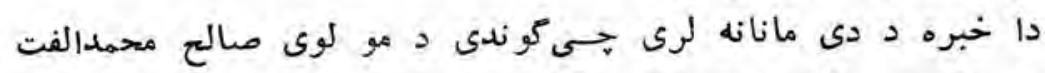

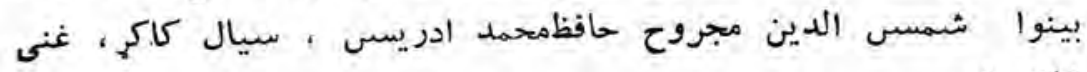
خان او ... 


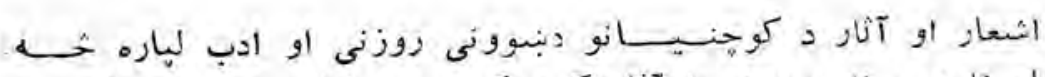

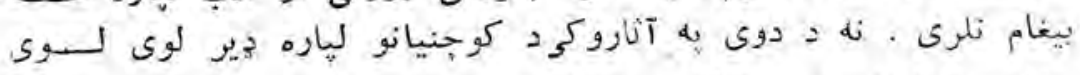

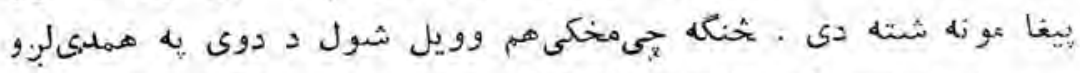

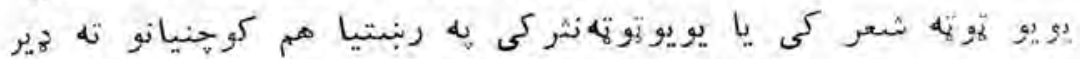

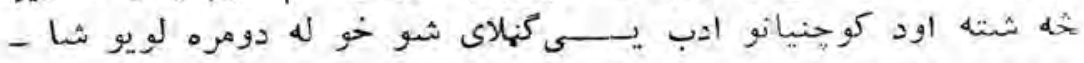

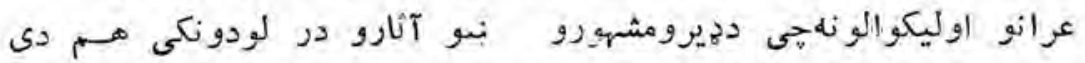

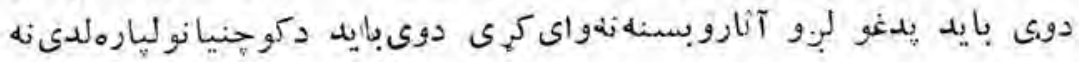

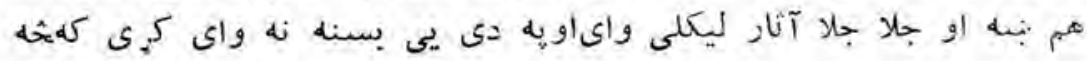

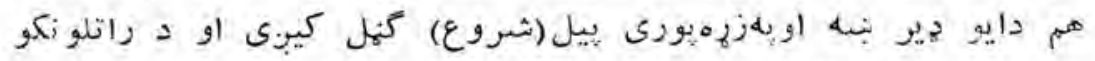

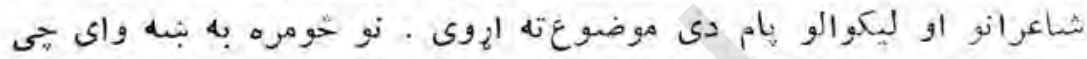

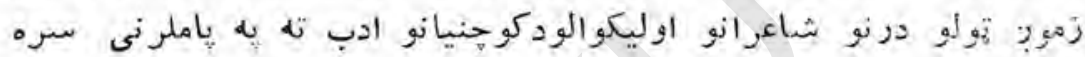

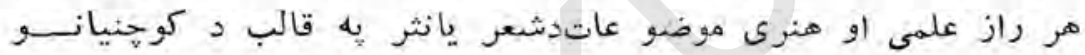

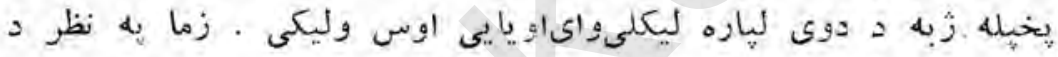

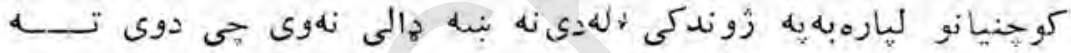

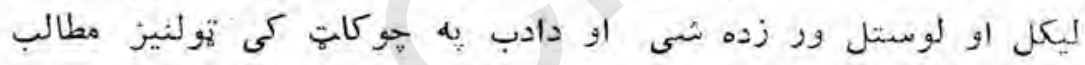

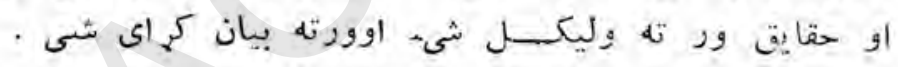

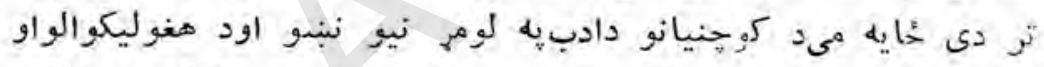

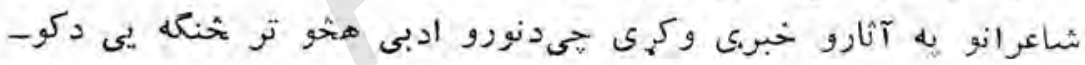

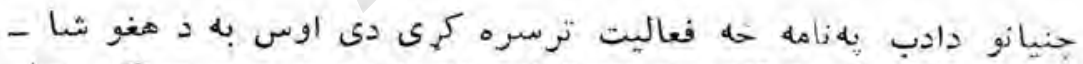

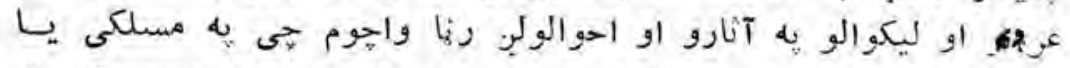

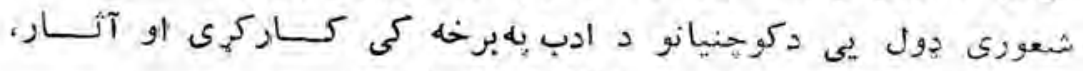

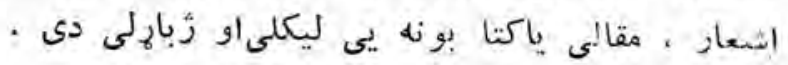




\section{دكو جنيانود ادبمسملكى ليكو الان اوشاءر ان}

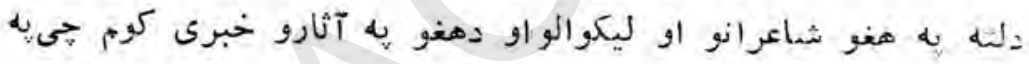

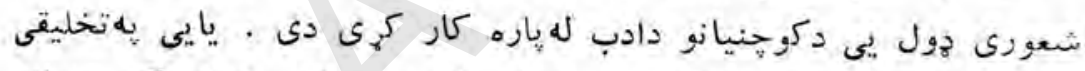

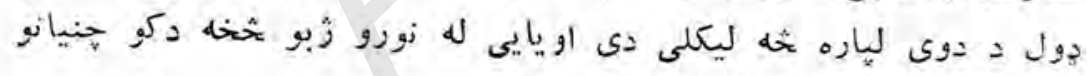

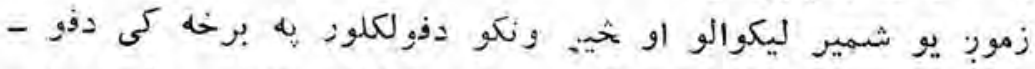

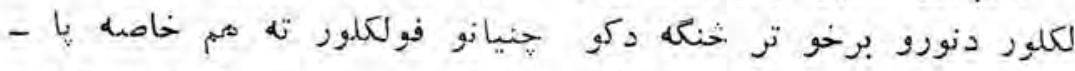

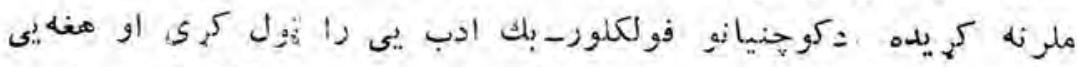

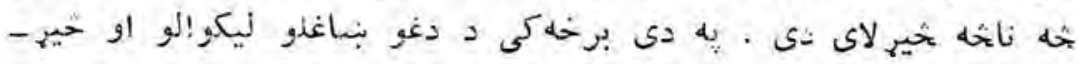

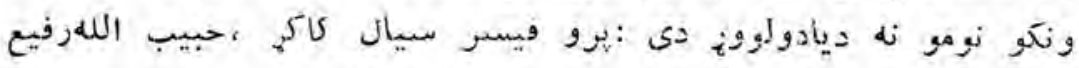

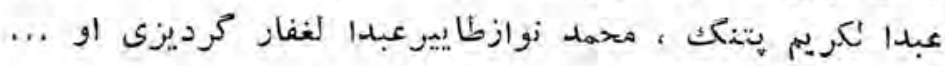
$-|r|$ 


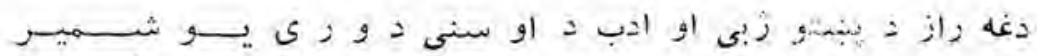

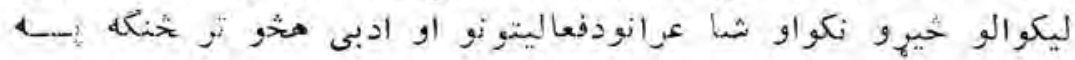

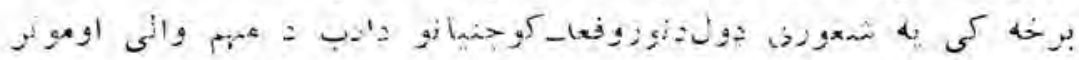

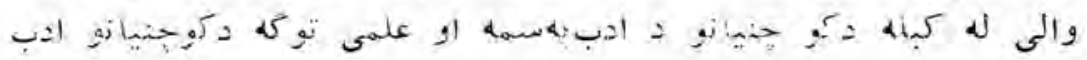

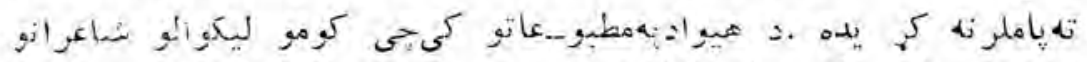

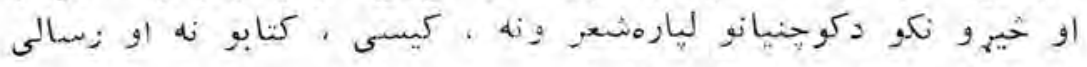

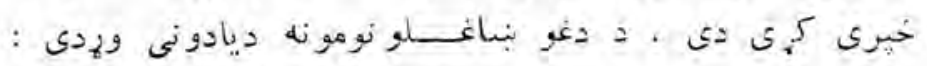

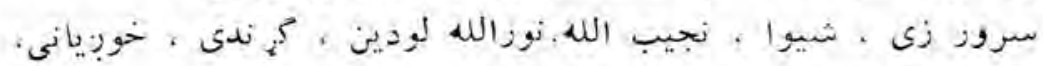

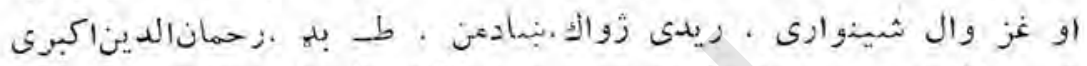

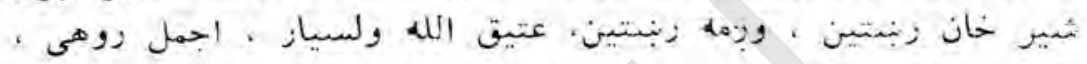

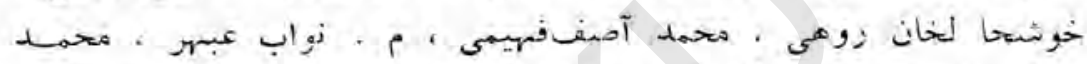

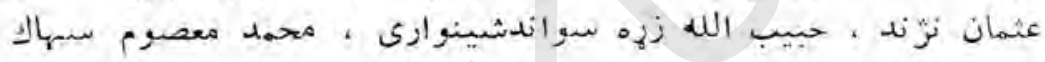

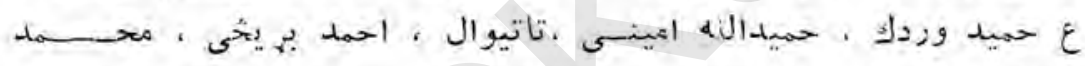

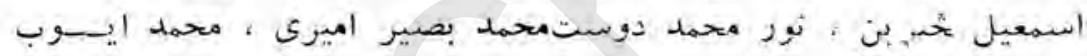

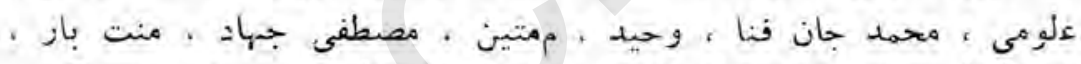

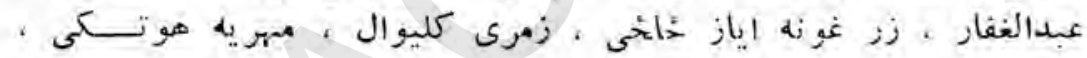

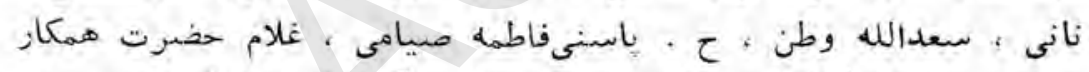

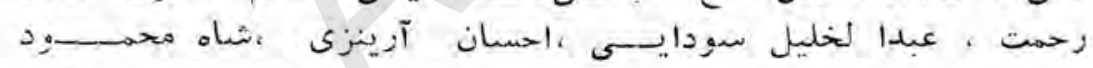

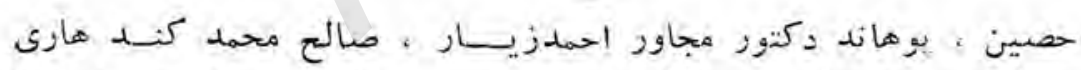

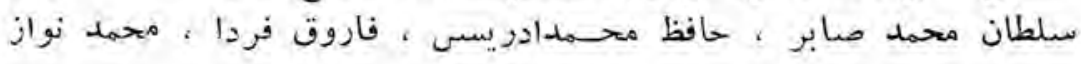

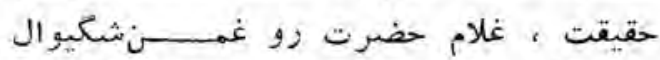

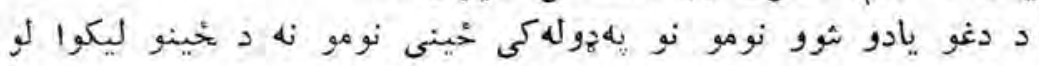

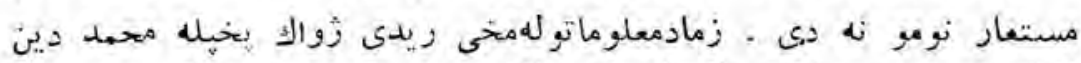

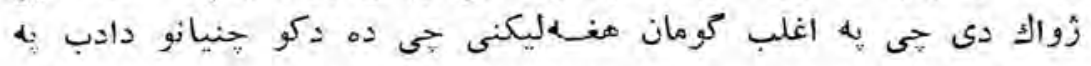

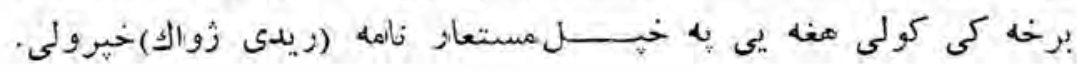




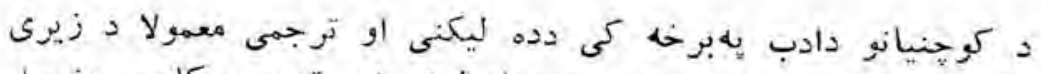

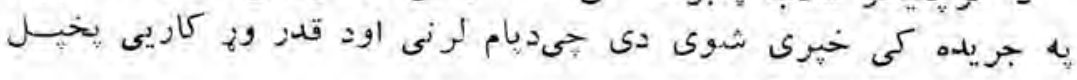

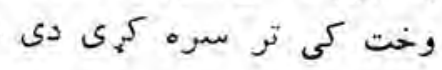

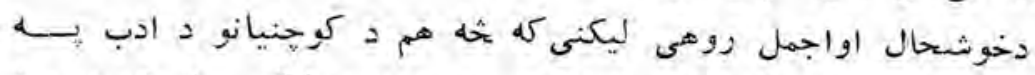

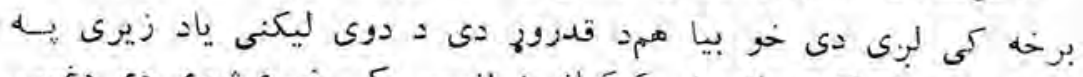

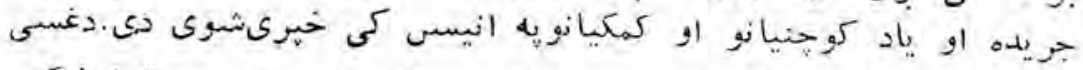

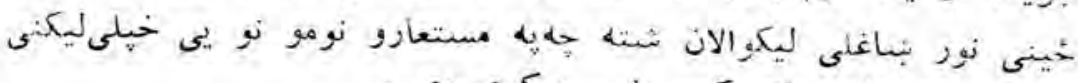

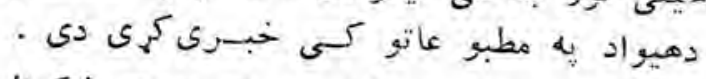

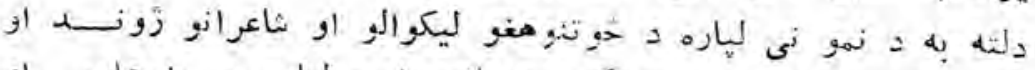

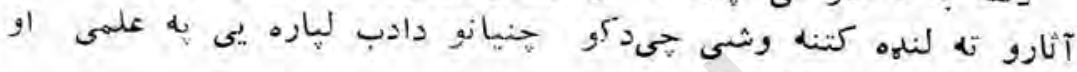

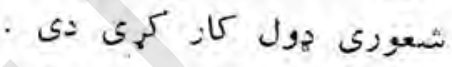

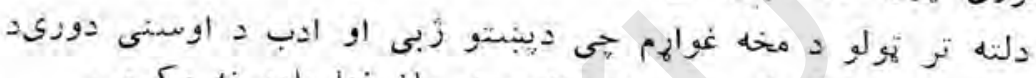

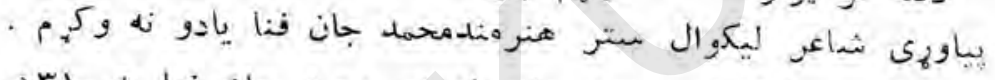

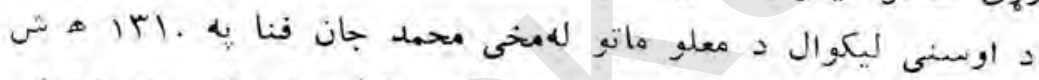

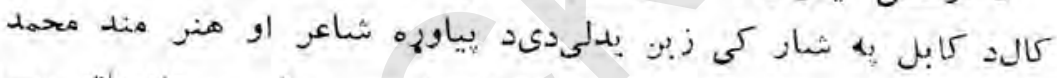

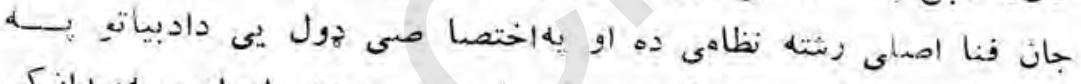

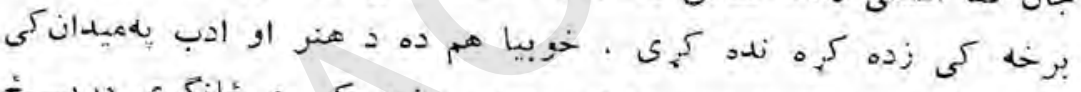

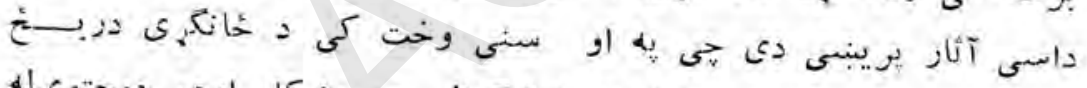

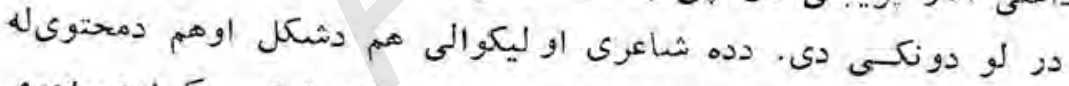

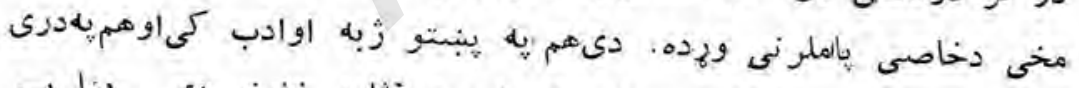

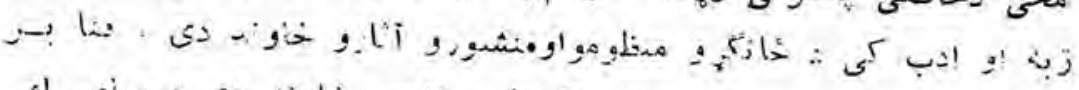

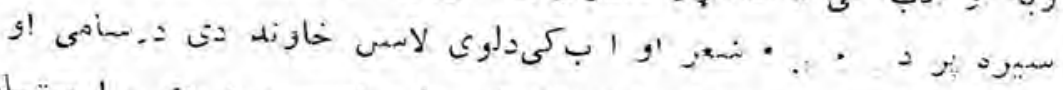

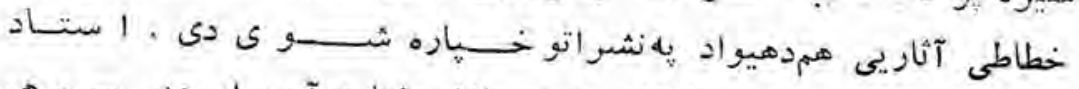

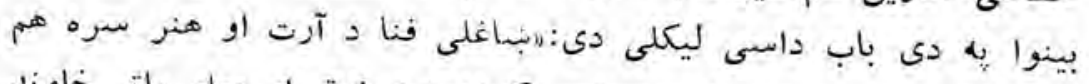

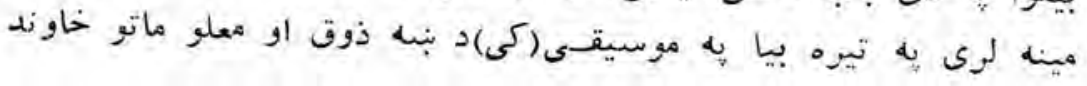




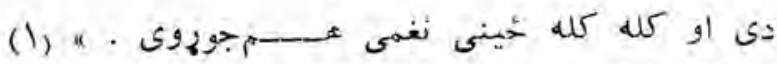

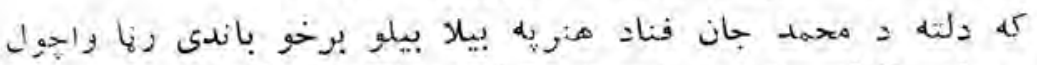

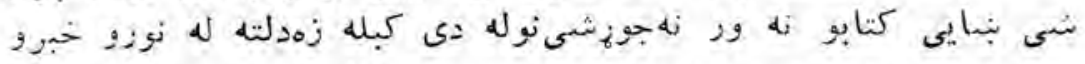

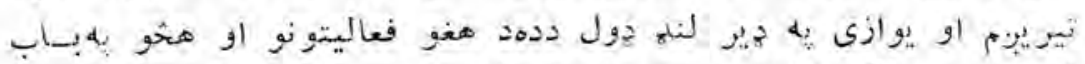

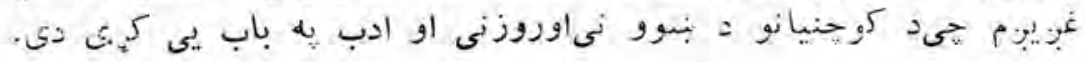

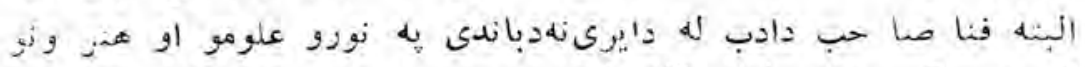

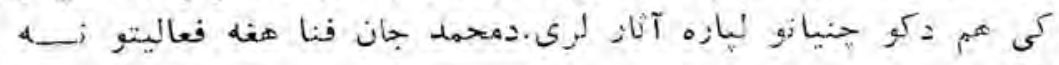

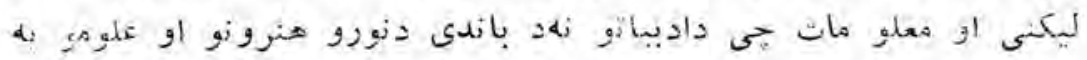

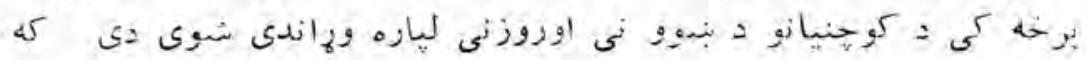

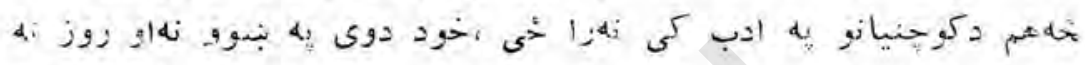

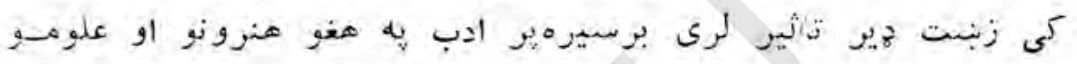

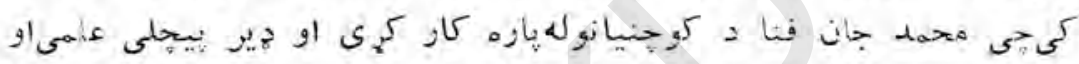

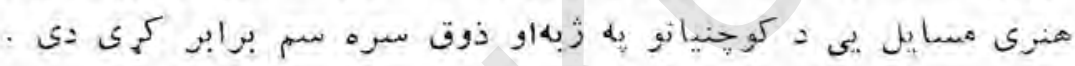

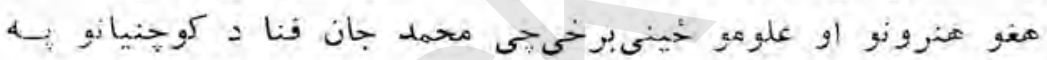

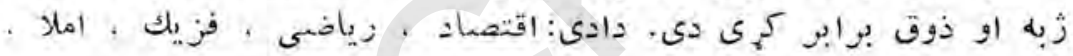

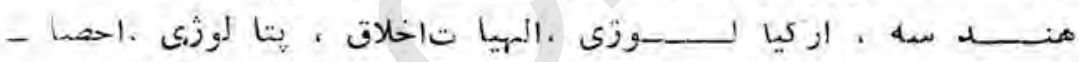

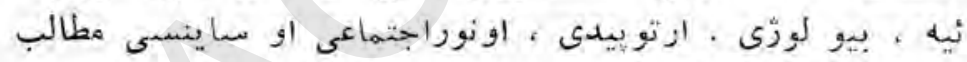

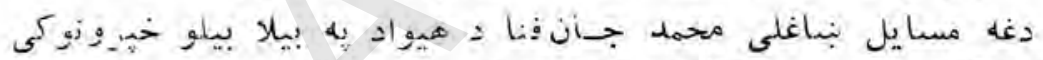

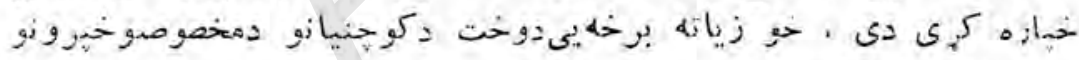

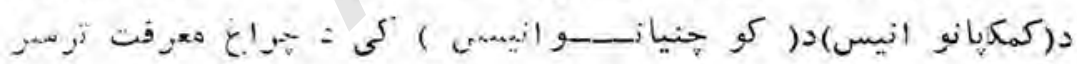

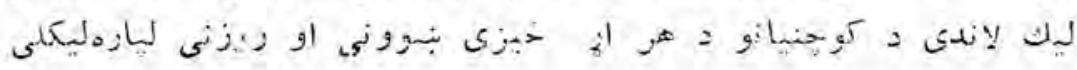

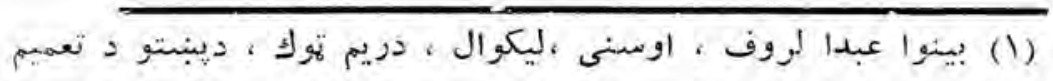

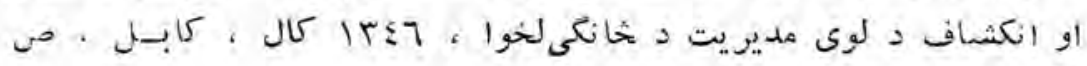
1.ro 


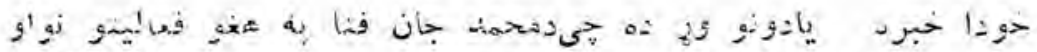
ق

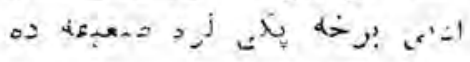

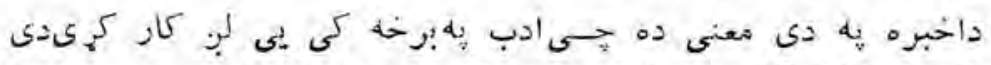

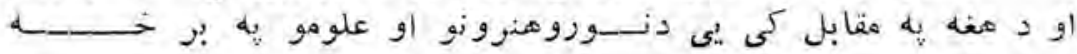

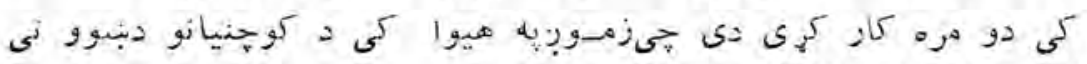

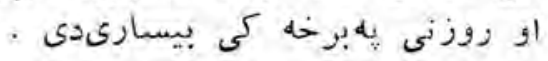

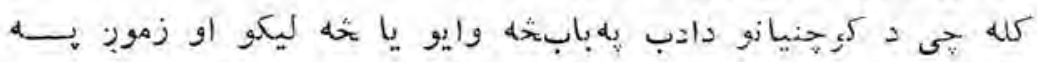

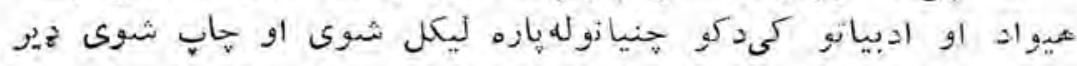

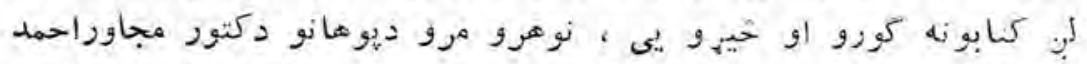

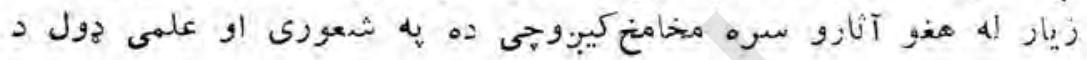

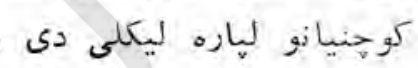

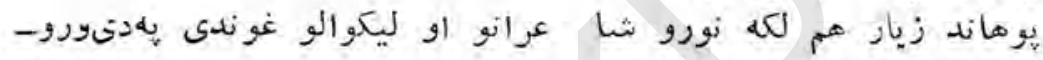

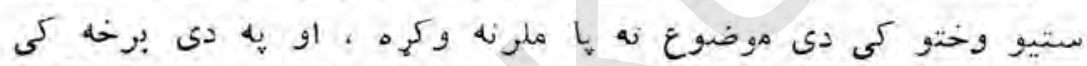

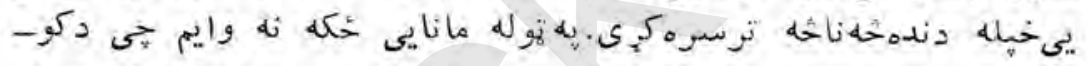

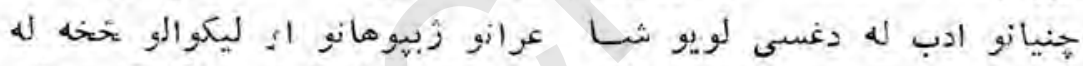

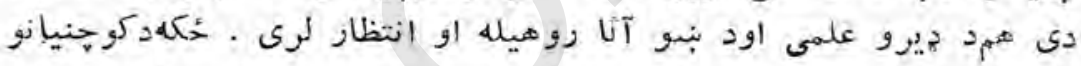

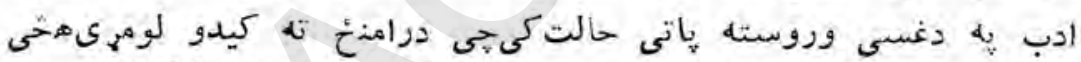

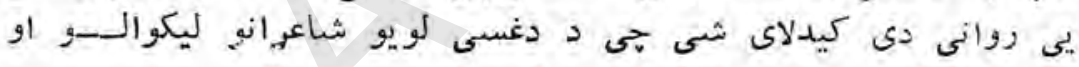

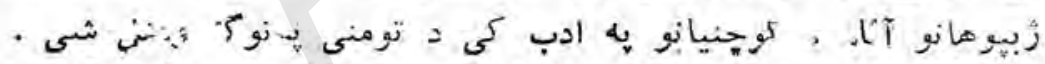

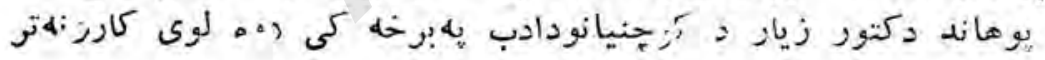

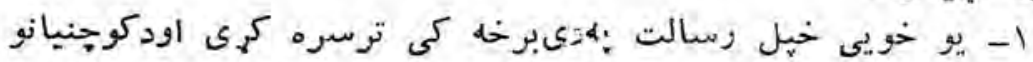

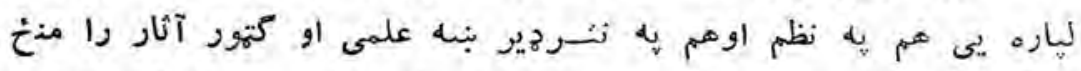

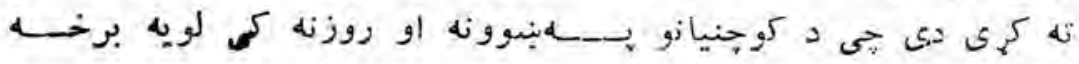
- لرى 
ا

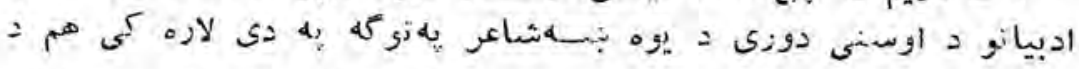

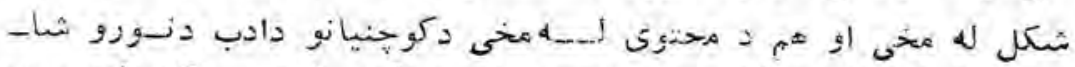

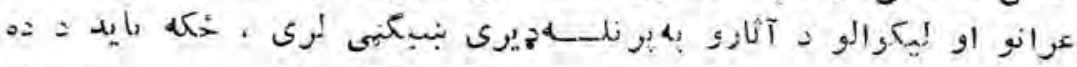

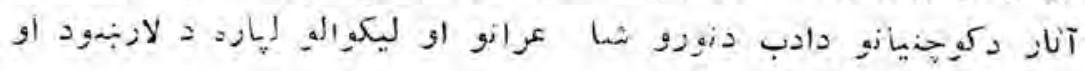

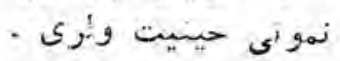

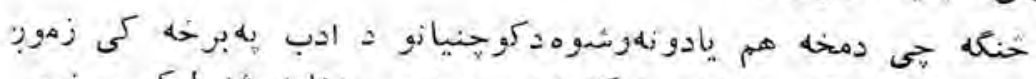

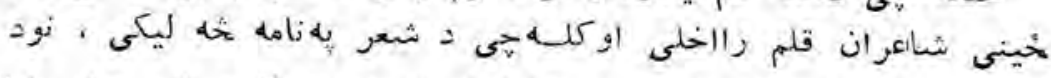

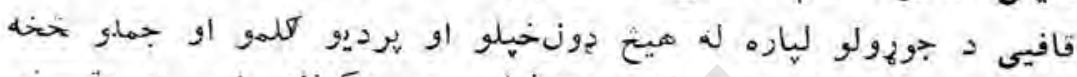

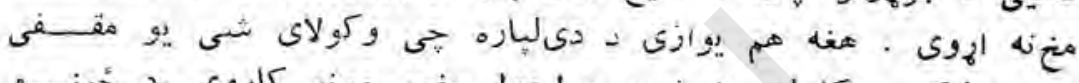

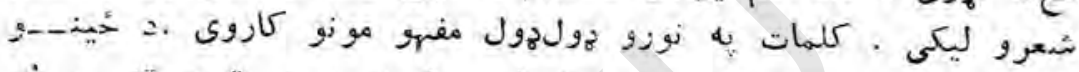

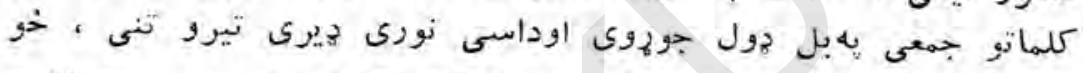

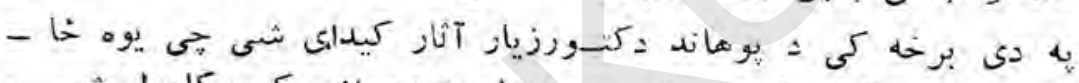

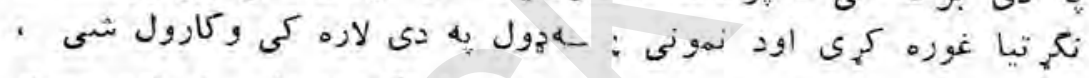

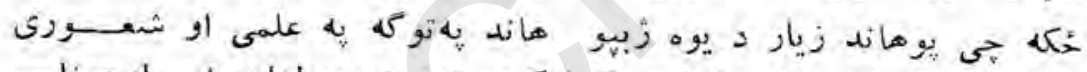

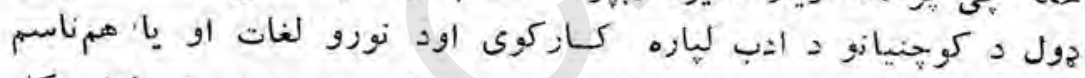

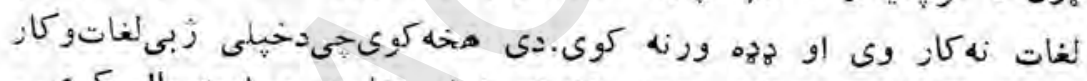

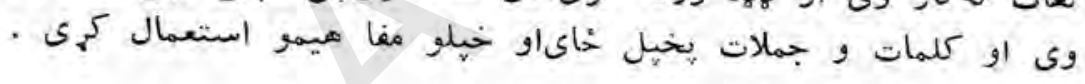

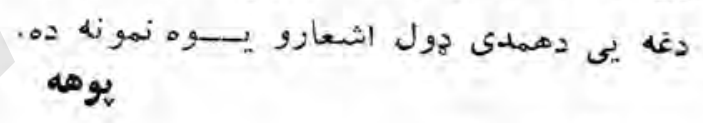

$$
\begin{aligned}
& \text { يوهله منر دى } \\
& \text { o } \\
& \text { يوها ثروندون ده } \\
& \text { بورها } \\
& \text { بوهه توان دى نى }
\end{aligned}
$$

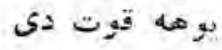

$-157$ 


$$
\begin{aligned}
& \text { يو ها بيسيى }
\end{aligned}
$$

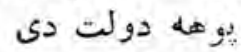

$$
\begin{aligned}
& \text { يوهن كله نه وله }
\end{aligned}
$$

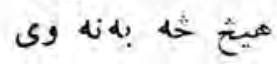

$$
\begin{aligned}
& \text { دغه نهى } \\
& \text { توزه تياره وى ني ته } \\
& \text { ا نمونه هم وكورى : }
\end{aligned}
$$

باران

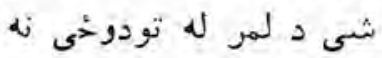

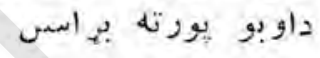

توره وريتح شى ورنه جويه

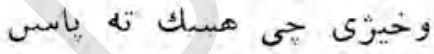

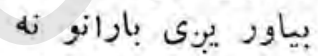
اوبرى وخى بيد ياوى برى بانو

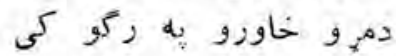

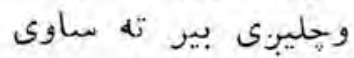

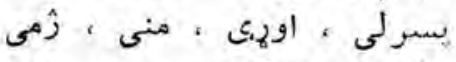

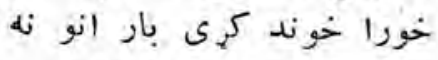

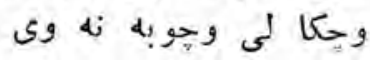

(r) بنير ازى وى اوكنيتون

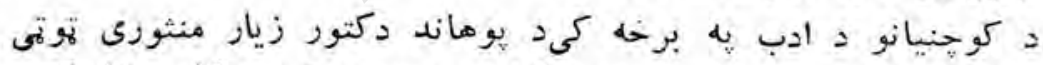

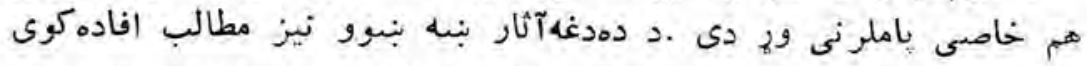

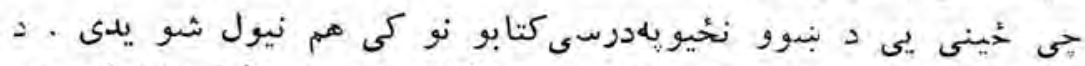

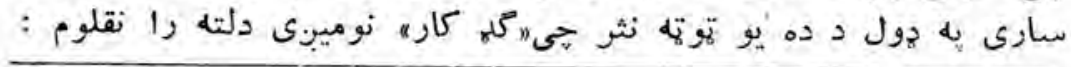

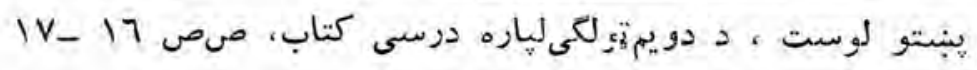

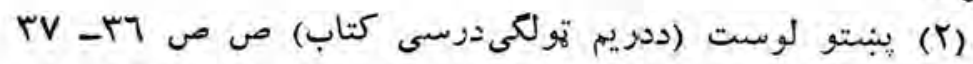
مخنونه -1 rVt 
S2

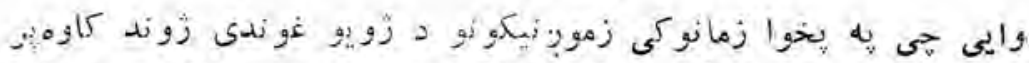

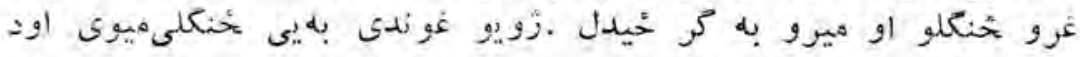

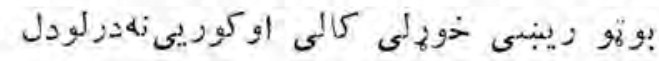

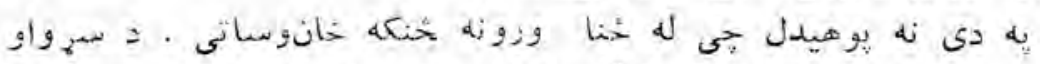

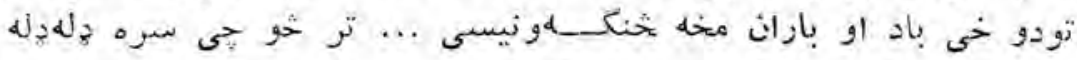

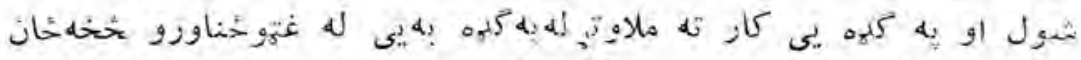

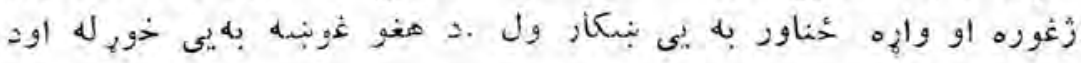

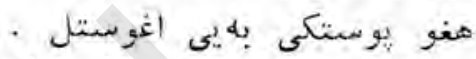

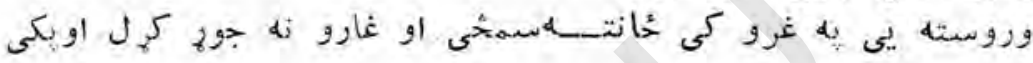
اوسيدل به .

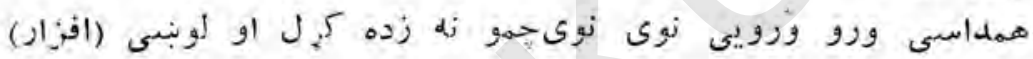
ب. ب.

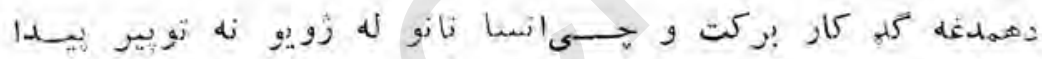

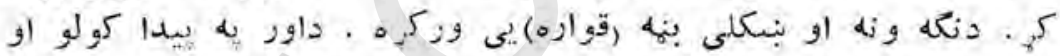

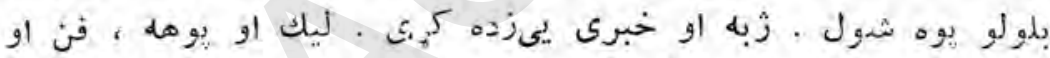

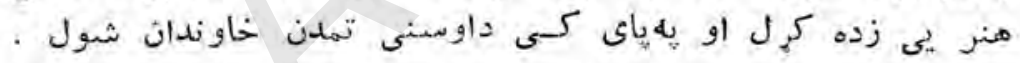

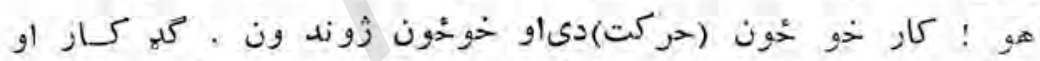

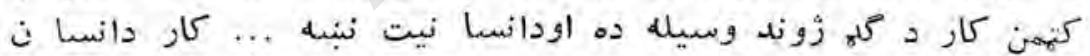

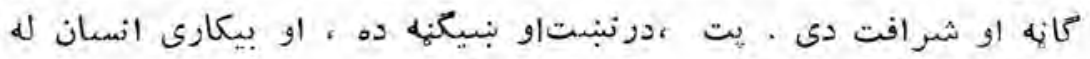

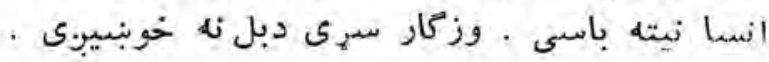

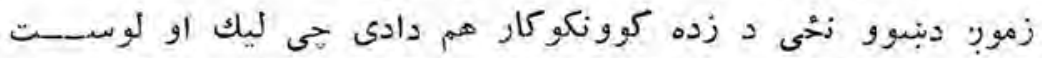

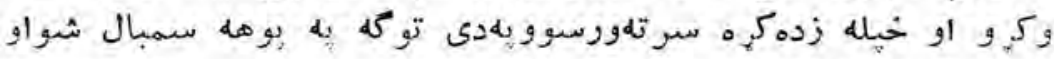

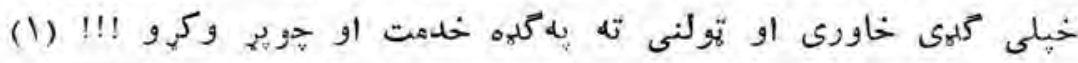
$|T|-1$ | (1) $-\mid r \Lambda$. 


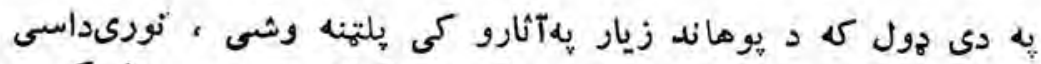

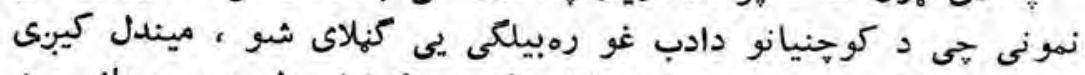

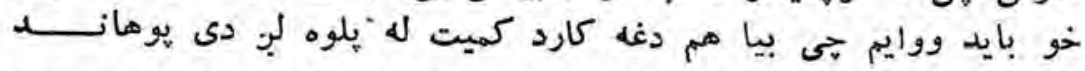

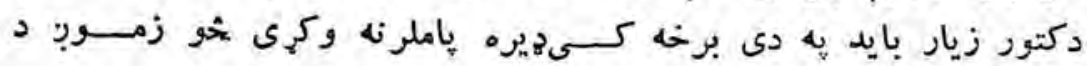

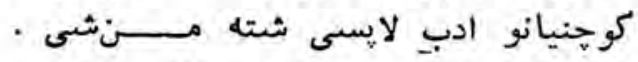

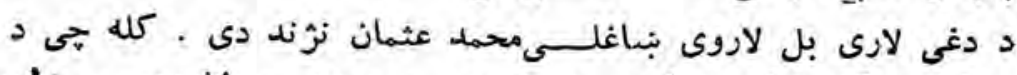

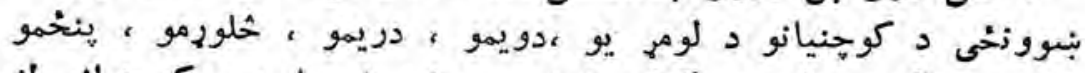

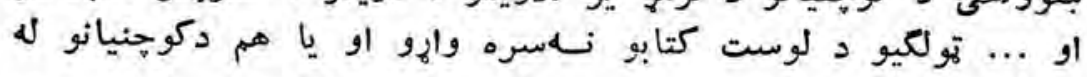

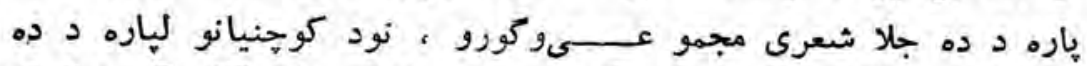

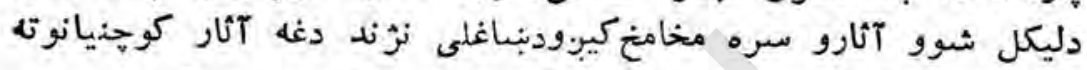

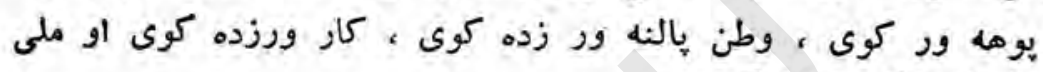

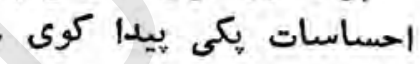

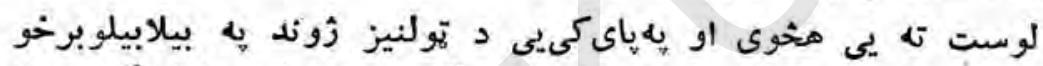

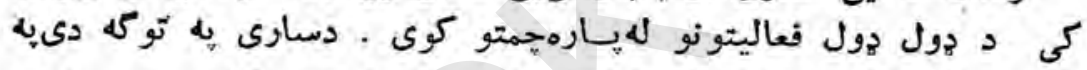

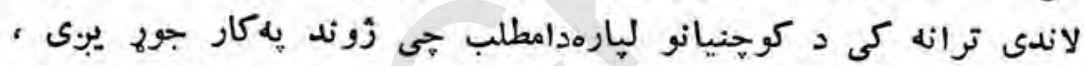

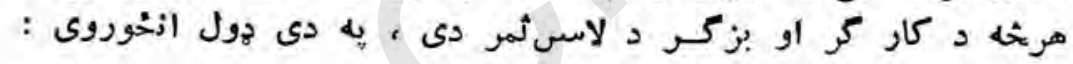

$$
\text { اي بزكره }
$$

زيار كنيه وروره د زئى سره

$$
\text { كرانه بزكره تكره كار كري كره }
$$

شين كلستان دى د د لاسى ثمر كره دى كره

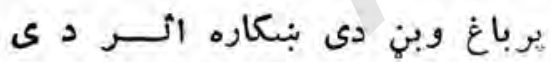

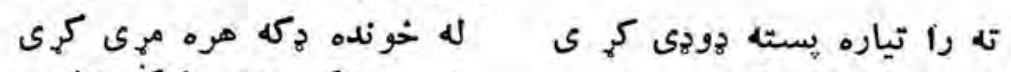

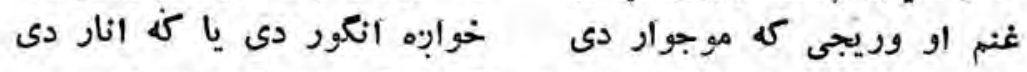

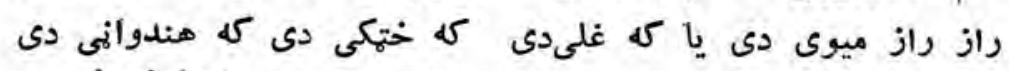

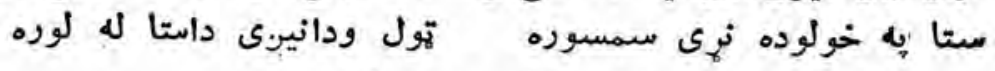

$$
\begin{aligned}
& \text { د قدر وه ينى جير مهر بانه } \\
& \text { يونثند كرانه يونزئد وكرانه } \\
& -1 \text { - }
\end{aligned}
$$




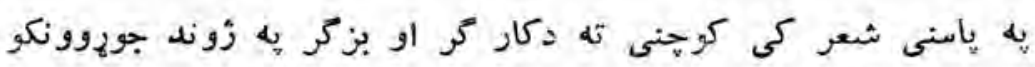

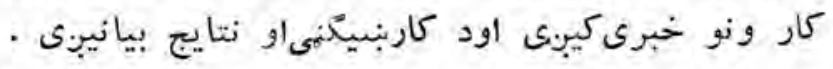

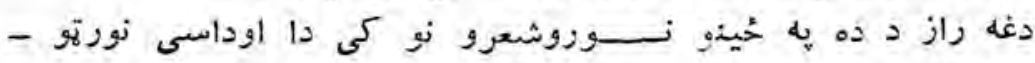

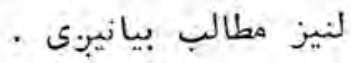

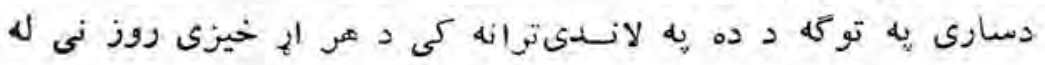

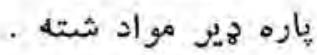

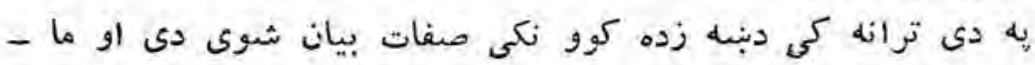

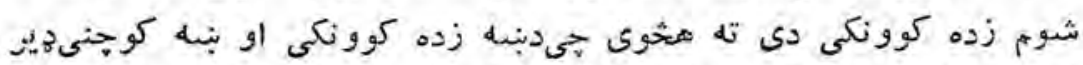

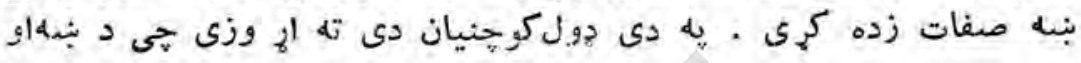

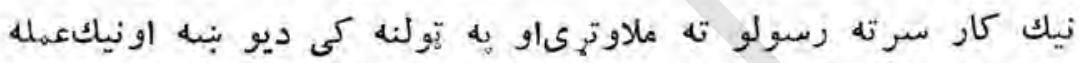

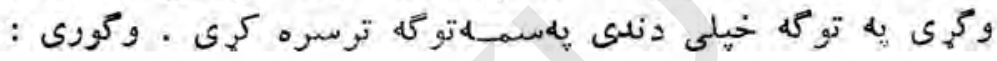

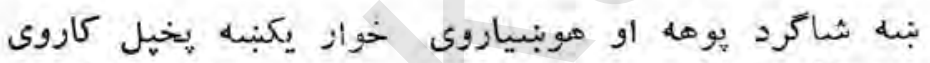

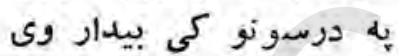

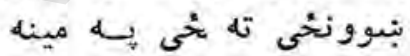

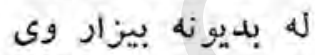

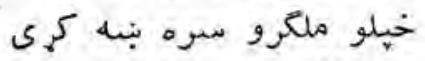
نيك عمله نيك كرد ارئه واري

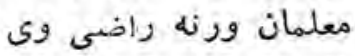

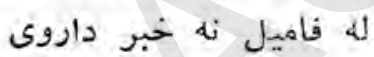

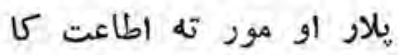

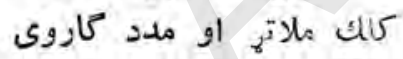
كورنى يه اقتصاد اوكى إنى

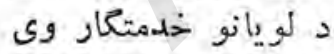

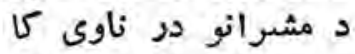

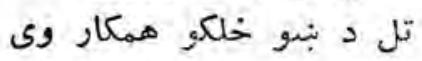

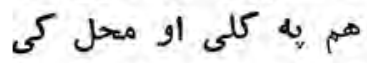
مخالف داستثماروى تل دبنهن داستشماروى

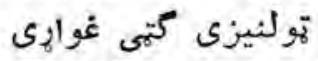
استعملر نه كوى كمئ غوري دنزئل زيره ته منلى

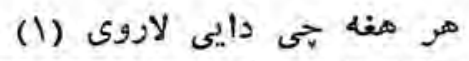

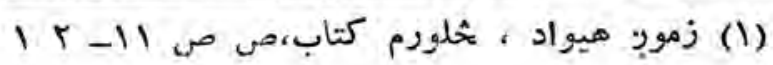
$-11 \%$ 


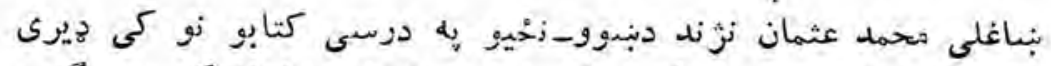

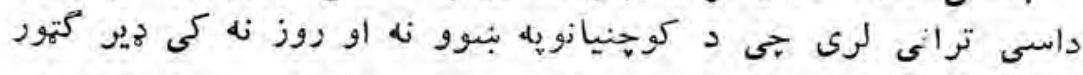

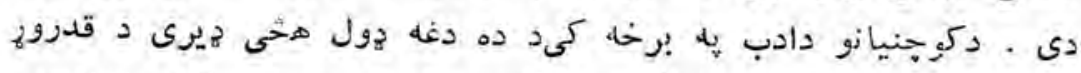

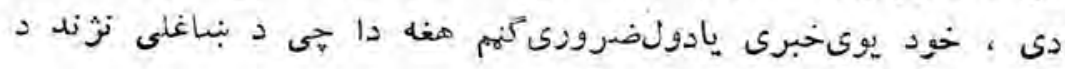

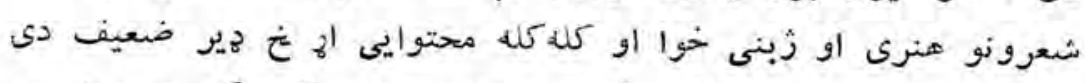

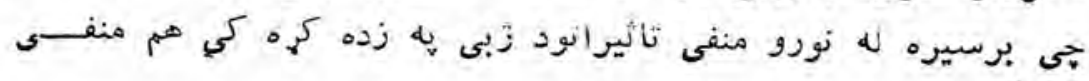
اثر لرى . لرسيره

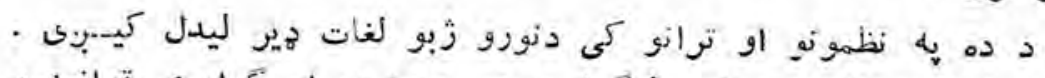

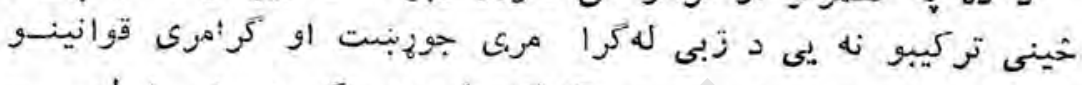

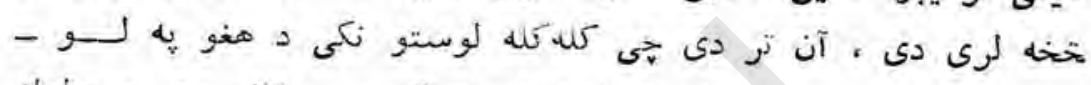

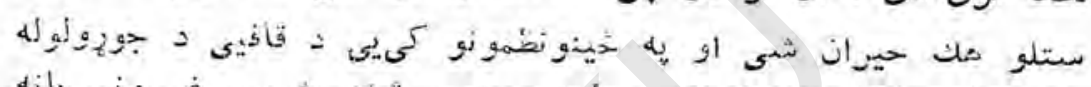

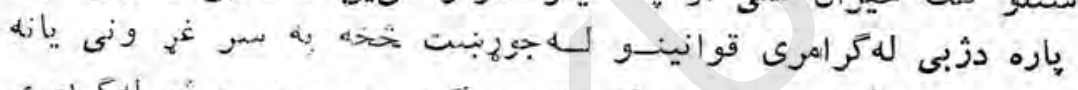

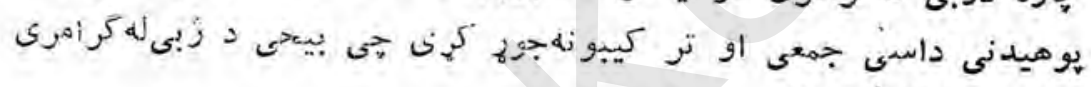

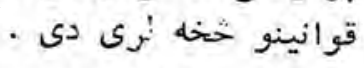

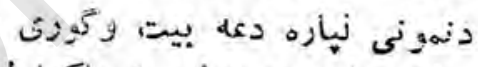

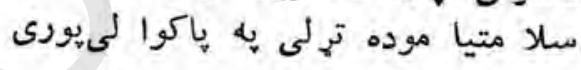

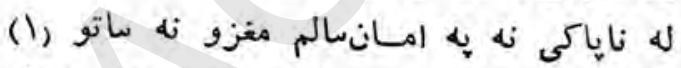

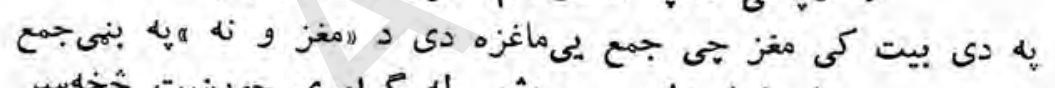

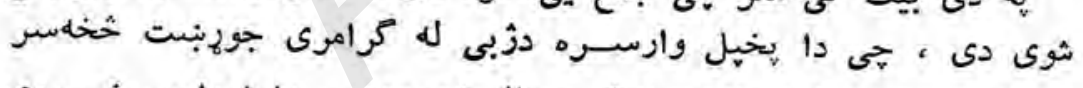

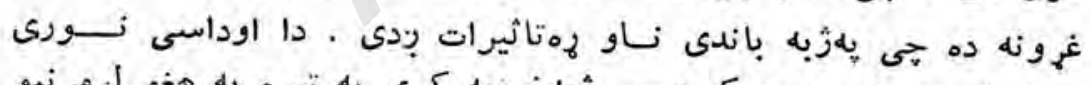

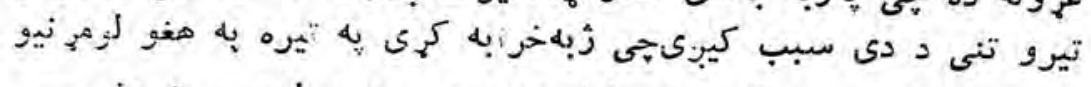

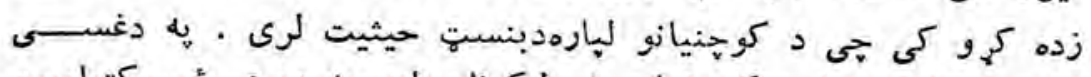

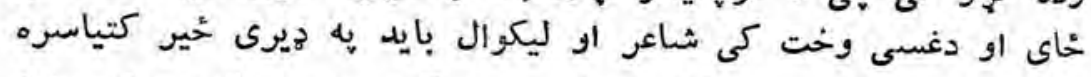

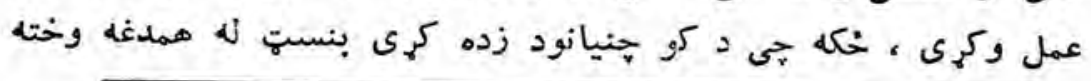

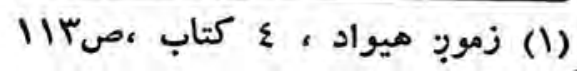
-iris 


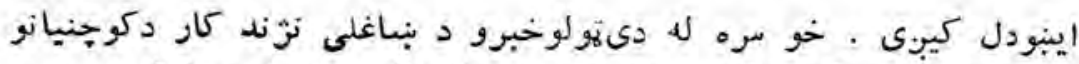

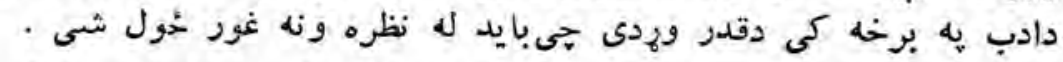

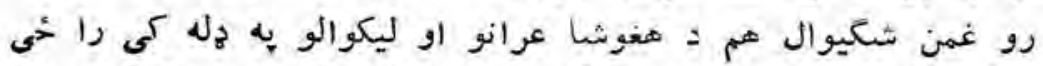

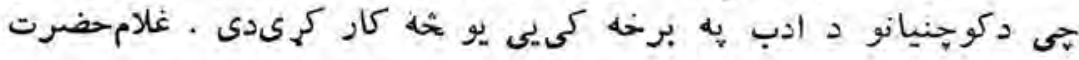

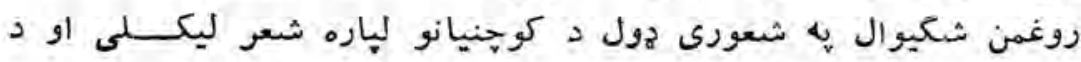

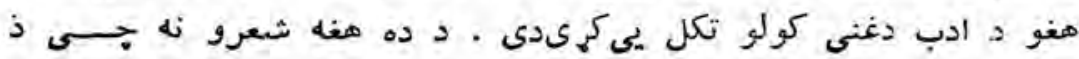

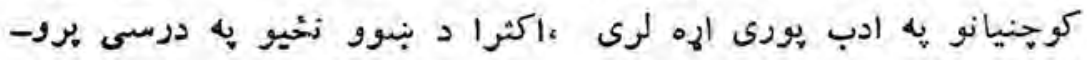

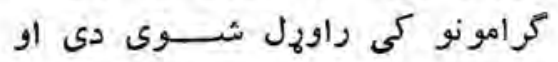

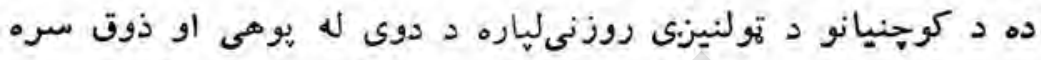

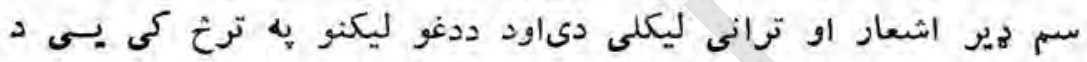

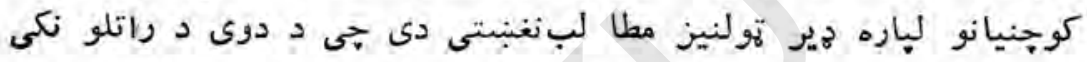

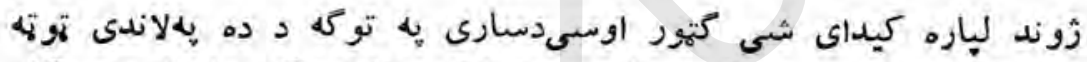

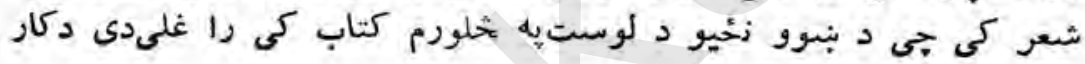

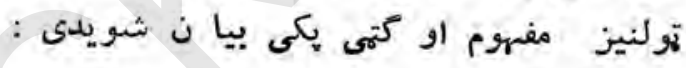
كار

$$
\begin{aligned}
& \text { كار روز نه } \\
& \text { كار خيه نه } \\
& \text { كار بنبوو نه } \\
& \text { كار بومنه } \\
& \text { سموي فكر كارونه } \\
& \text { جوريوى بنه تاريخو نه كارونه }
\end{aligned}
$$

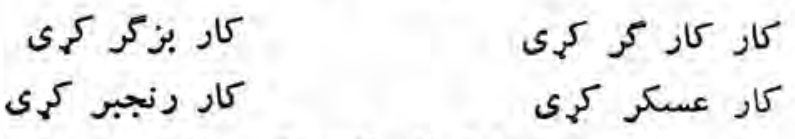

$$
\begin{aligned}
& \text { جا تهناكى كهم لاسو نه }
\end{aligned}
$$

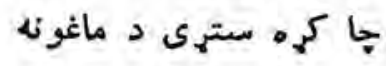

$$
\begin{aligned}
& \text {-irre }
\end{aligned}
$$




$$
\begin{aligned}
& \text { كار صحت دى } \\
& \text { كارد دولت دى عار } \\
& \text { كار عزت دى صن } \\
& \text { كار د روند بندلى معنا ده }
\end{aligned}
$$

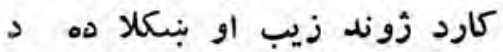

$$
\begin{aligned}
& \text { كار بدلون دى بند } \\
& \text { كار سمون دى بدل دى } \\
& \text { كار غيرت دى دولت دى } \\
& \text { به نهى كى نيكمر غى ته }
\end{aligned}
$$

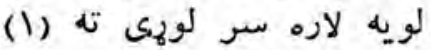

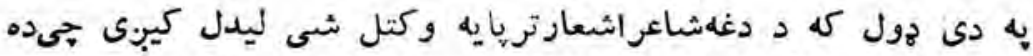

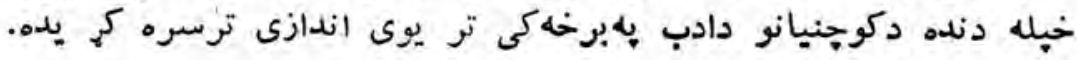

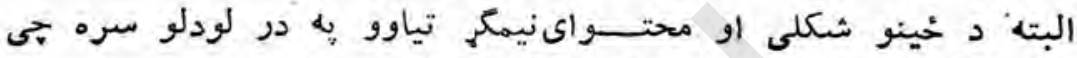

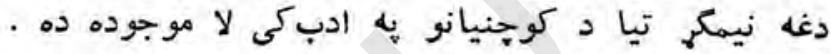

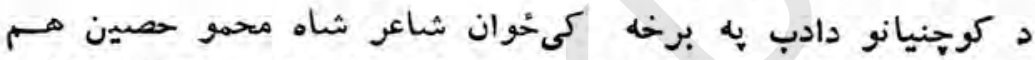

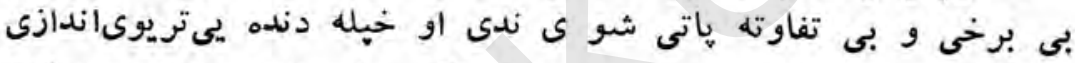

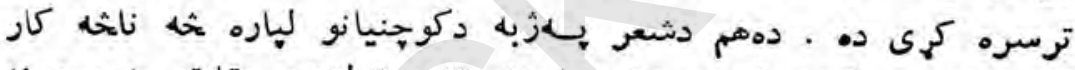

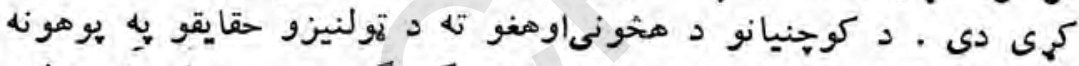

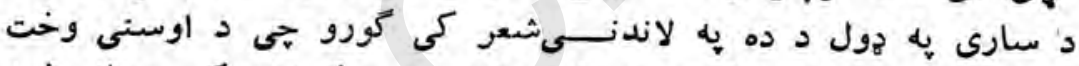

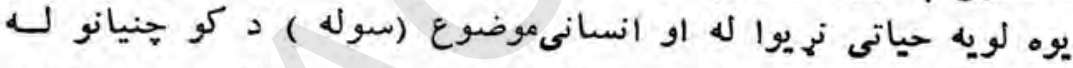

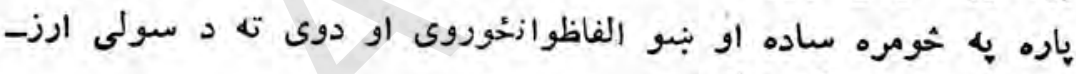

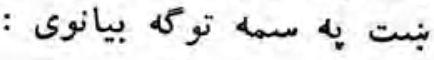

سوله

د زحمت كنبدو بحيان غوارو دسولى دوردان

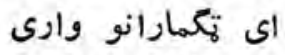

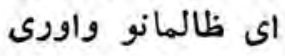

موبز د نهى ماشومان جنك سره جنك دو دى زموب مانو جكه جه مار نوو اونى ولى جهان ني مان نووى

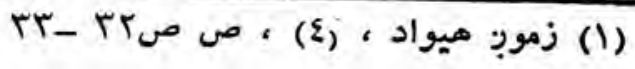

- Irr. 
زازه فكر ونه واورى

دانوى كام يور ته كئى

هم يى رنجبر خوبنسوى

دا خوار بزمر خونينوى

نوى دوران دسولى

دا دي ارمان دسولى دوران دسولى
يويبندى جنكو نه واورى

دسولى جام يور ته كئى نه

سوله كار كر خونينوى

د مزدورانو ارمان

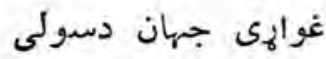

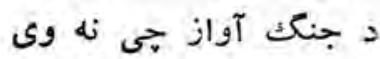

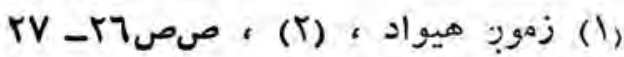

$-1 r \varepsilon$. 


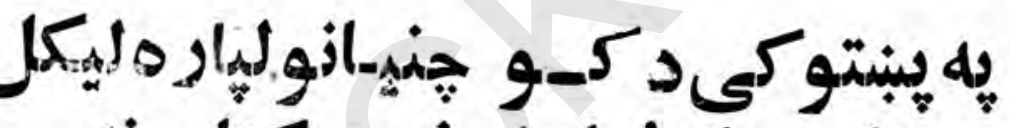
شوى اوز بارل شوى كتابونه

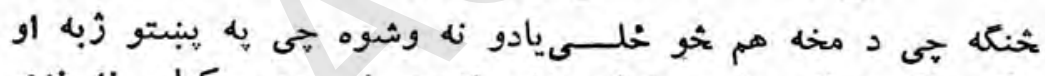

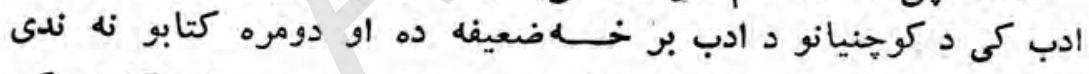

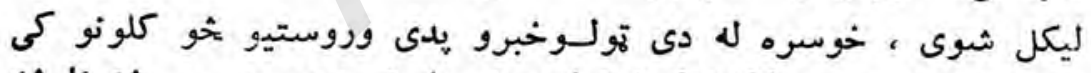

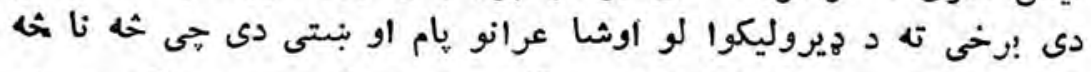

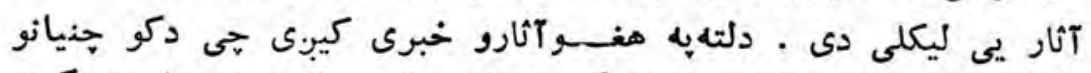

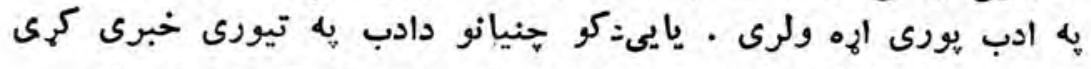

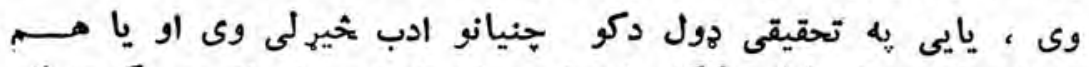

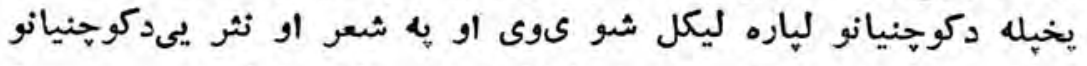

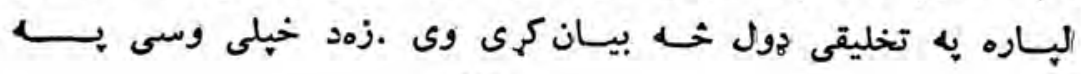
- Iro. 
اندازه اود امكاناتو به جو كاتِ كىدغه آثار جي دله كرانو لوستونكو

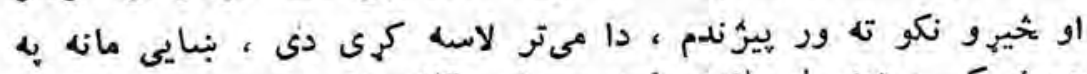

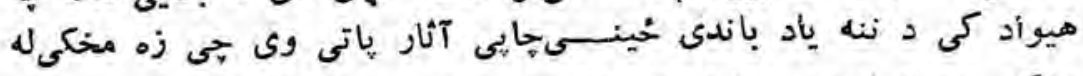

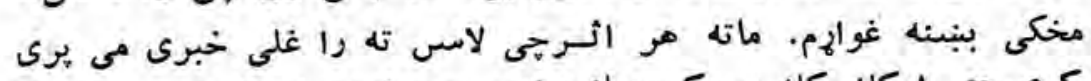

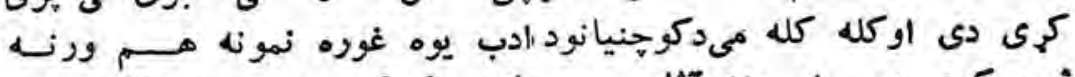

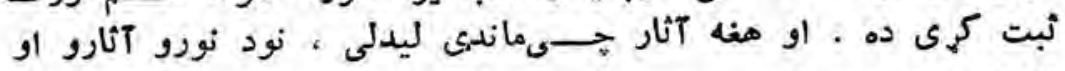

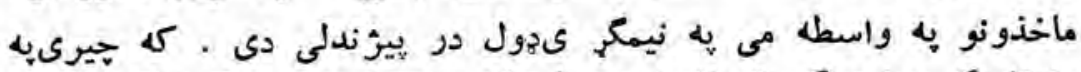

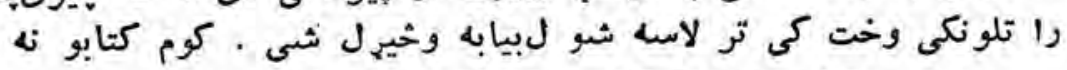

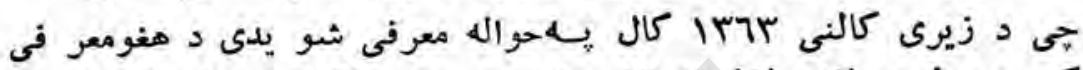

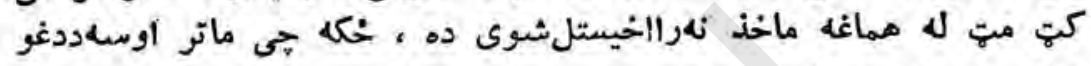

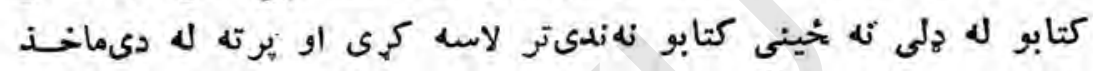

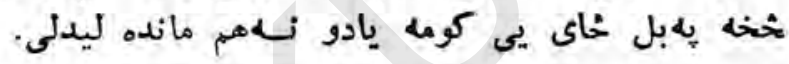




\section{آدمخمـان اودر خانيى}

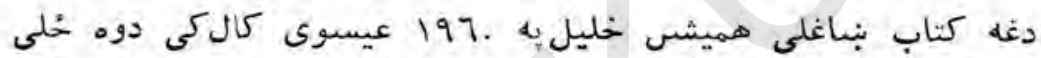

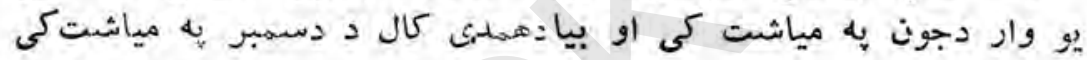

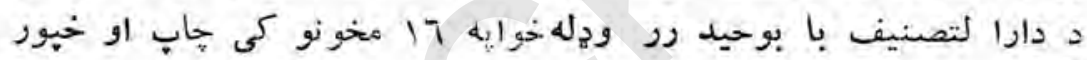
$\cdot r^{2}$

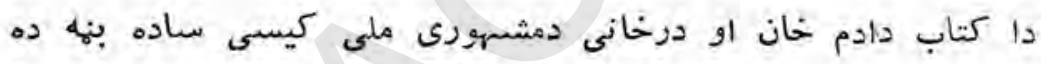

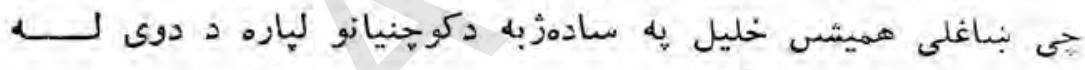

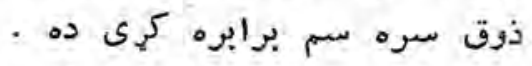

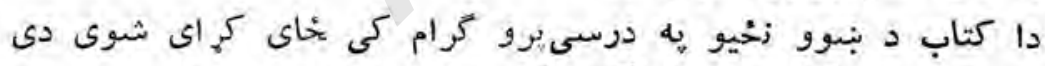

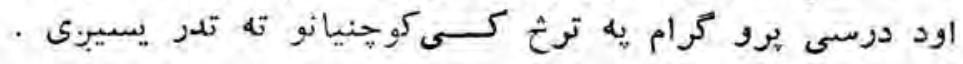

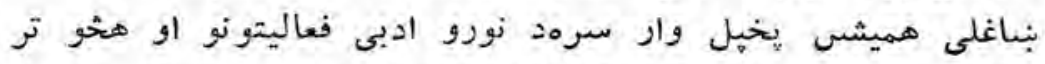

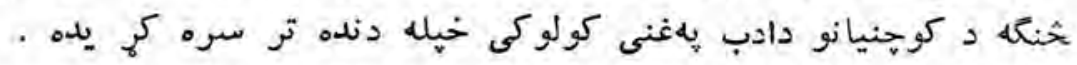

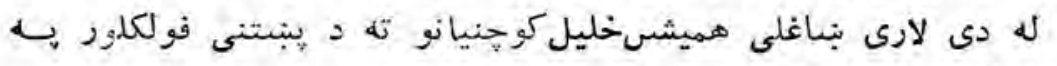

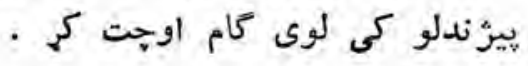




\section{اسلامى قصىى}

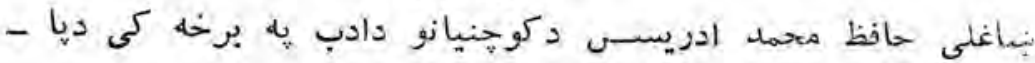

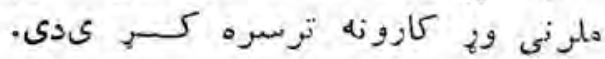

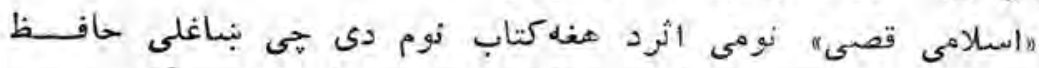

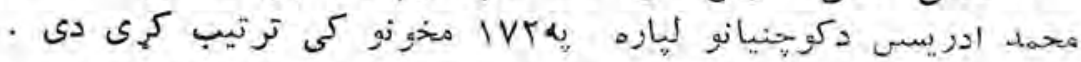

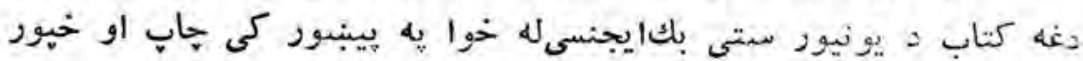

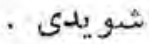

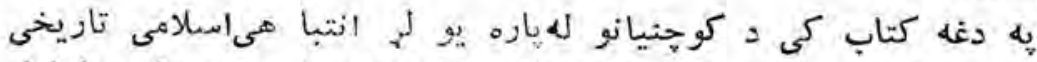

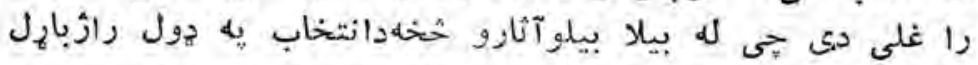

5

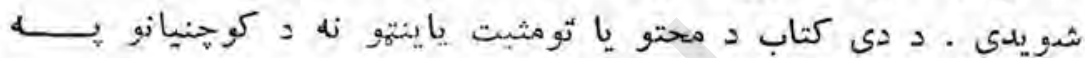

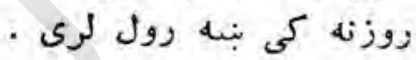

\section{افسانوى آس山}

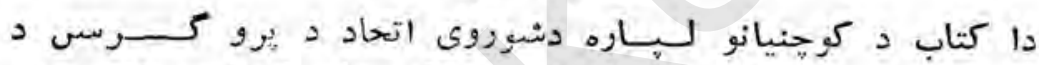

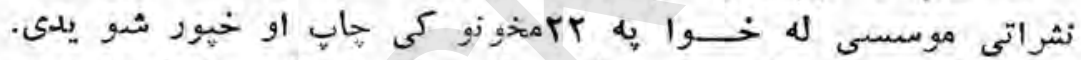

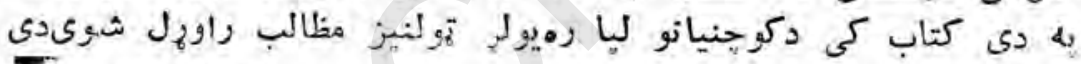

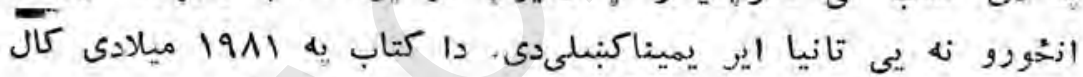

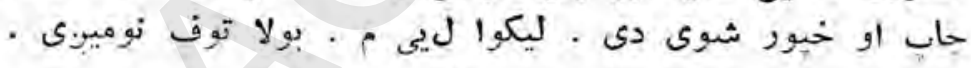
الفبى

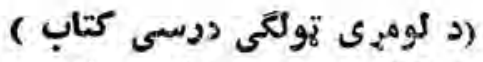

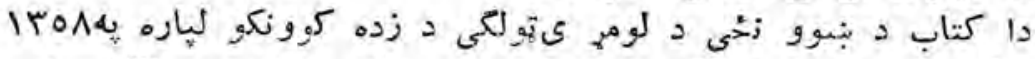

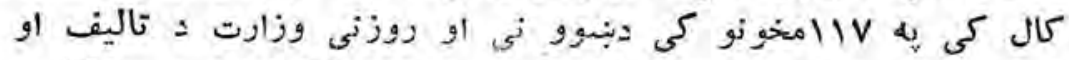

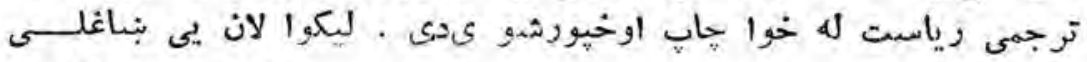

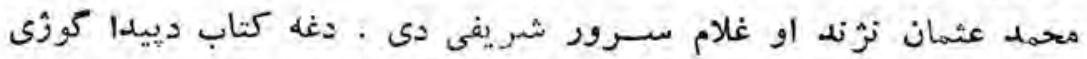

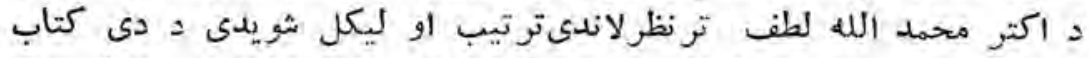

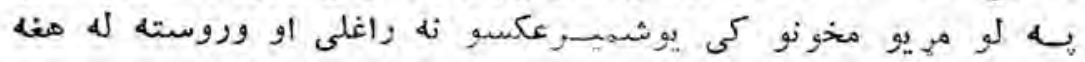




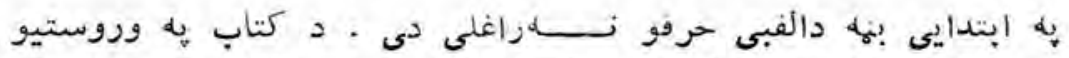

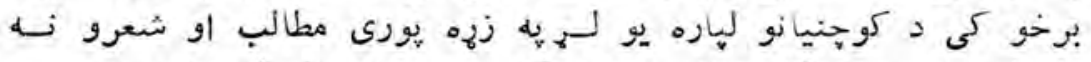

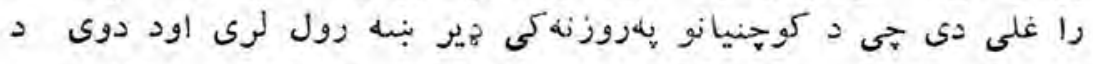

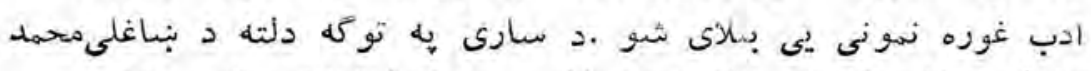

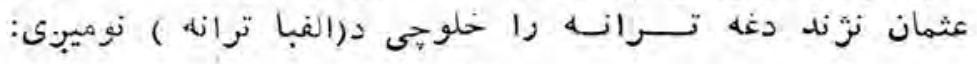
دانفبا ترانه

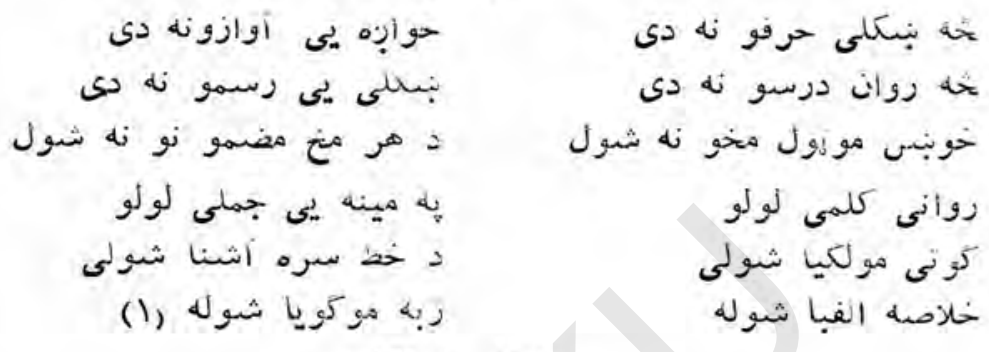

\section{ينبنتى فوثلكلود}

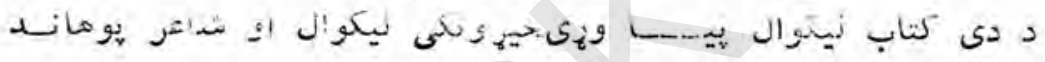

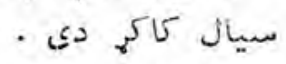

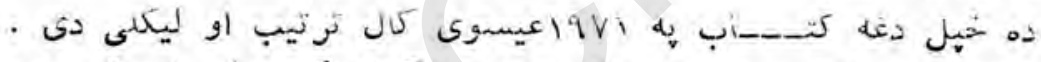

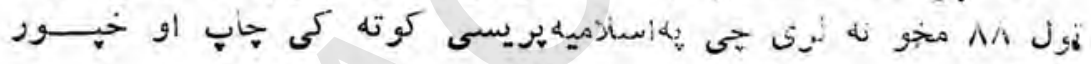

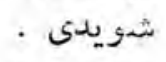

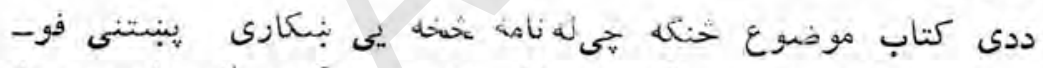

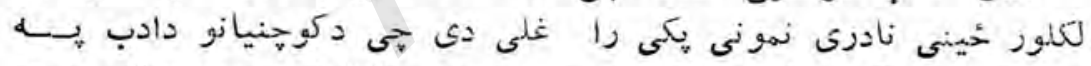

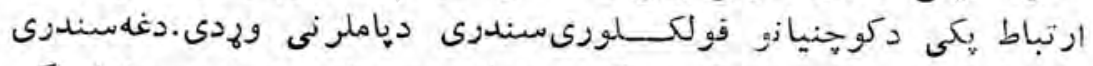

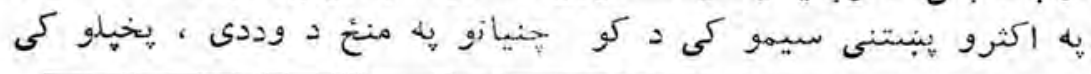

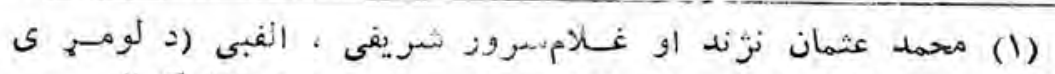

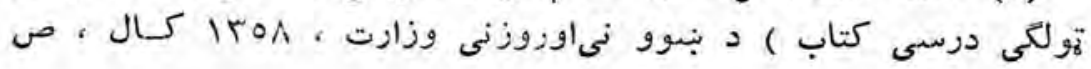




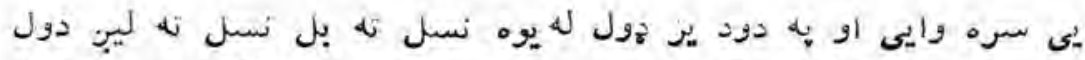

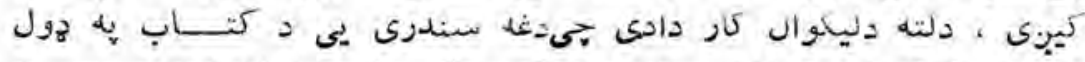

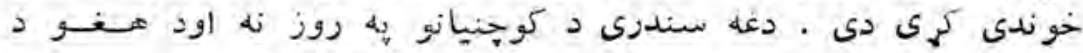

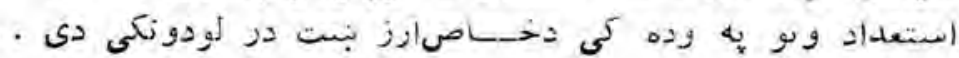

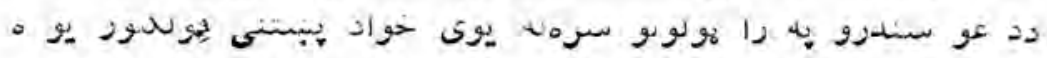

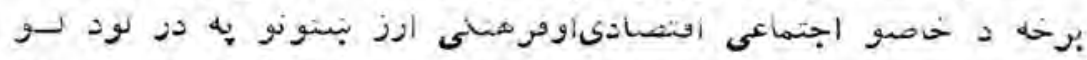

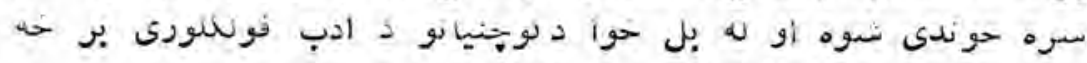

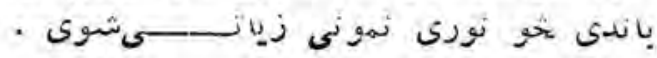

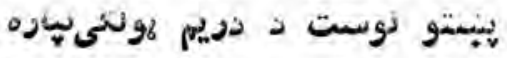

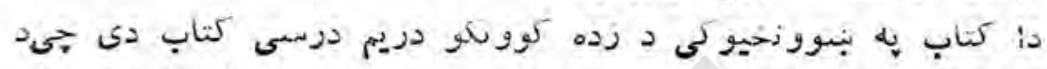

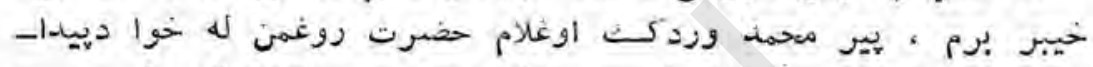

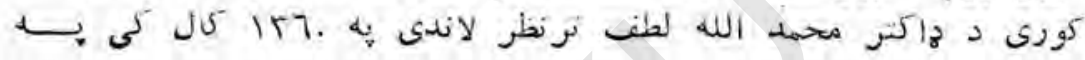

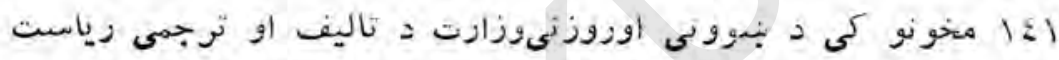

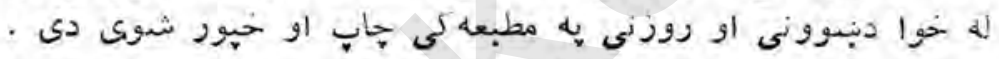

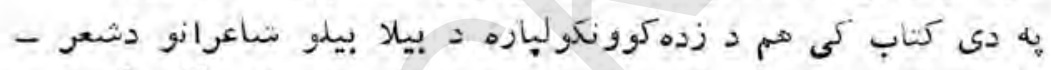

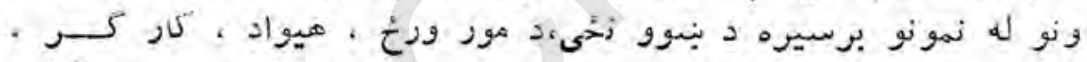

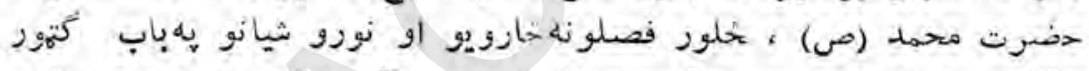

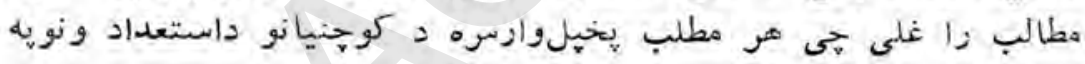

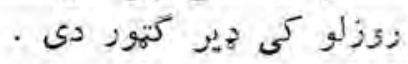

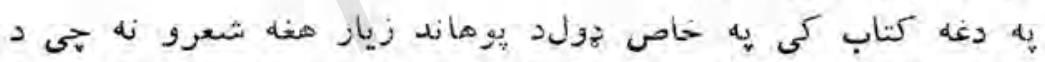

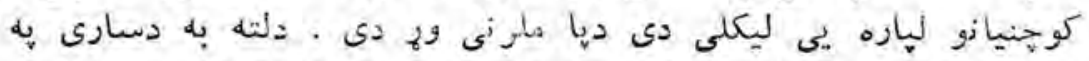

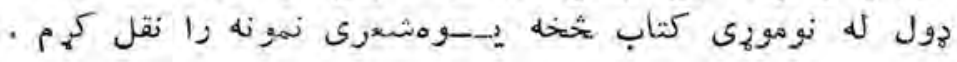

$$
\text { زمى }
$$

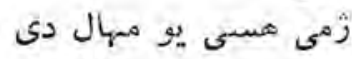

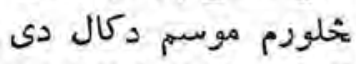
كله باد كله باران وى 
سور سمختح خمكله آسمان وى كله اورى بلى بلى واوره

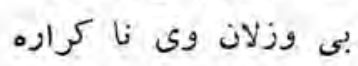

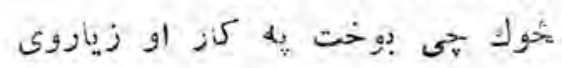

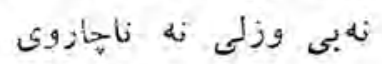

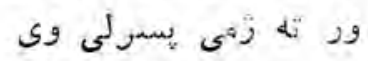

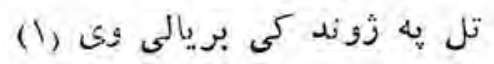
ييل

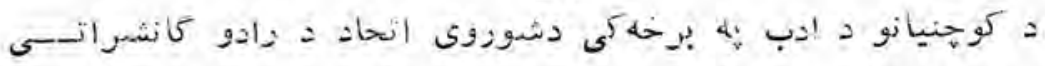

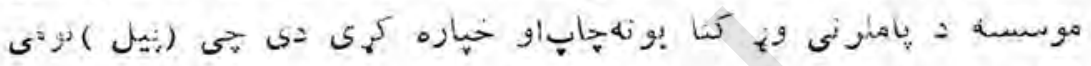

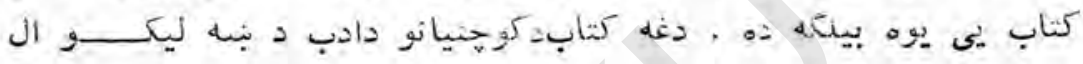

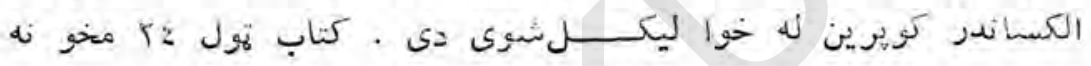

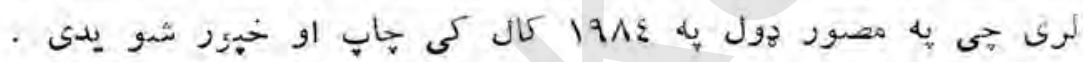

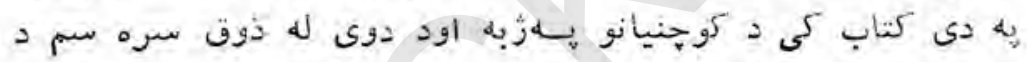

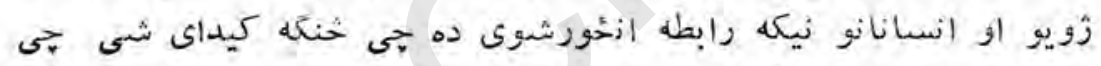

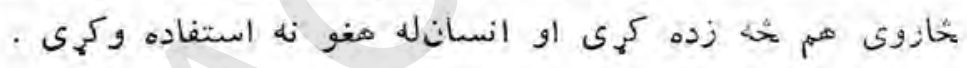

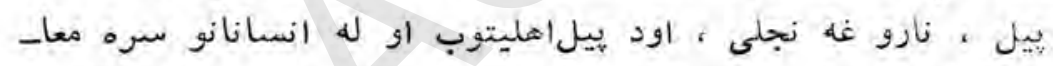

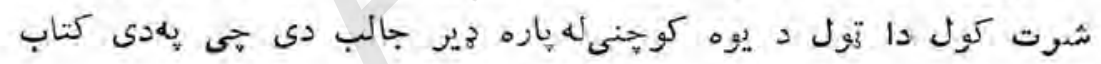

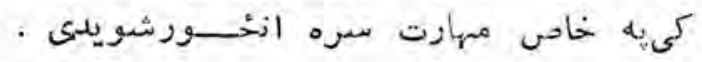

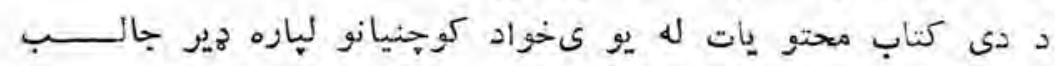

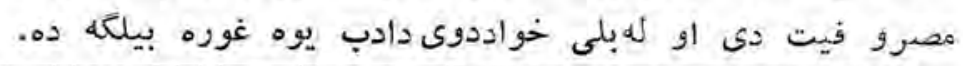

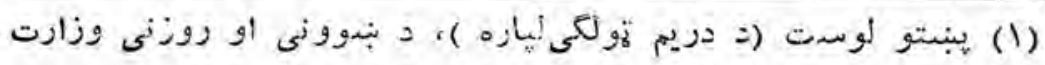

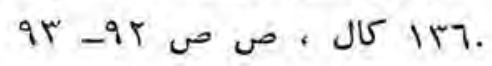




\section{وبيينى كيسى}

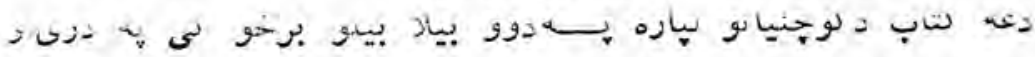

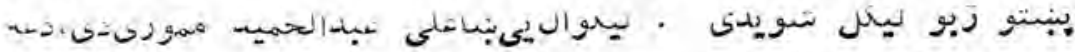
سب به

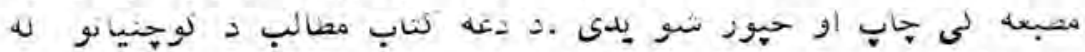

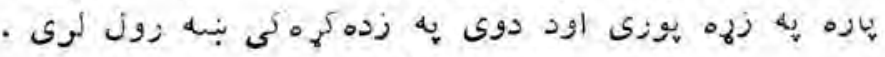

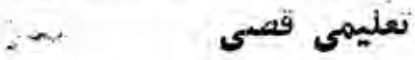

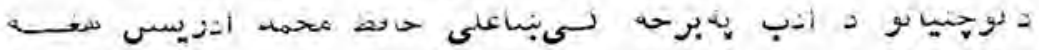

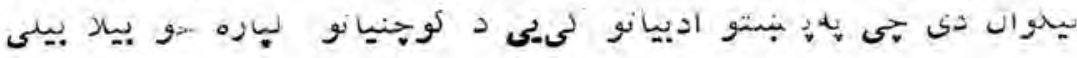

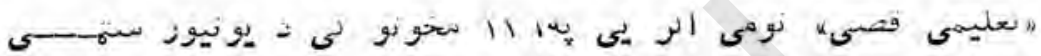

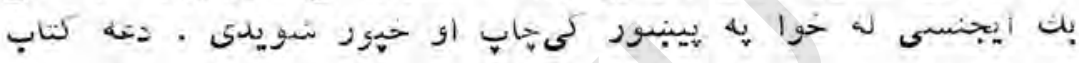

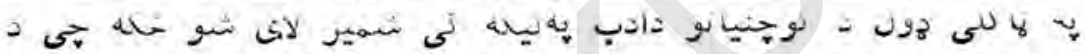

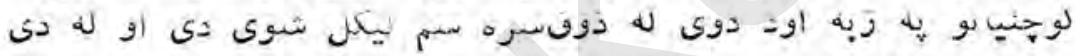

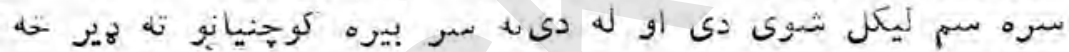

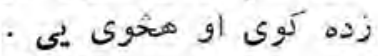

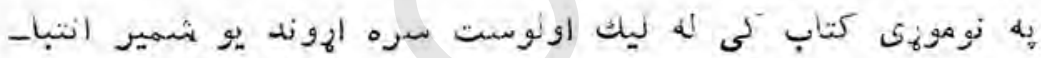

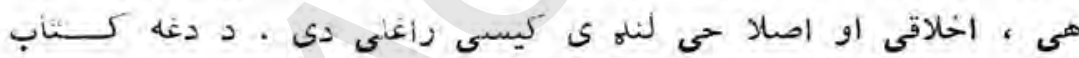

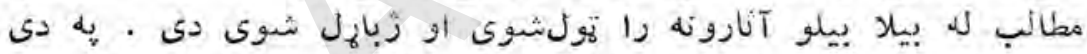

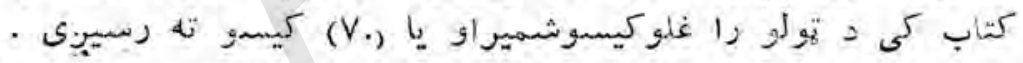

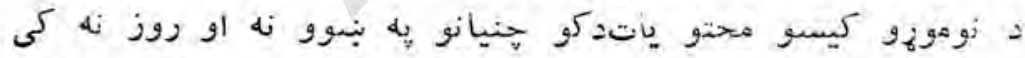

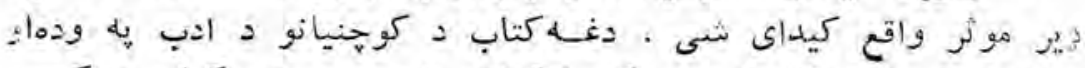

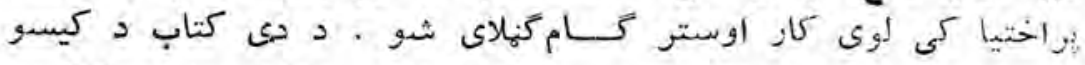

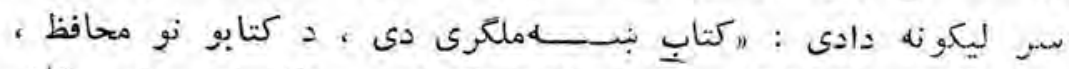

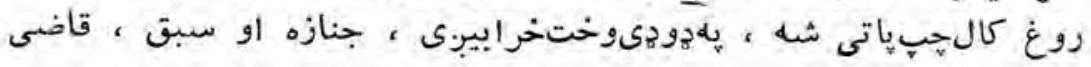

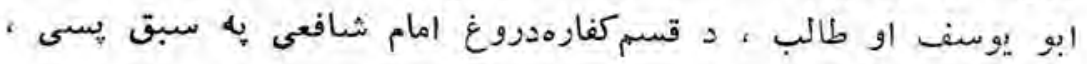




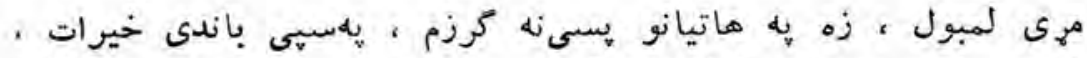

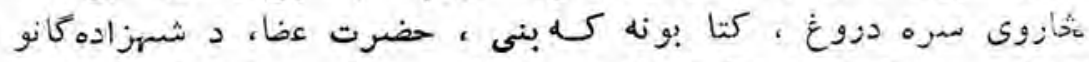

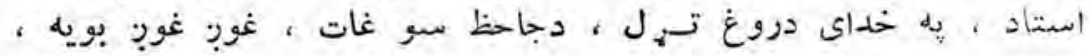

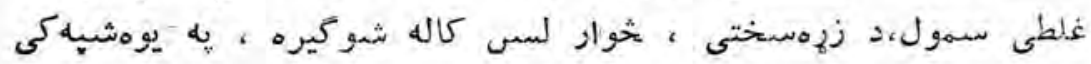

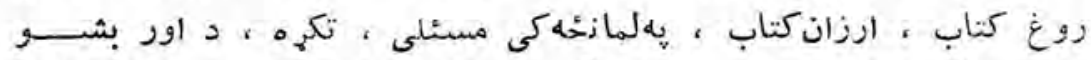

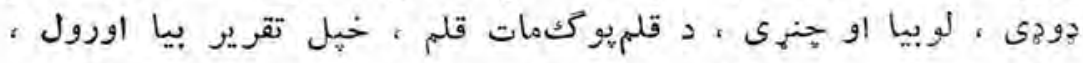

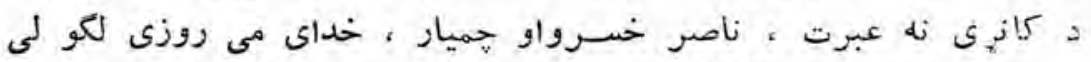

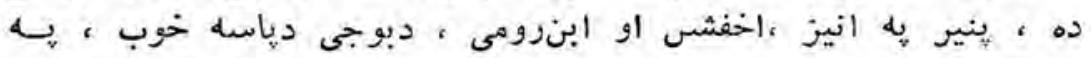

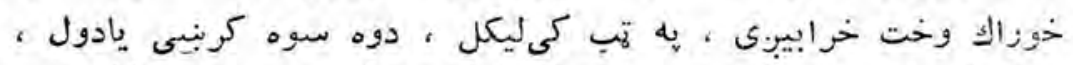

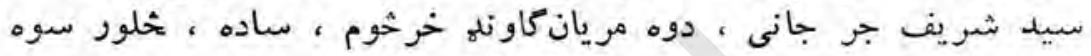

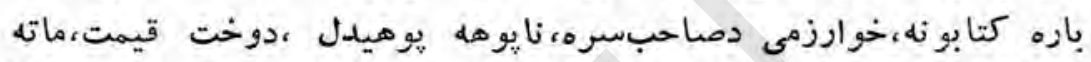

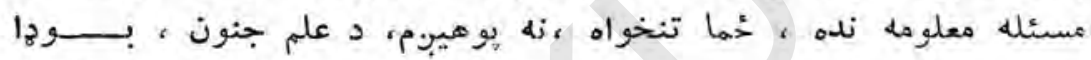

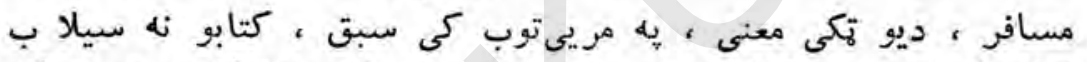

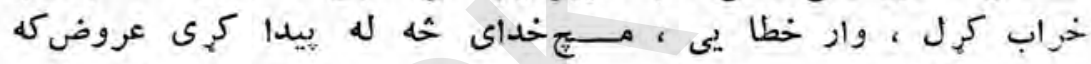

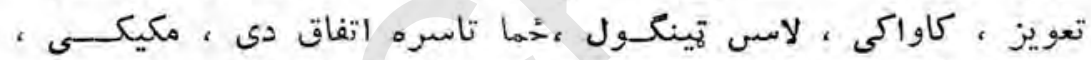

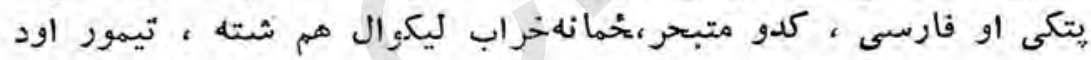

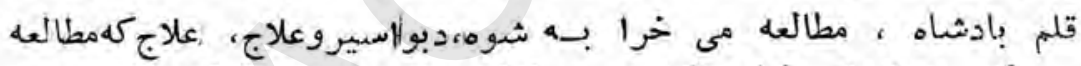

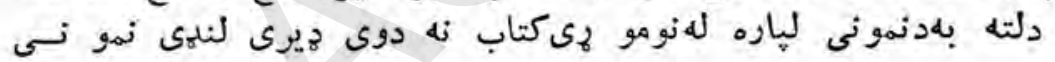

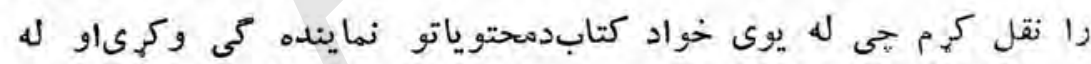

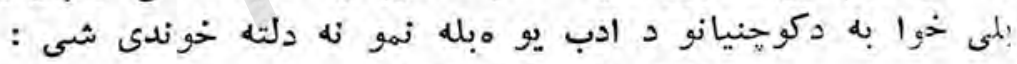

\section{خوار لس كاله شوكيره}

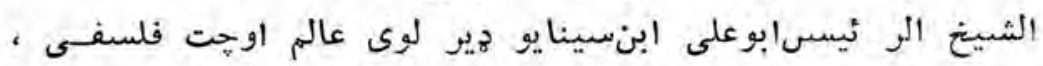

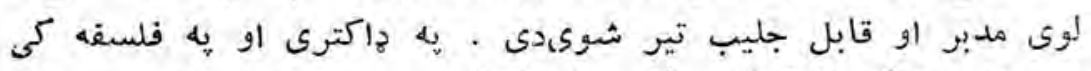

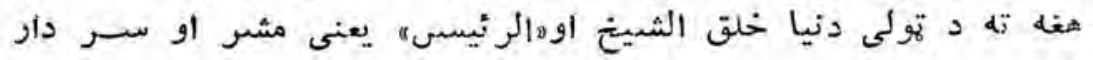
وايى . 


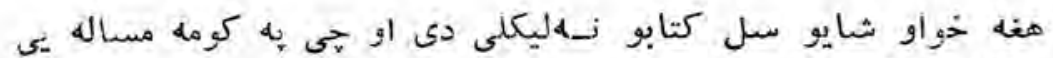

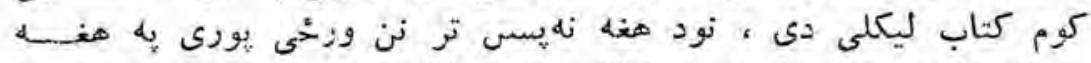

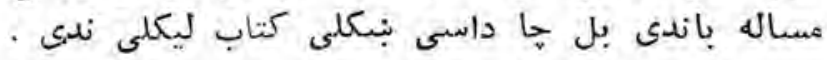

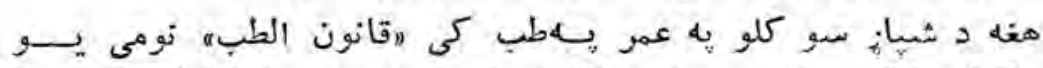

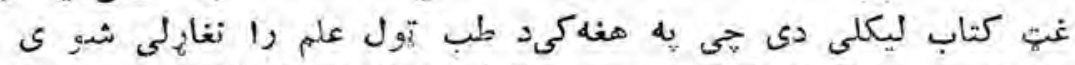

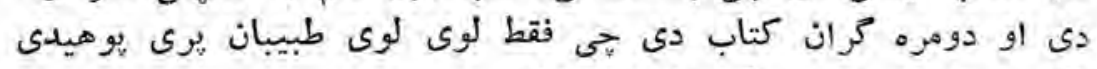

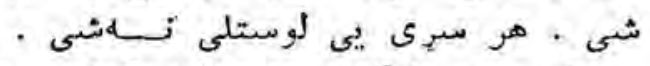

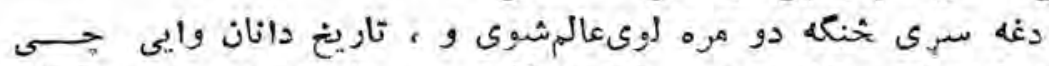

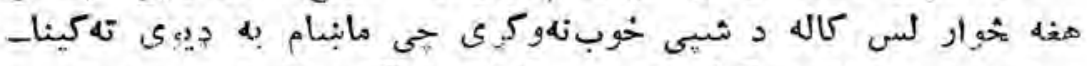

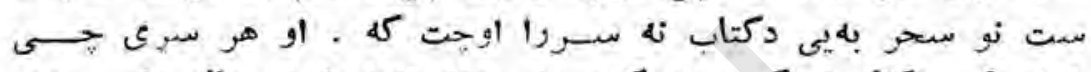

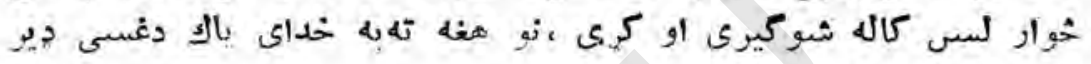

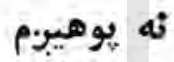

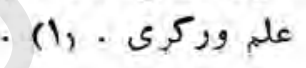

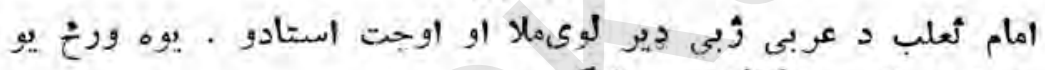

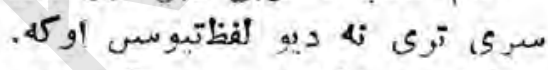

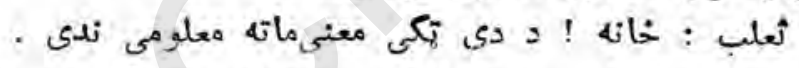

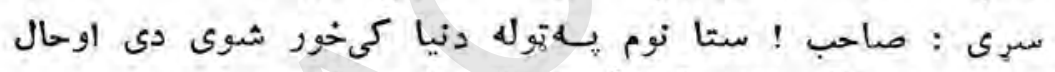

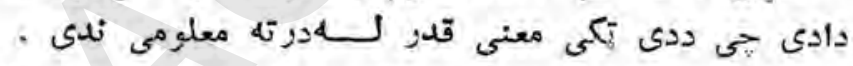

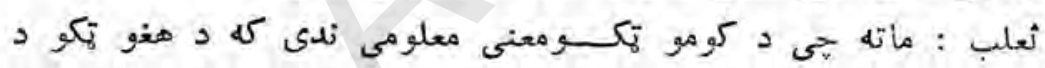

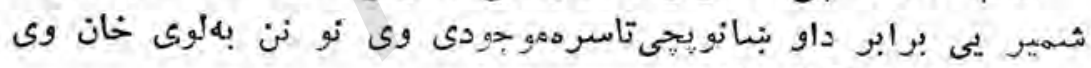

\section{تثكى هيلى}

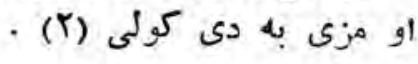

دغه كتاب د بنوونى او دوزنسىوزازت د تاليف او ترجمى رياست

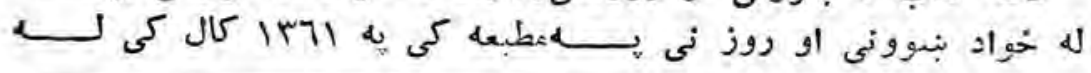

$$
\begin{aligned}
& \text { ص صليـ (1) (1) }
\end{aligned}
$$

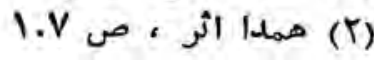




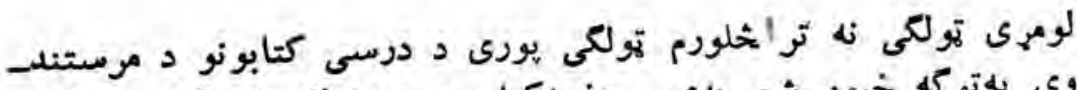

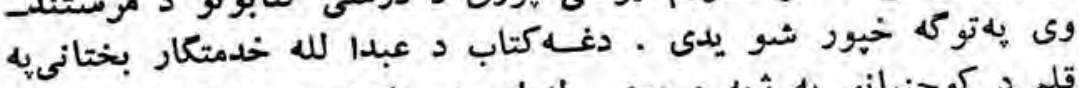

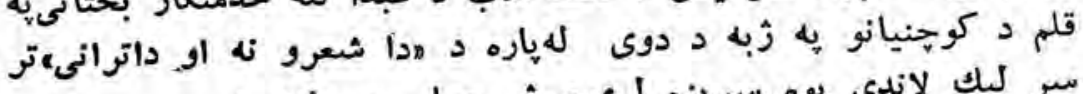

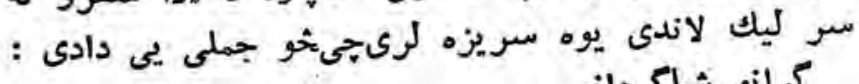
كرانو شاكردانو

$$
\begin{aligned}
& \text { دا شعرو نه أو ترانو توانى ولولى }
\end{aligned}
$$

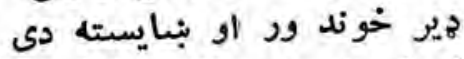

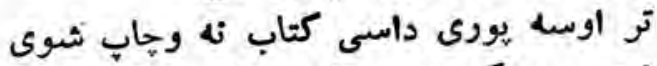

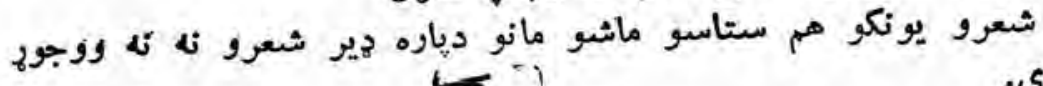

$$
\begin{aligned}
& \text { كي } \\
& \text { أوسى دى خبرى ته حيره توجهشوى ده . } \\
& \text { يوه بله خبره هم رلا ياده شوه هو مورو }
\end{aligned}
$$

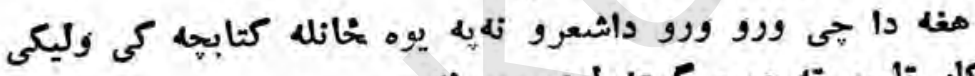

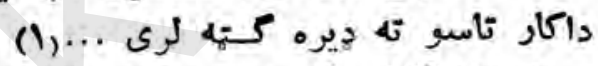

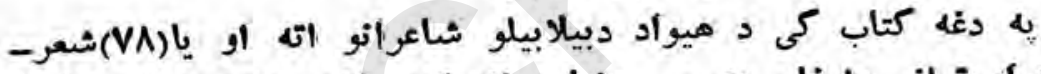

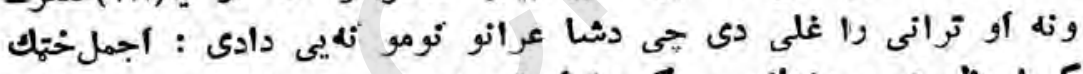

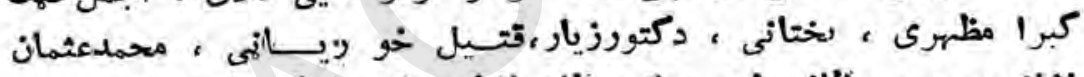

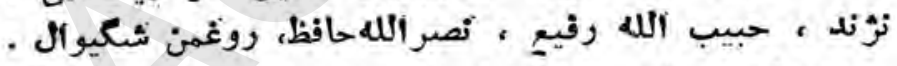

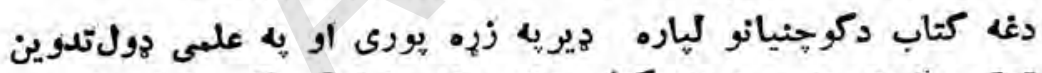

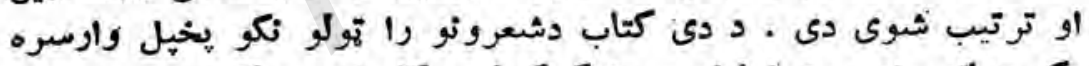

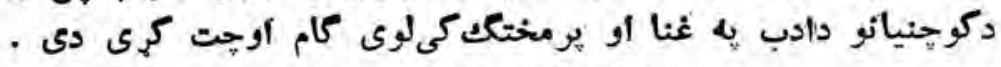
خنكه كولاى شم بنبه رأيورترشيم

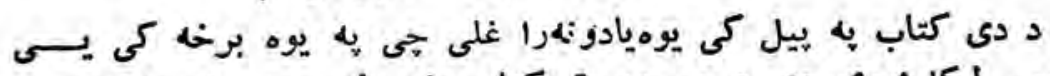

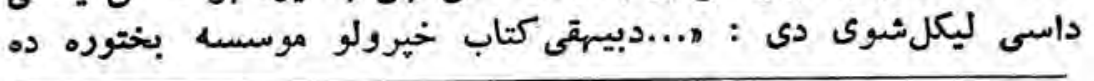

$$
\text { r-l (1) }
$$




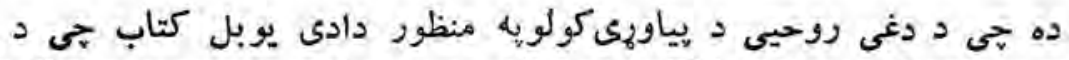

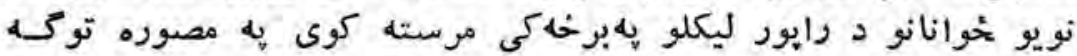

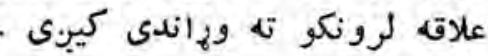

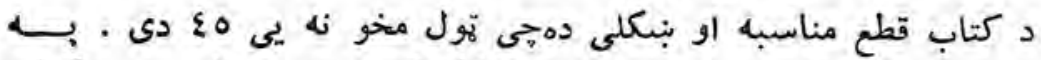

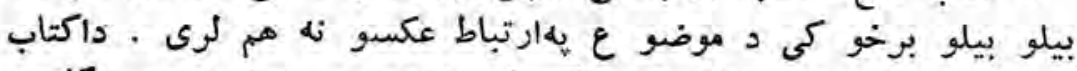

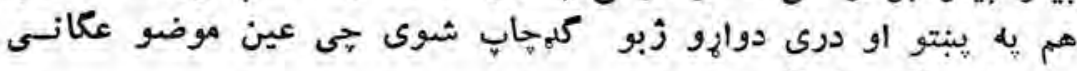

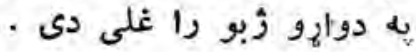

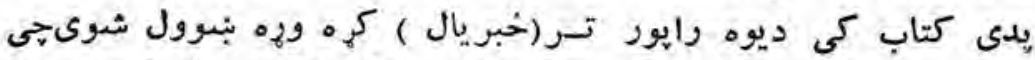

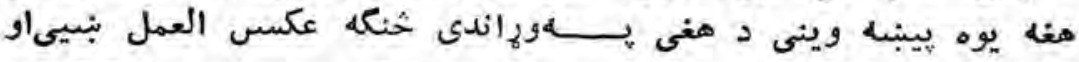

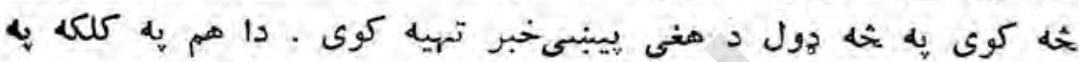

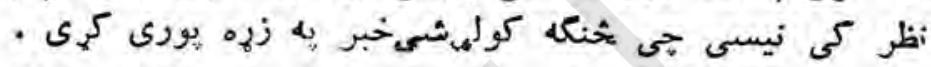

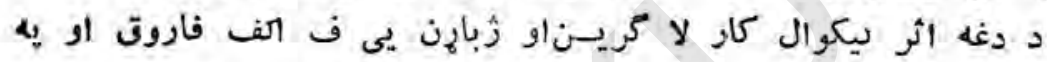
(1) . Tros خوبرى لطيفى

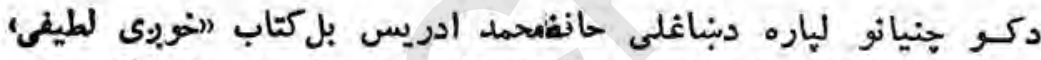

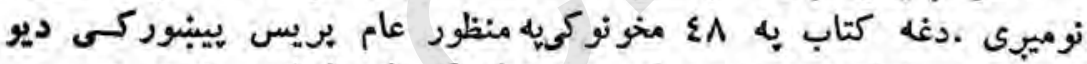

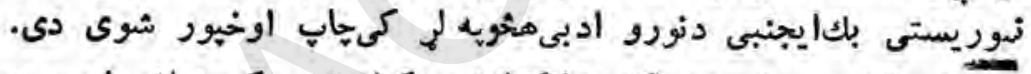

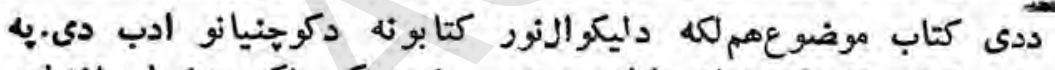

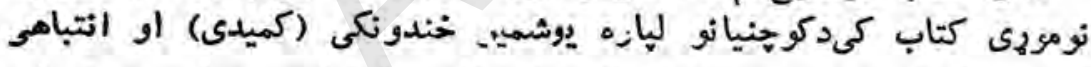

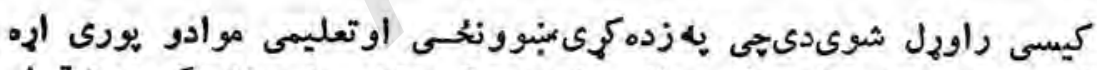

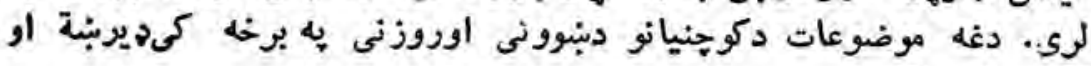

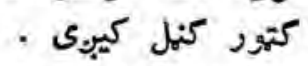

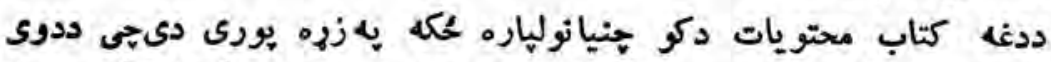

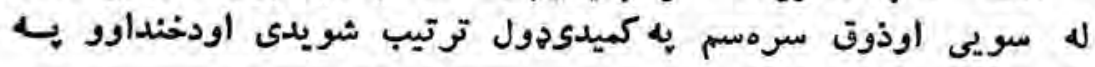

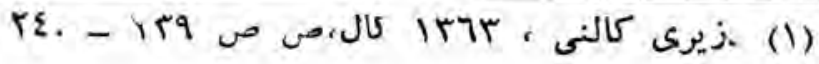


توخ كى كتور تولنيز بنوونيز مطالبكوجنيانز تهورليز دولاى شى. خوثدنا كى قصى دما شوثو لياره

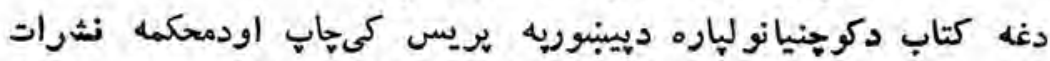

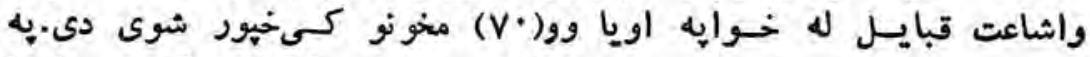

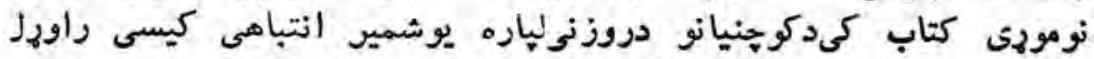

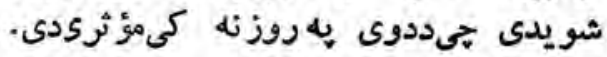

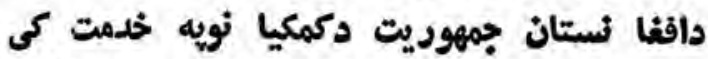

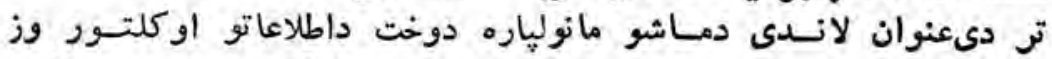

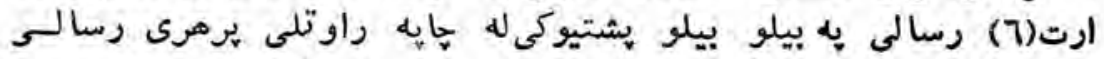

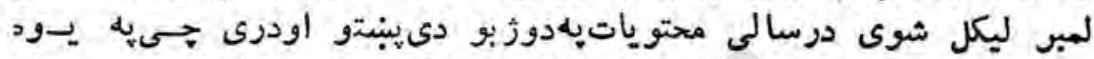

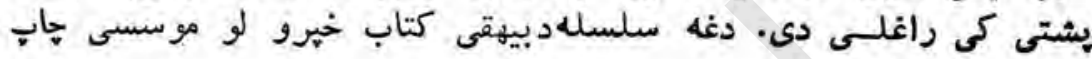

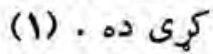

ديهانع خوربحه

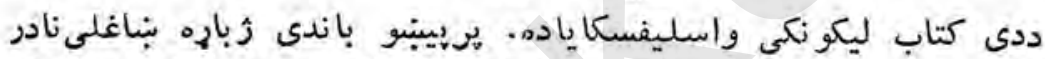

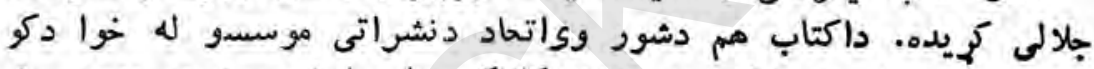

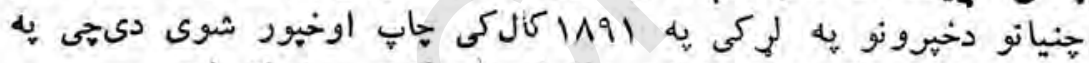

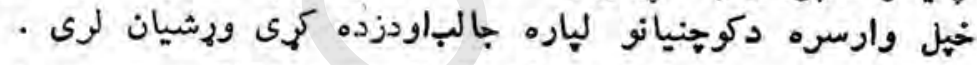

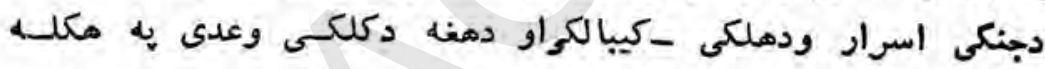

اوفسانه دونه

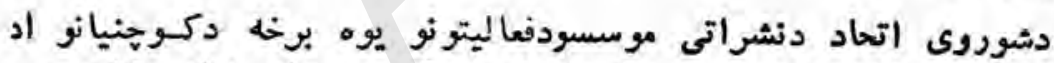

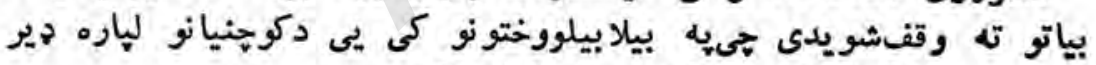

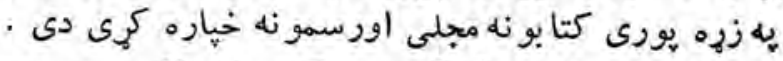

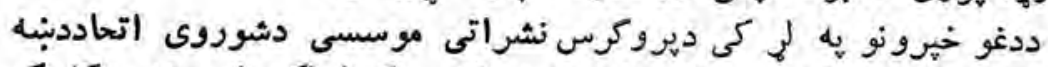

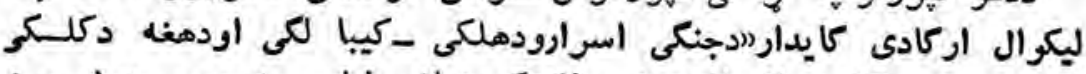

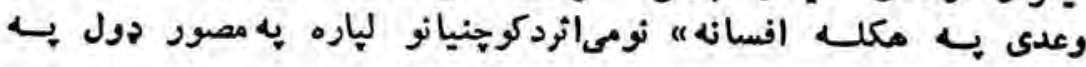

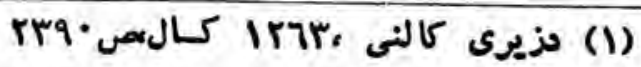
- IEV_ 


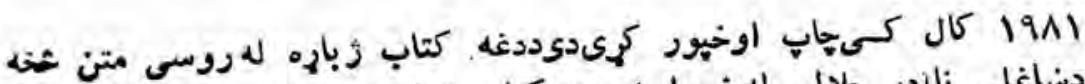

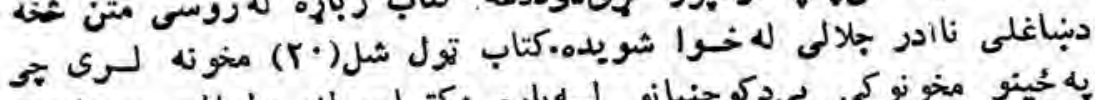

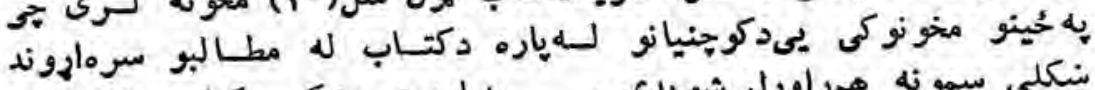

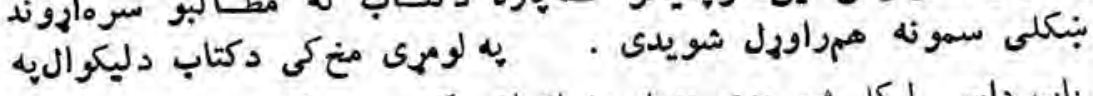

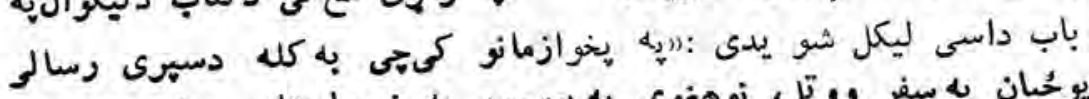

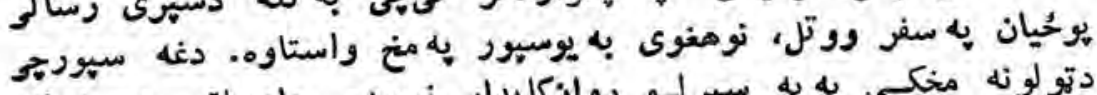

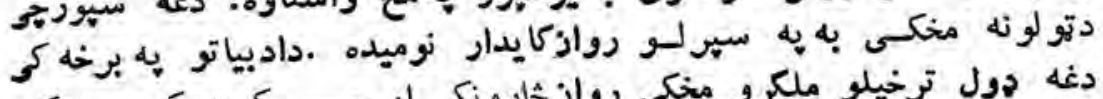

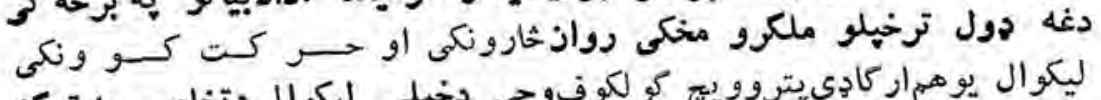

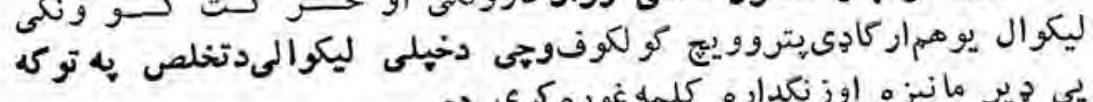

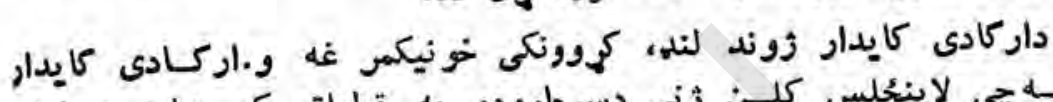

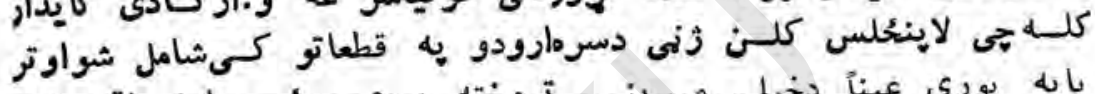

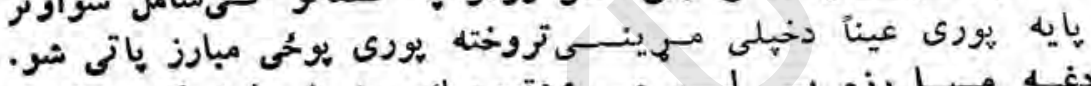

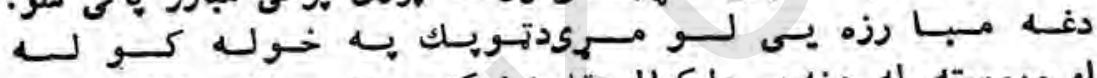

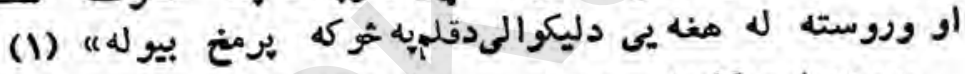

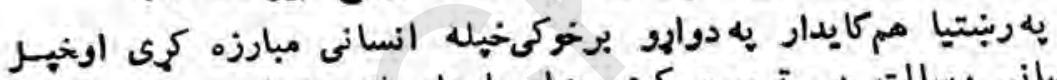

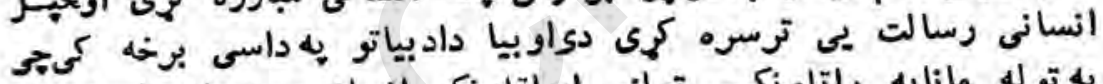

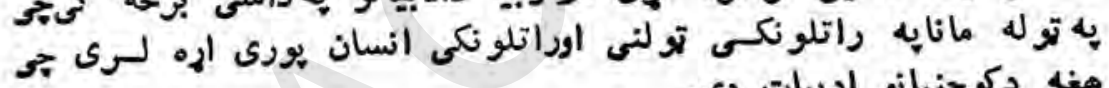

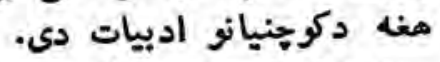

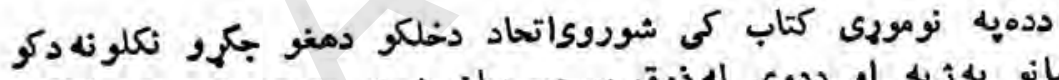

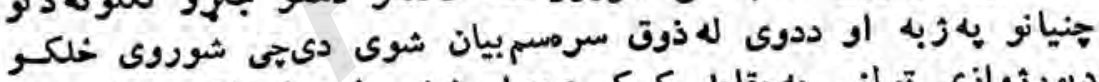

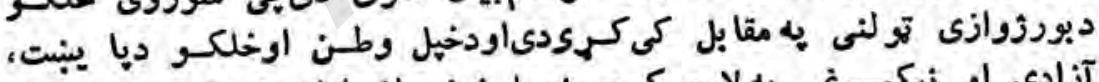

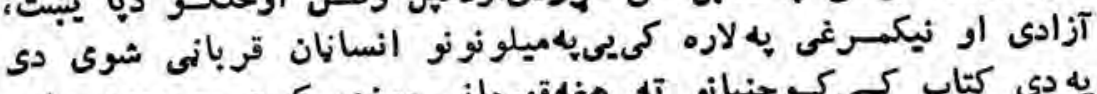

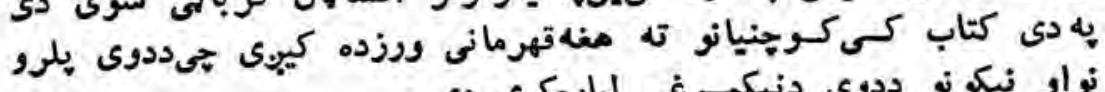

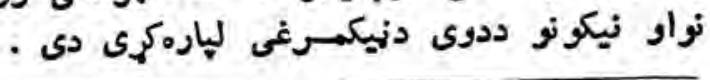

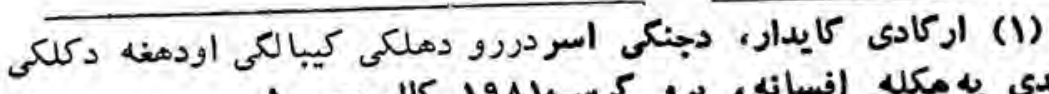

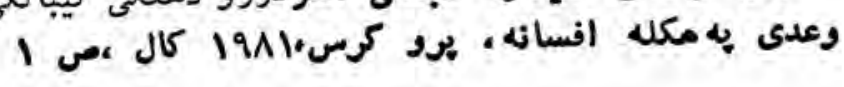




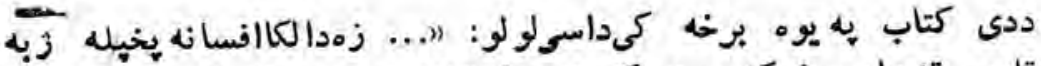

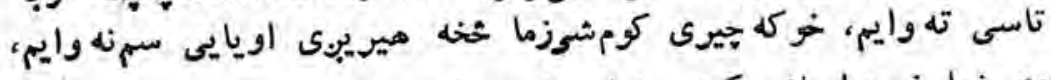

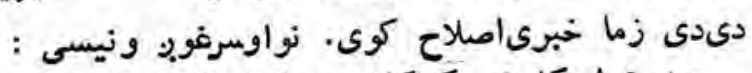

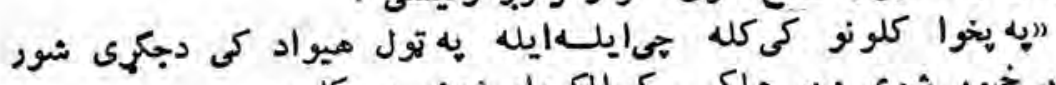

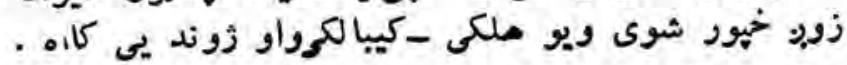

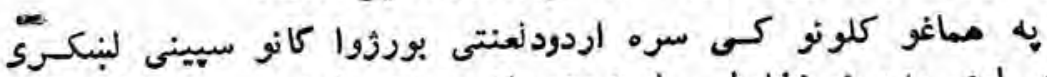

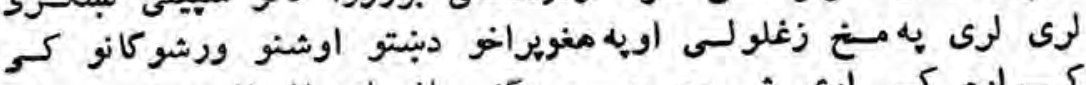

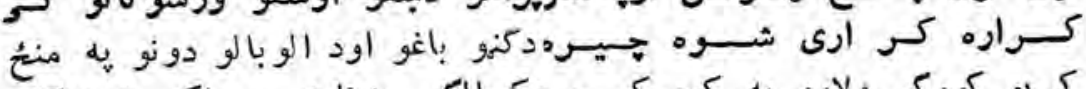

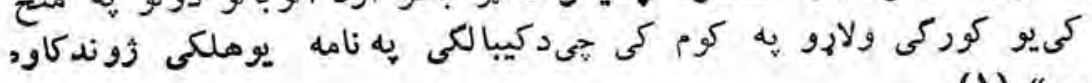

(1) $11 .$.

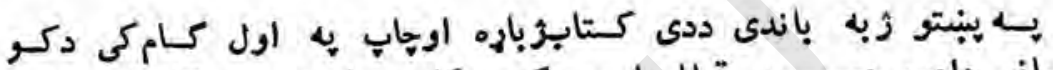

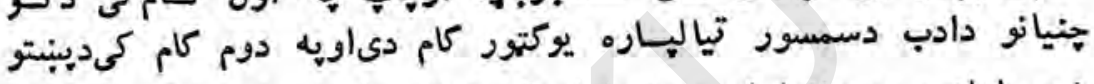

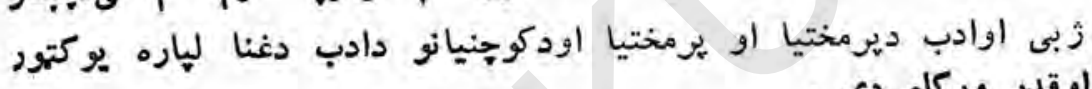
اوقدر وركام دى - ارئ

\section{دخلكو سبندرى}

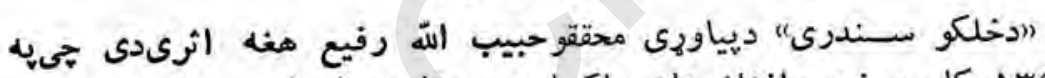

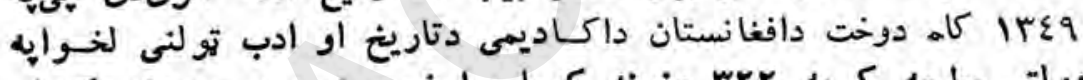

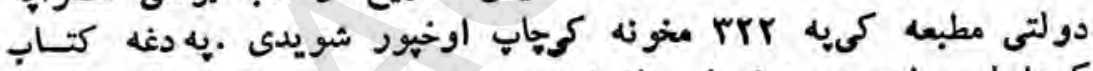

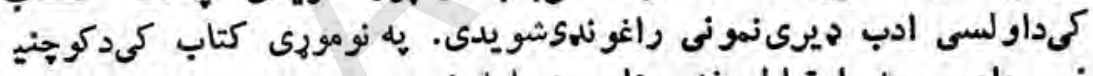

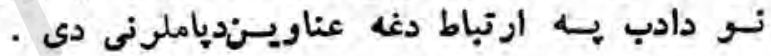

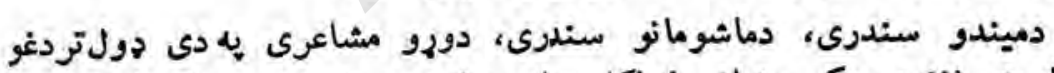

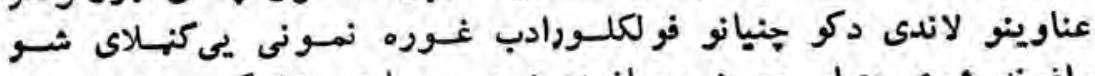

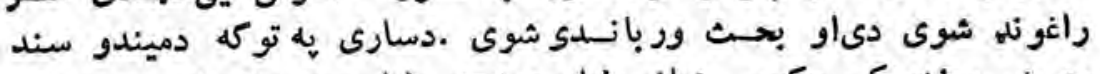

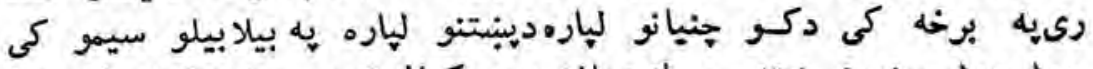

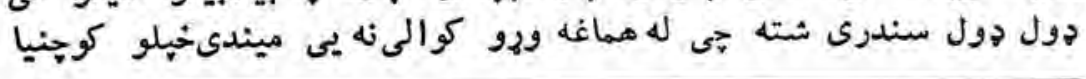

$$
\text { r تي اثر، م (1) }
$$




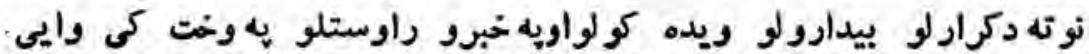

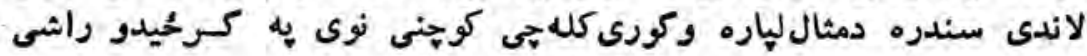

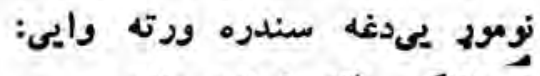

دروازكى ته وكيه مثنده

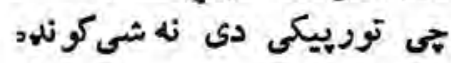

$$
\text { (دخلكو سندرى : (2) }
$$

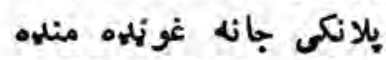
بكلمان دى اتيات وكئه

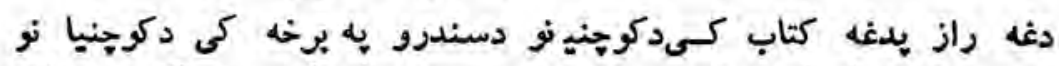

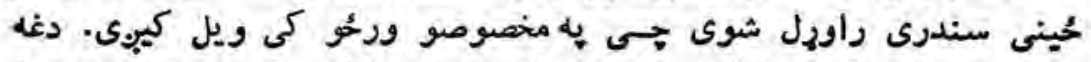

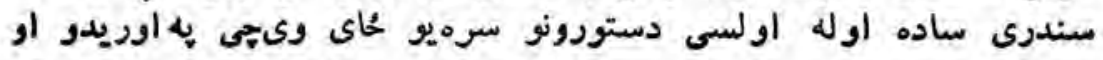

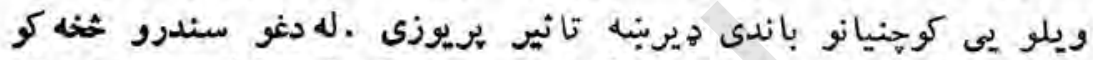

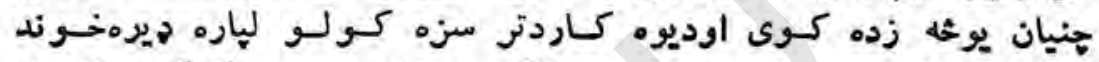

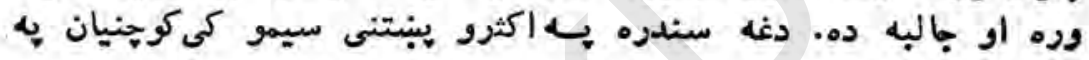

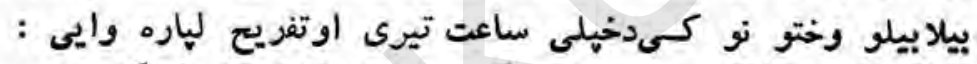

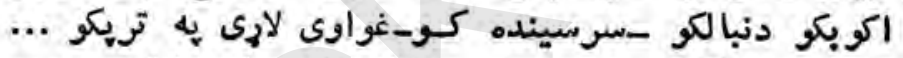

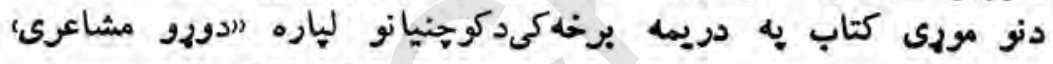

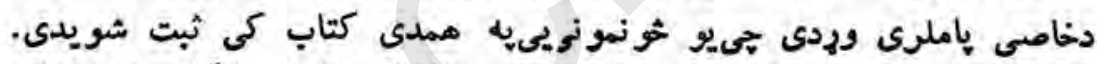

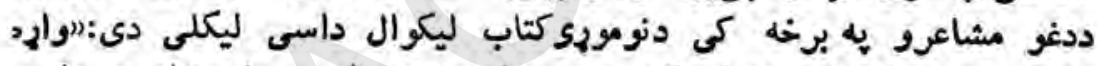

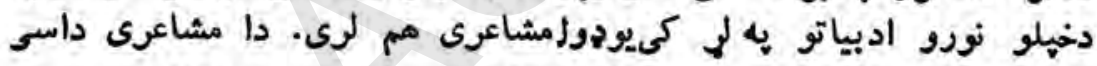

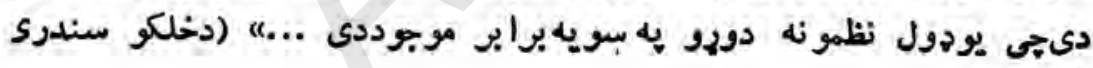

(10

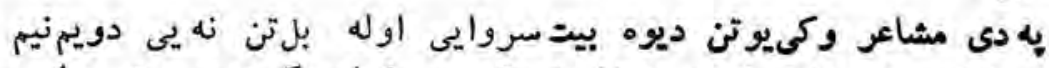

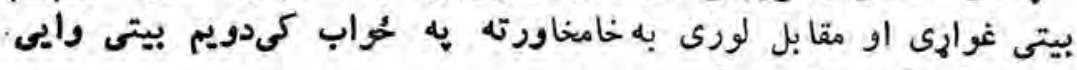

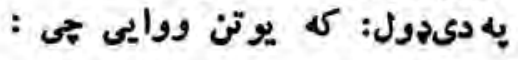
دغره به سرنغرى

بلتن يىبايد بهمواب كىووايى . يكى مئ دوت دى زمرى 


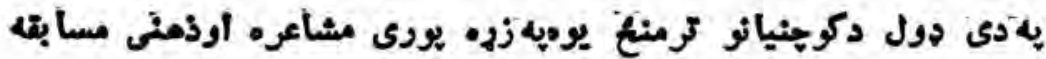

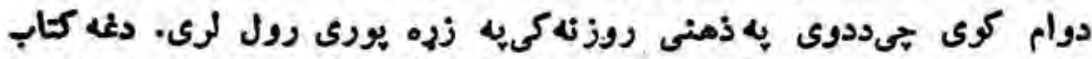

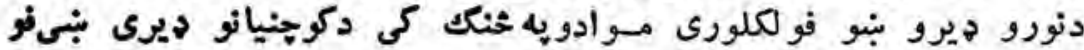

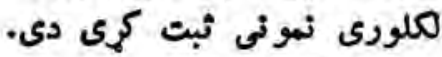

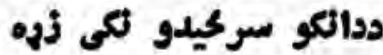

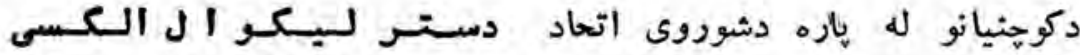

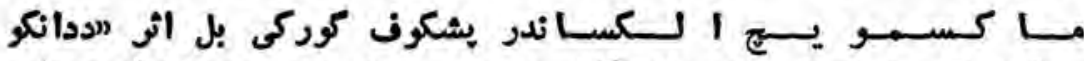

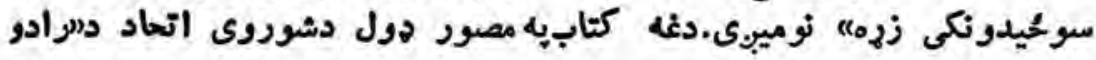

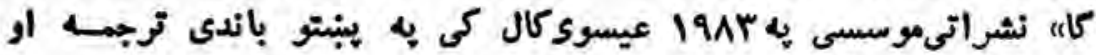

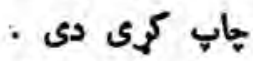

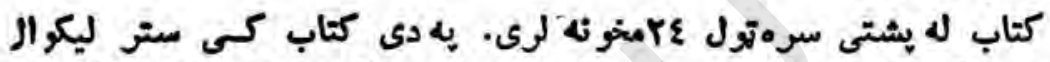

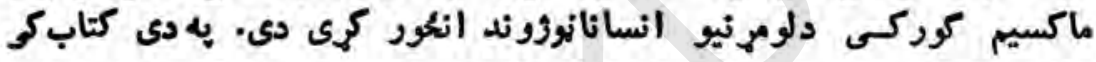

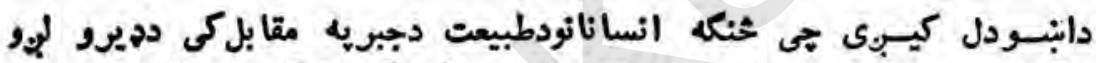

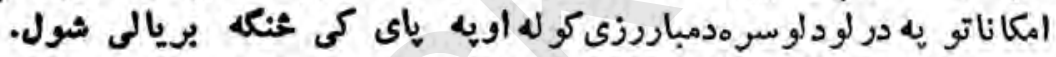

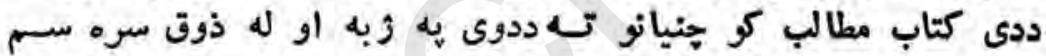

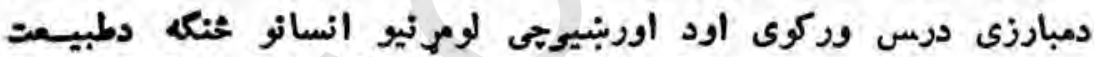

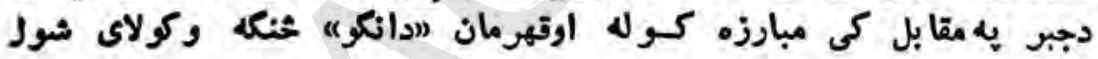

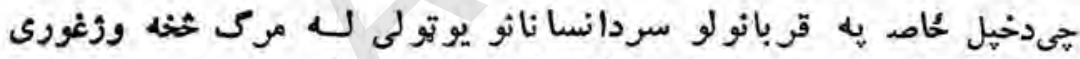

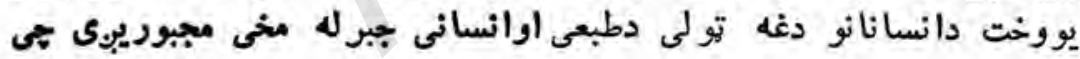

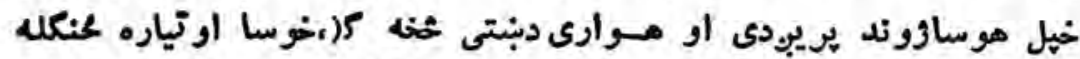

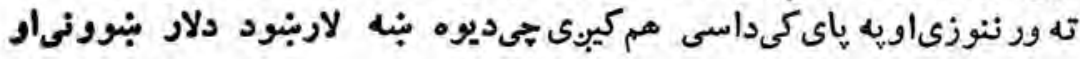

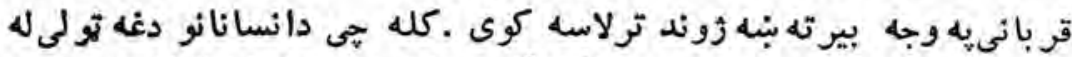

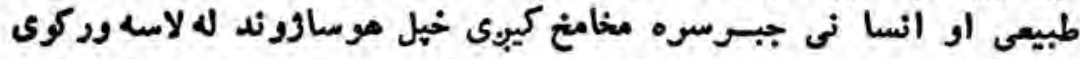

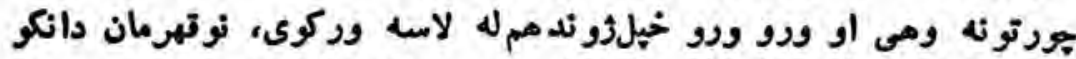

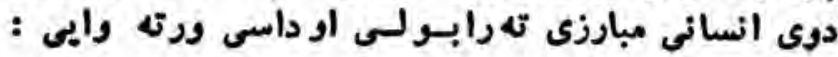




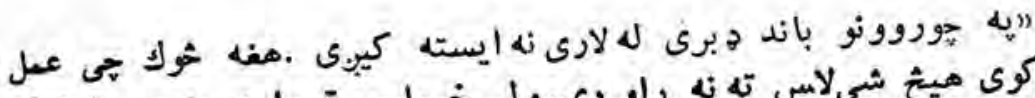

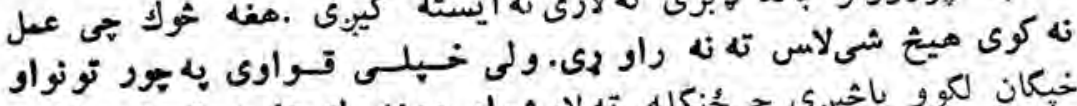

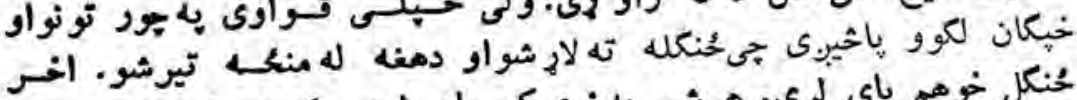

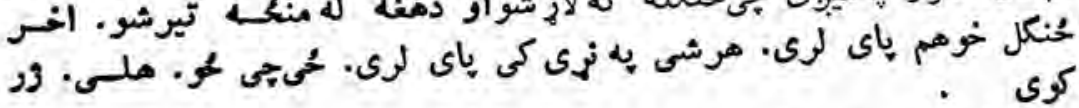

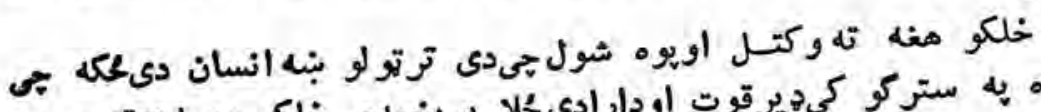

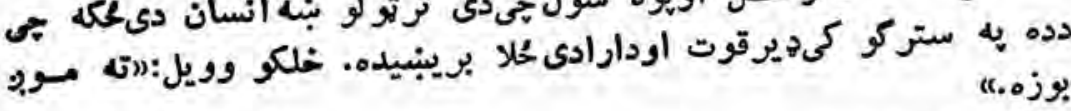

هنه وخت نودى دهغو خلكسو لاربنوونكى شواوبحنكله ته يق بوتلل....

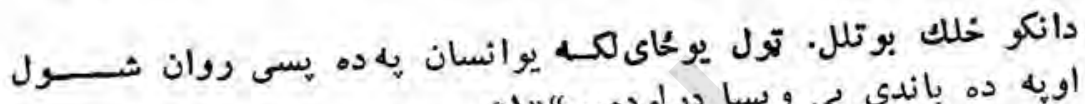

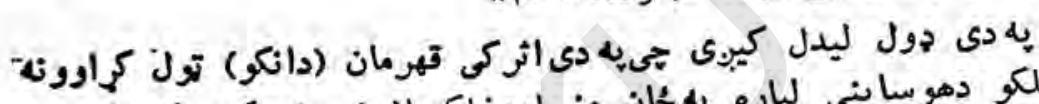

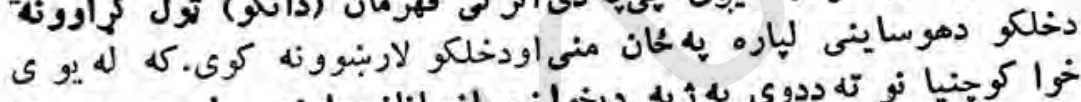

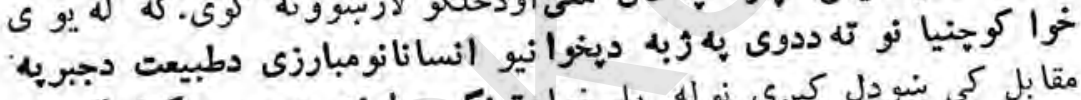

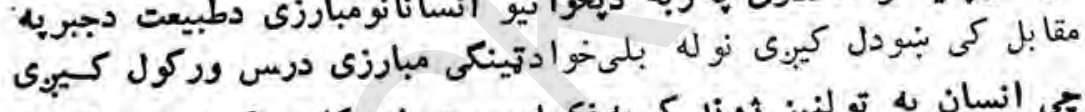

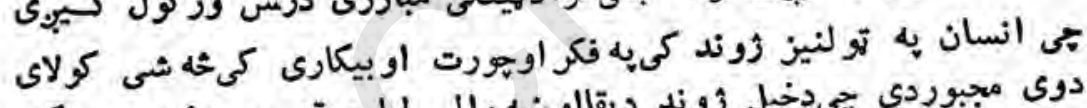

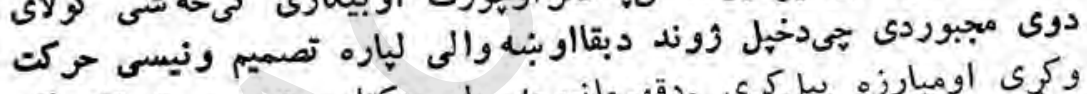

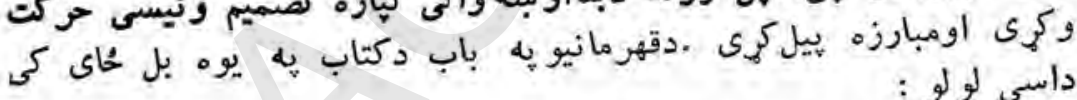

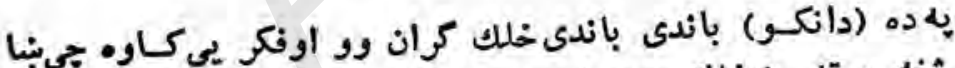

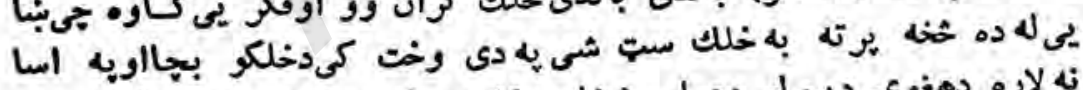

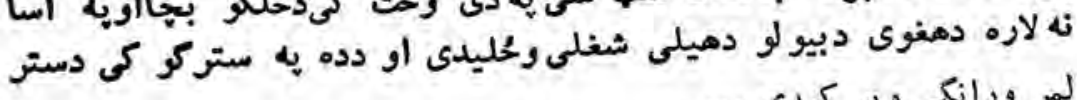

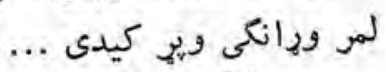

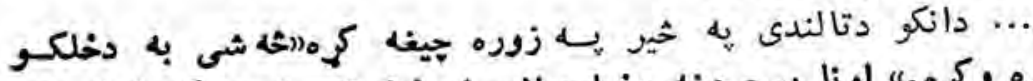

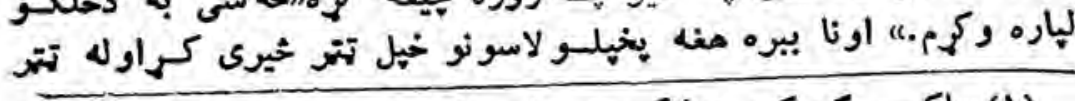

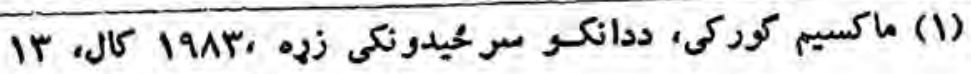
lor 


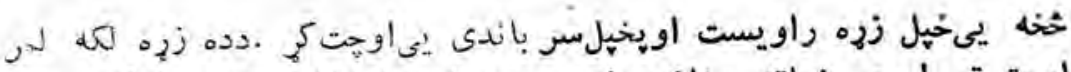

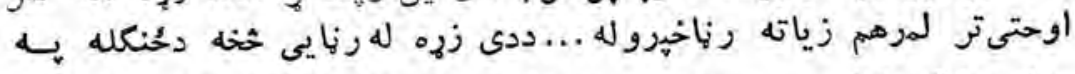

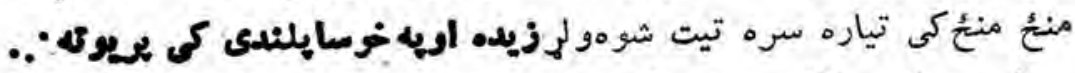

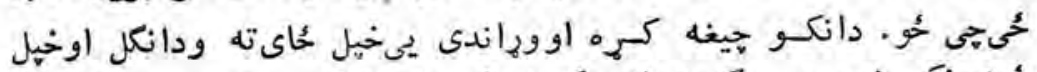

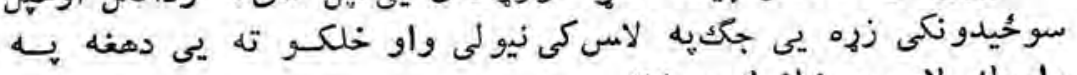

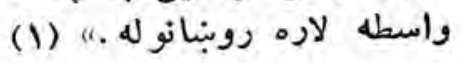

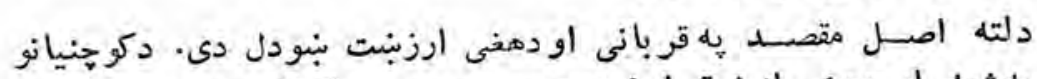

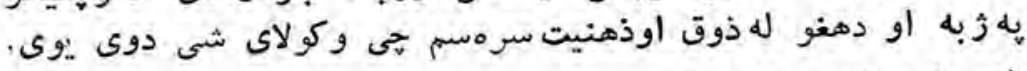

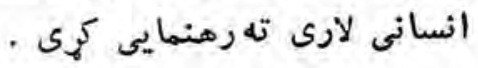

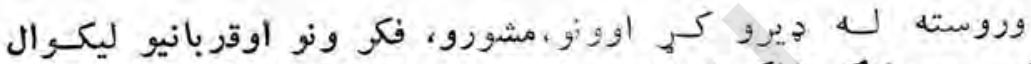

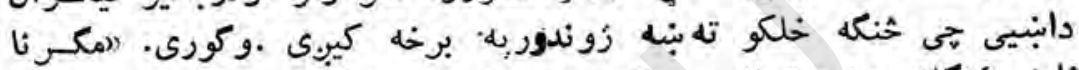

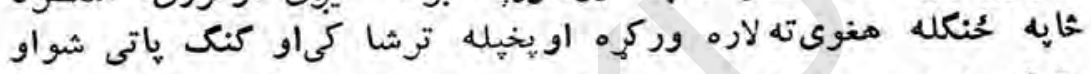

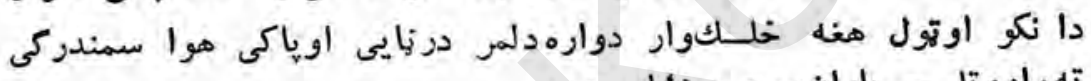

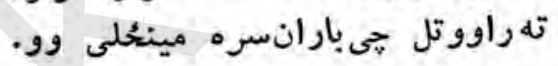

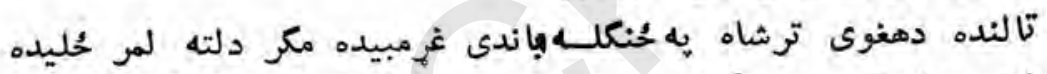

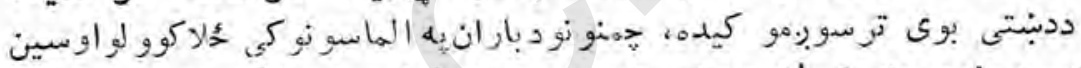

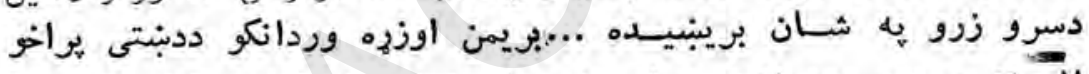

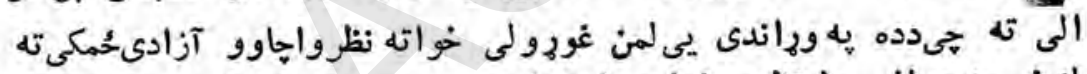

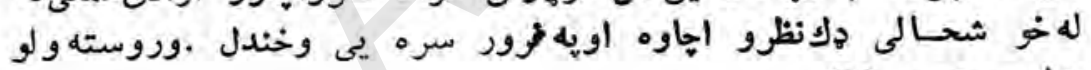
يداومي شو." (1)

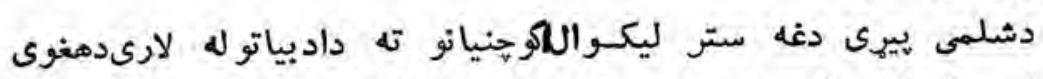

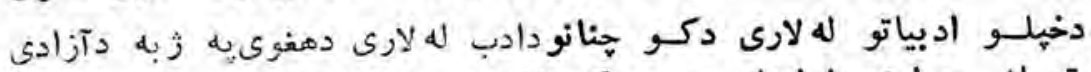

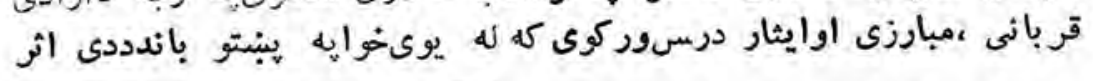

IV ممدا مُاى نص (1)

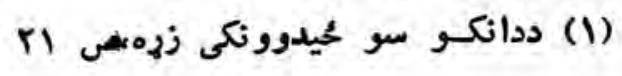
104 


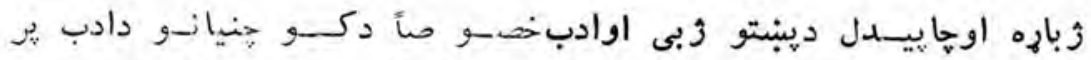

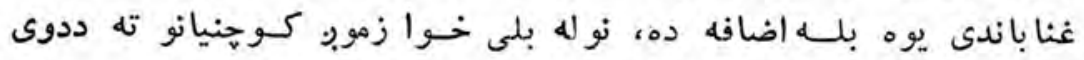

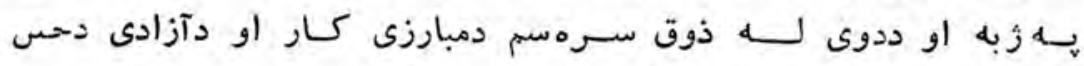

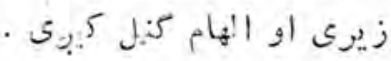

$$
\begin{aligned}
& \text { درى خرسه }
\end{aligned}
$$

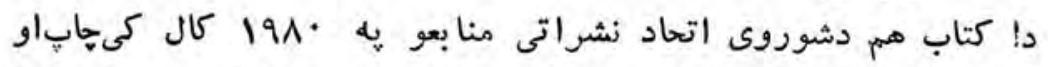

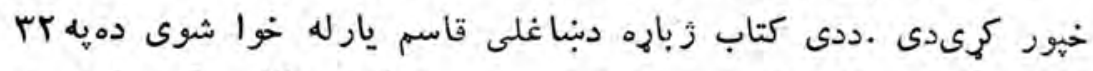

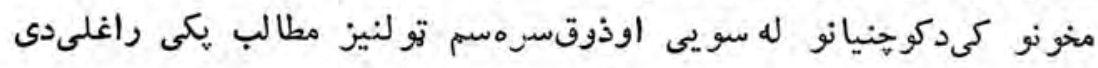

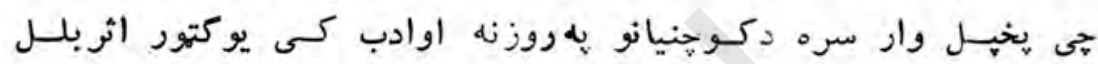
كيرى

\section{دساعت يه باره كىثه معلو مات كلى}

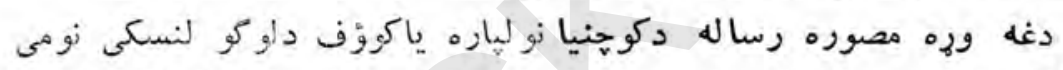
ليكوال ليكلى دهإى تول شبهب ويشتمخو نه لرى. دشوروى اتحاد درادوكا

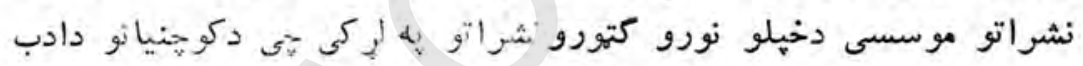

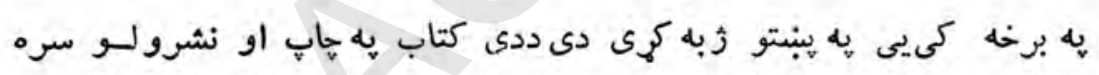

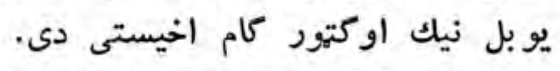

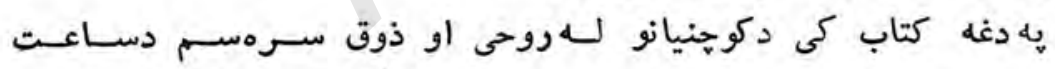

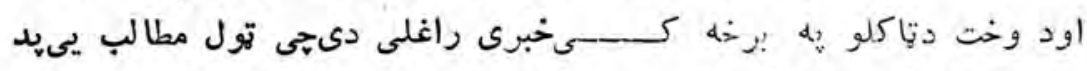

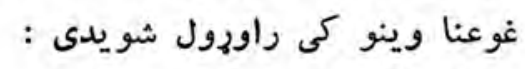
- إ- كيسى

r- دوخت ديّاكلو دوه طرزوثه

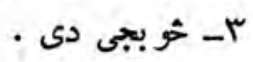

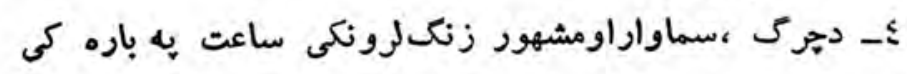
$10 \varepsilon$ 


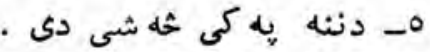

T- دغانبور كباوختيكيه بارنه

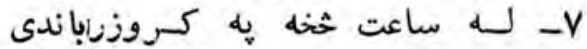

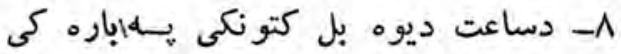

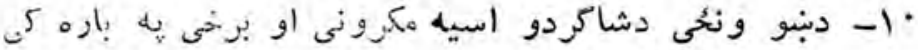

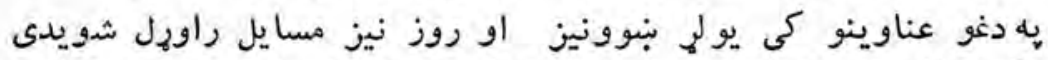

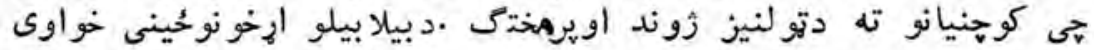

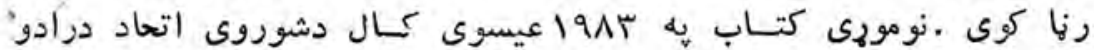

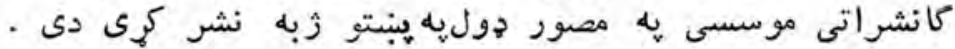
دسيين سرى همراد ختهـو كيسى

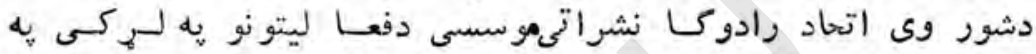

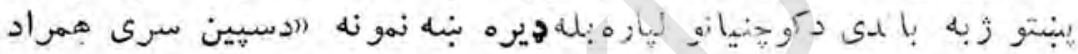

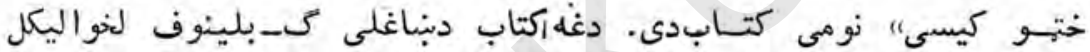

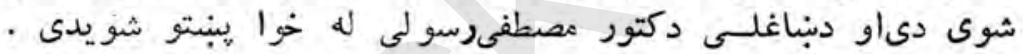

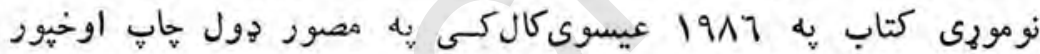

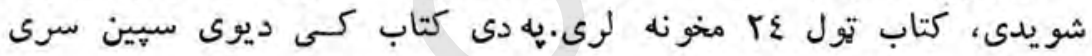

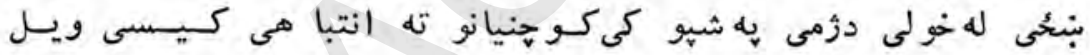

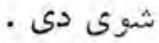

\section{دببار مكتبونه او دكلى مكتبونه}

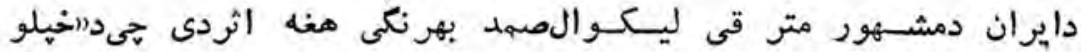

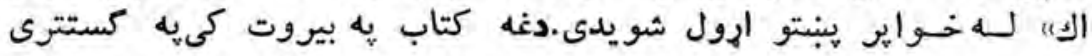

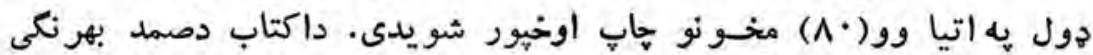

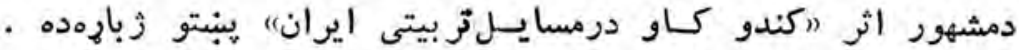

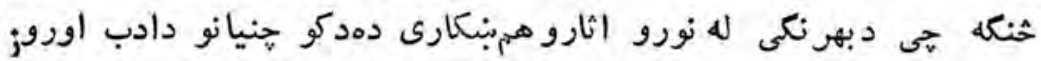

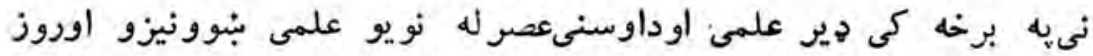
100 


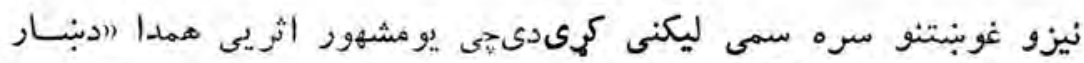

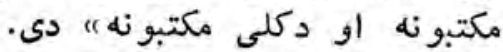

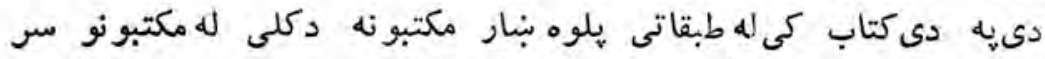

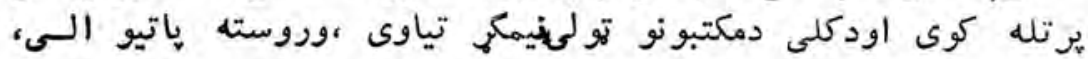

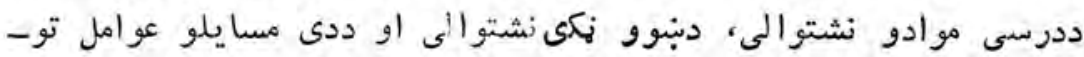

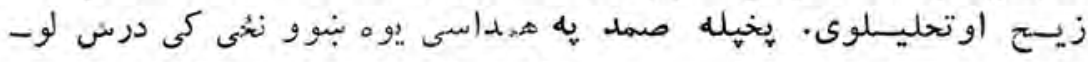

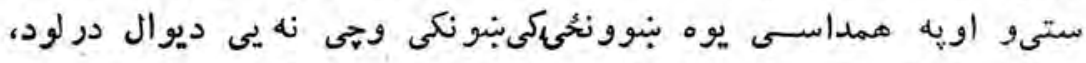

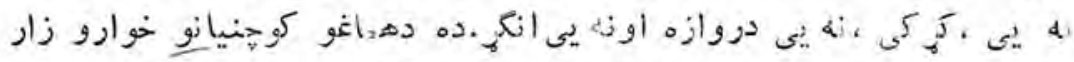

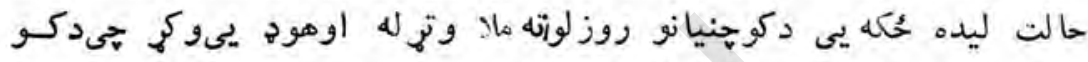

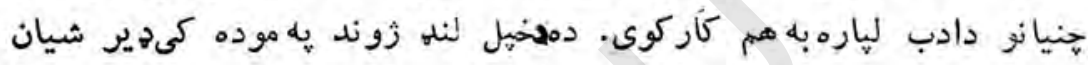

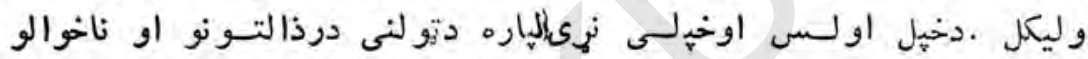

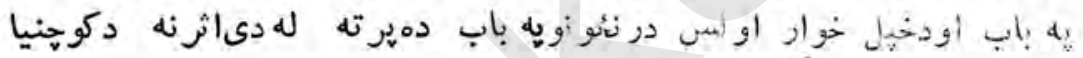

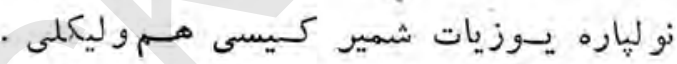

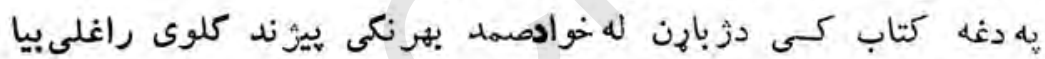

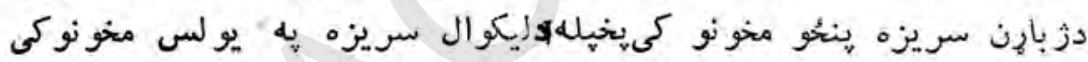

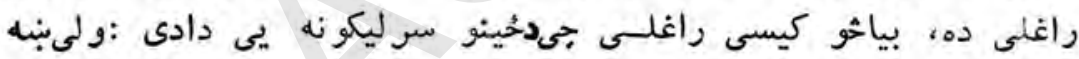

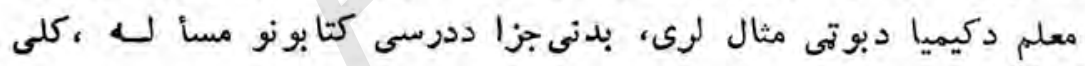

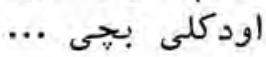

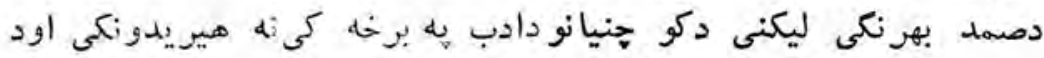

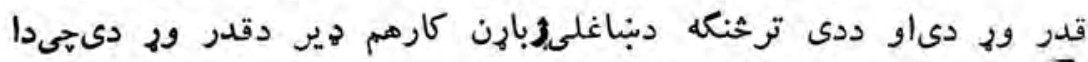

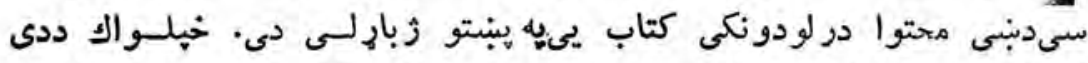

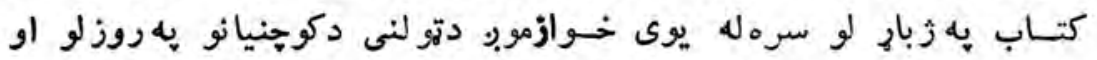

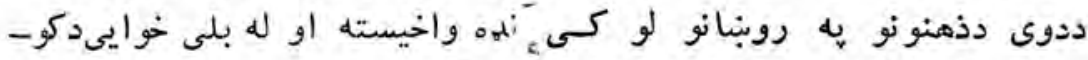

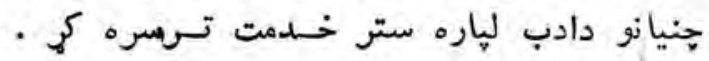




\section{دكوحنيانو كتاب}

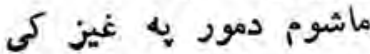

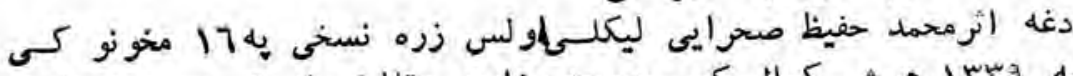

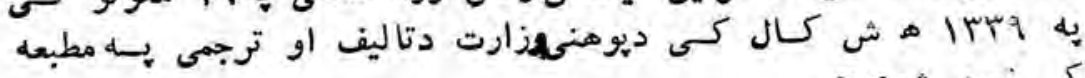
كى خيور شوىدى . نه

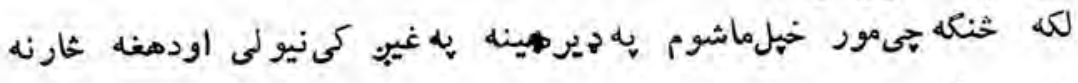

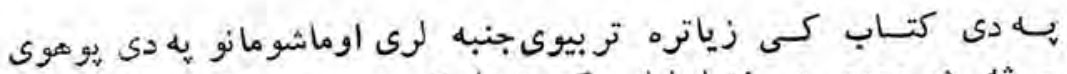

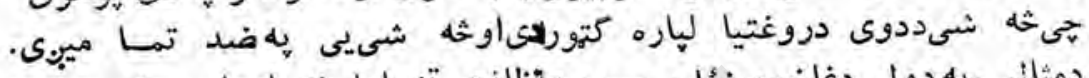

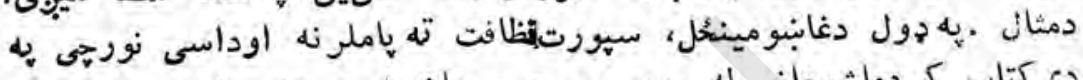

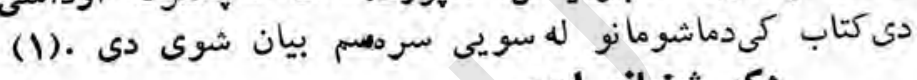

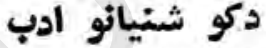

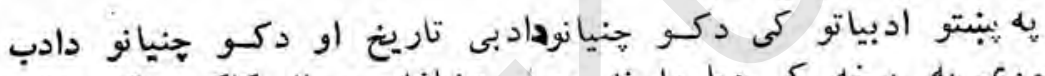

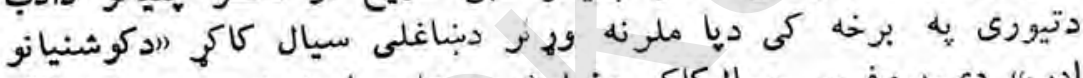

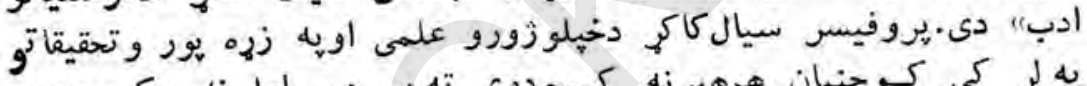

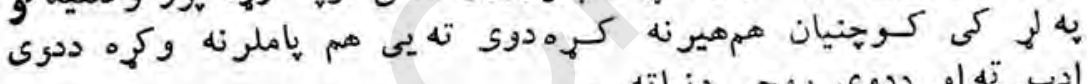

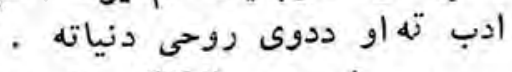

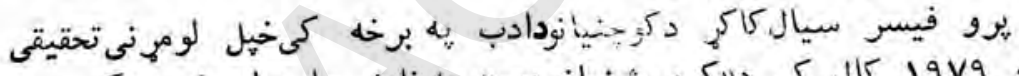

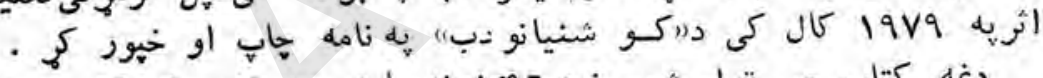

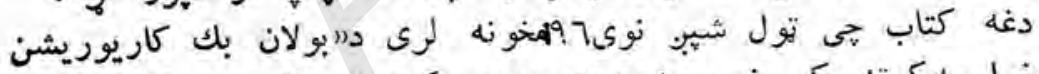

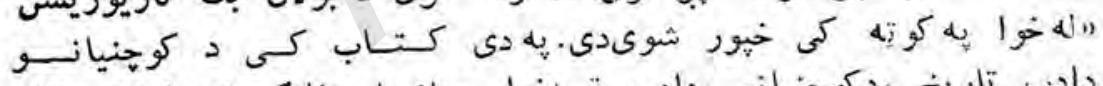

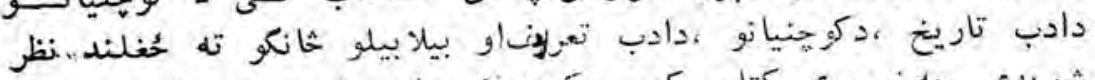

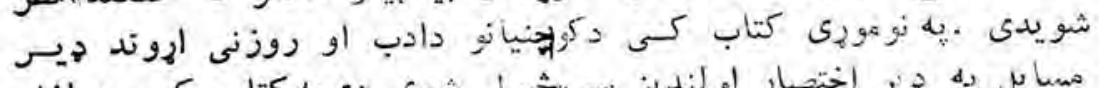

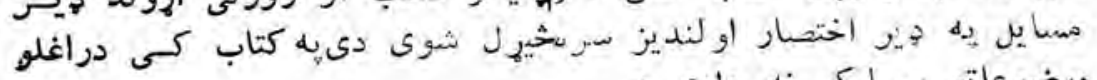

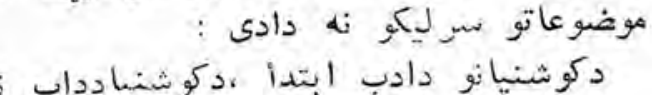
دكوشنيانو دادب ابتدأ ،دوشئيادداب نعريف، دكوشنيانو ادب ميها

(1) 


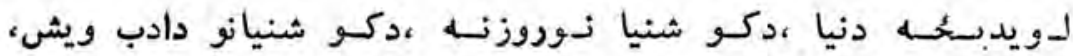

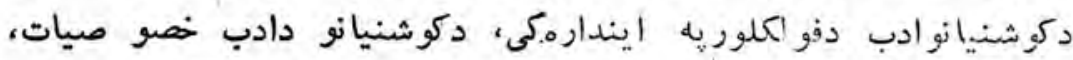

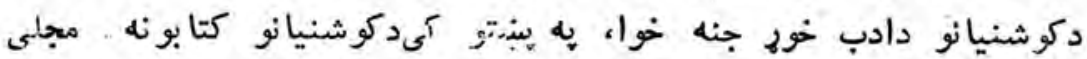

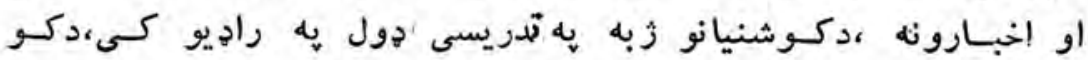

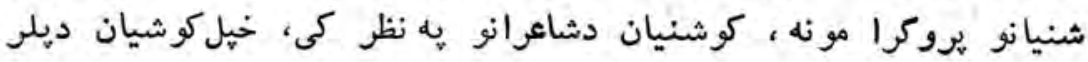

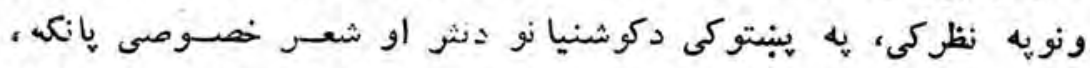

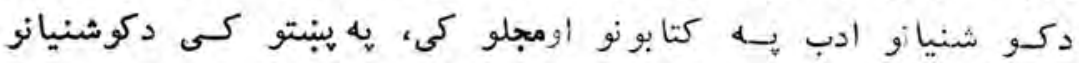

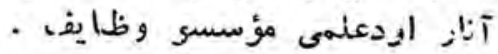

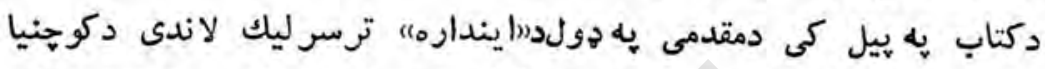

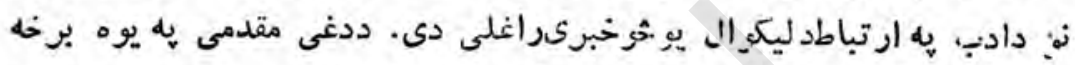

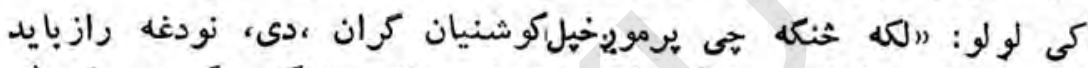

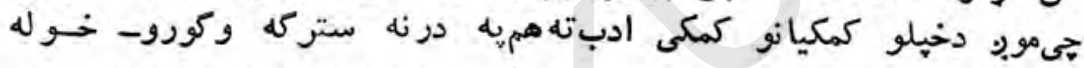

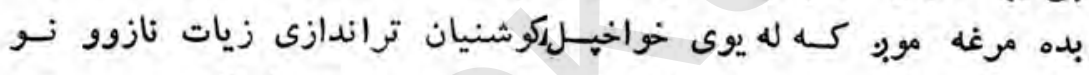

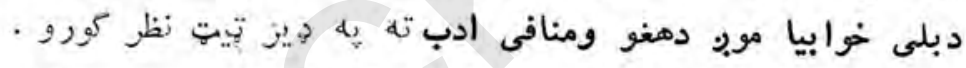

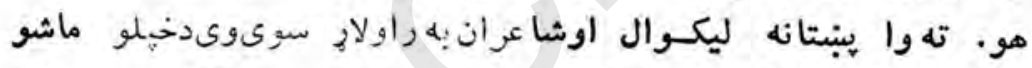

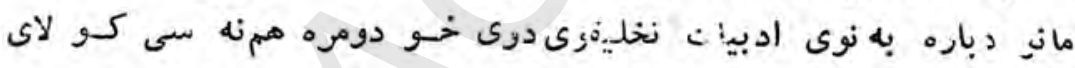

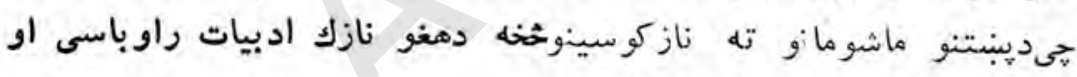

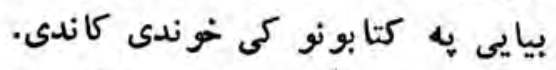

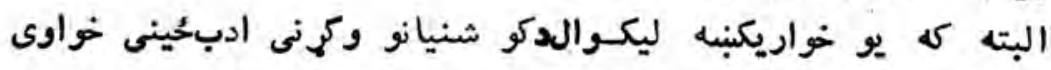

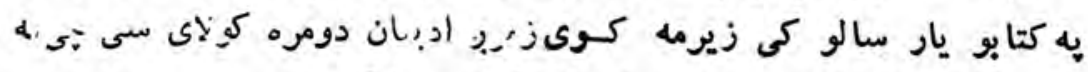

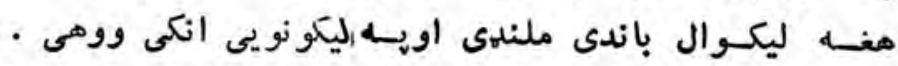

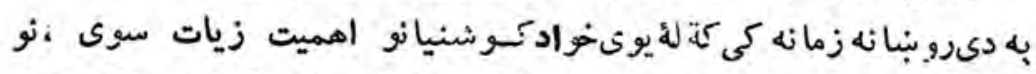

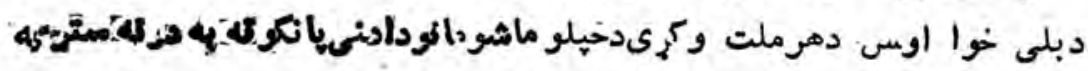

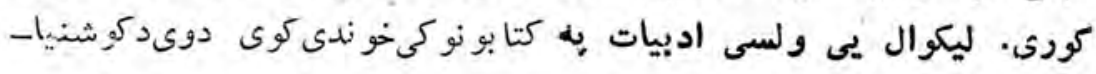


نوله فطرى غوبتتنو اودعصر دايـباناتو سرهسم نوى ادبيات تخليقوى."

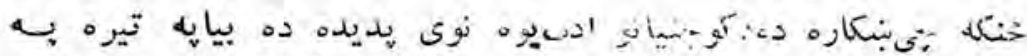

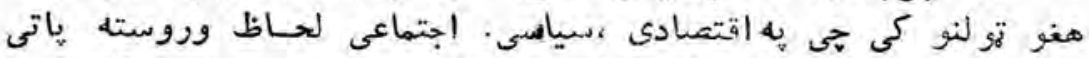

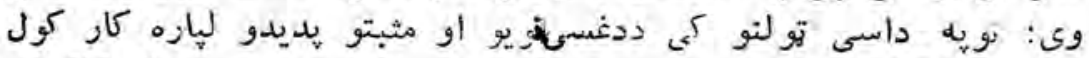

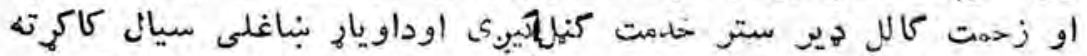

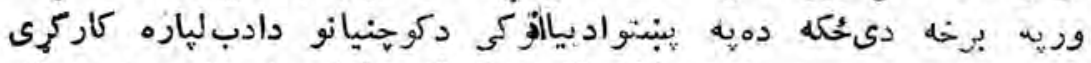

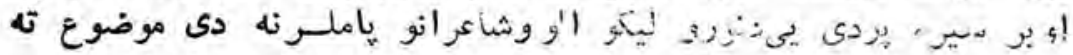

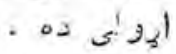

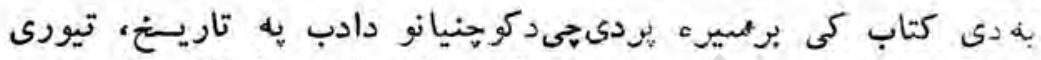

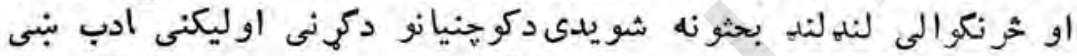

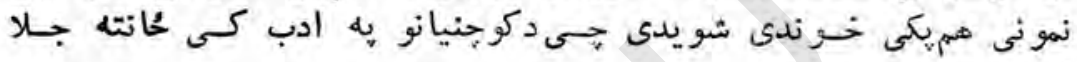

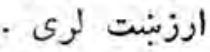

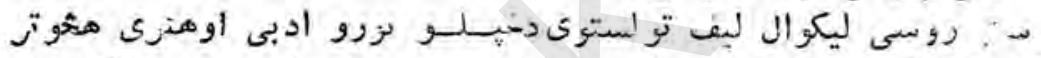

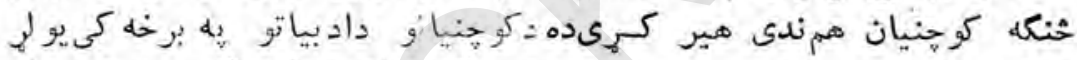

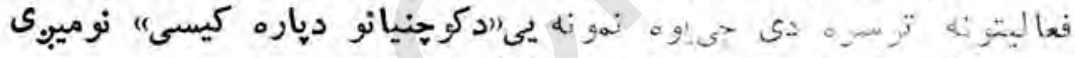

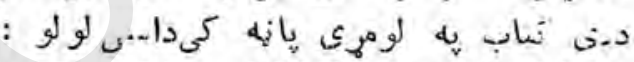

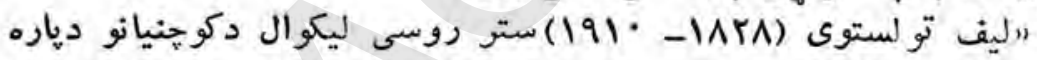

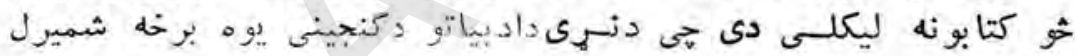
- مئر

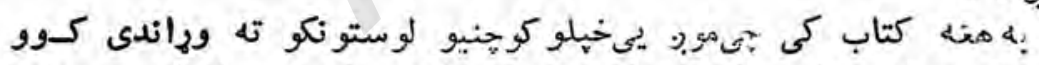

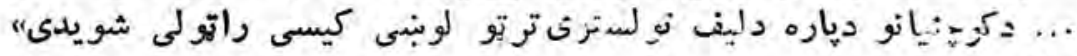

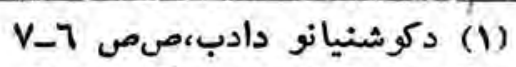

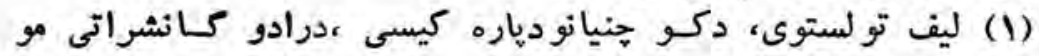

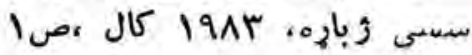




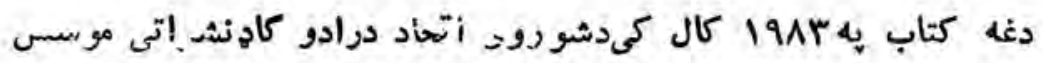

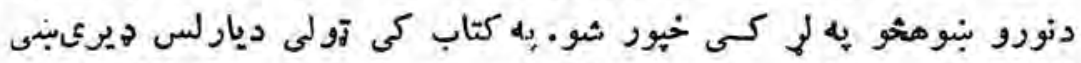

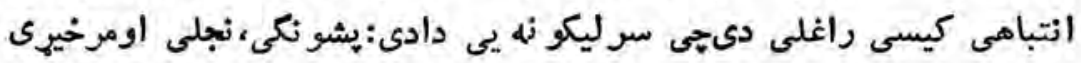

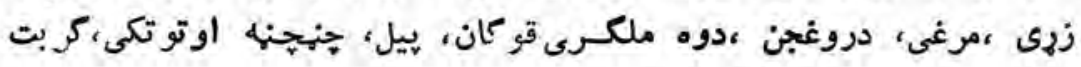

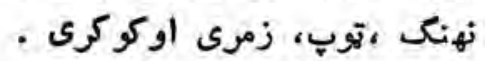

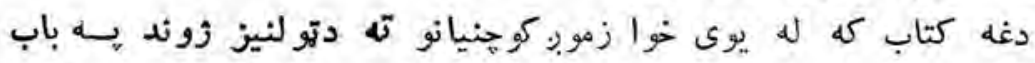

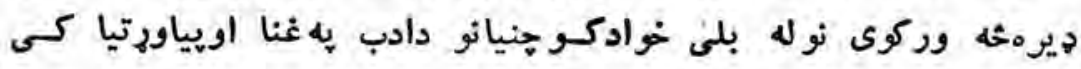

هيرينه رول لرى مونه

17. 


\section{دلمسو تو أنج}

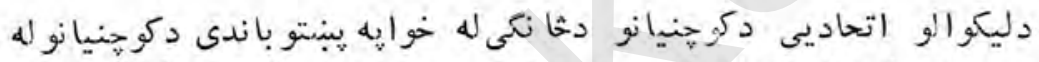

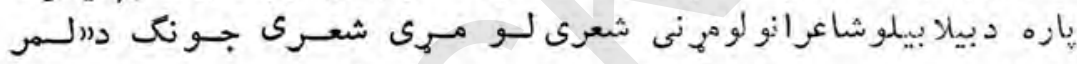

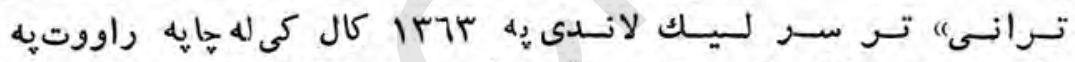

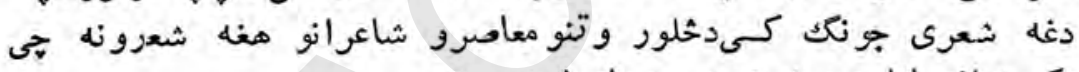

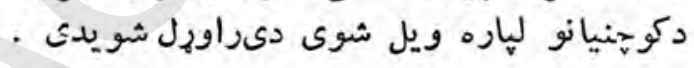

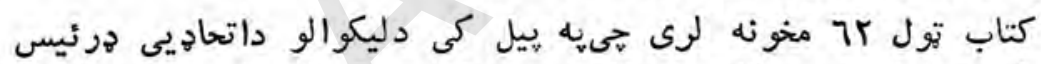

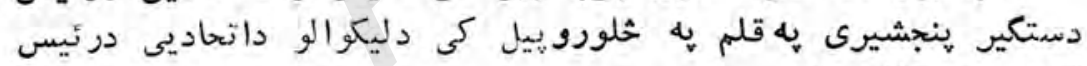
اصل متن راغلى دى .

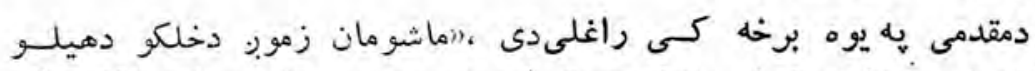

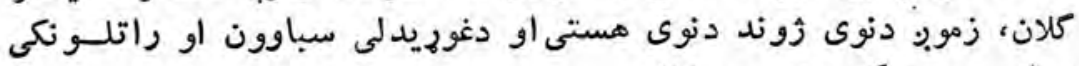

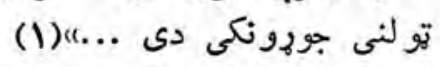

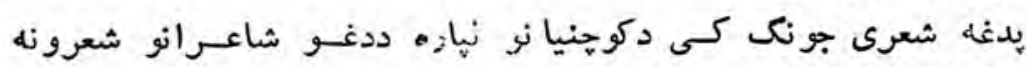
راغلى دى :

(1) كني شاعـران، دلمسر ترانى،دليكـو الـو اتحاديه ، احسا كـال،

$$
\begin{aligned}
& \text { - إن- } \\
& \text { دمقدمى الف منخ - ماعـران }
\end{aligned}
$$




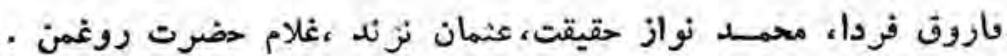

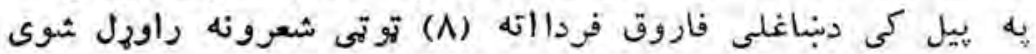

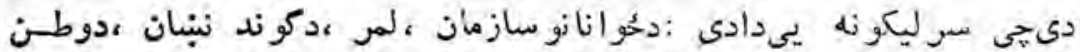

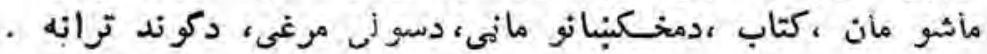

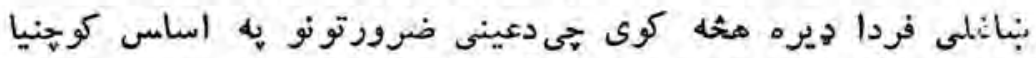

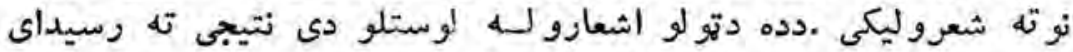

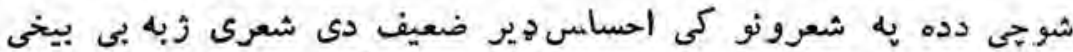

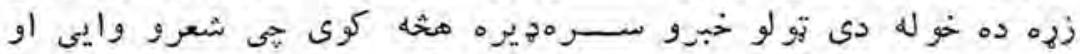

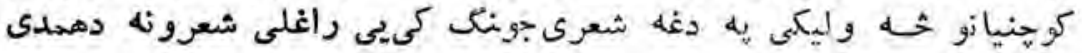

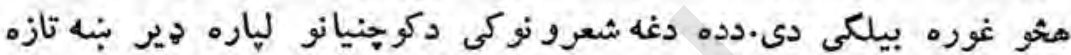

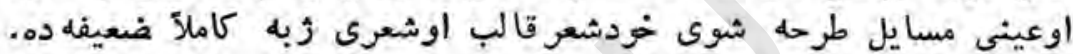

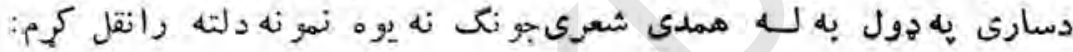

\section{لهر}

$$
\begin{aligned}
& \text { مزموب. دزو ندون لمسره } \\
& \text { زمـوبر دسمى لـمره } \\
& \text { لمره را وحمليزه }
\end{aligned}
$$

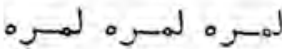

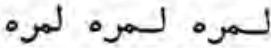

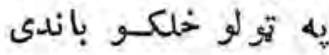

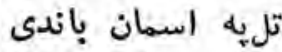

لمره درجادى شمه

$$
\text { زموب. دسمون لمره زمون دمبن }
$$

كبهـ تامسو تسن روبنيانه ته جى تليا تى اوسى تصى

هرى خوا وى فصلسو نه

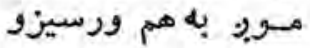
لسمبه لمسره لهمبر ورسيزو لمسره لمسره لهمبره

r (1) 


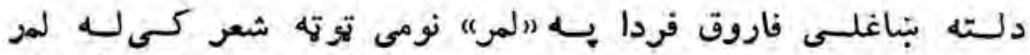

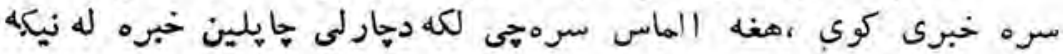

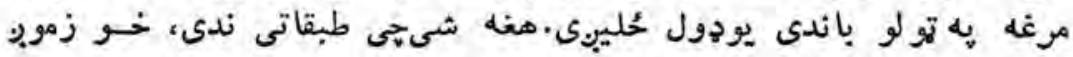

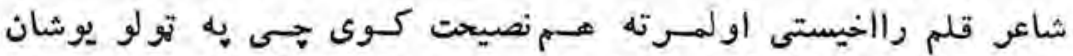

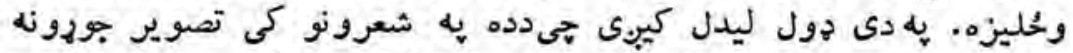

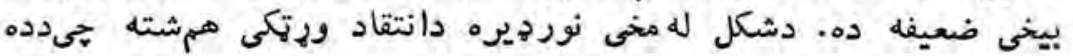

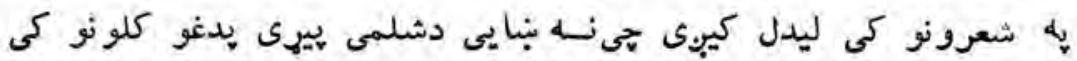

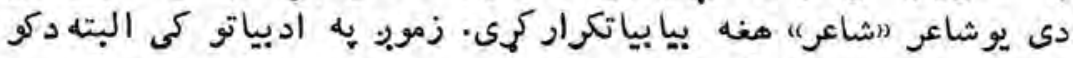

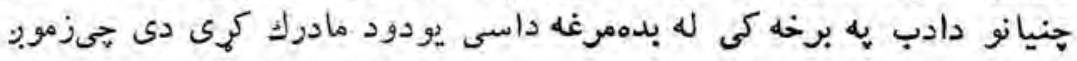

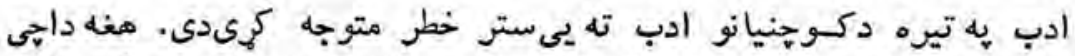

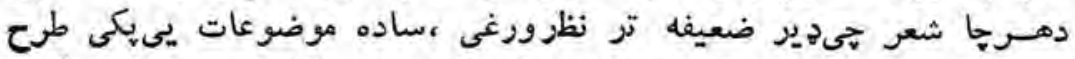

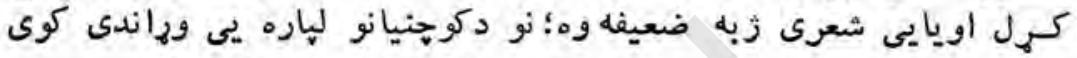

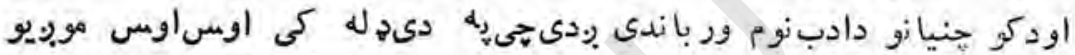

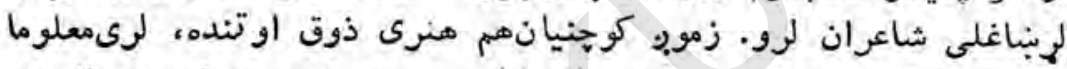

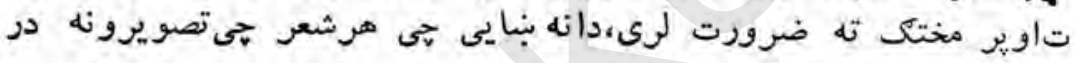

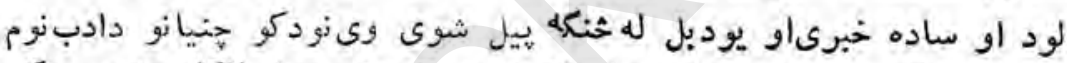

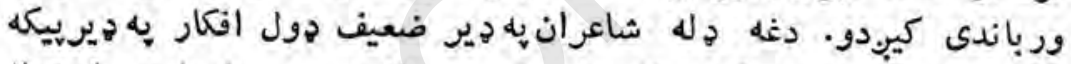

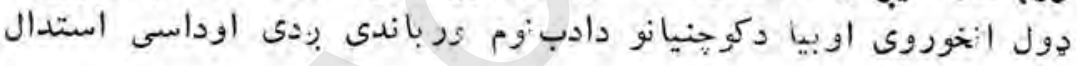
كوى جیى

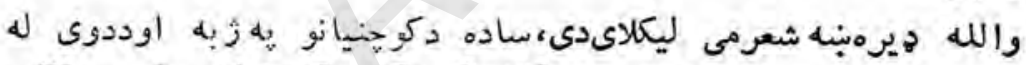

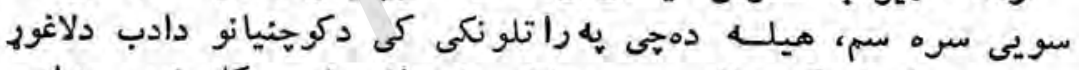

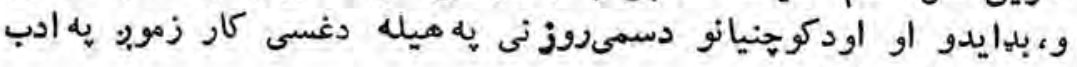
كى بيا بيا تكرارنه شيد اودئ

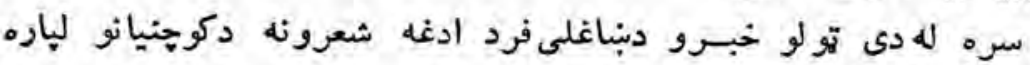

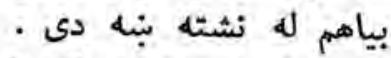

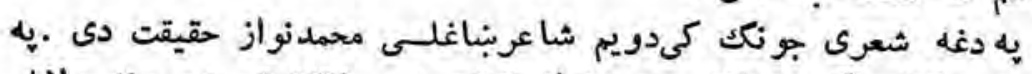

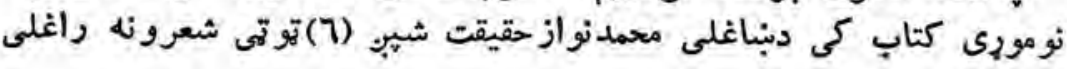


4

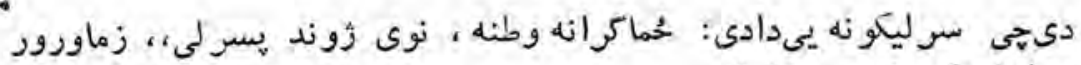

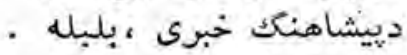

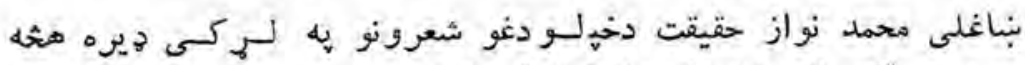

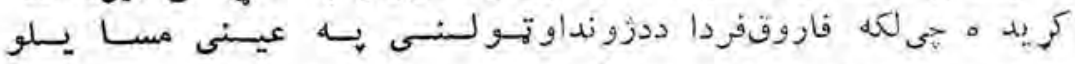

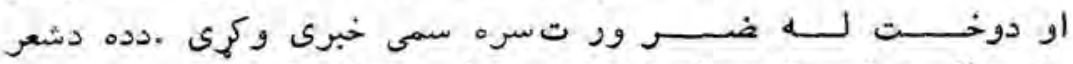

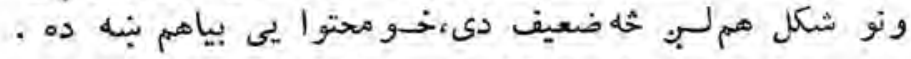

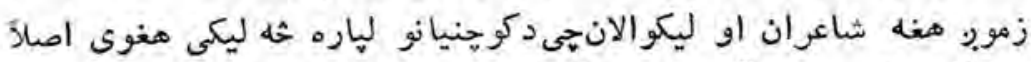

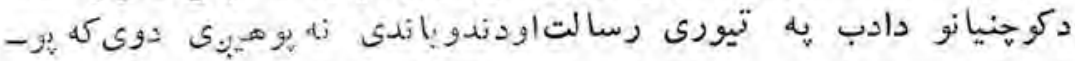

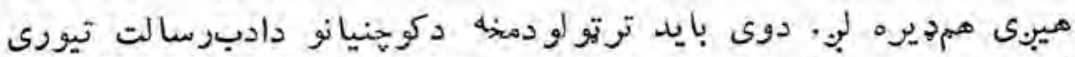

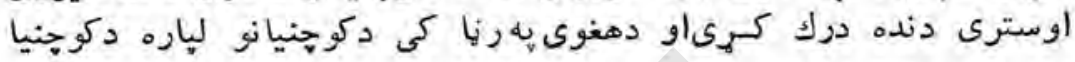

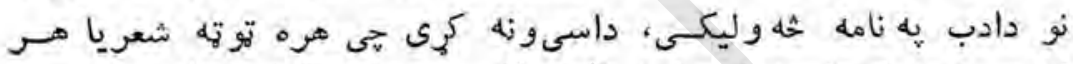

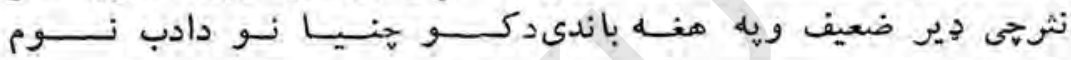

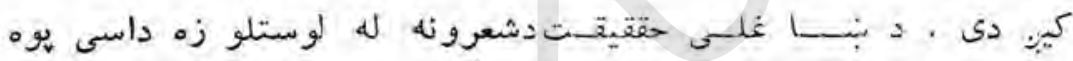

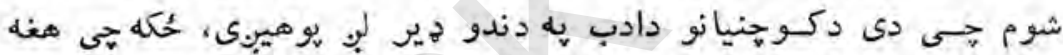

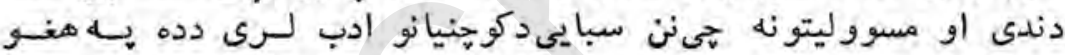

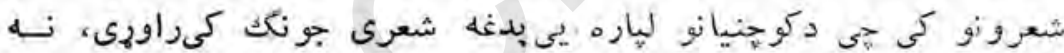

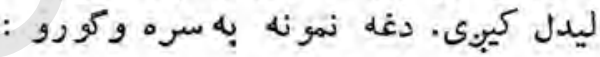

ملكرى دكارك دى دي

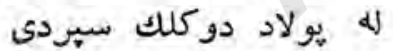

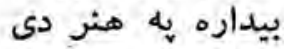

قوى او زئه وردى (1) ونه

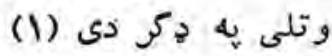

\section{زما ودور}

دانقلاب عسكر دى

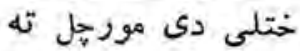

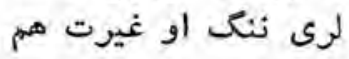
اتـل دنوى ثروند دئ دئ

دغليه مقا بلى تــ

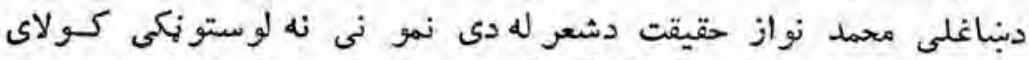

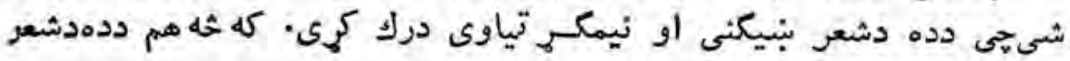

19 (1) 


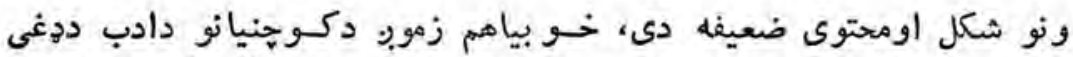

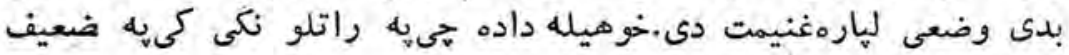

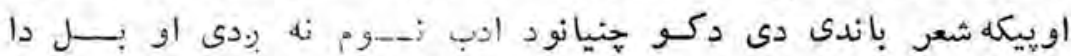

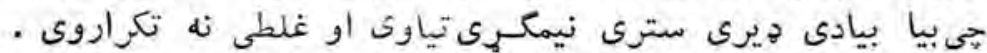

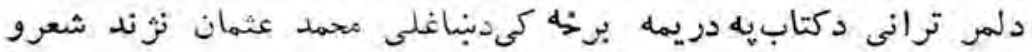

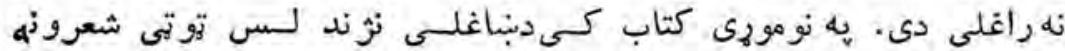

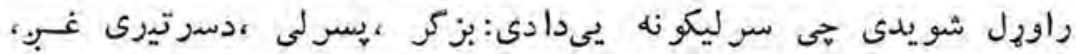

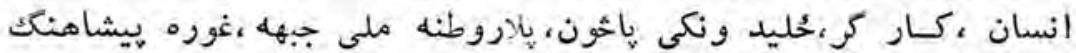

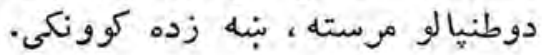

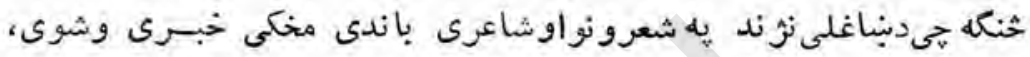

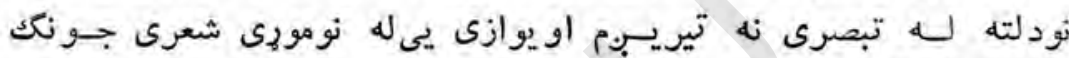

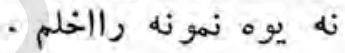

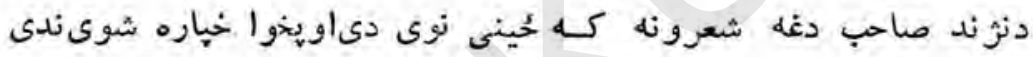

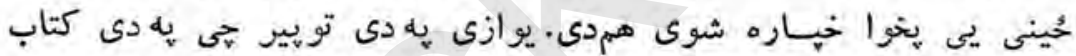

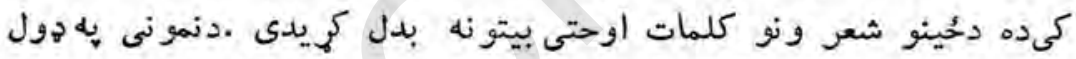

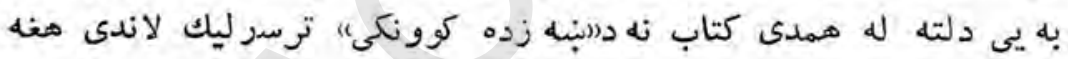

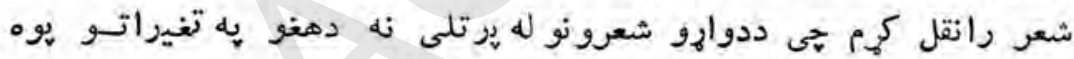

$$
\begin{aligned}
& 2 \\
& \text { نبه زده كـوونكى } \\
& \text { نبه شاكرد يوه او هوبنياروى }
\end{aligned}
$$

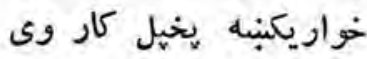

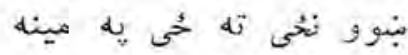

$$
\begin{aligned}
& \text { يه درسو نوكى بيدار وى }
\end{aligned}
$$

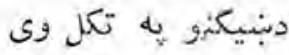

$$
\begin{aligned}
& \text { له بديو نه بيزاروى }
\end{aligned}
$$


معلمان ورنه راضى وى نم نيك عمله نيك كرداروى وري تل قانون ته احترام كئى

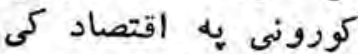
كلك ملاته اومدد كاوى

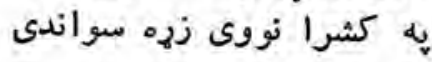
مهر بانه الكه يلار وى كي هم به كلى او محل كلى دتولنى خد متكار وى إى تلوردا نكى رضا كاري

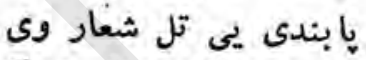

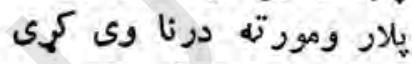
كورنى نه خبردار ون ون تو نتيز كارته تياروى تو لنيزى كتهى غواري مسنالف داستثمار وى دا دنبوزده كيهو شعاروى لاري

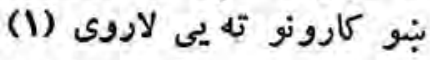

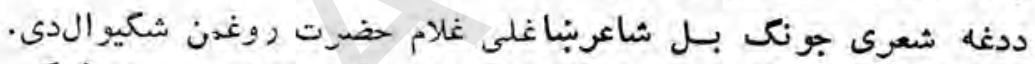

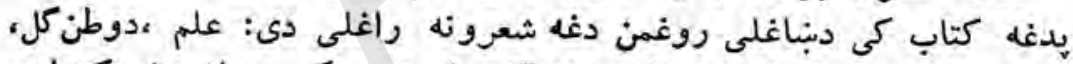

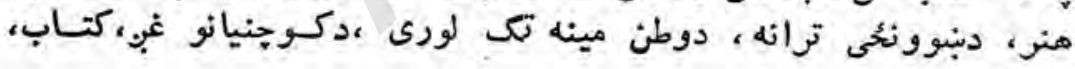
ملكرى .

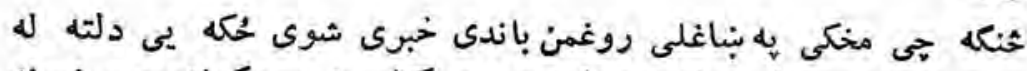

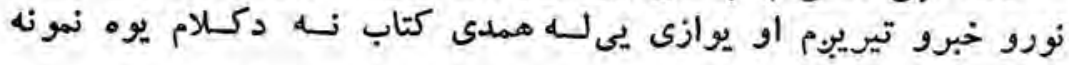
رانقلوم : نيرو

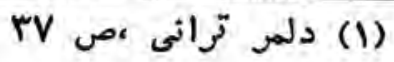


كتاب لـيــلهي شمه

بنه يى ساتلى شمه

زه يـا دو لـى شمــ

ورتـه ويسلـى شمه

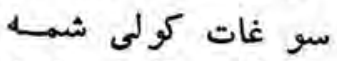

ورباندى تلـلمى شمه

خلك يیيز ندلى شمه

\section{كتاب}

كتاب لو ستلى شمه

كتاب ملكرى زما

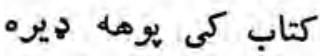

كتاب بنوونكى زموب كماب

كتاب بزكى كار كرته

كتاب رابنايى لارى كنى

دانقلاب كتاب كى

غوبر كى نيولى شمهل

\section{دلينين يه باره كى تكلونه}

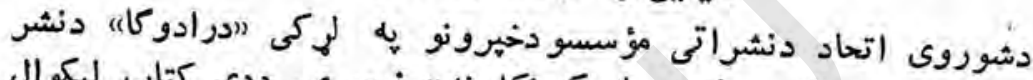

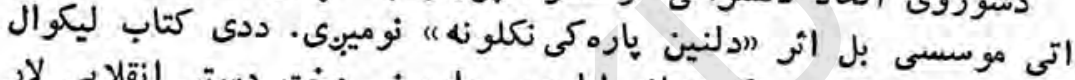

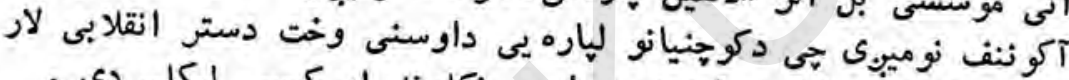

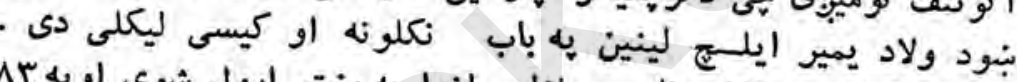

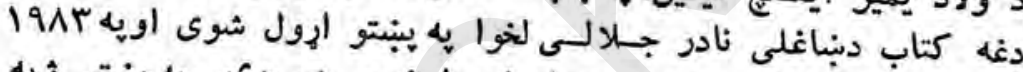

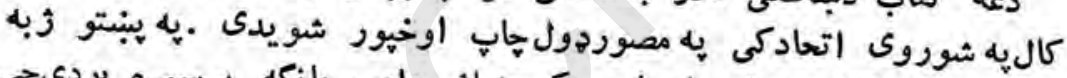

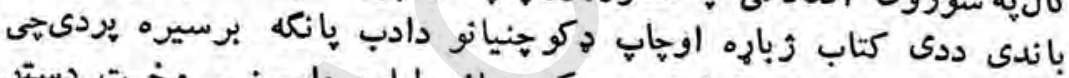

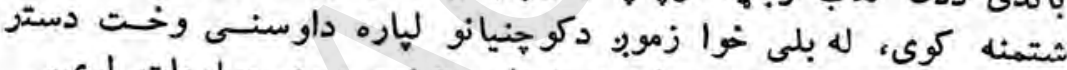

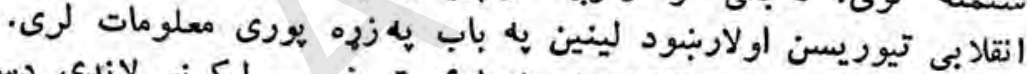

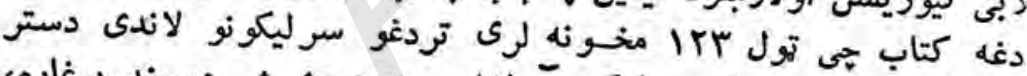

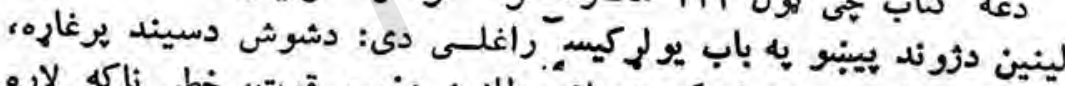

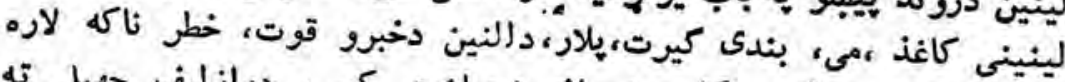

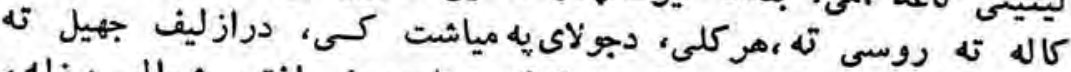

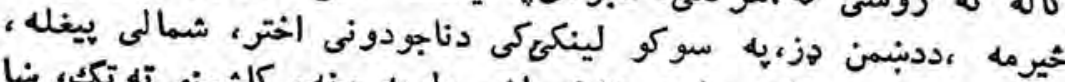

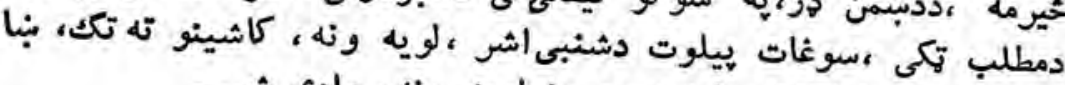

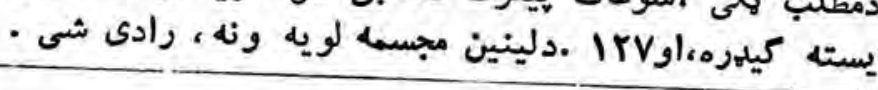

(1) 


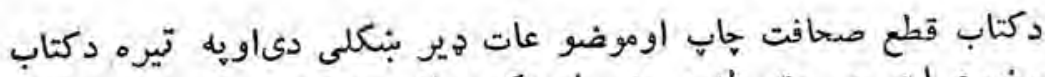

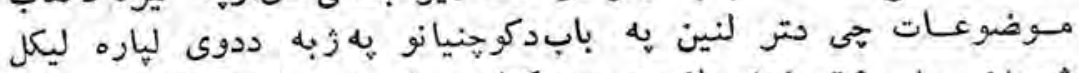

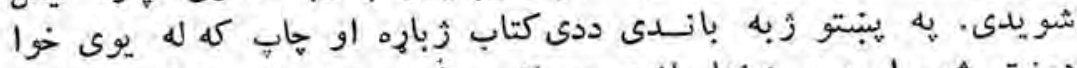

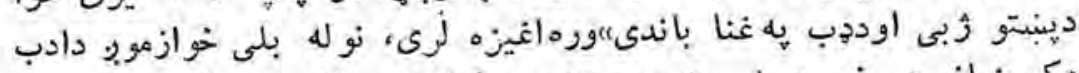

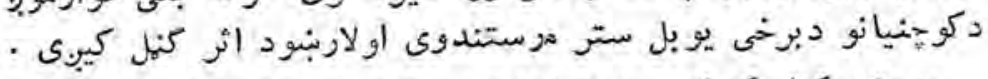

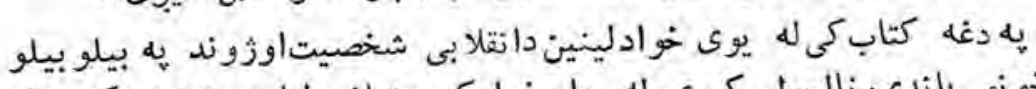

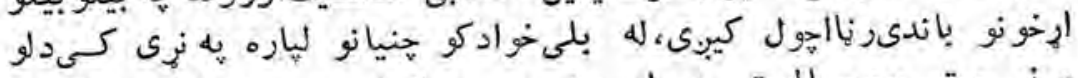

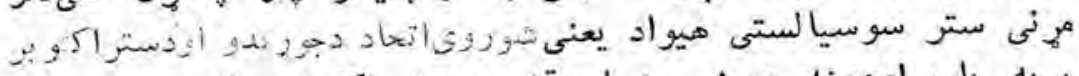

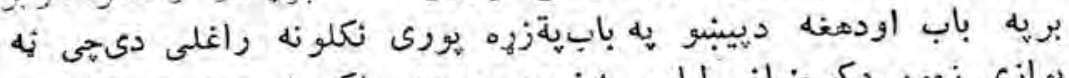

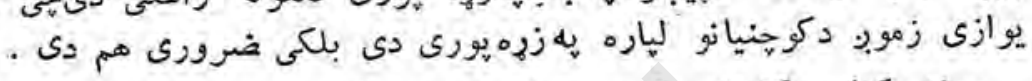

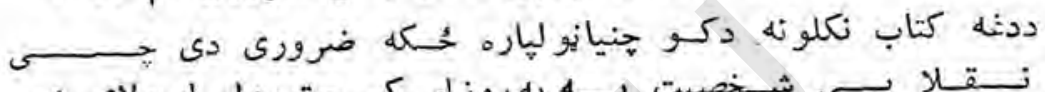

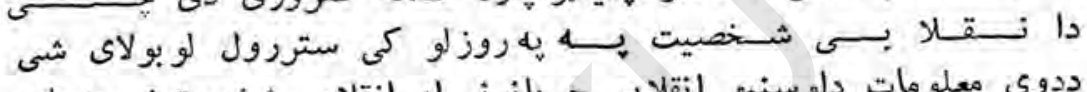

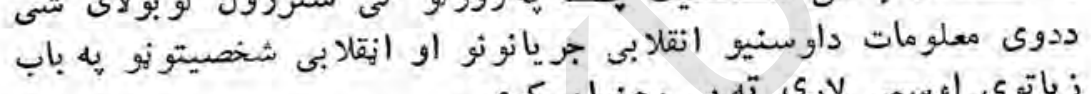

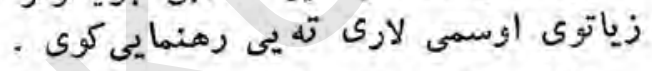

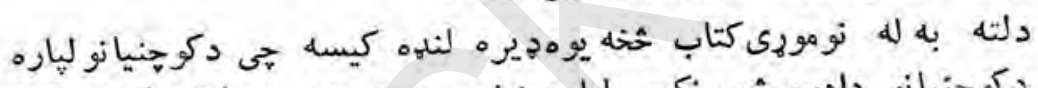

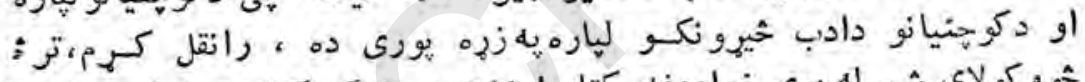

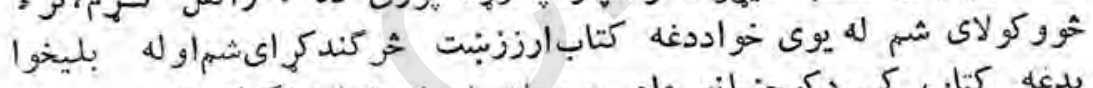

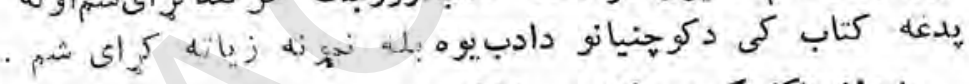

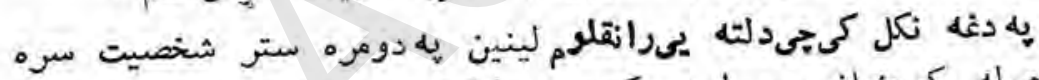

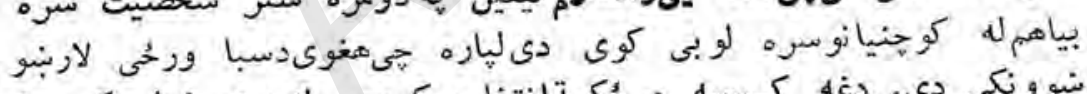

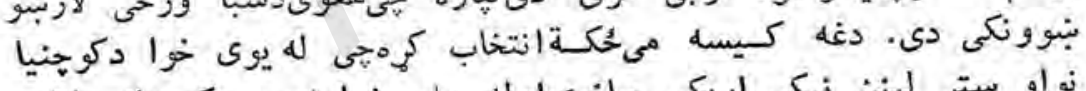

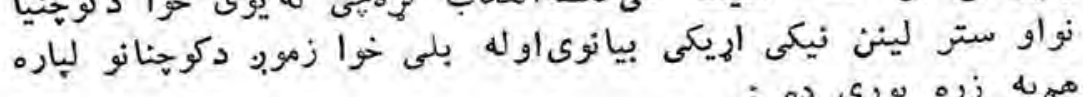

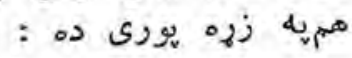

\section{وزه سوكو لنيكى كى دناجو دونى اختر}

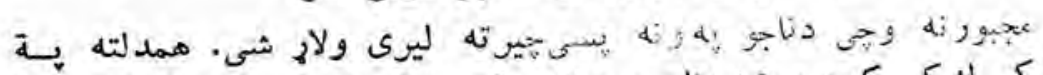

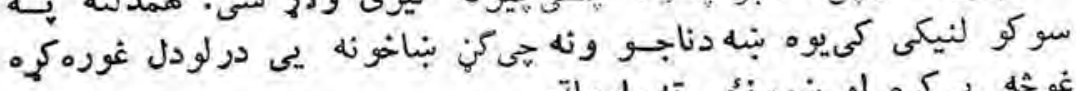

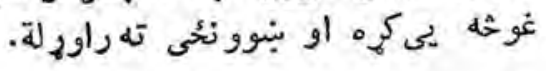




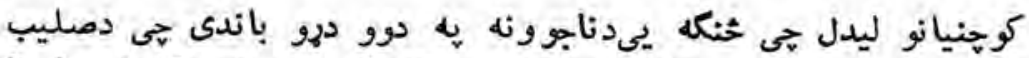

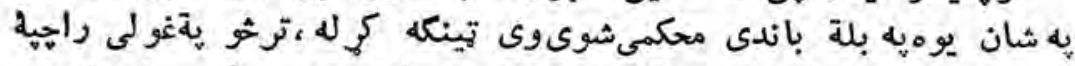

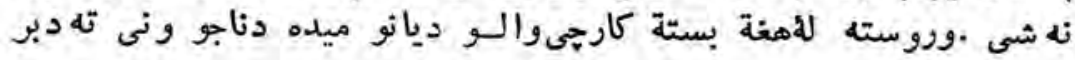

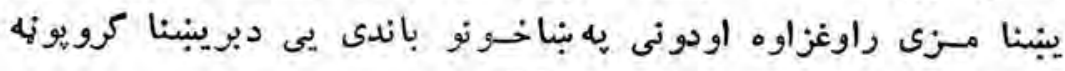

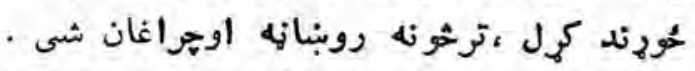

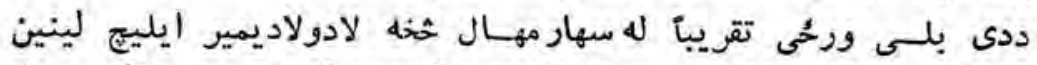

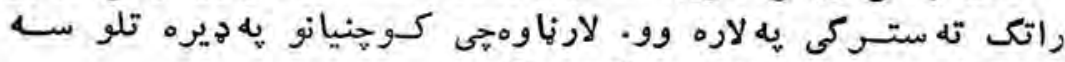

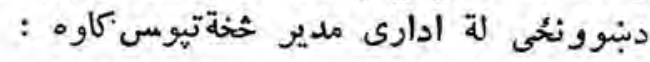

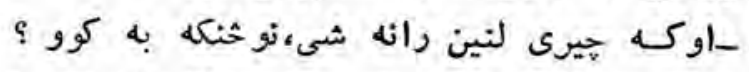

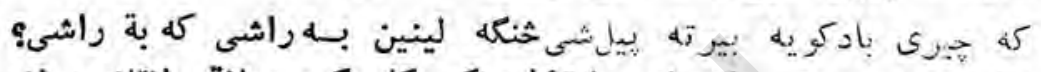

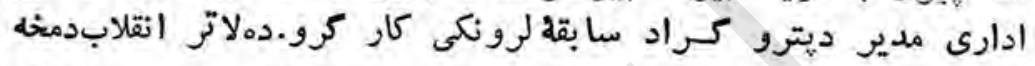

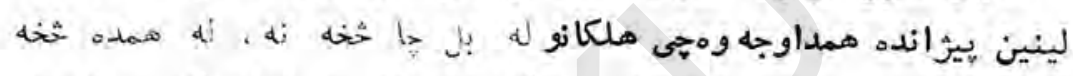

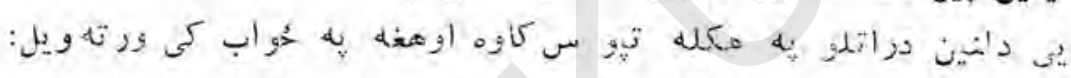

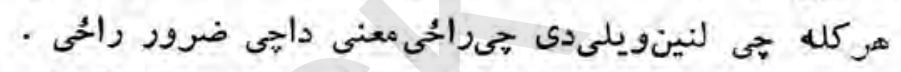

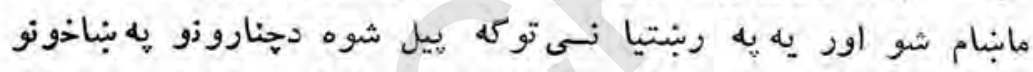

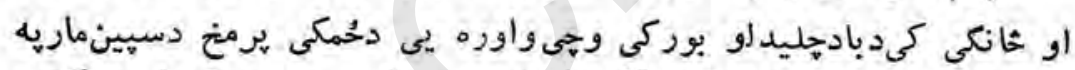

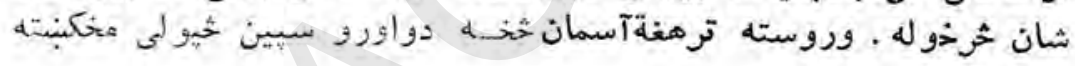

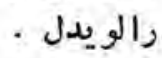

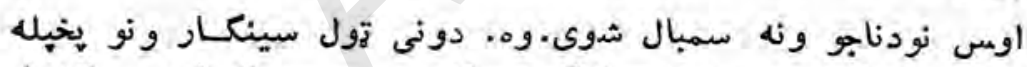

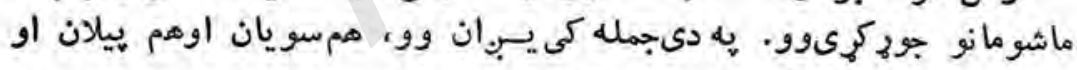

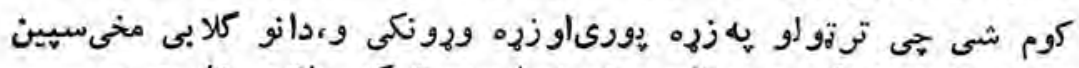

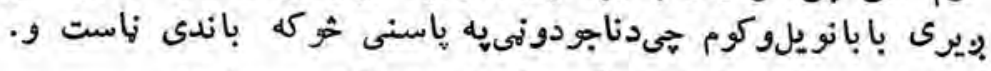

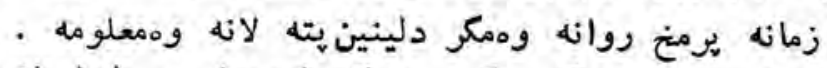

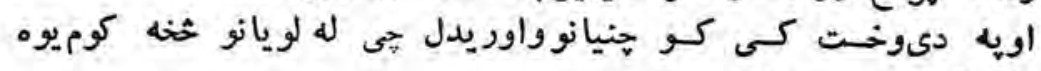

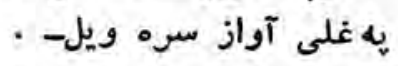
هو! طبيعى دهجى به دغسى سيلى اويا دوريه كى كى نى نه راحقى - 
كوجنيانو بيا سابقه لرونكى ادارى مدير ته ورغنل . ورئ

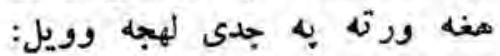

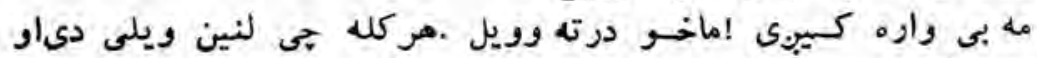

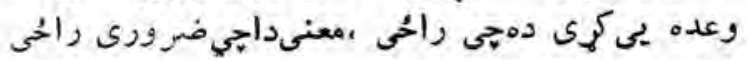

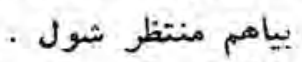

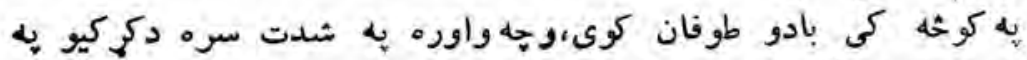

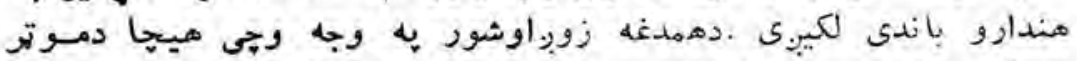

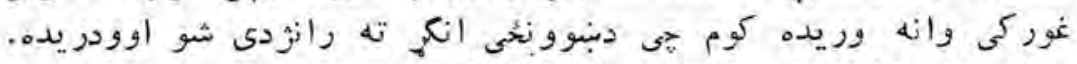

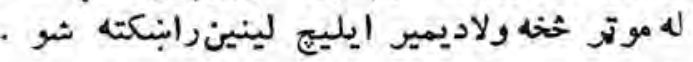

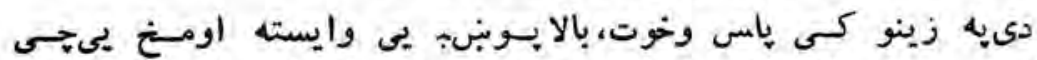

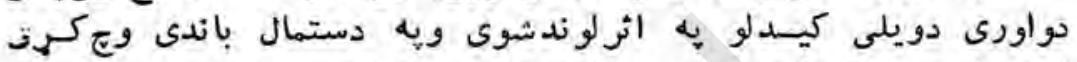

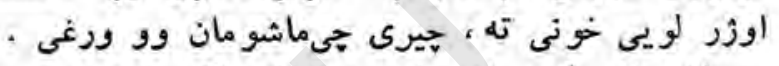

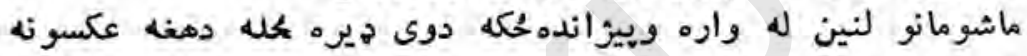

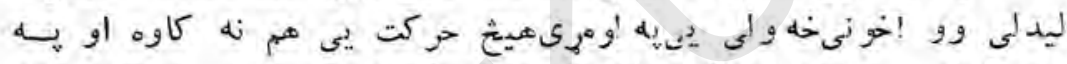

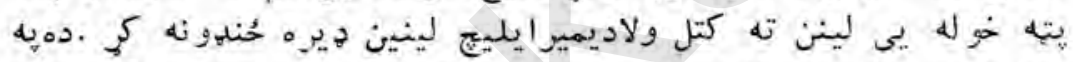

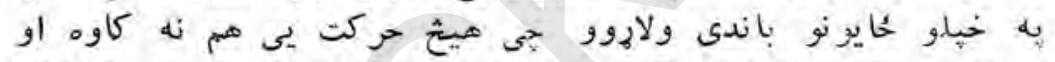

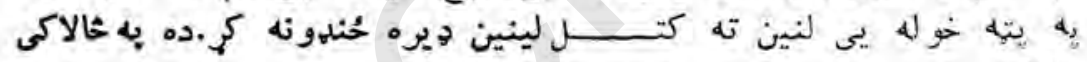

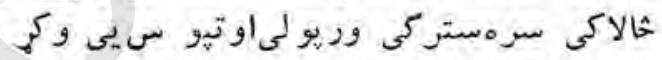

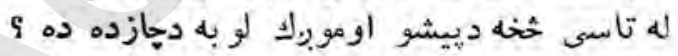

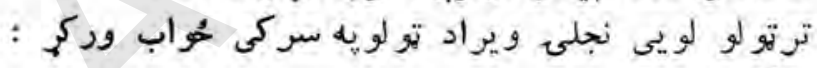

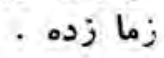

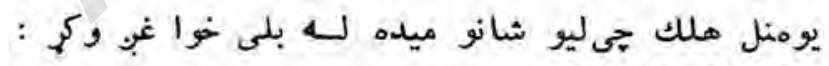

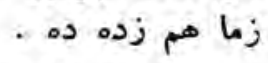

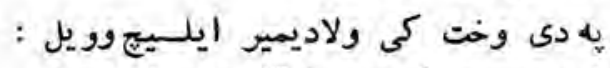

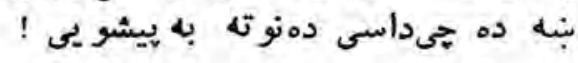

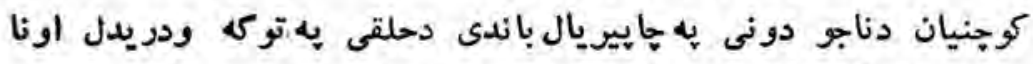

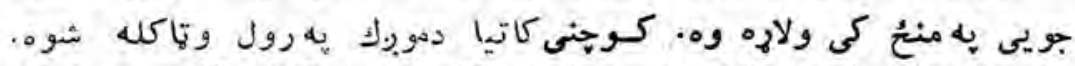

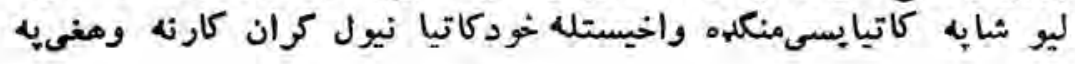


لنين يورى خحان ونبنلاوه اوولاديميرايليج به لاسونو كىله حمكى ثخيه

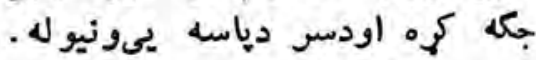

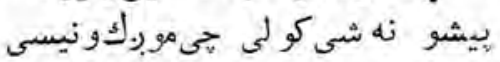

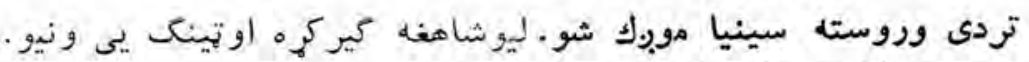

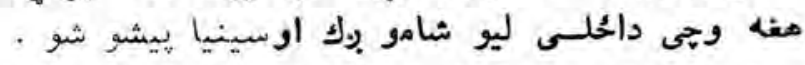

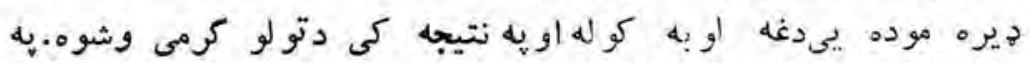

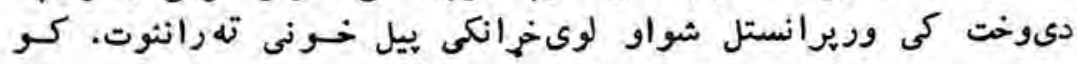

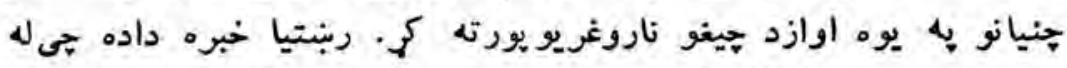

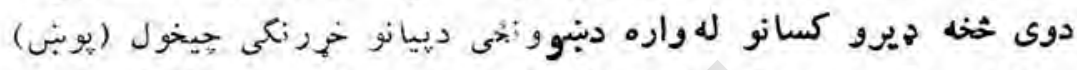

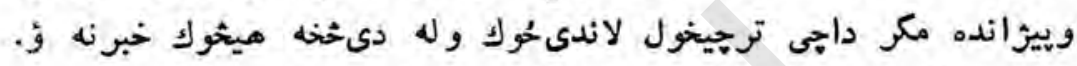

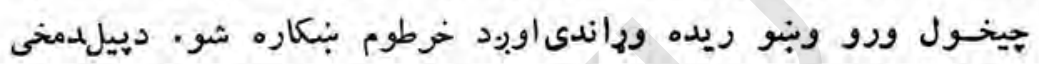

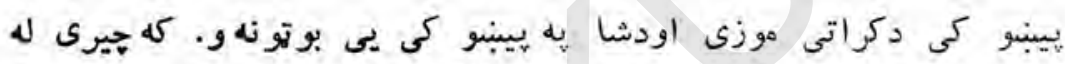

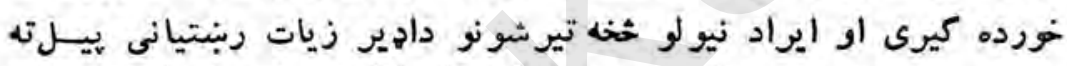

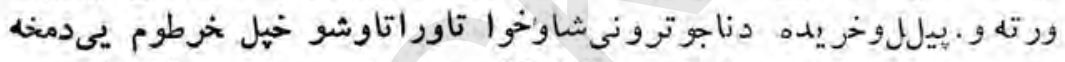

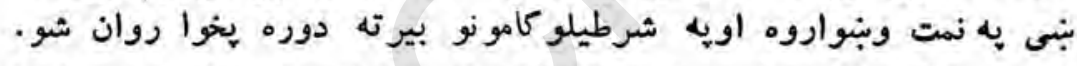

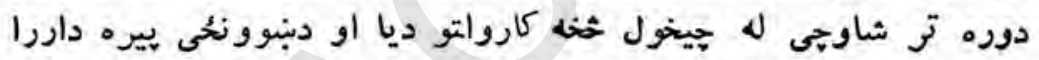

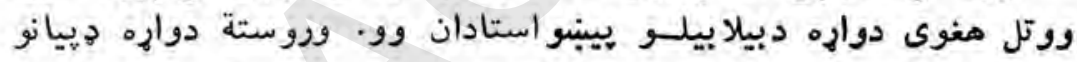

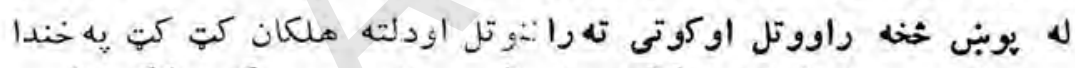

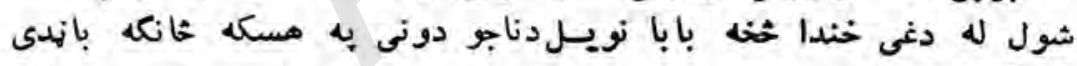

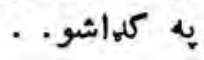

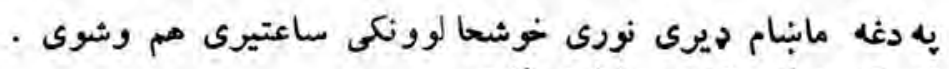

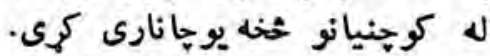

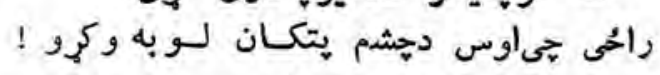

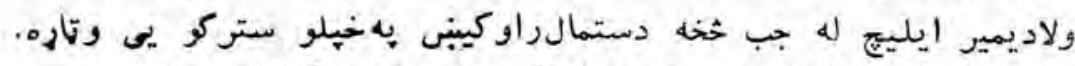

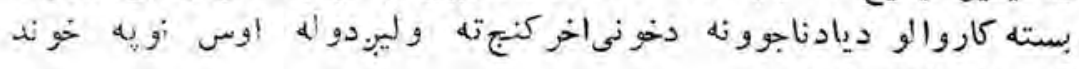

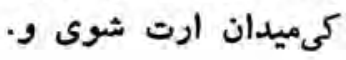


لنين لاسوثه سره خلاص كهل لاوئمنخ دوان شو. دىدكوتو يرسوونو روان و.

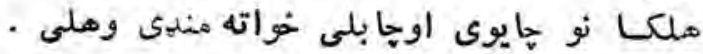

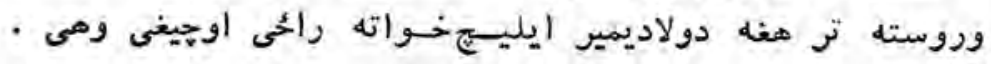
كرمى ده . ن. اوكله جى ولاديمير ايلج بيخسى ورنبودى شوى وملكانو ورباندى غبر

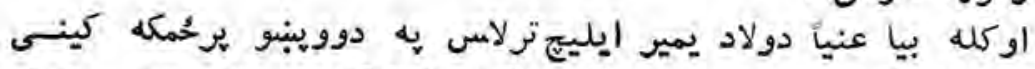

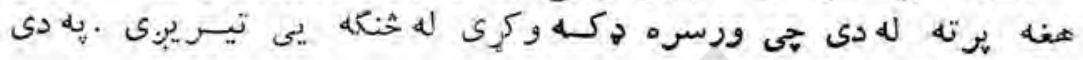
وخت كى كوجنيان نأرى وهى ورئ

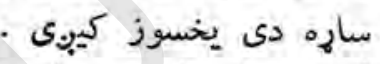

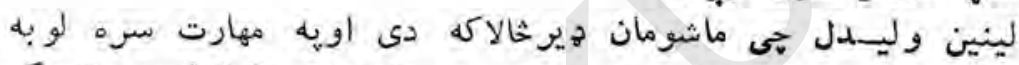

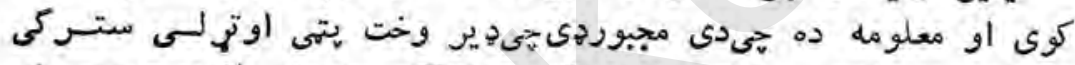

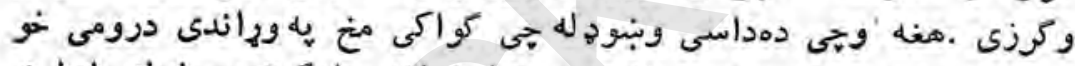

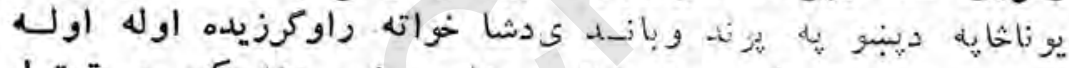

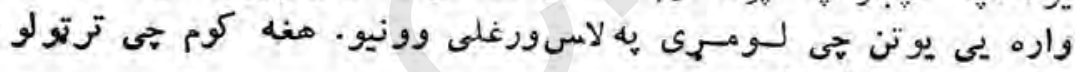

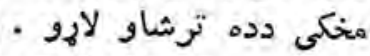

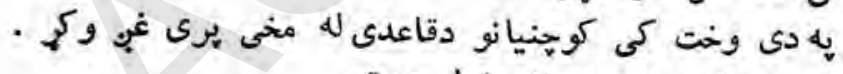

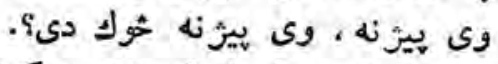

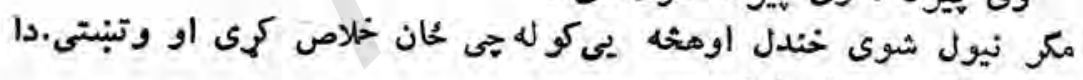

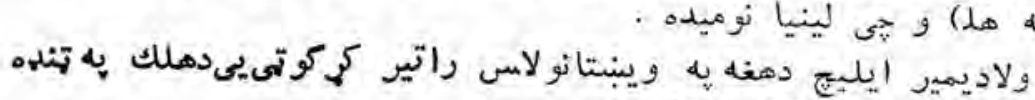

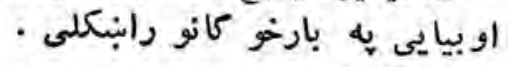

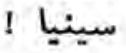

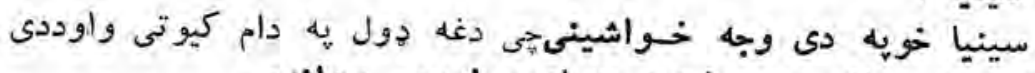

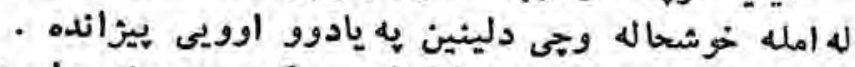

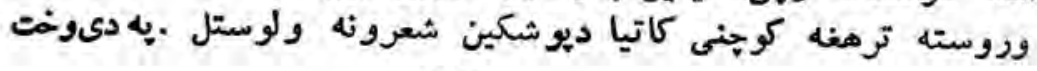
-IVT- 


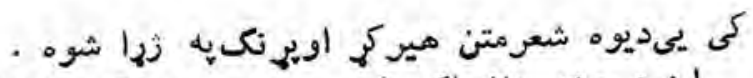

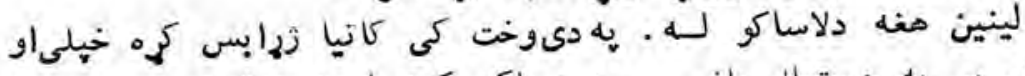

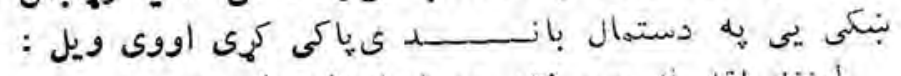

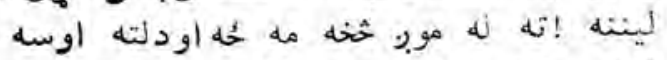

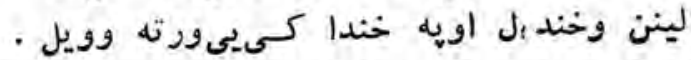

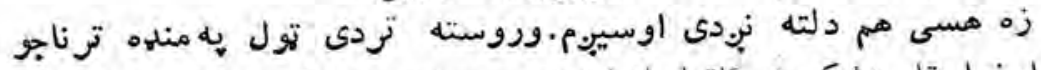

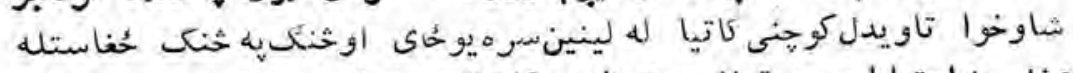

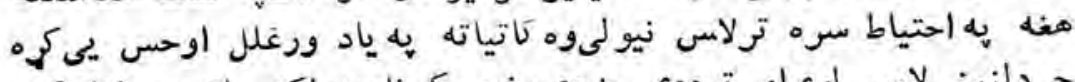

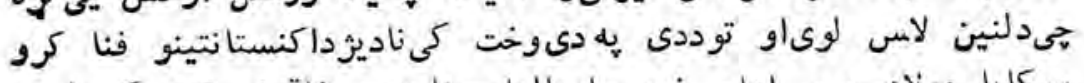

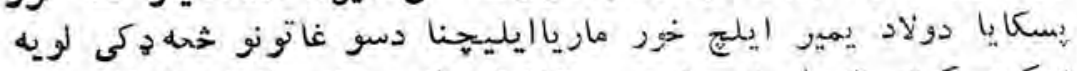

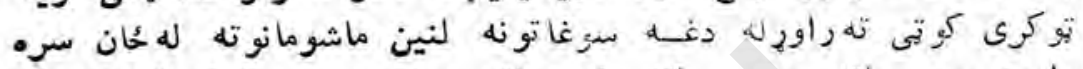

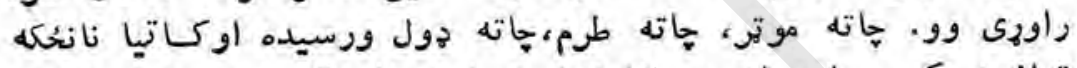

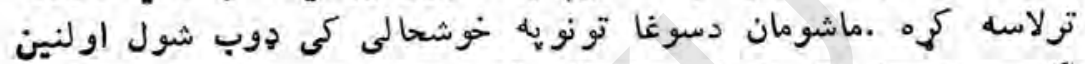

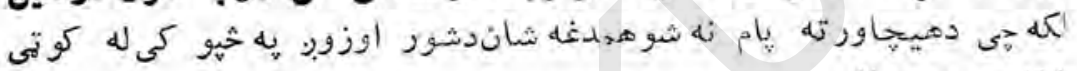

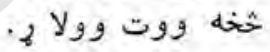

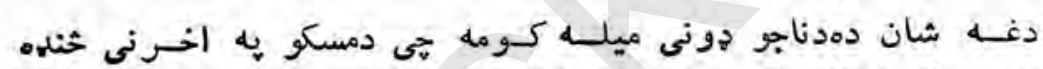

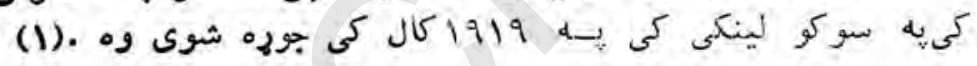

\section{دمينى افسانه}

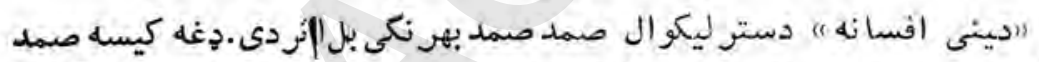

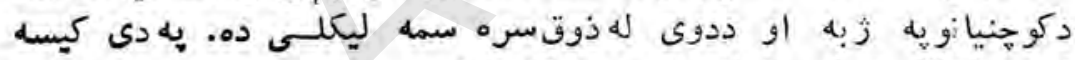

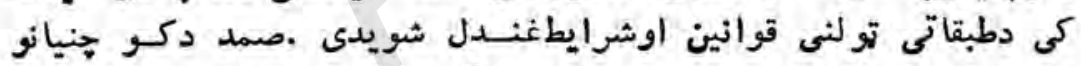

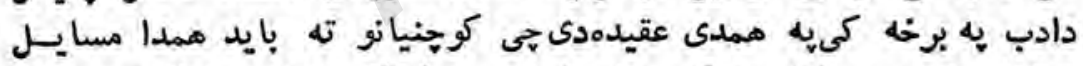

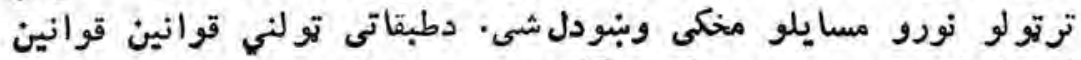

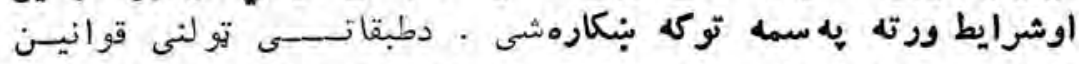

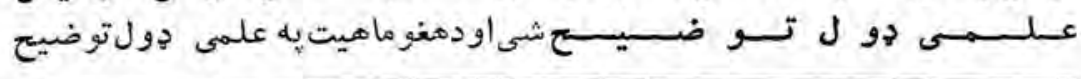

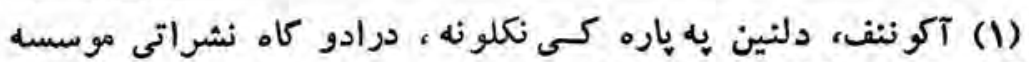

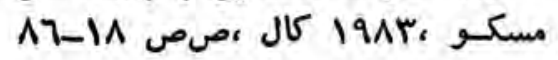
$-i v r-$ 


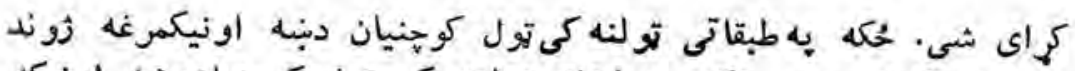

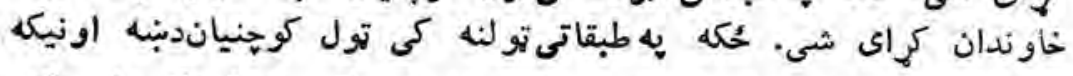

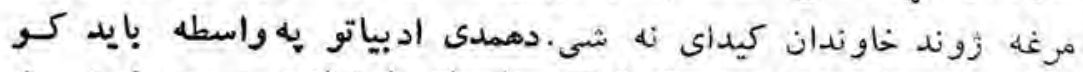

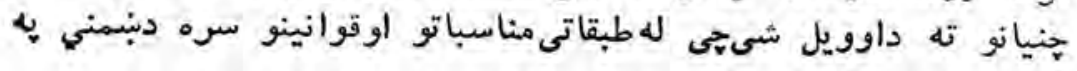

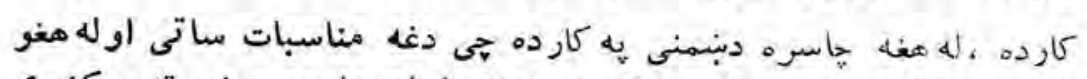

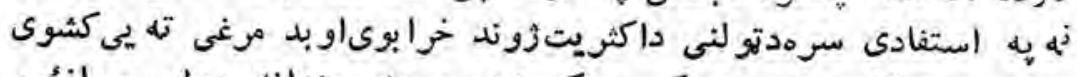

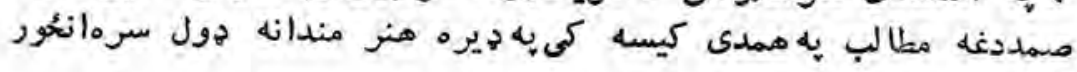

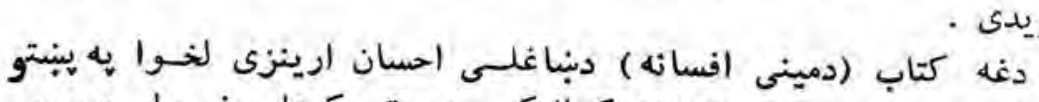

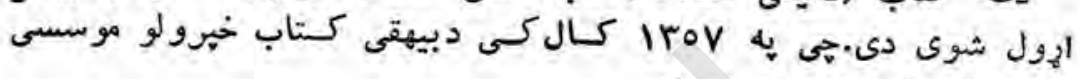

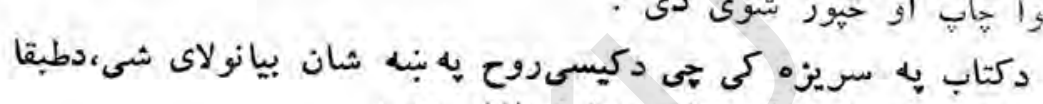

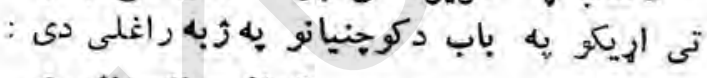

\section{كرانو ماشومانو !}

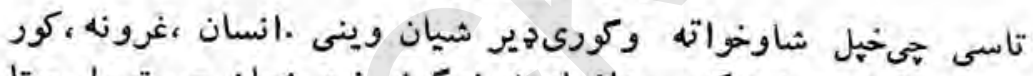

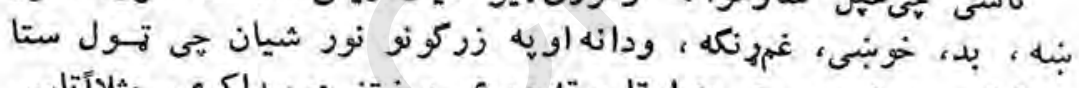

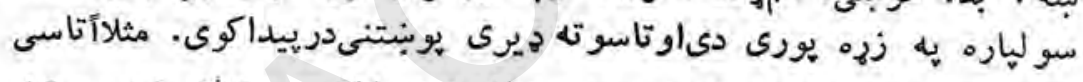

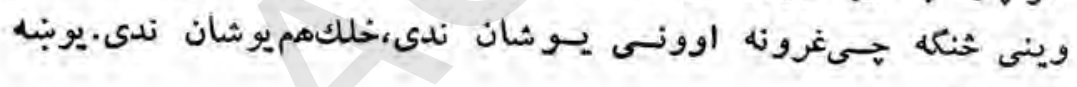

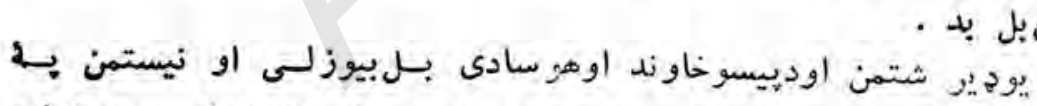

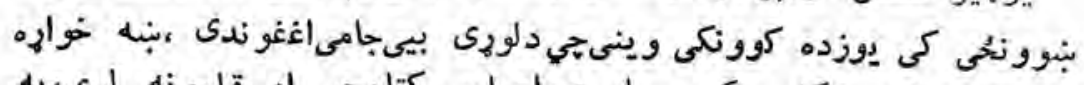

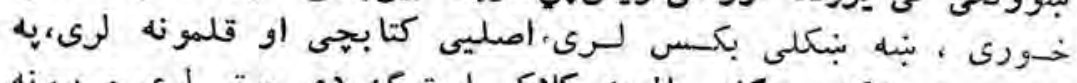

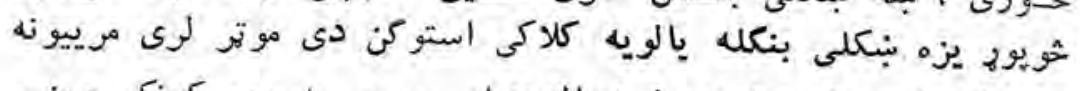

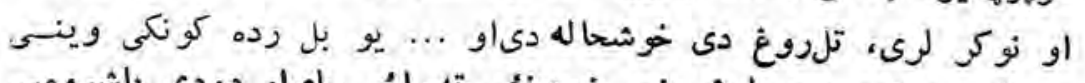

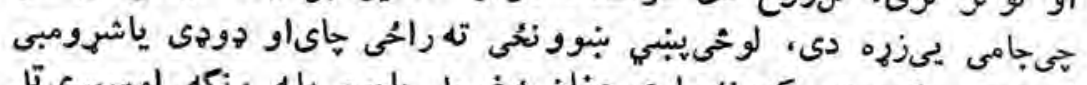

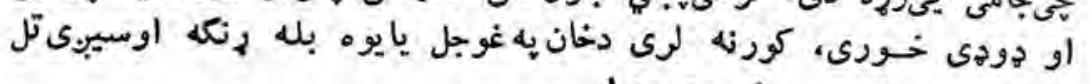

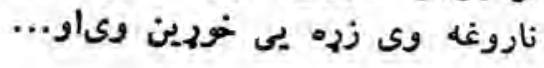




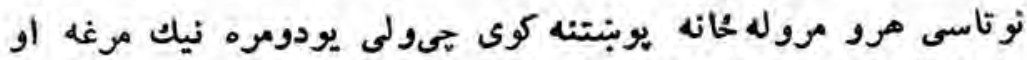

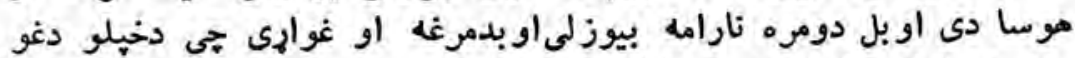

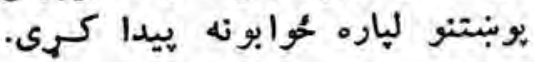

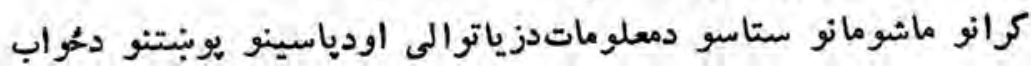

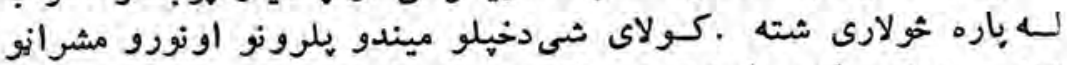

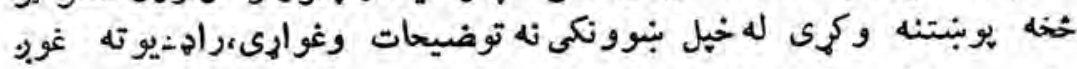

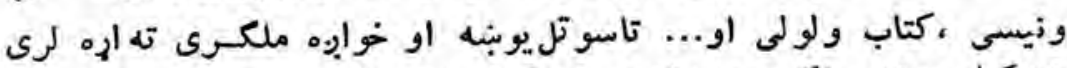

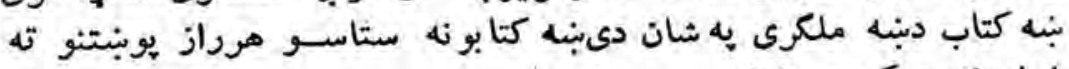

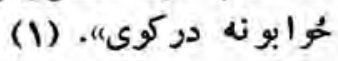

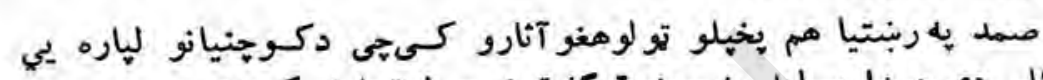

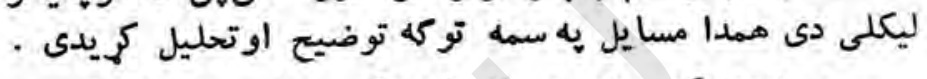

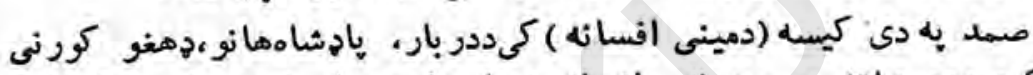

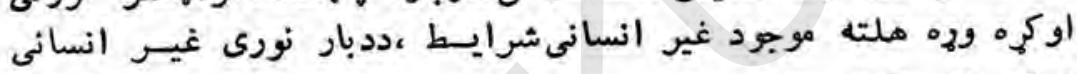

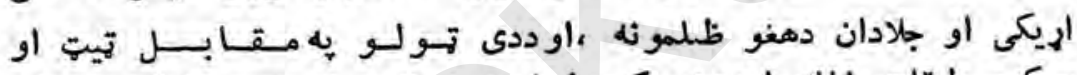

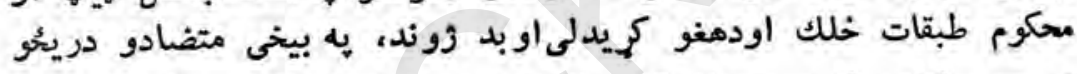

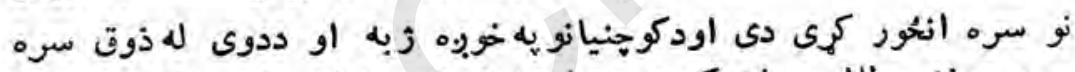

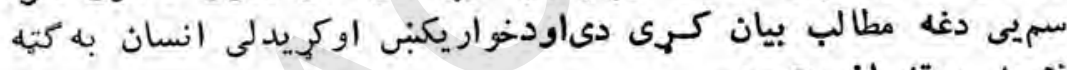
نتيجه ورته اخيستى ده.

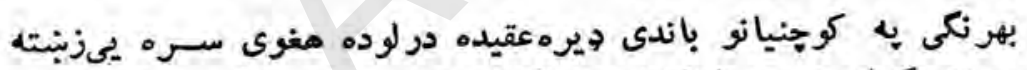

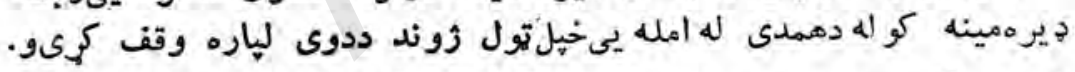

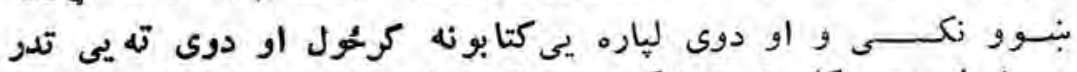

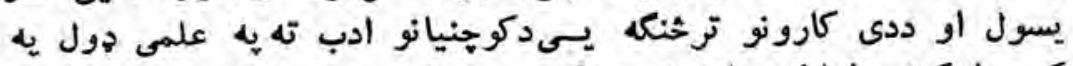

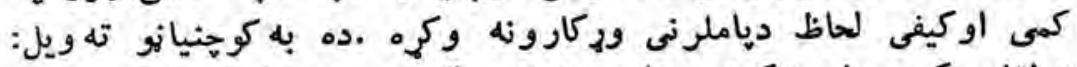

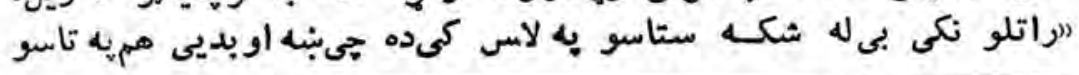

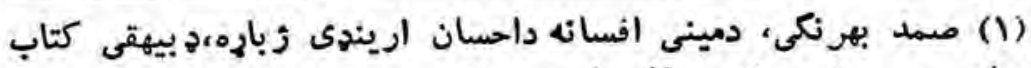

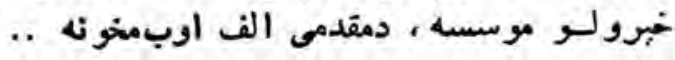
$-1100$ 


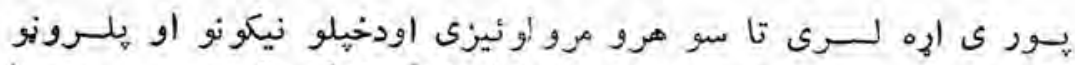

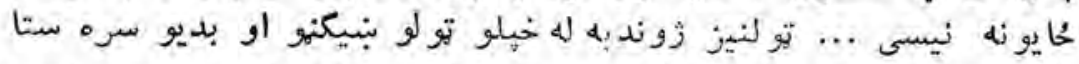

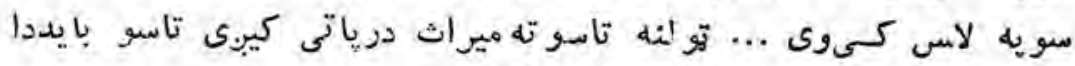

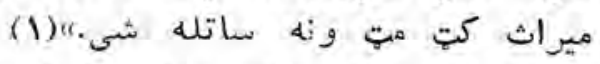

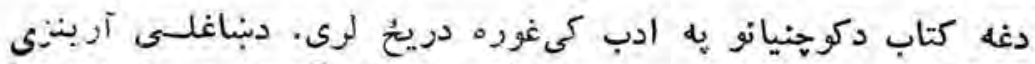

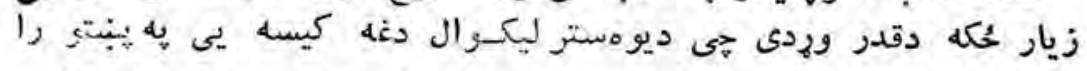

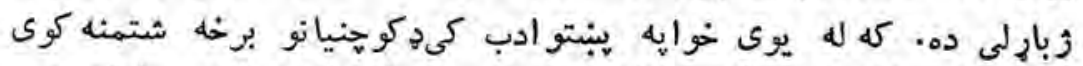

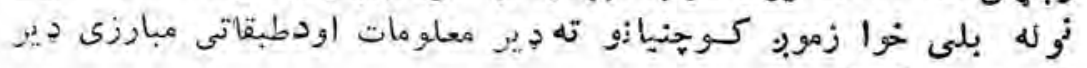

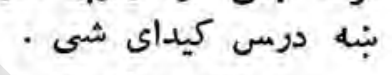

\section{دماكسيم كودكى مود}

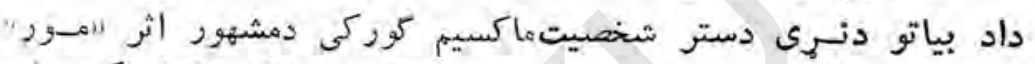

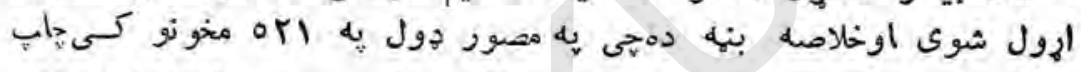

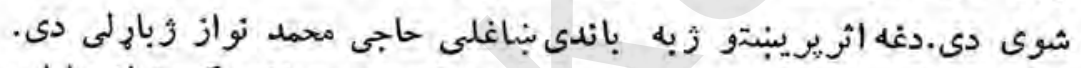

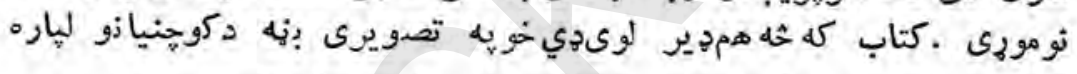

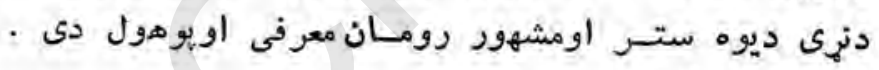
دواورو لوبى دوب لئي ددى اثـر ليكوال كيـت هويرسا لسبرى دى هيى دعبدالسمع حميد له

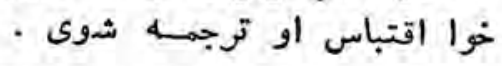

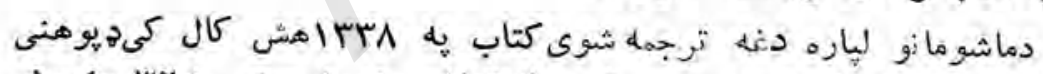

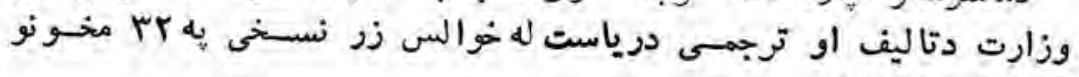

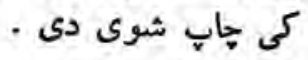

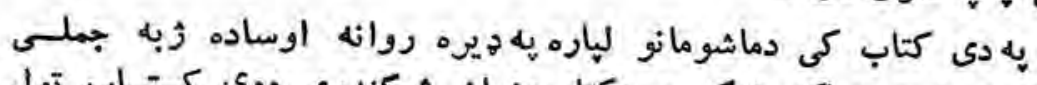

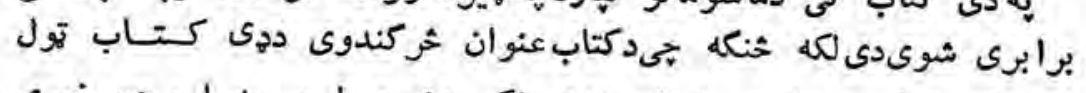

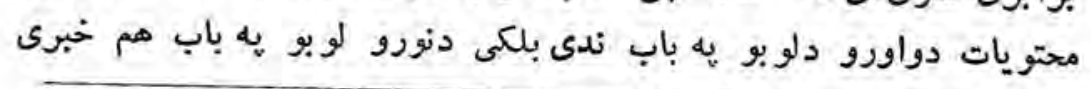

(1) 


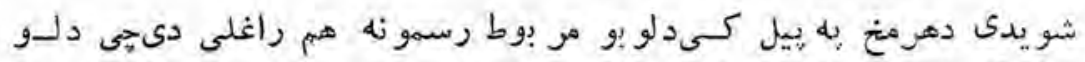

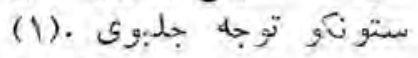

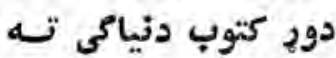

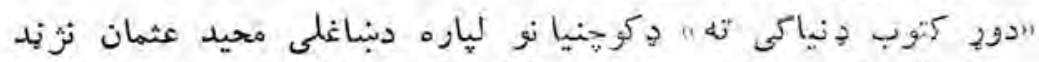

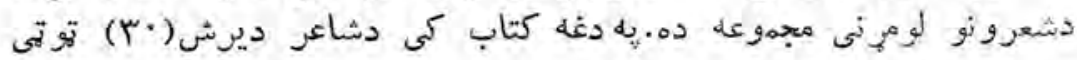

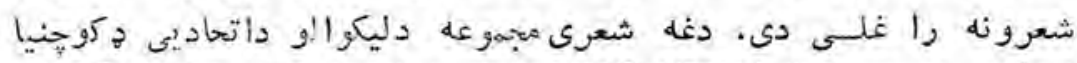

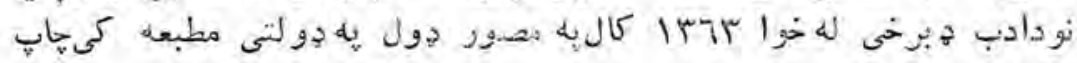

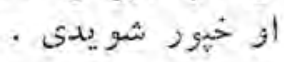

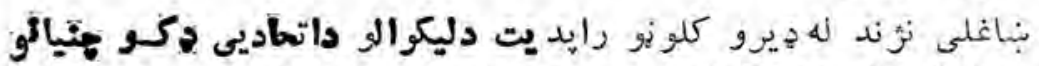

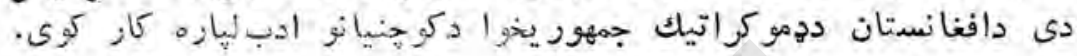

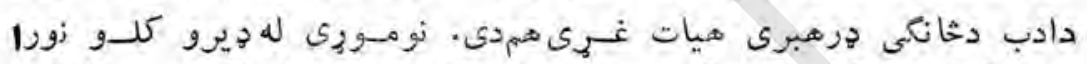

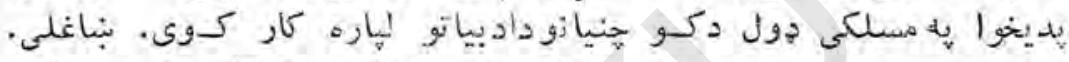

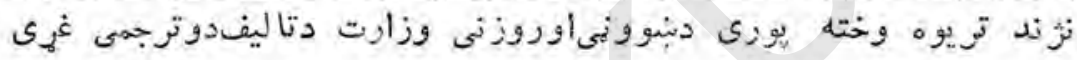

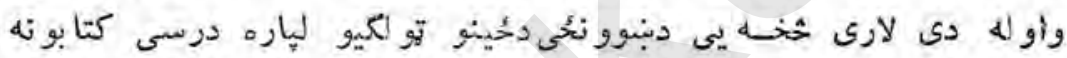

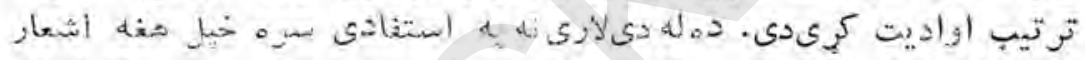

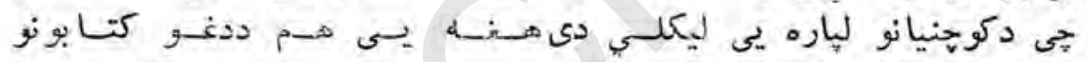

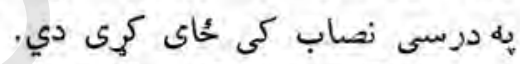

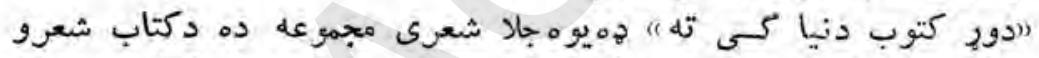

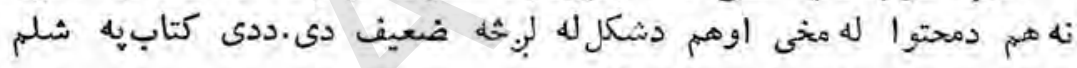

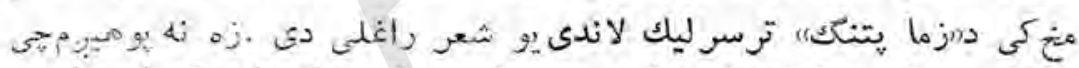

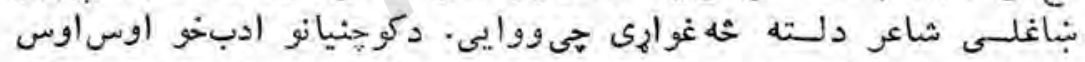

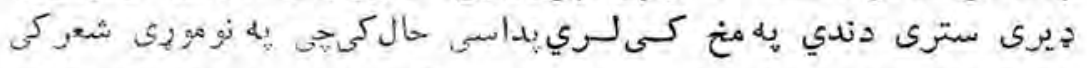

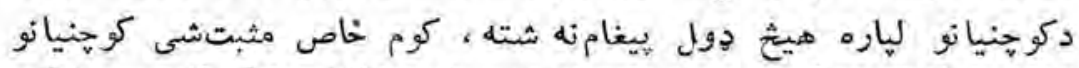

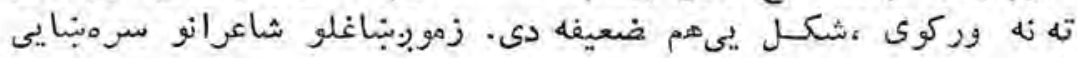

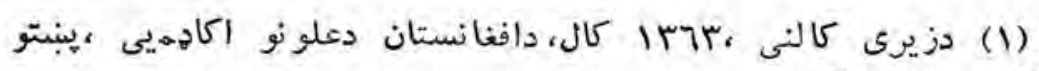
تو لنه، ص (1) دزيرى 


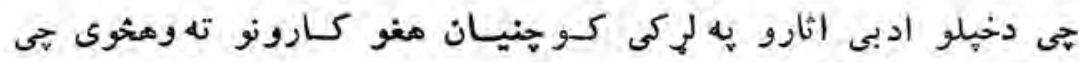

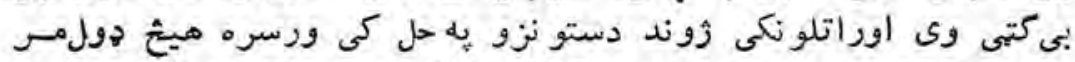

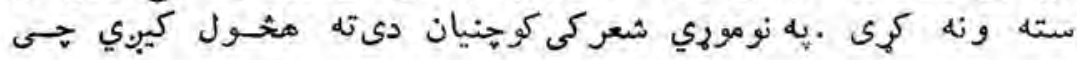

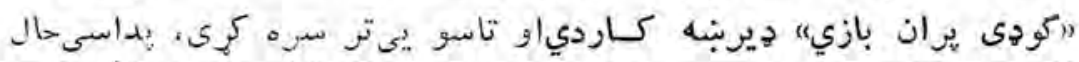

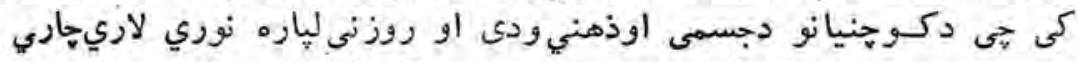

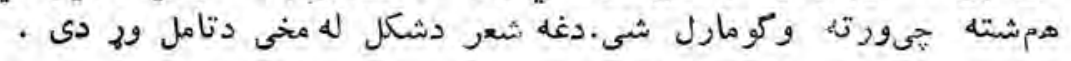

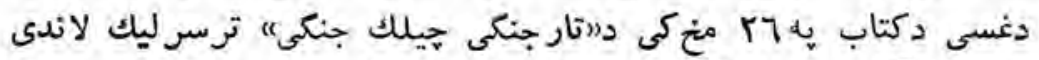

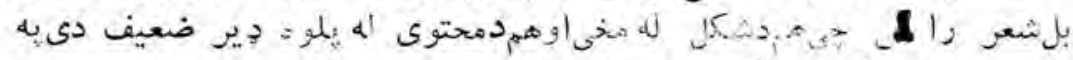

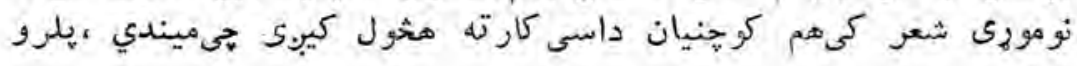

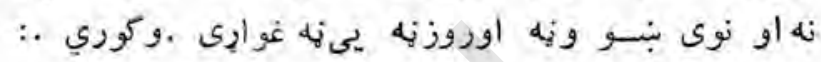

$$
\begin{aligned}
& \text { زميو مزى كرم تار } \\
& \text { غوثوى هرتار هيه وار تار }
\end{aligned}
$$

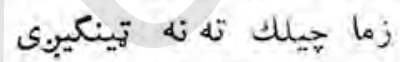

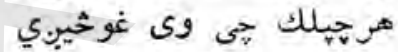

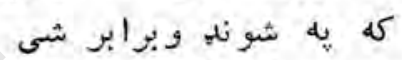

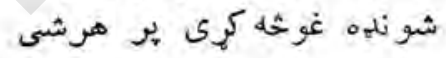

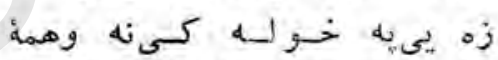

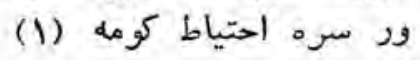

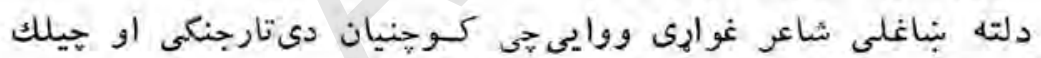

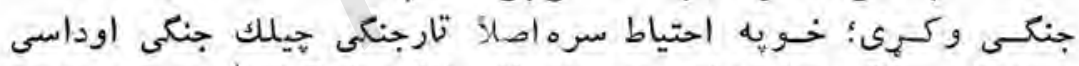

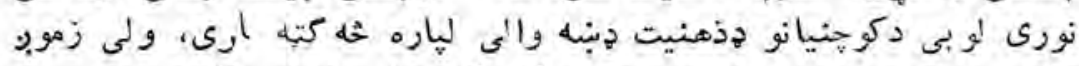

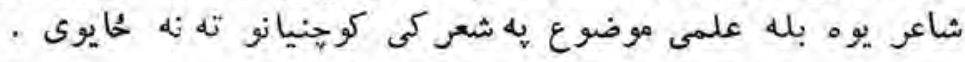

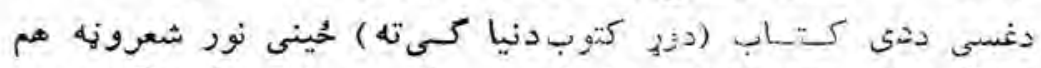

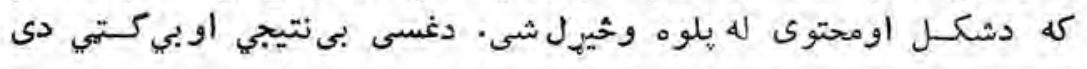

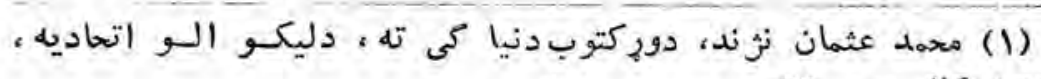

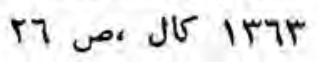




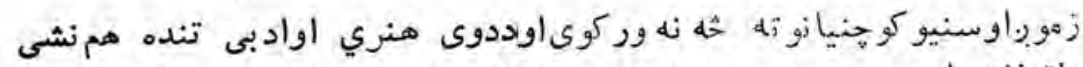

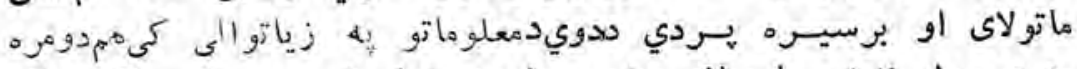

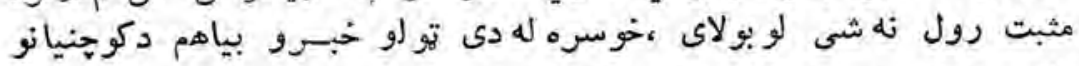

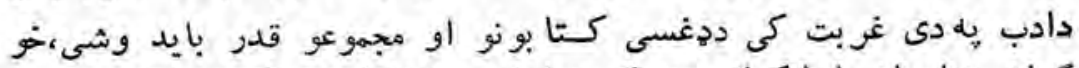

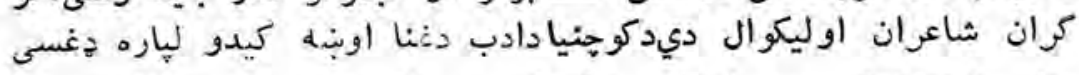

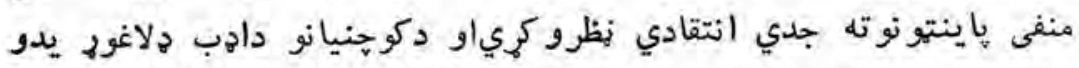

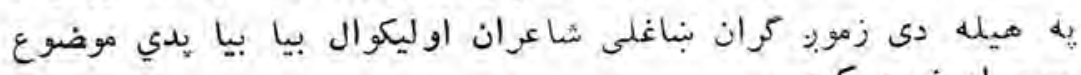

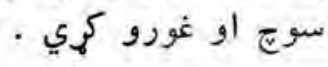

\section{دويم كتاب}

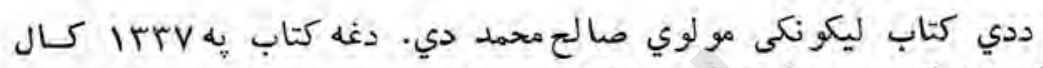

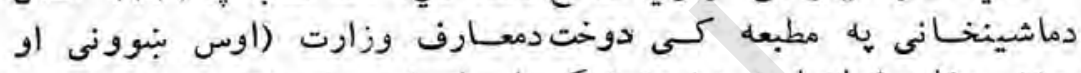

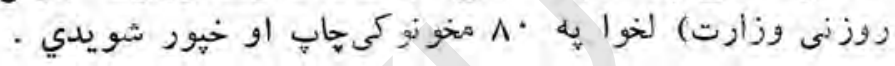

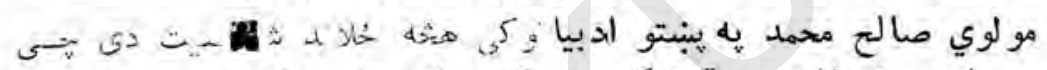

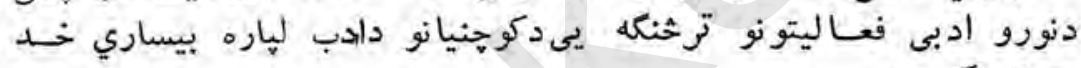

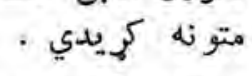

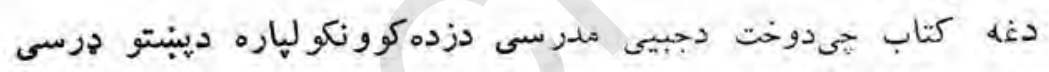

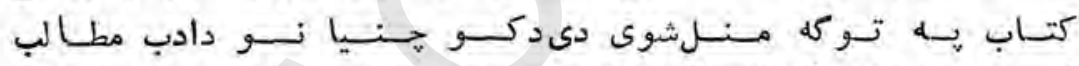

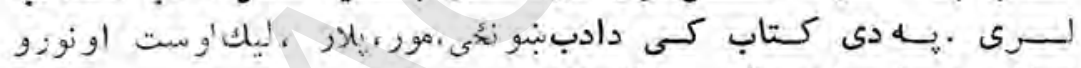

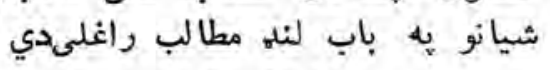

\section{دهيواد ادبيات}

(دوبنتم تو إكى دلوست كتاب)

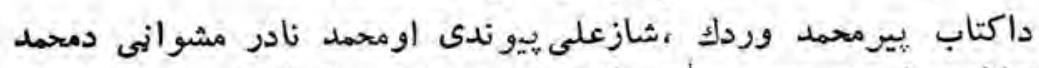

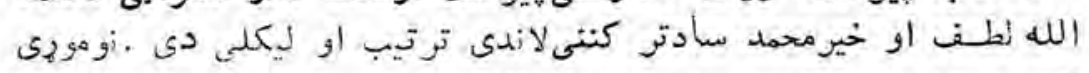

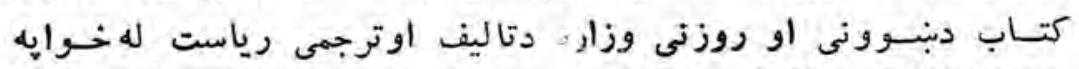

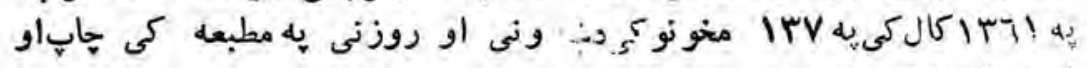
خيور شو يدى : 
دجى كتاب به بيل كىزهي كوونكو ته اولسى ادبيات وريبيزندل شوى

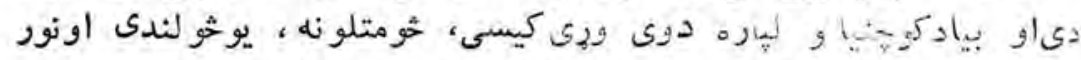

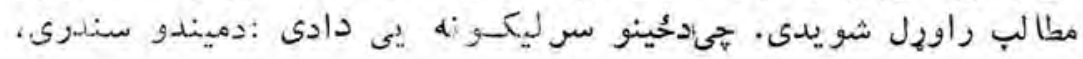

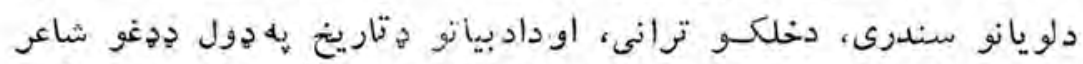

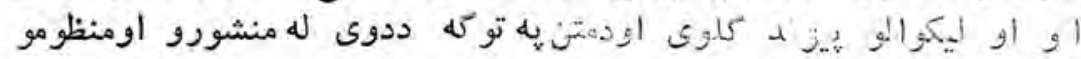

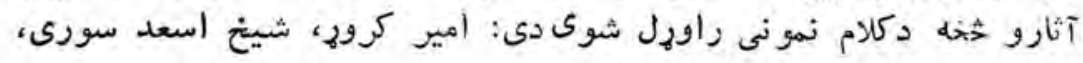

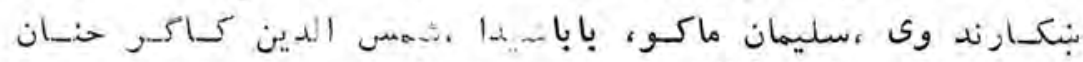

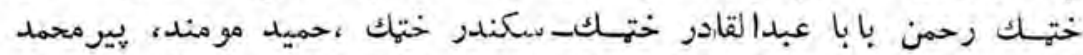

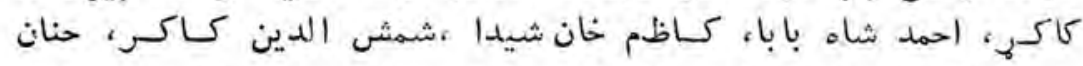

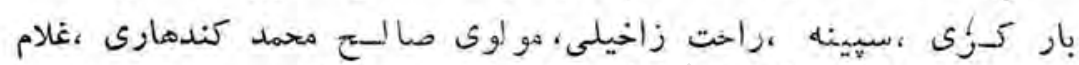

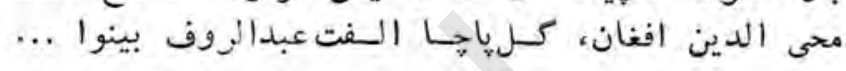

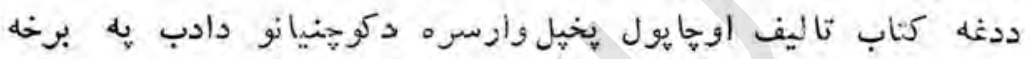

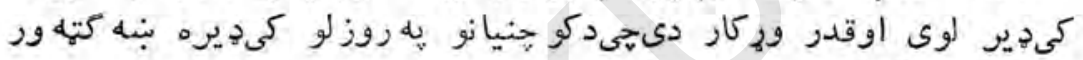

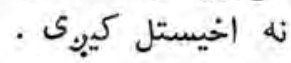

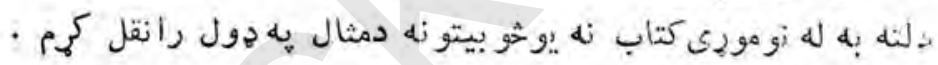

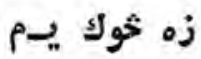

\section{زه بلثوكنه يمه اولاددغر يبايمه}

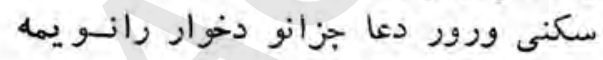
ماته آغا ماته بادار ماته صاحب مرونه وايه جرانه

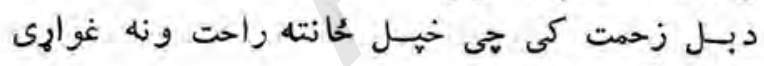

هير ويريدلى له نامه دصاحبانو يمه زحت دئ

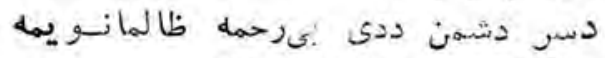

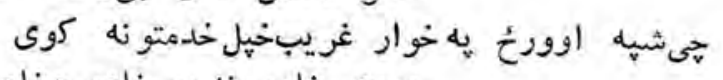

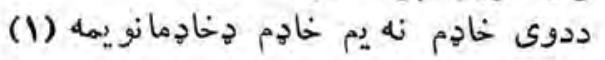

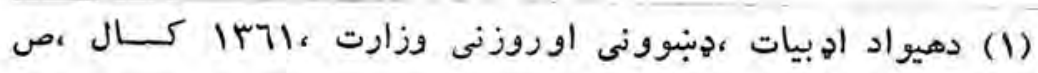


رسمي شوى قصى (ن رسم

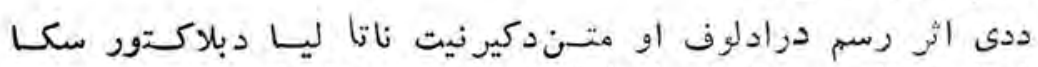

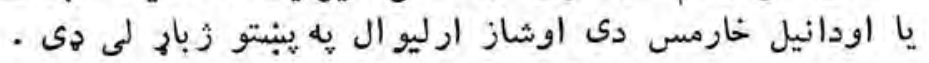

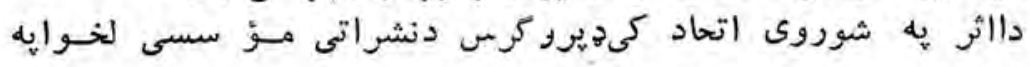

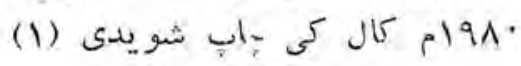
رنكه تصويرى مجله

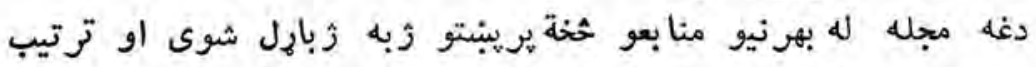

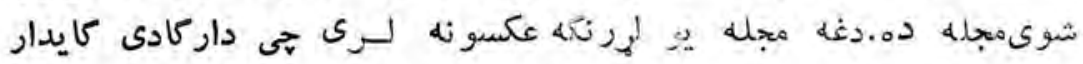

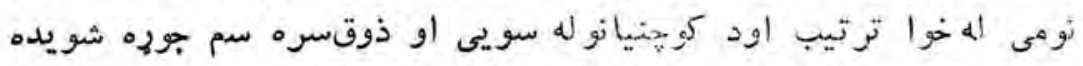

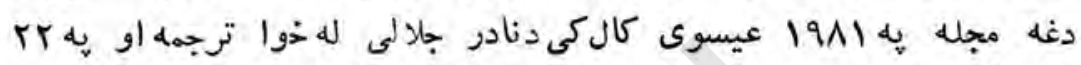
حاب إ او خيره شويده

زموب جغرافيا

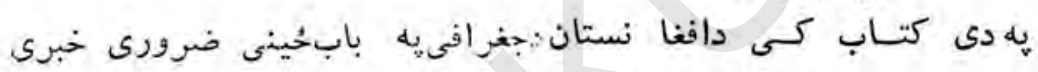

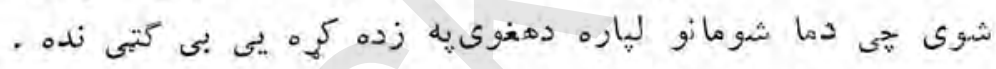

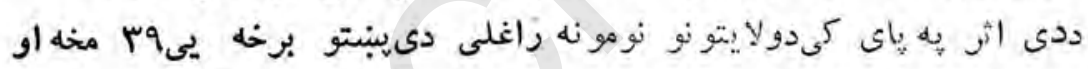

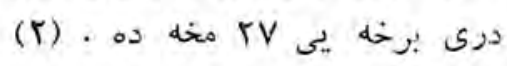
زموبٍ درّيم

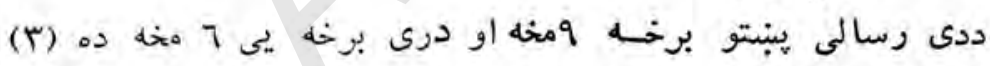
زموب ملـى سرود

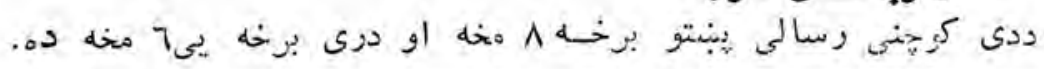

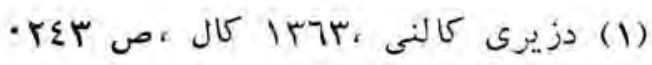
(r)

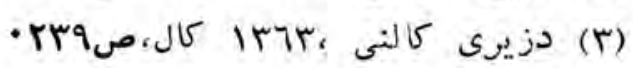
$-\backslash \wedge \mid-$ 


\section{زموبن وطن}

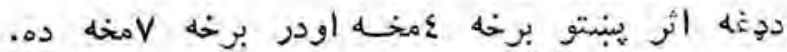

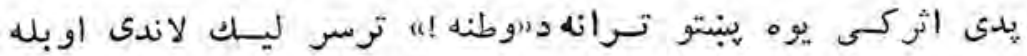

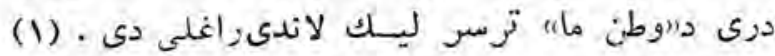

زموب هيواد) مناد

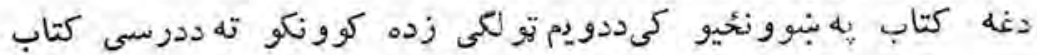

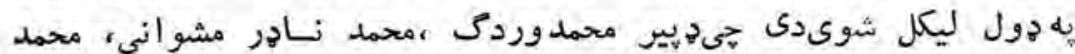

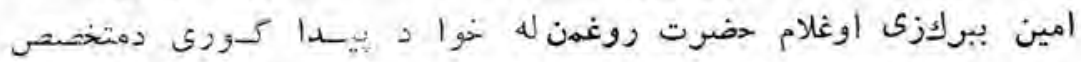

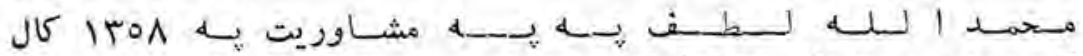
كى يه مه هخونو كى تاليف اودنبوو نىاو روزنى دتاليف اوترجسمى درينا

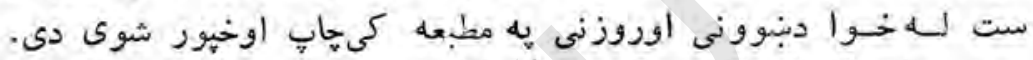

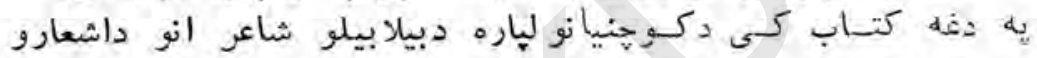

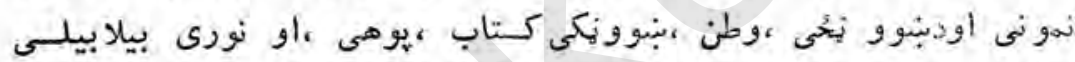

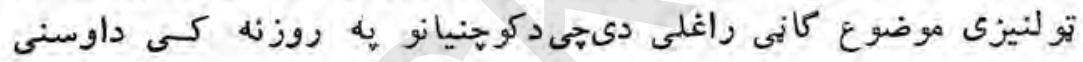

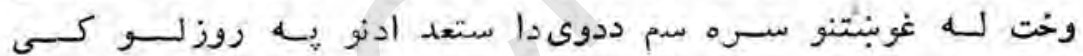

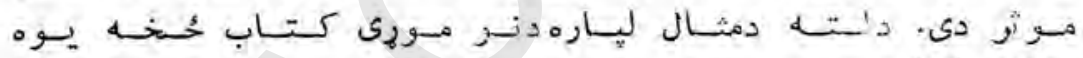
ترانه رانتلوم تون. ماشــو مان

هوخا ته هير كران يومان

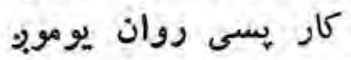
مكتب ته توروان يو يو مورون ننك ماشومان يو مورو تهو

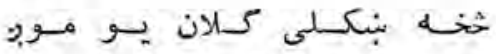

$$
\begin{aligned}
& \text { خوب نه جابى نإخيزو } \\
& \text { كار كوو سبق إه لو } \\
& \text { موبر يودسبا زلميان }
\end{aligned}
$$

دزيرى كالنى ،rاצו كسال، وبr. 
بنكلى زيار كبنبان يوموبر.

$$
\text { بايو دهيواد يه مينه }
$$

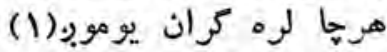

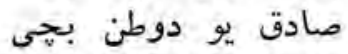

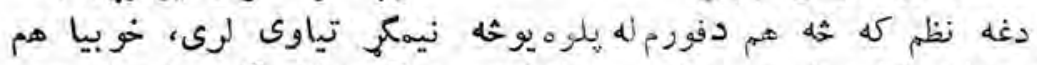

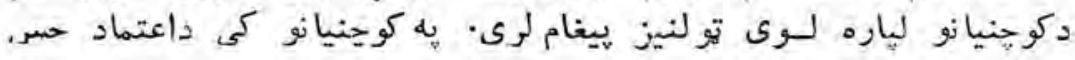

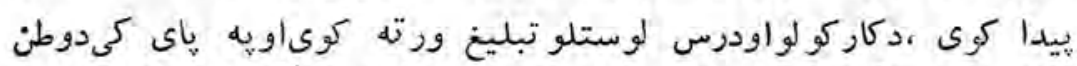

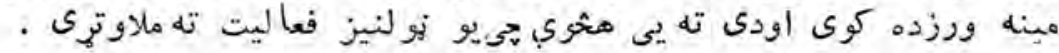

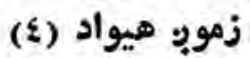

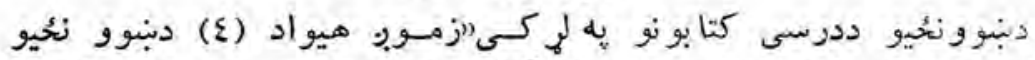

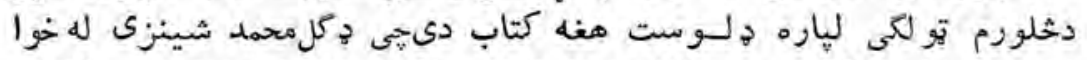

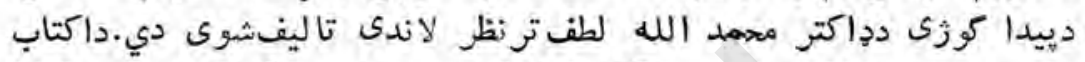

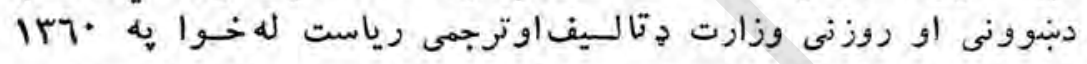

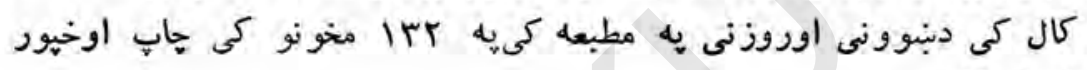

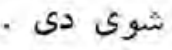

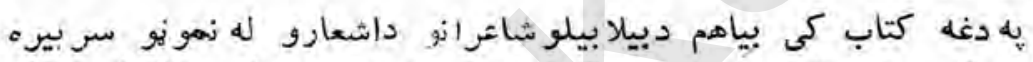

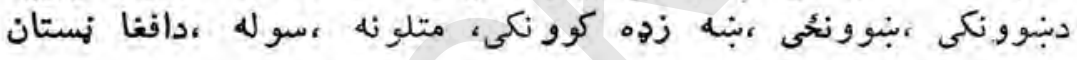

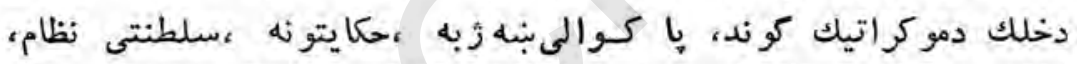

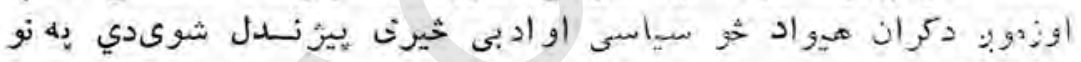

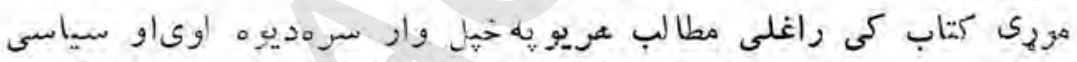

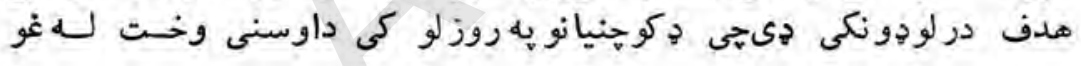

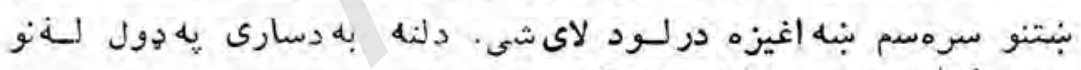

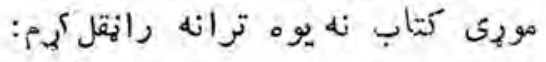

\section{بنبوونكى}

تإيتنكان دو زلى كلى

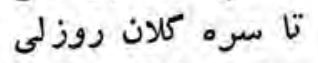

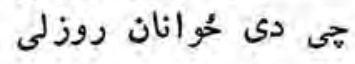

$$
\begin{aligned}
& \text { ته يى ديوهى هيوه } \\
& \text { ددى جهمن لهاره } \\
& \text { ته هيه هيو اد مين يساره يسى }
\end{aligned}
$$

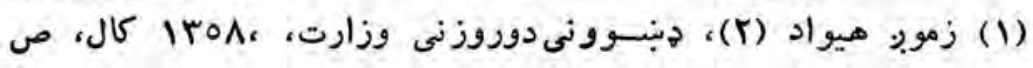


لوى انسا نان روزلهي

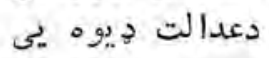

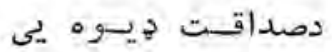

ته ويليدونكى شمعل دوني

ته روزيد ونكى شمعه

ديثيو زوينى نه نحار

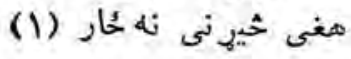

تسا دتاريخ خيو كى دي

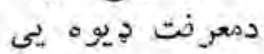
جيى نوى نسل روزى

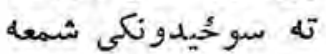
دنيا ريه تا روبينانه ستا دنبورنى نه نهار

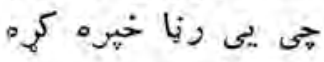

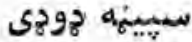

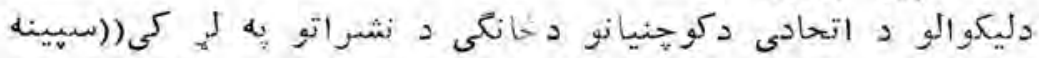

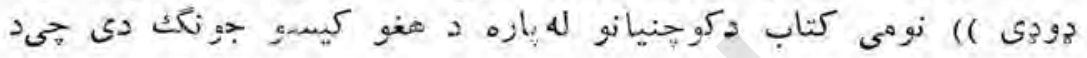

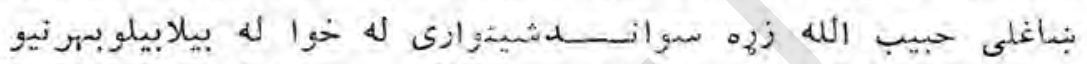

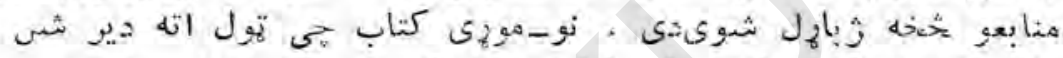

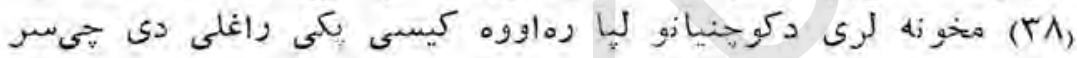

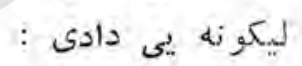

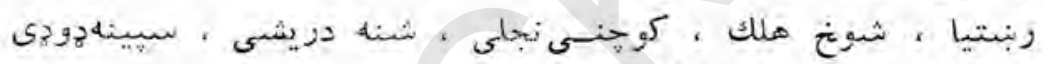

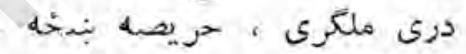

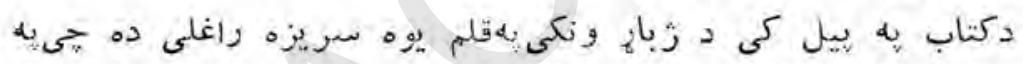

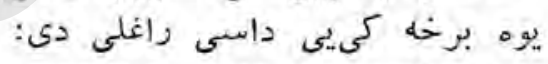

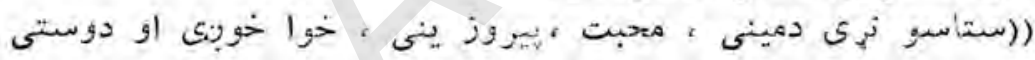

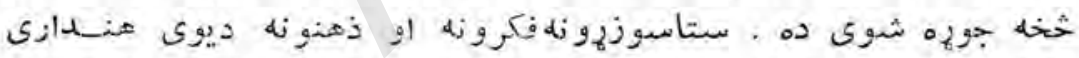

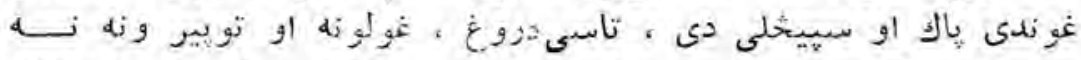

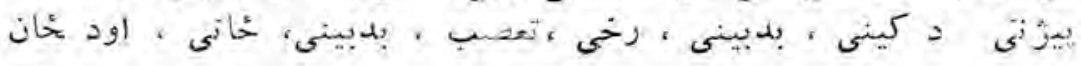

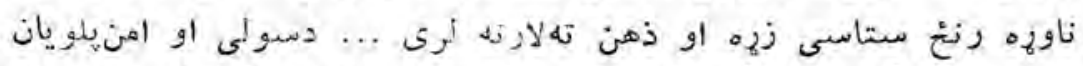

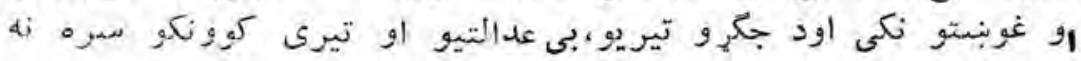

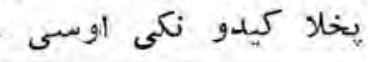

(1) $-1 \wedge \varepsilon$ 


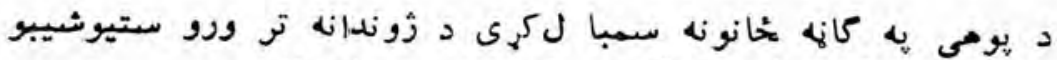

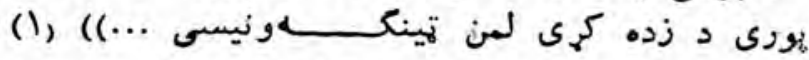

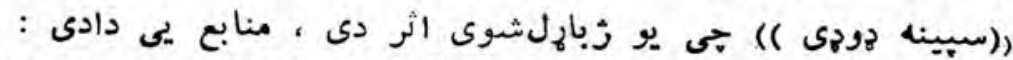

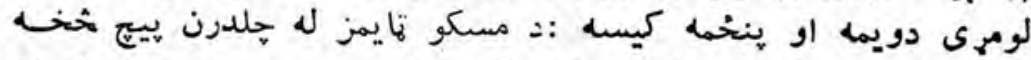

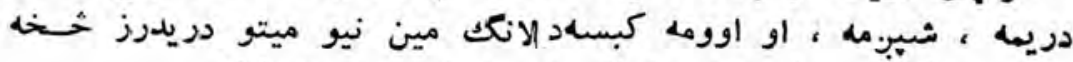

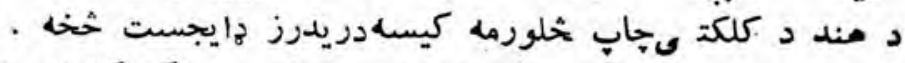

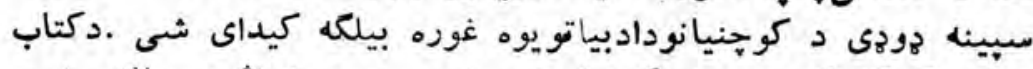

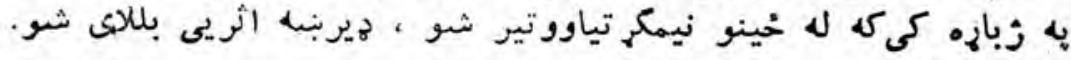

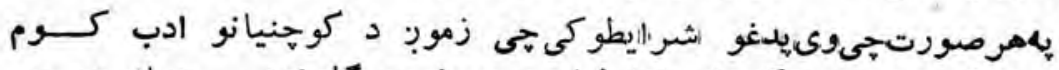

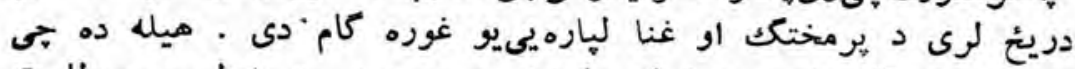

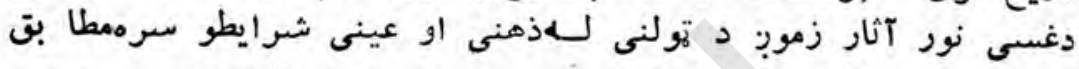

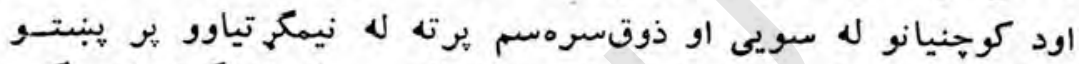

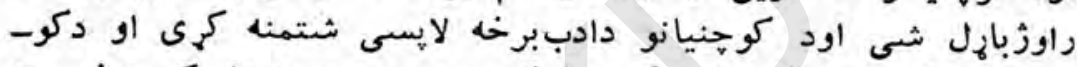

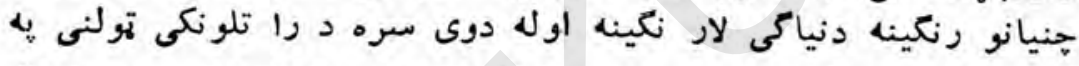

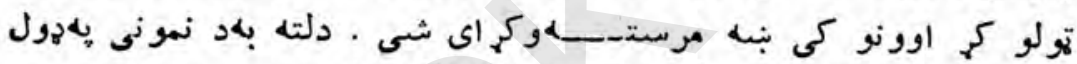

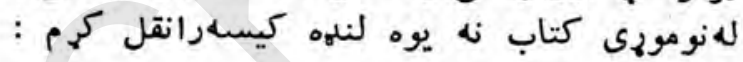

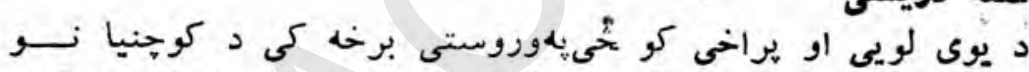

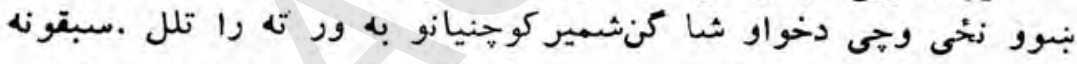

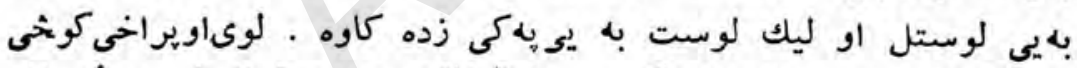

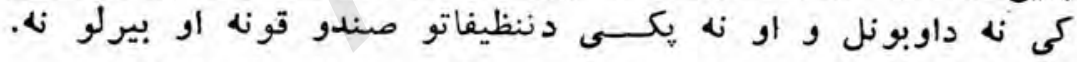

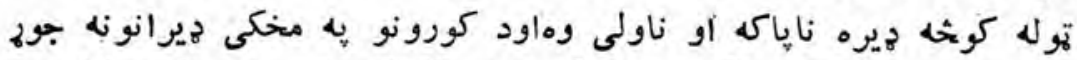

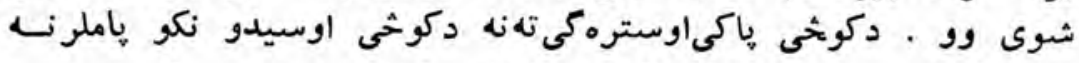

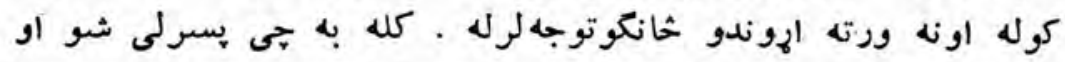

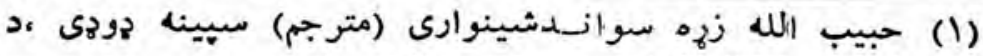

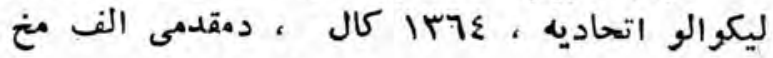
-110_ 


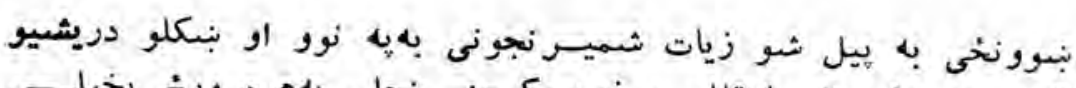

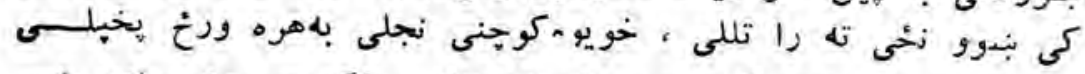

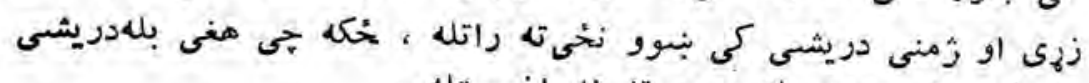

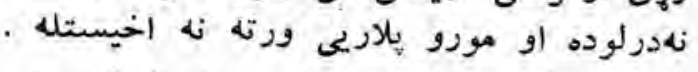

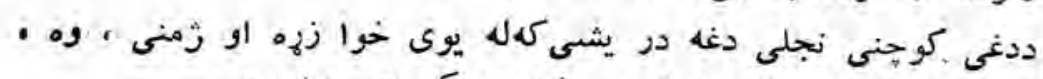

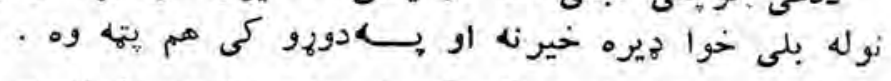

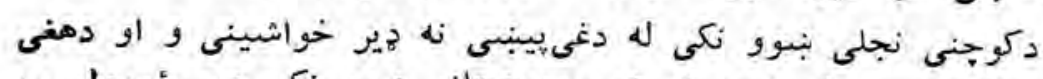

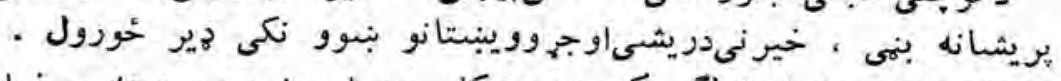

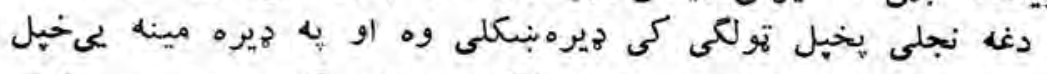

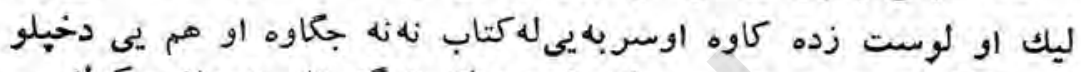

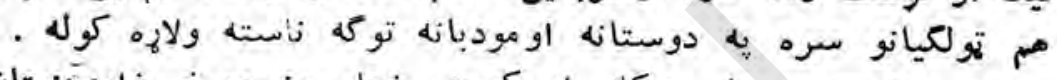

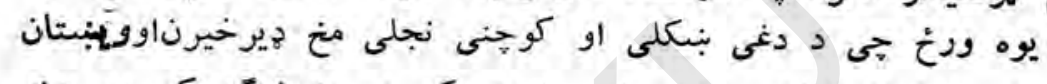

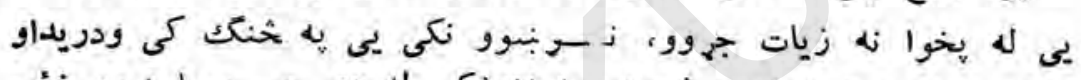

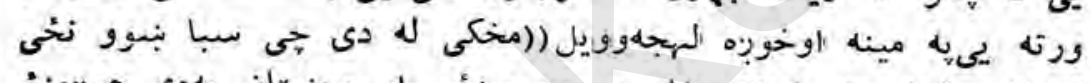

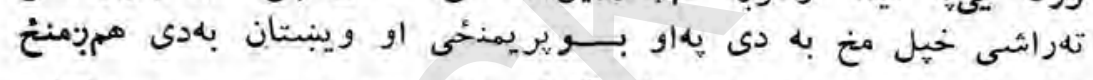

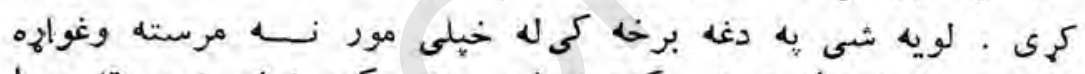

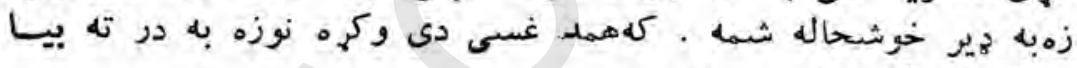

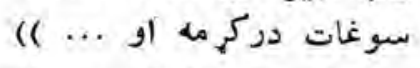

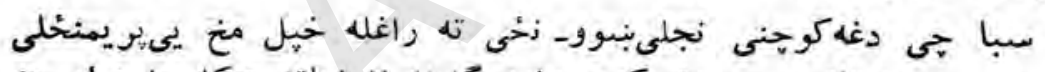

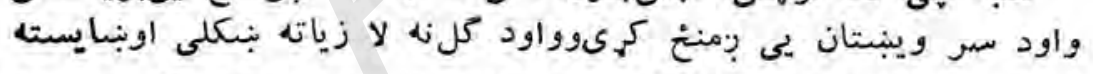

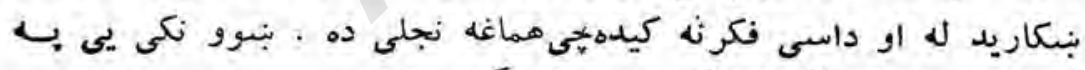

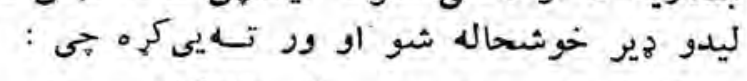

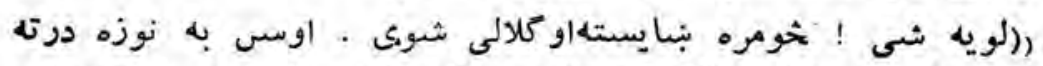

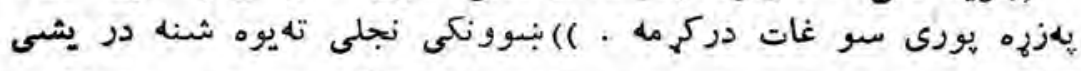

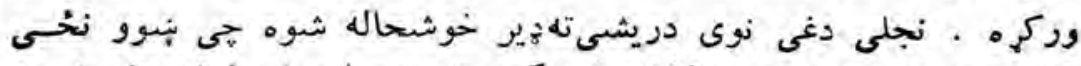

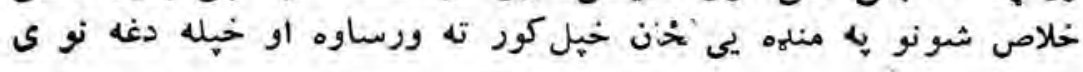


دريشى يى خهلى مور ته وبنسود لهاو موريى ور ته هيره خوشحا لـى . و

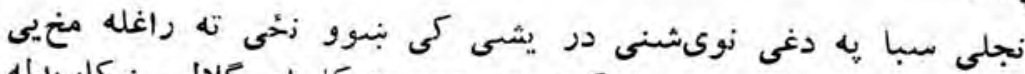

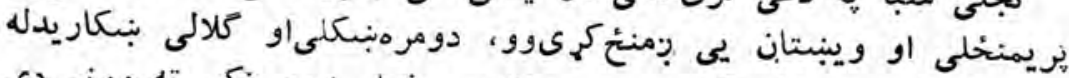

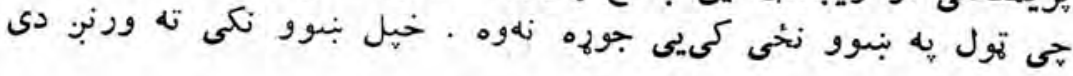

شوه او ورته يى وويل :

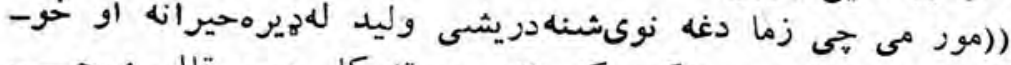

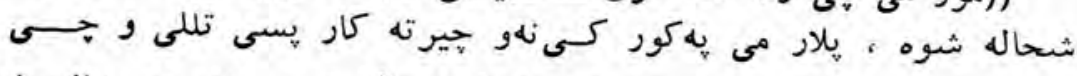

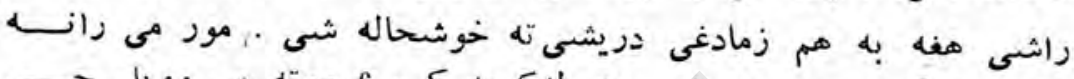

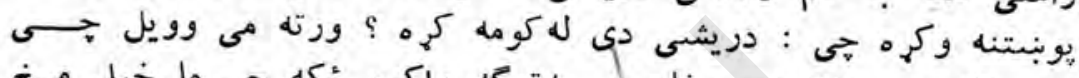

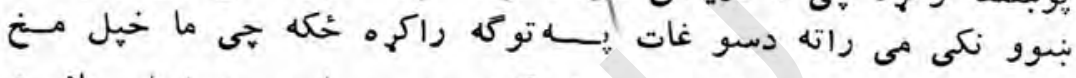

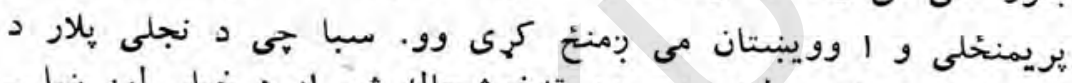

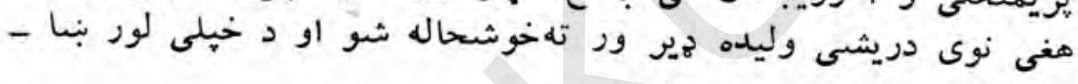

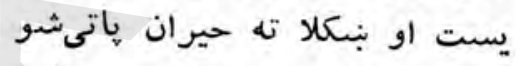

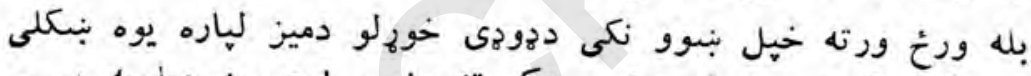

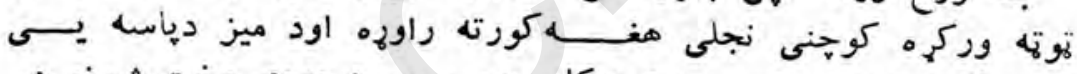

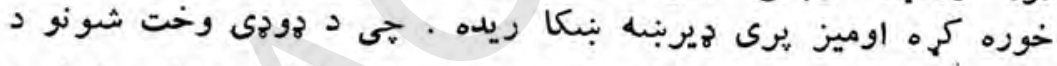

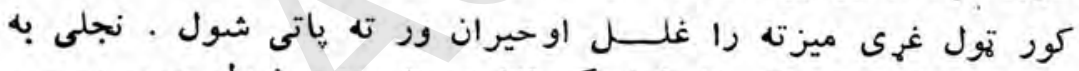

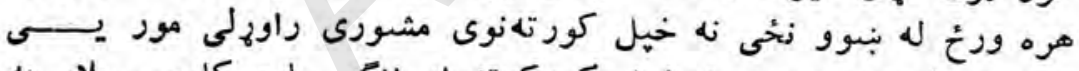

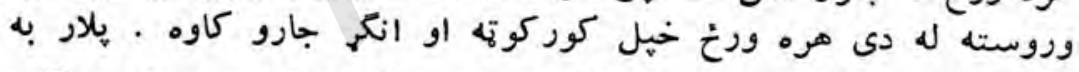

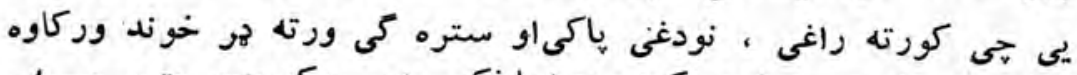

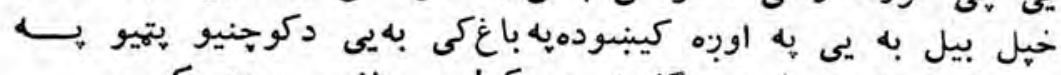

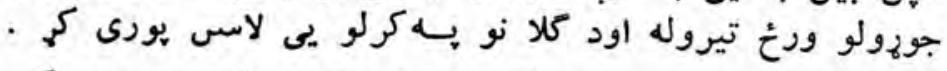

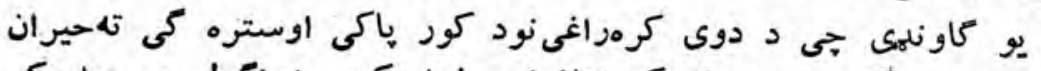

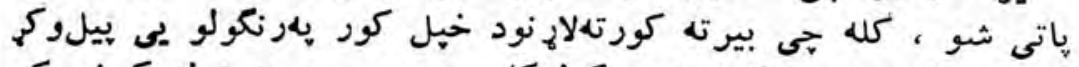

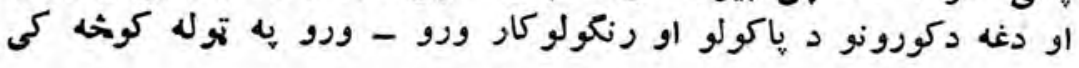




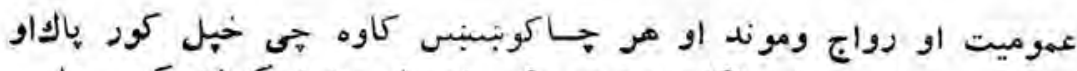

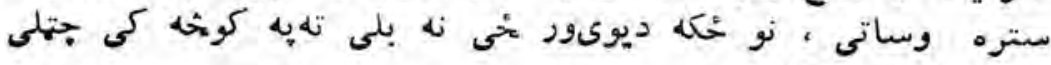

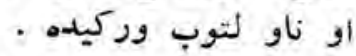

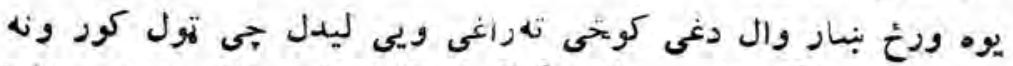

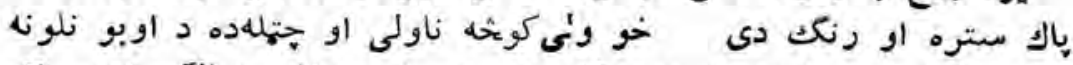

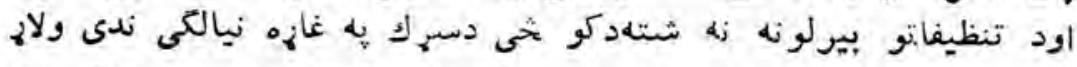

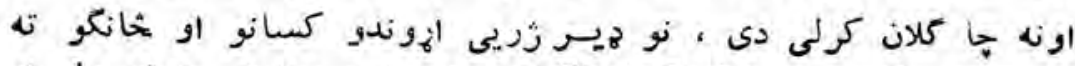

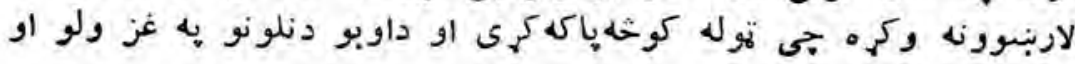

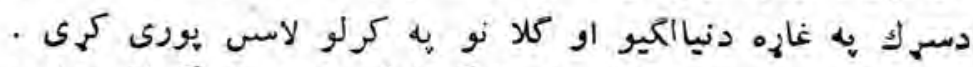

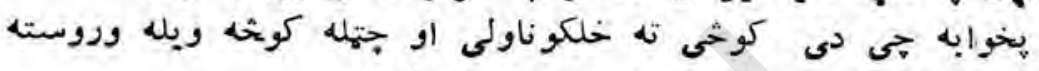

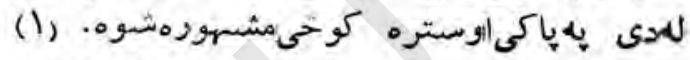

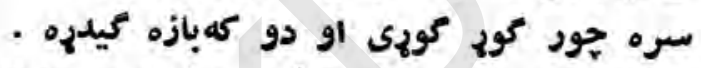

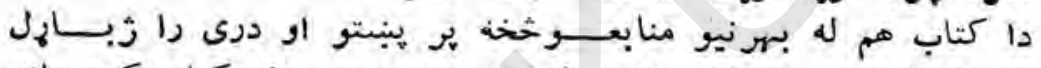

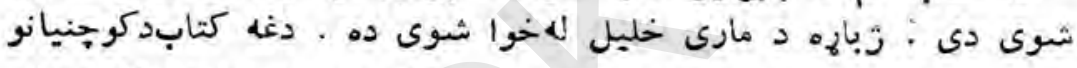

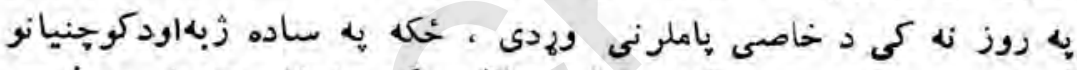

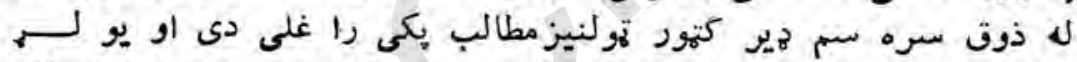

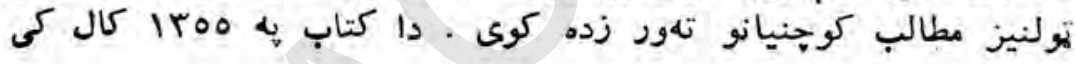

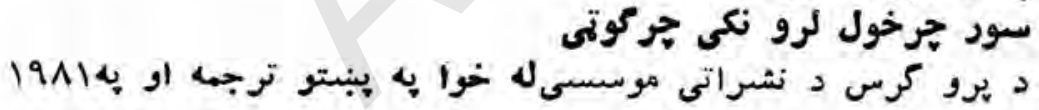

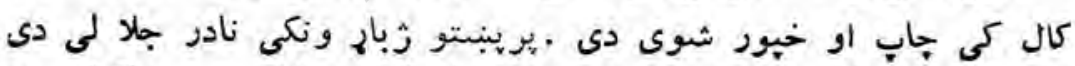

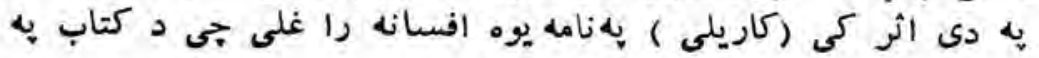

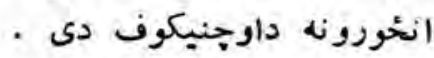

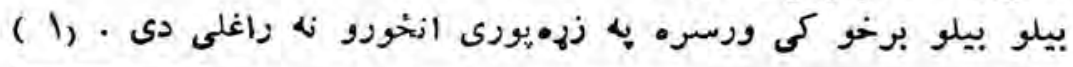

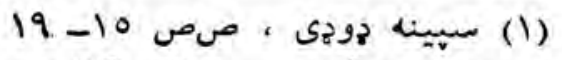

r 


\section{سور حور كورى}

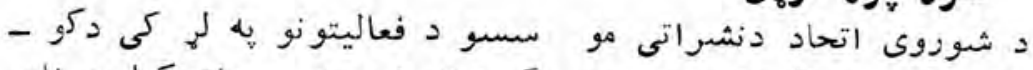

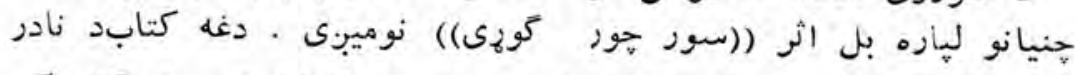

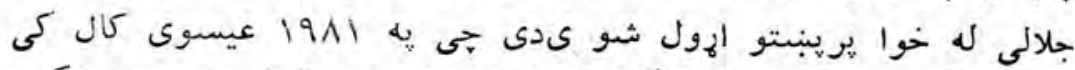

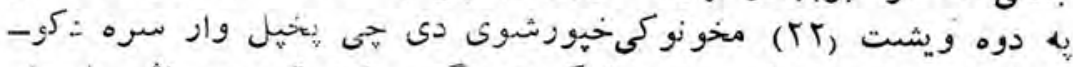

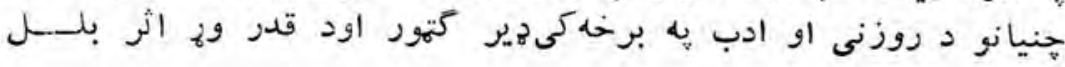
كيبنى

\section{شو كتاغان}

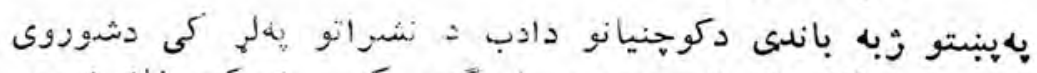

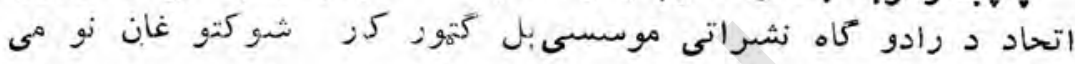

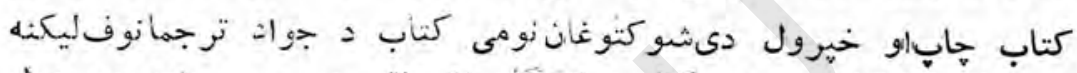

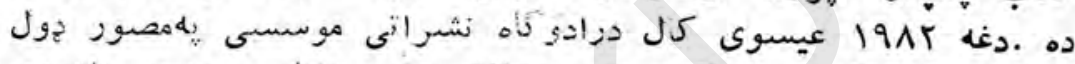

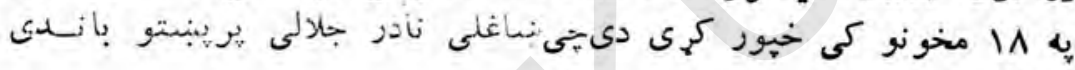

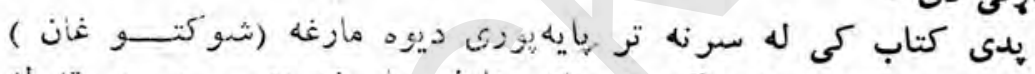

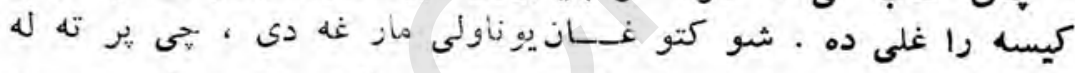

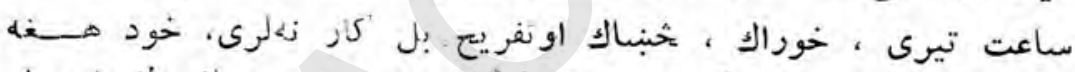

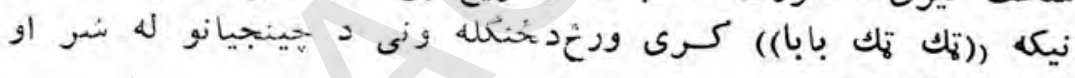
آفت نه خلاصوى نه

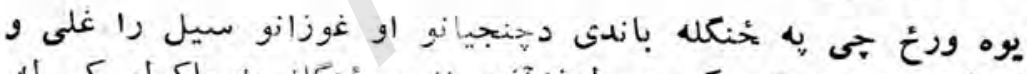

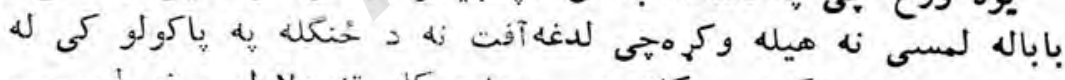

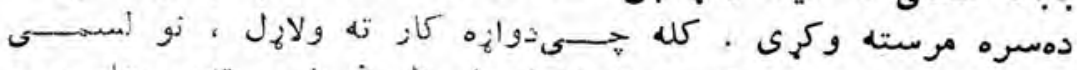

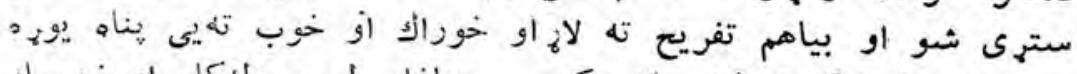

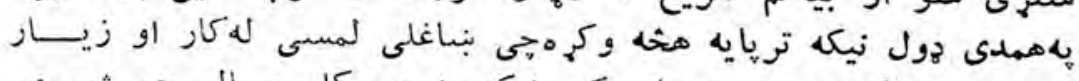

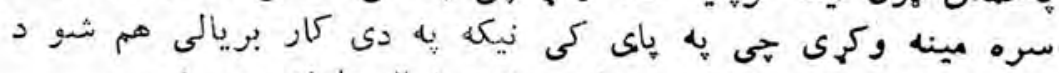

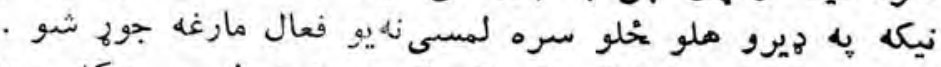

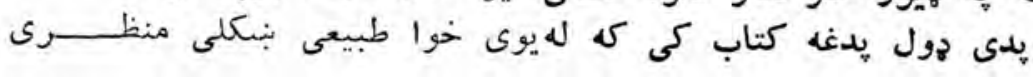




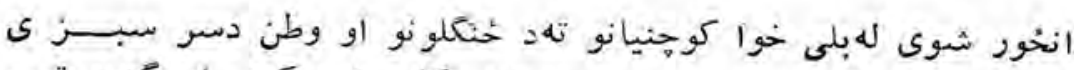

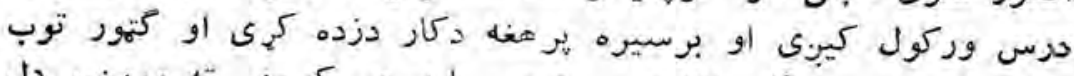

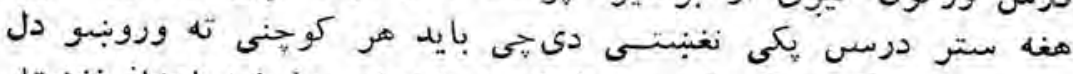

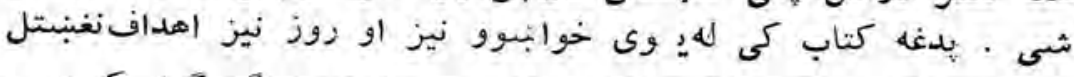

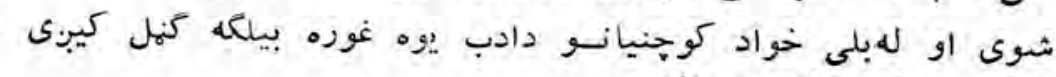

\section{غير عادى مسافت}

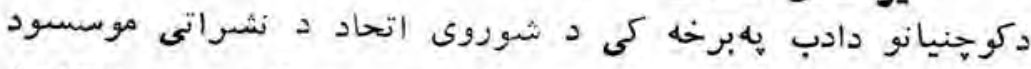

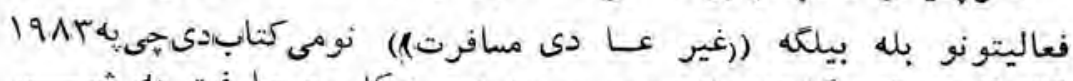

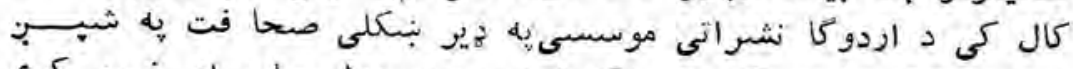

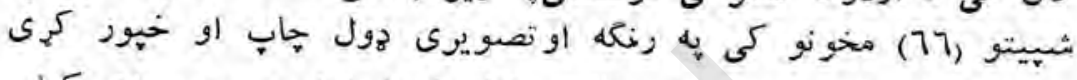

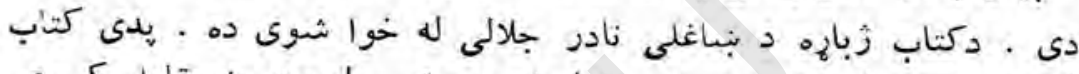

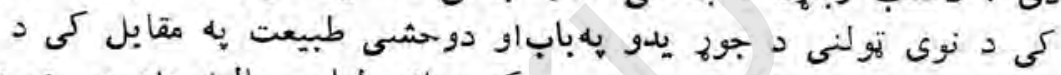

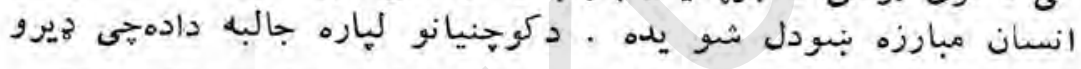

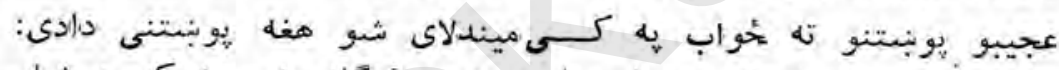

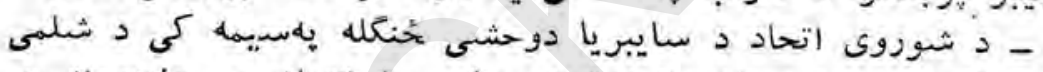

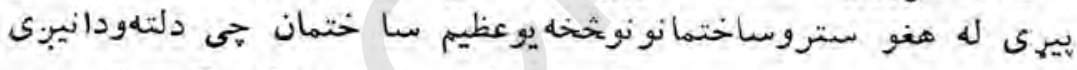

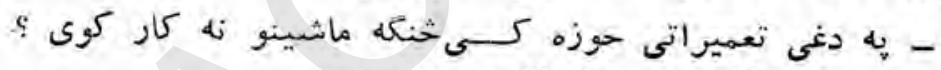

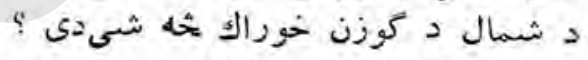

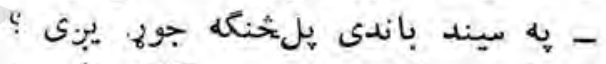

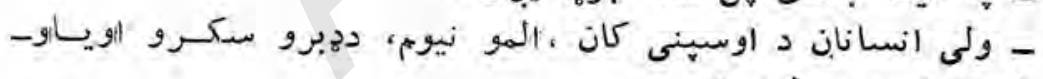

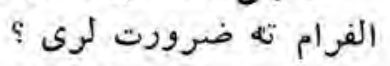

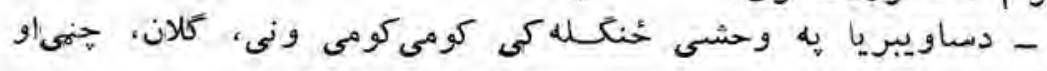

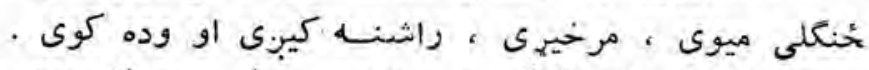

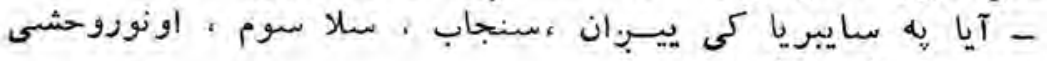
خناور زوند كوى كهنه

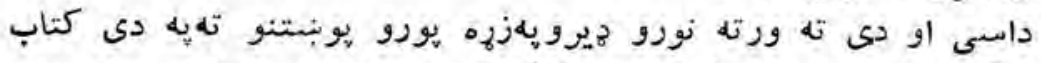

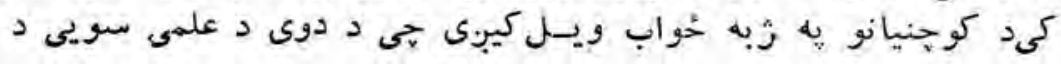
$-19 \cdot-$ 


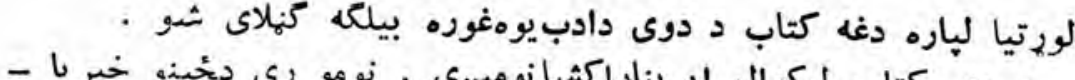

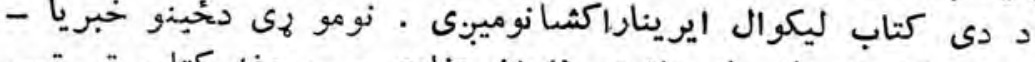

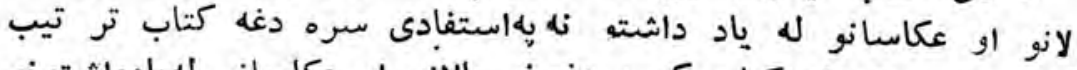

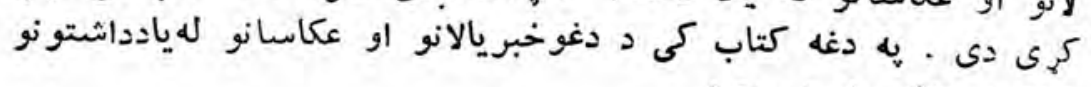

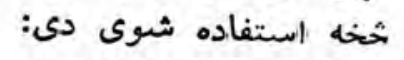

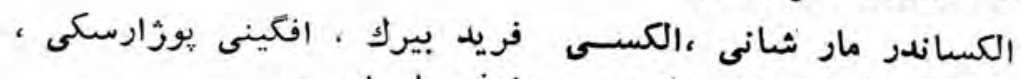

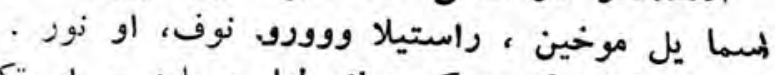

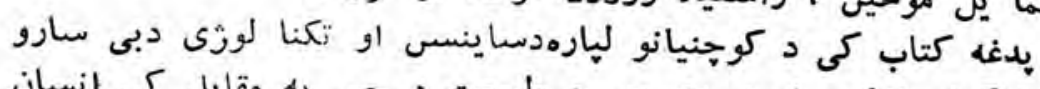

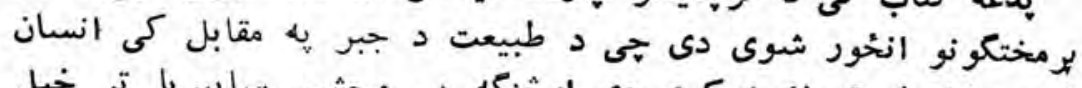

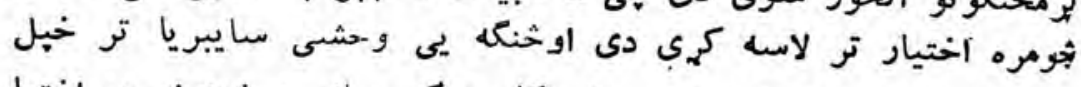

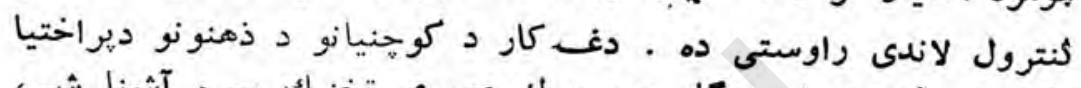

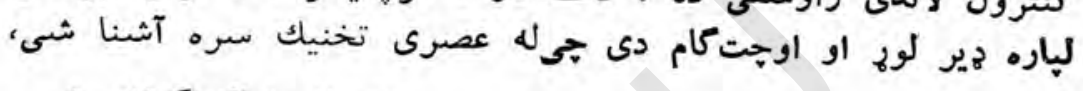

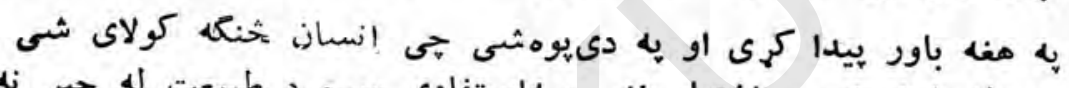

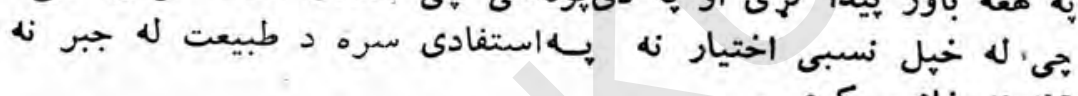

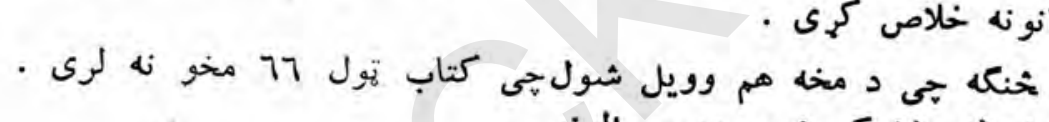

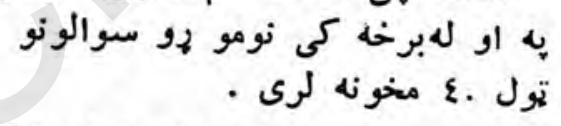

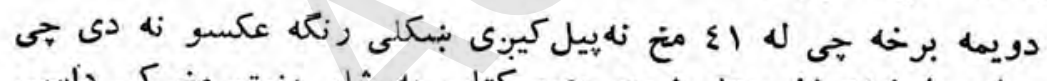

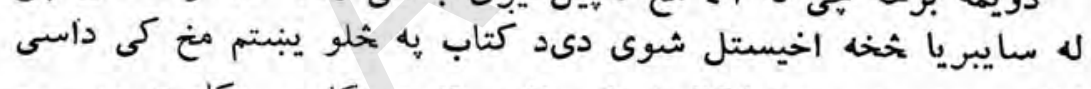

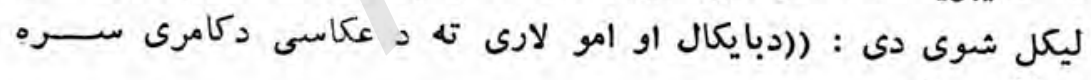

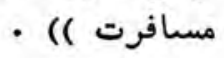

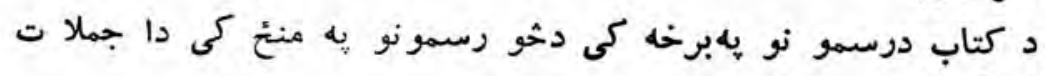

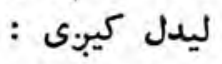

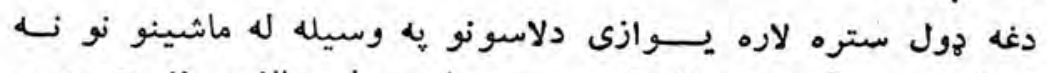

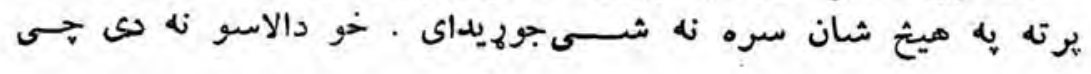




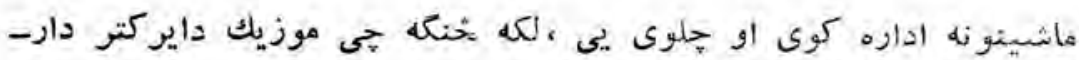

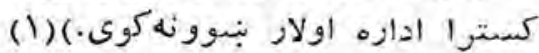

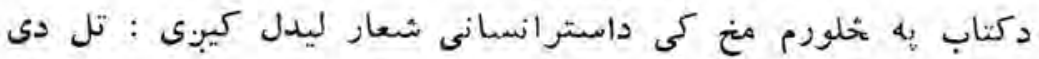

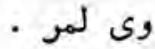

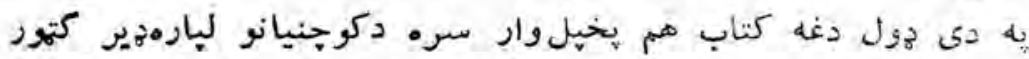

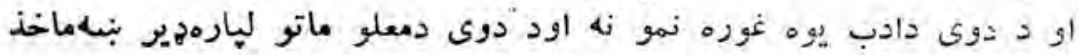

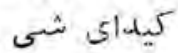

فولا دى مُوتى

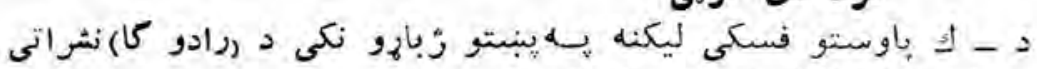

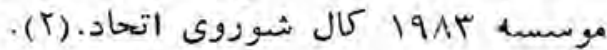

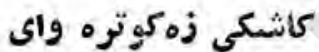

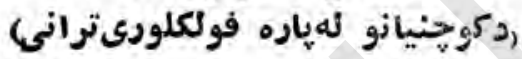

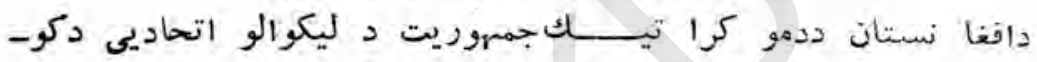

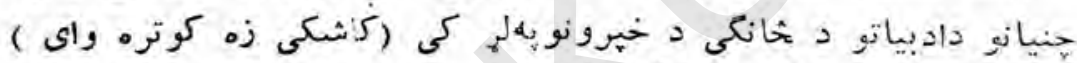

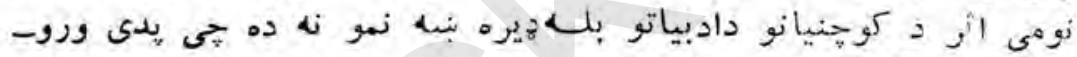

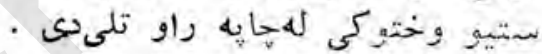

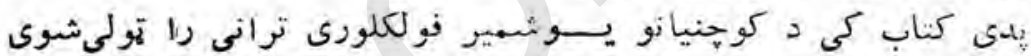

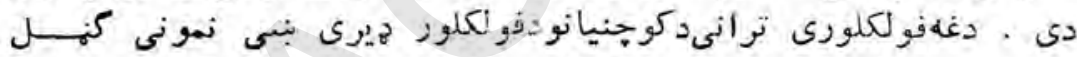

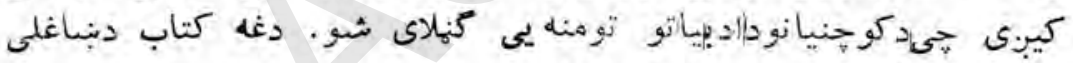

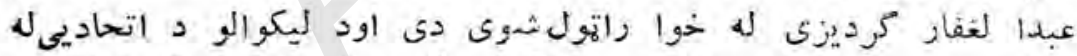

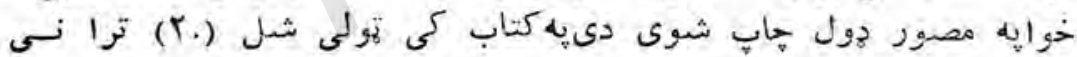

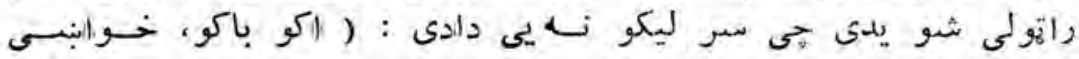

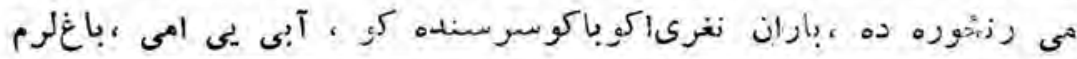

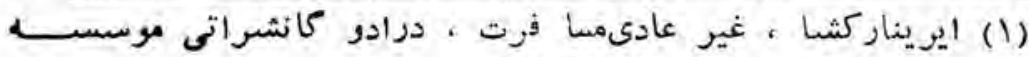

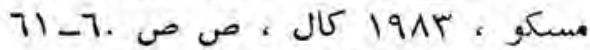

.

-l9r_ 


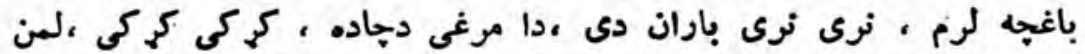

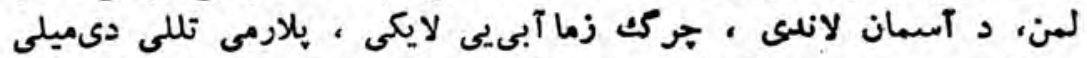

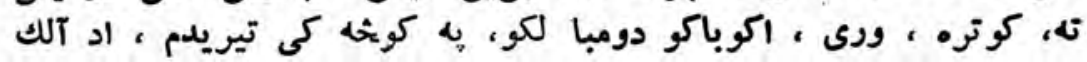

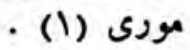

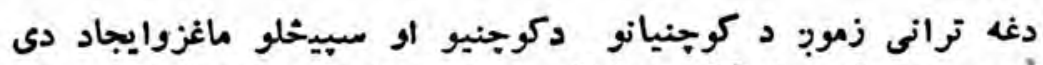

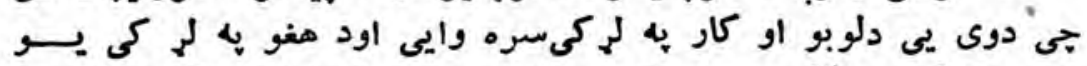

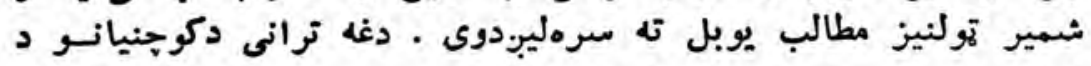

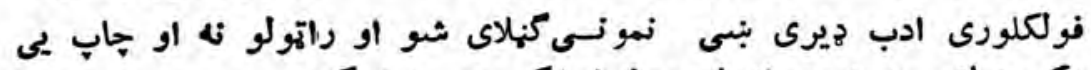

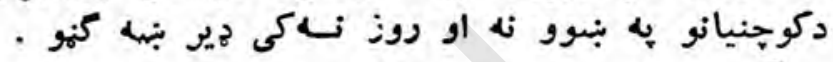
كيرى

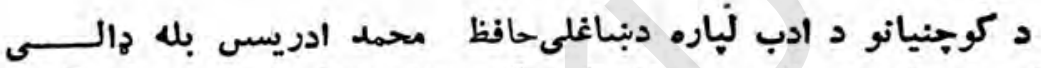

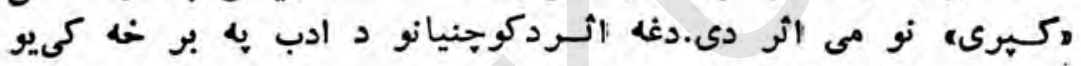

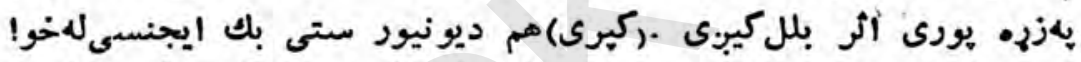

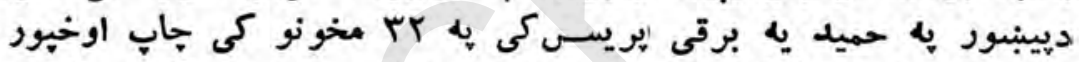

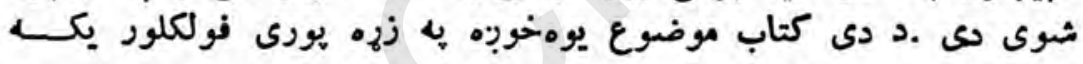

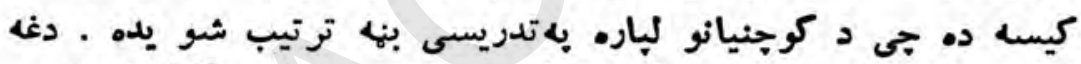

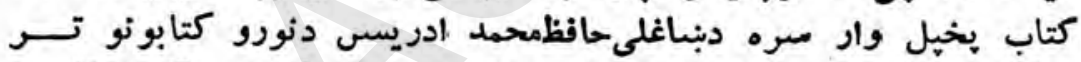

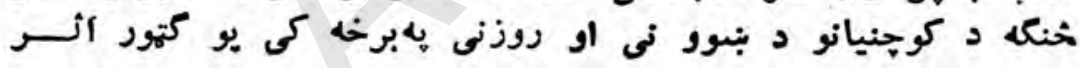

\section{بللاى شو •معى كناور}

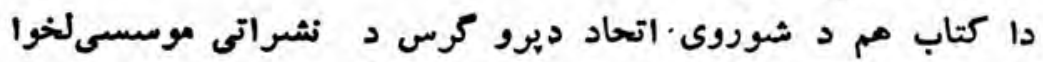

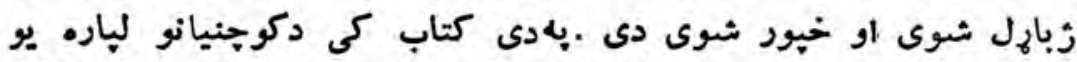

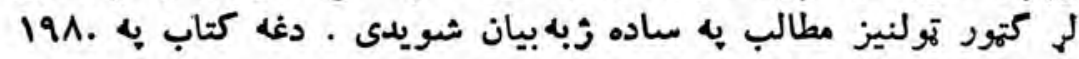

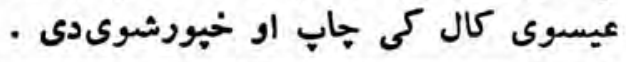

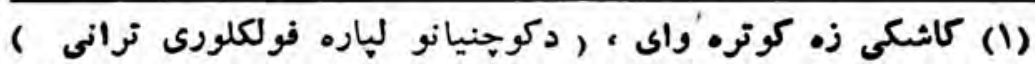

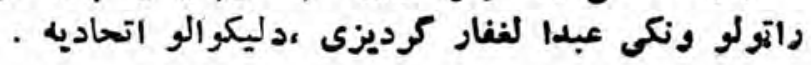
-19r- 


\section{كوجنيان}

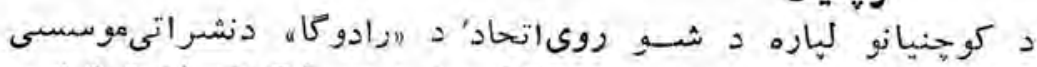

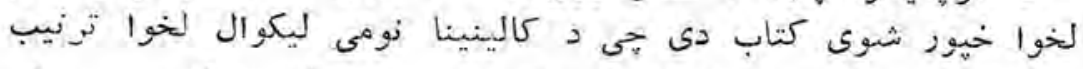

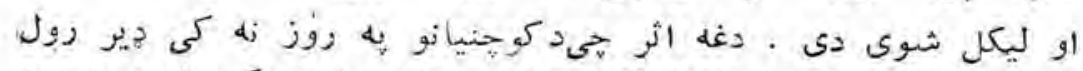

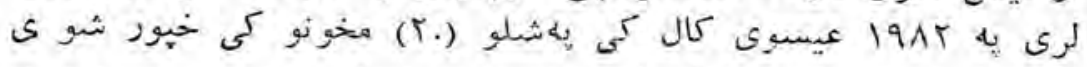

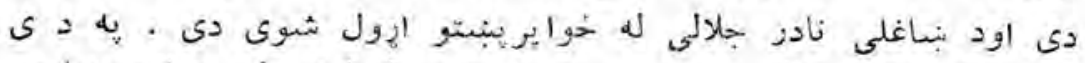

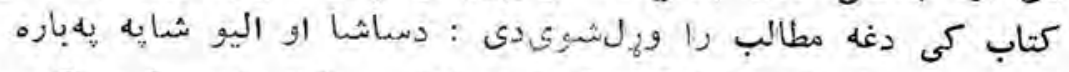

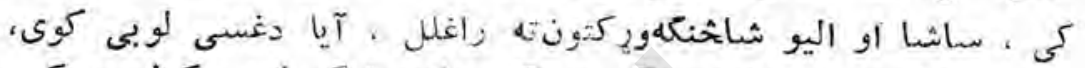

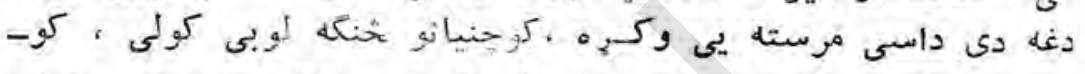

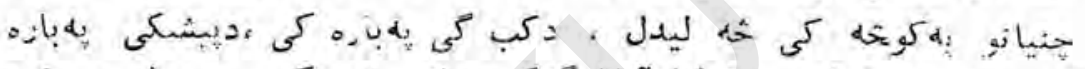

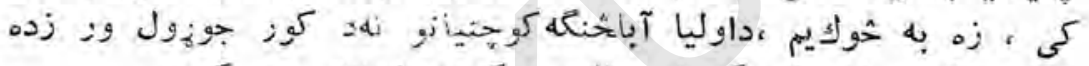

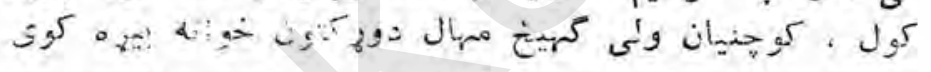

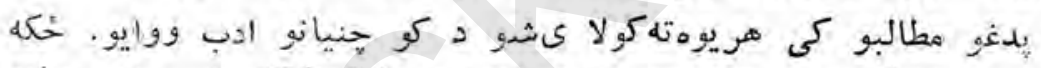

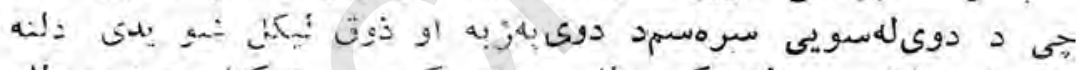

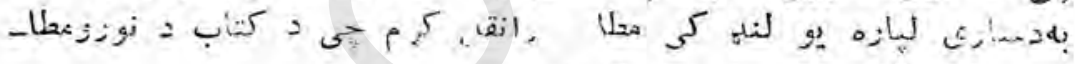

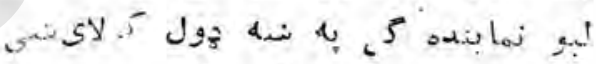

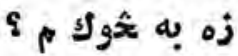

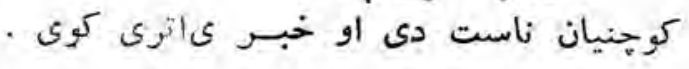
- زه به بيلوته يم

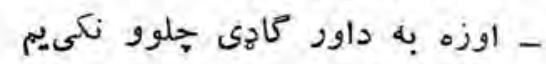
- زه بهزئ بهايوريم

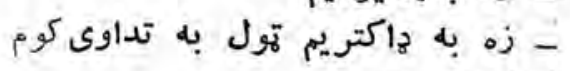

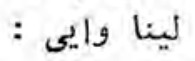

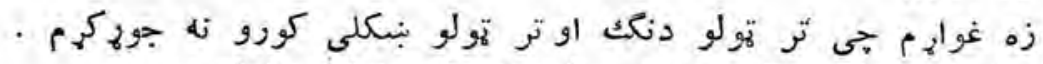

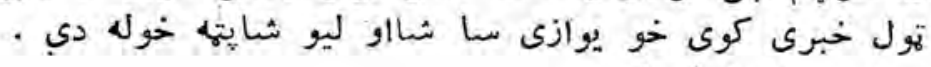
- تاسى به خوك كوى ياست. 
هغوى فكر وكه او وى ويل :

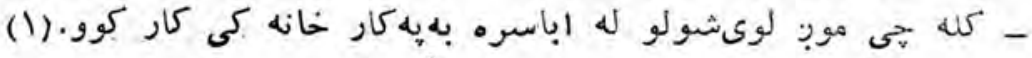
تمريت

د كوخينيانو دادب ليلره دشوروى:اتحاد = رادو كادنشراتى موسسـى

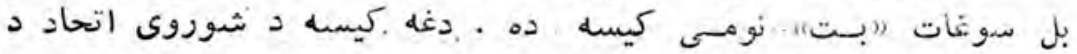

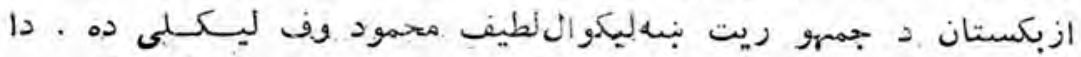

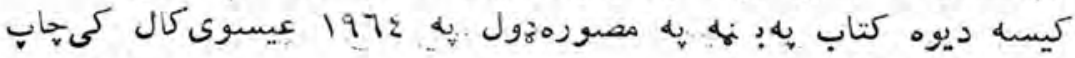

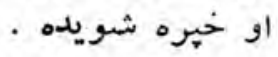

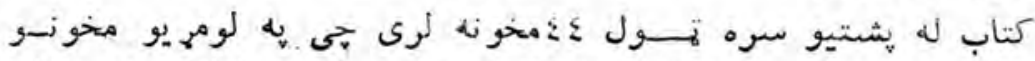

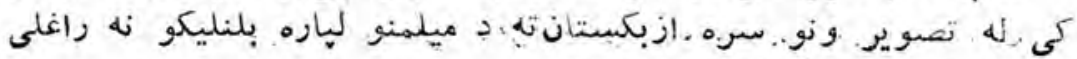

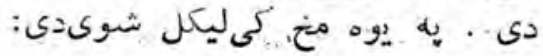

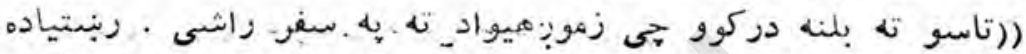

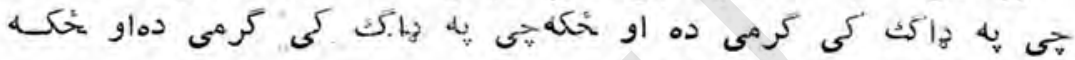

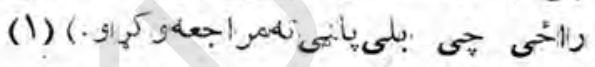

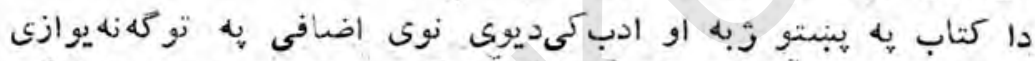

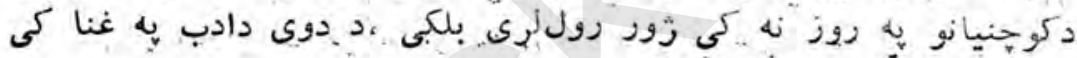

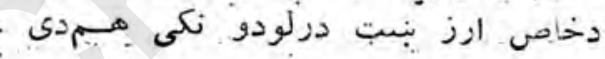
لقه موتر

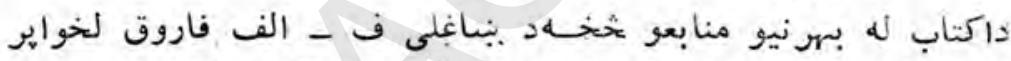

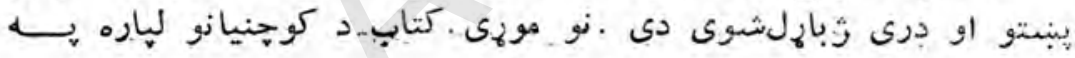

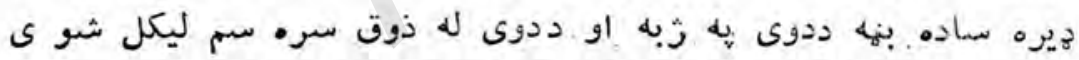

1) (1) كالينينا ،كوجنيان · درادكانشراتى موسسه ،

ع (1) 7 1915 $-190$ 


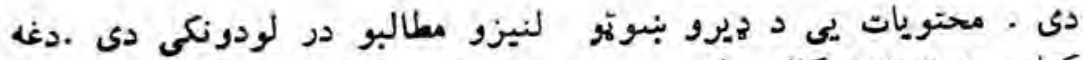

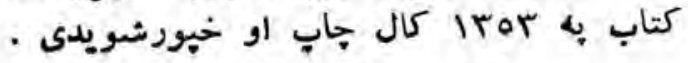

\section{لومئى كتاب}

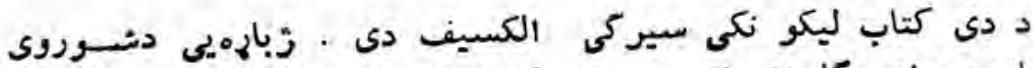

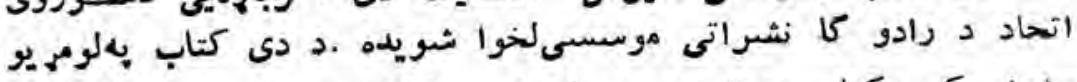

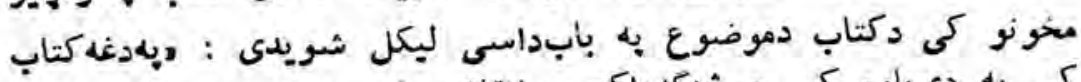

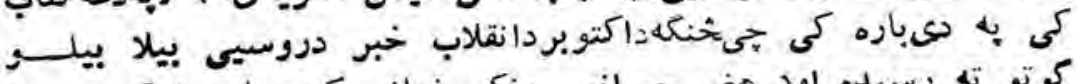

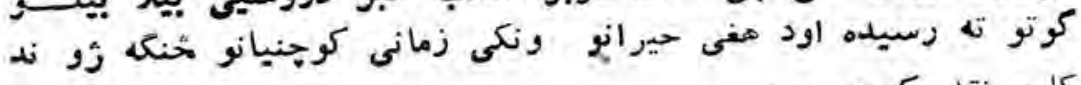

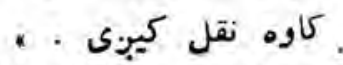

دى به دى كتاب كى دكوجنيانولياره د دوى بهزبه او ددوىلهسويى

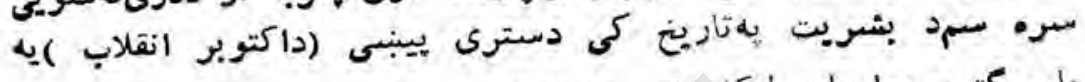

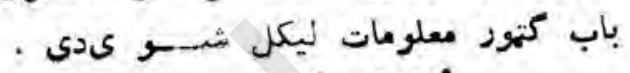
كومجى ماهي

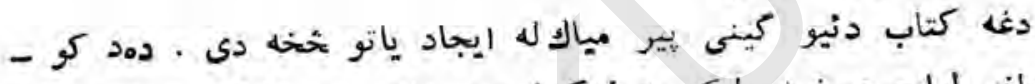

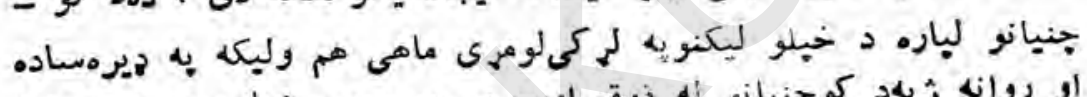

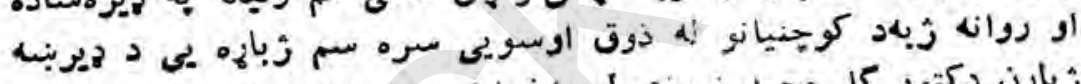

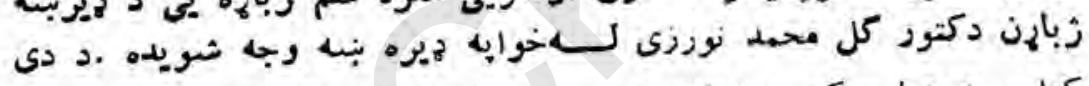

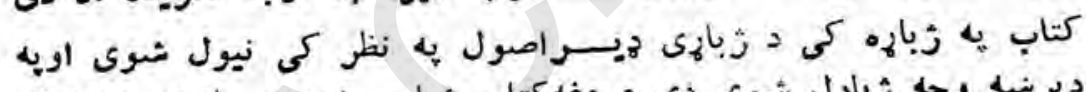

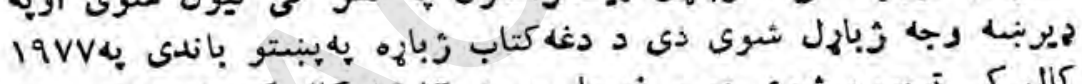

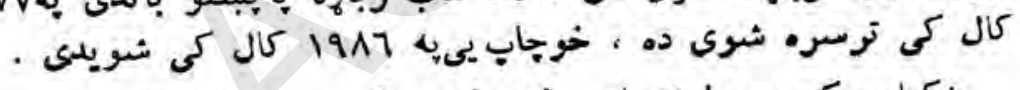

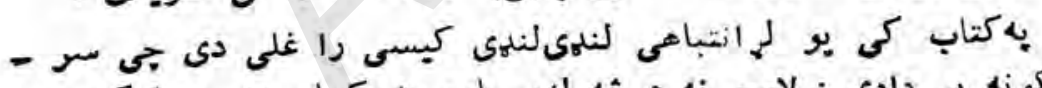

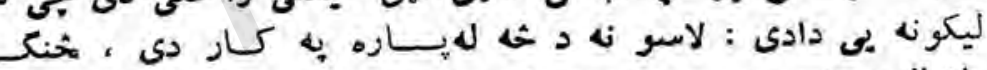

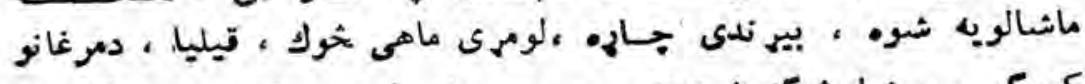

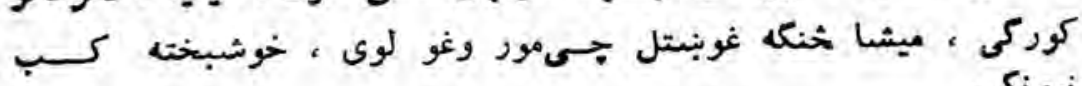
كتاب بِ مصود هول يو يبنتسوزبارل ثبوى او جاب شوى دى.دغه 


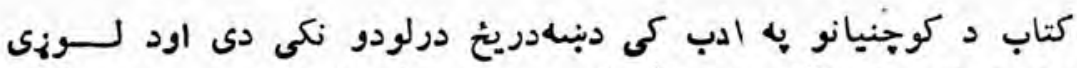

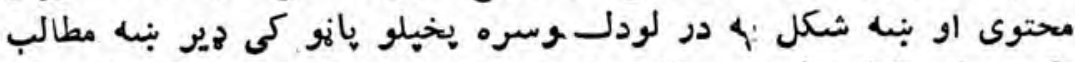

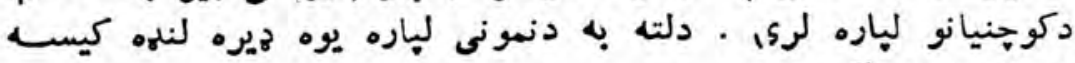

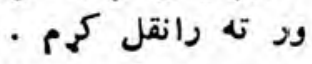

\section{خنكه ماشا لويه شوه}

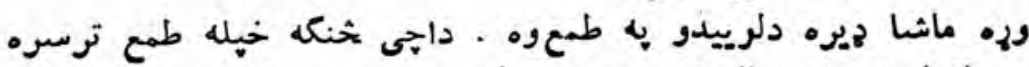

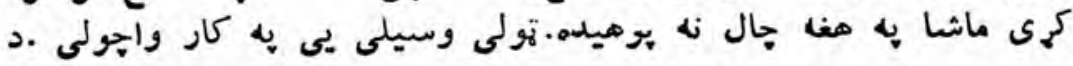

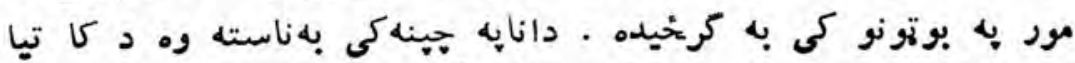

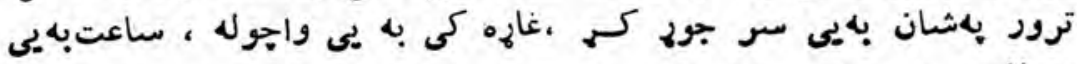

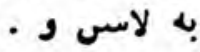

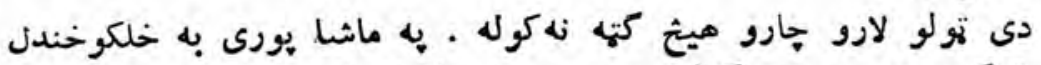

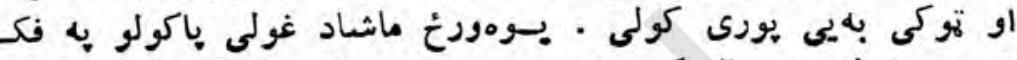

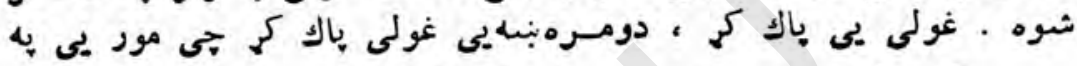

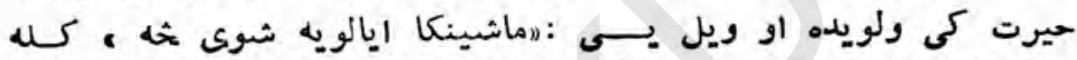

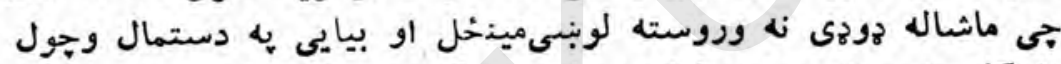

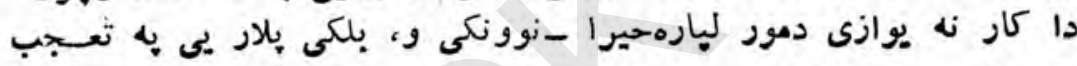

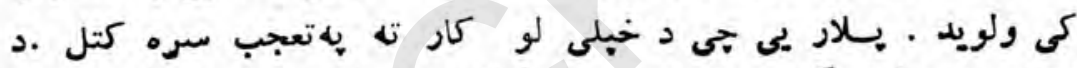

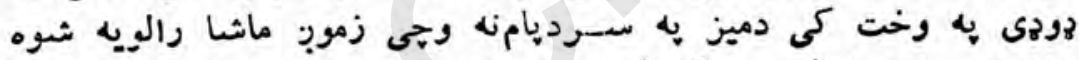

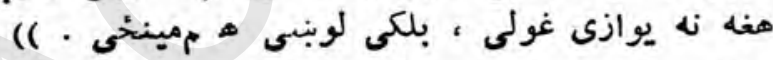

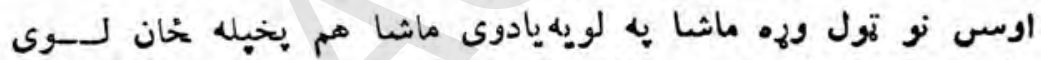

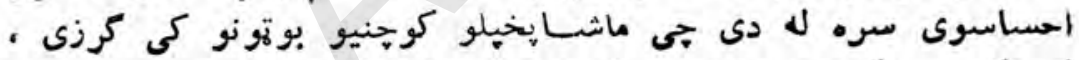

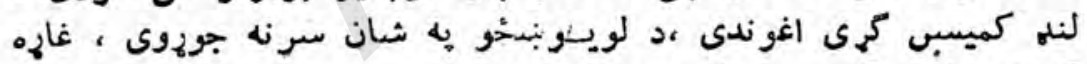

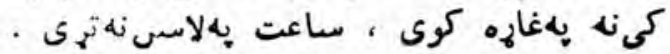

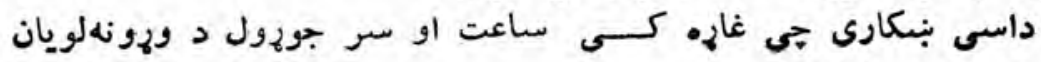

(1) · نهوجودى

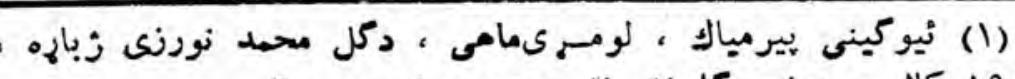

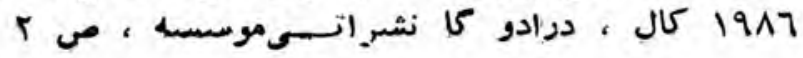
$-19 v-$ 


\section{ميبزى او كيهانى ييلوتي}

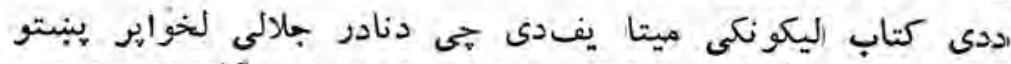

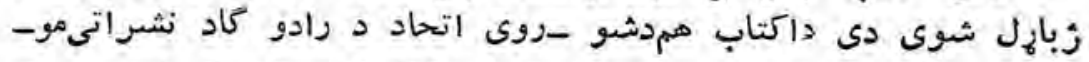

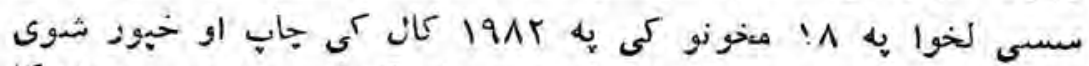

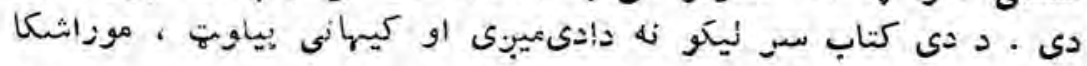

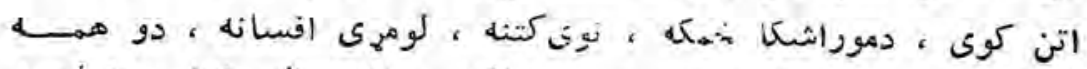

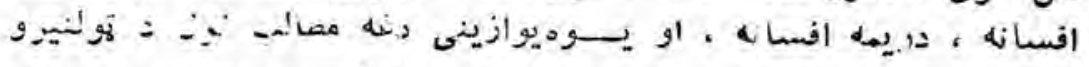

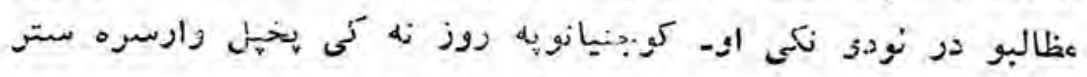

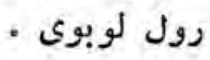

\section{ناديده}

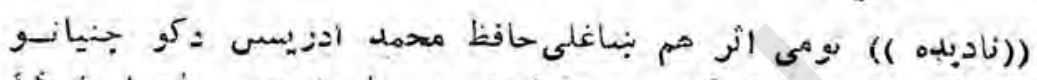

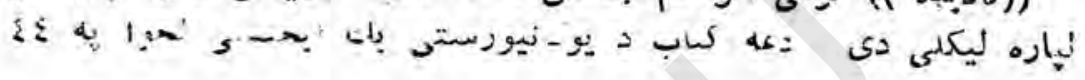

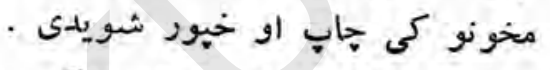

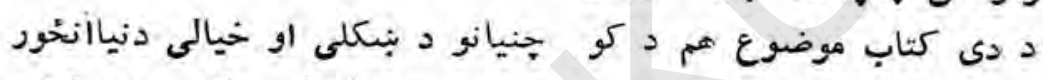

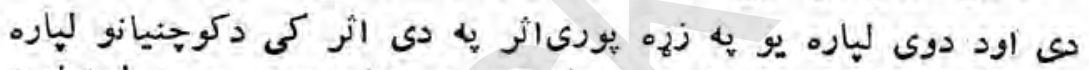

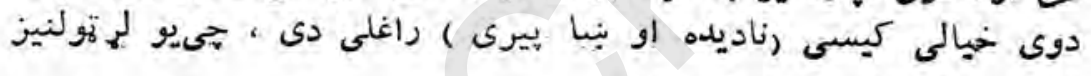

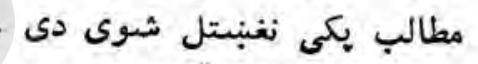
وهى قصى

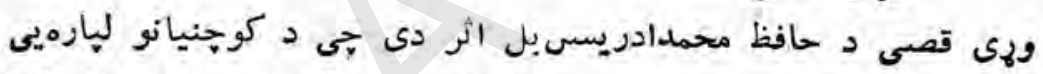

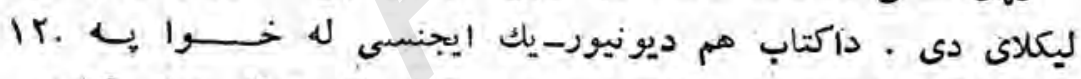

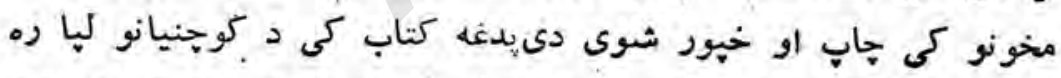

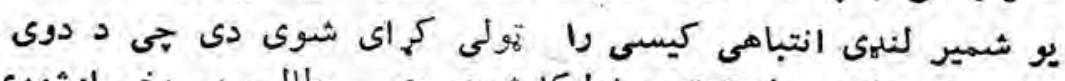

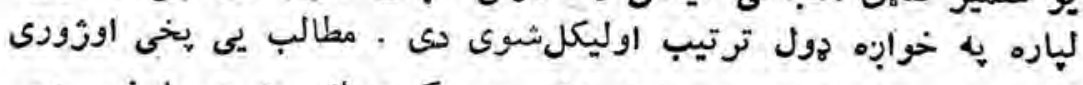

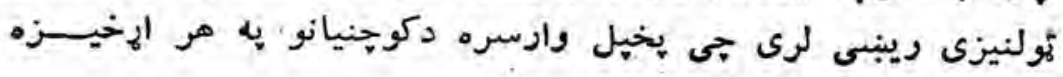

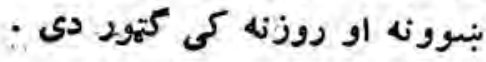


هر خوك يخيل دستود زوندكوى

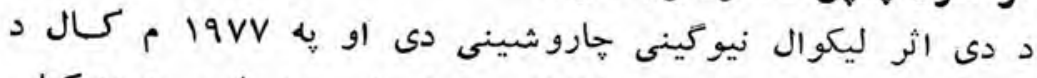

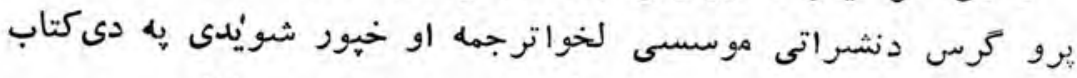

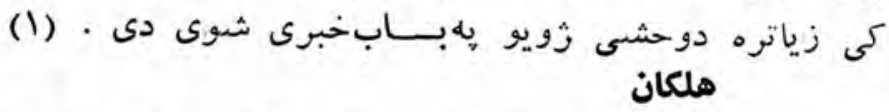

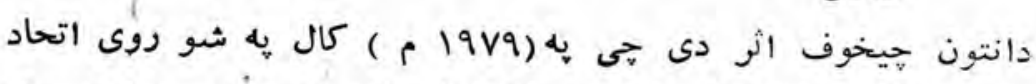

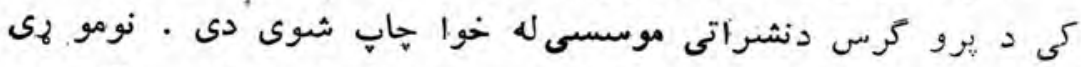

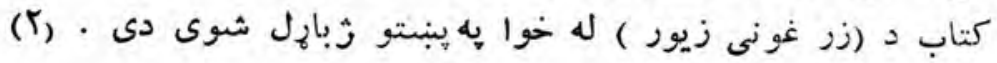
يوشكا

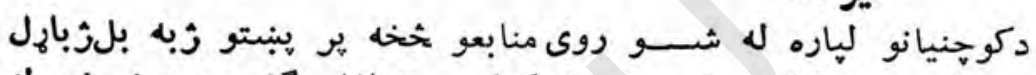

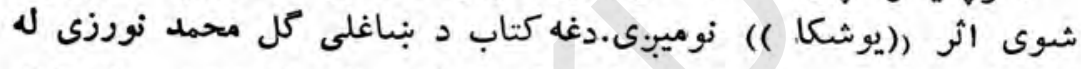

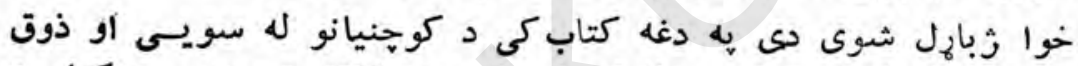

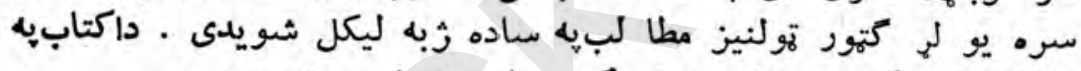
I IVV

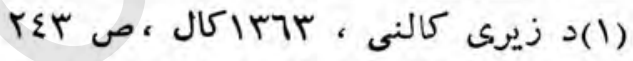

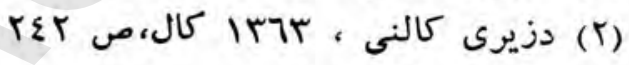




\section{دوكنينياتود ادبياتوز باري}

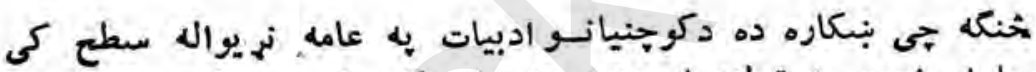

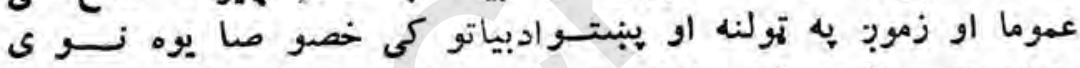

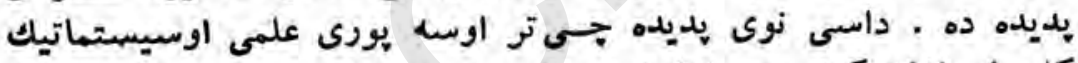

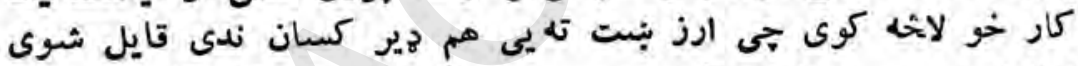

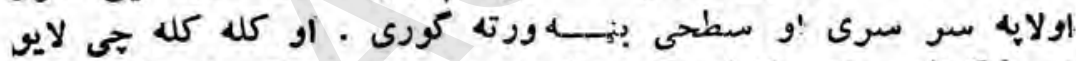

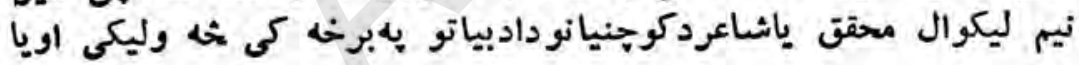

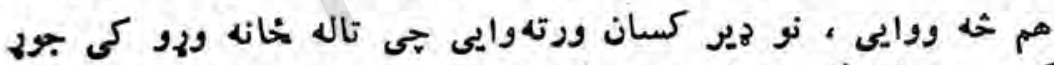

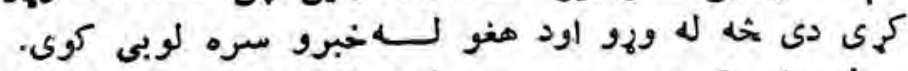

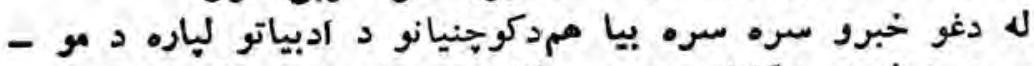

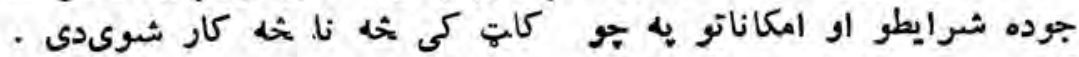

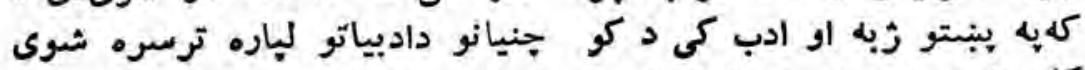

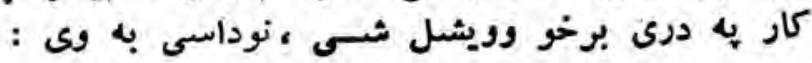

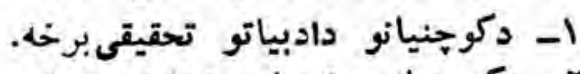

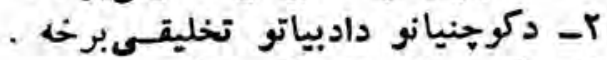

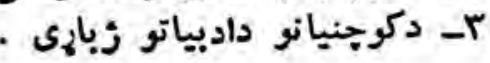




\section{- 1}

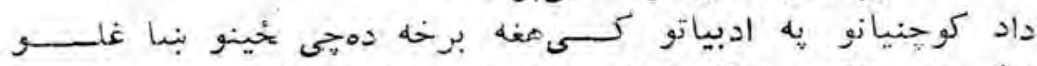

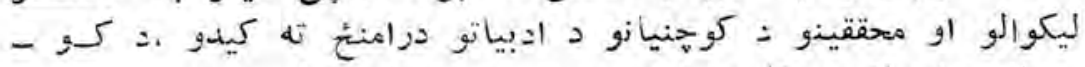

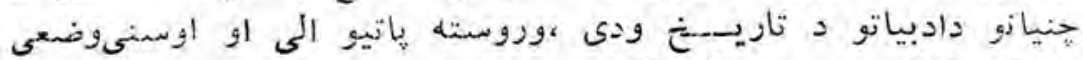

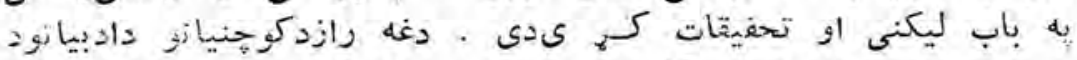

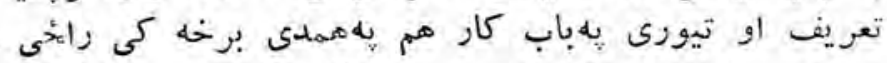

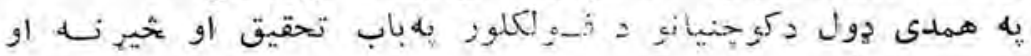
اسمى نوز شيان

\section{ז- د كوحنيانو دازبياتو تخليقى}

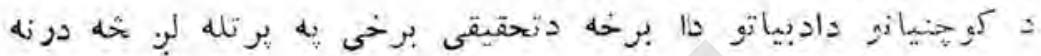

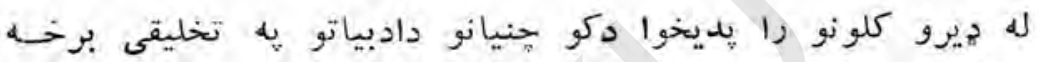

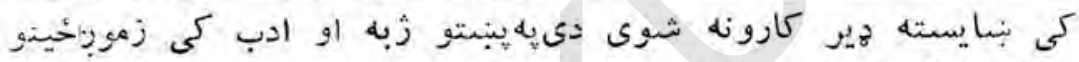

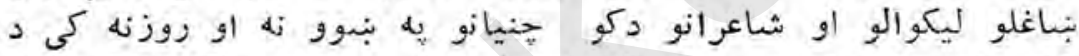

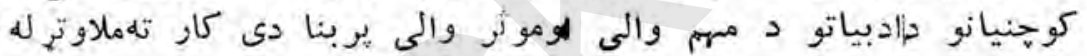

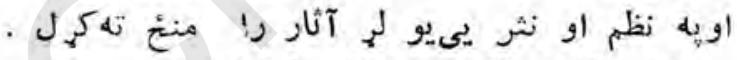

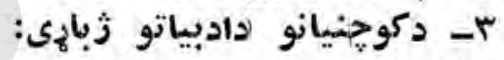

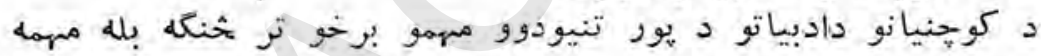

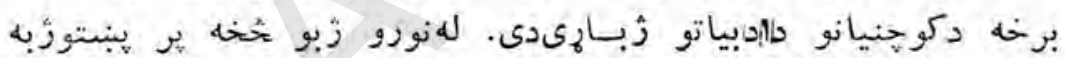

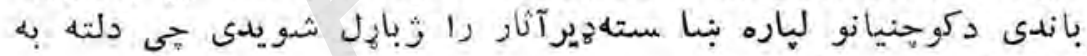

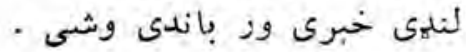

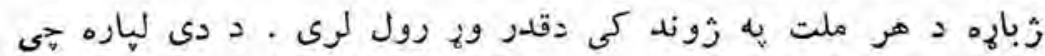

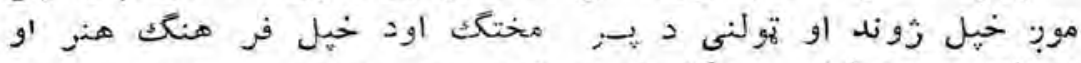

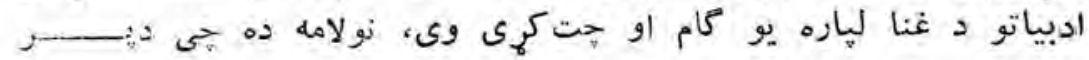

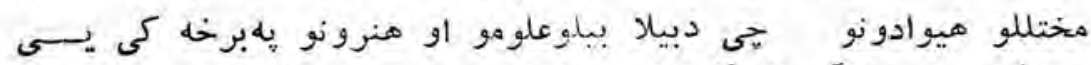

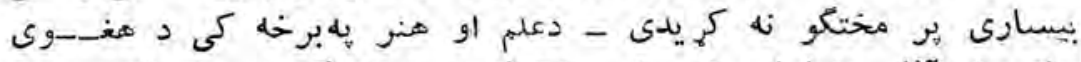

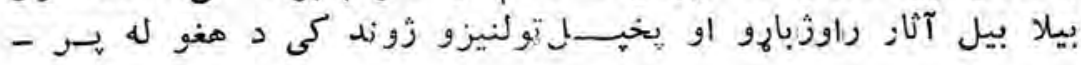




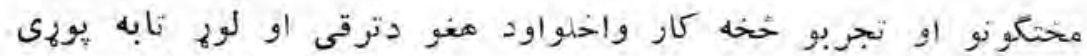

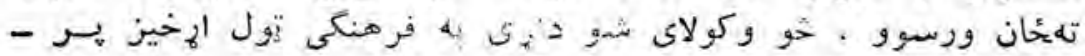

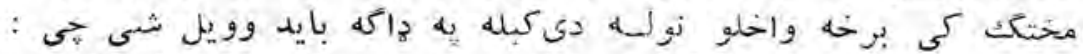

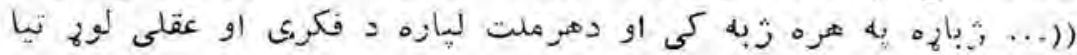

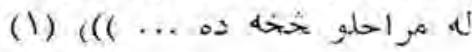

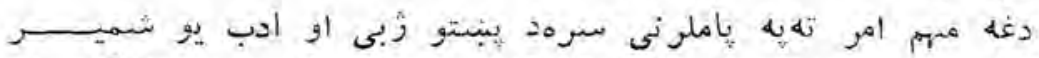

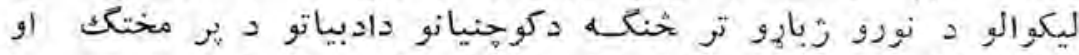

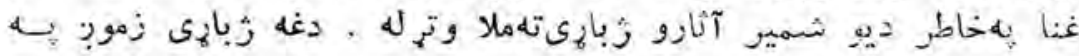

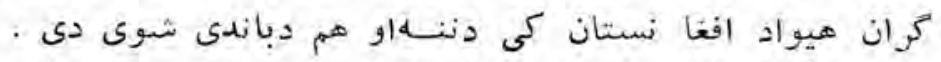

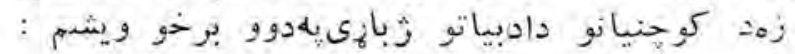

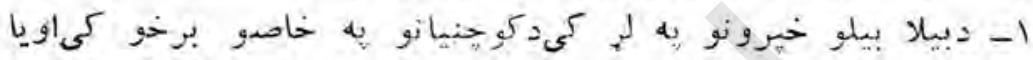

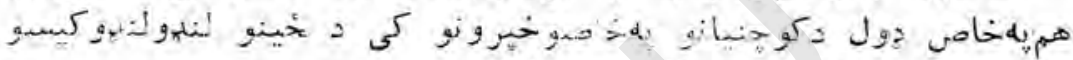

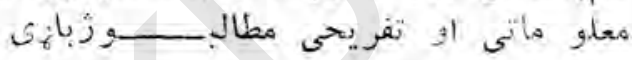

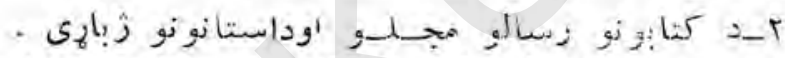

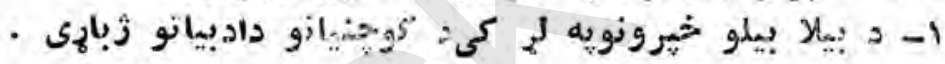

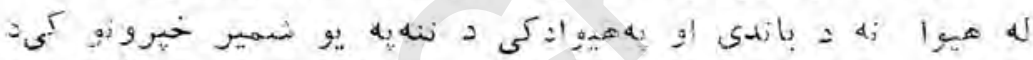

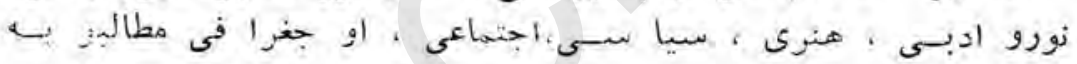

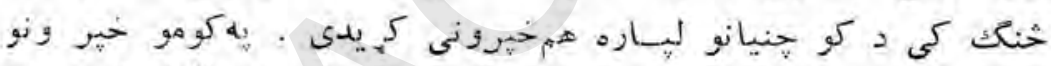

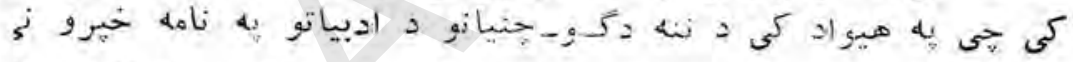

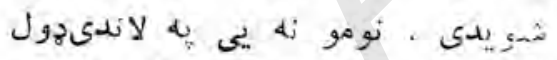

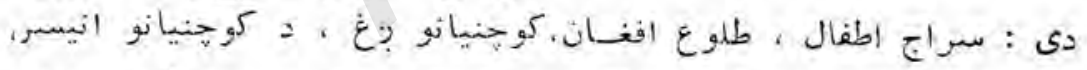

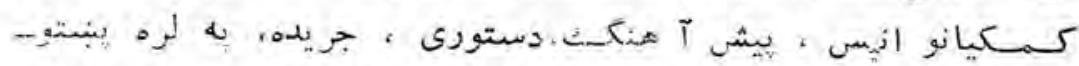

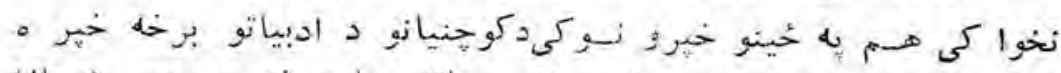

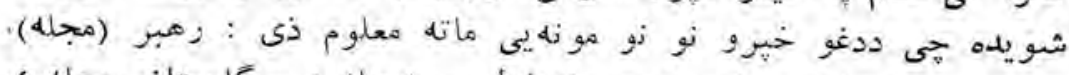

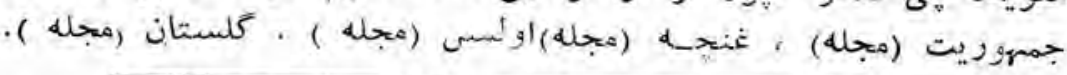

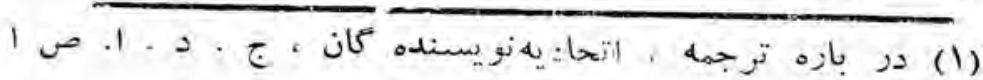




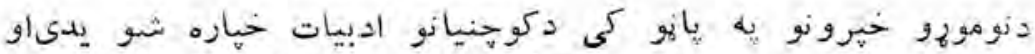

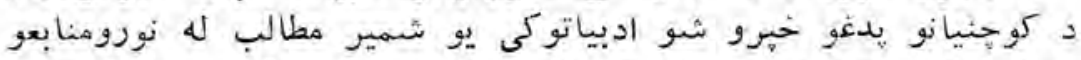

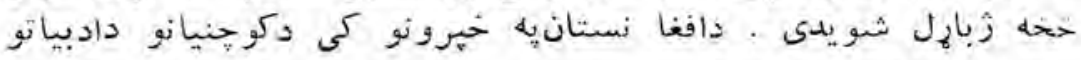

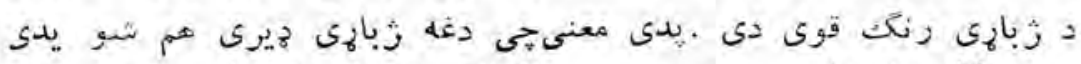

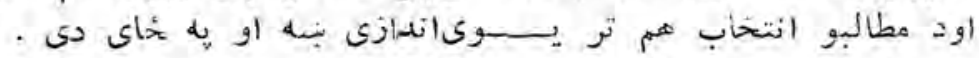

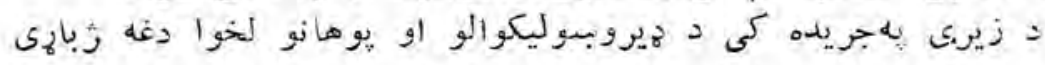

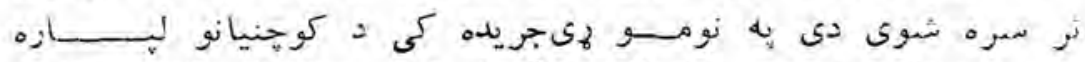

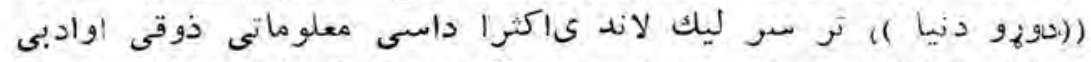

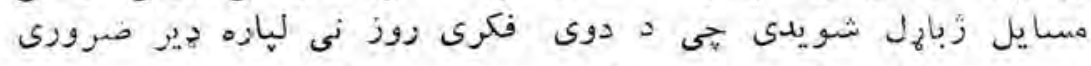

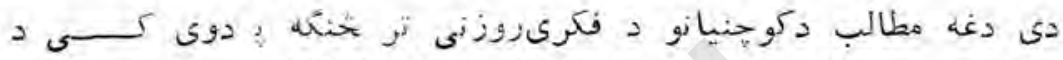

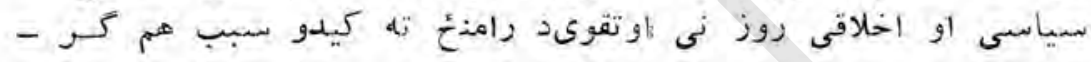

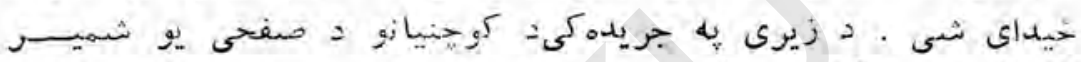

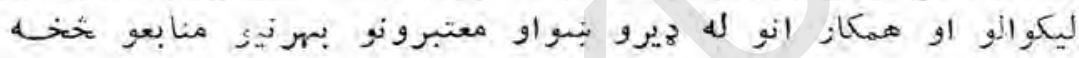

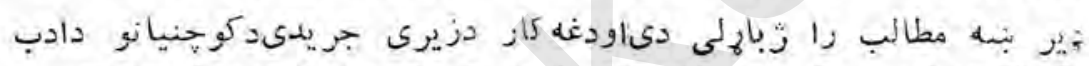

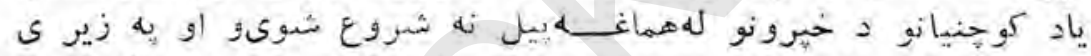

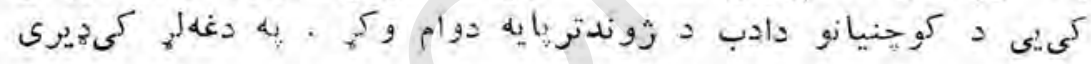

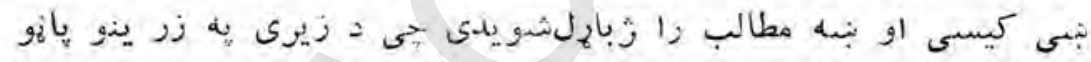

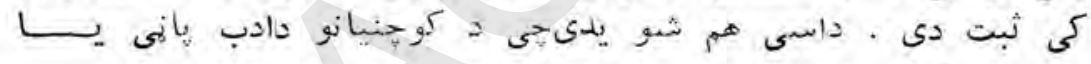

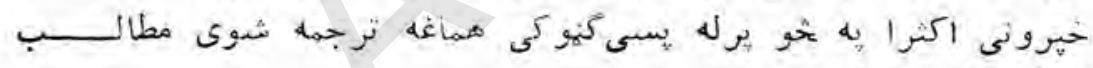

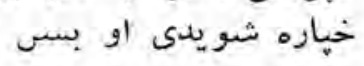

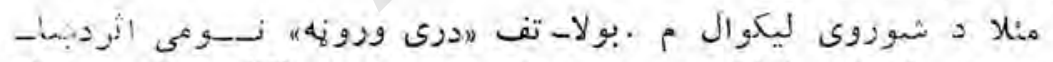

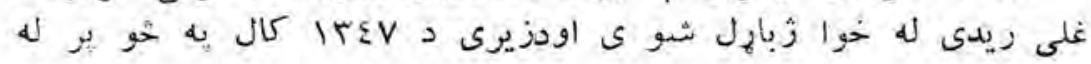

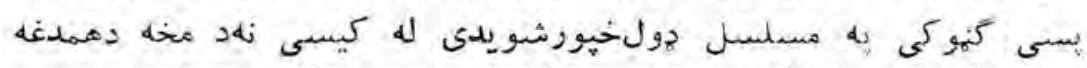

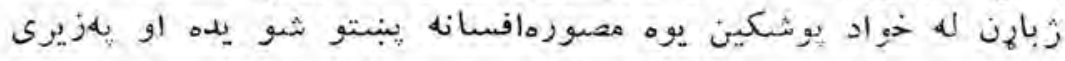

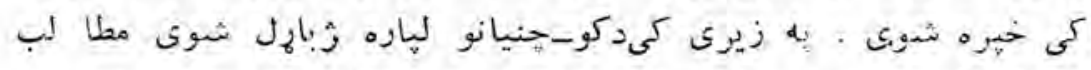

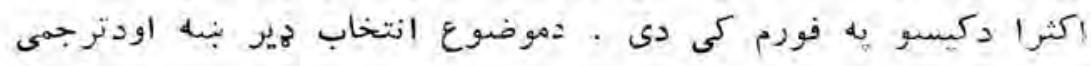
$-r \cdot r^{-}$ 


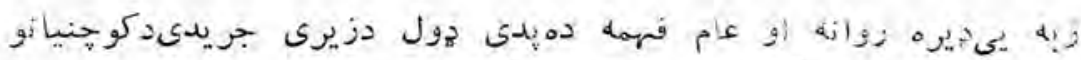

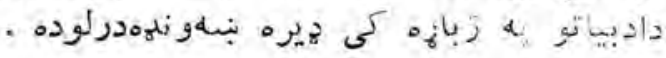

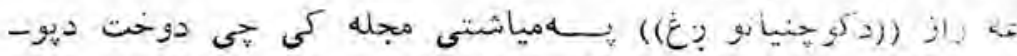

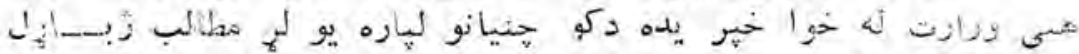

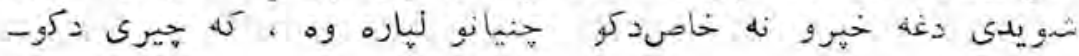

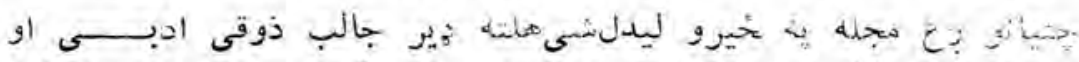

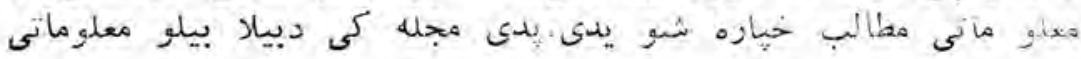

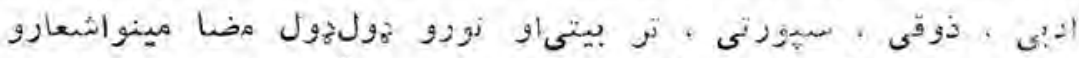

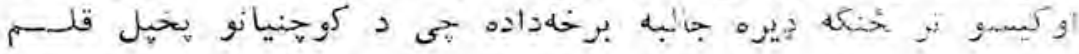

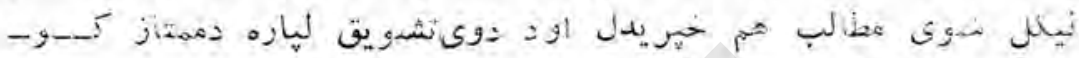
.

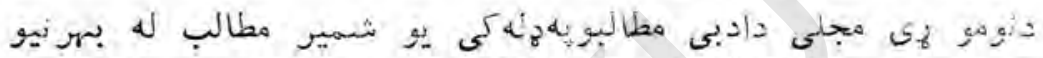

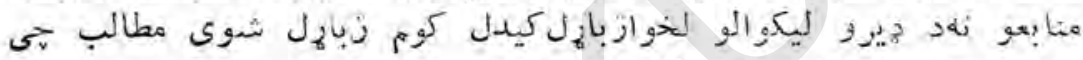

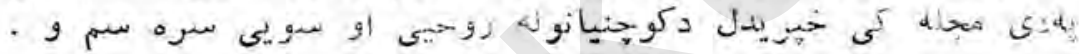

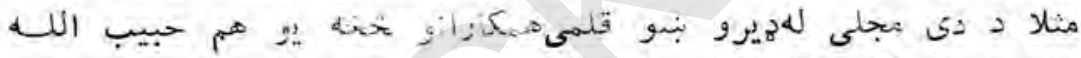

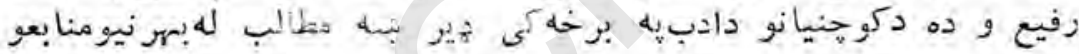

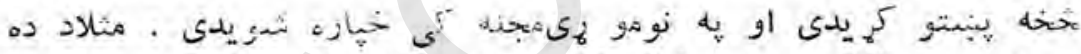

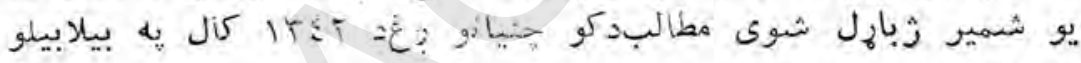

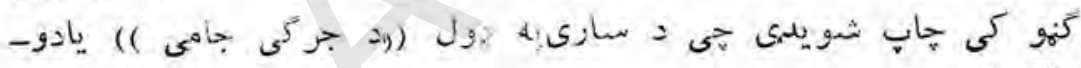

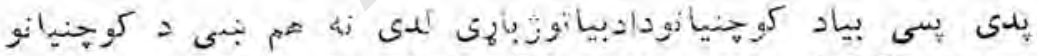

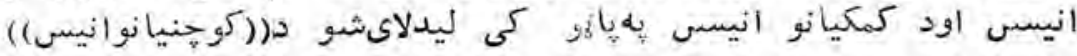

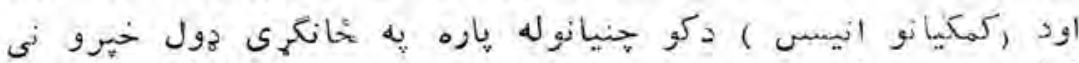

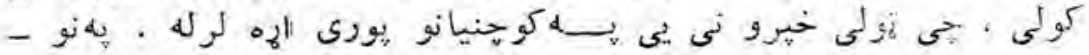

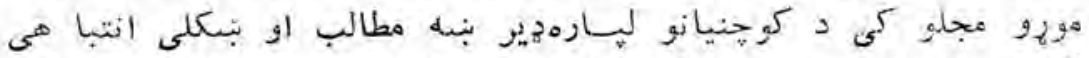

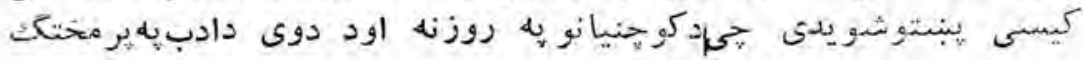




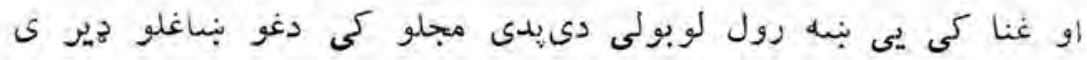

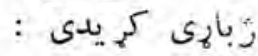
نانى ، مهريه هوتكى ، زمر ىكنيوال ، زرغونه اياز خائسـى او

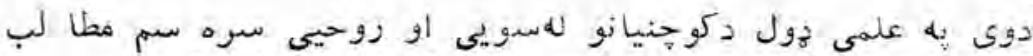

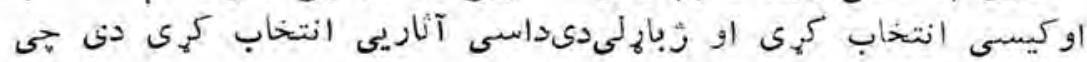

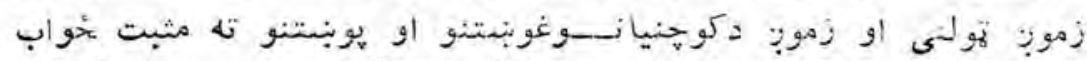

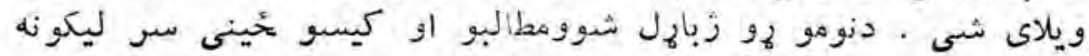

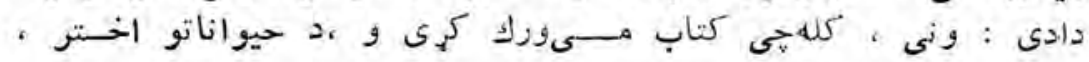

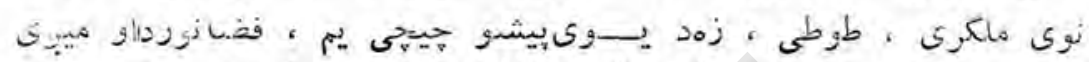

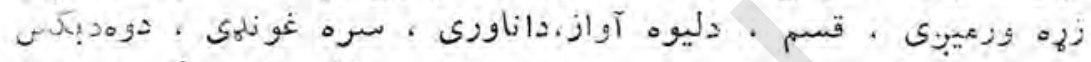

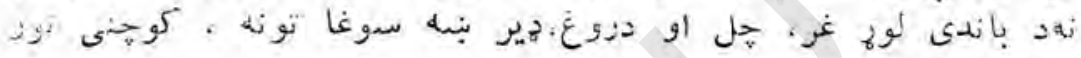

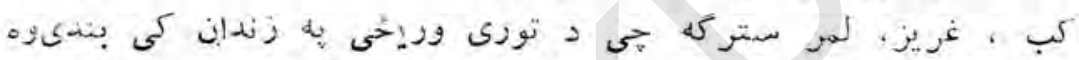

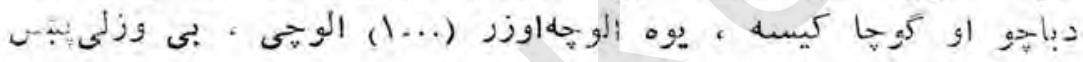

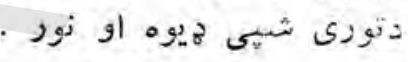

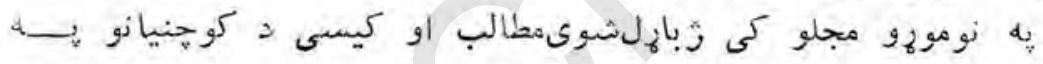

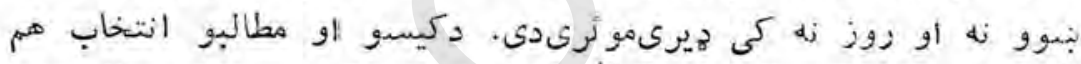

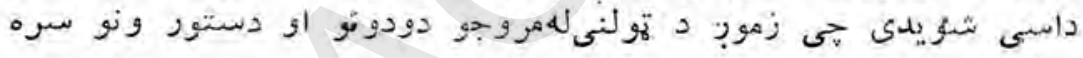

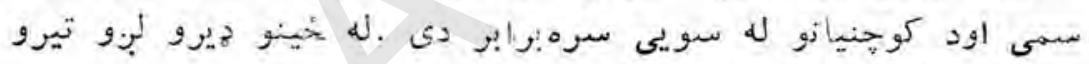

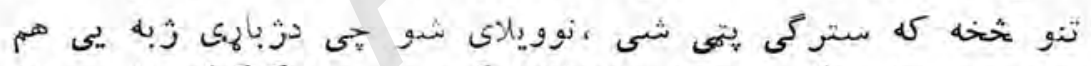

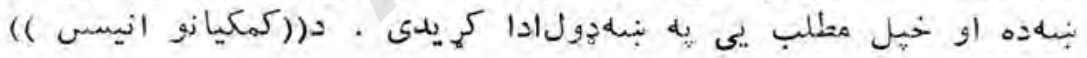

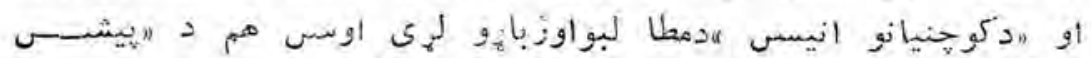

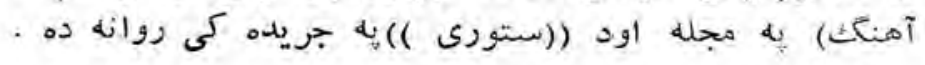

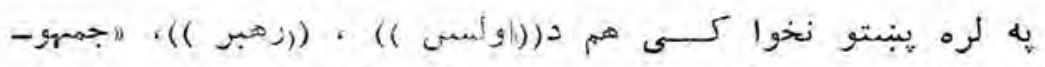

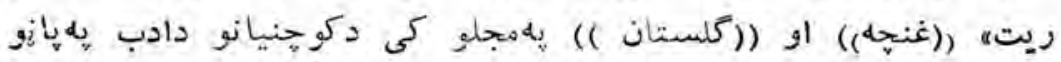

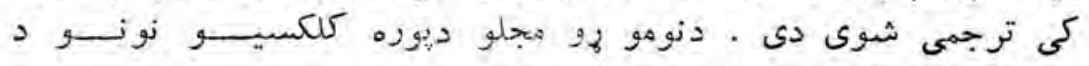
$-r \cdot 0_{-}$ 


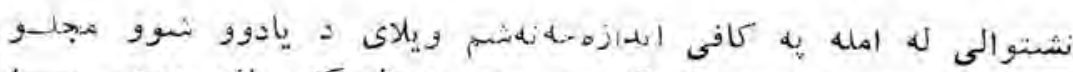

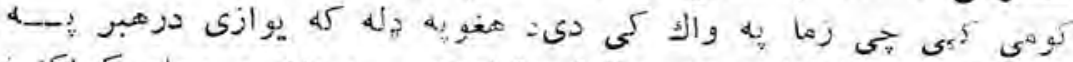

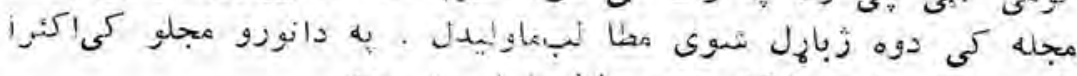

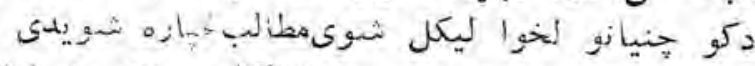

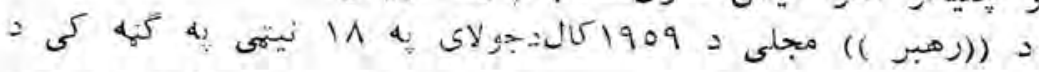

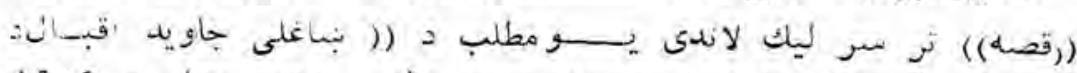

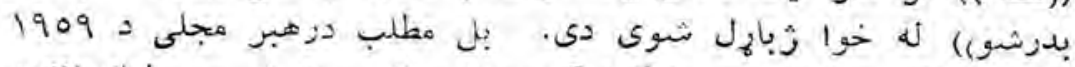

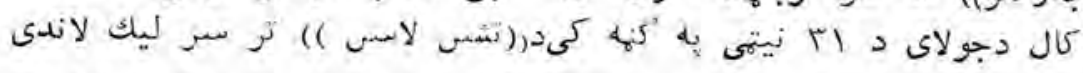

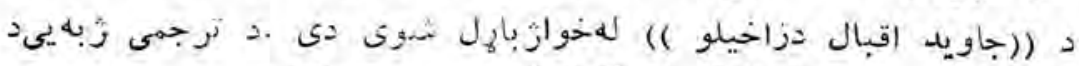

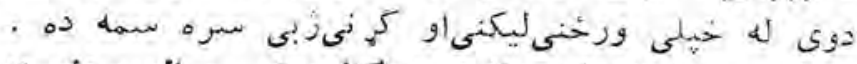

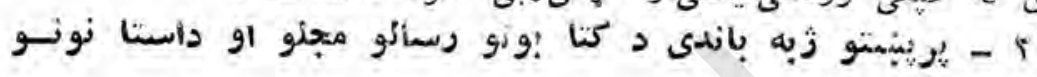
$: 0_{8}+\hat{j}$

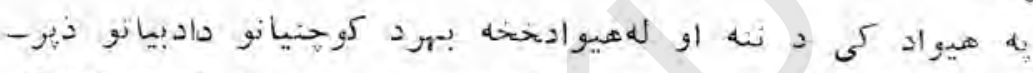

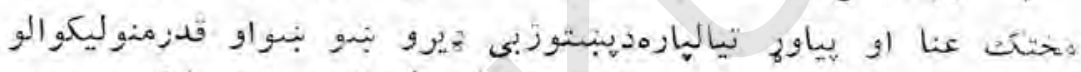

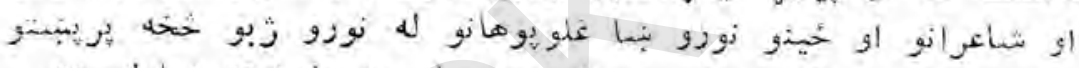

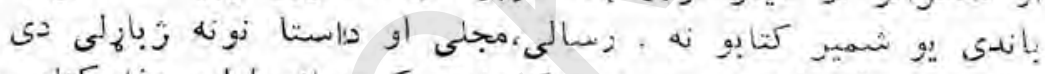

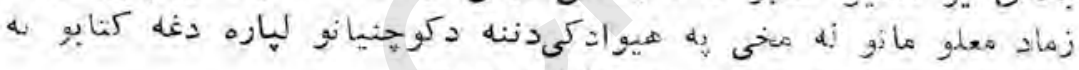

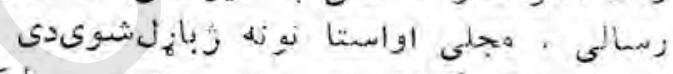

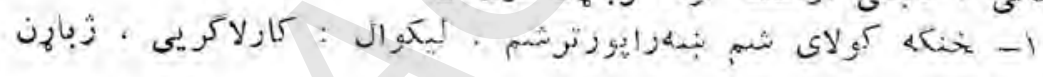

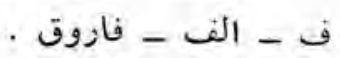

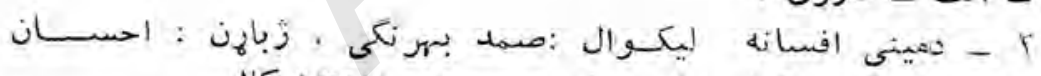

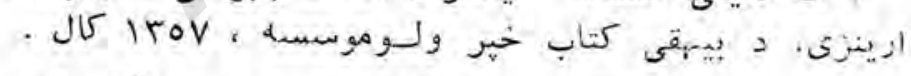

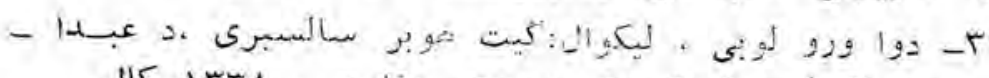

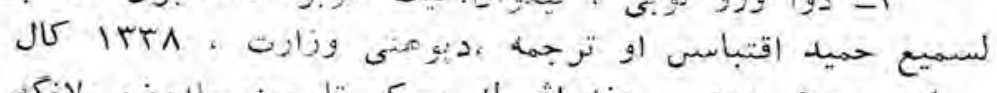

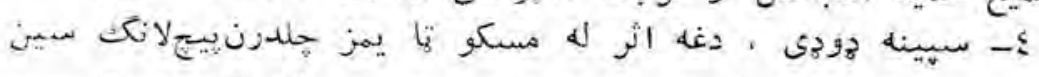

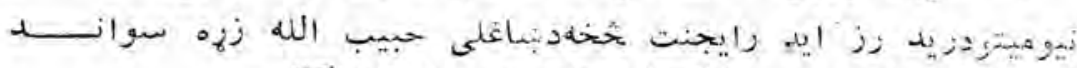

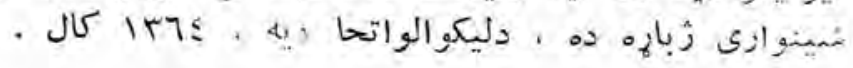




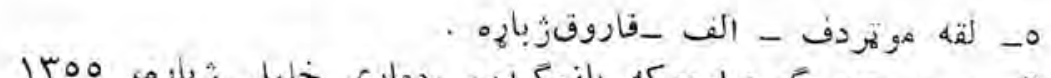

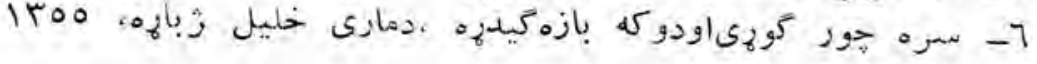

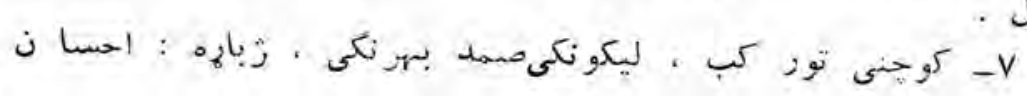

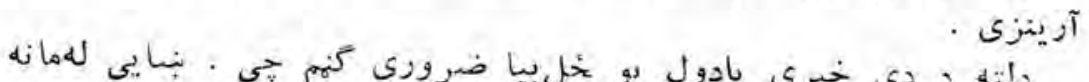

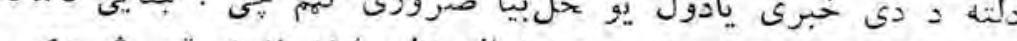

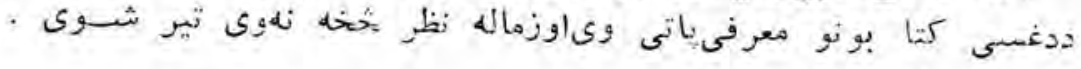

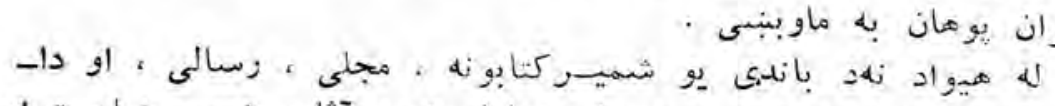

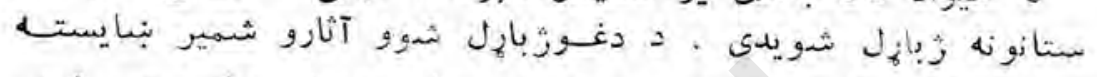

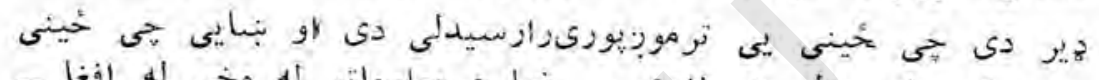

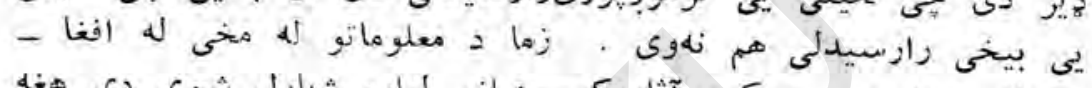

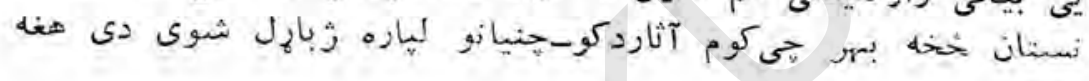

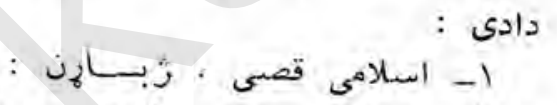

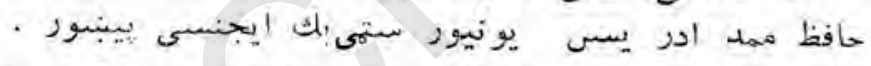

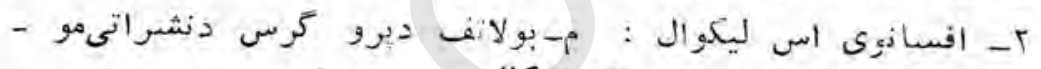

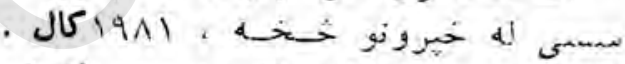

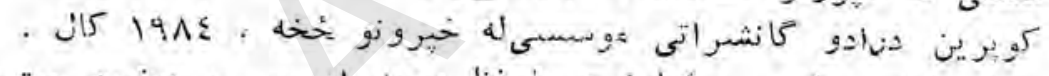

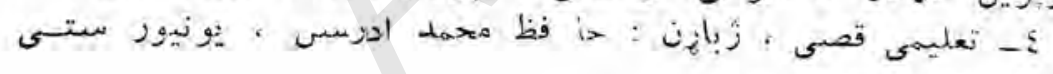

$$
\begin{aligned}
& \text { بلك ايجنسى بيبنور }
\end{aligned}
$$

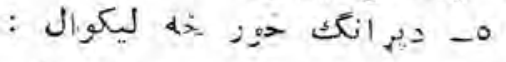

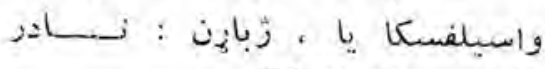

$$
\begin{aligned}
& \text { - } 1911 \text {. }
\end{aligned}
$$

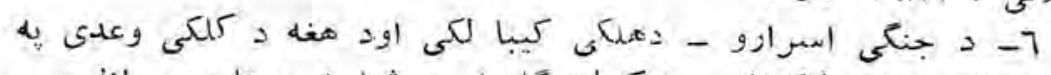

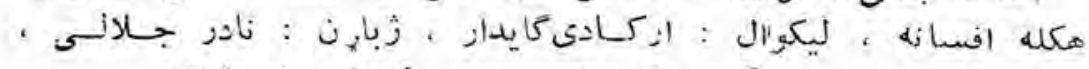

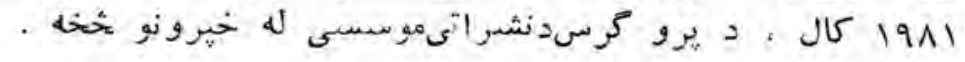
$-r \cdot v_{-}$ 


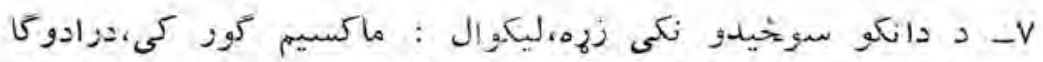

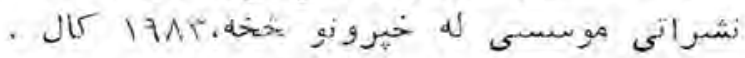

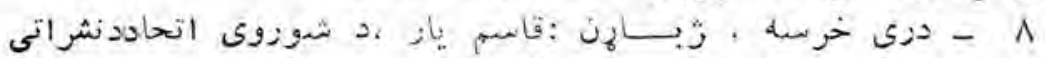

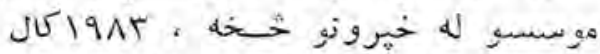

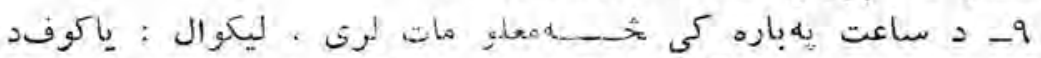

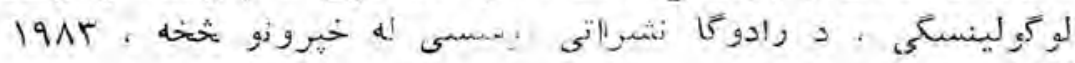

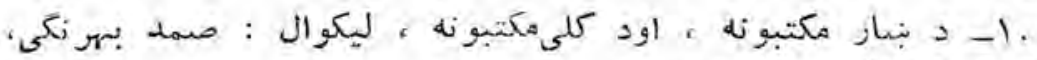

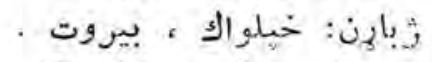

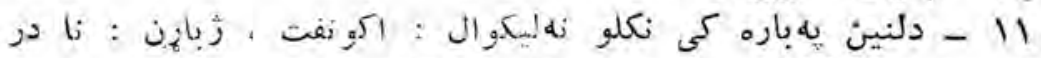

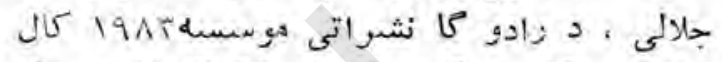

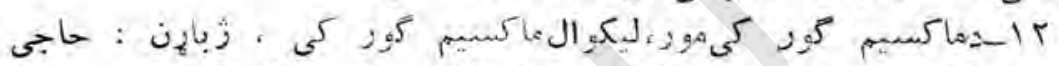

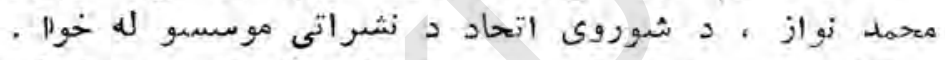
نا

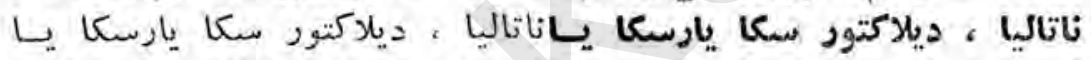

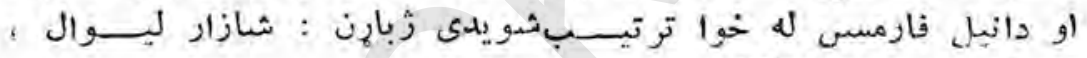

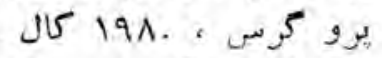

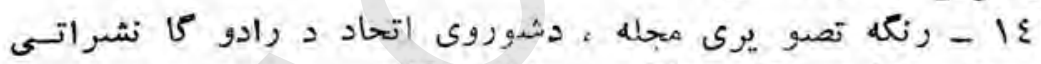

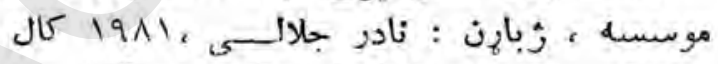
2. 10

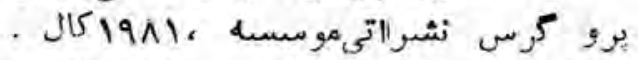

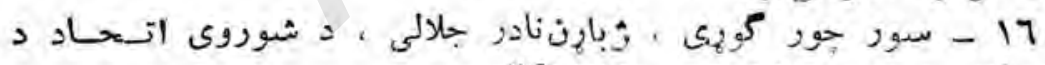
نشرالتى موسسو

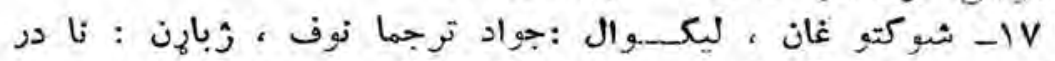

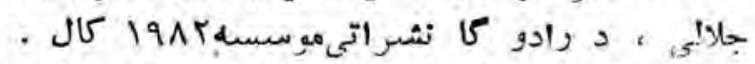

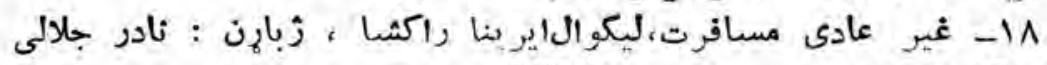

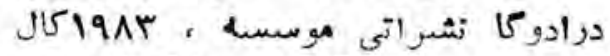

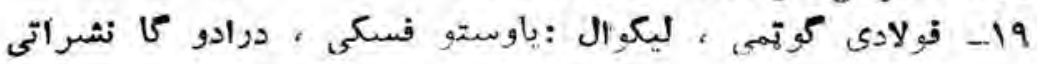
$-r \cdot \Lambda_{-}$ 


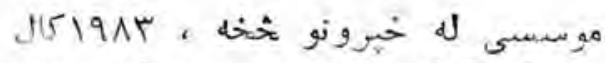
.

J 191.

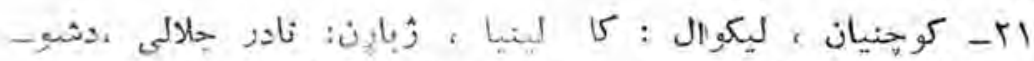

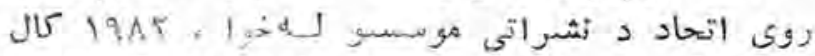

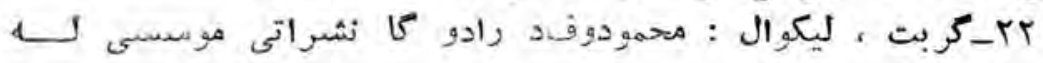
خبرون

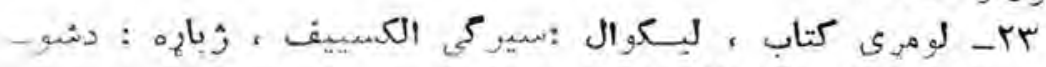

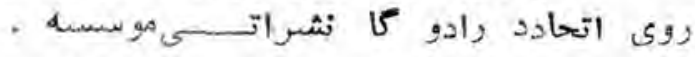

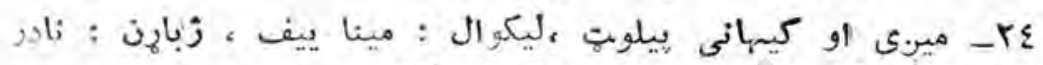

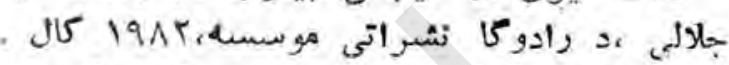

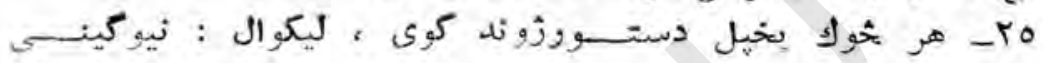

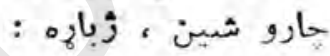

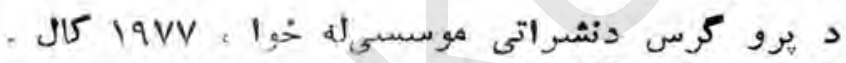

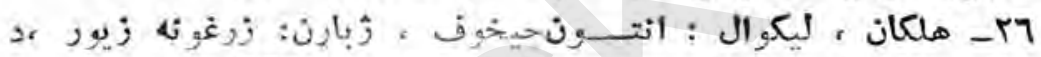

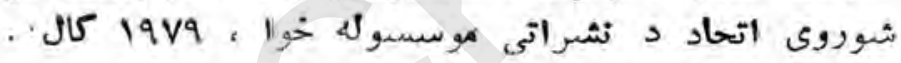

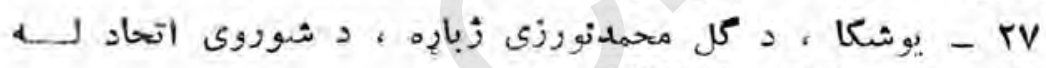
نشر اتى منابعو خخه ،

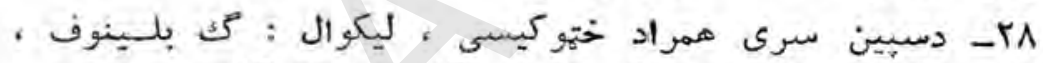

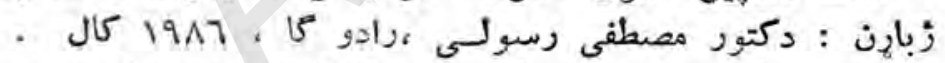

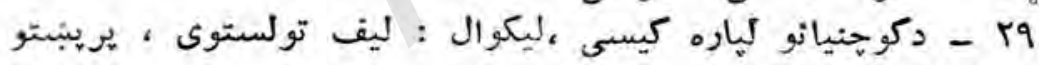
باندى زبايه .

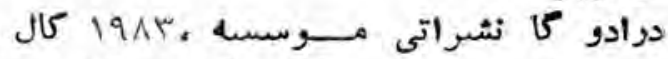

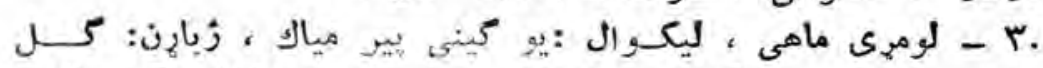

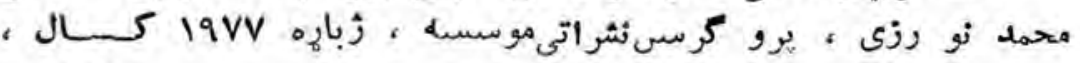

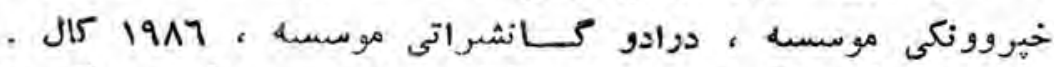

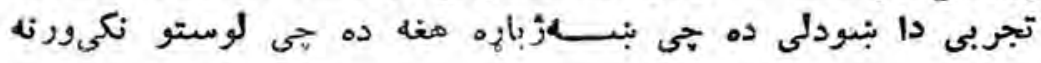

$$
-r \cdot 9-
$$




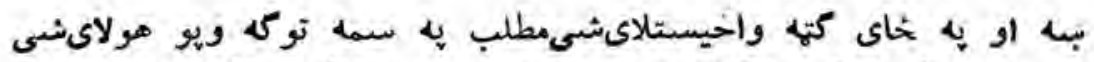

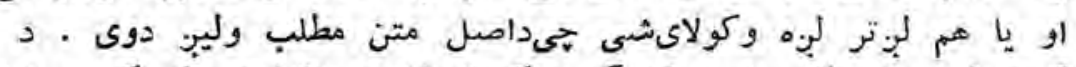

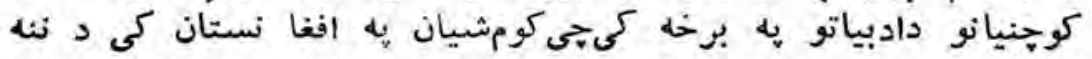

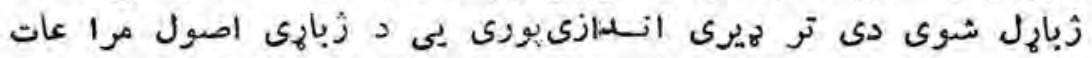

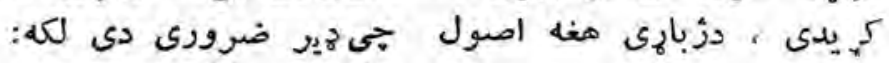

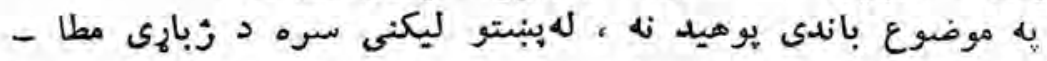

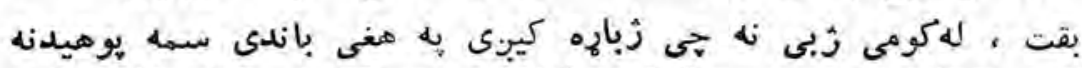

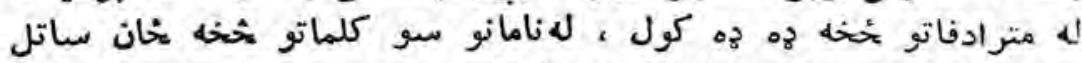

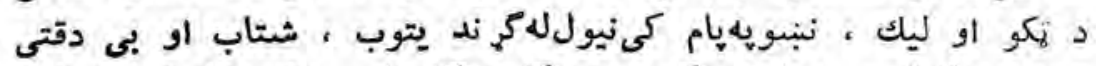

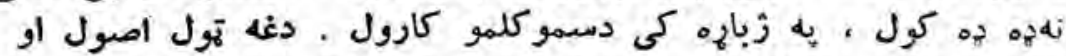

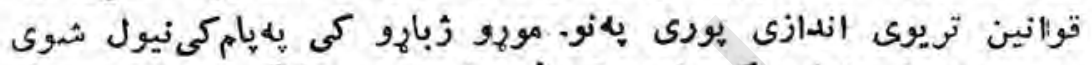

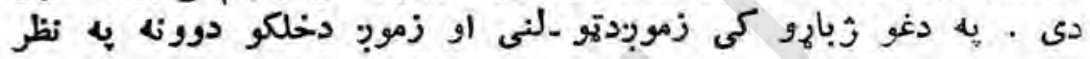

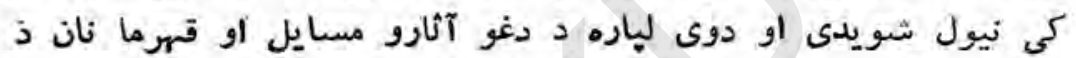

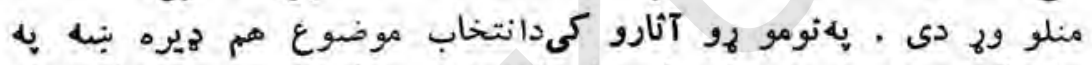

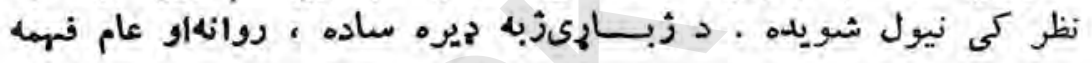

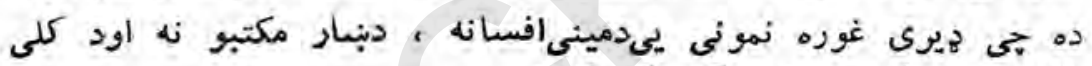

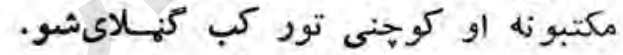

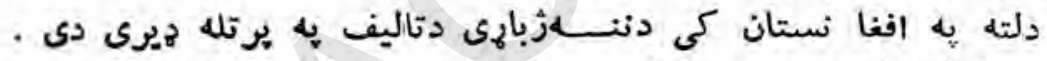

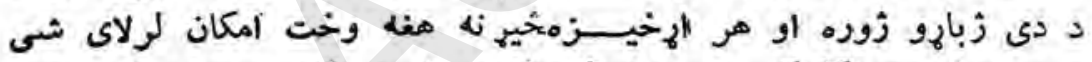

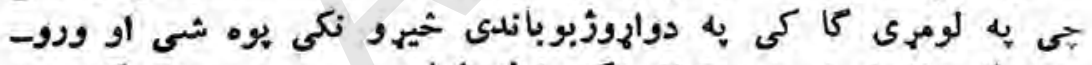

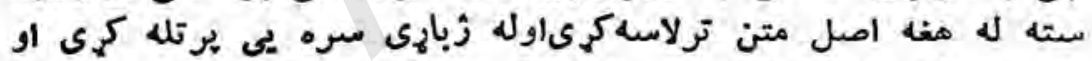

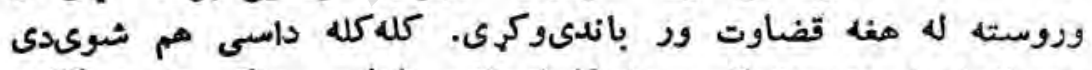

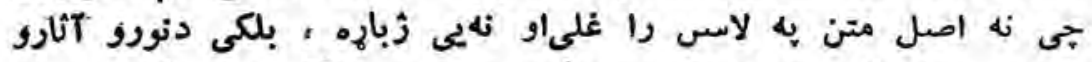

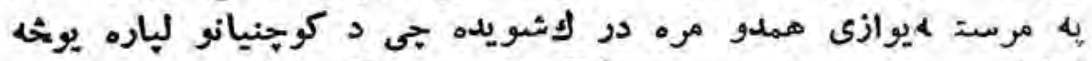

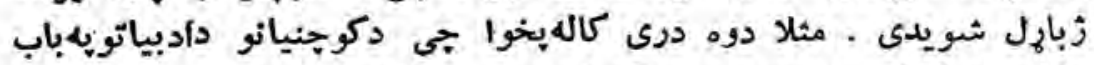

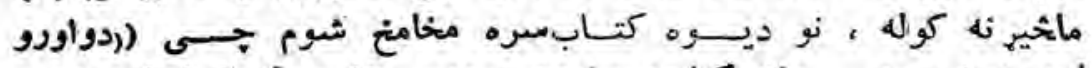

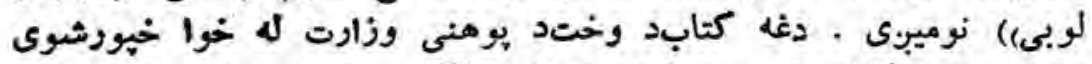

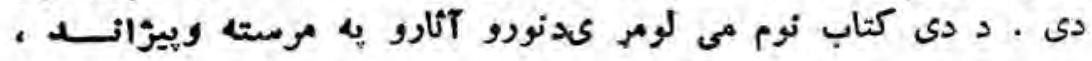




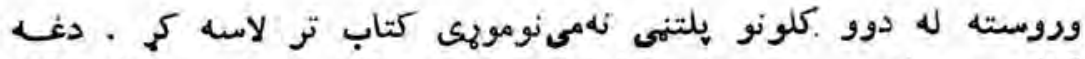

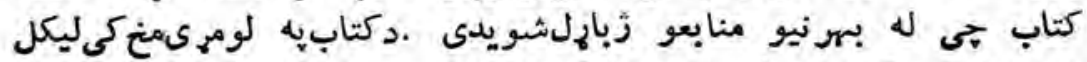

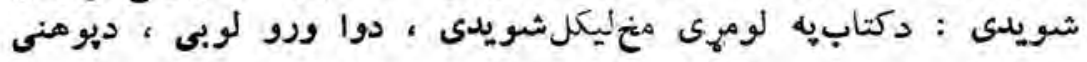

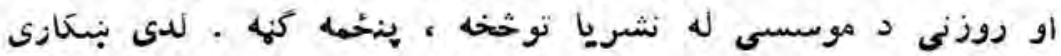

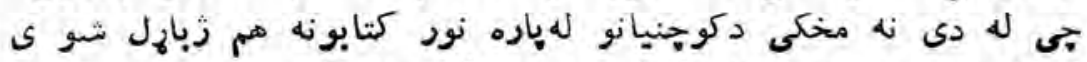

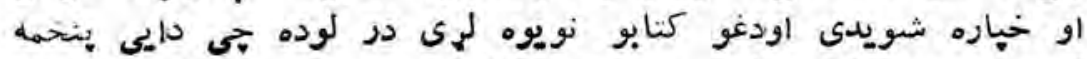

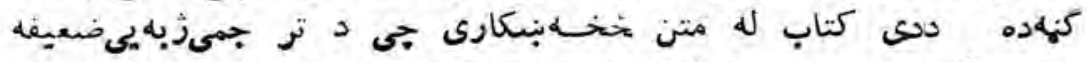

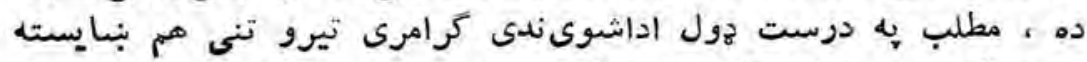

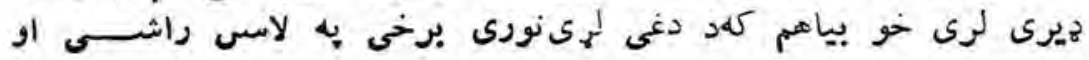

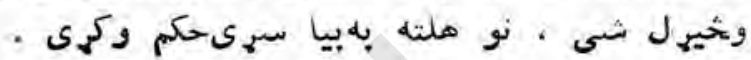

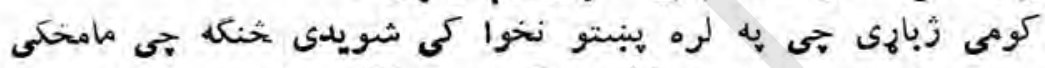

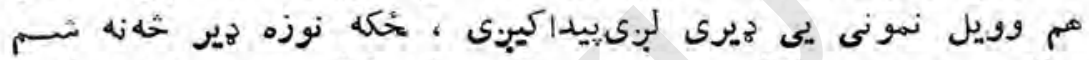

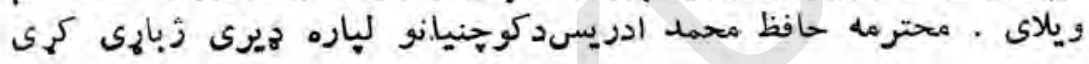

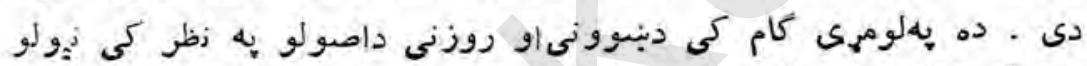

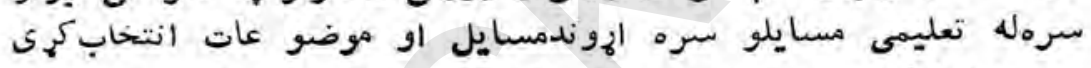

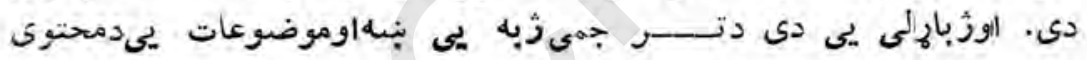

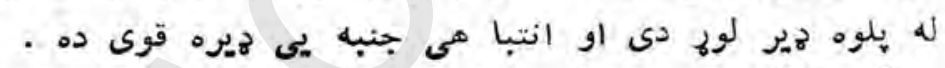

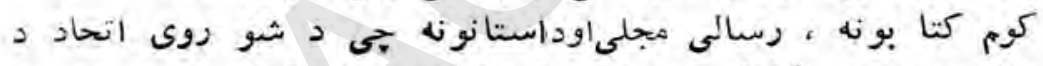

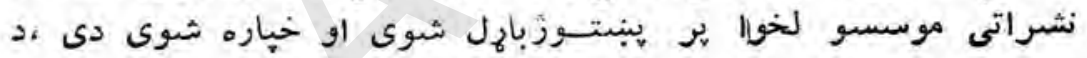

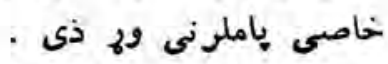

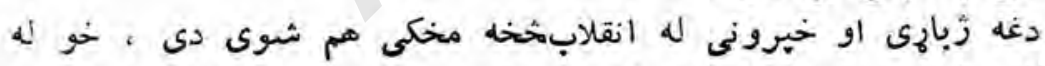

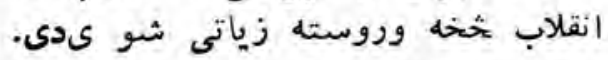

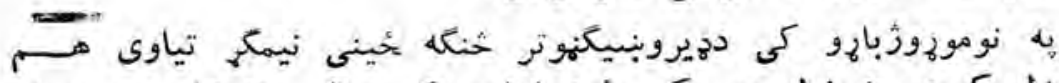

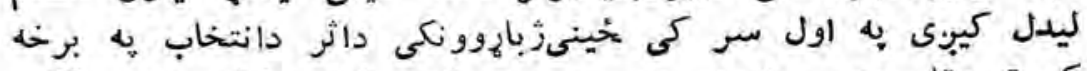

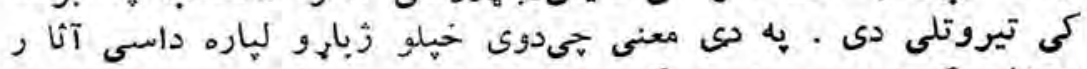

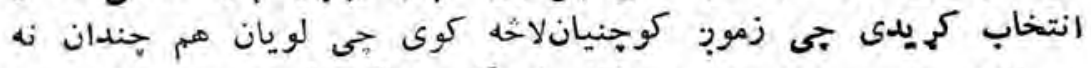

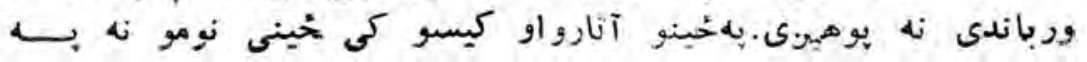


ستونزو سره تلفظ كيبنى جى د كوجنيانو لياره ينىنومونو اوهغوته

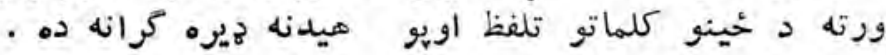

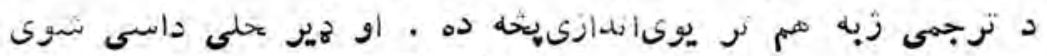

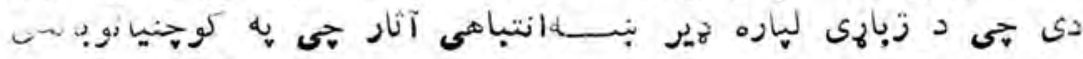

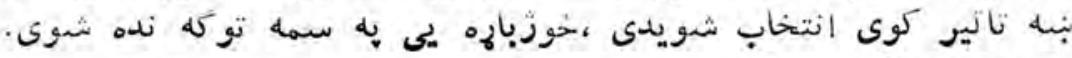

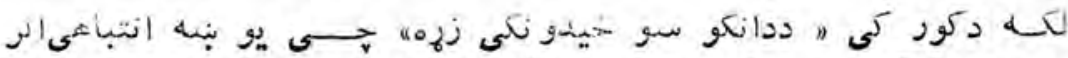

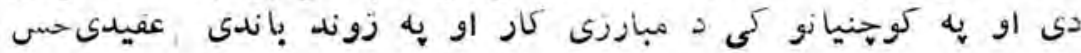

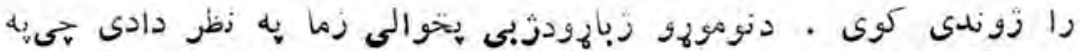

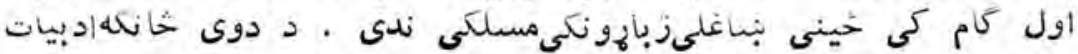

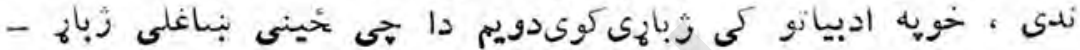

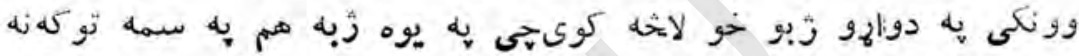

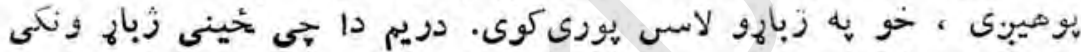

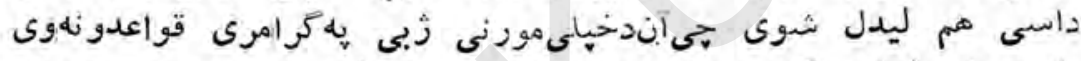

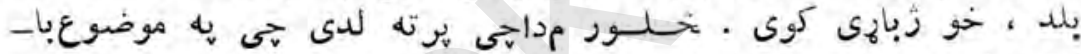

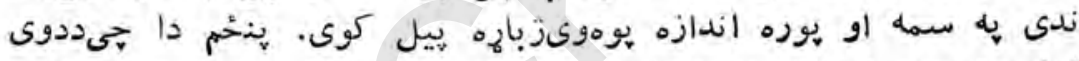

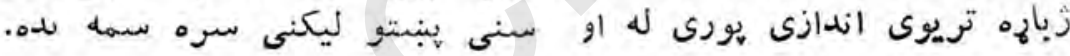

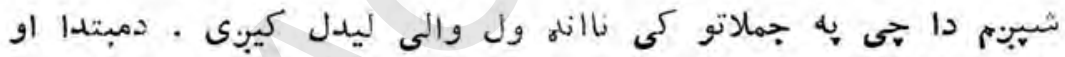

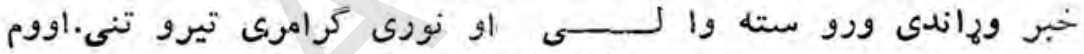

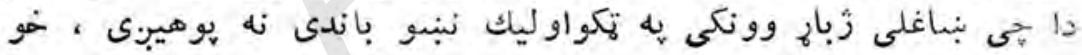

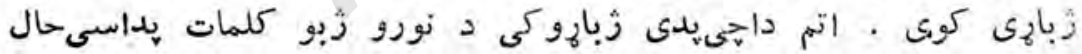

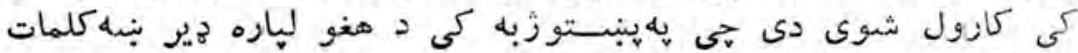

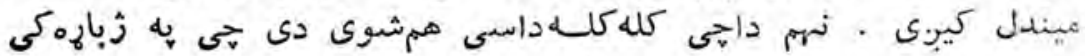

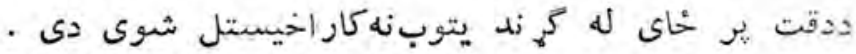

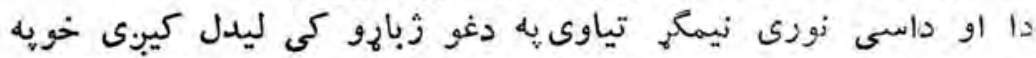

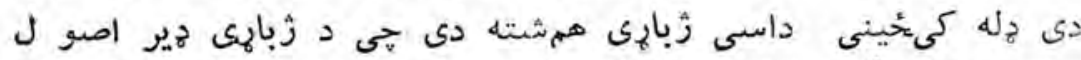

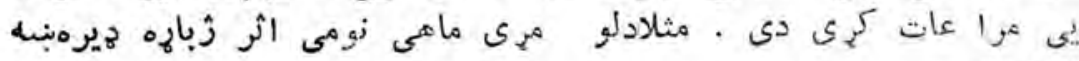




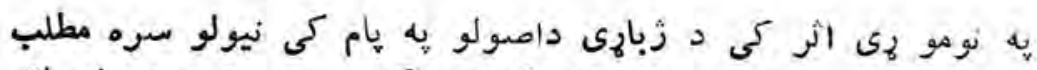

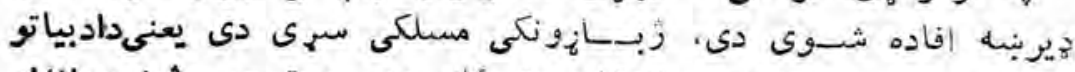

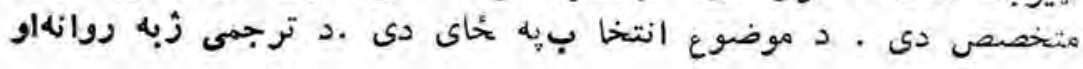

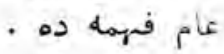

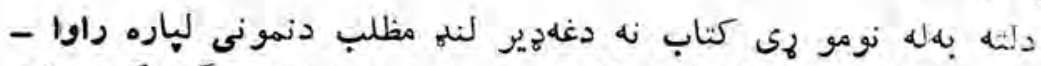

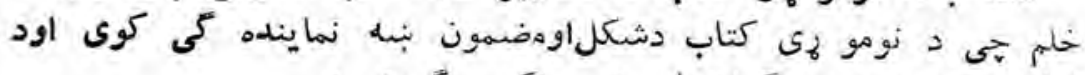

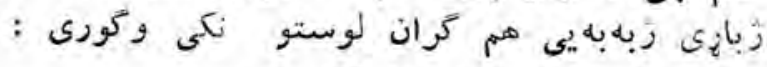

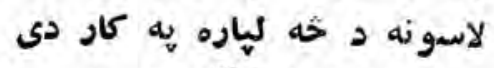

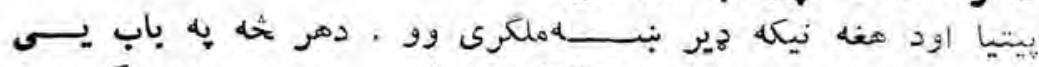

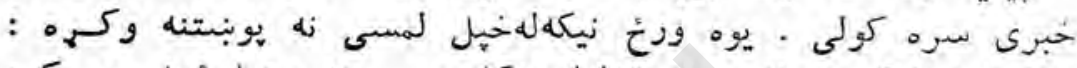

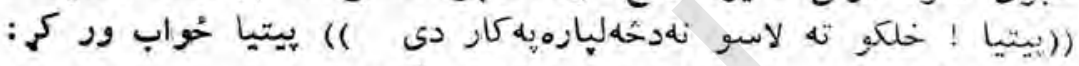

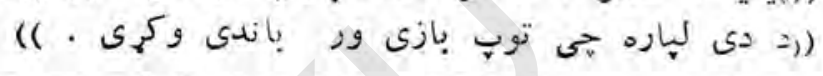

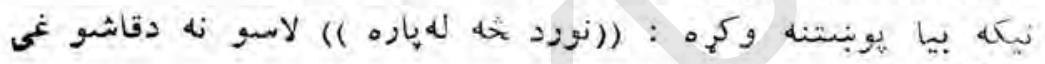

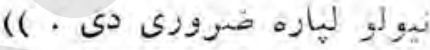

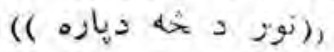

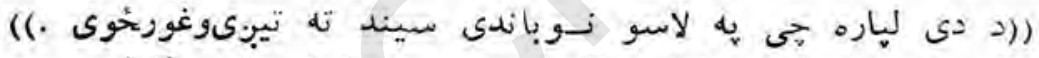

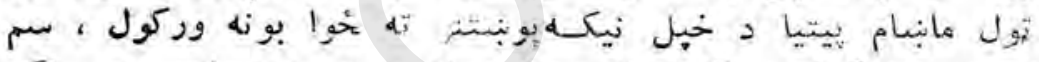

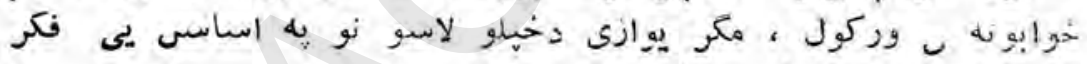

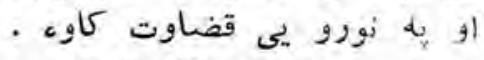

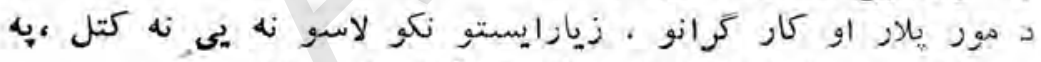

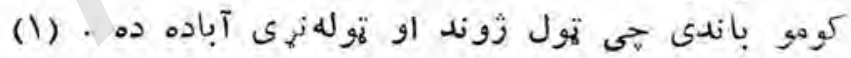

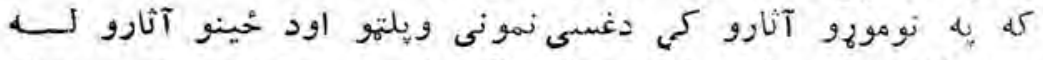

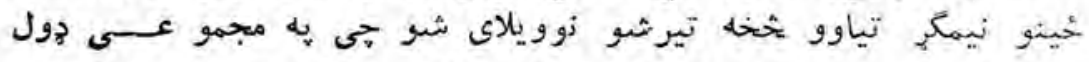

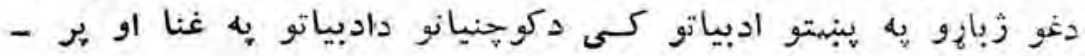
.

(1)

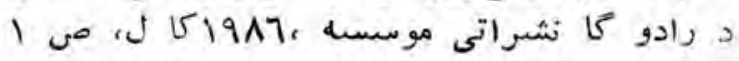
-rir- 


\section{دكوجنيادادب دندى}

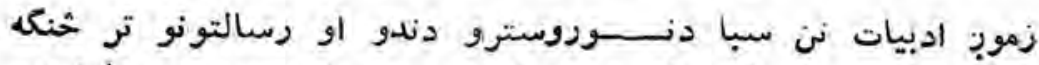

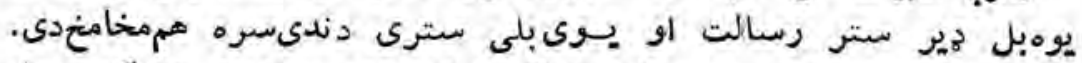

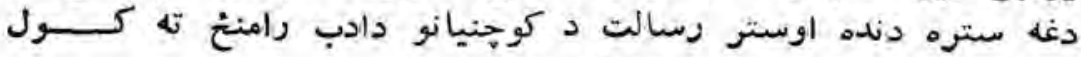

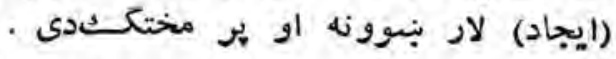

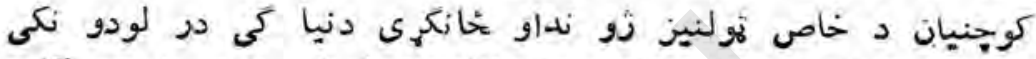

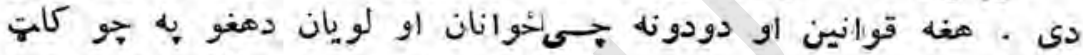

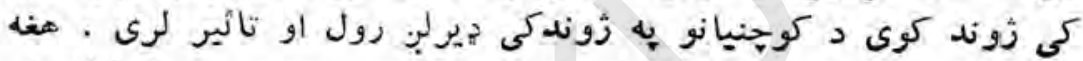

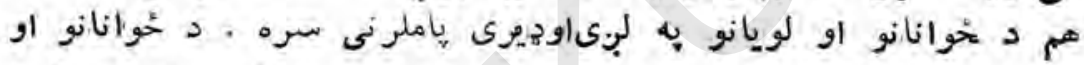

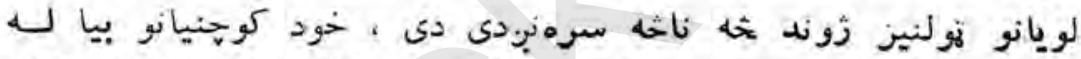

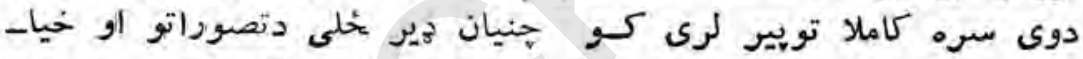

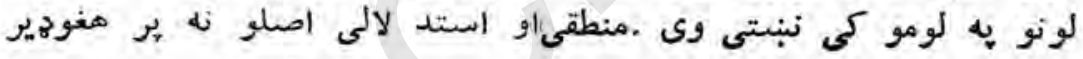

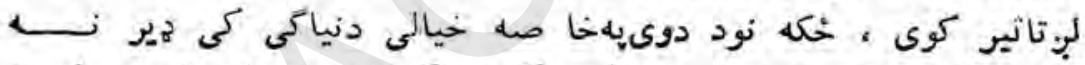

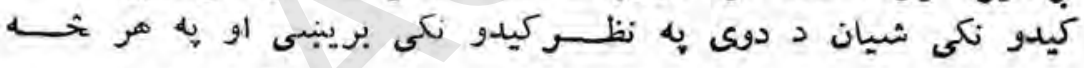

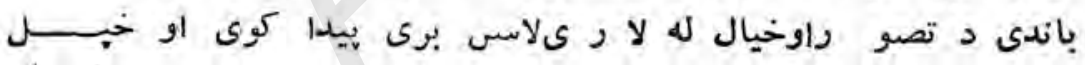

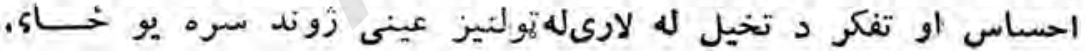
كوى.

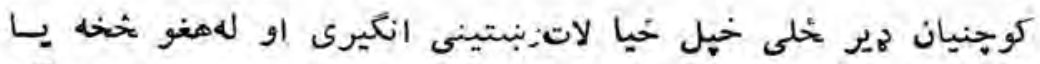

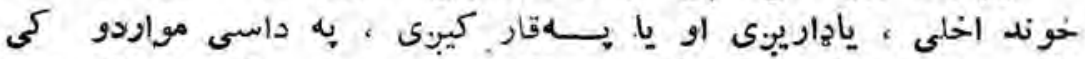

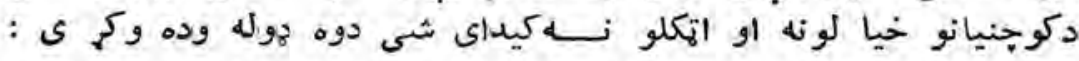

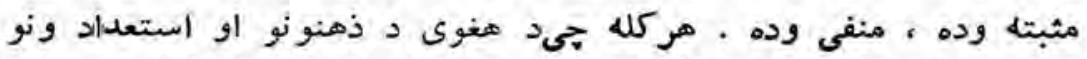

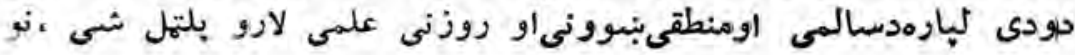


مثبته وده كوى اود تولنى لبا ره ديوه مثبت اود بنه شخصيت لخهاوند

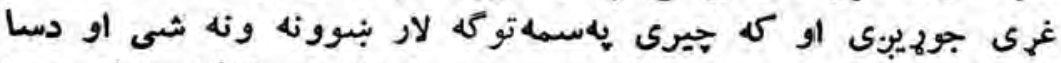

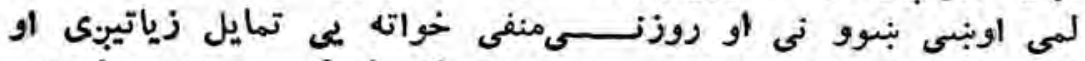

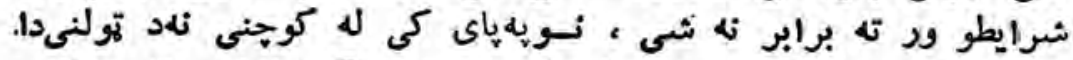

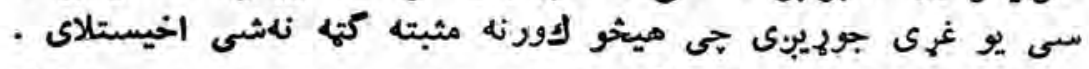

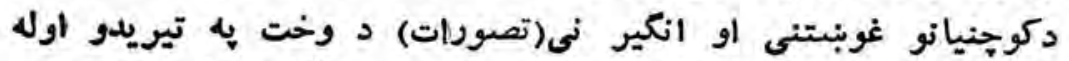

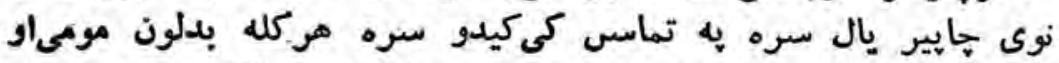

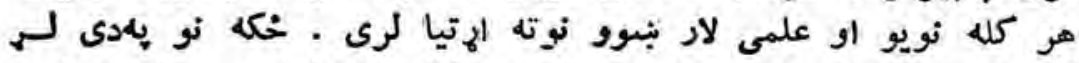

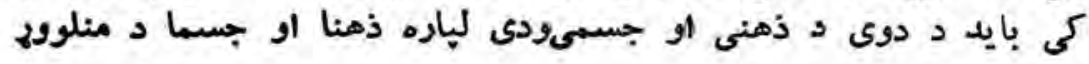

هنه كوجنيان جي تازه دلوستلوواك تر لاسه كوى غوازى جيدكيسو

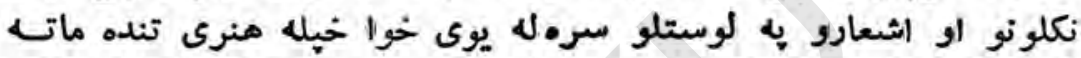

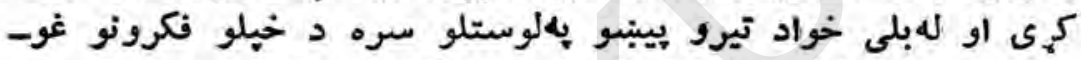

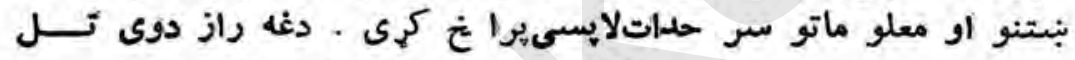

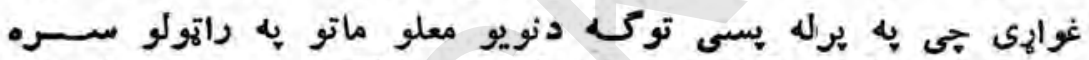

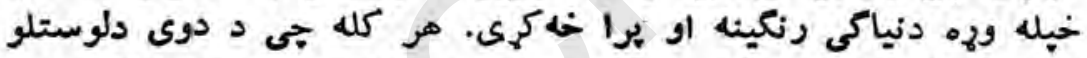

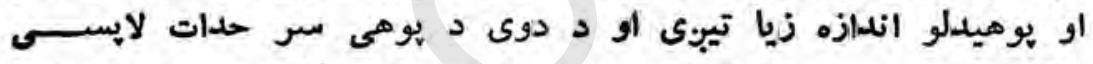

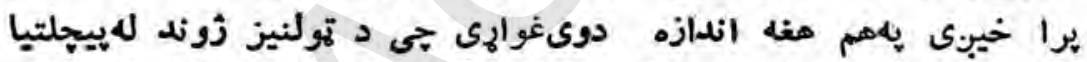

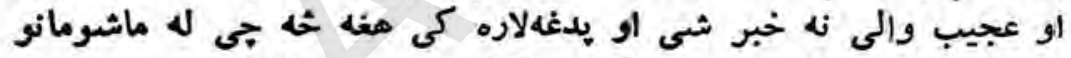

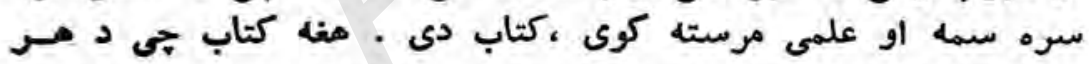

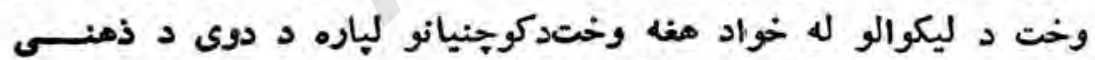

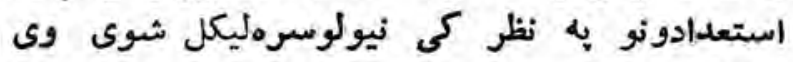

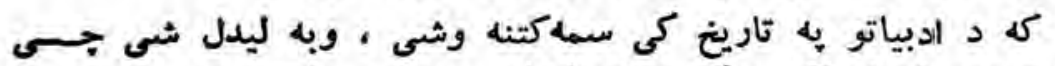

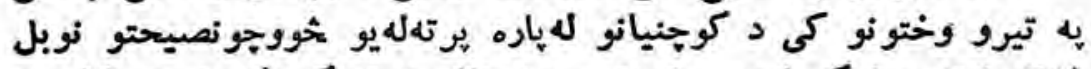

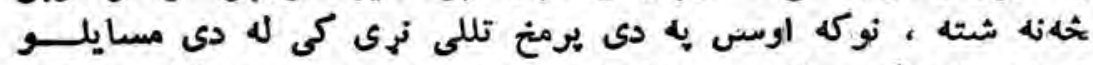

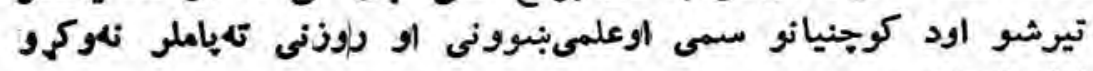

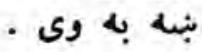




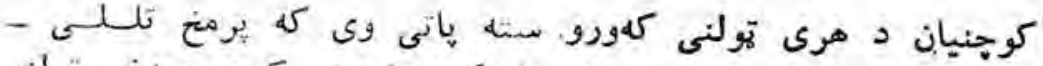

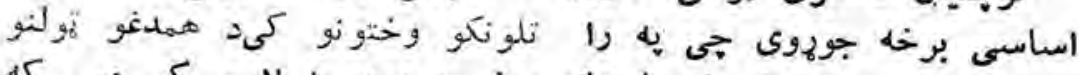

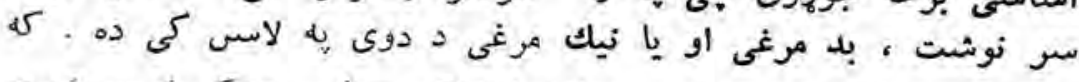

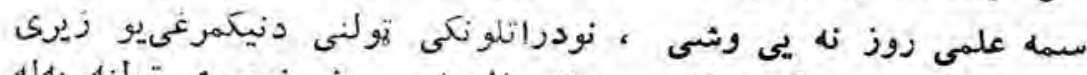

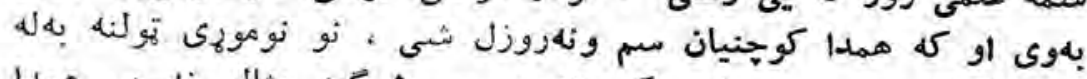

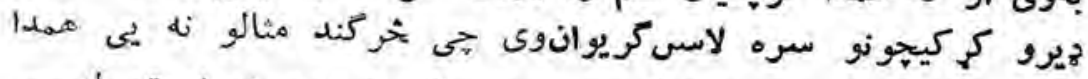

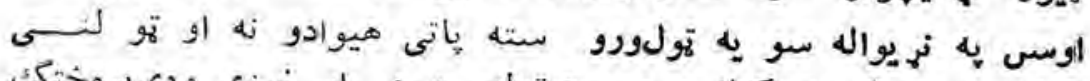

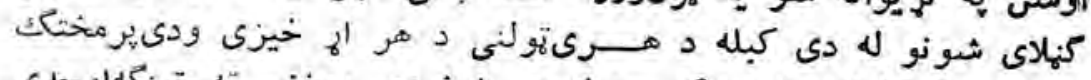

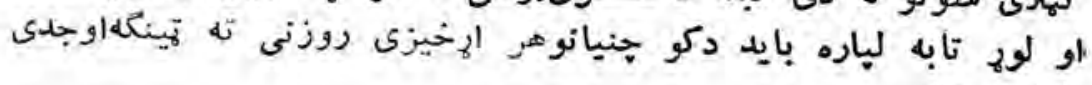

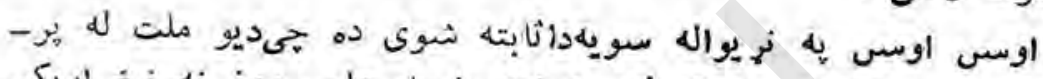

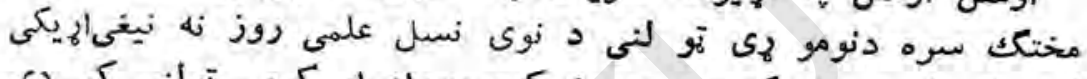

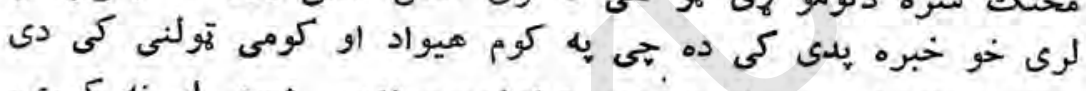

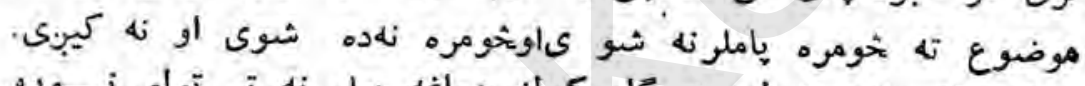

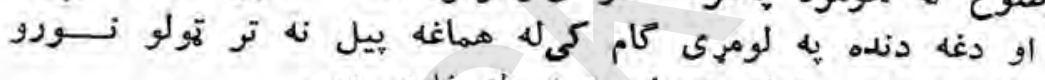

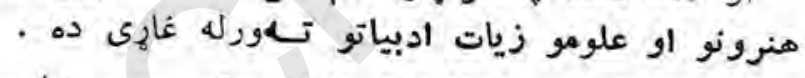

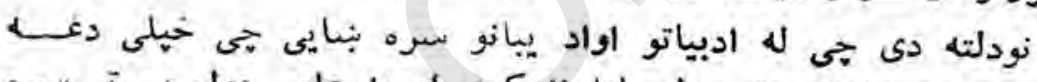

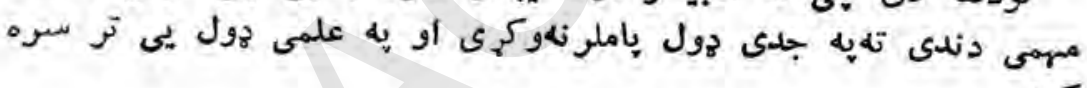
كي

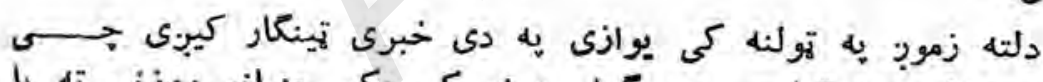

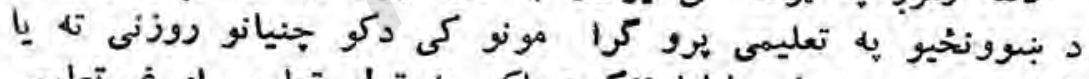

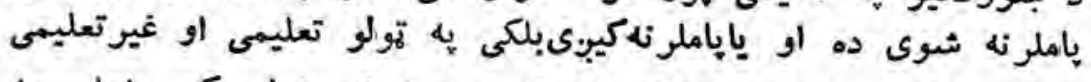

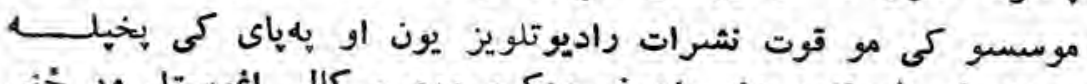

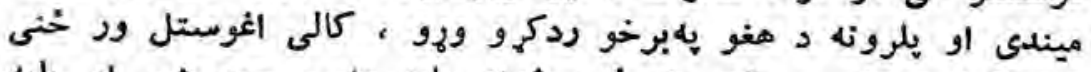

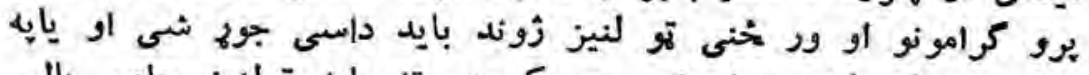

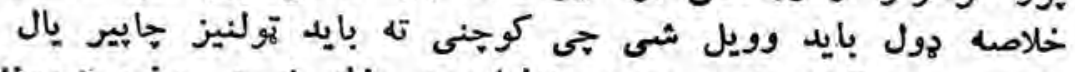

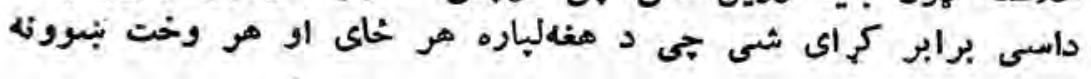


او ووزنه وى او تر تولو د مخه د ادبياتو ستره دنده دمجىدكوجنيانو

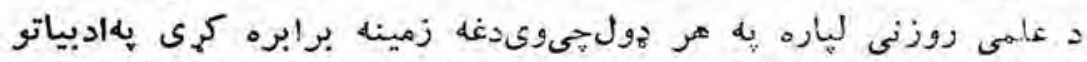

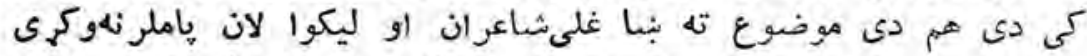

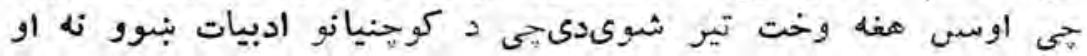

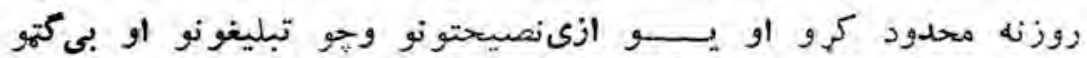

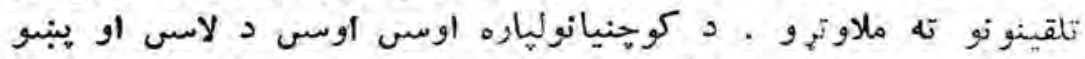

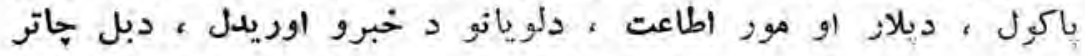

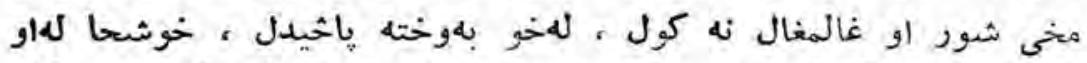

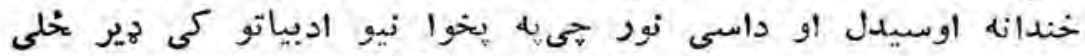

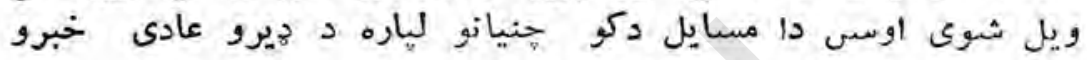

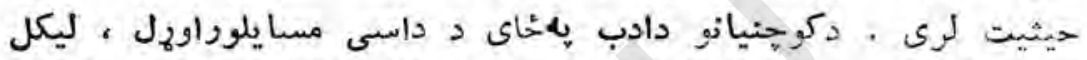
اويا دول د دوى دنبوو نىاوروزنىيه برخها كى دئ يوازى يه همدى شيانو

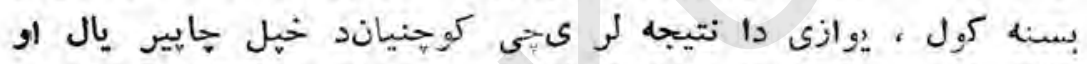

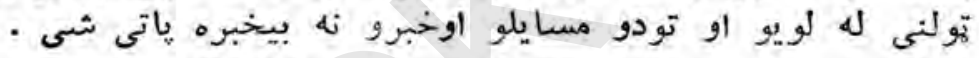

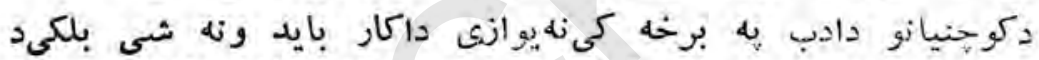

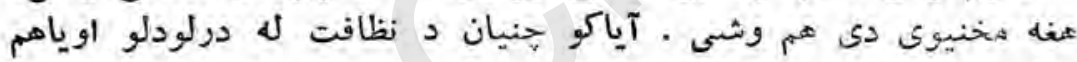

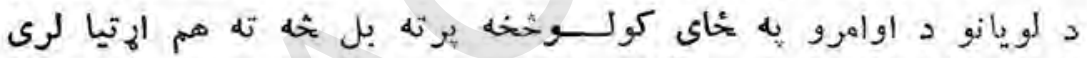

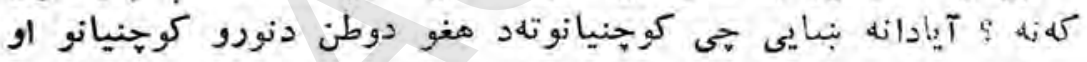

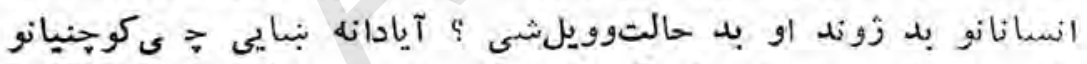

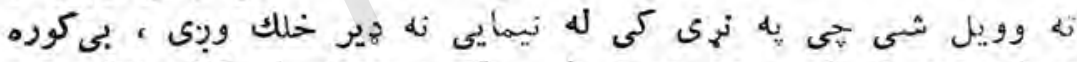

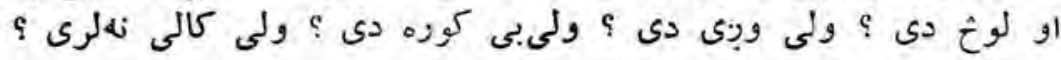

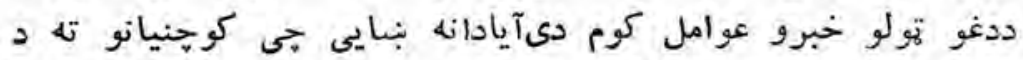

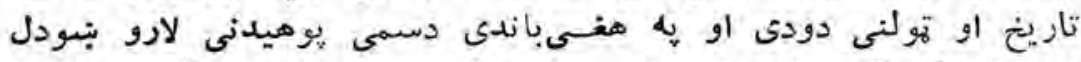

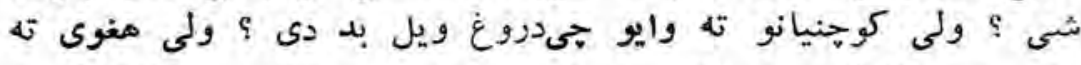

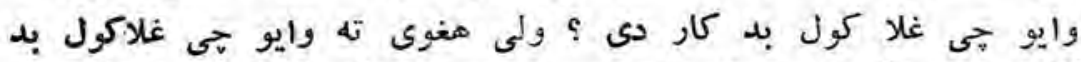

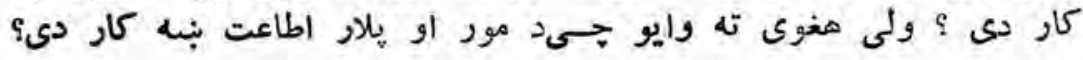




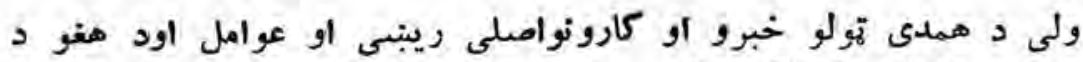

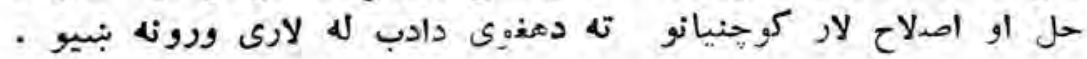

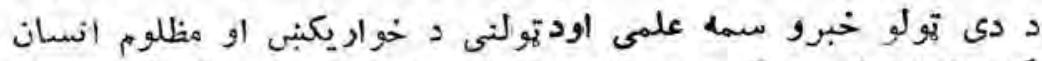

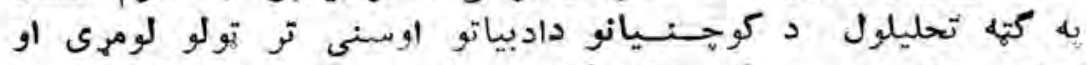

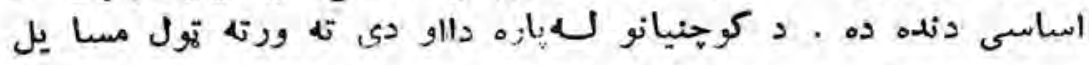

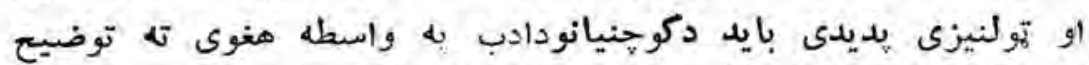

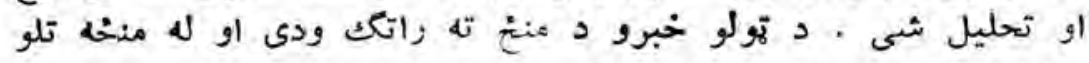

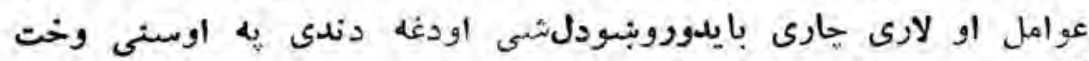

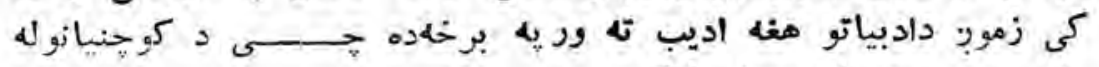

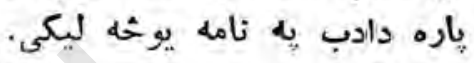

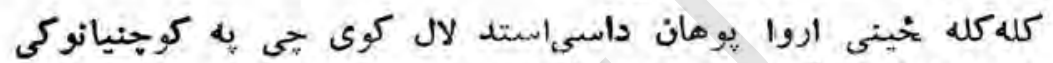

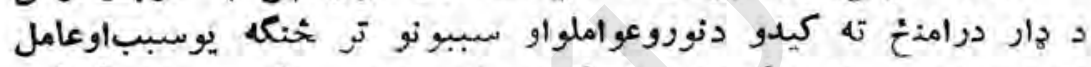

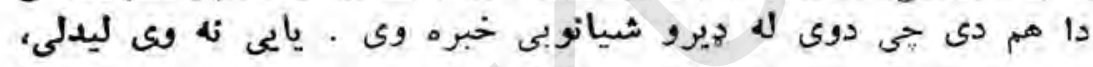

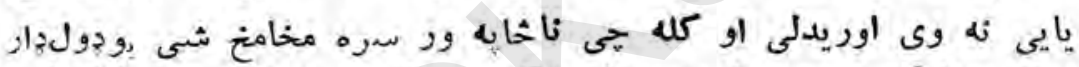

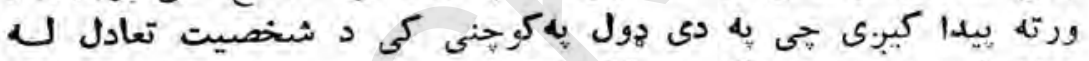

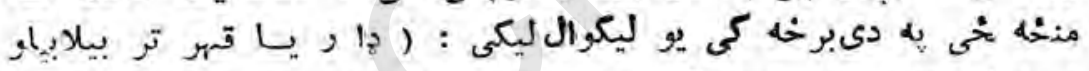

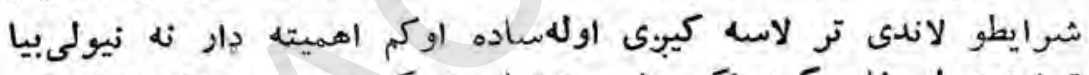

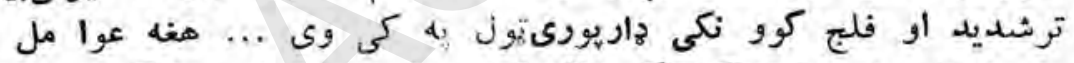

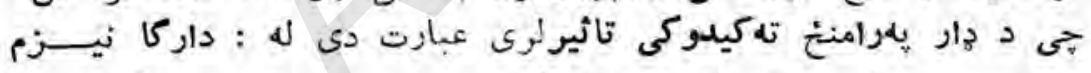

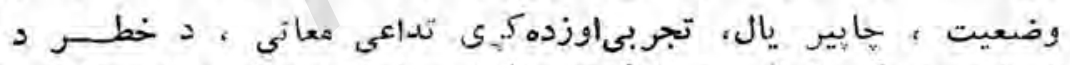

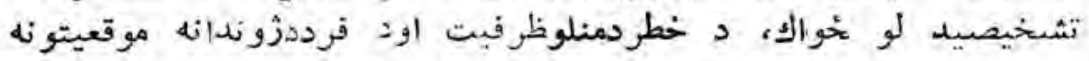

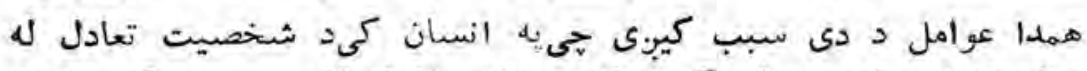

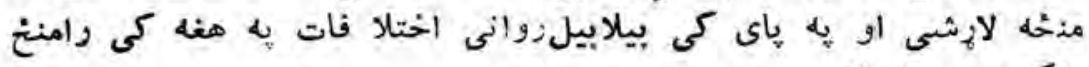

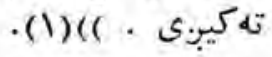

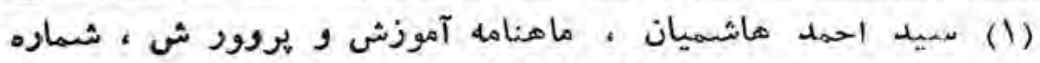

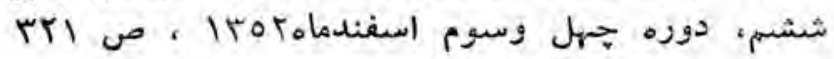
-rin_ 


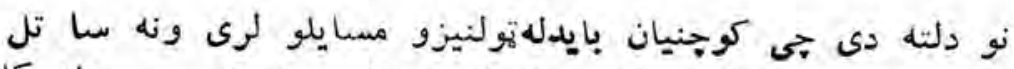

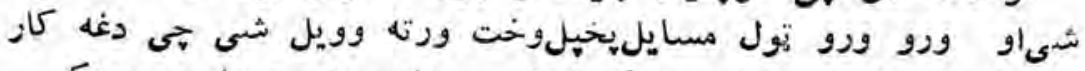

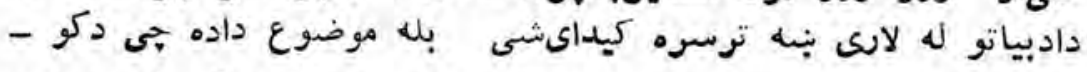

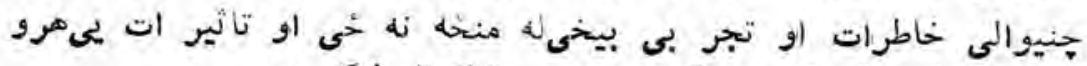

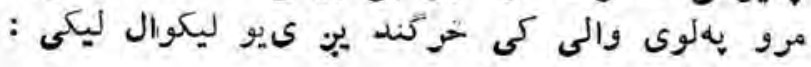

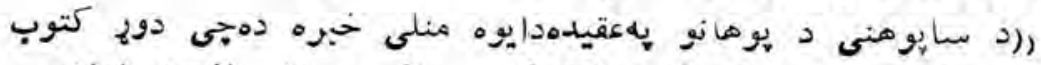

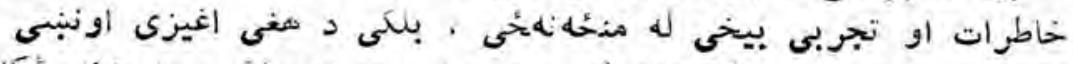

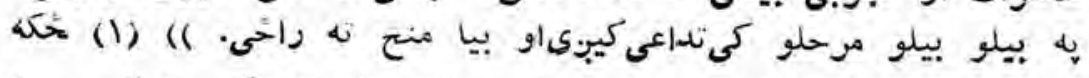

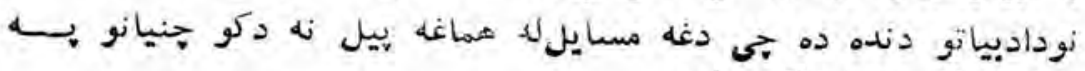

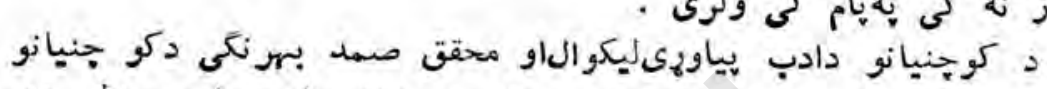

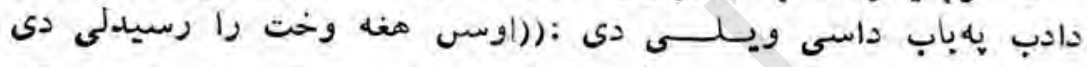

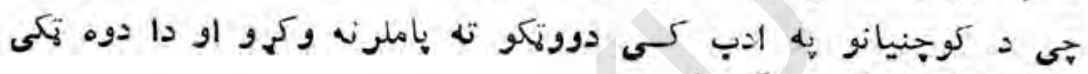

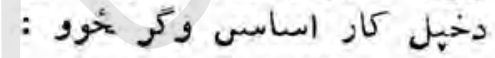

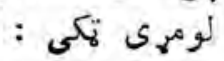

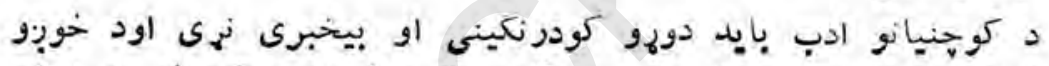

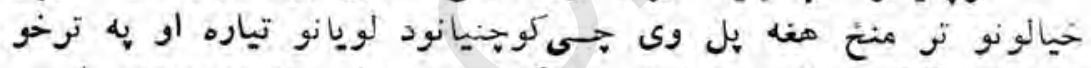

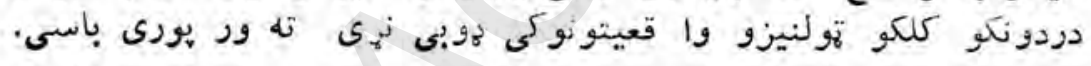

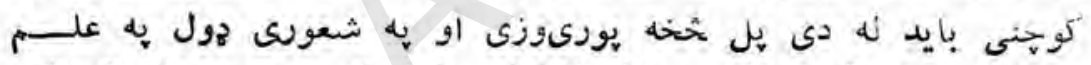

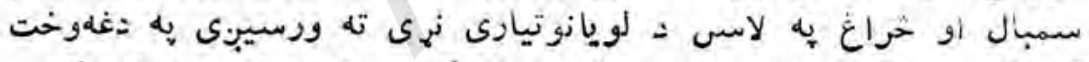

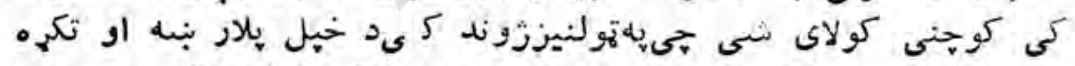

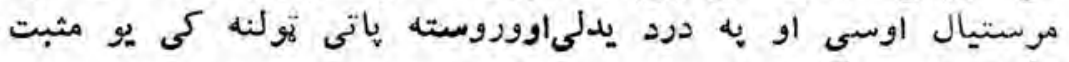
- لملون راوهو نكينى اونى

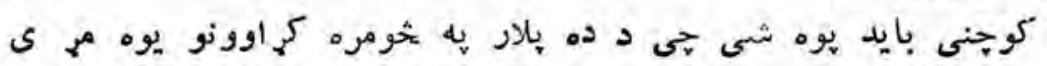

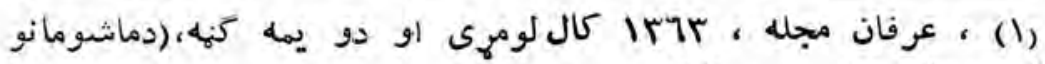
سالمه روز نه ) ، ص مان مجه ، 


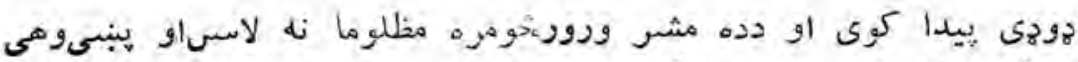

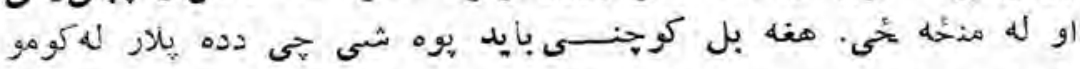

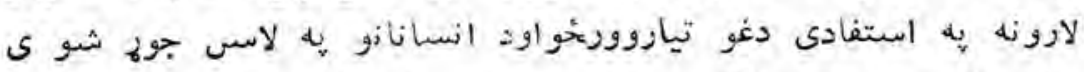

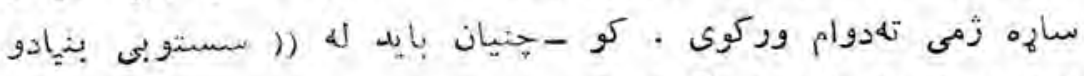

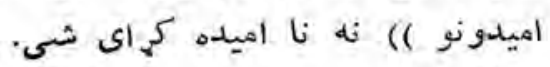

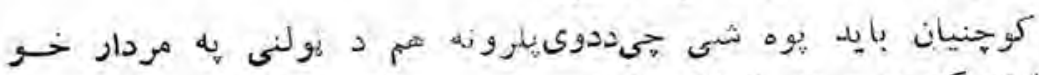

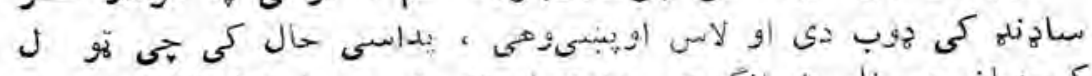

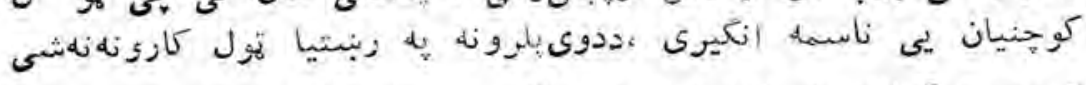

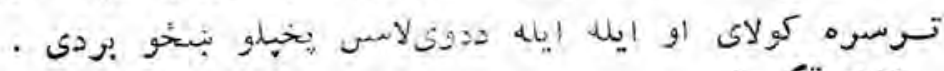

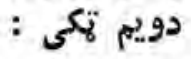

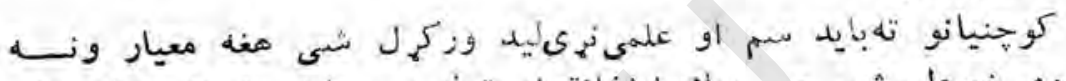

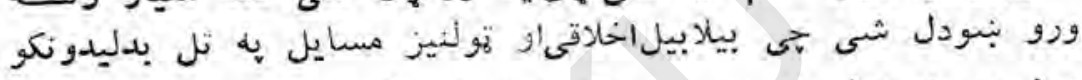

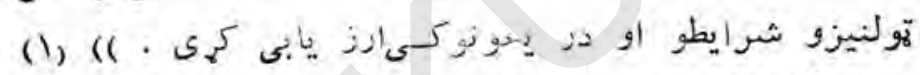

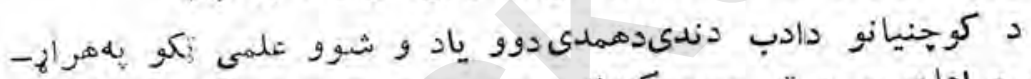

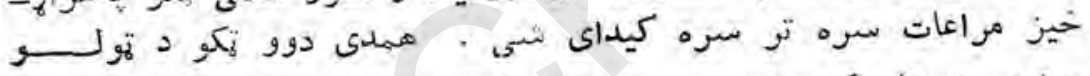

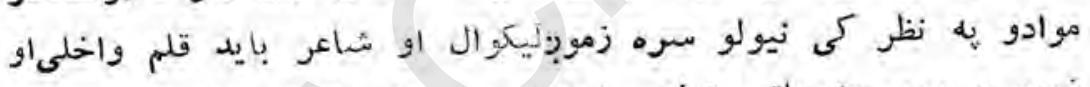

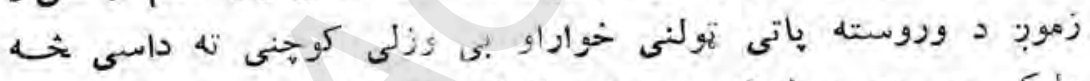

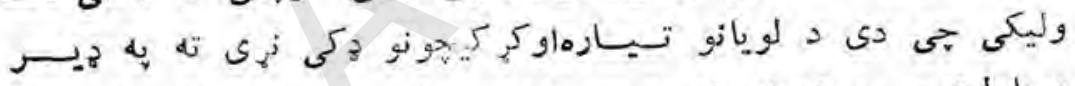

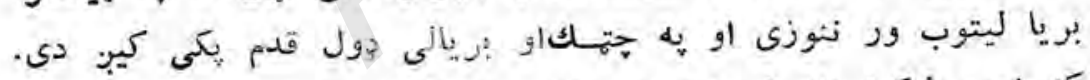

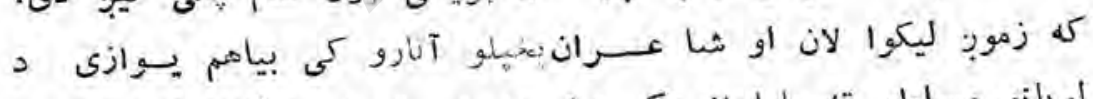

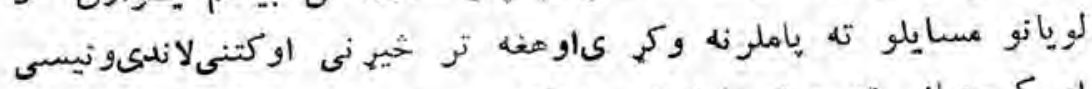

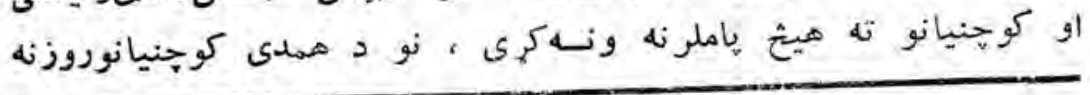

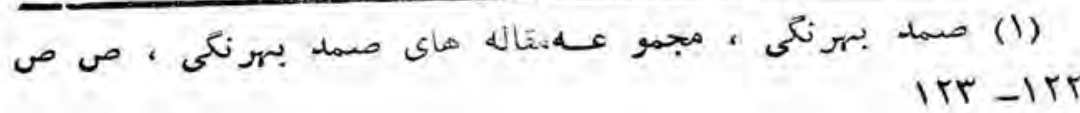




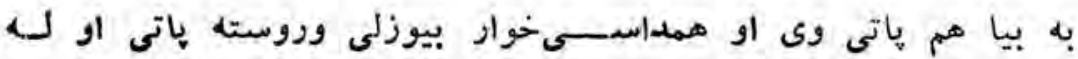

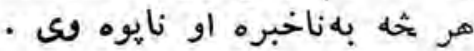

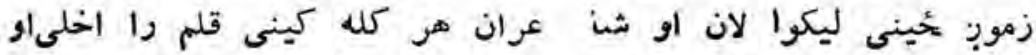

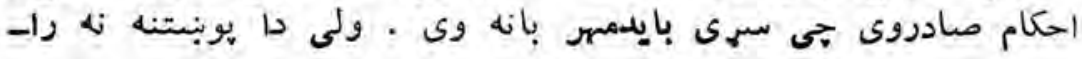

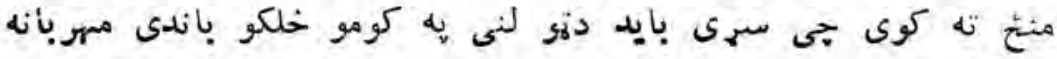

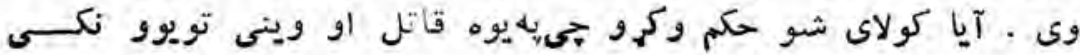

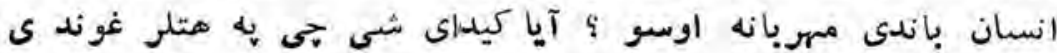

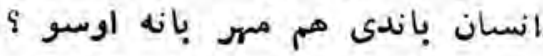

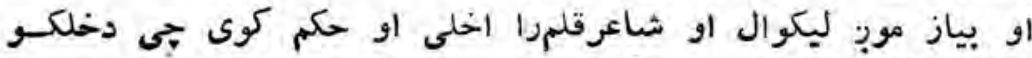

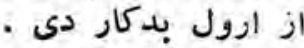

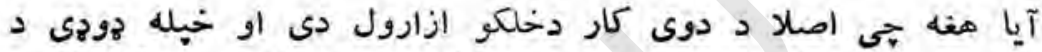

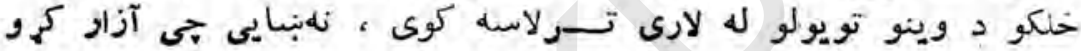

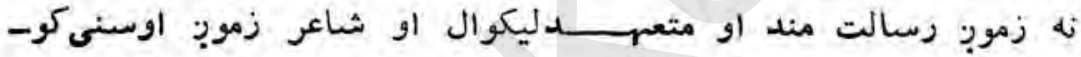

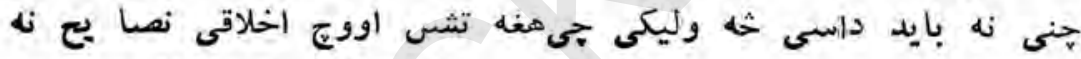

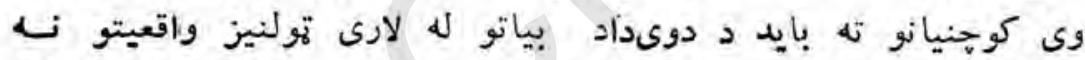

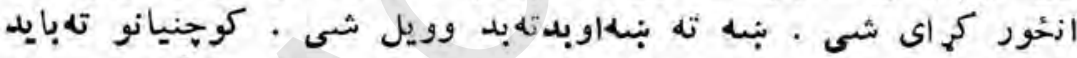

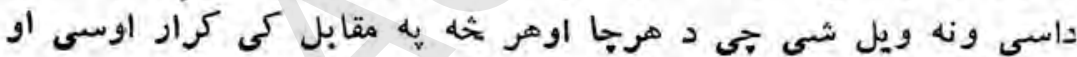

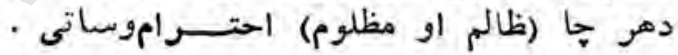

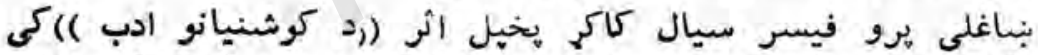
د (دكوشنيانو دادب خصو صيا ت)ترسر ليك لاندي لاندى د كوجنيانو دادب

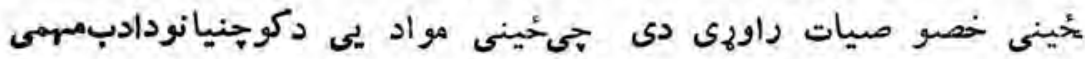

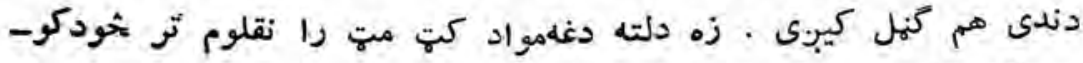

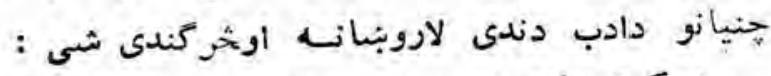

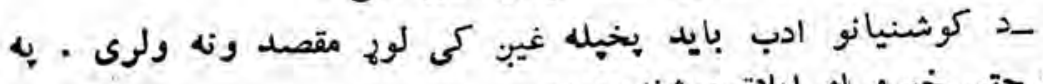

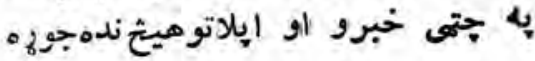




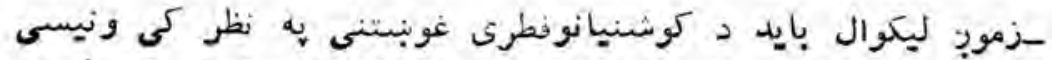

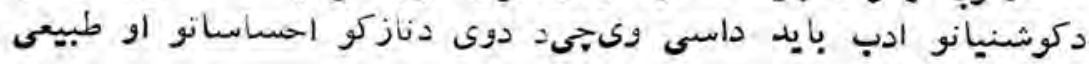

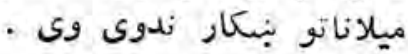

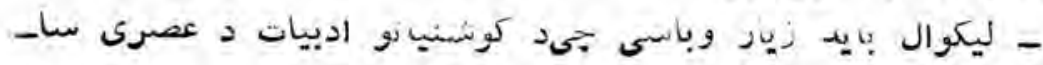

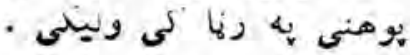

ـد كوشنيانو له باره بايد دكو شنيانو د ذوف او شوق سره سمى ليكنى وسنى ·

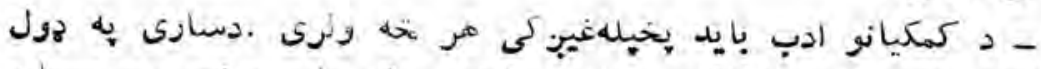

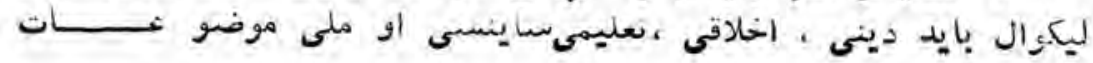

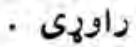

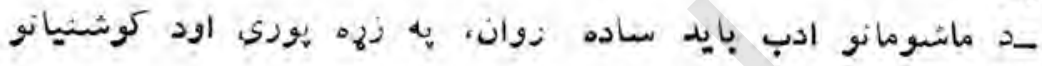

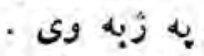

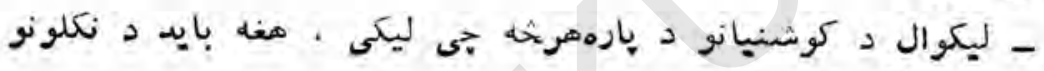

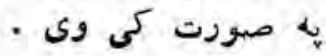

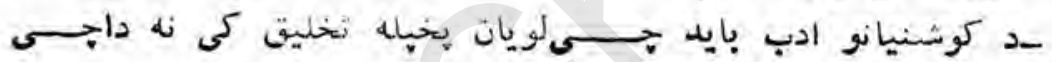

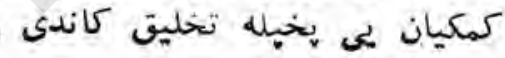

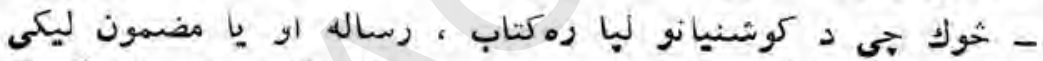

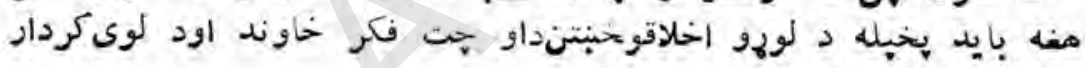

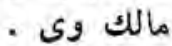
- د كوشنيانو دادب موضو عاتبايد دلجسبه او لله شنا ختهشبانو

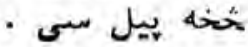

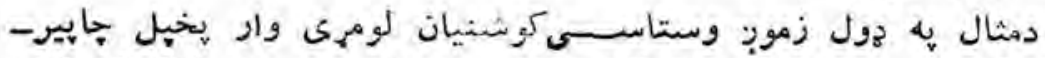

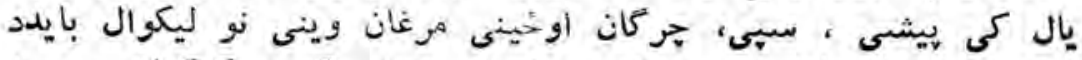

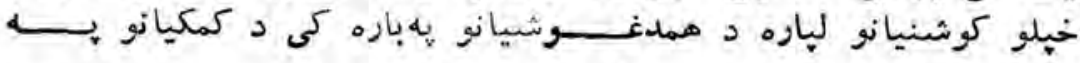

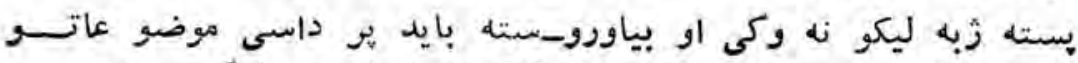

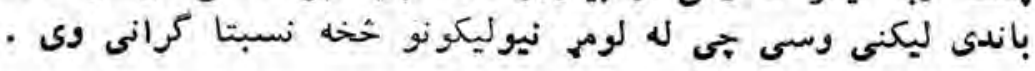
-rrr- 


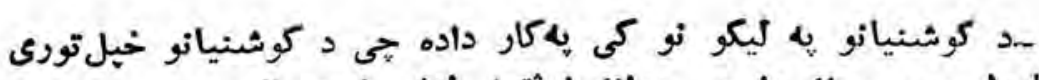

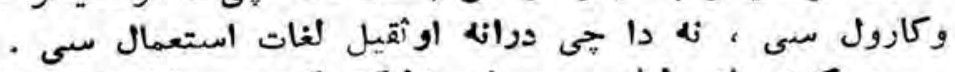

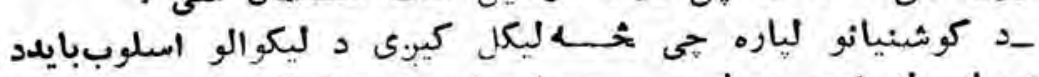

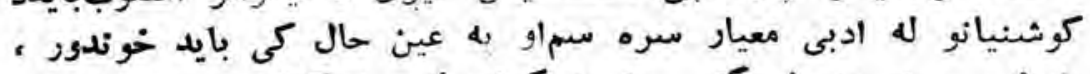

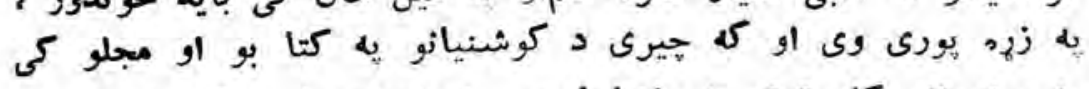

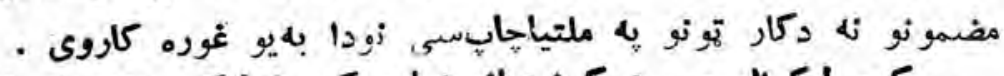

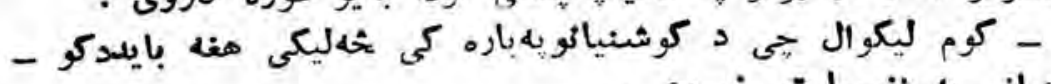

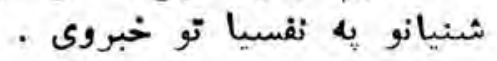

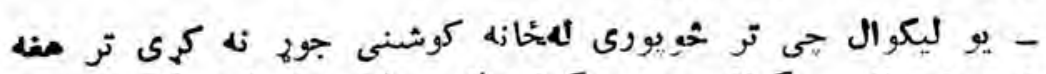

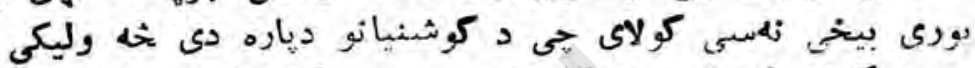

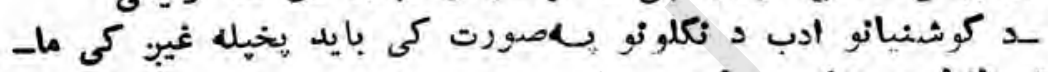

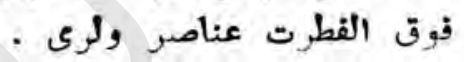

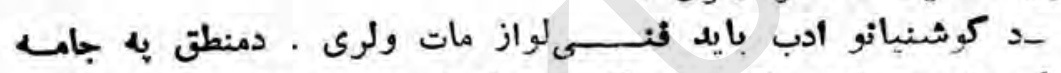

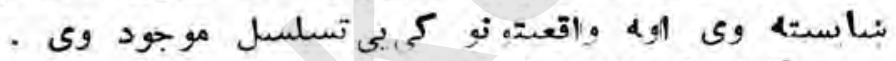

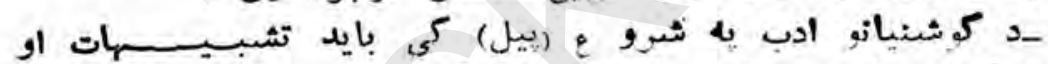

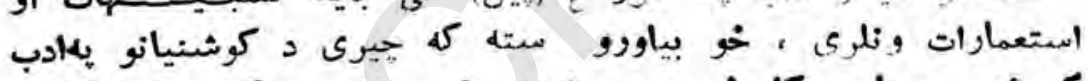

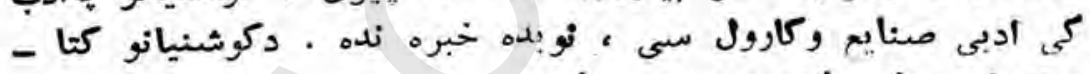

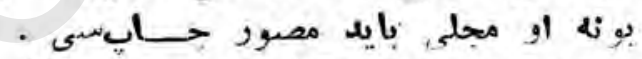

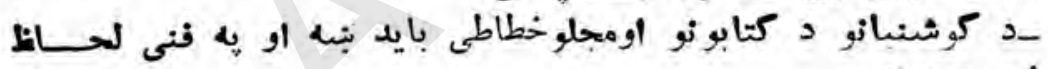

- (1) (1) و

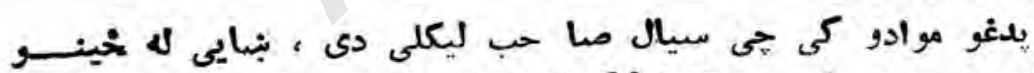

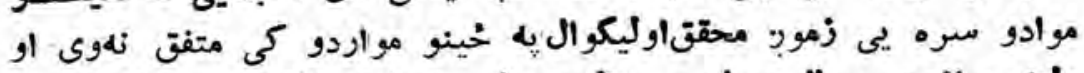

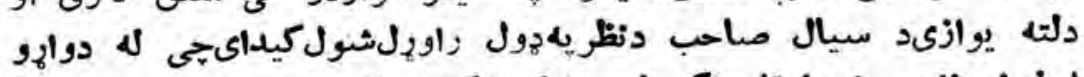

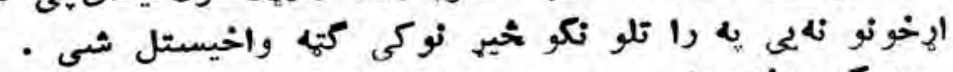

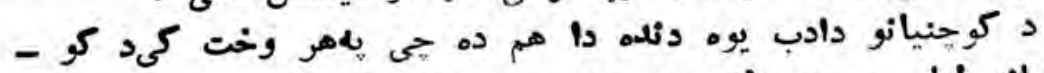

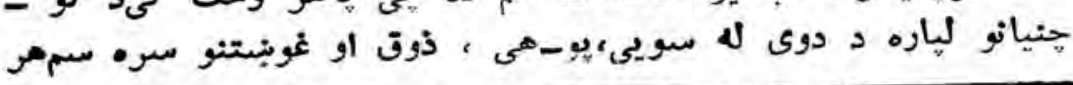
ro -rrr_ 


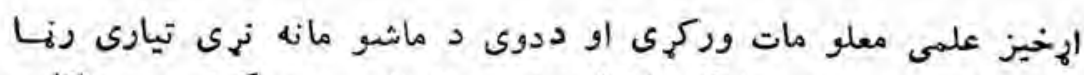

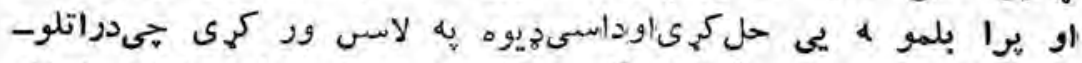

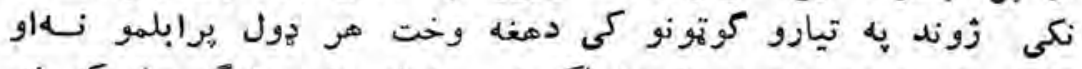

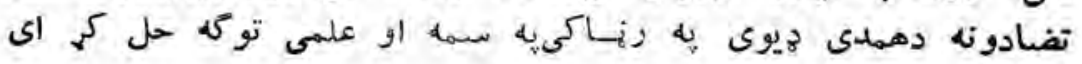

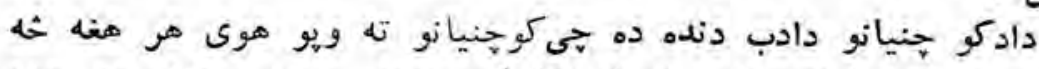

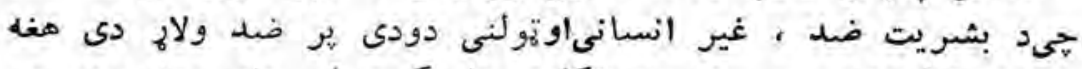

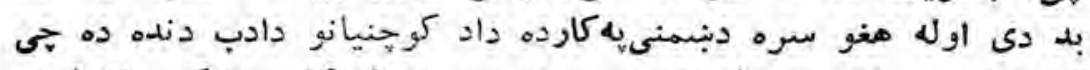

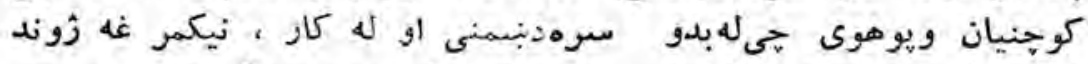

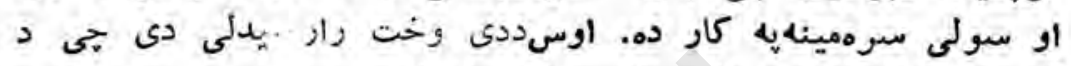

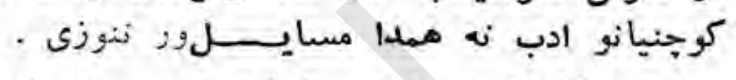

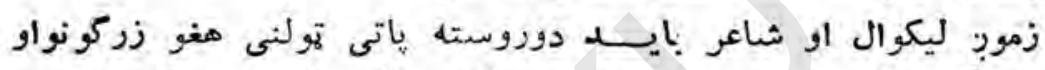

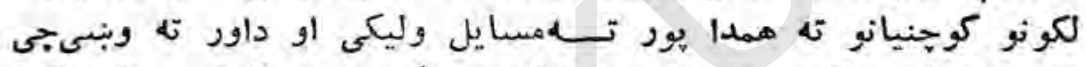

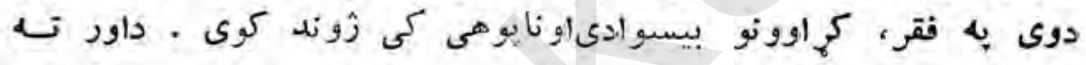

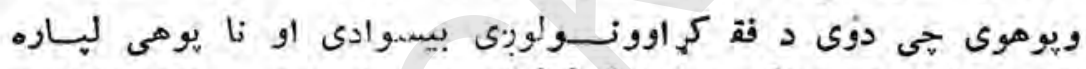

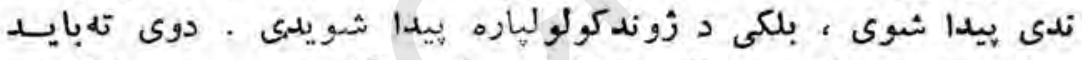

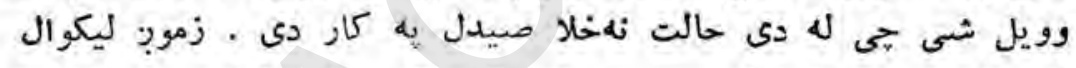

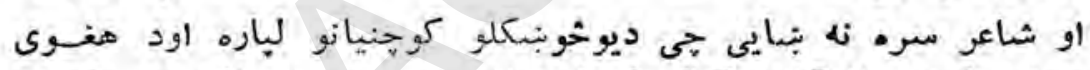

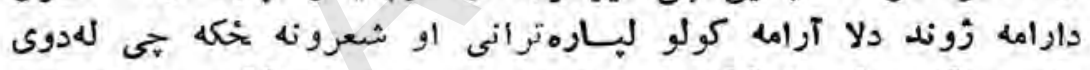

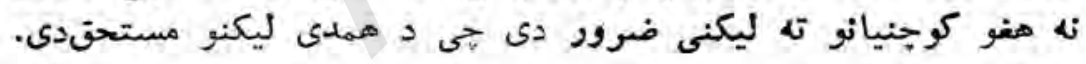

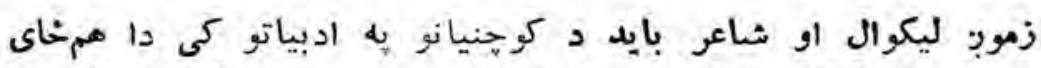

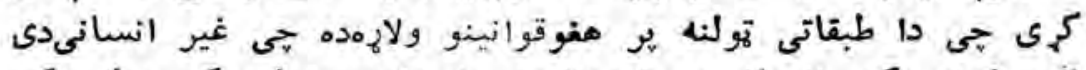

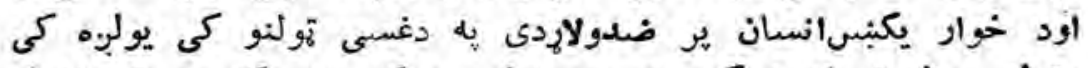

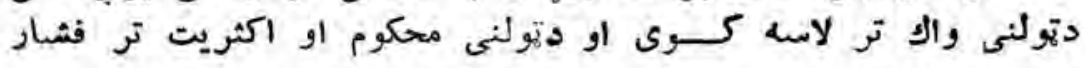

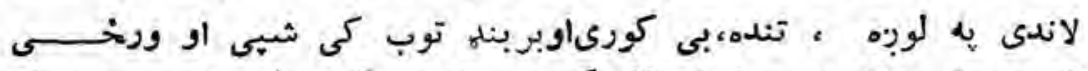

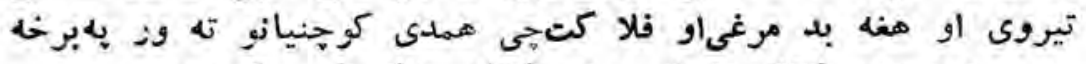

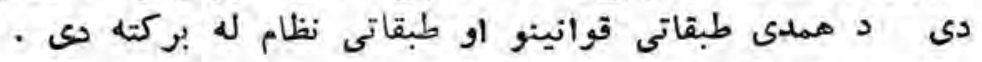




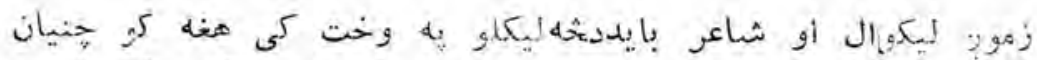

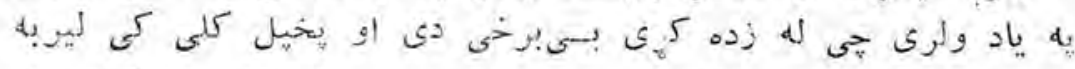

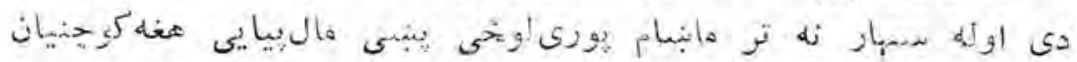

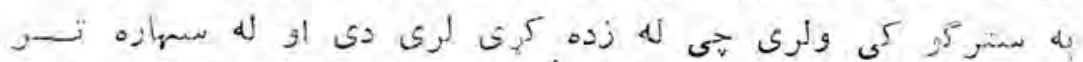

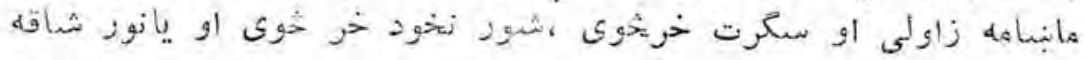

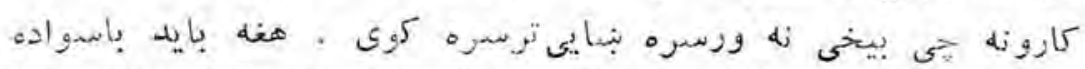

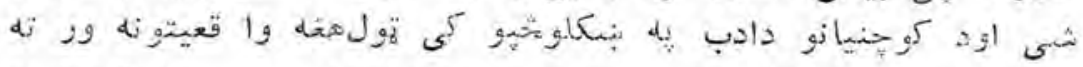

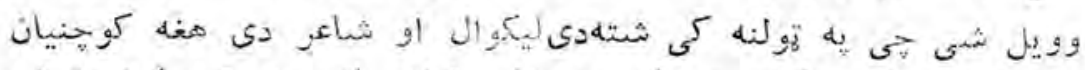

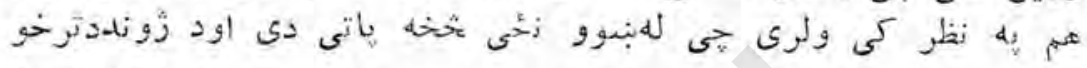

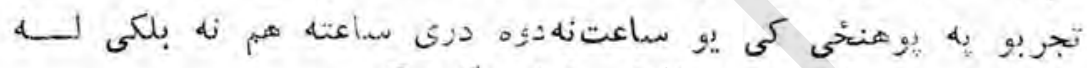

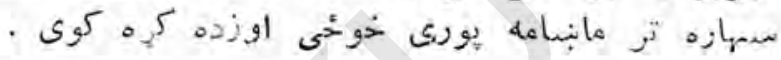

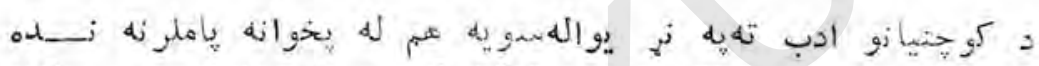

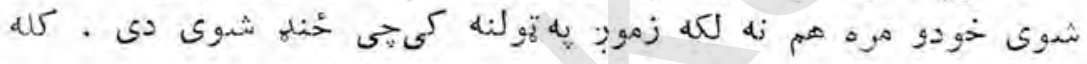

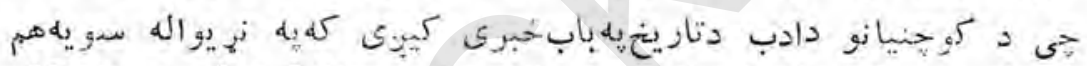

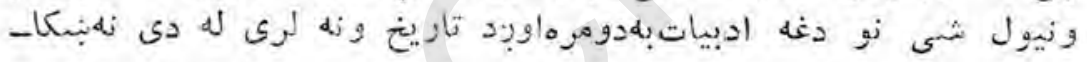

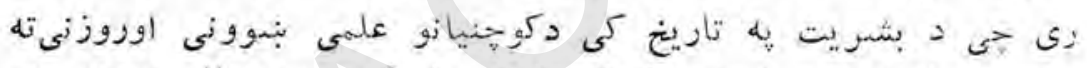

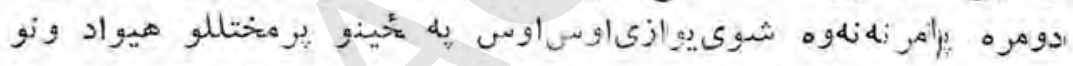

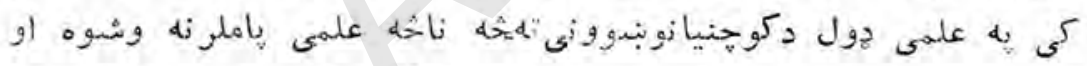

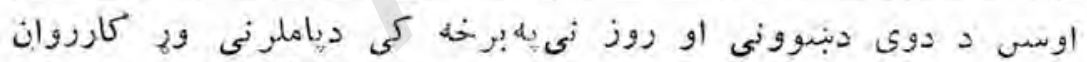

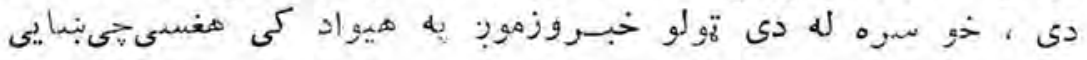

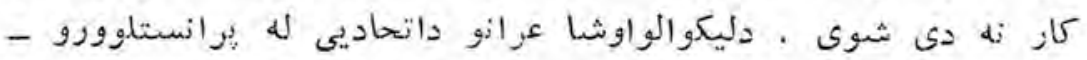

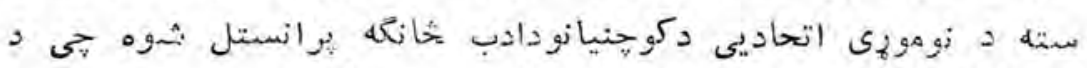

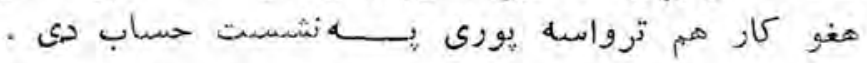

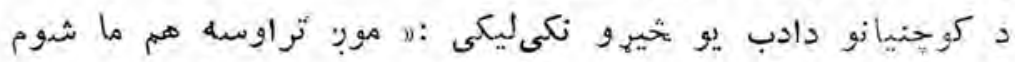

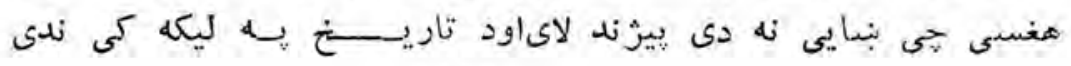




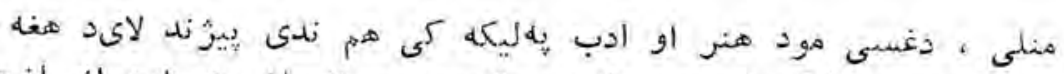

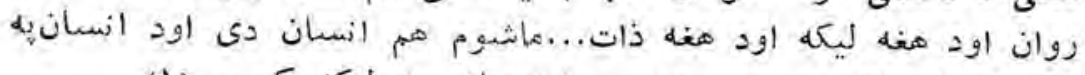

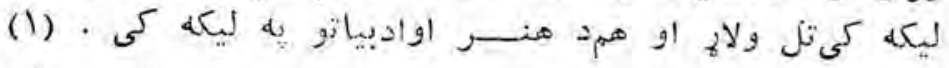

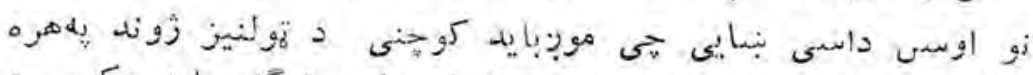

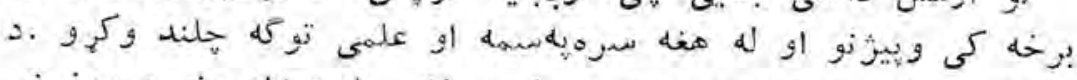

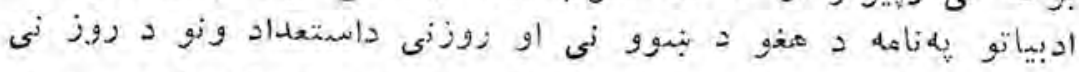

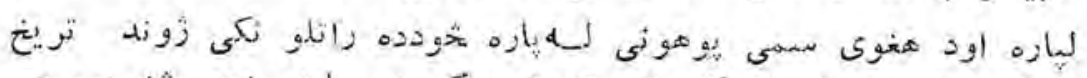

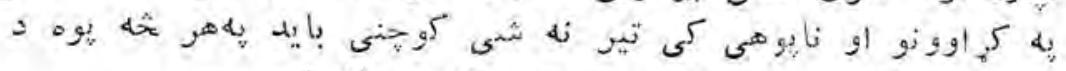

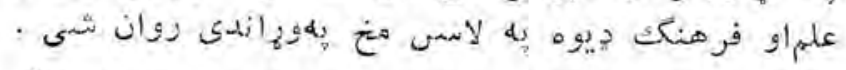

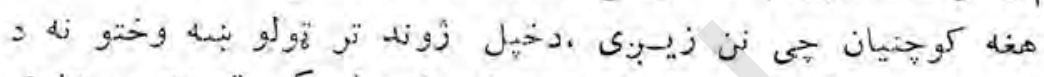

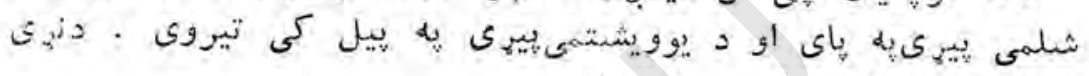

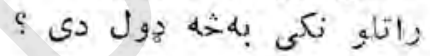

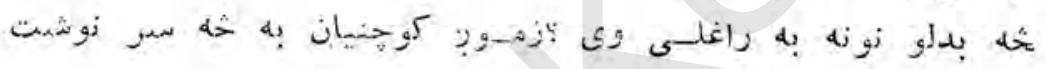
ولנى

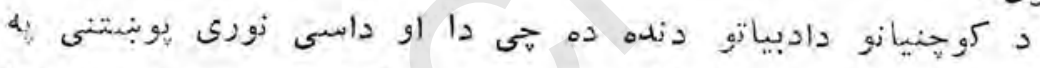

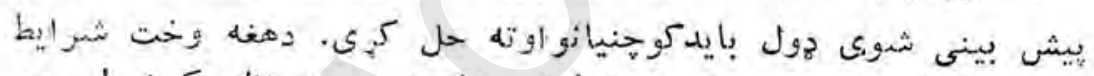

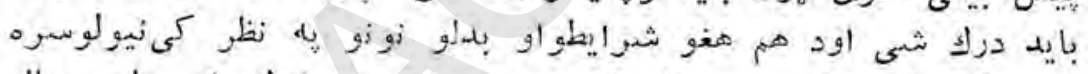

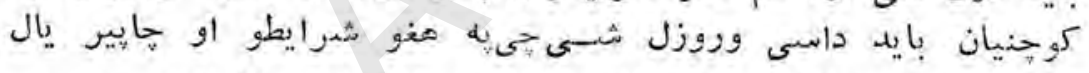

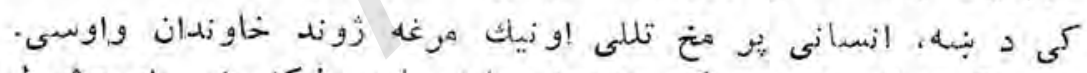

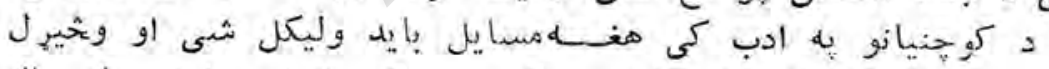

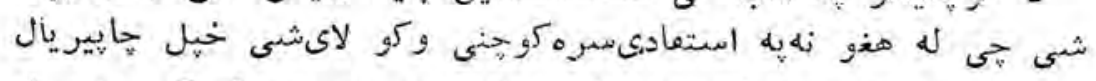

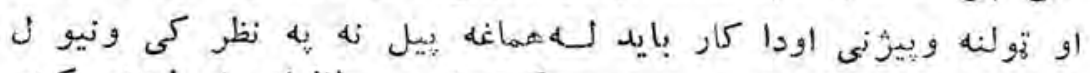

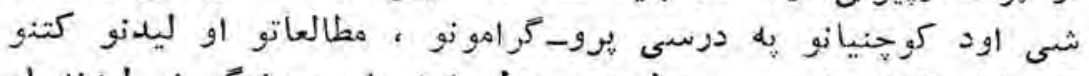

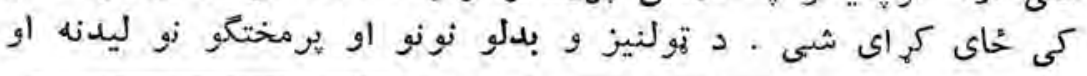

$$
\begin{aligned}
& \text { 1r7.2 }
\end{aligned}
$$

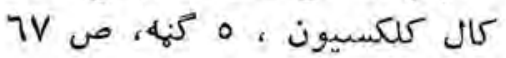




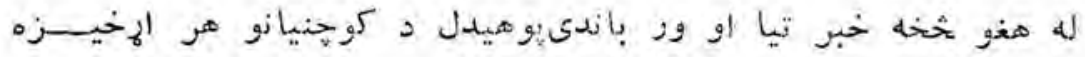

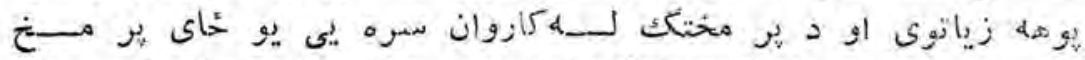

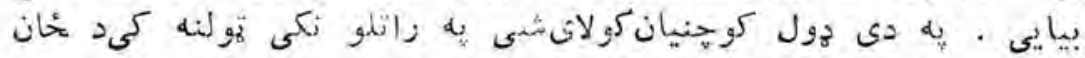

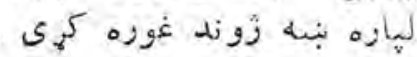

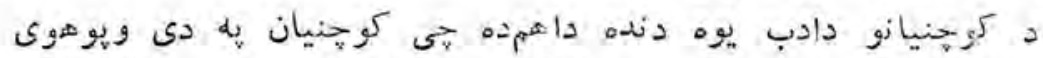

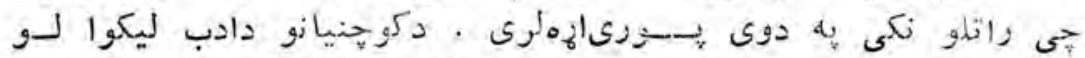

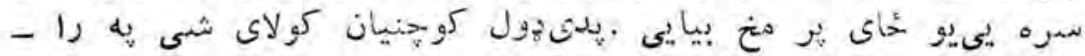

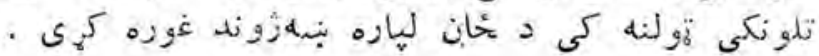

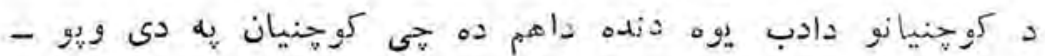

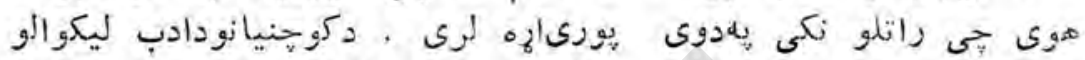

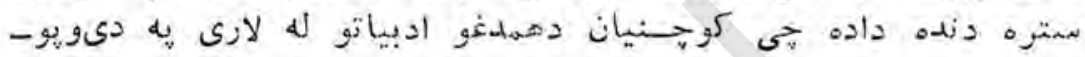

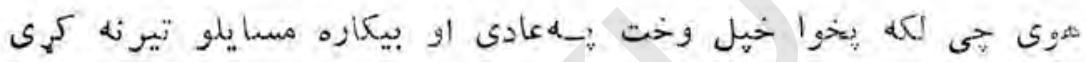

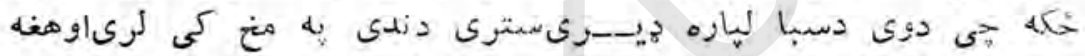

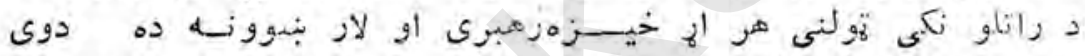

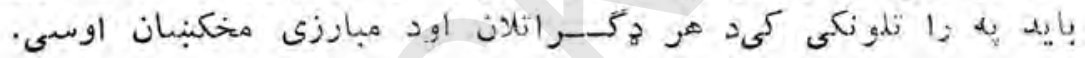

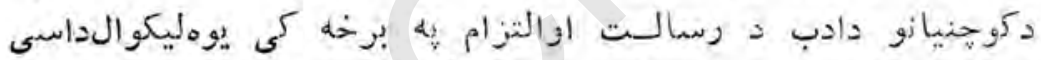

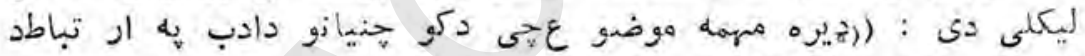

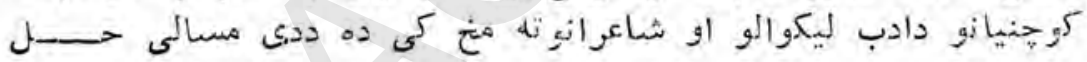

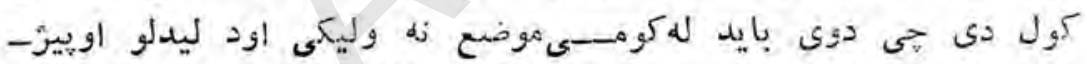

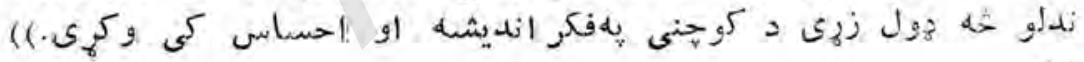

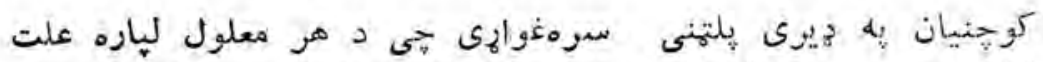

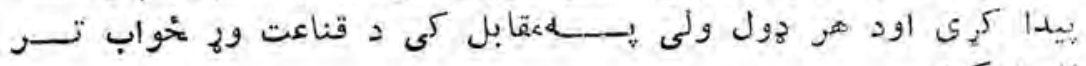

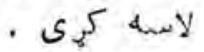

دغه تولى دندى او رسما لتونه حكوخنيانو ادب ته ورله غاهه دى .

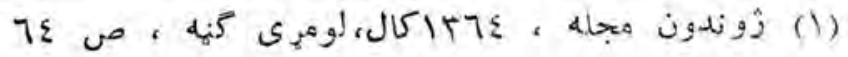




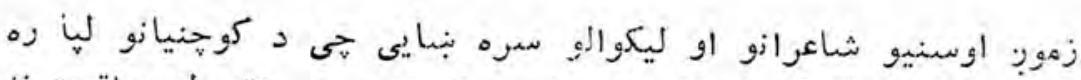

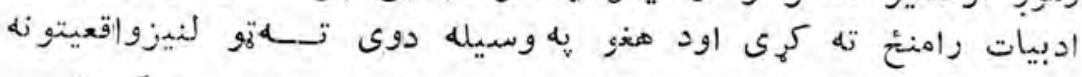

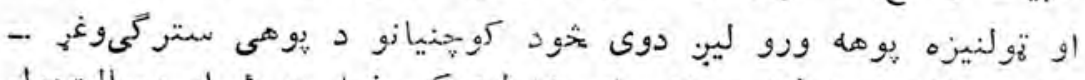

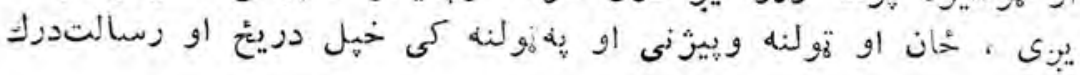

. 15

ماخذونه

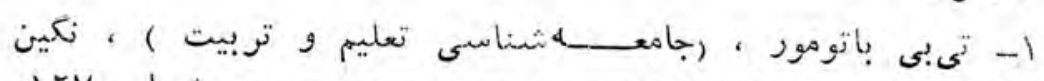

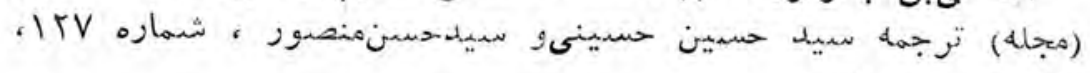

09 ue, Iros

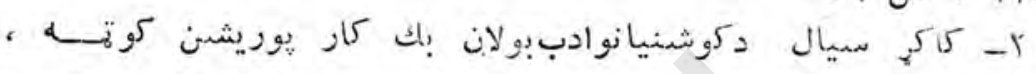

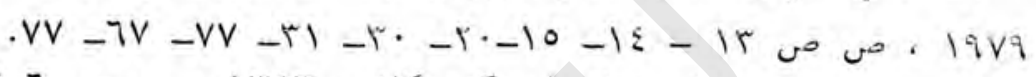

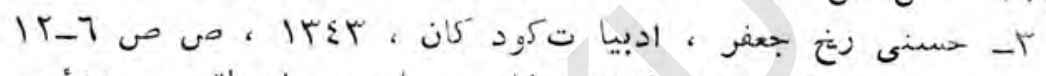

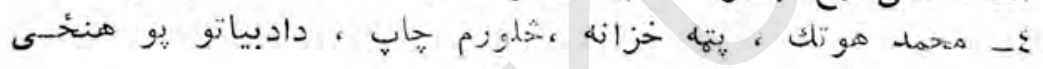

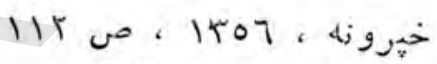

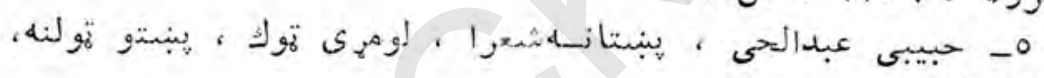

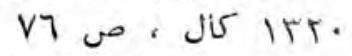

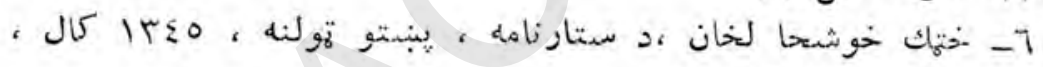

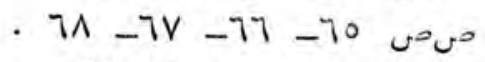

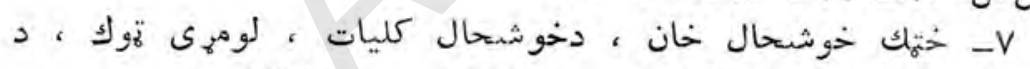

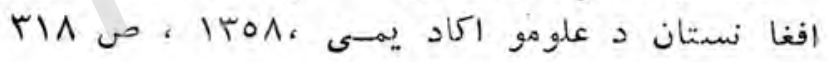

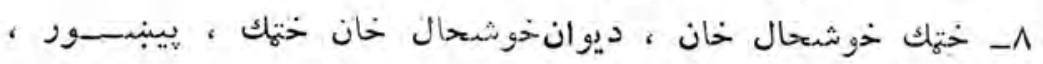

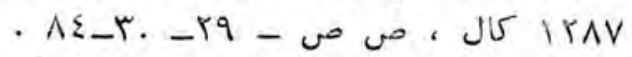

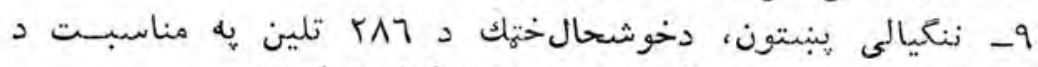

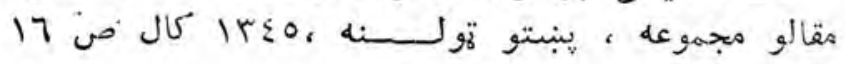

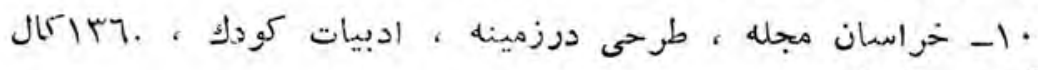

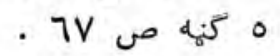

$-r Y \Lambda_{-}$ 


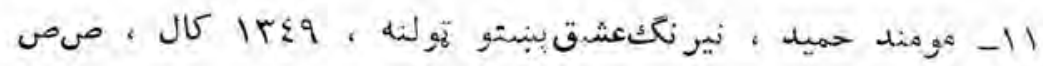

$$
\text { rT. }- \text { rIO }
$$

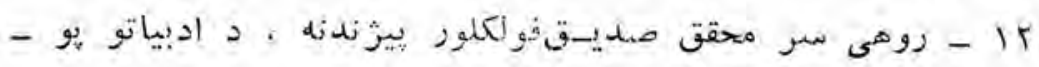

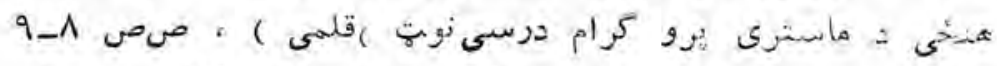
- أ

$$
09 \text { - } 01
$$

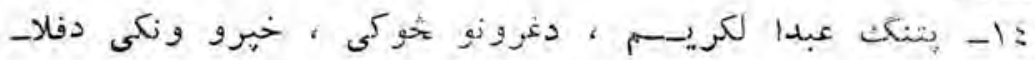

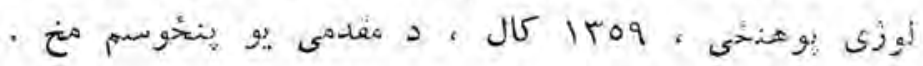

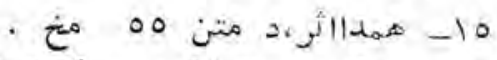

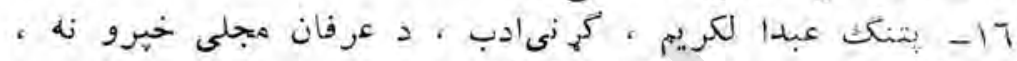

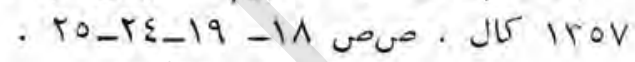

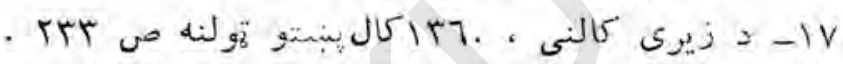

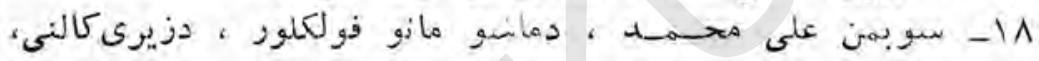

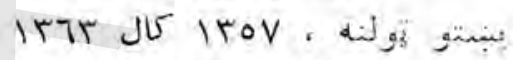

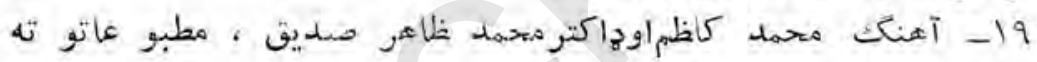
.

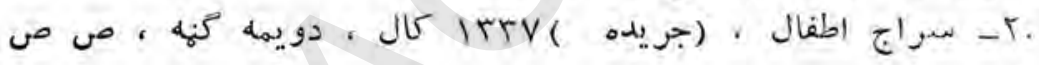

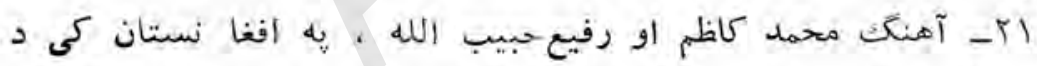

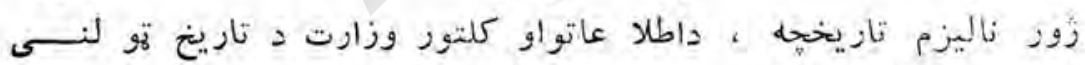

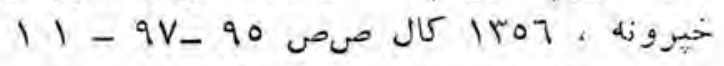

r ك

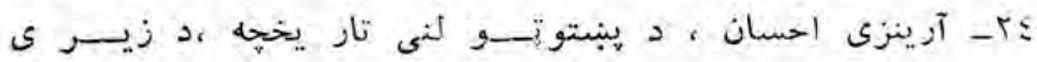

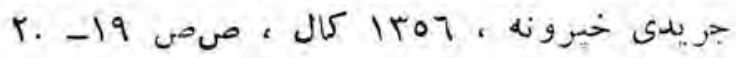
-rra 


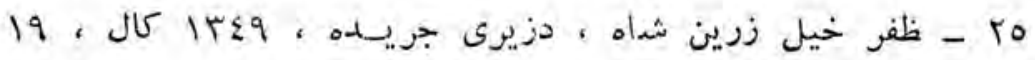
1 ص 1.40

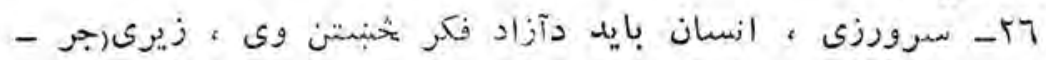

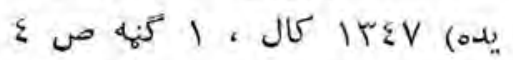

-

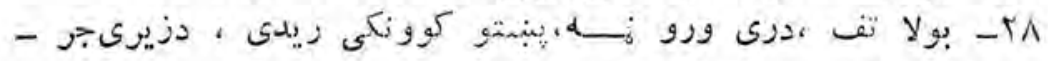
يده . و it 0

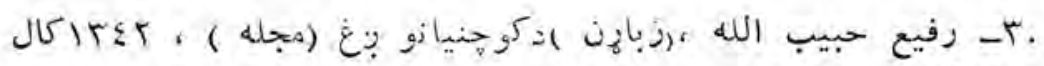

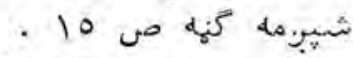

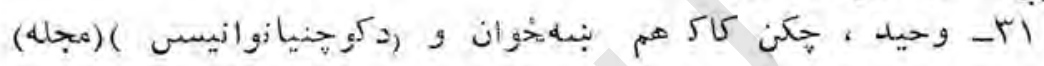

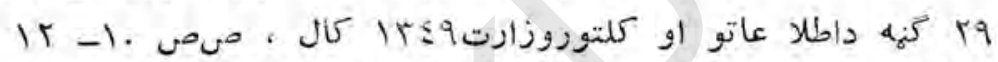

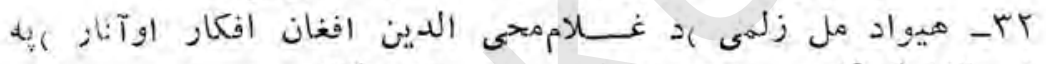

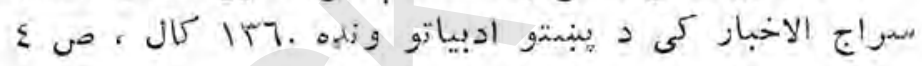

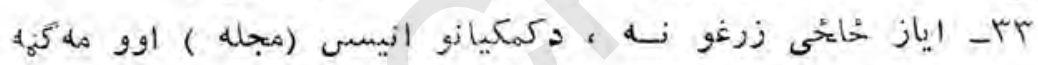
IV صص E

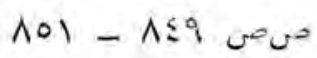

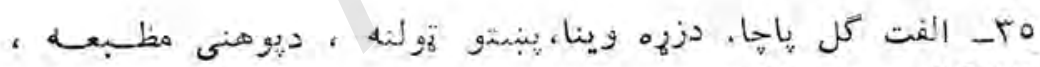

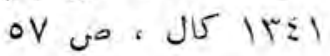

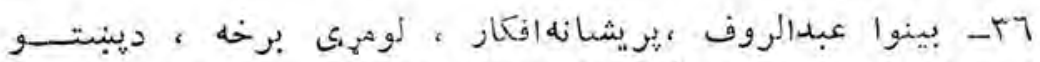

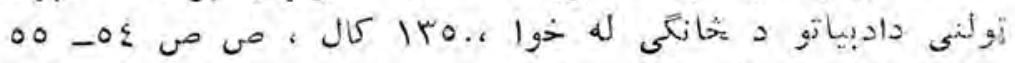

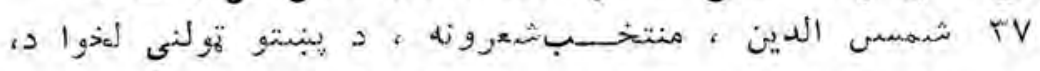
ro ro ro

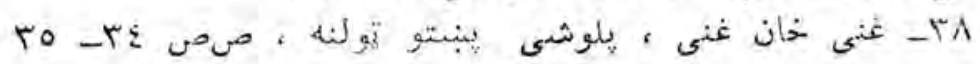
- RH. 


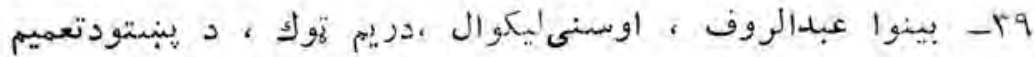

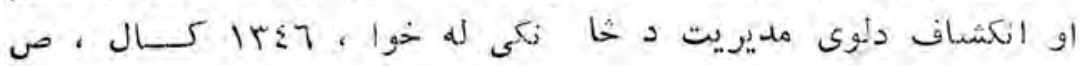

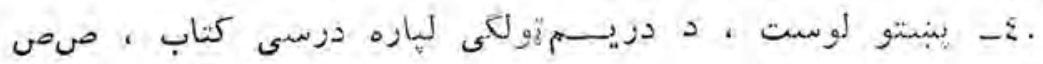

$$
\text { rV - r - IV - } 17
$$

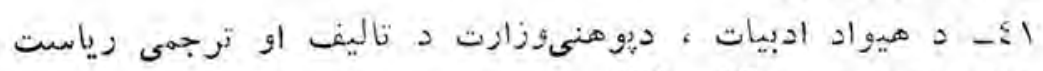

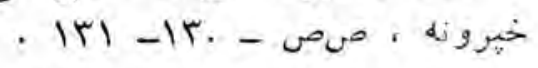

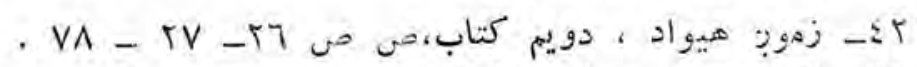

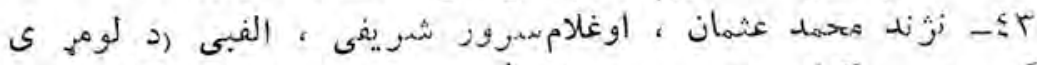

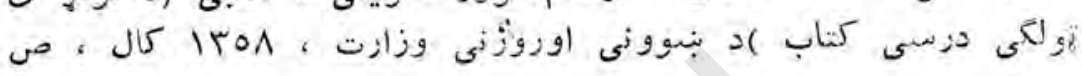

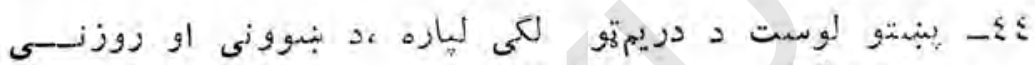
وزازت ، . . .

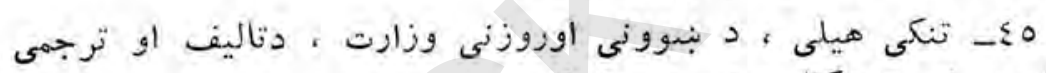

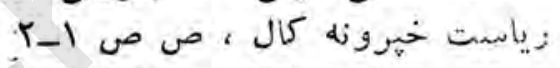

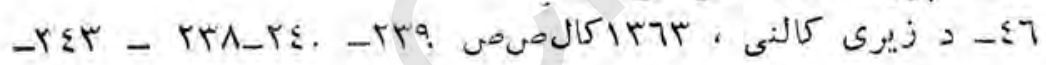
$-r \leqslant 0$

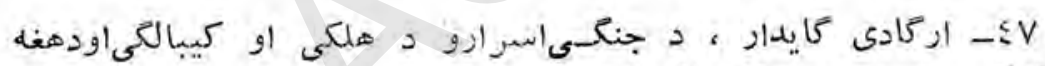

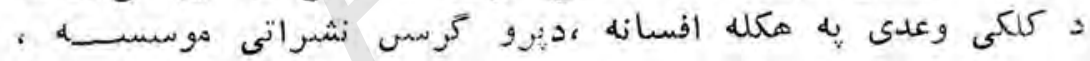

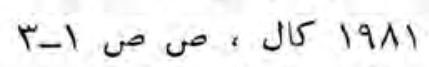

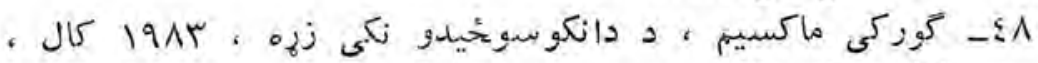

$$
\text { (r) ص ص ص }
$$

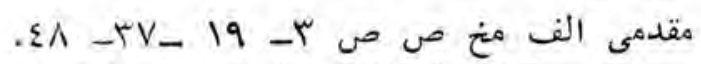

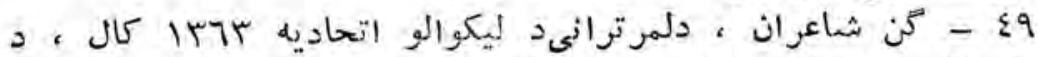

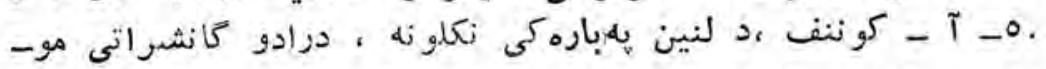

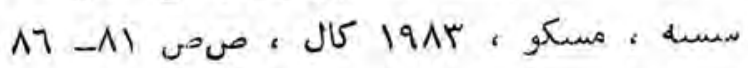
- rm- 


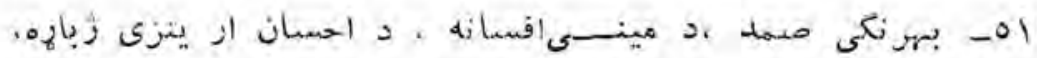

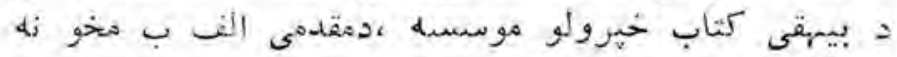
ونه $r 7$ e.

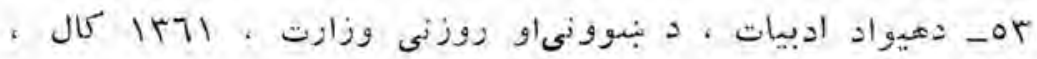
.99 ve r

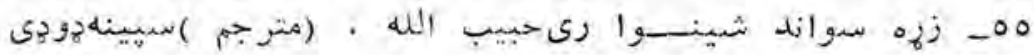

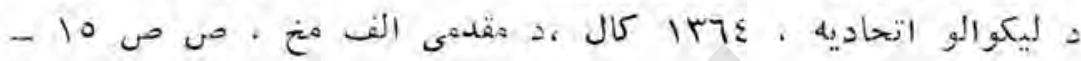
.19

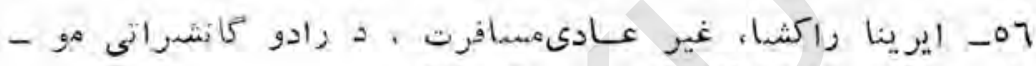

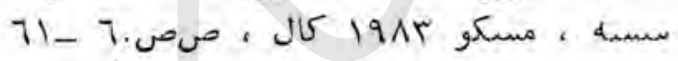
صن 17 ص

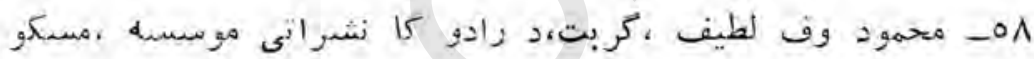

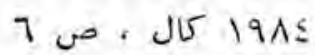

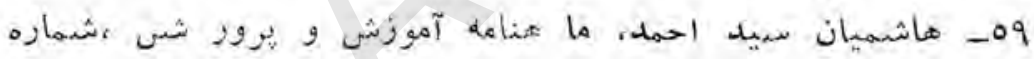

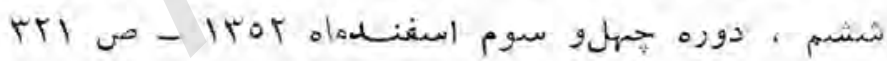

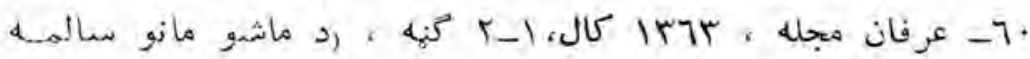
زوز is

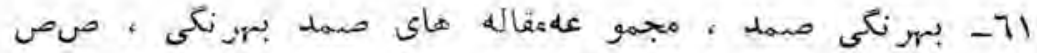

$$
1 T H-1 K 5
$$

TV rآ- زوندون مجله ، - trT- 


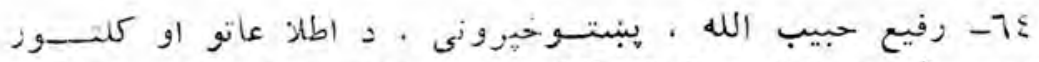

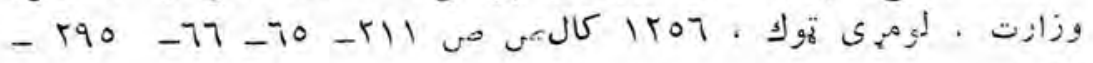
$r 97$

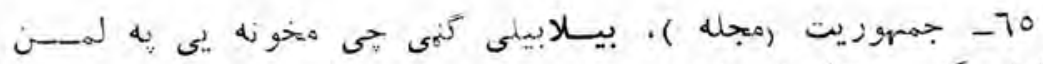

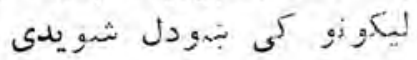

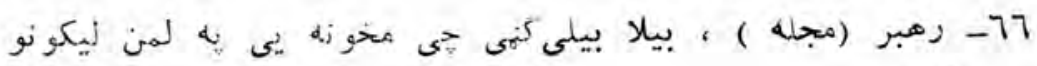

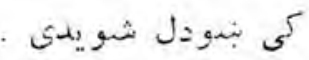
ك

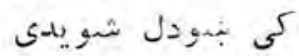

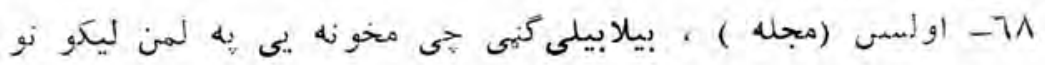

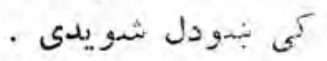

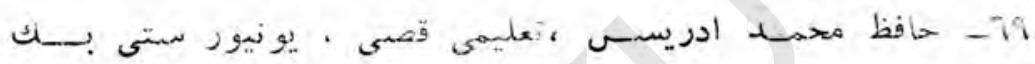

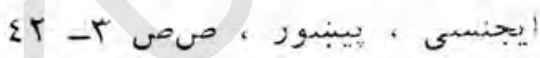

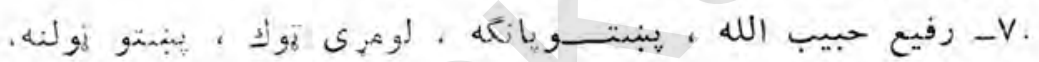
rAr - 10 ous

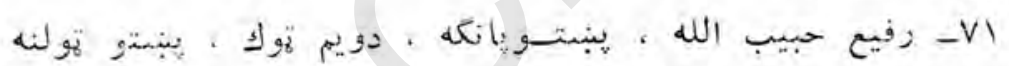
rAl-071-07. v0 إل

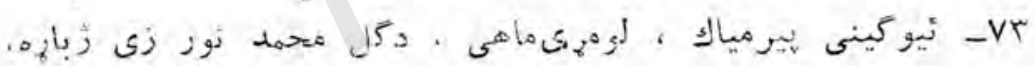

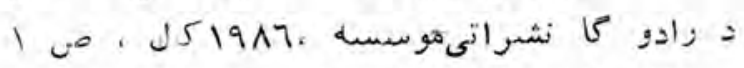

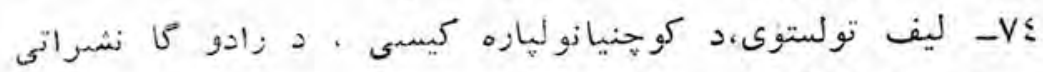

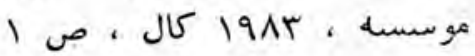

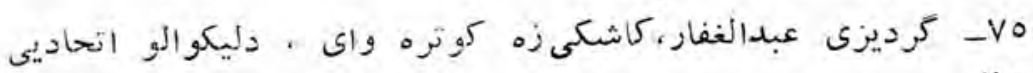
- rre خهرونه

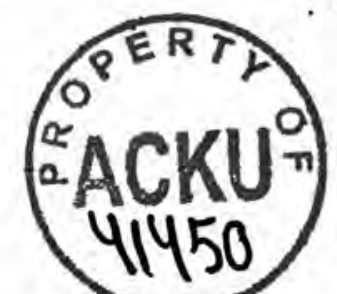




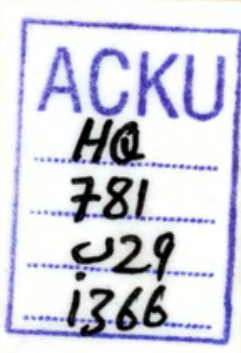

बै, 